\title{
An integrated approach
}

\section{for the investigation of unconsolidated aquifers}

\author{
in a brackish environment
}

- A case study on the Jordanian side of the lower Jordan Valley

\author{
Dissertation \\ zur Erlangung des Doktorgrades \\ der Mathematisch-Naturwissenschaftlichen Fakultäten \\ der Georg-August-Universität zu Göttingen \\ vorgelegt von \\ Mathias Toll \\ aus Bensheim
}

Göttingen 2007 
D 7

Referentin/Referent:

Korreferentin/Korreferent:

Tag der mündlichen Prüfung:
Prof. Dr. M. Sauter

Prof. Dr. T. Ptak-Fix

16. Januar 2008 


\section{الخلاصة}

إن أنظمة المياه الجوفية في أغلب المناطق شبه الجافة لم تتم دراستها بشكل واف، كما أن تسجيلات البيانات الضرورية لنمذجة المياه الجوفية على المدى الطويل غير منوفرة. هذه البيانات تعتبر ضرورية جدا من أجل وضع استراتيجيات

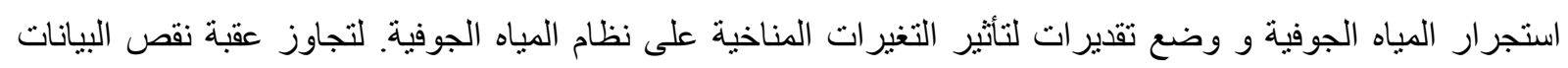

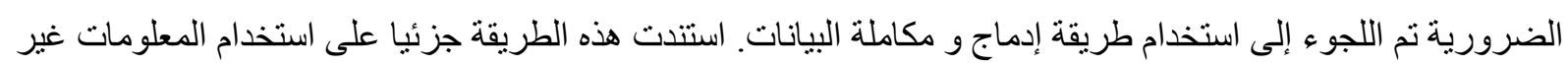
المباشرة و قد تم تطبيقها على الجزء الجنوبي من وادي الأردن الأدنى (غور الأردن).

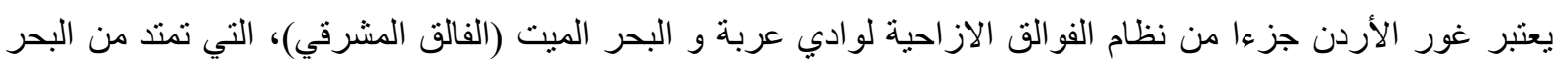

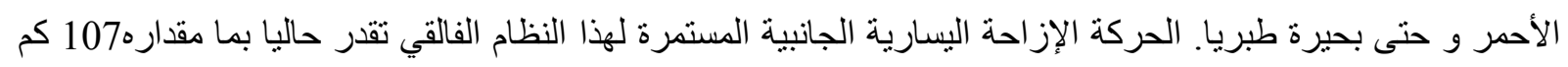
تقريبا تحدث في منطقة تصادم الصفيحة التكتونية العربية التي تقع شرقا مع الجزء الثمالي الثرقي للصفيحة التكتونية

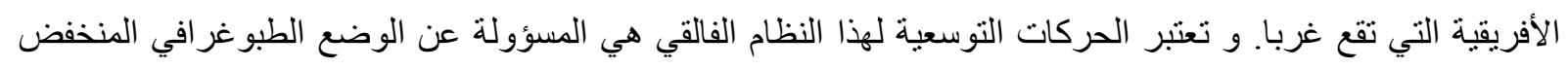

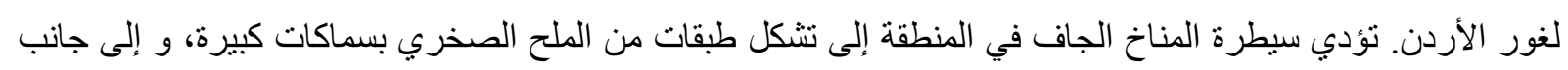

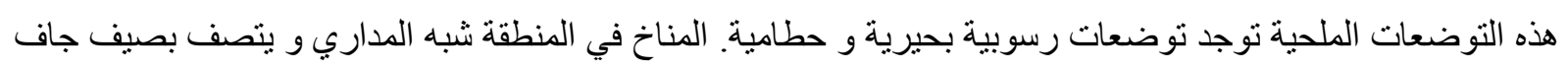
و طويل و شتاء معتدل و رطب يوفر ظروف مو اتية جدا للزر اعة. و لذللك يوصف غور الأردن بأنه سلة غذاء الأردن و يتم فئن استثماره زر اعيا بشكل كبير. هذاو لأنه لا يمكن القيام بالأعمال الزر اعية على مدى شهور الصيف وليف الطويل إلا من خلال

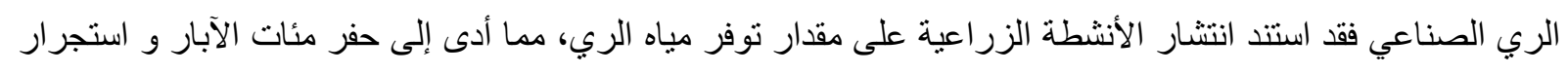

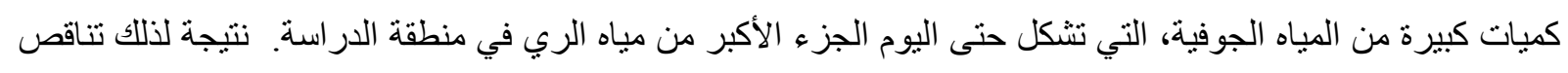
مخزون المياه الجوفية منذ الستينات بشكل مستمر حتى الان و مؤشرات ذلك و اضحة للعيان من خلال الاستجرار الجائر للمياه الجوفية و ازدياد تملح التربة. من أجل الاستخدام المستدام لمصادر المياه الجوفية و تقدير تأثثر التغيرات المناخية عليها يجب أن وضئ أنسع تقدير شامل لكصادر المياه المتوفرة و جودتها. للتمكن من وضع وصف للنظام الهيدروجيولوجي المعقد تم استخدام الطر ائق الجيولوجية

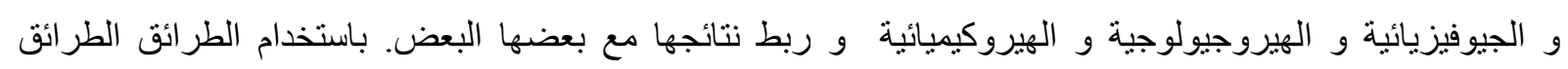

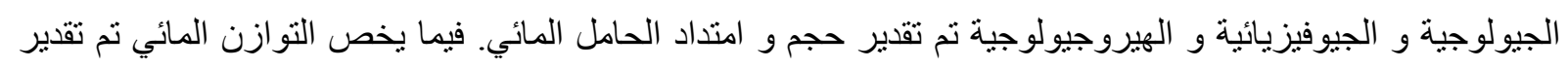

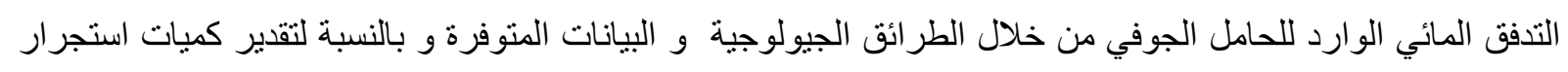

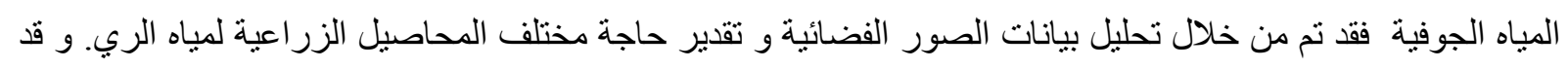

تم إجر اء تحليل للظروف التي خضع لها نظام المياه الجوفية في الماضي و الوضع المر افق الذي كان عليه هذا النظام.

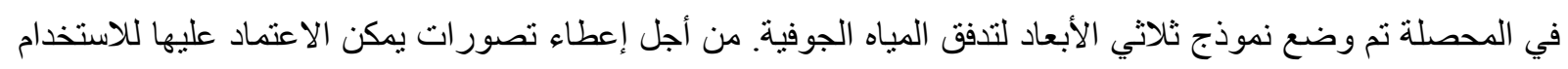

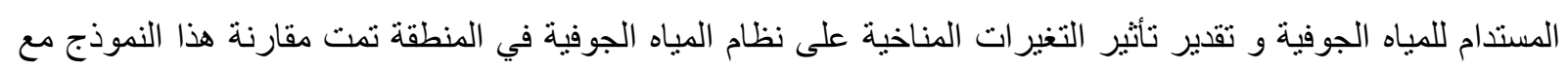

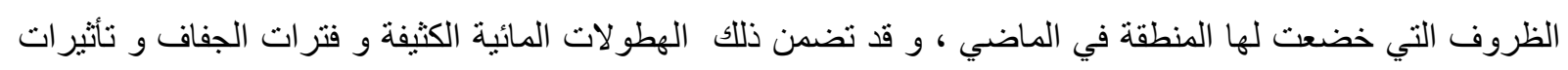

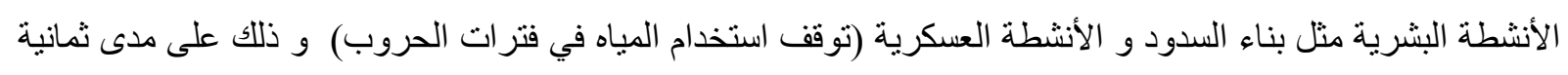
و ثلاثون عاما (منذ بداية النمو الزراعي في عام 1955 و حتى عام 2002) و على أساس ذاللك تم وضع بعض التص النصائح فيما يخص استير اتيجية الاستخدام المستدام للمياه الجوفية. 


\section{KURZFASSUNG}

Grundwassersysteme in semi-ariden Gebieten sind meist nicht ausreichend hydrogeologisch charakterisiert und langfristige Datenaufzeichnungen sind generell nicht erhältlich. Langfristige Datenaufzeichnung sind hingegen notwendig, um zukünftige Grundwasserentnahmestrategien festzulegen oder um den Einfluss von Klimaveränderungen auf das Grundwassersystem zu prognostizieren. Um das Problem unvollständiger Datensätze zu umgehen wurde ein integrierter Ansatz gewählt. Dieser Ansatz basiert zum Teil auf der Verwendung von weichen Informationen. Demonstriert wird dieser integrierte Ansatz am südlichsten Teil des unteren Jordantals/ Jordanien.

Das untere Jordantal ist Teil des Wadi Araba- Totes Meer Transform Störungssystem, welches sich vom Roten Meer bis zum See Genezareth und darüber hinaus fortsetzt. Die andauernde linksseitige Lateralverschiebung, die mittlerweile einen Versatz von ungefähr 107 km aufweist, findet zwischen der Arabischen Platte im Osten und dem nordöstlichen Teil der Afrikanischen Platte im Westen statt. Extensionsbewegungen sorgten für die Bildung und tiefe topographische Lage des unteren Jordantals. Das vorwiegend aride Klima führte zur Ablagerung mächtiger Salzhorizonte. Lakustrine und klastische Sedimente komplettieren das sedimentologische Bild. Das subtropische Klima, mit langen warmen Sommern und milden und humiden Wintern, sorgt für exzellente landwirtschaftliche Bedingungen. Daher ist das untere Jordantal auch unter dem Namen „Brotkorb Jordaniens“ bekannt und wird daher intensiv landwirtschaftlich genutzt. Da Landwirtschaft in den langen Sommermonaten nur mit künstlicher Bewässerung möglich ist, werden landwirtschaftliche Aktivitäten durch die Menge des vorhandenen Bewässerungswassers begrenzt. Dies führte zum Abteufen von mehreren hundert Brunnen und zur Abstraktion großer Mengen Grundwasser. Grundwasser liefert heute immer noch den größten Teil des Bewässerungswassers im Arbeitsgebiet. Dieses führt zu einer zunehmenden Beeinträchtigung des Grundwassersdargebots und dessen Qualiät seit den sechziger Jahren und Anzeichen von Überpumpung und ansteigender Bodenversalzung sind deutlich erkennbar.

Voraussetzung für eine nachhaltige Nutzung der Wasserressourcen und die Abschätzung der Auswirkung von Klimaveränderung auf die vorhandenen Wasserressourcen ist eine möglichst vollständige Einschätzung der vorhandenen Wasserressourcen einschließlich ihrer Qualität. Um das komplexe hydrogeologische System ausreichend beschreiben zu können, werden geologische, geophysikalische, hydrogeologische und hydrochemische Methoden miteinander kombiniert. Mit der Hilfe von geologischen, hydrochemischen und geophysikalischen Methoden wird die Aquifergeometrie bestimmt. Was die Wasserbilanz betrifft: der Grundwasserzustrom in den betrachteten Aquifer wird mit der Hilfe von geologischen Methoden und vorhandenen Datensätzen abgeschätzt, während Grundwasserentnahmeraten mit der Hilfe von Fernerkundungs- und Pflanzenwasserbedarfsansätzen abgeschätzt wird. Ein historischer Ansatz wurde gewählt, um den Rand- und Extrembedingungen, unter denen das Grundwassersystems in der Vergangenheit stand, nachzugehen. Anschließend wurden diese Informationen in einem instationären 3-dimensionalen finite Elemente Grundwasserströmungsmodell verarbeitet. Um verlässliche Aussagen über zukünftige nachhaltige Grundwasserentnahmestrategien und Einfluss von Klimaänderungen auf das Grundwassersystem zu treffen wurde das Modell gegen die Rand und Extrembedingungen aus dem historischen Ansatz simuliert. Diese Stressperioden schließen Zeiträume extremen Niederschlags, Trockenperioden und einschneidende anthropogene Einflüsse, z.B. Konstruktion von Staudämmen und militärische Konflikte, mit ein. 38 Jahre, von dem Beginn der landwirtschaftlichen Entwicklung bis 2001, wurden simuliert. Empfehlungen über zukünftige nachhaltige Grundwasser-entnahmestrategien werden gegeben. 


\section{ABSTRACT}

In semi-arid areas groundwater systems are frequently not sufficiently characterized hydrogeologically and long term data records are generally not available. Long-term time series are necessary, however to design future groundwater abstraction scenarios or to predict the influence of future climate change effects on groundwater resources. To overcome these problems an integrated approach for the provision of a reliable database based on sparse and fuzzy data is proposed. This integrated approach is demonstrated in the lowermost area of the Jordan Valley/ Jordan.

The lower Jordan Valley is part of the Jordan Dead Sea Wadi Araba Transform Faults system, which extends from the Red Sea to lake Tiberias and beyond with a major $107 \mathrm{~km}$ sinistral strike-slip fault between the Arabian plate to the east and the northeastern part of the African plate to the west. Due to extensional forces a topographic depression was formed. As a result of an arid environment it is filled with evaporites, lacustrine sediments, and clastic fluvial components. Due to the availability of irrigation water and a subtropical climate with hot, dry summers and mild humid winters provide excellent farming conditions. Therefore the Jordan Valley is considered as the food basket of Jordan and is used intensively for agriculture. Since groundwater is the major source for irrigation hundreds of shallow wells were drilled and large amounts of groundwater were abstracted. Consequently groundwater quality decreased rapidly since the sixties and signs of overpumping and an increase in soil salinity could clearly be seen.

In order to achieve a sustainable utilization of water resources and to quantify the impact of climate change on water resources a proper assessment of the groundwater resources as well as their quality is a prerequisite. In order to sufficiently describe the complex hydrogeologic flow system an integrated approach, combining geological, geophysical, hydrogeological, historical, and chemical methods was chosen. The aquifer geometry and composition is described with the help of geological, hydochemical, and geophysical methods. As far as the water budget is concerned, the recharge to the considered aquifer is estimated with geological methods and available data sets, while the abstraction from the aquifer is estimated with the help of remote sensing techniques. A historical approach is used to detect the general conditions under which the groundwater system has been in the past. Afterwards this information is implemented into a numerical 3-D transient model integrating all important features of the hydrogeological system. In order to be able to give reliable predictions about the impacts of climate change scenarios on the groundwater system the flow model was tested against stress periods depicted during the historical review of the test area. These stress periods include periods of intense rainfall, of drought, and of anthropogenic impacts, like building of storage dams and of violent conflicts. 38 years, starting from the agricultural development of the lower Jordan Valley until 2001 were simulated. Recommendations for future sustainable groundwater abstractions are given. 


\section{ACKNOWLEDGEMENTS}

This thesis would not exist but for the support and assistance of many individuals and organizations. I would like to start by thanking Prof. Dr. Sauter from the University of Götttingen, who supported and guided me in these couple of years. I would like also to thank Prof. Dr. Salameh of the University of Jordan for his efforts and support, thank you for your supervision and help through the last years. Thanks goes also to the whole Salameh family, who offered me a second home in Jordan. Many thanks go Prof. Dr. Ing. Ptak-Fix (Göttingen University) for many helpful tips and advise.

Thanks to Dr. P. Dietrich of the Umweltforschungszentrum in Leipzig (formerly University of Tübingen) for the many fruitful discussions I had with him as well as for making the geophysical field equipment available.

My thanks go also to both the Ministry of Water and Irrigation and the Jordan Valley Authority for the information and data they supplied me with. Many thanks go especially for Engineer Ali Zubah for his advise, comments, and continuous support.

Dr. M. Al-Farayat for interesting discussions and for his help at the customs in Aqaba. Without him most of the field truck of Tübingen University would still be at the customs.

I would like the German Ministry of Education and Research (BMBF) for funding "The German - Israeli - Jordanian - Palestinian Joint Research Program (GIJP)- Water Resources Evaluation for a Sustainable Development in the Jordan Rift Basin” project which gave me the opportunity to undertake this research project. Special thank goes to Dr. Metzger (Forschungszentrum Karlruhe) for his continuous support and understanding, when things did not always went by the book.

I would like to thank Mr. William Al-Khoury for his help in the field and his assistance during the visits at official places. My gratitude also goes to his whole family who made me feel home and for their friendship.

My thank goes to Abu Jawad, for his willingness to support me in the field. Because of him I always got what I wanted quicker than I expected.

Many thanks to all the colleagues from Germany, Israel, Jordan and Palestine of the multilateral project "Water Resources Evaluation for a Sustainable Development in the Jordan Rift Basin” for the motivating discussions and their support during the last years of scientific cooperation and friendship.

Member of the department of Applied Geology University of Göttingen; especially to Mr. Steffen Fischer for his assistance during the field work.

Finally, my deepest thanks go to my family and friends. You have been a constant help. I will promise to compensate for the last few months, where I was either physically or mentally absent.

I am deeply indebted to my wife Diala, who took all my weird moods and periods of absence without complaints. Despite my inexcusable strange behaviour she always managed to cheer me up and carried me along with her funny spirit. 


\section{CONTENTS}

الخلاصة

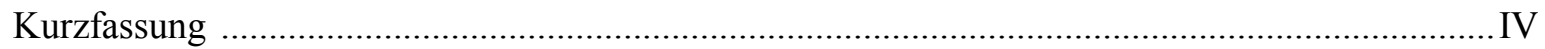

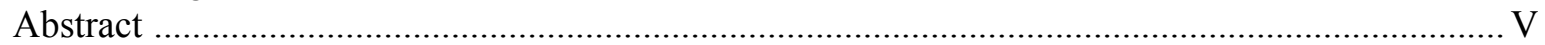

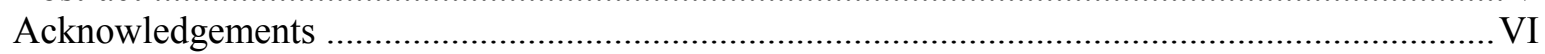

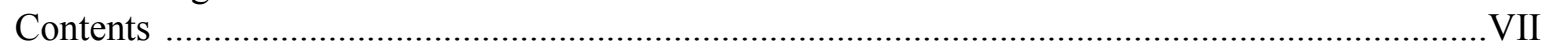

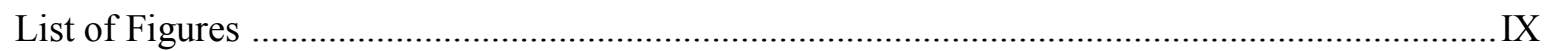

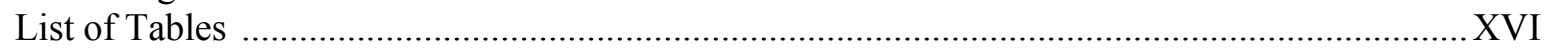

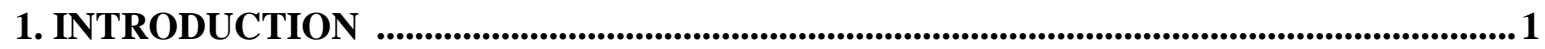

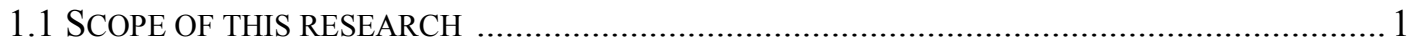

1.2 THE GERMAN - ISRAELI - JORDANIAN - PALESTINIAN JOINT RESEARCH PROGRAM (GIJP)- WATER RESOURCES EVALUATION FOR A SUSTAINABLE DEVELOPMENT IN

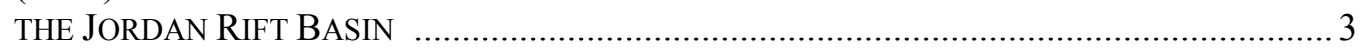

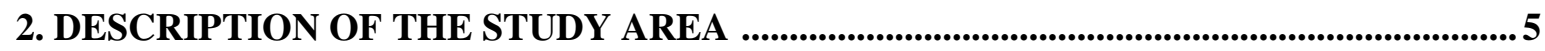

2.1 GEOGRAPHY, LAND- USE, VEGETATION, AND CLIMATE …….................................... 5

2.1.1 Geography, land-use, and vegetation ………....................................... 5

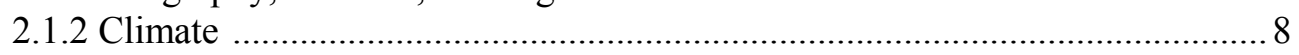

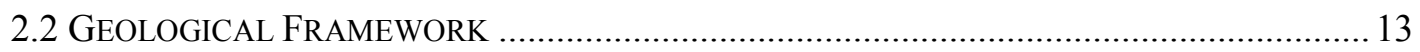

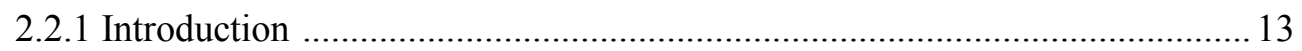

2.2.2 Supra- regional geodynamics ............................................................ 13

2.2.3 Regional Geology of the wider area of interest ............................................ 20

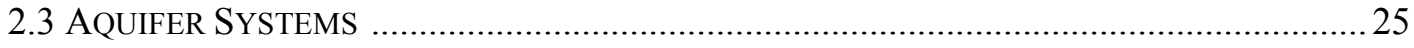

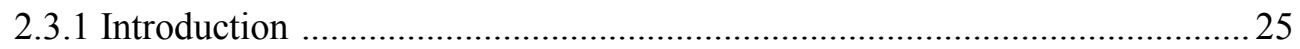

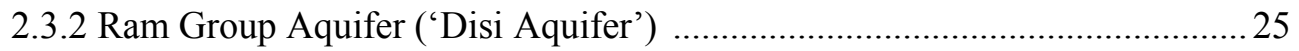

2.3.3 Lower Aquifer Complex ...........................................................................2 26

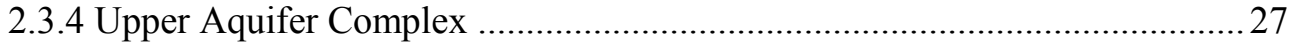

2.3.5 Jordan Valley Aquifer Complex ............................................................. 30

3. HISTORICAL REVIEW OF THE LAND- AND WATER USE IN LOWER JORDAN

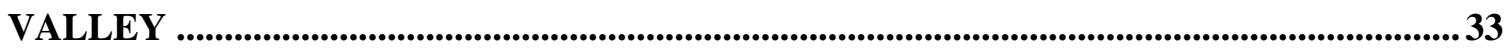

3.1 PRE-DEVELOPMENT HISTORY OF THE LOWER JORDAN VALLEY ..................................... 33

3.2 INTENSIVE DEVELOPMENT OF THE JORDAN VALLEY (1948 TO PRESENT) ........................... 34

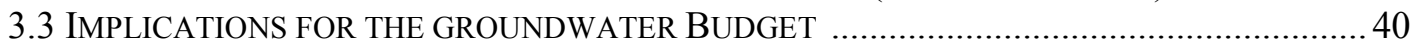

3.3.1 Prior to the development of the Jordan Valley ............................................... 40

3.3.2 Beginning of the early development phase in the Jordan Valley, the events of 1968 and their aftermath ............................................................. 41

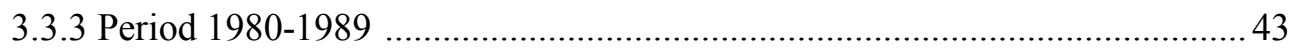

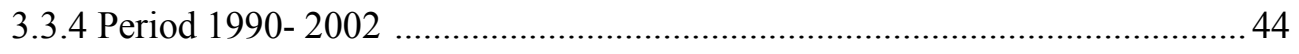

4. AQUIFER GEOMETRY AND PARAMETER CHARACTERISTICS .............................46

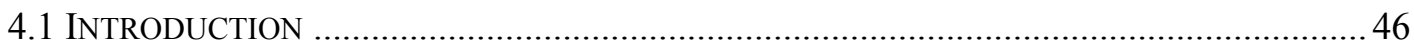

4.2 DEPOSITS AND DEPOSITIONAL ENVIRONMENT OF THE UNCONSOLIDATED STRATA ..... 46

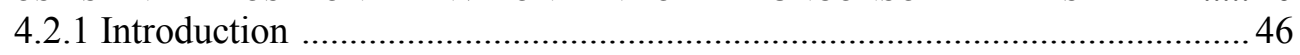

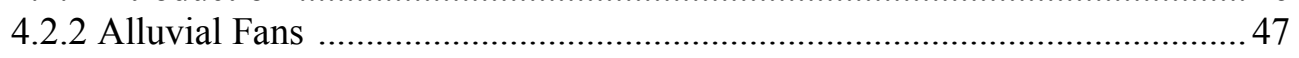

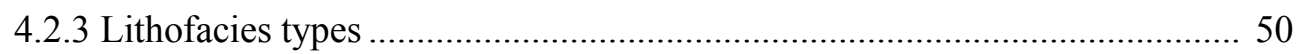

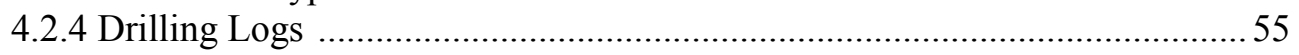

4.2.5 Estimating the amount of eroded material ………....................................... 57

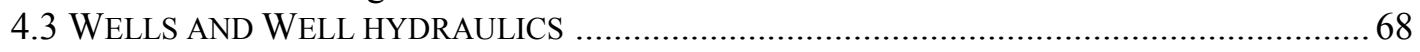

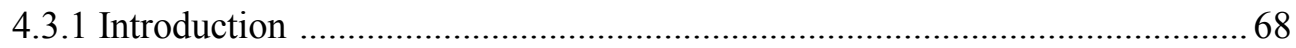

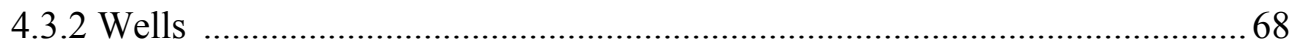

4.3.3 Short-term single well pumping tests ......................................................... 70 


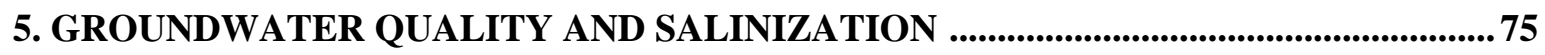

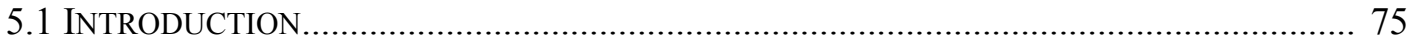

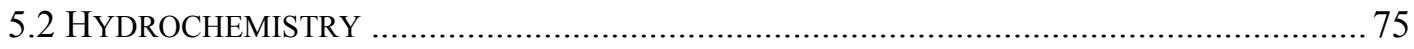

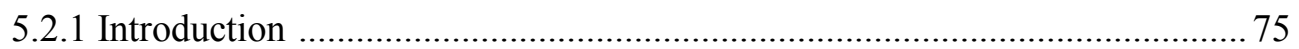

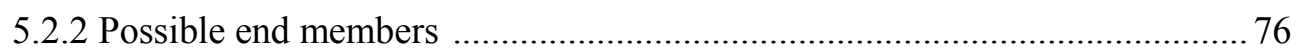

5.2.3 Chemical composition of groundwater from the unconsolidated aquifer

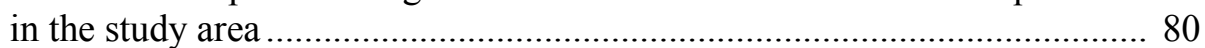

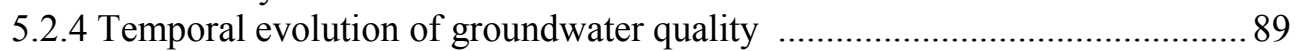

5.2.5 Salinization sources ................................................................................. 97

5.2.6 Dating with the ${ }^{3} \mathrm{He}$-Tritium method ...................................................... 107

5.3 SPATIAL DISTRIBUTION OF SALINE GROUNDWATER FROM RESISTIVITY

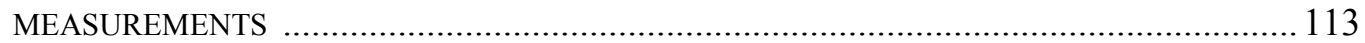

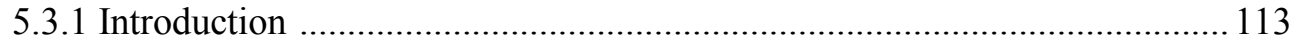

5.3.2 Electromagnetic Measurements (MaxMin) ………..................................... 113

5.3.3 Vertical Electric Soundings (Schlumberger depth soundings) ................... 121

5.3.4 Geoprobe direct-push geoelectric measurements ....................................... 125

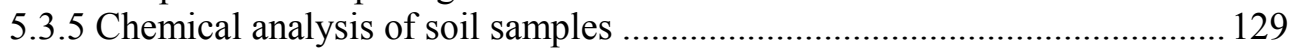

5.3.6 Collected data of vertical electric soundings ........................................... 135

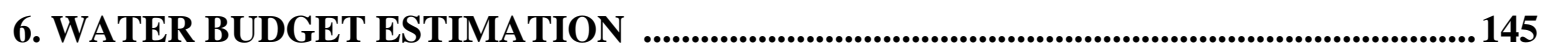

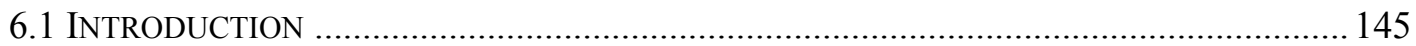

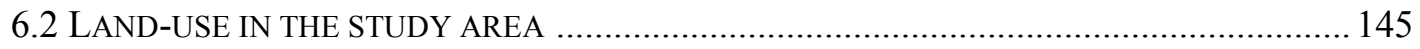

6.3 IRRIGATION TECHNIQUES USED IN THE LOWER JORDAN VALLEY ............................... 146

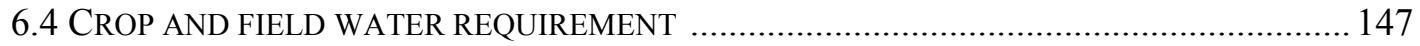

6.5 CHANGE IN LAND-USE DETERMINED BY THE USE OF AN AERIAL PHOTOGRAPH AND

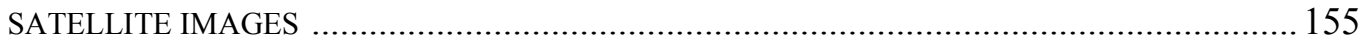

6.5.1 Analogue aerial photographs .............................................................. 155

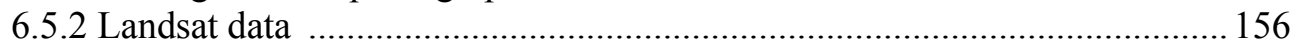

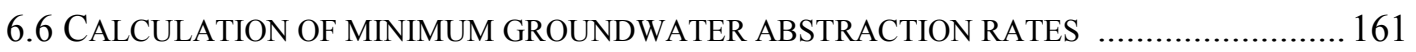

6.7 A SAMPLE WATER BUDGET CALCULATION FOR THE STUDY AREA …............................ 164

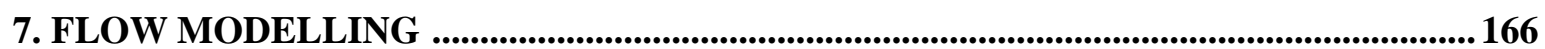

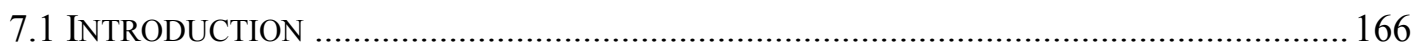

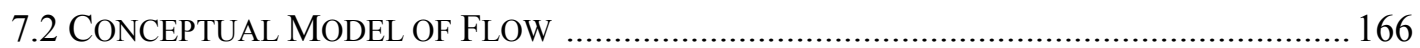

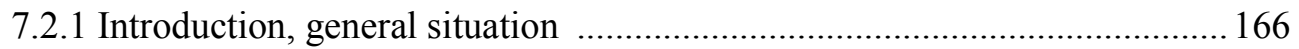

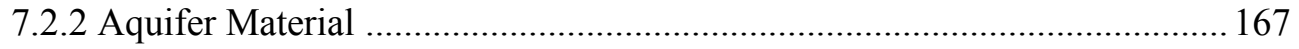

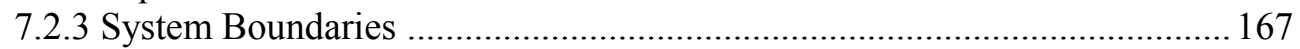

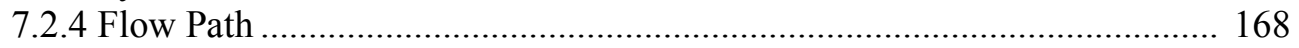

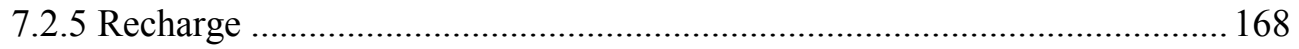

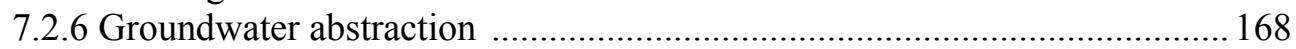

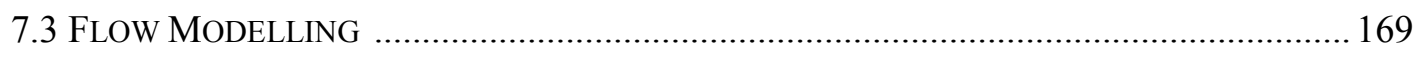

7.3.1 Model set-up and parameter estimation ..................................................... 169

7.3.2 Steady state calibration and results ...................................................... 173

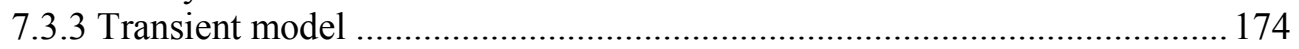

8. SUMMARY AND IMPLICATIONS FOR GROUNDWATER MANAGEMENT/

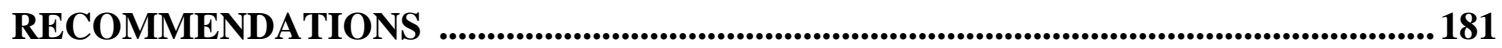

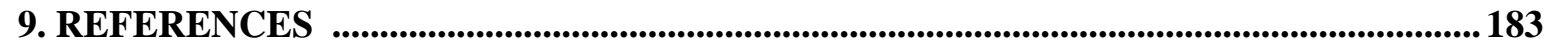

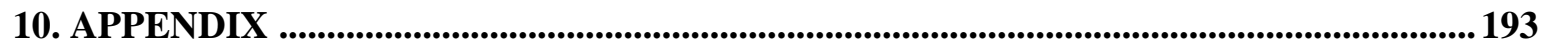




\section{LIST OF FIGURES}

Fig. 1.1-1: Flow chart of the integrated approach applied in this study.

Fig. 2.1-1: Location of the study area. A: Middles East; B: Study area in the regional context; C: Study area. 5

Fig. 2.1-2: Major catchment areas and drainage patterns within the wider area of interest. 6

Fig. 2.1-3: Sketch: Geographic zones in the Jordan Valley. Lower left: the flood plains of River Jordan (Zor) with the flanks of the Qatar in the background. Lower middle: eastern Ghor area. Intensively used for agriculture; here banana plantation. Lower right: western side of the Ghor area with the djebel area in the background.

Fig. 2.1-4: Annual rainfall for the hydrologic years 1975/76 to 2001/02 together with the longterm average at three selected sites: Highlands (Jordan University), eastern part of the Western Slopes (Naur), and the Jordan Valley (South Shuneh) (MWI open files). 9

Fig. 2.1-5: Annual rainfall 1942/43 - 2002/03 for the meteorological station in Naur with short (5 years) to long term (60 years) averages (MWI open files).

Fig. 2.1-6: Mean monthly rainfall, low temperatures and high temperatures in the Highlands (Jordan University), calculated for the period 1975 - 2002 (MWI open files).

Fig. 2.1-7: Mean monthly rainfall, potential evaporation, low temperatures, and high temperatures in Jordan Valley (Deir Alla), calculated for the period 1975 - 2002 (MWI open files).

Fig. 2.1-8: Mean monthly rainfall, potential evaporation, low temperatures, and high temperatures in Jordan Valley (Jericho), calculated for the period 1968 - 1999 (data kindly provided by the Israeli Hydrologic Survey).

Fig. 2.1-9: Daily rainfall for the hydrologic year 1996/97 and 1997/98 in the Highlands (Jordan University). (MWI open files).

Fig. 2.1-10: Daily rainfall for the hydrologic year 1996/97 and 1997/98 in the Jordan Valley (South Shuneh). (MWI open files).

Fig. 2.2-1: Supra- regional tectonic map (Johnson 1998).

Fig. 2.2-2: Lithofacies belts during Cretaceous times: a) Early Cretaceous facies belts: (1) mostly continental sandstone, (2) sandstones-shale-limestone facies, (3) thick marine shaley sequence and volcanism; b) Mid-Cretaceous (Aptian-Turonian) lithofacies: (1) thin carbonate sequence, interbedded with sandstone, (2) mostly carbonates (limestones and dolomites), (3) mostly calcilutite facies; c) Senonian lithofacies belts: (1) sand, flint, and chalk, (2) chalk ,marl, and flint (3) mostly chalk, sparse flint (Flexer 2001).

Fig. 2.2-3: Regional setting of the Dead Sea Transform (Garfunkel and Ben-Avraham 1996). ..17

Fig. 2.2-4: Development sketch of the Dead Sea Transform (Bayer 1988).

Fig. 2.2-5: Lake- level curve of Lake Lisan (55,000 - 15,000 cal yr B.P.) and present level of the Dead Sea (slightly modified from Bartov et al. 2002).

Fig. 2.2-6: Stratigraphic table of Rock Units in the wider area of interest (modified after Shawabkeh 2001).

Fig. 2.2-7: Main structural features in the wider area of interest. 23

Fig. 2.2-8: Geological Map of the wider area of interest (after McDonald and Partners 1963; Shawabkeh 2001; Diabat and Abdelghafoor 2004).

Fig. 2.2-9: Geological cross section in the northern part of the wider area of interest (slightly modified after Shawabkeh 2001). Location of the cross section is indicated in fig. 2.2-8. 
Fig. 2.3-1: Aquifer Systems in the study area (map is based on the maps prepared by McDonald and Partners 1963; Shawabkeh 2001; Diabat and Abdelghafoor 2004).

Fig. 3-1: Contemporary earth ditch channel carrying water derived from the KAC. ................. 34

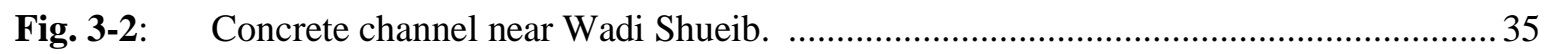

Fig. 3-3: $\quad$ KAC in middle Jordan Valley (left) and in its third extension in lower Jordan Valley (right).

Fig. 3-4: Water sources for irrigation in the study area (slightly modified after GTZ 2002). ... 38

Fig. 3-5: Leaky private off-farm irrigation network near Kafrein. ............................................. 39

Fig. 3-6: Truck loading station near South Shuneh; selling of well water to farmers. ............... 39

Fig. 3-7: Privately owned desalinisation plant in South Shuneh. Brackish well water is desalinated. Desalinated water is mainly used for irrigating banana farms.

Fig. 3-8: Location of the wells drilled in 1938. The bold black numbers refer to the numbers given by the Ionides report. The gray ID code refers to the well ID code of the MWI.

Fig. 3-9: Relative water table fluctuation in the observation wells and monthly precipitation recorded at the rainfall station in Madaba for the period 1938-41 (well data taken from Tleel 1963, precipitation data taken from MWI open files).

Fig. 3-10: Water level changes in study area between 1938 and 1966 (Tleel 1963 and MWI open files). Between 1941 and 63 no measurement records were available.

Fig. 3-11: Location of the wells monitored from 1962 to 1972 and 1980-2002 (MWI open files).

Fig. 3-12: Relative water table fluctuation in the observation wells and monthly and annual precipitation values recorded in Naur for the period 1962 till 1971 (MWI open files) 43

Fig. 3-13: Relative water table fluctuation in the observation wells and monthly and annual precipitation values recorded in Naur for the period 1980 - 89 (MWI open files)...... 44

Fig. 3-14: Relative water table fluctuation in the observation wells and monthly and annual precipitation values recorded in Naur for the period 1990 - 2002 (MWI open files).. 45

Fig. 4.2-1: Drainage net of the major catchment areas based on $1: 50,000$ scale topograhic maps provided by the Royal Geographic Center of Jordan (center map). Surface bedrock of the different catchments based on the $1: 50,000$ scale geological maps provided by the National Resources Authority of Jordan. Note, that the scale of the bedrock catchments differ from the drainage net map. Lower Right: Table of the surface bedrock area of each catchment for each geological Formation.

Fig. 4.2-2: Left: Map of the studied locations along the drainage nets together with fan apex locations of the major wadis. Right: (A) Photograph of the present mid-fan incised channel of Wadi Kafrein, a backpack (R) $65 \mathrm{~cm}$ long is provided for scale. In the background the $6 \mathrm{~m}$ high wall cut of the incised channel. (B) Photograph of a small gully at station 15, a hammer (H) $33 \mathrm{~cm}$ long is provided for scale. The bed consists of well rounded pebble gravel, while the wall cuts consists mostly of fine to middle sand.

Fig. 4.2-3: Determination of grain size distribution of the components bigger than $1.6 \mathrm{~cm}$. Left: Outcrop photo; taken at distal fan location No. 16. A hammer $(33 \mathrm{~cm})$ is provided for scale (centre of the photo). Right: Five different digitized component classes: green: $>25.6 \mathrm{~cm}$; blue: 12.8 - $25.6 \mathrm{~cm}$; beige: $6.4-12.8 \mathrm{~cm}$; purple: $3.2-6.4 \mathrm{~cm}$; red: $1.6-3.2 \mathrm{~cm}$.

Fig. 4.2-4: Photographs of Facies A; a hammer $(\mathrm{H}) 33 \mathrm{~cm}$ long is provided as scale. (A) View at station 2, proximal cobble pebble bed. (B) View at station 8 (mid- fan location) 
couplets of pebble gravel beds and gravels sand beds. (C) View at station 10, alternation of Facies A and C. Boundaries between the facies are sharp. No gravel couplet were found within Facies D. (D) View at station 13 (distal fan area), couplets of pebble granule gravel beds alternating with fine gravel sandy beds.

Fig. 4.2-5: Photographs of Facies B gully deposits (encircled areas); a hammer (H) $33 \mathrm{~cm}$ long is provided for scale (upper photographs). (A) View at station 14, pebbly cobble gravel lens $120 \mathrm{~cm}$ thick with basal trough surfaces on a sandy environment, open framework pebble gravel bed (o) within the gully deposits. (B) View from station 13, two lenses of well rounded gravel beds 7 to $20 \mathrm{~cm}$ thick deposited within a sandy matrix. (C) View from station 7, lenticular bed of bed of pebbly gravel of Facies B.

Fig. 4.2-6: Photographs of Facies C lacustrine Deposits; Field book (F) $15 \mathrm{~cm}$ long and a hammer (H) $33 \mathrm{~cm}$ long provided for scale. (A) view at an outcrop close to the Baptism site of Jesus in Jordan, interlayered thin laminae of white aragonite and laminae of dark detrius. (B) view at station 3 (upper fan area) Lisan marls overlying Facies A.

Fig. 4.2-7: Photographs of channels developed by secondary processes that are filled with alluvial material; a measuring rod (M) where each segment is $20 \mathrm{~cm}$ long, a hammer (H) $33 \mathrm{~cm}$ long, and a finger (F) are provided as scale. All photographs were taken in the vicinity of station 12 . The area is used as a quarry for sand and gravel. Therefore, contacts at these filled channels could be studied in detail. (A) Alluvial sheetflood deposits (A) deposited in a washed out channel in the Lisan Formation (L). Couplets of pebble gravel beds alternate with coarse sandy, granule pebble beds. (B) Lacustrine Lisan Formation (L) in the background. Cobbly, pebble gravel (G) separated by a sharp boundary from the overlying medium to coarse sand beds (S) The gravel bed is graded. A Couplet of granule gravel (B) is intercalated into the sand bed. Precipitated salt crusts (C) can be found on top of the gravel and sand beds. The source of these salt crusts could be the dissolution of salts within the Lisan Formation by drainage water. (C) Sand beds (S) deposited next to the white and grey laminated Lisan Formation (L). The boundary is very sharp. Sand beds deposited parallel to the deposition of the different laminae of the Lisan Formation indicating that its deposition took place in a channel developed after the deposition of the lacustrine sediments.

Fig. 4.2-8: Structure contour map of the base of the Kurnub Group. ........................................... 58

Fig. 4.2-9: Principle of determination of the eroded rock volume between two surfaces (Abel 2003).

Fig. 4.2-10: Eroded thickness for the top of the Amman Formation.

Fig. 4.2-11: 3-dimensional view of the reconstructed wider area of interest.

Fig. 4.2-12: Left: Results of the structural 3-D Model of some major wadis in the wider area of interest (based on the structure contour map of Fig. 4.2-8). The empty areas are the outcrop areas of the Triassic Zerqa Main Group. Right: Geological Map of the modelled area (NRA open files).

Fig. 4.2-13: Base of Jordan Valley Group. This map was prepared with the help of drilling logs of water wells (MWI open files), the two oil wells Jordan Valley 1 \& 2 (NRA open files), the $1: 50,000$ geological maps of Karameh (Shawabkeh 2001) and the interpretation of seismic lines (Al-Zoubi et al. 2006).

Fig. 4.3-1: Wells that were subject of the well survey.

Fig. 4.3-2: Left: torch-cut inflow to the well pump. Right: Irrigation water storage pool. 69 
Fig. 4.3-3: Left: Access to the well hole; well pump is held by iron cross bars. Right: Pollution source, deriving from the diesel generators located direct in the vicinity of the open well hole (lower left corner).

Fig. 4.3-4: Concrete well house. Outside: a former truck engine that is used as a diesel driven generator powering the well pump.

Fig. 4.3-5: Discharge measurements by using A) the direct method and B) the projectile in motion assumption for a free jet of water.

Fig. 4.3-6: Time drawdown and residual drawdown during pumping and recovery period........... 73

Fig. 4.3-7: Recovery test data of Well 040 plotted after the Cooper- Jacob Straight Line Method.73

Fig. 4.3-8: Well tests in the study area. The light gray numbers represent the specific capacity values $\left[\mathrm{m}^{3} / \mathrm{hr} / \mathrm{m}\right.$ ] (data taken from Hizrallah 1973, Ionides 1939), the dark gray numbers transmissivity values $\left[\mathrm{m}^{2} / \mathrm{d}\right.$ ] as a results of pumping tests (Hizrallah 1973 , MWI open files), and the black numbers transmissivity values $\left[\mathrm{m}^{2} / \mathrm{d}\right]$ as a results of pumping test performed in the course of this study in not previous investigated areas. 74

Fig. 5.2-1: Relationship between groundwater contour lines (middle gray color) and isoelectrical conductivity lines (in $\mu \mathrm{S} / \mathrm{cm}$; black color) of well water samples taken 1961 . The gray dots represent gw level measurements locations at the different wells (based on the data given by Tleel 1963). The results of the analysis together with its location are the base of the interpolated lines. Groundwater contour lines are not labeled for better visibility of the iso- EC contour lines. Groundwater flow is from east to west; groundwater contour intervals are $5 \mathrm{~m}$.

Fig. 5.2-2: Relationship between groundwater contour lines (middle gray colors) and IsoChloride concentration lines (meq/L; black color) of well water samples taken 1961. The black dots represent gw sampling locations. The results of the analysis together with its location are the base of the interpolated lines. Groundwater contour lines are not labeled for better visibility of the iso- EC contour lines. Groundwater flow is from east to west; groundwater contour intervals are $5 \mathrm{~m}$.

Fig. 5.2-3: Relationship between groundwater contour lines (middle gray color) and isosulphate concentration lines (meq/L; black color) of well water samples taken 1961 (data was taken from Tleel 1963). The black dots represent gw sampling locations. The results of the analysis together with its location are the base of the interpolated lines. Groundwater contour lines are not labeled for better visibility of the iso- EC contour lines. Groundwater flow is from east to west; groundwater contour intervals are $5 \mathrm{~m}$.

Fig. 5.2-4: Flow path from the village of South Shuneh in the east towards the southwest. The red values of the different wells represent the electrical conductivity of the well water, the black number the Well ID number used in the report of Tleel 1963 (data taken from Tleel 1963).

Fig. 5.2-5: PIPER diagram for the flow path of Fig. 5.2-4. A1/2 waters: middle gray; A4 waters: light gray; Kurnub waters: dark gray areas; Lisan Waters: hatched areas; Ram Group: small black area (data taken from Tleel 1963, colored areas are based on data from the MWI open files).

Fig. 5.2-6: Flow path from the village of Rama in the east towards the southwest. The red values of the different wells represent the electrical conductivity of the well waters, the black number the Well ID number used in the report of Tleel 1963 (data taken from Tleel 1963).

Fig. 5.2-7: PIPER diagram for the flow path of the Wadi Kafrein/ Wadi Hisban alluvial fan flow path. A1/2 waters: middle gray area; A4 waters: light gray area; Kurnub waters: dark gray area; Lisan waters: hatched areas; Ram Group: small black areas 
(data taken from Tleel 1963 and the colored areas are based on data from the MWI open files).

Fig. 5.2-8: Wells located between the major Flow Paths of South Shuneh and Rama. The red values of the different wells represent the electrical conductivity of the well waters, the black number the Well ID number used in the report of Tleel 1963 (data taken from Tleel 1963).

Fig. 5.2-9: PIPER diagram for the wells located between the flow paths of South Shuneh and Rama (Tleel 1963).

Fig. 5.2-10: Variation in electrical conductivity during pumping, after pumping, and after restarting the pumping activity of a well near Rama along with the recorded water level. Electrical conductivity depends strongly on the sampling time.

Fig. 5.2-11: Well selected for the temporal evolution of groundwater quality in the study area (locations taken from MWI open files).

Fig. 5.2-12: Location and electrical conductivity values of some wells drilled in 1938. Electrical conductivity was calculated on the basis of TDS values (data is taken from Ionides 1939).

Fig. 5.2-13: Electric Conductivity measurements (in a range from 500 to $2400 \mu \mathrm{s} / \mathrm{cm}$ ) of water samples taken in the early to late 70ies of some selected wells in the study area versus monthly and yearly rainfall values at Naur station (MWI open files).

Fig. 5.2-14: Electric Conductivity measurements (in a range from 500 to $5,000 \mu \mathrm{s} / \mathrm{cm}$ ) of well water samples taken in the early to late 70ies of some selected wells in the study area versus monthly and yearly rainfall values at Naur station (MWI open files). ..... 94

Fig. 5.2-15: Increasing salinities of wells in the study area. In all five figures (A through E) the iso-electrical conductivity contour lines from 1961 (Fig. 5.2-1) are placed for orientation. Yellow squares mark groundwater of wells with increased electrical conductivity at different time steps. A: Autumn 1971 (MWI open files); B: Autumn 1972 (MWI open files); C: Spring 1977 (MWI open files); D: Autumn 1995 (Kuisi 1998); E: Spring 1996 (Kuisi 1998).

Fig. 5.2-16: Electric Conductivity measurements (in a range from 500 to $3,000 \mu \mathrm{s} / \mathrm{cm}$ ) of well water samples taken in the early 90ies to the end of 2002 of some selected wells in the study area versus monthly and yearly rainfall values at Naur station (MWI open files).

Fig. 5.2-17: Theoretical remaining Tritium concentration for rainwater samples taken and conserved between 1963 - 1995. The plot shows the theoretical results of an analysis of all samples on the 01.01.2002 (Sültenfuß and Massmann 2004).

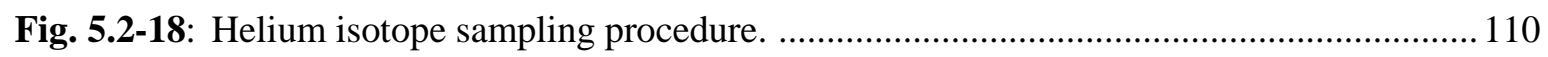

Fig. 5.2-19: Location of isotope sampling sites. ....................................................................... 110

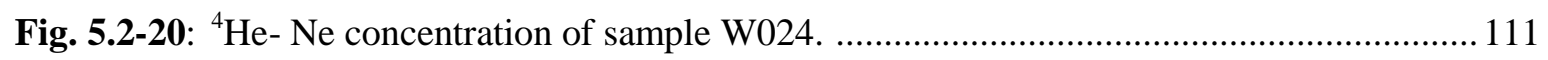

Fig. 5.2-21: ${ }^{4} \mathrm{He}$ - sample from well W024 split into its different components. ............................ 112

Fig. 5.3-1: Sketch of a EM survey (after Grand and West 1965). ............................................. 114

Fig. 5.3-2: Sketch of the MaxMin apparatus (Knoedel et al. 1997). ........................................... 114

Fig. 5.3-3: In- and outphase plotted along a survey transect near the town of Kafrein in eastwest direction.

Fig. 5.3-4: Left: Phasor plot of inphase and quadrature (after Reynolds, 1997); right: MaxMin sounding curve of the inphase and quadrature for the different recorded frequencies. 
Fig. 5.3-5: Location of the conducted geophysical surface profiles. The MaxMin profiles are shown as solid red lines. The Schlumberger depth sounding locations are shown as points of different color, depending on the principal investigators (brown = BGR 1963/64; blue = BGR 1984/85; red = JICA 1995; dark green = Dr. Abou Karaki 1998; light green = Prof. Salameh; yellow = Dr. Al-Zoubi 1999; and black = Toll in 2003).

Fig. 5.3-6: Interpolated (universal kriging) plot of the apparent conductivity for one (888 Hz) frequency calculated by the MaxMin apparatus. Violet points represent the conducted profiles.

Fig. 5.3-7: Interpolated (universal kriging) plot of the apparent conductivity for one (3,555 $\mathrm{Hz}$ ) frequency calculated by the MaxMin apparatus. Violet points represent the conducted profiles.

Fig. 5.3-8: Interpolated (universal kriging) plot of the apparent conductivity of the best fit calculated by the MaxMin apparatus. Violet points represent the conducted profiles.MaxMin best fit conductivity.

Fig. 5.3-9: The basic Principle of a geoelectric resistivity measurement using a general fourelectrode configuration, that consists of a pair of current electrodes (A and B) and a pair of potential electrodes ( $\mathrm{M}$ and N) (Flathe and Leibold 1976).

Fig. 5.3-10: Geometry of current and potential electrodes of the Schlumberger configuration (Lowrie 1997).

Fig. 5.3-11: Left: Smooth sounding graph of VES No. 2 undertaken within the course of this study (the location can be found in Fig. 5.3-5 (numbering of the VES goes from south to north). Right: Possible interpretations of a four layered model together with equivalence models (up to a mean error of $4 \%$ ).

Fig. 5.3-12: Problem of ambiguity illustrated for one measured Schlumberger sounding curve. A: interpreted as a four layer case (including equivalent interpretations); B: interpreted as a five layer case (including equivalent interpretations); C: interpreted as a six layer case (including equivalent interpretations); D: interpreted as a seven layers case (including equivalent interpretations); E: sounding curve that formed the basis for the interpretations. All equivalence models for each layered model are in a range of up to $4 \%$ error tolerance.

Fig. 5.3-13: Direct-push geoelectric depth profile versus a surface Schlumberger depth sounding. The soundings are made in the same location, about six km north of the Dead Sea.. 127

Fig. 5.3-14: Geoprobe geoelectric depth sounding points.

Fig. 5.3-15: Results of the Geoprobe geoelectric soundings. In places where the groundwater table was encountered the encountered depth below ground level is plotted as a straight line.

Fig. 5.3-16: Determingion multipliers for salt solutions of different concentrations (after Desai and Moore 1969).

Fig. 5.3-17: Calculated electrical resistivity of the soil analysis (black dots) and the geophysical calculated electrical resistivity of the direct-push measurement (gray line) for the samples E17 and E05.

Fig. 5.3-18: VES soundings conducted in the course of this study. Location of sounding points can be found in Fig. 5.3-5, whereby the numbering of the sounding locations is from south to north (shot point 1 to shot point 10).

Fig. 5.3-19: 3-D view of all available VES soundings, classified into six different classes; dark red $=0.1-1 \Omega \mathrm{m}$, red $=1-10 \Omega \mathrm{m}$, pink $=10-25 \Omega \mathrm{m}$, beige $=25-50 \Omega \mathrm{m}$, green $=50-100 \Omega \mathrm{m}$, blue $=>100 \Omega \mathrm{m}$. The north-south flowing Jordan River 
(blue line), where north is on the left hand side and south on the right hand side, is shown for orientation.

Fig. 5.3-20: 3-D cross sections of all available VES soundings, classified into six different classes; dark red $=0.1-1 \Omega \mathrm{m}$, red $=1-10 \Omega \mathrm{m}$, pink $=10-25 \Omega \mathrm{m}$, beige $=25-$ $50 \Omega \mathrm{m}$, green $=50-100 \Omega \mathrm{m}$, blue $=>100 \Omega \mathrm{m}$. The north-south flowing Jordan River (blue line), where north is on mid-bottom side and south on the middle-right side, is shown for orientation.

Fig. 5.3-21: 3-D cross sections of all available VES soundings, classified into six different classes; dark red $=0.1-1 \Omega \mathrm{m}$, red $=1-10 \Omega \mathrm{m}$, pink $=10-25 \Omega \mathrm{m}$, beige $=25-50 \Omega \mathrm{m}$, green $=50-100 \Omega \mathrm{m}$, blue $=>100 \Omega \mathrm{m}$. The north-south flowing Jordan River (blue line), where north is on the left hand side and south on the right hand side, is shown for orientation.

Fig. 5.3-22: VES sounding curves of soundings taken at the same location at different time steps. The location is given above each sounding curve pair (data taken from Flathe et al. 1965, Worzyk 1985, and JICA 1995).

Fig. 6-1: Left: Drip irrigation in combination with plastic mulch. Right: Irrigation water pool.146

Fig. 6-2: $\quad$ Furrow irrigation with water from the King Abdallah Canal water. 146

Fig. 6-3: Left: Aerial photograph, 22nd of April 1961. Right: Digitised area of land-use together with well location (well locations after Tleel 1963).

Fig. 6-4: Left: Irrigated farmland. Right: Grassland near the shore of the Dead Sea.

Fig. 6-5: Left: Irrigation water sources 2002 (GTZ 2003). Right: Overlay of irrigation water sources with the results of the supervised classification of the ETM+ image of March 2002.

Fig. 6-6: Left: MSS satellite scene (channel combination 321). Right: Supervised classification results of the irrigated fields, 1st of January 1973.

Fig. 6-7: Left: TM satellite image (channel combination 541). Right: Supervised classification results of the irrigated fields, 14th of August 1987.

Fig. 6-8: Left: ETM+ satellite image (channel combination 541). Right: Supervised classification results of the irrigated fields, 7th of August 1999.

Fig. 6-9: $\quad$ Left: ETM+ satellite image (channel combination 541). Right: Supervised classification results of the irrigated fields, 25th of May 2000.

Fig. 6-10: Left: ETM+ satellite image (channel combination 541). Right: Supervised classification results of the irrigated lands, 8th of March 2002.

Fig. 6-11: Possible errors leading to underestimation of cultivated areas. Left: early growing stages of plants, which are already irrigated. Right: Vegetables grown under a fleece.

Fig. 6-12: Yearly rainfall values of Naur climatic station versus available surface flow values (Rainfall data taken from Ministry of Water and Irrigation open files, surface flow data taken from GTZ 1977).

Fig. 7-1: Incorporation of the information of previous chapter into a geodatabase. With the help of the information gathered in the geodatabase a flow model is set up. The results of the flow modeling are stored afterwards in the same geodatabase.

Fig. 7-2: Conceptual model of flow of the unconsolidated aquifer in the study area.

Fig. 7-3: Assumed influence are of alluvial fans sediments; depicted from the interpretation of VES and EC contour plots.

Fig. 7-4: Left: Consolidated strata underlying the unconsolidated valley fills. Right: Finite Element mesh of the study area. 
Fig. 7-5: Left: Transmissivity values for the different areas of the model domain [10E-04 $\left.\mathrm{m}^{2} / \mathrm{sec}\right]$. Right: Fluxlines assigned to the model domain. 1 through 10 represent inflow along the different wadis section and Rama and Shuneh represents the inflow of groundwater into the model domain.

Fig. 7-6: Left: Well locations and groundwater extraction zones. Right: 17 different groundwater extraction zones depicted from the well location map.

Fig. 7-7: Groundwater contour map of the steady state model versus available groundwater heads.

Fig. 7-8: Hydraulic conductivity values assigned to the different zones of the model

domain $[10 \mathrm{E}-04 \mathrm{~m} / \mathrm{s}]$.

Fig. 7-9: Water budget for the period of $1962 / 63$ to 1969/1970 of the transient model run;

Total Inflow = Inflow of water along the different wadi sections (infiltration of surface water) together with flux through the eastern flux boundaries, Border = Inflow of groundwater through the flux boundaries (groundwater inflow), Out Border = Outflow of groundwater through the western flux boundaries (effluent groundwater to the Jordan River); Total Outflow = Out Border together with groundwater pumped from the different extraction zones.

Fig. 7-10: Calculated versus measured groundwater heads for the period of 1963 to $1970 \ldots . . . .176$

Fig. 7-11: Water budget for the period of 1980/81 to 2000/01 of the transient model run; Total Inflow = Inflow of water along the different wadi sections (infiltration of surface water) together with flux through the eastern flux boundaries, Border = Inflow of groundwater through the flux boundaries (groundwater inflow), Out Border $=$ Outflow of groundwater through the western flux boundaries (effluent groundwater to the Jordan River); Total Outflow = Out Border together with groundwater pumped from the different extraction zones.

Fig. 7-12: Calculated versus measured groundwater heads for the period of 1980 until 2001... 180

\section{LIST OF TABLES}

Tab. 2.3-1: Hydrogeologic units and its characteristics.

Tab. 3-1: Wells drilled between 1938 - 1963 (after Tleel 1963).

Tab. 4.2-1: Lithofacies-code for description of gravel deposits in outcrops (modified and extended after Keller, 1996; Kleineidam, 1998).

Tab. 4.2-2: Alluvial/ Lacustrine distribution along with remarks of the wells drilled in 1939 (Ionides 1939). PGE = Palestine Grid Easting; PGN = Palestine Grid Northing; All $=$ fraction of Alluvial material; Lac $=$ fraction of Lacustrine material.

Tab. 4.2-3: Stratigraphic Table of the Jordanian and Israeli terminology for the considered areas (Jordanian Nomenclature after Masri 1963; Israeli Nomenclature after Fleischer 2002)

Tab. 4.2-4: Calculated eroded rock volume. Left: Values calculated for the Top of the Belqa Group (including "missing Formations”. Right: Calculated eroded rock volume for the Top of the Amman Formation.

Tab. 4.2-5: Calculated carbonate denudation rate for two different time steps and two different $\mathrm{pCO}_{2}$ pressures; atm $=$ atmospheric pressure $(3.16 * 10-3)$ and $\max =3.16 * 10-2$, which is the highest $\mathrm{pCO}_{2}$ one can expect in soils. 
Tab. 4.2-6: Calculated carbonate denudation rate for different effective rainfall scenarios for a CO2 partial pressure of 0.01 [atm]. Since nothing is known about the lift of the East Bank shoulders, values for the Begin and the End of the Pliocene are calculated. ..... 65

Tab. 5.2-1: Groundwater classification using Total dissolved solids (after Davis and Dewiest 1967).

Tab. 5.2-2: Water samples from the recharge area in the Mountain Highland (data taken from Werz 2006).

Tab. 5.2-3: Water samples taken from wells located close to study area (MWI open files) and from leaching of soil samples from the Lisan Formation.

Tab. 5.2-4: Surface water samples taken at the outlets of major wadis (Wadi Shueib and Wadi Kafrein) (data taken from Kuisi 1998).

Tab. 5.2-5: Water samples from the King Abdullah Canal (data taken from Kuisi 1998).

Tab. 5.2-6: Ionic ratios of the water samples from the recharge area.

Tab. 5.2-7: Ionic ratios of surface water samples taken at the outlets of major wadis (Wadi Shueib and Wadi Kafrein).

Tab. 5.2-8: Ionic ratios of water samples taken from wells located close to study area and of leached soil samples from of the Lisan Formation.

Tab. 5.2-9: Ionic ratios of water samples taken from the King Abdullah Canal.

Tab. 5.2-10: Groundwater samples before and after the events of 1967/68. No samples before 1971 were available (MWI open files).

Tab. 5.2-11: The range of composition for the depicted wells in the study area. The lowest and highest content of each species for the available samples were chosen from MWI open files. (For well locations see Fig. 5.2-11.)

Tab. 5.2-12: The range of ionic ratios of the selected wells. The lowest and highest content for each species of all available samples were chosen from MWI open files and its resulting ratios calculated; $\mathrm{rQ}=\mathrm{rCa} /\left(\mathrm{SO}_{4}+\mathrm{HCO}_{3}\right)$. (For well locations see Fig. 5.2-11.)

Tab. 5.2-13: Representative samples of the selected wells. Min = representative sample of the lowest mineralized category; inter = representative sample of the intermediate mineralized category; $\max =$ representative sample of the highest mineralized category (data taken from MWI open files). (For well locations see Fig. 5.2-11.) ... 104

Tab. 5.2-14: Ionic ratios of the representative samples of the selected wells. Min = representative sample of the lowest mineralized category; inter = representative sample of the intermediate mineralized category; max = representative sample of the highest mineralized category (data taken from MWI open files). (For well locations see Fig. 5.2-11.)

Tab. 5.2-15: Results of Tritium analysis. For each sample two analyses were conducted in the Helium Isotope Laboratory at the Institute of Environmental Physics (University of Bremen). The Tritium concentrations in the table are average values.

Tab. 5.3-1: Specific electric resistivity of some selected material (average values: (a) after Parchomenko 1965 and Dortman 1976, (b) after Nosske 1977; taken from Schön 1983).

Tab. 5.3-2: Depth oriented soil samples analysed for major ion components from soil eluates given by the DIN38414 Teil 4. The water extract was analysed by using ion chromatography. Anions were analysed on Dionex D320 KOH isocratic ASMHC and the cations on Dionex DX500 MSA isocratic CS16. The number, that fallows the location name is the depth below ground level in $\mathrm{dm}$. 
Tab. 5.3-3: Grain size distribution of depth oriented soil samples of a drilling core, taken next to the direct-push geoelectric depth sounding E17. The carbonate content was determined after Müller and Gastner (1971). The grain size distribution was determined after Köhn 1929(DIN ISO 11277). On the right hand side the calculated electric resistivity using the chemical composition and the water content (which is multiplied by four) of the depth samples versus the measured direct-push geoelectric resistivity is shown.

Tab. 5.3-5: Resistivity of water and sediments (modified after Zohdy et al. 1993 and Nowroozi et al. 1999).

Tab. 6-1: Crop coefficients $\mathrm{k}_{\mathrm{c}}$ (FAO 1992, Euroconsult 1989).

Tab. 6-2: Weekly crop water requirement (CWR) for Squash in lower Jordan Valley in $\mathrm{mm} /$ week (Gtz 2003).

Tab. 6-3: Weekly crop water requirement for eggplant in the lower Jordan Valley in $\mathrm{mm} /$ week (GTZ 2003).

Tab. 6-4: Weekly crop water requirement for tomato in lower Jordan Valley in mm/week (GTZ 2003).

Tab. 6-5: Weekly crop water requirement for potato in the lower Jordan Valley in mm/week (Gtz 2003).

Tab. 6-6: Weekly crop water requirement for sweet corn in the lower Jordan Valley in $\mathrm{mm} /$ week (Gtz 2003).

Tab. 6-7: Weekly crop water requirement for wheat/ barley in lower Jordan Valley in $\mathrm{mm} /$ week (Gtz 2003).

Tab. 6-8: Weekly crop water requirement for banana in the lower Jordan Valley in $\mathrm{mm} /$ week (GTZ 2003).

Tab. 6-9: $\quad$ Monthly Field Water Requirement of different crops in the lower Jordan Valley $\left[\mathrm{m}^{3} / \mathrm{du}\right]$. Two different irrigation systems are considered (drip = drip irrigation; furr = furrow irrigation). Calculations are based on the ET values from the climatic station located in Karameh and from the information listed above. Min and max refer to different planting seasons, where min stands for the growing season with the lowest irrigation water amount needed and max for the planting season with the highest irrigation water requirement.

Tab. 6-10: Average monthly Field Water Requirement values.

Tab. 6-11: Summarized results of the area of irrigated land derived from the supervised classification of Landsat data sets (1973 - 2002) together with Calculated minimum water demand $(\mathrm{MCM}=$ million cubic metre) for the different periods.

Tab. 6-12: Yearly water demand for the irrigated fields (excluding the portion irrigated areas from King Abdullah Canal).

Tab. 7-1: A: Irrigated area depicted for the different Landsat scene categorized into the extraction zones. B: Field water requirement (drip irrigation) for the different extraction zones.

Tab. 7-2: Field water requirement (drip irrigation) of different extraction zones. The values were calculated on the base of land-use (vegetable or banana) of the extraction zone and the area depicted from the different Landsat scenes.

Tab.7- 3: Estimated surface flow in the different wadis. Rainfall was recorded at Naur rainfall station. 


\section{INTRODUCTION}

\subsection{SCOPE OF THIS RESEARCH}

Today, Jordan, already among the ten water poorest countries in the world, faces a severe water crisis. It was estimated, that only $20 \%$ of the renewable water resources can be used. The rest is lost through evaporation (Salameh and Haddadin 2006). Because of the inflow of refugees from neighboring countries, which took place over the last 66 years, the population grew 11.5 fold (Salameh and Haddadin 2006). This population increase along with the rapid socio-economic development put stress on the water demand. Groundwater resources are overused at a rate of $104 \mathrm{Mm}^{3} / \mathrm{y}$ and this rate is still increasing despite the government's efforts to reduce overexploitation (Salameh and Haddadin 2006). Despite the overuse of blue water resources, the per capita share of water in Jordan (2004) is only 396 $\mathrm{m}^{3} / \mathrm{y}$ (Salameh and Haddadin 2006). The overexploitation of groundwater resources has degraded water quality, which resulted in the abandonment of many water wells (Chebaane et al. 2004, AlKharabsheh-Atef 1999) and which endangers a future use of the limited groundwater resources (Salameh 1996; Dottridge and Abu-Nizar 1999).

In the light of the report on world climate, published in early 2007 by the Intergovernmental Panel on Climate Change (IPCC), a bigger challenge regarding water management awaits Jordan in the future. The discovery that global warming is man made and that an increase in global temperature is inevitable even when immediate measurements are taken, has consequences for the future water availability in the region. Climate models of the Mediterranean Basin for the end of this century show a decrease in the total amount of yearly precipitation (up to $-57 \mathrm{~mm} / \mathrm{y}$ for the whole Mediterranean basin) and an increase in evaporation rates (Ulbrich et al. 2006). Less rainfall however has direct influence on soils and vegetation and therefore on human and animal life.

Although the current and future water crisis in Jordan cannot only be overcome by using more blue water resources, it is however an integral part of the solution. In order to achieve a sustainable state of water resources and to quantify the impact of climate change on water resources a proper assessment of the groundwater resources as well as their quality is demanded. Groundwater systems in semi-arid areas are frequently not being sufficiently characterized hydrogeologically and long term data are generally not available. Long-term time series are necessary however to design future groundwater abstraction scenarios or to predict the influence of future climate change effects on groundwater resources. To overcome these problems an integrated approach for the provision of a reliable database based on sparse and fuzzy data is proposed (Fig. 1.1-1). This integrated approach combines geological, geophysical, hydrogeological, historical, and chemical methods and is demonstrated using the lowermost area of the Jordan Valley.

A historical approach (chapter 3) is used to detect the general conditions under which the groundwater system has been in the past. These conditions include the natural flow conditions, the impact of the rapid development of the Jordan Valley from the 1950s onward, as well as the influence of periods of drought and of intensive rainfall on the groundwater system. The aquifer geometry and composition is described in chapter 4. Based on field investigations and intensive literature studies the depositional environment and its sedimentological and hydraulic characteristics are evaluated. Chapter 5 describes the spatial distribution and the temporal development of groundwater quality. Possible origins of groundwater in the study area are proposed and the effect of major stress periods, which were described in chapter 3, on the groundwater quality are addressed. Information about soil and groundwater salinization and their spatial distribution that can be acquired by the application of surface geophysical methods (resistivity measurements) are described as well as their limitations in unconsolidated brackish environments. A water budget is calculated by the application of direct and indirect information. A minimum water demand for the test area is estimated with the help of fuzzy information and remote sensing techniques. This type of fuzzy information includes, information about irrigation techniques, about cultivated crops, and about growing seasons. The area under cultivation was identified for different periods by the classification of Landsat images. The findings of the different chapters are implemented into a steady-state and transient flow model (chapter 7). In 
order to be able to predict the impacts of climate change scenarios on the groundwater system, this flow was tested against the depicted stress periods on the groundwater systems for a period of 40 years. The flow model provides the means for testing the consistency of the rather heterogeneous quality of the historical data set and would allow the simulation of the future impact of management strategies as well as climate change scenarios.

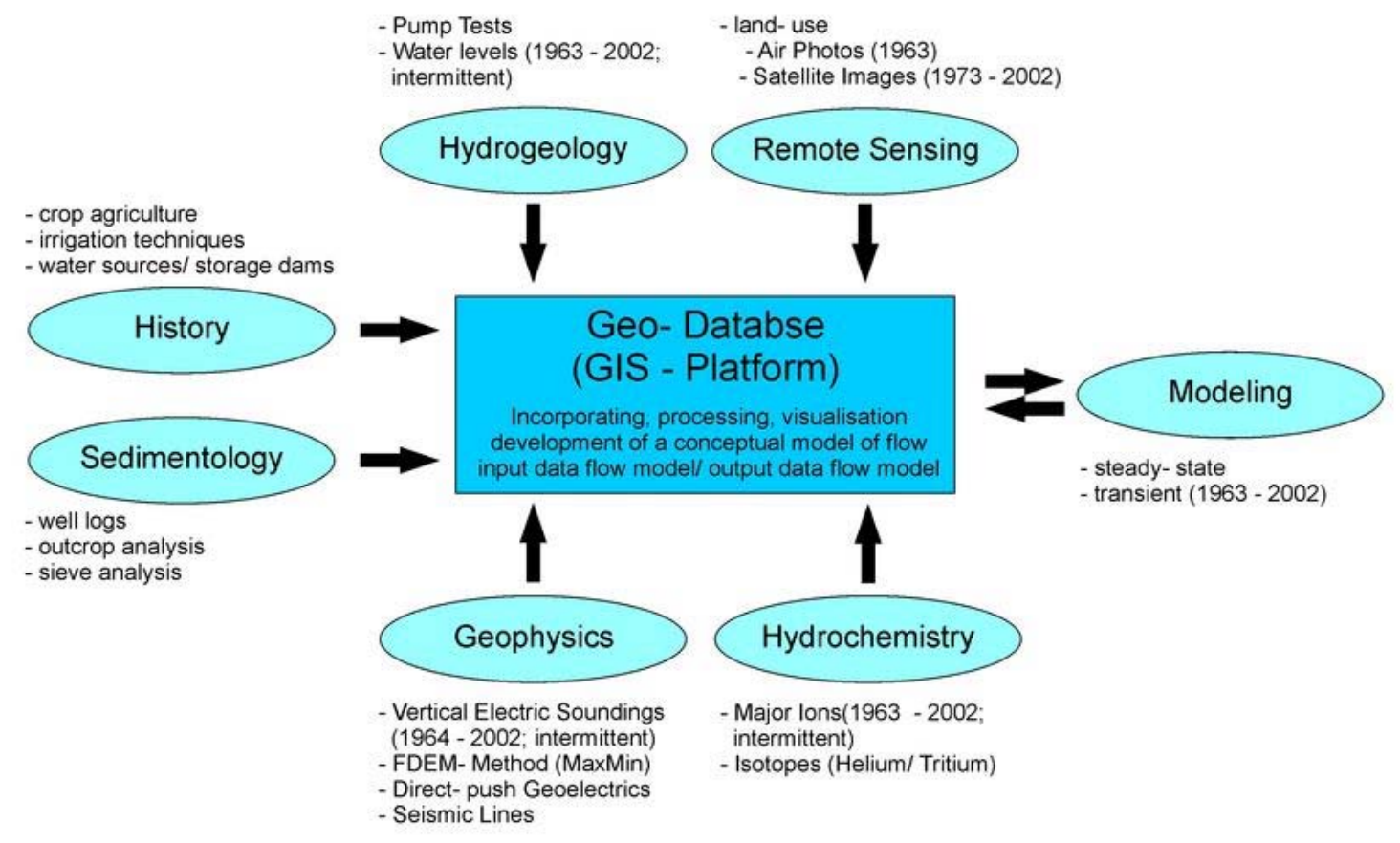

Fig. 1.1-1: Flow chart of the integrated approach applied in this study. 


\subsection{The German - Israeli - Jordanian - Palestinian Joint Research Program (GIJP)- Water Resources Evaluation for a Sustainable DEVELOPMENT IN THE JORDAN RIFT BASIN}

This research was carried out under the German-Israeli-Jordanian-Palestinian Joint Research Program for Water Resources Evaluation in the Jordan Rift Basin (GIJP). The GIJP project is a project supported by the German Ministry of Education and Research (BMBF) and the Israeli Ministry of Science and Technology (MOS). The scientific coordinator of the project is Prof. H. Hötzl, Karlsruhe University in Germany. More than 12 institutions participate in the joint research program and work together on one of the main issues in the Middle East region: water resources.

The evaluation of fresh water resources and their sustainable management in the Jordan Valley are essential to satisfy the increasing water demand of the growing Israeli, Palestinian, and Jordanian population living in this region. One of the greatest challenges not only for scientists but also for landuse planners and politicians is the scarcity of water due to climate conditions in the region. Detailled investigations of the geological, hydrogeological and hydraulic conditions are important to find out more about the interrelations between groundwater storage, groundwater protection and the outflow to the Jordan valley.

\section{Joint Working Groups}

The structure diagram below shows the organisation of the Joint Research Program. In a symbolic way it is shaped like a building, which is shared jointly by all counterparts. The foundations is formed by three methodical service blocks including the hydrogeologic database VEGA, the laboratory facilities for isotope and rare earth elements and the numerical modelling base group. The main part of the house is taken up by the four Joint Working Groups which are connected in an integrated way like the open rooms of a house. The roof of this house is formed by the co-ordination group, which consists of the scientific co-ordinator and the project board. Like an umbrella the Steering Committee is placed on the building with the representatives of the ministries and the scientific advisors.

\section{First Phase of the Research Project 1997-2000}

From 1997 to 2000 the German Federal Ministry of Education and Research (BMBF) and the Israeli Ministry of Science and Technology (MOS) supported the multinational research project "Sustainable utilization of aquifer systems bordering the lower Jordan Valley and the Dead Sea". The results obtained during the first project phase are essential for water resources planners in the region to understand the hydrodynamic and hydrogeological conditions of groundwater flow in the lower part of the Jordan valley and the northern Dead Sea. The objectives of the first phase of the research project were to

(a) encourage the co-operative aspects between the researchers in the region to solve water problems in teamwork.

(b) understand the hydrodynamic and hydrogeological conditions in the lower Jordan valley and the surrounding escarpments on both sides of the Jordan river.

(c) evaluate the effects of Dead Sea water level changes on the adjacent aquifers.

The investigations in the period 1997 to 2000 were concentrated on a regional hydrological, hydrogeological and hydrochemical database as well as on an exemplary detailed study along a section from Jerusalem to Amman crossing the Jordan rift valley. The investigations included the collection of hydrochemical and hydraulic data of the main aquifers and the development of a software for an integrated hydrogeological database. The investigations also dealt with the effects of the Dead Sea level decrease on the bordering aquifers and the salt-/fresh water interface. A numerical groundwater model for a restricted part of the catchment and a new comprehensive hydrodynamic concept for a groundwater model in the region was developed. The results of this research project were encouraging in every aspect and lead to a second project phase from 2000 to 2003. 


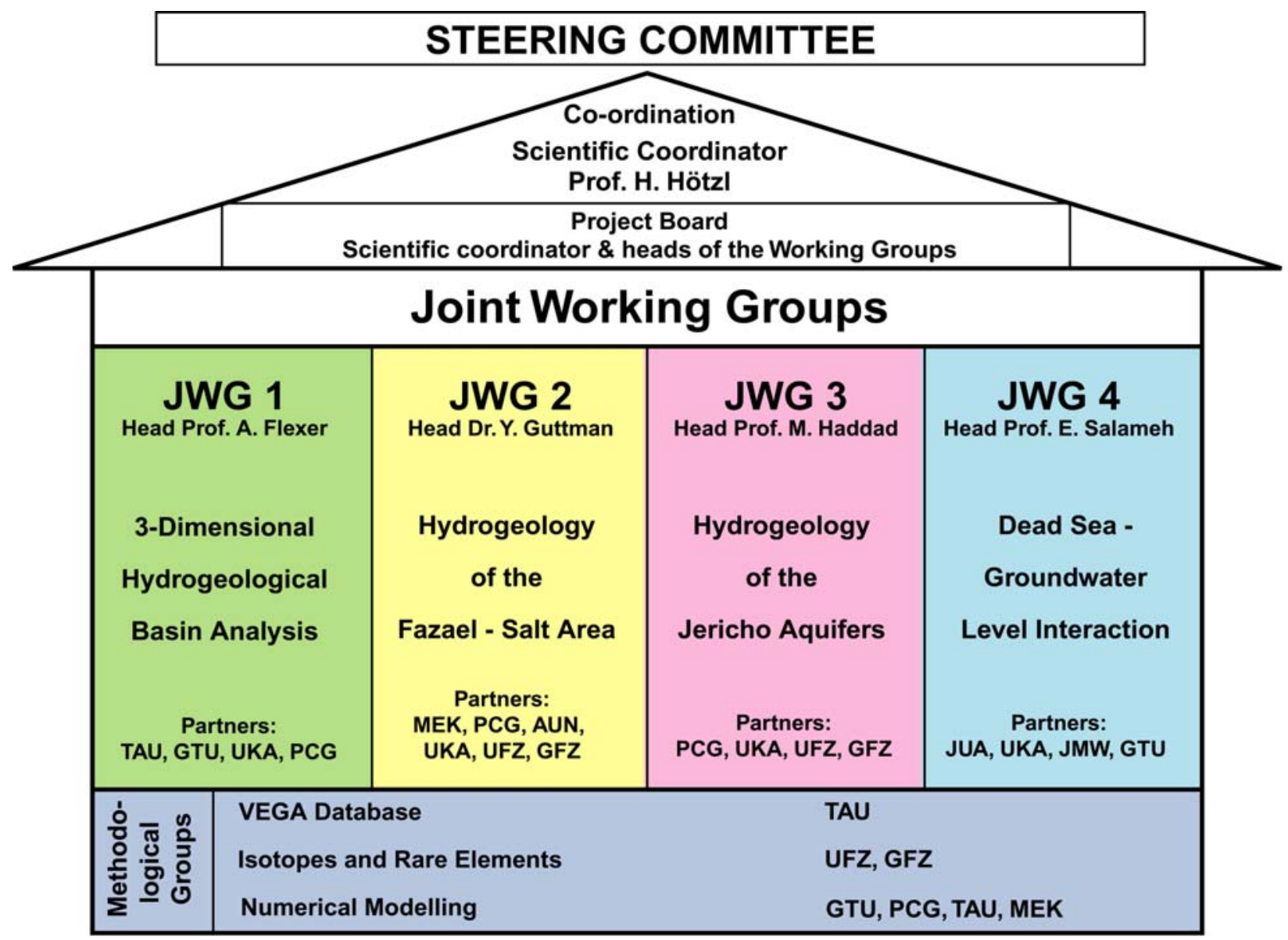
JUA: Jordan University Amman
JMW: Jordan Ministry of Water
MEK: Mekorot Company, Israel
TAU: Tel Aviv University
GTU: University Group (Goettingen University, Tuebingen University)

\author{
UFZ: Environmental Research Center Leipzig-Halle \\ GFZ: Geo Research Center Potsdam \\ UKA: Karlsruhe University \\ PCG: Palestinian Consultancy Group (incl. \\ Palestinian Hydrology Group, Water \\ Authority of the West Bank)
}

\section{Second Phase of the Research Project 2000-2004}

In continuation of the first project phase the existing relevant data in the region are collected, evaluated and summarized in an integrated database. Another main part of the second project phase are hydrogeological and geophysical investigations along several transsects normal to the graben system. The results of these studies will be helpful for the three-dimensional interpretation of the catchment area which will result in a 3D - basin analysis. Large-scale vulnerability maps are produced to support the groundwater protection and management in the future. Detailed studies deal with the salt-/fresh water interface at the Dead Sea. Together with the hyrochemical data and results of isotope studies the research work will be a great step forward regarding aspects of water budget, quantities of fresh water resources and an improved groundwater management. The presented research was carried out during the second phase of the GIJP project.

The results of the GIJP project are summarized and published in the book "Sustainable water resources management in the Jordan-Dead Sea Rift System”. 


\section{DESCRIPTION OF THE STUDY AREA}

\subsection{GEOGRAPHY, LAND- USE, VEGETATION, AND CLIMATE}

\subsubsection{Geography, Land-use, and Vegetation}

The study area lies in a geographical unit commonly known as the Jordan Valley (in Arabic called 'Al Ghor'). Thus a short introduction into the different landscape units and their surroundings will be given below. The Jordan Valley and its adjacent areas lie on the western margin of the Asian continent (Fig. 2.1-1) and belong geographically to the Eastern Mediterranean Basin. The research area is located in the lower Jordan Valley/ Jordan. The centre is located at WGS84 coordinates $31^{\circ} 52^{\prime} \mathrm{N}$ and $35^{\circ} 36^{\prime} \mathrm{E}$, and has an area of $150.66 \mathrm{~km}^{2}$, and an average elevation of 270 metres below mean sea level (b.m.s.l.), and, compared to the bordering area to the east, a very smooth average slope of one to two degrees. The lowest point is located at the Dead Sea shore in the south with an elevation of $420 \mathrm{~m}$ below mean sea level (2006; the elevation depends on the water level of the Dead Sea), and the highest point at the fan apex of Wadi Hisban with $160 \mathrm{~m}$ b.m.s.l. The detailed study area includes the unconsolidated strata of lower Jordan Valley and extends from the Dead Sea in the south to the town of Karameh in the north, from the Jordan River in the west until the margin of the western hills of the East Bank in the east. The maximum extension is $14 \mathrm{~km}$ in east- west and around $20 \mathrm{~km}$ in northsouth direction.

Nevertheless, the consolidated strata in the east were included in this study, henceforward called wider area of interest, because it is considered that the major part of recharge and of sediment supply to the unconsolidated aquifer derives from this area.
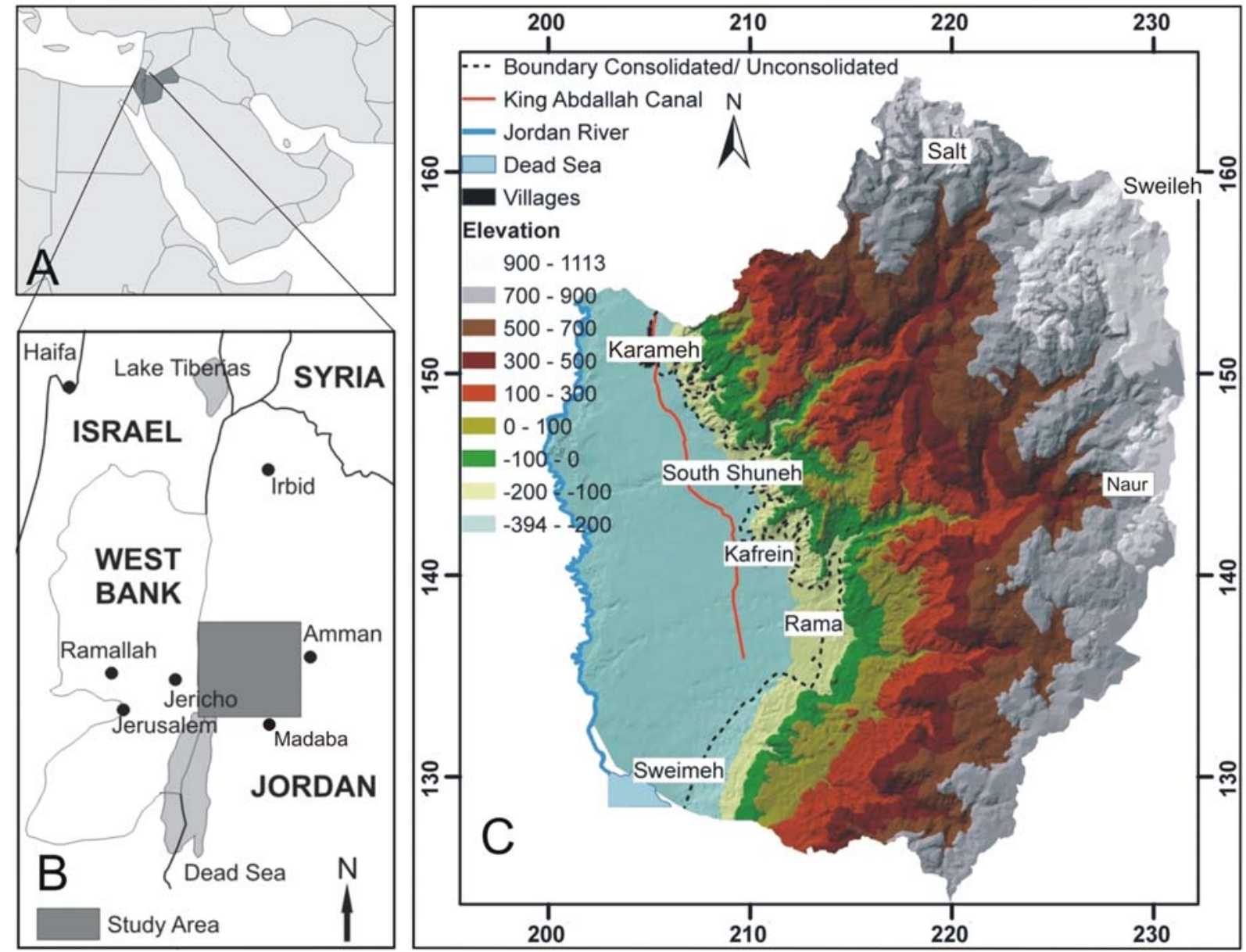

Fig. 2.1-1: Location of the study area. A: Middles East; B: Study area in the regional context; C: Study area. 
This wider area of interest can be subdivided into three morphological units: the Highlands, the Western Slopes of the East Bank, and the Jordan Valley, which is the main area of this study.

\section{The Highlands}

The highest elevations are located on the eastern border of the wider area of interest. Whereas the highest point is located to the west of the city of Sweileh at an elevation of 1,096 m a.m.s.l. This area, henceforward referred to as the Highlands are characterized by medium to smooth slopes. This area is densely populated. Large cities like the capital Amman (1.8 million inhabitants, SJ 1998), Salt (116,900; SJ 1998); and Madaba (93,700; SJ 1998) are situated in or near the border of the wider area of interest. Most of the industrial activities take place near these densely populated areas. Except for the area around Madaba, where rain-fed agriculture and irrigation by shallow wells prevail, only minor agricultural activities are abundant.

\section{The Western Slopes}

This area is topographical complex. The highest points are located near the Highlands area of Madaba, Amman, and Salt. From the Highlands area, which is the apex of the East Bank, slopes descend down to the Jordan Valley. Three major wadis incise deeply into these slopes: Wadi Shueib, Wadi Kafrein, and Wadi Hisban. Apart from these major wadis several minor wadis are located on the western slopes of the East Bank northeast of the Dead Sea (Fig. 2.1-2). None of them shows perennial flow. However, during and after the rainy events, they drain floodwater down to the Jordan Valley. The floodwater carries sediments and sometimes even rocks forming fan deposits in the Jordan Valley. Only smaller

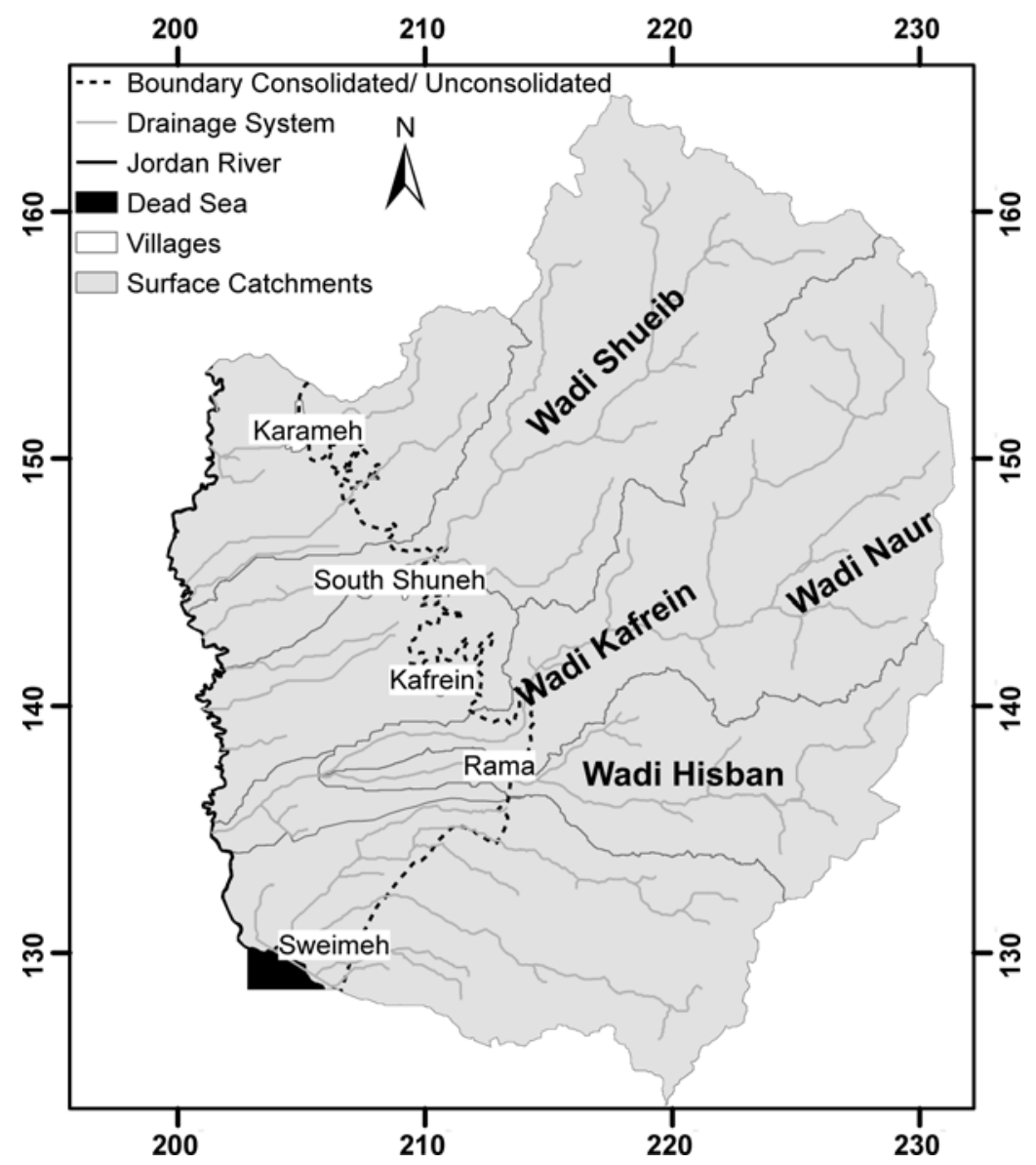
cities and villages are located within these areas. They are mostly situated close to the eastern border of the Western

- Hills. Only a few villages are scattered towards the west. Like in the Highlands only minor agricultural activities take place. These agricultural activities are restricted to abundant soil cover.

Most of the area is covered by bare karstic limestone and consequently unusable for agriculture. Weathering remaining fractions like clay usually accumulate in depressions like wadi floors or small depressions. In these areas the existence of farms is usually restricted to available water resources. Agriculture is usually rain-fed and or spring irrigated, and mostly planted with olive trees. Nevertheless, other trees (almonds, apples, figs), cereals, and animal farming can be found.

Fig. 2.1-2: Major catchment areas and drainage patterns within the wider area of interest.

\section{Jordan Valley}

The Jordan Valley, often referred to as the "food basket" of Jordan, is the most important area for agriculture and therefore it is intensively used. However, farming activities in the middle and the northern part of the Jordan Valley exceed by far the production of the lower Jordan Valley. Farmers in 
the Jordan Valley generally refer to three different zones along the Valley (Fig. 2.1-3): the Zor, Qatar, and Ghor areas. These zones represent different morphological features.

The Zor (Arabic for 'throat') area represents the flood plain of River Jordan. The Jordan River cut itself into a 30 to $60 \mathrm{~m}$ deep gorge and eroded the soft lacustrine sediments of Lake Lisan, the predecessor of the Dead Sea (e.g. Kaufman et al. 1992). The slopes ascending to the smooth alluvial plain are called the Qatar (Arabic for 'badland') area. They are characterized by steep slopes (20 to $50^{\circ}$ ). The Ghor area is the alluvial plain that ascends smoothly until the mountain slopes of the East Bank. The mountain slopes are known as Djebel (Arabic for 'mountain').

The different soils which developed from the different sediments can be subdivided into three different groups (Hunting Technical Services Ltd. 1993):

Zor Formation: comprises clay, silt, and fine sands and represent former flood plains of the Jordan River. Hence, its occurrence is restricted to the surroundings of the Jordan River. Since most of the water of the Jordan River is diverted before reaching the Jordan Valley and most of the runoff is stored at water storage dams at the outlets of the major wadis, floodings only occur in very wet years (i.e. $1991 / 92$ or $2002 / 03)$.

Ghor Formation: The Ghor Formation can shortly be described as alluvial fan deposits, which was deposited at the mouths of the various Wadis in Jordan Valley. These interfinger or are underlain by the Lisan Formation. The soils developed from the Ghor Formation are mostly used for agriculture.

Lisan Formation: comprises sediments of the former Lisan lake. The lacustrine sediments of the Lisan Formation consist of laminated chalk, gypsum, marl, and clay. High concentrations of salt can be found within these sediments. This formation underlies the Zor Formation and makes up the badlands of the Qatar area.

Villages in the lower Jordan Valley are situated close to the western border of the western slopes (from north to south): Karameh, South Shuneh, Kafrein, Rama, and Sweimeh (Fig. 2.1-1).

Seminomadic Bedouins who live in tents are scattered randomly mostly around the middle to western part of the study area (Fig. 2.1-3).
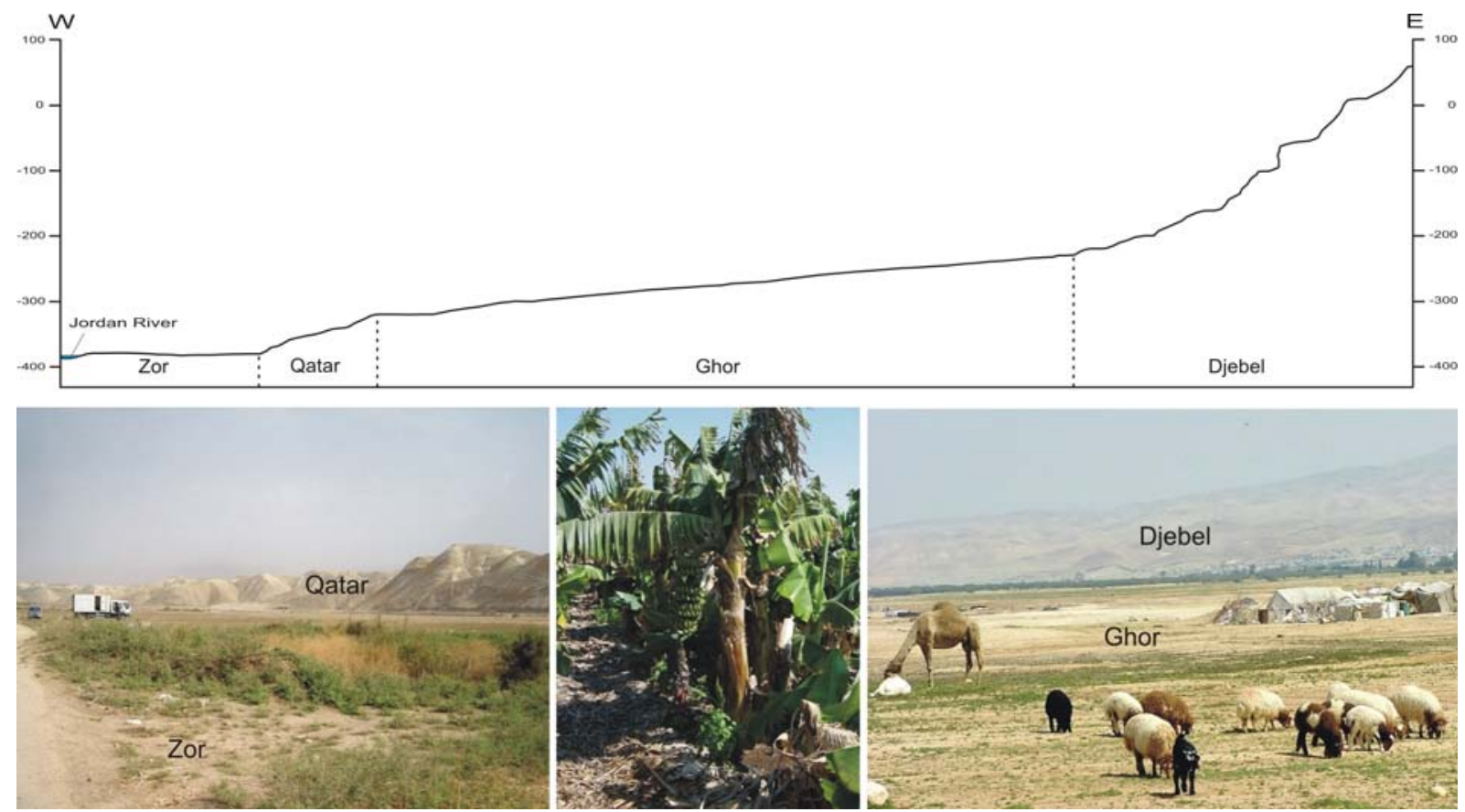

Fig. 2.1-3: Sketch: Geographic zones in the Jordan Valley. Lower left: the flood plains of River Jordan (Zor) with the flanks of the Qatar in the background. Lower middle: eastern Ghor area. Intensively used for agriculture; here banana plantation. Lower right: western side of the Ghor area with the djebel area in the background. 
These seminomads descend to the Jordan Valley in winter because of its warm temperatures. Traditionally, many of these seminomads farm plots of land in the valley. In summer they move their herds up into the hills to avoid the intense heat. In addition to these people farm workers, mostly Pakistanis, Palestinians, and Egyptians live in small huts near the farm sites. No industrial activities are found in this area. Farming is mostly restricted to the east of the Jordan Valley. Towards the west soil salinity increases and only salt tolerant crops can be planted. The eastern part is intensively used for agriculture, mostly banana plantation and some vegetables like tomato, zucchini, and egg plant. As a result of the favourable climatic hot conditions three harvesting seasons are planted: autumn, winter, and spring. But due to the lack of precipitation large amounts of water are used for irrigation. Irrigation water comes from dam storage water, from the King Abdullah Canal, and, unlike the middle and northern Jordan Valley area, to a large extent from groundwater. Since agricultural activities have a strong influence on groundwater chemistry and flow, a special chapter (chapter 3 ) is devoted to the historical to present development of the lower Jordan Valley.

Some touristic activities exist near the Dead Sea shore in the south and at the Baptism Site of Jesus in the west, near the Jordan River.

\subsubsection{Climate}

According to Köppen (1931) the wider area of interest can be classified as a Group B Dry (arid and semiarid) climate, since precipitation is less than the potential evaporation, but further subdivisions can be made. Morphology has the largest influence on the prevailing climate. Following the morphological division, a subdivision into three different climatic zones can be made: the Highlands area, the Western Slopes of the East Bank, and the Jordan Valley. The climate in the Highlands is of Mediterranean type. It is characterized by long, hot, dry summers and short, cool, rainy winters. Towards the west, the climate undergoes a rapid change to semi-arid and arid climate in the Jordan Valley. The western Slopes act as a transition zone between the Mediterranean climate along the Highlands in the east and the arid climate in the Jordan Valley in the west.

Rain falls only during the winter months. Then the climate changes abruptly from dry hot summer conditions to humid, cold, and stormy conditions. Usually it starts to rain in November and rainfall continues until the end of April, whereby $70 \%$ of the annual precipitation falls between November and February. Snow falls once to twice a year in the Highlands. In Fig. 2.1-4 the annual rainfall for the hydrologic years 1975/76 till 2001/02 for three selected sites together with their long- term seasonal average is given. The average annual precipitation on the western ridges of the Highlands (Jordan University) is around $505 \mathrm{~mm} / \mathrm{y}$, on the eastern part of the Western slopes (Naur) $395 \mathrm{~mm} / \mathrm{y}$, and in Jordan Valley (South Shuneh) the long term average is around $166 \mathrm{~mm} / \mathrm{y}$ (Fig. 2.1-4). Thus a strong correlation with altitude and climate data for the area exists (Fig. 2.1-4). Strong variations regarding total annual amounts of rainfall is visible in Fig. 2.1-4. For the plotted period, the highest amount of annual rainfall for the Highlands is 1,135 mm/y in the hydrologic year 1991/92, whereas the lowest recorded amount was $234 \mathrm{~mm} / \mathrm{y}$ in the hydrologic year 1988/89 (a difference of factor 4.85). This important nature of semi-arid areas is also one of the major challenge for water engineers. The water demand of the population increases or decreases constantly with time, while the water supply or input by rainfall is highly variable, both spatially as well as temporally.

The variability of annual rainfall and the necessity of long term records is addressed in Fig. 2.1-5 (data kindly provided by the Hashemite Kingdom of Jordan, Ministry of Water and Irrigation). The longest record for the wider area of interest was available for the Naur Station. Annual precipitation amounts are plotted for the period from the hydrologic year 1942/43 until 2002/03. Mean average values for time periods of $5,10,30$, and 60 years are displayed. In order to undertake future water budget calculations long- term mean averages of at least 30 years should be used. A short period of only five years might lead to considerable over- or underestimations regarding water availability. 


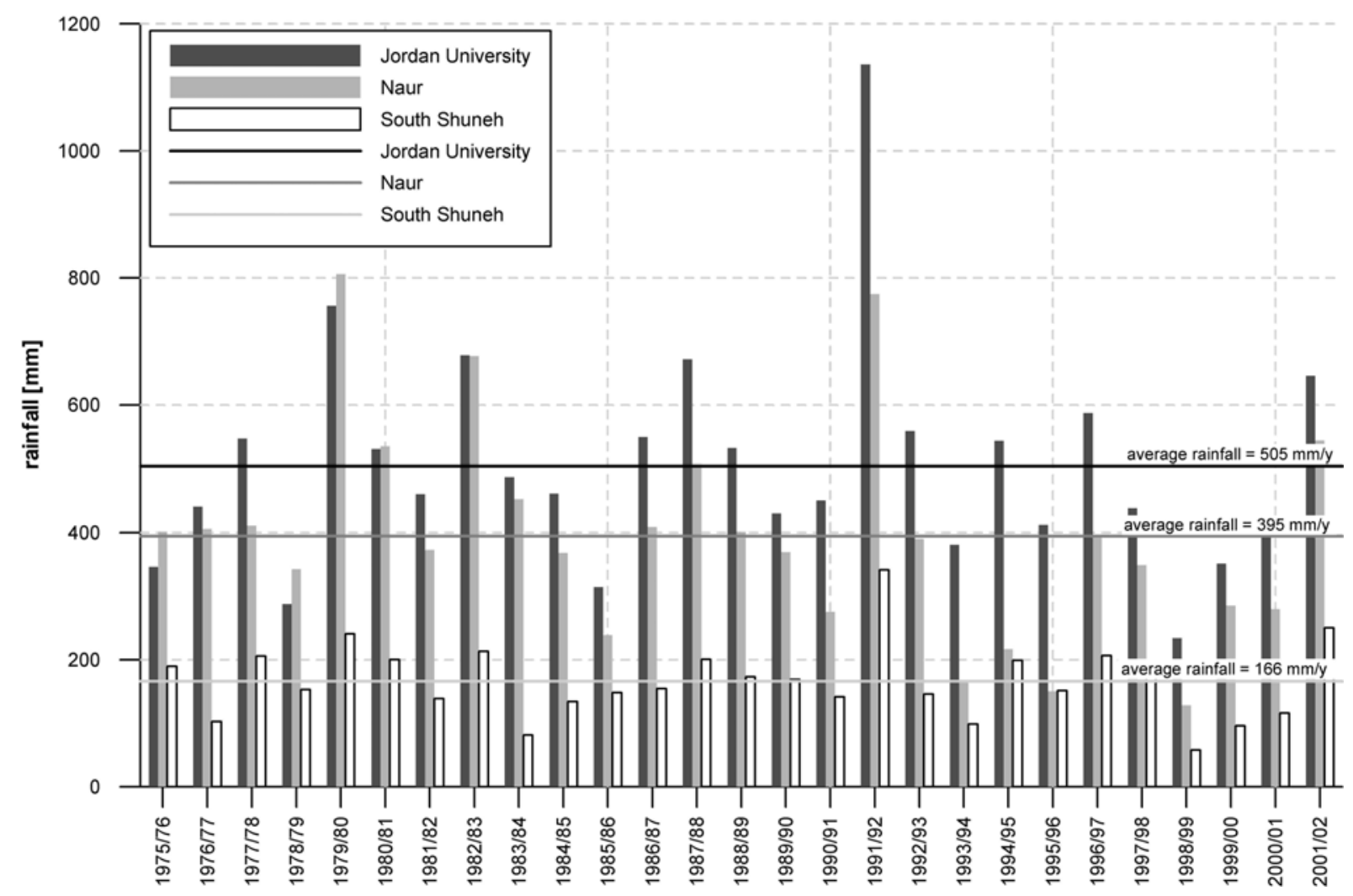

Fig. 2.1-4: Annual rainfall for the hydrologic years 1975/76 to 2001/02 together with the long-term average at three selected sites: Highlands (Jordan University), eastern part of the Western Slopes (Naur), and the Jordan Valley (South Shuneh) (MWI open files).

As stated at the beginning the annual mean potential evaporation exceeds by far the annual rainfall of the area. The mean annual potential evaporation in the Highlands is around 1,600 mm/y (Salameh et al. 2004), while the mean annual rainfall is not more than $505 \mathrm{~mm} / \mathrm{y}$. In the Jordan Valley (Jericho station) the mean annual potential evaporation increases to 2,082 mm/y for the period from 1968 till 1999, while, for the same period, the mean annual rainfall decreases to a mere $163 \mathrm{~mm} / \mathrm{y}$. Fig. 2.1-6 through Fig. 2.1-8 show mean average monthly climatic data for a period of around 30 years. No potential evaporation and temperature values for the South Shuneh area were available. Therefore two other stations located in Jordan Valley were used: Deir Alla, located $32 \mathrm{~km}$ to the north of South Shuneh, and Jericho, $16 \mathrm{~km}$ to the west of South Shuneh. The mean annual potential evaporation values of 2,240 mm/y and 2,082 mm/y respectively are very high. Rainfall decreases in the Jordan Valley from Deir Alla 291 mm/y in the north to South Shuneh 166 mm/y in the south.

In the cases of Deir Alla and Jericho monthly potential evaporation always exceeds precipitation. Consequently, no infiltration of rainwater can be assumed. However, as can be seen from Fig. 2.1-9 and Fig. 2.1-10 rainfall is not evenly distributed during the months and rainfall often happens during rain storms, where large amounts of precipitation falls in a short period of time. Precipitation either infiltrates directly, or, in cases of high rainfall amounts, flows downgradient as Hortonian overland flow. No data regarding daily evaporation values in the Jordan Valley could be obtained, but it can be assumed, that these values during the rainy season are not always higher than the daily amounts of precipitation. 


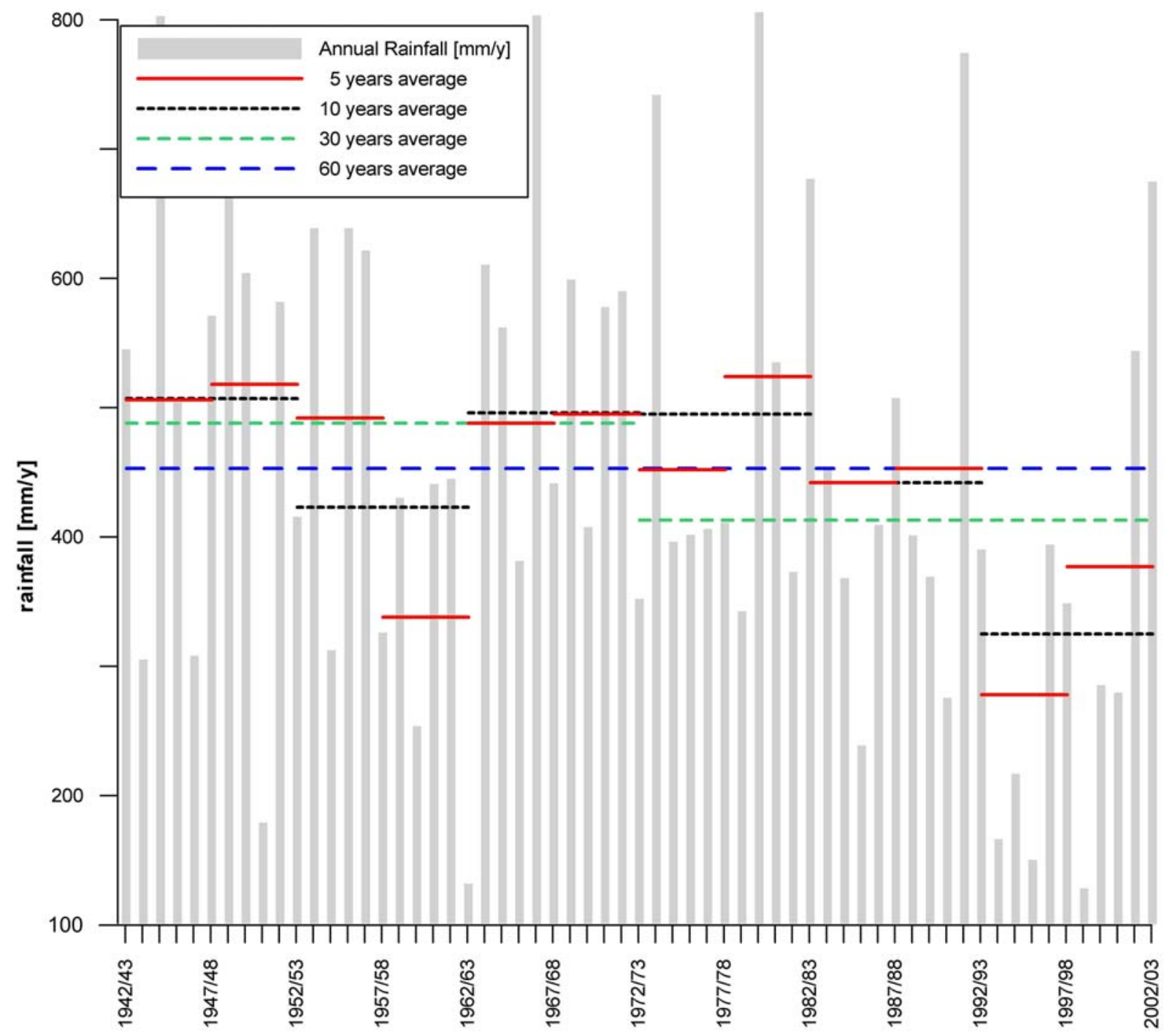

Fig. 2.1-5: Annual rainfall 1942/43 - 2002/03 for the meteorological station in Naur with short (5 years) to long term (60 years) averages (MWI open files).

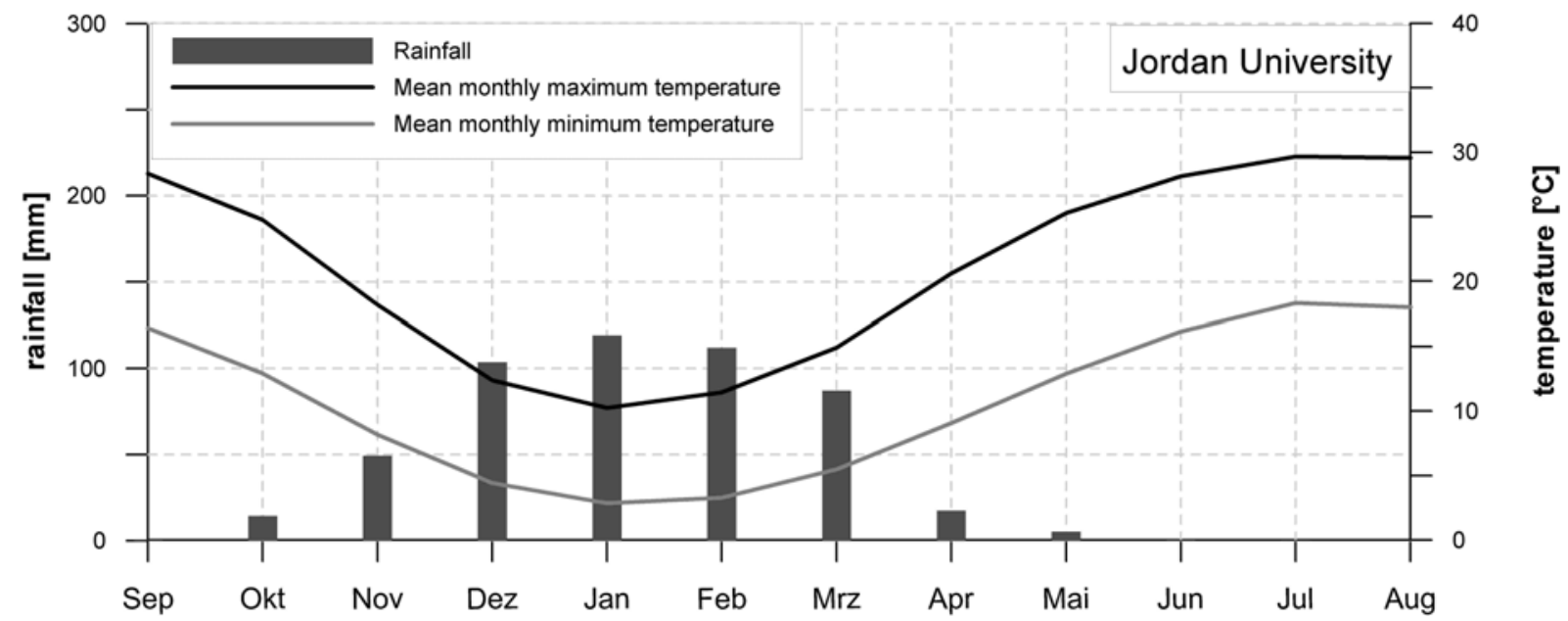

Fig. 2.1-6: Mean monthly rainfall, low temperatures and high temperatures in the Highlands (Jordan University), calculated for the period 1975 - 2002 (MWI open files). 


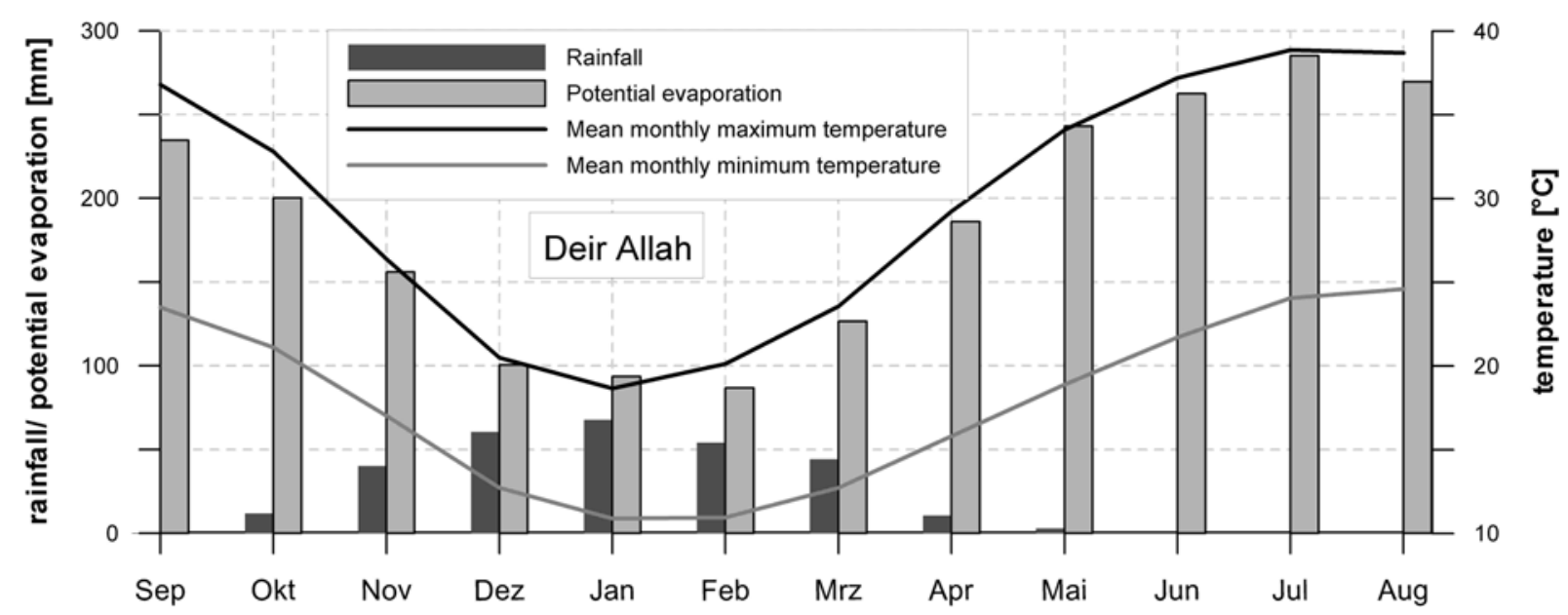

Fig. 2.1-7: Mean monthly rainfall, potential evaporation, low temperatures, and high temperatures in Jordan Valley (Deir Alla), calculated for the period 1975 - 2002 (MWI open files).

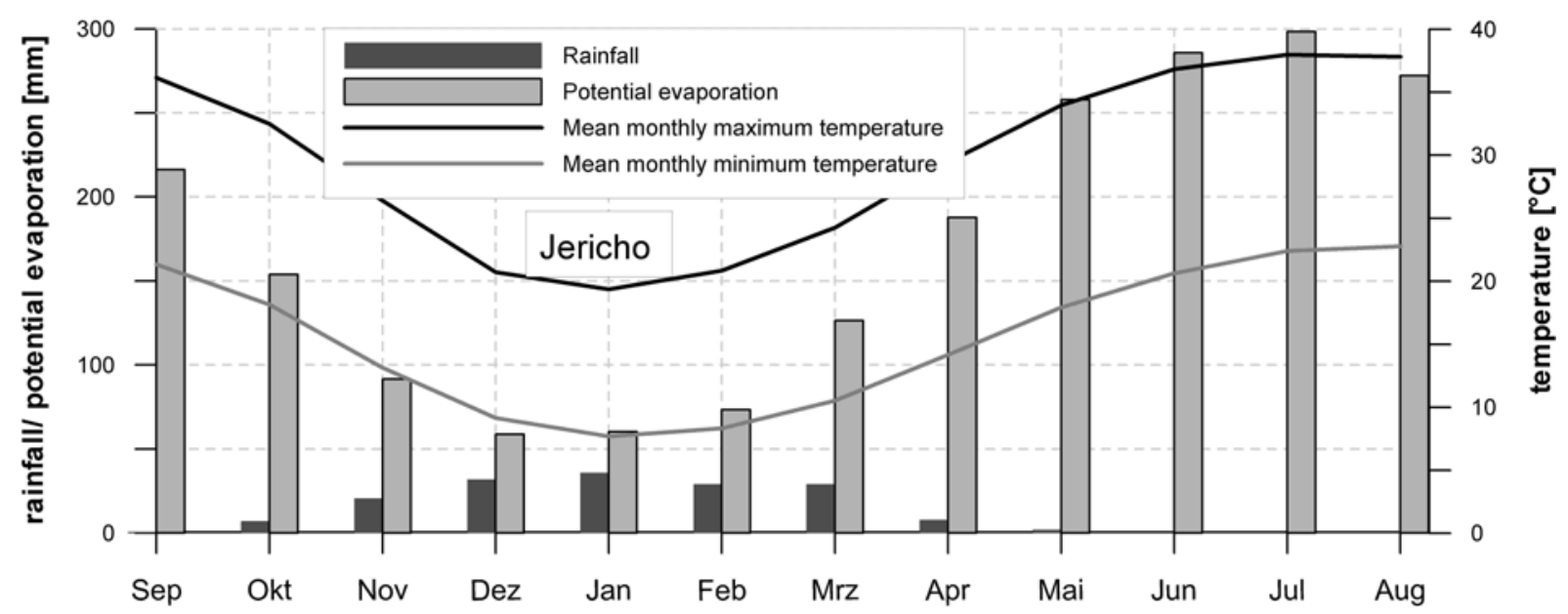

Fig. 2.1-8: Mean monthly rainfall, potential evaporation, low temperatures, and high temperatures in Jordan Valley (Jericho), calculated for the period 1968 - 1999 (data kindly provided by the Israeli Hydrologic Survey).

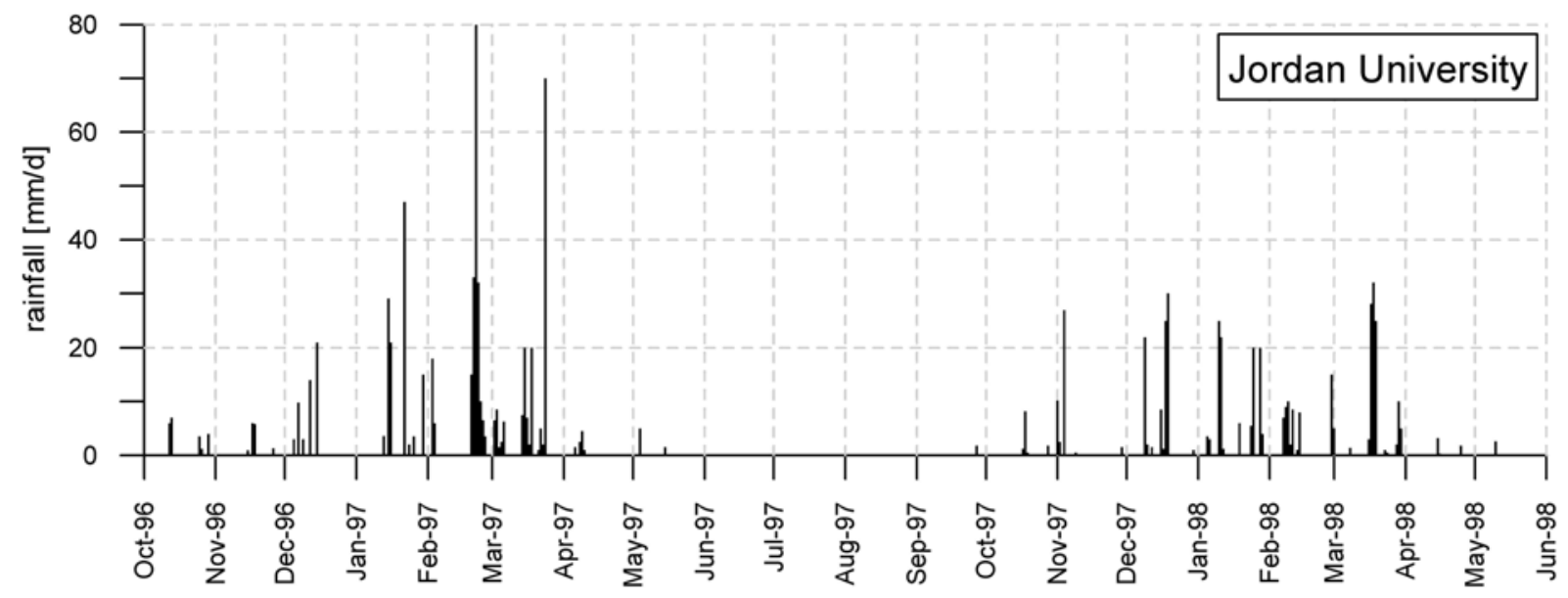

Fig. 2.1-9: Daily rainfall for the hydrologic year 1996/97 and 1997/98 in the Highlands (Jordan University). (MWI open files). 


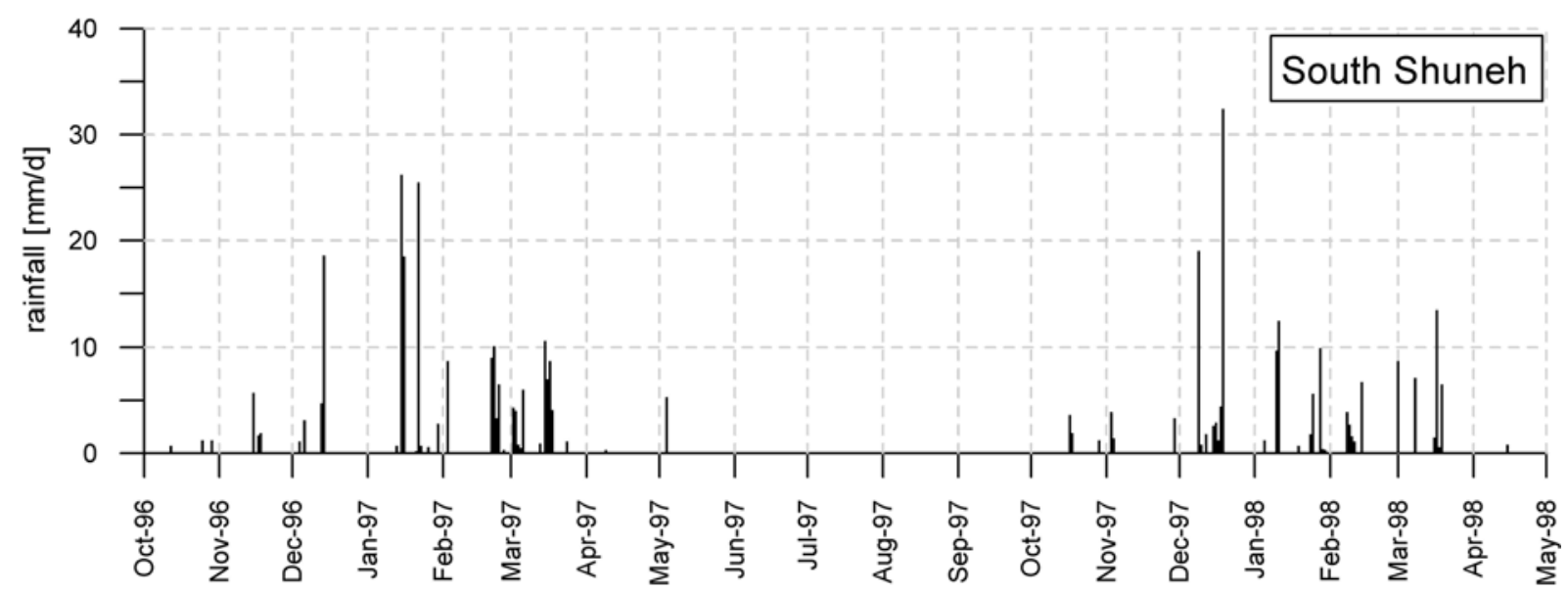

Fig. 2.1-10: Daily rainfall for the hydrologic year 1996/97 and 1997/98 in the Jordan Valley (South Shuneh). (MWI open files).

\section{Temperature}

As stated above the temperature within the study area varies significantly (Fig. 2.1-6 through Fig. 2.18). The lowest temperatures are found in the Highlands and the highest temperatures in the Jordan Valley. The average annual temperature in the eastern, middle, and western part are $17^{\circ} \mathrm{C}, 20^{\circ} \mathrm{C}$ and $23^{\circ} \mathrm{C}$, respectively. August is usually the hottest month (up to $34^{\circ} \mathrm{C}$ in Amman and $40^{\circ} \mathrm{C}$ in Jericho), whilst the coolest month is January and February (down to $0.3^{\circ} \mathrm{C}$ in Amman and $5^{\circ} \mathrm{C}$ in Jericho).

The cool temperature in the Highlands results from the high elevation (up to 1,096 m a.s.l.) and relatively strong wind coming mainly from the Mediterranean Sea in west east direction. However, extremely hot and dry air, originating from southern Iraq and Saudi Arabia changes the weather drastically during the so-called 'Khamaseen'. The name Khamaseen is derived from the Arabic word for " 50 " and refers to the approximately 50 -day period in which the wind annually occurs. It is most often observed between April and June, but can also occur in other months. The Khamaseen takes place when a low-pressure centre moves eastward over the Sahara desert or the southern Mediterranean Sea. On its front side, the centre brings warm, dry air (temperatures can increase up to $40^{\circ} \mathrm{C}$ ) northward out of the desert, carrying large amounts of dust and sand; on its rear side, it brings cool air southward from the Mediterranean (Encyclopædia Britannica 2002).

The temperatures in the Western Slopes are transient to the desert climate in the Jordan Valley.

The hottest temperatures are measured in the Jordan Valley. The Jordan Valley is situated at an extremely low elevation and is surrounded by a series of high mountains from both the east and west, which creates a natural greenhouse climate due to the absence (or lower degree) of cooling winds from the Mediterranean. Wind direction is mostly north south. In summer winds may come from the south (Salameh et al. 2004). The above-mentioned Khamaseen winds thereby can cause temperatures above $50^{\circ} \mathrm{C}$ at times.

After the cool winter months the temperature starts to rise, whereby the warming of the atmosphere in April and May is slower than the cooling in November (Fig. 2.1-6 through Fig. 2.1-8).

Dew

At night times, especially in windless nights, relatively large amounts of dew often precipitate in the Highlands and, to a lesser degree, in the upper parts of the Western Slopes. This moisture enables plants and animals to benefit from additional water outside the rainy season. 


\subsection{GEOLOGICAL FRAMEWORK}

\subsubsection{Introduction}

The lower Jordan Valley is a part of the Jordan Dead Sea Wadi Araba Transform Valley, which extends from the Red Sea to Lake Tiberias and beyond with a major $107 \mathrm{~km}$ sinistral strike-slip fault movement between the Arabian plate to the east and the northeastern part of the African plate to the west (Fig. 2.2-1). Due to extensional forces a deep depression, which is often called Jordan "Graben" (for historical reasons), has formed. As a result of the arid environment it is filled with evaporites, lacustrine sediments, and clastic fluvial components (Niemi at al. 1997). The lower Jordan basin is the major target area of this study. But, in order to understand the geology of the wider area of interest and its evolvement this chapter is divided into two sub chapters: supra- regional geodynamics and regional geodynamics. The sub chapter supra- regional geodynamics gives an overview about the main supraregional geologic features and events that influenced the wider area of interest either directly or indirectly. The overview begins with the formation of the Arabo- Nubian Shield in Late Precambrian times, which was the source area of clastic sediments in Cambrian through Early Cretaceous times. The regional geology of the Cretaceous times onwards will be discussed in more detail, because it has strong influence on the recent geology of the study area. The first sub- chapter commences with the Holocene to sub- recent clastic alluvial fan sedimentation in the study area. The second sub- chapter deals with the regional geology of the wider area of interest and includes stratigraphic, facies, tectonic, as well as initial hydrogeologic information.

\subsubsection{Supra- regional geodynamics}

\subsubsection{Precambrian - Palaeozoic}

During late Proterozoic times the Arabo- Nubian Shield was formed. Eyal et al. (1991) described the aggregation in four stages. Most of the massif was formed during the second phase ( 850 - $650 \mathrm{Ma})$ during which andesitic to dacitic rocks together with their sedimentary derivates underwent deformation and metamorphism of various degrees. During the last two stages the new built massif was intruded by alkaline to perialkaline granites and rhyolithes as well as by volcanic rocks and lava (Flexer 2001).

During the "Lipalian" interval (Picard 1943) in Infracambrian times the Arabo- Nubian Shield underwent intensive erosion, denudation, and peneplainization. As a result the Cambrian Ram Group sandstone series overlies the Precambrian methamorphic rocks unconformable (Weissbrod 1969 a,b). During Cambrian to Silurian times Jordan was located at the southern edge of the Palaeotethys Ocean. The area was part of a stable passive continental margin. No evidence of Caledonian deformation was found (Flexer 2001). Consequently, the area was mostly characterized by the deposition of clastic fluviatil to aeolian sediments, which were derived from the Arabo- Nubian Shield in the south to southeast. Shallow marine sediments accumulated in the north of Jordan on the subsiding passive continental margin. Sedimentation was affected by global Eustatic sea level changes (Andrews 1991).

The next tectonic event that affected the area was the Variscian event. It was manifested in the commencing subduction of the Palaeotethys near the margin of Gondwana (along present Turkey and Iran). This had a strong influence on the area. While uplifted areas eroded during late Carboniferous as well as in Triassic times glacio- fluviatile and marginal marine conditions prevailed in the downfaulted areas (Hussein 1992). No complete representation of a Palaeozoic rock column can be found in the area and the total thickness of the Palaeozoic adds up to only 2,200 m. Consequently either low sedimentation rates existed or extensive erosion took place (Flexer 2001). During Permian times, very much like during former Paleozoic times, deposition of fluviatile to deltaic sediments in southern Israel and central Transjordan prevailed (Weissbrod 1981, Eshet 1983). In Late Permian, as well as in the Triassic, active rifting along the Zagros suture projected extensional stresses across the Arabian plate. This caused substantial extensional movements along most of the basement-controlled fault systems (Flexer 2001). 


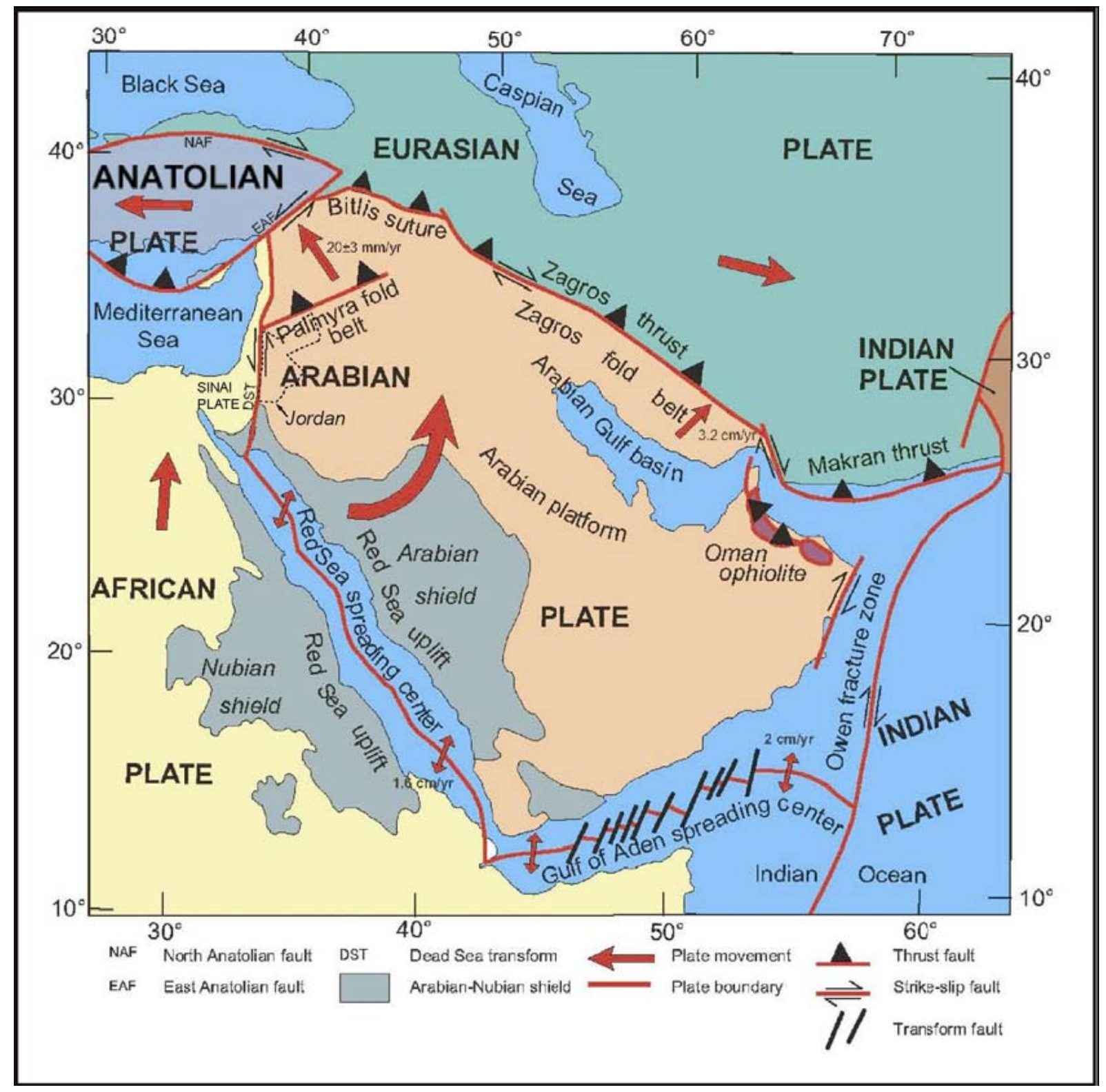

Fig. 2.2-1: Supra- regional tectonic map (Johnson 1998).

\subsubsection{Mesozoic- Paleogene}

During Triassic times the Tethys Ocean advanced over the Arabian Craton and sediments of shallow marine environments covered the eroded Palaeozoic relief. The thickness and the facies of the Triassic sediments were controlled by vertical block movement (Flexer 2001). During four shallow marine cycles a 1,000 m thick sequence of near shore, terrestrial, intertidal, and sabkha lagoonal sediments deposited in Central Jordan and were described by Bandel and Khoury (1981). However, the area affected by these four cycles of transgressions and regressions was no wider than several tens of kilometers (Druckman et al. 1982). The shore was situated north of the Dead Sea and south of Amman (Bandel and Khoury 1981). The volcanic activity associated with the spreading of the Tethys completed the picture of Triassic times.

During Early Jurassic times an Eustatic sea- level rise led to the development of a shallow marine platform. An important tectonic feature of the Jurassic was the appearance of a "hinge belt", which was the basis for a wide carbonate platform along the present coast line of Sinai, Gaza Strip, Israel, and Lebanon. The Late Jurassic to Early Cretaceous time was also characterized by rifting and volcanism. 
While the transition from the Triassic to Jurassic times is marked by a rather small unconformity, the crossover to Cretaceous times is marked by extensive erosion throughout Jordan (Bandel 1981). Thus sandstones of Lower Cretaceous age directly overlie rocks of Triassic age in the south of the wider area of interest or even overlie rocks of Ordovician age in the south of Jordan. During Early Cretaceous times (Neocomian) most of the Levante was covered by these terrigenous sediments. Fluvial systems still eroded the hinterland of present SE Jordan and Saudi Arabia thus building up huge alluvial floodplains. The main transport direction was north to northwest (Powell 1989). Since sedimentary conditions were essentially the same from Cambrian times onward most of the sediments are of similar origin. As a result the whole sedimentary section from Cambrian to Early Cretaceous times is often referred to as the "Nubian series". However, Schneider et al. (1984) proved for the whole series and Bandel and Khoury (1981) for the Triassic series, that subdivisions can be made.

During late Albian to early Cenomanian times a major transgression of the Tethys flooded most of the eastern Mediterranean region. According to Braun et al. (1990), the Cretaceous sequence in the area is "part of the Peri-Arabian hinge belt between the Gondwanaland (African - Arabian platform) and Tethys realms.” This hinge belt, which was formed during Jurassic times, separates the open Tethys to the west from the Arabo-Nubian shield to the SE and runs approximately along the present coastline of Israel, Gaza Strip, and Sinai (Bein 1976; Bein and Weiler 1976; Sass and Bein 1982). The palaeocoastline was near contemporary NW Saudi Arabia and SE Jordan (Philip et al. 2000). The Lower Cretaceous transgression mainly intruded from $\mathrm{N}$ to $\mathrm{NW}$ directions. It was oscillating and progressing slowly during late Aptian and Lower Albian. In the Upper Albian a stable shelf carbonate platform had been established. From Cenomanian to earliest Turonian times shallow marine conditions prevailed (Fig. 2.2-2).
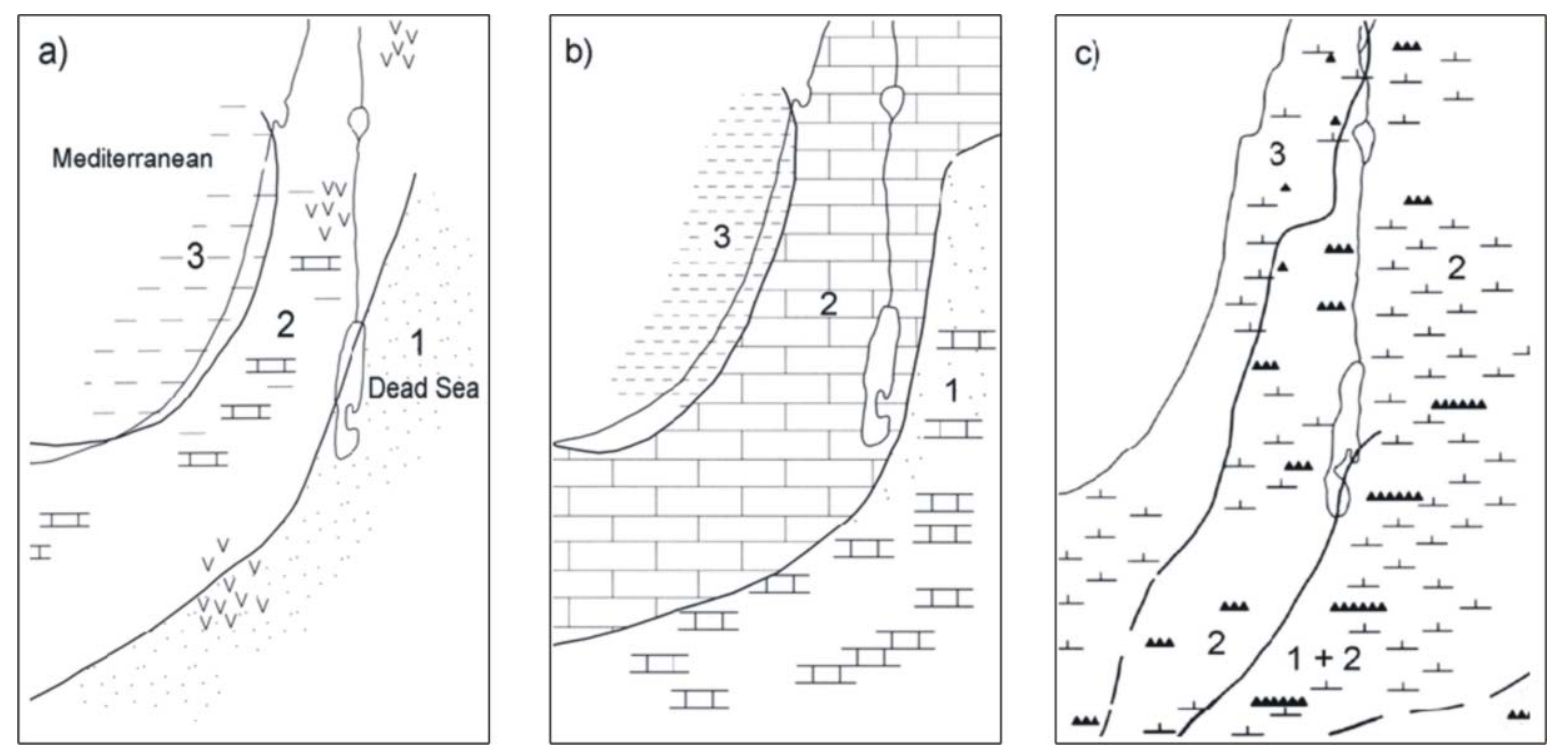

Fig. 2.2-2: Lithofacies belts during Cretaceous times: a) Early Cretaceous facies belts: (1) mostly continental sandstone, (2) sandstones-shale-limestone facies, (3) thick marine shaley sequence and volcanism; b) MidCretaceous (Aptian-Turonian) lithofacies: (1) thin carbonate sequence, interbedded with sandstone, (2) mostly carbonates (limestones and dolomites), (3) mostly calcilutite facies; c) Senonian lithofacies belts: (1) sand, flint, and chalk, (2) chalk, marl, and flint (3) mostly chalk, sparse flint (Flexer 2001).

On a local scale, sedimentation was controlled by basin-swell morphology, probably as a relict of the presedimentary landscape. These laterally rapidly changing facies differences are documented by the change of lithologies, often within a few kilometre's range. However, the dominating facies is described as a typical Tethyian shallow and stable warmwater carbonate platform. The water was very clear and low energy deposition was predominant (Sass and Oppenheim 1966). At times, the basins were very shallow and partly even exposed, as proven by Dinosaur tracks and primary Sabkhadolomites in the Late Albian Israeli Soreq Formation and by mud cracks, ferruginous crusts, and dissolution-precipitation phenomena at the top of the Middle Cenomanian Israeli Amminadav 
Formation (Lewy and Avni 1988) just some tens of kilometers southwest of the study area. In these shallow basins the shoreline undulated due to small sea level changes. The low energy depositional system was guaranteed by extended rudist reefs, that isolated the basin from the open marine condition to a, however locally, varying extent. This setting resulted in the deposition of dolomite in shallow and limestone in deep basins during Cenomanian times. Calcareous deposits mostly cover the area to the north and south of the study area, where thick marly and clayey intercalations deposited within the wider area of interest (Schultze et al. 2003). To the south and southeast an increase in sliliciclastic components can be observed (Powell 1989; Al Rifaiy and Cherif 1987; Abed and El-Hiyari 1986).

During early Turonian times deep water deposits within the lower Jordanian Shueib Formation mark the sea level high stand (Schultze et al. 2003). As indicated by shallow water deposits, the water depth decreased during Turonian times, before another major transgression flooded the area. The barrier function of the reef in Turonian times was not effective and sedimentation was controlled by a series of elongated basins (Bein 1976; Freund 1961). A major Late Turonian sea level drop is indicated by an exclusively non-marine ostracode fauna in the upper part of the Turonian beds together with the development of an extensive karst system (Weiler 1966; Weiler and Sass 1972; Buchbinder et al. 1983).

Beginning with the initial stages of the African-Eurasian plate collision during Late Cretaceous times, large mountain chains formed in the Mediterranean area, such as the Alps and the Hellenids. At the same time a dextrally transpressive reactivation of the Triassic/Jurassic halfgrabens took place along the North African-Arabian plate boundary. As a consequence, an intraplate fold belt was formed (often called the "Syrian Arc" system). This fold belt is represented by a system of folded (inverted) grabens associated with compressive intraplate deformation. Although most of the area was covered by the sea some areas may have partly emerged above sea level (Fig. 2.2-4). The first stages of reverse tectonics and basin inversion commenced in northeast Egypt during Turonian times, but more extensive uplift phases with varying intensities in different regions had been proven for younger intervals, e.g. during Coniacian - early Santonian, late Campanian (Flexer 2001). The most indicative criteria for uplift are locally confined lateral facies and thickness changes and unconformities.

\subsubsection{Cenozoic}

The most prominent feature within and around the wider area of interest is the Dead Sea Transform (DST). Its evolvement formed the area to its present shape. The DST fault zone marks the boundary between the African and Arabian tectonic plates, whereas the Sinai Peninsula is the northeastern tip of the African plate. It extends from the Gulf of Aqaba in the south until the Zargos Mountains, located in southeastern Turkey, in the north with a total length of around 1,000 km (Fig. 2.2-3). The DST drew the attention of geologist for more than 150 years (Lartet 1869; Hull 1886; Blanckenhorn 1914; Suess 1909; Gregory 1921). Although the transform hypothesis is nowadays widely accepted it is still disputed whether the area can be considered as an active Rift (Horowitz 2001) or a Transform Zone.

Most researchers agree that in total $\sim 107 \mathrm{~km}$ of sinistral motion has taken place (e.g. Dubertret 1932). Many authors suggest that the lateral motion of the DST occurred during two different episodes (e.g. Quennell 1956; Freund et al. 1970; Beydoun 1999). In this scenario $65 \mathrm{~km}$ of movement happened during the late Middle Miocene, and the remaining $\sim 42 \mathrm{~km}$ of movement from earliest Pliocene until present (Rotstein et al. 1991). The most prominent argument (among others) for displacement can be seen at the displacement of the Kurnub Facies on both sides of the transform (e.g. Bandel 1981).

The evolvement of the DST is closely linked with the opening of the Red Sea-Suez Rift (Fig. 2.2-3). Its formation history starts after the opening of the Read Sea-Suez rift in the late Oligocene (Hempton 1987). During Middle Miocene much of the area of contemporary Jordan was still draining westwards into the direction of the Mediterranean Sea across the present DST area (Neev 1960; Garfunkel and Horowitz 1966; Garfunkel 1970; Gerson et al. 1985). Consequently the first tectonically controlled basins induced by faulting did not form before Middle Miocene (Fig. 2.2-4). Probably its formation is closely linked to the reduced spreading of the Suez Rift (e.g. Steckler et al. 1988; Shaliv 1989) which resulted in the curved break-up along the present DST (transform fault) using older lines of weakness developed during Precambrian times (Bender 1968). Garfunkel (1981) constructed an Euler pole at $32^{\circ} 42^{\prime} \mathrm{N}$ and $18^{\circ} 48^{\prime} \mathrm{E}$ for the rotation of the Arab plate along its sinistral movement to the north. 


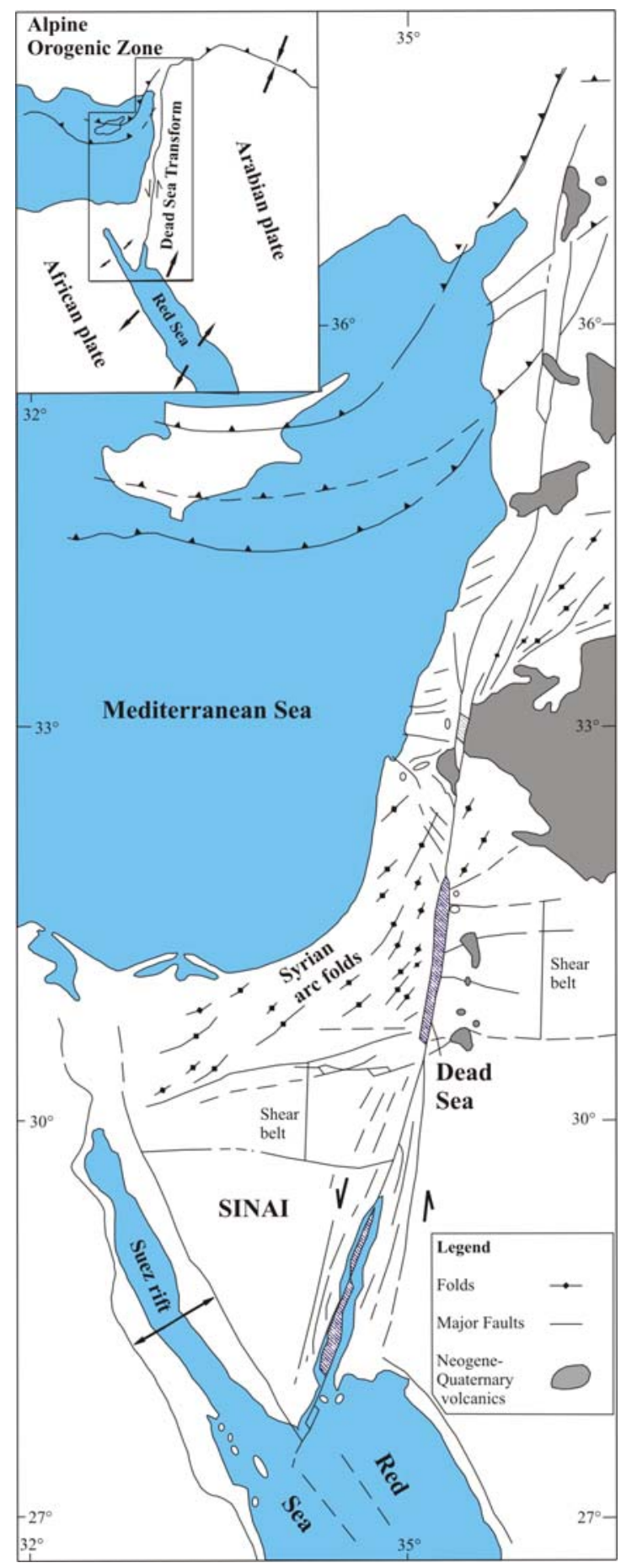

Fig. 2.2-3: Regional setting of the Dead Sea Transform (Garfunkel and Ben-Avraham 1996).

During Pliocene/ Pleistocene times the northward drift of the Arabian plate closed the Biltis ocean (in the area of contemporary northern Syria and Iraq) and led to the collision with the East Anatolian mountain chain (Fig. 2.2-1), which resulted in a short period of angular distension and consequently to parallel detachment faults and in sinking of the DST to a topographic low of another $600 \mathrm{~m}$ (Bender 1974).

The DST jumps at some places sinistral and continues as a parallel fault. As a result of the sinistral movement 'pull apart' basins were developed at the former 'jumping places'. The largest pull apart basins is the Dead Sea Basin, whose basement is believed to be subsided by several kilometers. Because of the arid climate this basin is poorly filled with clastic sediments. Several hundred meters of evaporites, mainly halite, were deposited in the basin. Along the bordering margins of the Dead Sea-pull-apart basin semi-circled slipping faults can be observed, along which clastic sediments slid into the newly opened basin. The formation of the DST was accompanied by igneous activity mainly on the eastern flanks of the region (Jordanian desert). After the withdrawal of the ocean in Plio-/Pleistocene times three different continental depositional environments prevailed in the Dead Sea Basin: terrestrial/fluvial, to deltaic/limnic, and limnic/brackish lake environments.

No detailed description regarding the deep valley fill in central Jordan Valley is available. For oil exploration purposes two deep wells (Jordan Valley 1 and Jordan Valley 2) were drilled in an almost central position. But the geophysical and geological drilling logs are poor for the rather shallow unconsolidated strata. The oldest outcrops of Jordan Valley fill sediments are the Shagur and Ghor el Qatar conglomerates (Bender 1968). The type localities of the Shagur conglomerates are found three kilometers southeast of Kafrein in Wadi Abu Qaraf, 2.5 kilometers southeast of Sweimeh, and three kilometers east of Shagur. All of them are located in Jordan. Bender (1968) gave these massive fluvio- limnic conglomerates, which interlayer with travertine, Upper Plio- to Lowermost Pleistocene age. The type locality of the Ghor el Qatar conglomerates is around $27 \mathrm{~km}$ north of the Dead Sea, next to the village of Ghor el Qatar (Jordan). The age of this fluvio- limnic series was estimated to Early Pleistocene (Bender 1968).

On the other side of the Jordan River the oldest outcrops of the Jordan Valley fill sediments are called Samra conglomerates. The term Samra was first introduced by Picard (1943), its type locality being Khirbet E-Samra $6 \mathrm{~km}$ NE of Jericho. The sediments of the Samra Formation were interpreted as a fluvio-limnic sequence (Picard 1943; Bentor 1960; Bentor and Vroman 1960). A detailed description of the Samra Formation can be found in Begin (1975). The lower age of Lake Samra is not fully known, but was estimated to be older than 350,000 y based on ${ }^{230} \mathrm{Th} / \mathrm{U}$ dated sediments at various location around the western side of the Dead Sea (Kaufman et al. 1992). 


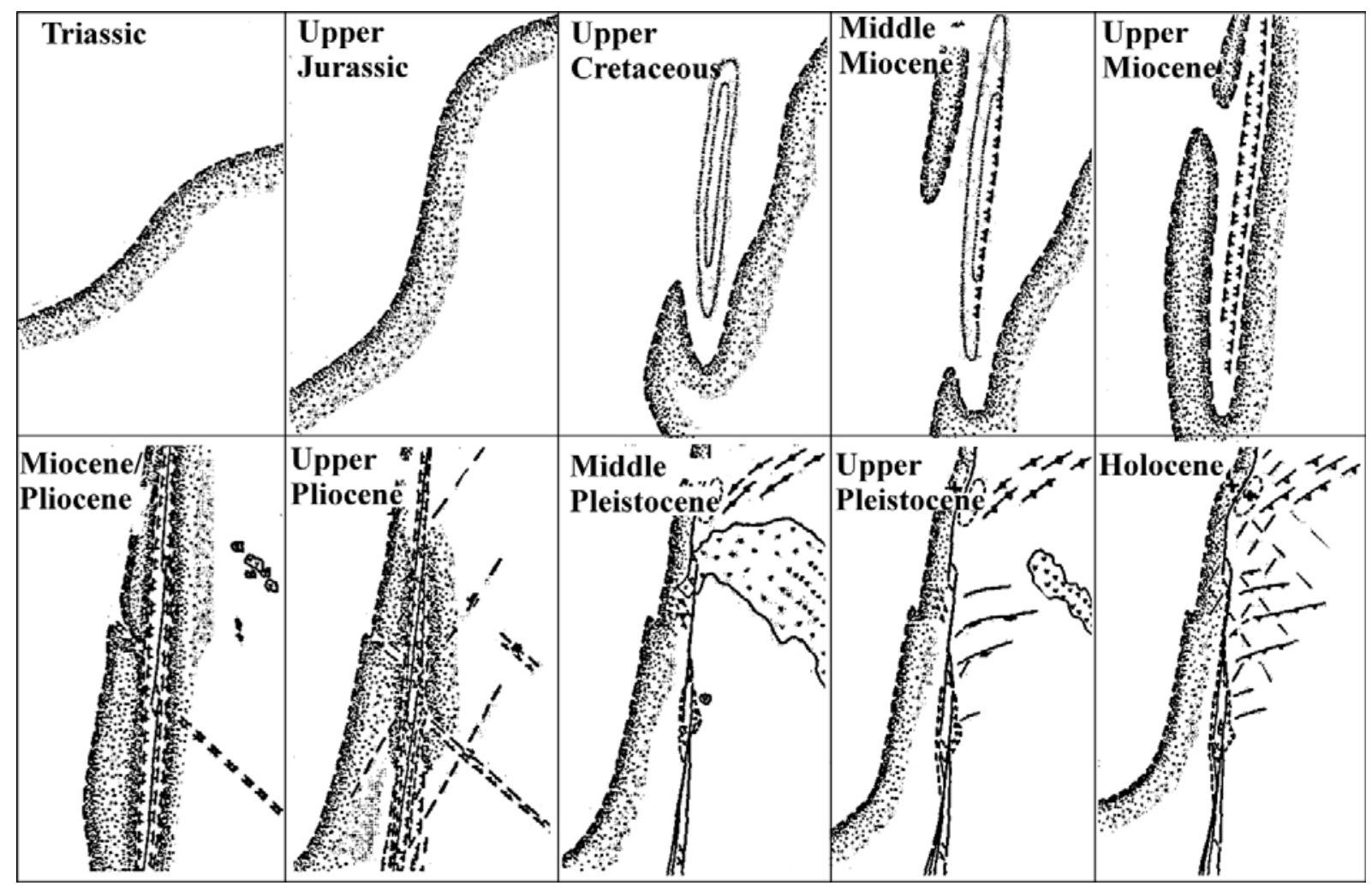

Fig. 2.2-4: Development sketch of the Dead Sea Transform (Bayer 1988).

Since the Pleistocene up to Present several lakes occupied the lower Jordan Valley area (e.g. Lake Samra, Lake Lisan, and the Dead Sea). Regarding the western side of the Jordan River confusion exists with the term Samra. As described above, Picard (1943), Bentor (1960), Bentor and Vroman (1960), and Begin (1975) described the Samra Formation as fluvio-limnic conglomerates of late Plioto Early Pleistocene age pre-dating the younger Lisan Formation. Other authors (e.g. Marie and Vengosh 2001; Khayat et al. 2006), mostly hydrogeologists, use the term Samra as a facies term for alluvial sediments coming from the adjacent West Bank, regardless of their age. Bender (1968) uses the term Samra and Lisan Formation for facies distinction of Pleistocene deposits. Where the Samra Formation refers to alluvial deposits and the Lisan Formation to lacustrine deposits. The third usage of the word Samra is to mean the predecessor of the Lake Lisan. Neev and Emery (1967) described Lake Samra as a freshwater lake with a length of about $220 \mathrm{~km}$ and a width of only $17 \mathrm{~km}$, which in its last phase increased in salinity to the same salinity as the present day Dead Sea (Gardosh 1987). The Samra Formation is conformably overlain by the Lisan Formation.

The bordering age between Lake Samra and Lake Lisan was estimated between 63,000 yr (Kaufman et al. 1992) and 55,000 yr BP (Waldman et al. 2000). The term Lisan was first introduced by Lartet (1869). Lake Lisan existed from around 63,000 to 15,000 yr before present (Kaufman 1971; Kaufman et al. 1992; Schramm 1997; Schramm et al. 2000). The lacustrine sediments of Lake Lisan left terraces of laminated marls of around $40 \mathrm{~m}$ thickness. The maximum thickness of $60 \mathrm{~m}$ was found in the Kalia well near the mouth of the Jordan River (Niemi et al. 1997). Bender (1974) gave a thickness of around 65m meter for the area between Damya and King Hussein Bridge. Detailed outcrop studies including stratigraphy, lithology, and mineralogy of lacustrine sediments at 13 outcrops along a north-south transect were done by Begin et al. (1974). Niemi et al. (1997) summarized in detail the structure and tectonics of the basin, physical, chemical, and biological aspects, as well as Quaternary history of Lake Lisan and the Dead Sea. The highest outcrop of the Lisan formation was reported to be $180 \mathrm{~m}$ below mean sea level around 25,000 BP (Begin et al. 1985), but morphological evidence for a water stand as high as $150 \mathrm{~m}$ (Bowman and Gross 1992) or even $130 \mathrm{~m}$ (Plakht 2000) below mean sea level (b.m.s.l.) was estimated (Fig. 2.2-5). The lowest Lake Lisan level was given by Bartov (1999) to be $340 \mathrm{~m}$ b.m.s.l. Numerous researchers attributed the rapid shrinkage of Lake Lisan (Fig. 2.2-1) to 
climatic changes, dry periods, and tectonic activities (Neev and Emery 1967, Horowitz 1979, Goldberg 1994, Niemi et al. 1997, Bar Yousef 1987, Druckman et al. 1987 among others). However, according to Salameh and Al Farajat (2007) the rapid shrinkage of Lake Lisan is the result of the reduction of the catchment area from $157,000 \mathrm{~km}^{2}$ during Late Pleistocene to $43,000 \mathrm{~km}^{2}$. The reduction in the catchment areas resulted from the eruption and formation of Jabal Arab-Druz. Therefore, the parts of the Lake Lisan catchment which lie north, east and south of Jabal Arab-Druz where cut off from the rest of the drainage area.. The salinity of Lake Lisan was around $15 \%$ (or about half of the present Dead Sea) during most of its existence (Katz and Kolodny 1977). Begin et al. (1974) based on 13 outcrop studies divided the Lisan Formation into the laminated and the "white cliff" member. Gibbs (1986) divided the Lisan Formation at Karameh dam site into three units: lower laminites, middle clays, upper laminites and gives a total thickness of around $44 \mathrm{~m}$. Within the study area the Lisan Formation overlies either older lacustrine and clastic sediments or rests unconformably over older bedrock. The mineral content of the Lisan Formation is: Aragonite, Gypsum, Calcite, Halite, Quarz, and different Feldspars (Landmann et al. 2002). The laminated part of the Formation consists of alternating white and brown to gray-greenish layers. The predominance of Aragonite as constituent of the white layers gives the lamina its white color. Neev and Emery (1967) among others observed 'whitenings' in the upper part of the Dead Sea during the hottest period of the year. These 'whitenings' in the upper part of the diluted water column, the fallout of Aragonite crystals and nonclastic deposition, is believed to have happened during Lake Lisan times (Katz et al. 1977). The graygreen to brown layers on the other hand are made up of detritus carried to Lake Lisan during storm events from the adjacent Wadis and from the increased sediment load of the perpendicular Jordan and Arava Valley during colder and wetter winter times. The presence of Chlorite gives the gray-greenish layers their color, while the presence of Montmorillonite and Illite gives the brown layers their peculiar appearance (Reid and Frostick 1993). A considerable variation of detrital and Aragonite layer thicknesses could be addressed to 'wetter' and 'drier' years respectively. According to Reid and Frostick (1993) in $80 \%$ of instances the detrital laminanae lying successive between the white layers. An exception is the white cliff member, where white layers are dominant. Begin et al. (1974) explained this as a shift to a more arid climate.

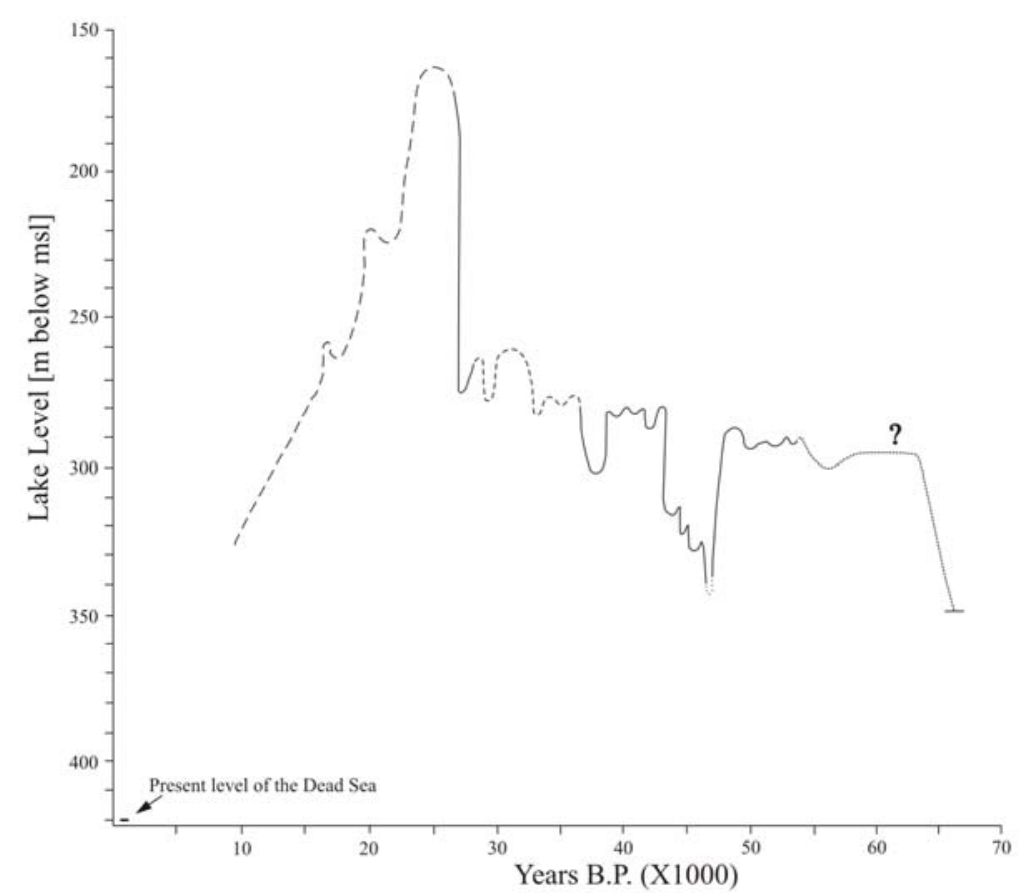

Fig. 2.2-5: Lake- level curve of Lake Lisan (55,000 - 15,000 cal yr B.P.) and present level of the Dead Sea (slightly modified from Bartov et al. 2002). 
Lisan sediments are interdigitated with coarse to very coarse deposits of alluvial fan-delta systems. They are fully described by Sneh (1979) and Frostick and Reid (1989). Frostick and Reid (1989) identified two alluvial facies: subhorizontally stratified, clast-supported but matrix-rich braided stream deposits of subaerial fans and steep-angled gravel-couplets of a Gilbert-type delta. At an outcrop at Nahal Rahaf a fan-delta system was described for a section of about 10,000 years. Only seven major coarse agradation cycles were identified. Reid and Frostick (1993) found out that major storm events carrying large amounts of detrial (coarse to very coarse) components only occur around every 1,000 years. The present day Dead Sea has developed over approximately the past 3,000 years (Klein 1982; Bowman 1997; Kadan 1997; Ben-David 1998; Enzel et al. 2000; Ken-Tor et al. 2001). Holocene gravels deposited as alluvial fan sediments in the Jordan Valley complete the picture of the supraregional geology. The following section is taken from Toll et al. (in preparation) and describes the regional geology of the study area and its surroundings.

\subsubsection{Regional Geology of the wider area of interest}

\subsubsection{Consolidated-rock stratigraphy and aquifers}

Along the lower Jordan/ NE Dead Sea foothills area three consolidated sedimentary sequences can be identified, which are separated from each other and from the underlying crystalline basement by major unconformities. The Cambrian to Early Ordovician Ram Group represents a fluvial sandstonetransgressive siltstone/limestone-regressive mature sandstone cycle draping all over the crystalline basement with southward increasing thickness from an estimated $700 \mathrm{~m}$ around the Wadi Zarqa area to about $1 \mathrm{~km}$ near Madaba. It comprises the Disi Aquifer, which was encountered in well JICA No. 5 $\mathrm{S}$ of Kafrein.

The overlying Permian to Jurassic Hudayb, Ramtha, Azab Groups (formerly agglomerated as Zarqa Group) consists of unconformity-bounded marginal marine sandstone-carbonate-shale associations most of which are classified as aquitards. To the SE all of them wedge out so that a total thickness of an estimated $1 \mathrm{~km}$ around Wadi Zarqa is reduced to about 250 to $300 \mathrm{~m}$ south of Kafrein where the Jurassic Azab has tapered out completely and only the lower part (eg. Scythian to Anisian) of the Triassic Ramtha Group intercalated between the Ram Group and the following Cretaceous strata. SE of Wadi Naur-Wadi Kafrein the Ladinian and Carnian gypsiferous formations (Umm Tina, Abu Ruweis) were completely removed by pre-Cretaceous erosion (Bandel and Khoury 1981).

Above the early Cretaceous transgressive unconformity follows the sandy Kurnub Group (Neocomian), the limestone-marl sequences of the Ajlun Group (late-Albian to end of Turonian) and the predominantly chalky Belqa Group (Coniacian to Eocene). The fluvial to marginal marine sandstones of the Kurnub Group increase in thickness northwestward attaining 180 to $200 \mathrm{~m}$ at the NE end of the Dead Sea and 250 to $300 \mathrm{~m}$ in the Wadi Zarqa area. They form the Kurnub aquifer (Fig. 2.2-6 and Fig. 2.2-8) characterized by low salinities.

The lower Ajlun Group (Naur, Fuheis, Hummar, Shueib Formations; A1 to A6) with 300 m of subtidal to peritidal marls, nodular limestones, massive limestones reflect several transgressive to highstand cycles of a permanently submerged carbonate platform which however ends with a late middle Turonian lowstand generating upper Shueib F. shallow water dolostones and marls grading S-ward into supratidal gypsiferous claystones (Schulze et al 2003). Thus, mainly due to the Fuheis and the Shueib marls and claystones the lower Ajlun (A1 to A6) forms a multilayer aquitard, in some areas even an aquiclude with embedded aquifers e.g. the massive limestones of the upper Naur and of the Hummar Formations. In contrast, the overlying ca. 100 m of Wadi as Sir Formation (A7) of the area consists mainly of well bedded and massive limestones of a prograding and agrading carbonate platform and together with the basal Belqa Group forms the important Upper Aquifer (A7-B2 aquifer).

After an episode of non-deposition the pelagic chalks of the Wadi Umm Gudran and Amman cherty limestone Formations of the Belqa Group were deposited, which on the western-facing slopes are preserved in synclines. Only on the crest of the Transjordanian Mts. and beyond they form a gently 
eastward sloping continuous layer where they are overlain by bituminous marls and chalks of the B3 aquitard (Muwaqqar Form.).

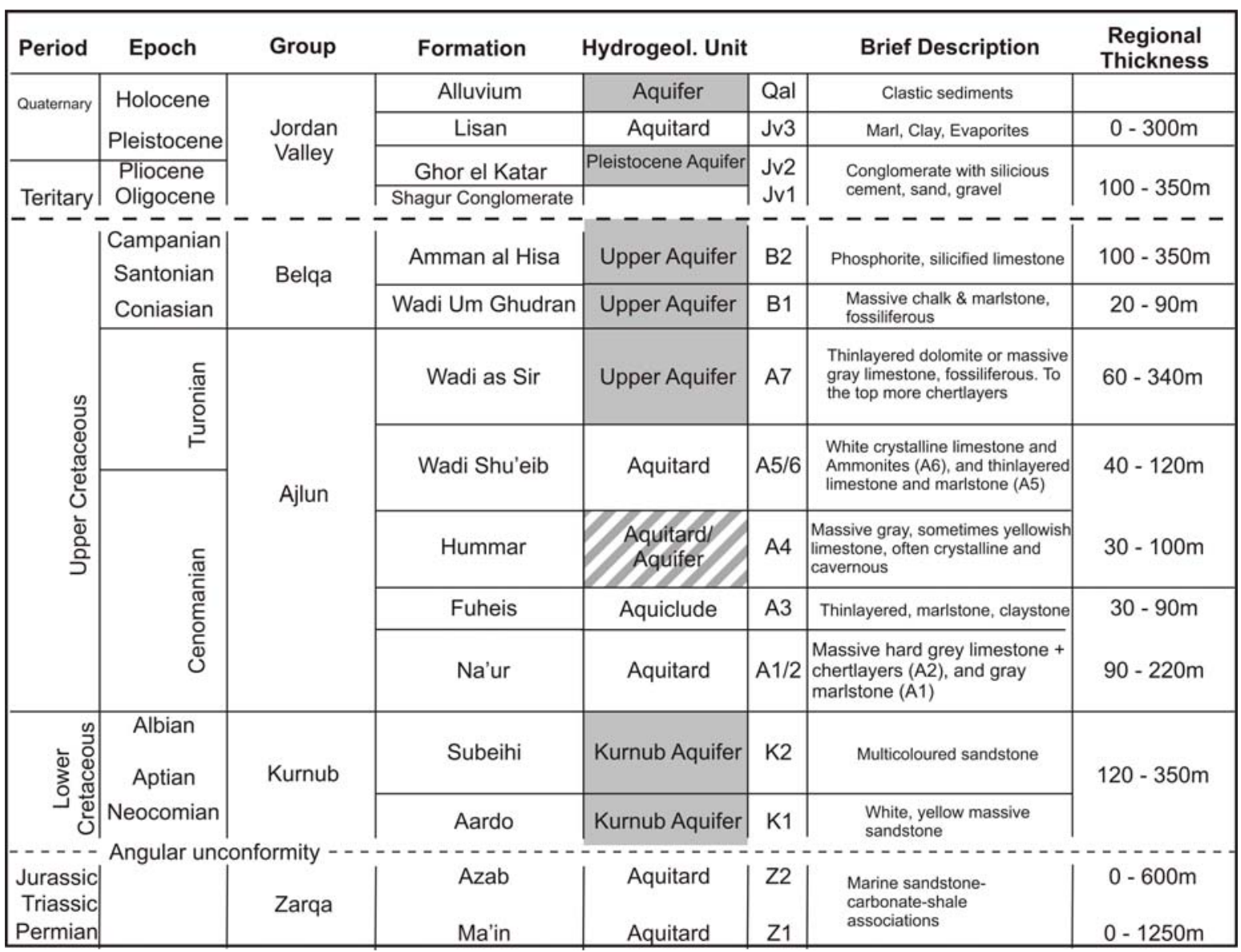

Fig. 2.2-6: Stratigraphic table of Rock Units in the wider area of interest (modified after Shawabkeh 2001).

\subsubsection{Unconsolidated rocks - Jordan Valley Group}

Three different continental depositional environments have played a major role since the development of the Jordan Valley basin. These environments are terrestrial/fluvial, deltaic/limnic, and limnic/brackish environments.

Upper Pliocene to lower Pleistocene Unit

As stated above, the early history of the Jordan Valley Group is not fully known. In the study area the above described Shagur Formation is believed to be the oldest formation deposited in the Jordan Valley (Upper Pliocene - Lower Pleistocene). The Shagur Formation consists of massive, crudely bedded fluvio- limnic conglomerates that alternate with crudely bedded travertine and marl or claystone. This unit overlies unconformable older consolidated rocks. Clasts are angular to subangular and siliceous cemented. In the type localities in the east and south the terrestrial to fluvio- limnic Shagur Formation has a thickness of approximately $75 \mathrm{~m}$. However, thickness changes significantly within the different facies types (Bender 1965). While the Shagur Formation crops out in the east and southeast of the study area, it was not reported, neither in the deep oil wells Jordan Valley 1 and 2, nor in the wells drilled by the Ministry of Water and Irrigation. No outcrop of the Ghor al Qatar Formation exists in the study area.

Pleistocene Unit

During Pleistocene times, three members can be distinguished. The three members (the coarse clastic, the silt and the lacustrine) are a vertical and lateral facies succession from terrestrial/fluvial, to deltaic/limnic and limnic/brackish lake environments. As stated above, Bender (1965) divided these different depositional environments into two members: Samra and Lisan. But in order to avoid confusion with the word Samra, the term Pleistocene Aquifer will be used for the coarse clastic and 
the silt member henceforward. The "Pleistocene aquifer" consists of the coarse clastic and the silt member. However, exploitable water resources are principally restricted to the coarse clastics member. The lacustrine member (Lisan Formation) consists of marl, gypsum and silt, and is generally considered an aquiclude, void of exploitable water. It crops out mainly in the west of the study area. Since the Lisan Lake reached an elevation of $-180 \mathrm{~m}$ above mean sea level its sediments can be found in incised channels of the major wadis up to the margin of the Jordan Valley (Fig. 2.2-8). Its total thickness is around $40 \mathrm{~m}$. The coarse clastic member consists of gravel, interbedded with clay, sand and marl horizons. Both, the coarse clastic and the silt member underlie, overlie, or interfinger with the Lisan Formation .

Holocene or sub-recent Unit

This unit is built up of sub-recent terrigenous sediments deposited along the outlets of major wadis. These alluvial fans are still accumulating as a result of large floods. They consist of debris from all neighbouring lithologies and are deposited according to their transport energy. The biggest components are found close to the apex and the smallest close to the fan margin. The transport normally takes place along alternating channels or after very heavy rain storms as sheet, or debris flow. Thus permeable horizons alternate with less permeable lithologies within these deposits. It is believed that the thickness maximum is near the valley margins, thinning out towards the centre of the basin. Well depth is rarely beyond several tens of metres. Often the alluvial aquifer directly overlies the Pleistocene gravel aquifer and because of that is hydraulically interconnected with this aquifer.

Since the study area is made up of this unconsolidated strata a special chapter (chapter 4.2) is devoted to the sedimentology of the unconsolidated strata.

\subsubsection{Geologic Structure}

Pre-Cretaceous structural imprint on the subsurface rocks of the area is virtually unknown. Triassic and/or Jurassic phases of extension are indicated by a number of basaltoid dykes and sills in the Ramtha and Azab Groups which did not intrude the Cretaceous cover (e.g. Bandel and Khouri 1981). The structures most pertinent to groundwater flow is manifested in the unconformity between the Turonian limestones/ dolomites and the Senonian chalks. Thus the variable stratigraphic gap is associated with the embryonic 'alpidic' phase of folding in the Syrian Arc and is followed by the Coniacian-Santonian world-wide transgression (Braun et al. 1987; Haq et al. 1987). The Syrian Arc System that formed in early Senonian (Bentor and Vroman 1951, 1954, 1960; Bartov 1974) evolved under a regional WNW-ESE compressional stress field that dominated the region until Miocene (Eyal and Reches 1983; Eyal 1996). These structures were modified during the following Miocene to present-day deformation associated with shear on the N-S-trending Dead Sea Transform Fault (DSTF) which in the area runs close to the River Jordan.

The Syrian Arc deformation produced the following fold and fault structures exposed in the eastern slopes of the southern Jordan Valley between Wadi Zarqa and the eastern shore of the Dead Sea. Salameh (1980) and Mikbel and Zacher $(1981,1986)$ on the base of structural field measurements, aerial photograph interpretation gave a time frame between Maastrichtian and Oligocene/Miocene for the evolvement of the Wadi Shueib Anticline and Amman-Halabat structure or Amman Flexure. The major fold and fault structures are listed from $\mathrm{N}$ to $\mathrm{S}$ (Fig. 2.2-7):

- a dome-like structure around Salt where the base of the Cretaceous (bCr) rises to $+400 \mathrm{~m}$ aSL;

- the Wadi Shueib Syncline, where bCr drops to -500 m bSL near Shuna;

- the Wadi Shueib NW -facing monoclinal flexure plus associated normal faults;

- the Wadi Shueib composite anticline where bCr between Shuna and Kafrein rises to -250m;

- the NNE-trending Kafrein normal fault and associated faults bounding the Kafrein syncline to the $\mathrm{W}$;

- the Kafrein asymmetric syncline (bCr ca -400 to $-800 \mathrm{~m}$ ):

- the NE- to ENE- trending Amman flexure and associated faults facing toward NW;

- the gently warped dip slope SE of the Amman flexure where bCr rises again to about $+300 \mathrm{~m}$ aSL. 


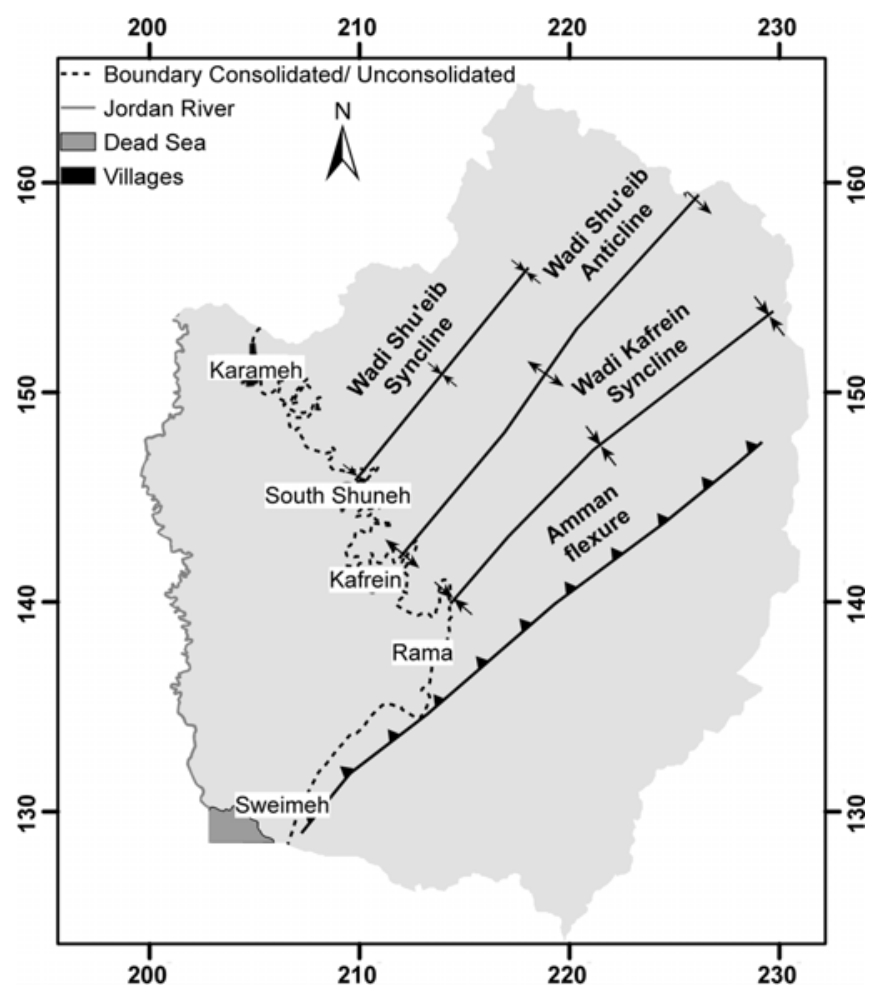

Fig. 2.2-7: Main structural features in the wider area of interest.

These structures are modified or enhanced by sets of normal faults trending NNW and NW which may be regarded as syn- and antithetic to the subsiding Jordan Valley depression.

The network of Wadis flowing down the western slopes of the Transjordanian Mountains toward the Jordan Valley depression seem fairly well controlled by the above structures of the Cretaceous rocks. For example wadis follow synclines (Wadi Shueib, Wadi Kafrein etc). They also follow a combination of structural dip with NWtrending antithetic or ac-faults on the dip slope SE of the Amman Flexure (Wadi Hisban/ ar Rama, Wadi al Muhtariqa, Wadi al Hiri E of Suwayma). This may reflect some of the controls geologic structure exerts on subsurface flow pathes of groundwater in the consolidated rock sequences.

\subsubsection{Subsurface contacts between consolidated rocks and unconsolidated Jordan Valley Group sediments}

Due to the spatial variability of the hydraulic potential and the multilayer nature of aquifers and aquitards in the consolidated rock sequence hydraulic contacts with the unconsolidated valley sediments play a major role in the hydraulic budget.

At the foothills of the highlands near Al Karameh, South Shuneh, Kafrein, Sweimeh the base of the Jordan Valley Group sediments (bJVG) crops out at an altitude of ca. $-200 \mathrm{~m}$ b.s.l. A preliminary analysis of reflection seismics in combination with the deep wells JV1 and JV2 shows that the late Cretaceous structures continue beneath the younger Jordan Valley Group sediments (Heinrichs et. al 2004; AlZoubi et al. 2006). The same data reveal a drop of the bJVG along the Wadi Shueib composite anticline from $-200 \mathrm{~m}$ at the surface to about $-500 \mathrm{~m}$ b.s.l. at 4 to $5 \mathrm{~km}$ distance WSW of the outcropping contact. This dip corresponds roughly to the dip of the Cretaceous strata $\mathrm{E}$ of the contact (Fig. 2.2-9). It can therefore be concluded that up to this location on this anticline Naur and Kurnub Formations are directly overlain by unconsolidated sediments. Further W and toward SW seismic data suggest that higher stratigraphic levels of the Cretaceous are preserved and in contact with the unconsolidated sediments in spite of the bJVG dipping steeply toward W and toward the Dead Sea in the south. A similar inference can be made for the Wadi Shueib Syncline where the Wadi as Sir Formation should be continuous for some distance under the base of the unconsolidated sediments. At the moment low density of seismic information does prevent tracing the major faults into the subsurface of the Jordan Valley. 


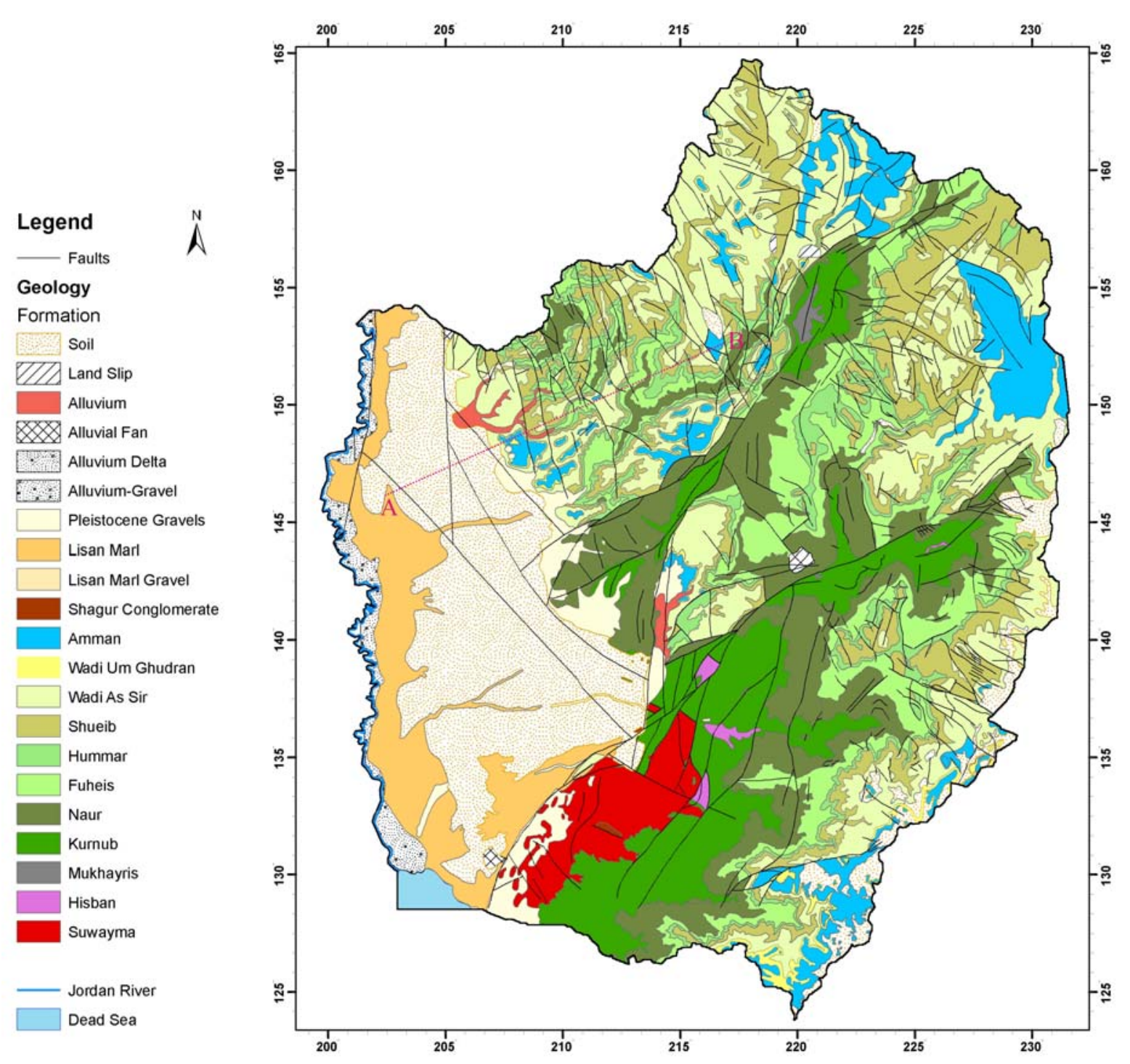

Fig. 2.2-8: Geological Map of the wider area of interest (after McDonald and Partners 1963; Shawabkeh 2001; Diabat and Abdelghafoor 2004).

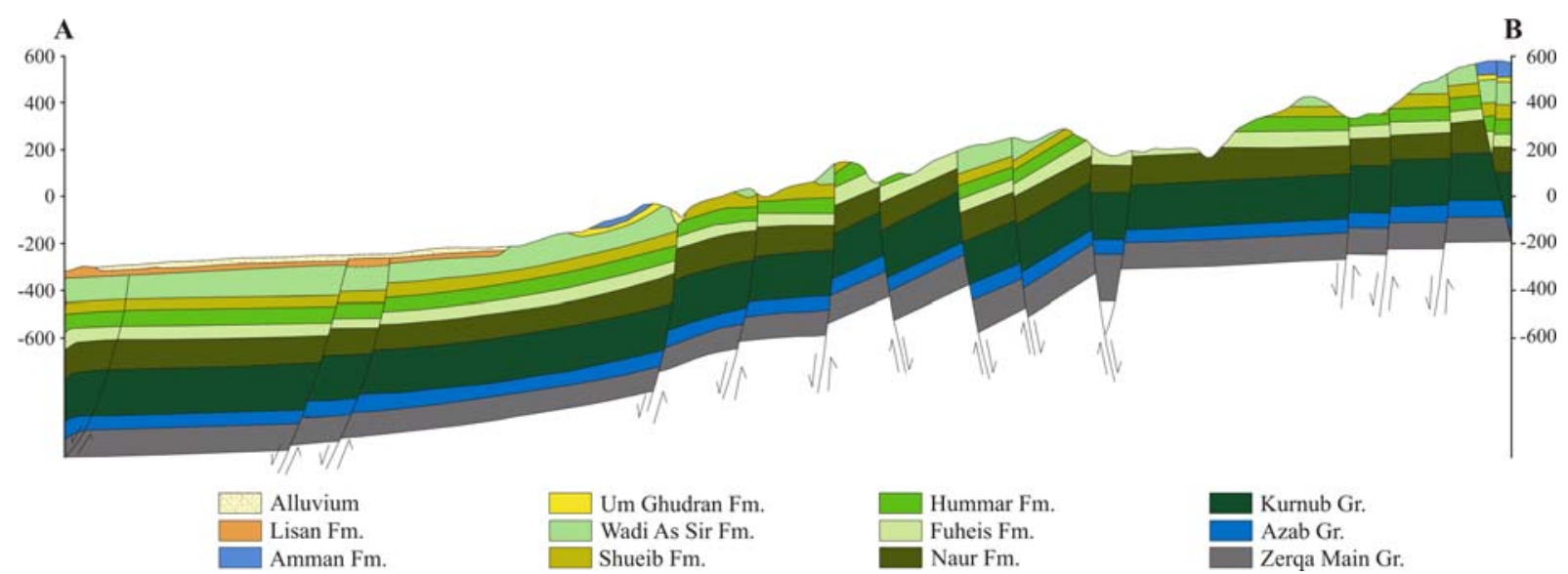

Fig. 2.2-9: Geological cross section in the northern part of the wider area of interest (slightly modified after Shawabkeh 2001). Location of the cross section is indicated in fig. 2.2-8. 


\subsection{AQUIFER SYSTEMS}

\subsubsection{Introduction}

Four major aquifer systems are known in Jordan. They are locally subdivided into subunits and cover a period from Cambrian to recent age. These four major systems are (from base to top):

First, the Cambrian through Ordovician, Ram Group Aquifer, which consists of friable, weeklycemented medium to coarse-grained sandstone, also known as 'Disi Aquifer'.

Second, the Permian through Lower Cretaceous, Lower Aquifer System. This aquifer covers the sediments deposited during Permian, Triassic, Jurassic (Zerqa Group), and Lower Cretaceous (Kurnub Group). The lower Aquifer System is made up mostly of thick sandstone beds, intercalating with marl and clay and sometimes limestone beds. In the southern part of the country this unit is hydraulically separated from the Ram Group Aquifer by the Khreim Group (Ordovician - Silurian) whereas this barrier disappears in the northern part of the country where both the Ram Group Aquifer and the Lower Aquifer System form the Deep Aquifer Complex.

Third, the carbonate sediments of Middle to Upper Cretaceous ages (Ajlun and Belqa Groups) build up the Upper Aquifer Complex. Compared to the previous units, this unit cannot be regarded as one unit. It is rather a combination of different sub aquifers.

Fourth, the Pleistocene to recent unconsolidated Aquifer. This aquifer is of local importance, and builds normally a shallow aquifer of limited extension along wadi courses in the Jordan Valley, and in local highland base levels. It is mostly used for agricultural purposes and is intensively used in lower Jordan Valley, the centre of this study. The aquifer consists of alluvial material. Adjacent and imbedded into this local aquifer are lacustrine sediments and evaporites.

\subsubsection{Ram Group Aquifer ('Disi Aquifer')}

Due to regional uplift the Ram Group Aquifer is exposed in the south of Jordan as well as in the southeastern desert and in some areas along the shoulders of Wadi Araba and east of the Dead Sea (Bender 1967). It underlies the entire country and its thickness increases towards the north and northeast and reaches around 3,000 m near the Iraqi border.

The Ram Group Aquifer consists mostly of sandstones with intercalations of limestone or siltstone layers. The Aquifer has no outcrop within the study area, but was tapped by JICA Well No. 5 at $345 \mathrm{~m}$ depth (-422.5 $\mathrm{m}$ a.s.l.) and is believed to be tapped in Well No. 6 ( $-486.1 \mathrm{~m}$ a.s.l.). Within the study area the aquifer is under artesian conditions. JICA Well No.5 penetrates the upper $50 \mathrm{~m}$ of this unit. While only small amounts of water discharged from the borehole during the drilling of the Zerqa Aquifer Unit, huge amounts of flowing water (100 l/s) flowed from the borehole after tapping the Ram Group Aquifer. The same happened in Well No. 6, where the base of the Zerqa was drilled at a depth of $275 \mathrm{~m}$ (-486 m a.s.l.). No rock samples could be taken from the depth of $275 \mathrm{~m}$ to the final depth of $298 \mathrm{~m}$. But huge amounts of flowing water $(20-300 \mathrm{l} / \mathrm{s})$ were encountered at a depth of $275 \mathrm{~m}$. This contrasts with the 1-2 l/s of flowing water during the penetration of the previous $11-274 \mathrm{~m}$. Therefore, a penetration of the upper $23 \mathrm{~m}$ of the Ram Group Aquifer was assumed (JICA 1995). Due to the fact that a large contrast of flowing water between the Ram Group Aquifer and the overlying Zerqa Aquifer exists, a good hydraulic separation of these two systems can be assumed. However, leakage of groundwater into the Zerqa Group Aquifer along preferential flow paths, e.g. along open faults, might take place as a result of the high hydraulic pressure of the Ram Group Aquifer.

Tab. 2.3-1 shows the hydraulic properties of the aquifers in the study area. Values were obtained from pumping tests in JICA Well No. 5 and Well No. 6 (JICA 1995). The salinity of the Ram Group Aquifer water is rather high $(5,000$ to $5,200 \mathrm{mg} / \mathrm{L})$. According to the structure contour map prepared by Margane et al. (2002) recharge to the Ram Aquifer, within the wider area of interest, can be attributed to seepage, leaking from aquifer units above. Most of the groundwater stored in the Disi aquifer is palaeowater. 


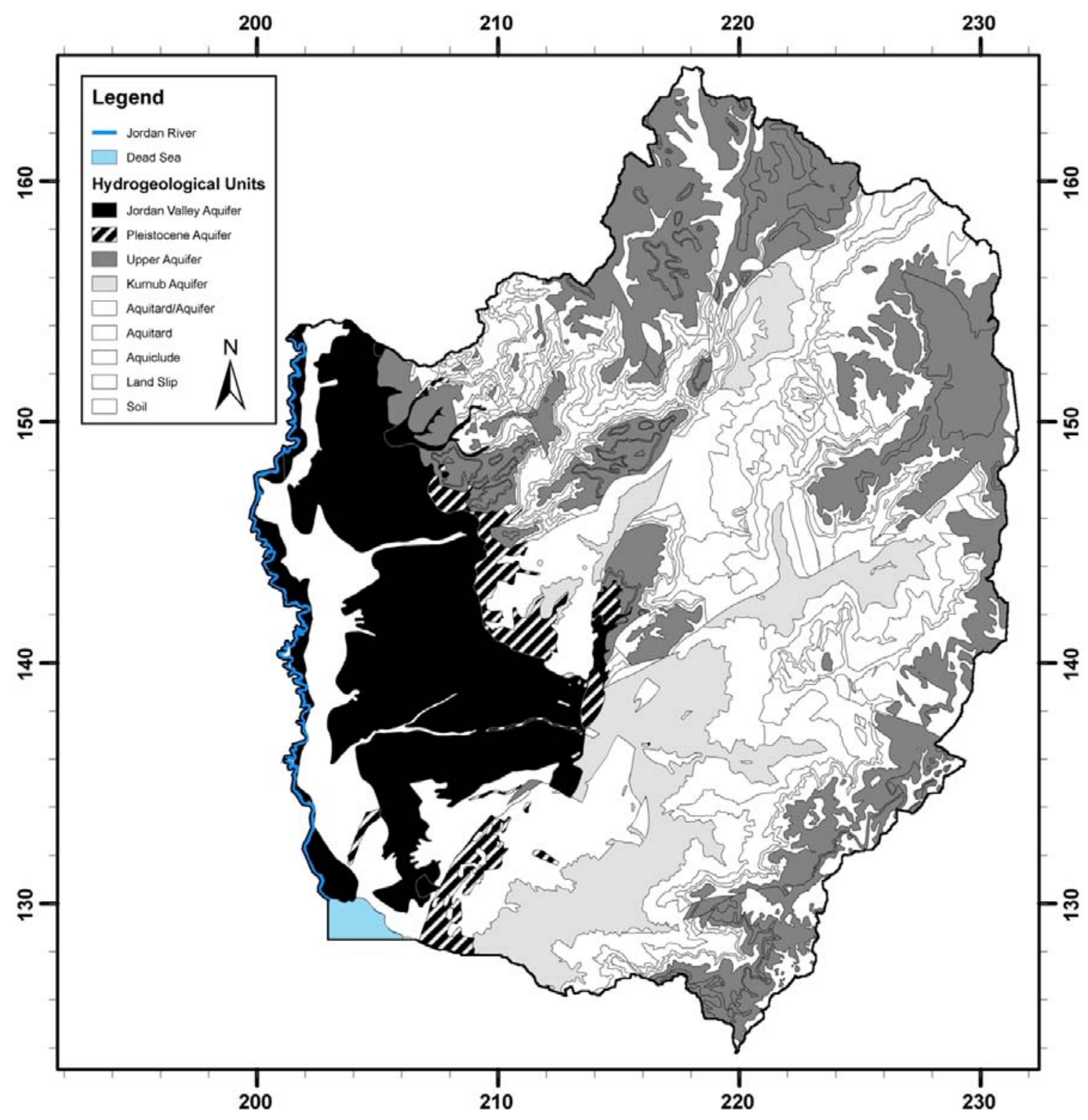

Fig. 2.3-1: Aquifer Systems in the study area (map is based on the maps prepared by McDonald and Partners 1963; Shawabkeh 2001; Diabat and Abdelghafoor 2004).

\subsubsection{Lower Aquifer Complex}

\section{Zerqa Group Aquifer:}

In the wider area of interest the less productive Zerqa Group Aquifer is subdivided into three formations: the Suwayma Sandstone Limestone-Shale Formation, the Hisban Limestone Formation, and the Mukhayris Sandstone- Shale Formation (Shawabkeh 2001). Consequently the aquifer can be described as an alternation of sandstones, limestones, marls, and shales. Permeable layers consist of sandstone or limestone or dolomitic limestone with porosities of $10-18 \%$ (Abu Ajamieh 1998) that alternate with less to poorly permeable clay and marl layers.

The Zerqa Group crops out mainly in the south and southeast of the wider area of interest (Fig. 2.2-8) and, to a smaller extent, along the Amman- Hallabad structure located to the northeast of Amman. The total outcrop area is around $28.9 \mathrm{~km}^{2}$ (Mukhayris: $1.5 \mathrm{~km}^{2}$; Hisban: $2.4 \mathrm{~km}^{2}$; Suwayma: $25.0 \mathrm{~km}^{2}$ ). Within the area of interest the aquifer is tapped in six wells: JICA Well No. 5 and 6, Hisban Well 1 and 2, and Kafrein 6 and 7. 
The thickness of the Zerqa Group is variable. In the Wadi Hisban area it is around $300 \mathrm{~m}$ of which $90 \mathrm{~m}$ are saturated with groundwater (JICA 1995). At the outlet of Wadi Mujib, around 35 kilometres to the south of the wider area of interest, the Zerqa Group is completely absent and the lower Cretaceous Kurnub Formation lies unconformable over the Ram Group (BGR/WAJ 1996).

During the drilling of JICA Wells No. 5 and 6 small amount of flowing water (1-2 l/s) were observed. Saman and Al Masri (1988) reported an initial yield of $1,839 \mathrm{~m}^{3} / \mathrm{h}$, but Salzgitter and JCE (1992) stated that more than $2,000 \mathrm{~m}^{3} / \mathrm{h}$ could be extracted from this unit.

The Zerqa Group Aquifer is separated from the Kurnub aquifer by a marl layer of 25 to $55 \mathrm{~m}$ in thickness. This marl layer can be considered as an aquitard. A leakage factor of $0.7 \times 10^{-4} \mathrm{~m} / \mathrm{d}$ was calculated from a combination of pumping tests (JICA 1995).

Due to the deposition of evaporites within this group (Abu Ajamieh 1998) the salinity of the Zerqa Aquifer water is high. Salinities of 5,000 mg/L in JICA Well No.5 (JICA 1995), 3,280 - 4,100 mg/L in the Hisban wells (Saman and Al Masri 1988), and 3,000 (Salzgitter and JCE 1992) to 5,750 mg/L (JICA 1995) in the Kafrein wells were reported. In Wadi Hisban salty springs emerge from the Zerqa Aquifer.

Recharge of the Zerqa Group Aquifer derives mainly from the lateral flows of the combined RamKurnub Aquifer in the south and from the percolation of overlying aquifer and to a smaller extent from direct infiltration of rainwater.

\section{Kurnub Group Aquifer:}

The Kurnub Aquifer crops out mainly along the southeastern part of the wider area of interest and along the axis of the Wadi Shueib anticline and along the Amman- Flexure. The total outcrop adds up to $83.9 \mathrm{~km}^{2}$.

The Kurnub Aquifer consists of white as well as varicoloured sandstone with thin clay layers and limestone and dolomitic intercalations (Bender 1968; Lenz 1999). Its effective porosity is around $3 \%$ (Abu Ajamieh 1998).

The thickness of the Kurnub Group varies from 244 - $270 \mathrm{~m}$ in the area of Zerqa Main, located around $18 \mathrm{Km}$ to south of the wider area of interest, to $168 \mathrm{~m}$ in the area of the Zerqa River (Powell 1989), located $30 \mathrm{~km}$ to the north of the wider area of interest. Within the wider area of interest a whole section of the Kurnub Group is not present and no borehole information regarding the thickness of the Kunrub Formation is available.

Several wells were drilled and filtered in the Kurnub Group. The wells Kafrein 8 and 10 and Rawda 3 penetrate solely the Kurnub Group. The wells Kafrein 2, 3, 4, and 5 extract water both from the Kurnub Group and the overlying lower Ajlun Group. Kafrein 6 is filtered in the Kurnub and the Zerqa Group (MWI). All wells, except for Rawda 3, are under confined conditions with an initial yield ranging from $40-600 \mathrm{~m}^{3} / \mathrm{h}$ (Saman and Al Masri 1988). In 1982 the total production of the Kurnub wells was $900 \mathrm{l} / \mathrm{s}$. The yield dropped considerably to $80 \mathrm{l} / \mathrm{s}$ in 1991 where hydraulic pressure seems to have stabilized (Salzgitter and JCE 1992). No hydraulic parameters were available for the wells drilled in the wider area of interest. Tab. 2.3-1 shows the hydraulic parameters of the Kurnub Aquifer outside the wider area of interest. Several springs emerge from the Kurnub aquifer.

The salinity of the Kurnub aquifer water is low, but varies considerably when influenced by the underlying highly saline Zerqa Group aquifer. The lowest salinity of $400 \mathrm{mg} / \mathrm{L}$ was found in the Kurnub well Rawda 3. The wells combining the Zerqa Group with the Kurnub water show an increasing salt content. The amount of total dissolved solids ranges from 1,500 mg/L (Saman and Al Masri 1998) to 6,000 mg/L (JICA 1995).

\subsubsection{Upper Aquifer Complex}

The Upper Aquifer Complex includes the water bearing formations of the Ajlun and Belqa Groups. While in the north and northeastern part of Jordan the lower Ajlun Group is considered as one unit, a 
multi-layered system prevails within the wider area of interest (Abu Ajamieh 1998). The multi-layered system consists of the Na'ur Aquitard, the Fuheis Aquiclude, the Hummar Aquitard/ Aquifer, the Wadi Shueib Aquitard and the highly productive Wadi As Sir to Amman aquifer. The Rjam and the Wadi Shallala Aquifers are not found in the considered area. Recharge to the Upper Aquifer complex derives mostly from direct infiltration of rainwater during the rainy season.

\section{Na'ur Aquitard}

The Na'ur Formation crops out mainly along the Amman and Wadi Shueib flexures. Moreover it can be found in the deep incised Wadi of lower Wadi Shueib and in some areas northwest of it. The total outcrop adds up to $106.0 \mathrm{~km}^{2}$.

The basal marls of the Na'ur Formation (Parker 1969) separate the underlying Kurnub Aquifer hydraulically from the overlying aquifers. The thick limestone or dolomitic limestones of the upper part form an aquifer of local importance, where the productivity depends on the marl to limestone ratio.

A more complete picture regarding thickness distribution of the nodular and dolimitic limestones/ dolomites of the Na'ur Formation is available. Schulze et al. (2003) reports a thickness of $140 \mathrm{~m}$ in Wadi Salihi, located around $30 \mathrm{~km}$ to the north and $150 \mathrm{~m}$ near Wadi Abu Khusheiba, located around 5 to $10 \mathrm{~km}$ to the south of the wider area of interest. Kuntz (2003) mapped a thickness of $110 \mathrm{~m}$ in the upper Wadi Shueib area and Becker (2000) a thickness of $110 \mathrm{~m}$ in the area of South Shuneh. The Na'ur Formation was penetrated by one well in the Wadi Hisban area, where a thickness of $101 \mathrm{~m}$ was drilled, but the drill log showed no clear indication if the Na'ur formation was fully penetrated. Hence a minimum thickness of $101 \mathrm{~m}$ has to be assumed.

Only Kafrein 9 well taps the Na'ur Formation. A salinity of $900 \mathrm{mg} / \mathrm{L}$ was reported (Saman and $\mathrm{Al}$ Masri 1998). Kafrein 4 well combines the Na'ur Formation with the Kurnub Aquifer. A TDS of 524 $\mathrm{mg} / \mathrm{L}$ was analysed (Saman and Al Masri 1998). Several springs emerge from the Na'ur Formation and contribute to the baseflow of various wadis. The transmissivity of the aquitard is not known, but was estimated at $3-10 \mathrm{~m} / \mathrm{d}$ by Parker (1969) and $8.6 \mathrm{~m} / \mathrm{d}$ by Margane et al. (2002).

Within the foothill area the aquitard is under confined conditions.

\section{Fuheis Aquiclude}

The Fuheis Formation is prominent in most of the area. In the southeast it crops out along the eastern part of the Western Slopes. Furthermore, it can be found along the axis of Wadi Kafrein and Wadi Shueib flexures as well as in some wadis lying north of lower Wadi Shueib. The total outcrop area of the Fuheis Formation is $75.9 \mathrm{~km}^{2}$.

The Fuheis Formation consists predominately of marls and argillaceous and nodular limestones. Towards the south its clay content increases. Schulze et al. (2003) gave a thickness of $65 \mathrm{~m}$ in the northern sections of Wadi Salihi and $18 \mathrm{~m}$ in Wadi Abu Khusheiba. While Lenz (1999) estimated a thickness of $55 \mathrm{~m}$ in the area east of Kafrein, Becker (2000) mapped a thickness of $70 \mathrm{~m}$ in the area of South Shuneh, Kuntz (2003) $80 \mathrm{~m}$ in upper Wadi Shueib, Masri (1963) $80 \mathrm{~m}$ in the area of Sweileh, and Powell (1989) $57 \mathrm{~m}$ in the area of Wadi Ash Shita (along the upper reaches of Wadi Kafrein). Hence a decrease in thickness from north to south can be seen.

The marls and marly limestone of the Fuheis Formation are almost impervious. A permeability of 8.6 x $10^{-5} \mathrm{~m} / \mathrm{d}$ was estimated by Margane et al. (2002).

\section{Hummar Aquitard/ Aquifer}

The Hummar Formation cannot be placed easily in one of the hydraulic categories, since it is variable within the study area. Depending on the karstic nature, the thickness, and occurrence of marl intercalations the Hummar Formation can form either an important aquifer like in the area of Amman, Zerqa, and Sukhna (Abu Ajamieh 1998) or, like in other areas, it is of only minor productivity. 
Like the Fuheis Formation the Hummar Aquifer/Aquitard crops out in the eastern part of the Western Slopes. It can be found also along the axis of Wadi Kafrein and Wadi Shueib as well as in some wadis to the north of lower Wadi Shueib. The total outcrop area of the Hummar Formation is $41.6 \mathrm{~km}^{2}$.

In the wider area of interest the Hummar Formation consists mostly of cliff-forming argillaceous medium to thick-bedded dolostone and dolimitic limestone. According to Schulze et al. (2003) the thickness is around $50 \mathrm{~m}$ in the area of Wadi Salihi and decreases towards the south to around $3 \mathrm{~m}$ in Wadi Abu Khusheiba. The mapping campaign carried out by Becker (2000) revealed a thickness of $45 \mathrm{~m}$ in the area east of South Shuneh, 45 - $50 \mathrm{~m}$ in the upper Wadi Shueib (Kuntz 2003), 40 - $45 \mathrm{~m}$ in the area east of Kafrein (Lenz 1999). Powell (1989) gives a thickness of $43 \mathrm{~m}$ for the area of Salt, $65 \mathrm{~m}$ for the area of Sweileh, and $60 \mathrm{~m}$ for the area of Wadi Ash Shita (Amman area). In a well drilled near Ash Shita the Hummar Formation has a thickness of $55 \mathrm{~m}$. A combination of these different results does not give a clear trend. According to Schulze et al. (2003) the thickness decreases from 50 to $3 \mathrm{~m}$ in a north-south section.

Kafrein well 2 is drilled in the Kurnub Group, Na'ur Formation, and in the Hummar Formation. The hydraulic head of the Hummar Aquifer was $8 \mathrm{~m}$ higher than that of the Wadi As Sir - Amman Aquifer, but in areas of high water demand the water table might have declined. Within the area of the Amman-Zerqa or Salt syncline the aquifer is under confined conditions. Whereas in the area of South Shuneh the aquifer is under unconfined conditions (Hizrallah 1973). Most of the springs in the area of interest or adjacent to it discharge either form the Na'ur or Hummar Formation.

Recharge to the Hummar Aquifer/ Aquitard derives mostly from direct infiltration of rainwater. The permeability of $1.73 \mathrm{~m} / \mathrm{d}$ was determined on the basis of a pumping test by Margane et al. (2002) and estimated by Salameh and Udluft (1985) to be $4.32 \mathrm{~m} / \mathrm{d}$.

The salinity varies from $780-1,850 \mathrm{mg} / \mathrm{L}$ in the area east of Karameh (Hizrallah 1973), and from 230 $-530 \mathrm{mg} / \mathrm{L}$ in the wells and springs along the foothills (Parker 1968; Abu Ajamieh 1998).

\section{Wadi Shueib Aquitard}

With its alternation of thick and thin bedded marls, marly limestone, and limestone the Wadi Shueib Formation can be classified as an aquitard. In the southeast, south, and northwest of the wider area of interest the Wadi Shueib Formation crops out mostly along the border Western Slopes/ Highlands. Other outcrops are located in the north of the wider area of interest and, in the western part of the Western Slopes, in the core of the Wadi Kafrein and Wadi Shueib flexures. The total outcrop area of the Wadi Shueib Formation is $87.4 \mathrm{~km}^{2}$.

The Wadi Shueib Aquitard has a thickness of $30 \mathrm{~m}$ in the area east of South Shuneh (Becker 2000), 35 - $50 \mathrm{~m}$ in the middle and upper area of Wadi Shueib (Kuntz 2003; Parker 1970), $35 \mathrm{~m}$ in the area east of Kafrein (Lenz 1999), $47 \mathrm{~m}$ in a well near Wadi Ash Shita (MWI database), and $72 \mathrm{~m}$ in the area of Na'ur (Parker 1970).

The permeability was estimated by Margane et al. (2002) to be $8.6 \times 10^{-5} \mathrm{~m} / \mathrm{d}$.

\section{Wadi as Sir - Amman Aquifer System}

The Wadi as Sir, Wadi Umm Ghudran, and Amman Formations build up the most important aquifer system in Jordan. Within the wider area of interest these Formations can be found both in the Highlands area and in the core of the synclines close to the Jordan Valley. It can be found also in the middle of Wadi Shueib. Direct infiltration during the rainy season is the major source of recharge in this system.

Wadi as Sir Formation consists predominately of limestone and sandy limestone. In some areas the limestone is dolomitic. Thin layers of marl are abundant (Parker 1969). A facies change towards a more continental facies is reflected by an increase in sand content. The thickness of Wadi as Sir Formation varies from $90 \mathrm{~m}$ in the Kafrein area (Lenz 1999), $130 \mathrm{~m}$ in the South Shuneh area (Becker 2000), $130-150 \mathrm{~m}$ in the upper Wadi Shueib area (Kuntz 2003), $85-97 \mathrm{~m}$ in the Amman area 
(Powell 1989), and $85 \mathrm{~m}$ in the Madaba area (Powell 1989). The total outcrop area in the wider area of interest adds up to $137.9 \mathrm{~km}^{2}$.

The massive chalk and marlstone of Wadi Umm Ghudran Formation, the lowermost member of the Belqa Group, succeeds the Wadi as Sir limestone. The massive chalk, marls, and brecciated chert beds of the Wadi Umm Ghudran Formation might work as a hydraulic barrier separating the Amman from the Wadi as Sir Formation. The effectiveness of the separation depends largely on the thickness of the chalk beds. In other areas, like in the area of As Salt, the Wadi Um Ghudran Formation cannot be distinguished from the overlying Amman Formation and is mapped as one unit B1/2. The Amman Formation consists of limestone, silicified limestone, phosphatic rocks, and sandstone (Parker 1969). The degree of karstification within this aquifer complex is low. Fractures and joints are often sealed by calcite (Parker 1969). As stated in chapter 2.2.3 active deformation in the wider area of interest before Senonian times is unknown. In Late Coniacian the so-called Syrian- Arc stress field evolved. Most of the prominent folds and fault systems were built during this active tectonic phase, which received their final shape before the Eocene. This affected the sedimentary conditions and consequently the thickness distribution. High sediment accumulation took place in anticlinal structures and less sediment accumulation along the flanks of the different fold structures. Poor or no sedimentation accumulation took place on top of synclinal or monocline structures. Lenz (1999) estimated a thickness of the Wadi Um Ghudran Formation of 20 - $30 \mathrm{~m}$ in the area east of Kafrein, Becker (2000) $40 \mathrm{~m}$ in the area east of South Shuneh, Powell (1989) a few metres in the area of As Salt and up to $60 \mathrm{~m}$ in the area of Amman.

The limestone of the Amman Formation is the youngest consolidated formation cropping out in the area. Powell (1989) gave a thickness of $60 \mathrm{~m}$ in the Amman area. The deposition of the Amman Formation falls also into the evolving phase of the Syrian Arc System. Hence the same depositional condition as for the Wadi Umm Ghudran Formation applies.

In the area of South Shuneh the aquifer complex dips gently under the Jordan Valley Group. Here the aquifer in under confined conditions (Hizrallah 1973). Many agricultural wells were drilled in this area. Most of the wells are screened both in the overlying unconsolidated Jordan Valley Group and the Amman Formation.

\subsubsection{Jordan Valley Aquifer Complex}

Aquifers of local significance are located within the study area. These aquifers are hydraulically interconnected and consist of terrigenous clastic components of Pliocene to recent age. Sedimentary facies of these aquifers are similar throughout this period. Three different continental depositional environments have played a major role since the development of the Jordan Valley basin. These environments are terrestrial/fluvial, deltaic/limnic, and limnic/brackish environments. The total outcrop within the wider area of interest is $150.7 \mathrm{~km}^{2}$. The thick soil cover that developed over this aquifer complex together with the natural hot house conditions between the mountain ridges of the West and East Bank and the long and warm season lead to excellent farming conditions. Therefore, the area is used intensively for agriculture and over 150 legal wells have been drilled, mostly during the sixties with a registration number from the Central Water Authority. In addition to the legal wells, many illegal wells have been drilled. Due to the high water demand in the area many illegal wells or observation wells have been transformed into legal production wells (Kafrein Observation well -> AM1032). The drilling of illegal wells seized since the abatement of hard penalties by the Ministry of Water and Irrigation.

The primary porosity of the Upper Pliocene to lower Pleistocene Shagur Formation (chapter 2.2.3) is small and might only play a role in structurally stressed areas. Therefore it won't be discussed in this section.

\section{Pleistocene gravel aquifer}

As discussed in chapter 2.2.3 three members are distinguished during Pleistocene times. The three members of the Pleistocene system (the coarse clastic, the silt, and the lacustrine) represent a vertical and lateral facies succession from terrestrial/fluvial, to deltaic/limnic, and limnic/brackish lake 
environments. The "Pleistocene aquifer" consists of the coarse clastic and the silt member. However, exploitable water resources are principally restricted to the coarse clastic member. The lacustrine member (Lisan Formation) consists of marl, gypsum and silt, and is generally considered as an aquiclude, devoid of exploitable water. It crops out mainly in the west of the study area. Since the Lisan Lake reached an elevation of $-180 \mathrm{~m}$ above mean sea level its sediments can be found in incised channels of the major wadis up to the margin of the Jordan Valley. Its total thickness is around $40 \mathrm{~m}$. The coarse clastic member consists of gravel, interbedded with clay, sand, and marl horizons. Both, the coarse clastic and the silt member underlie, overlie, or interfinger with the Lisan Formation.

\section{Alluvial Aquifer (Holocene or sub-recent)}

This aquifer is built up of sub-recent terrigenous deposits formed along the outlets of major wadis. During large floods these alluvial fans are still under accumulation. They consist of debris from all neighbouring lithologies and are deposited according to their transport energy, where the biggest components are found close to the apex and the smallest close to the fan margin. However, only a few sandstone pebbles were found, although the Kurnub Groups crops out in the vicinity. This might be attributed to the calcite binder and its general soft degree of cementation. Sediment transport normally takes place along alternating channels or after very heavy rainstorms as sheet flow. Thus permeable horizons alternate with less permeable within the deposits. It is believed that the thickness maximum is near the rift margins, thinning out towards the centre of the rift basin. Well depth is rarely above several tens of metres. Often the alluvial aquifer overlies directly the Pleistocene gravel aquifer and, because of that, it is hydraulically interconnected with this aquifer.

Meteoric recharge is low. Therefore, the aquifer is mainly fed by inflows from neighbouring aquifers, namely the consolidated Mountain aquifers to the east and by surface water infiltration from the wadis on the Western Slopes of the Highlands. Unlike the middle and northern part of the Jordan Valley recharge due to infiltration of irrigation water can be neglected for most of the study area, since drip irrigation is the main irrigation practice.

As a result of different depositional environments aquifer characteristics might change within short distances. Consequently a high number of hydraulic tests or well logs are essential to describe this complex system. But unfortunately hydraulic tests and well log information within the study area are poor. In general, the system can be roughly described as follows: the topographical high proximal fan area is an area of deep water table (around 40 to $50 \mathrm{~m}$ below ground level) and high hydraulic conductivity. Towards the distal fan area (topographic low) the groundwater flow mimics the depositional fan surface and groundwater flows from east to west. Along the flow path the hydraulic conductivity decreases as a result of the decreasing grain size and an increase in the lacustrine fraction that interfingers with the alluvial deposits. The lacustrine sediments dominate the centre of the Jordan Valley. The low transmissivities of the lacustrine sediments pond the groundwater either to very shallow depths, or, when the alluvial sediments are buried under lacustrine sediments, even under artesian conditions. A more detailed description regarding sedimentary processes and the conceptual flow model within the unconsolidated aquifer in lower Jordan Valley can be found in chapter 4.2 and 7 respectively.

The water quality is variable, with low chloride concentrations near the areas of recharge and high values in areas under the influence of the highly saline Lisan Formation, hyper saline brines and/or Dead Sea water in the south. 
Tab. 2.3-1: Hydrogeologic units and its characteristics. Thickness of the different formations within the study area can be found in chapter 4.2 .5

\begin{tabular}{|c|c|c|c|c|c|c|}
\hline Aquifer & $\begin{array}{c}\text { Aquifer } \\
\text { characteristic }\end{array}$ & $\begin{array}{c}\text { Transmissivity } \\
{\left[\mathrm{m}^{2} / \mathrm{d}\right]}\end{array} \mid$ & $k f[\mathrm{~m} / \mathrm{s}]$ & Storativity coefficient & Lithology & Source \\
\hline \multicolumn{7}{|l|}{ Belqa Group } \\
\hline Amman Fm. & Aquifer & & $2.0 \mathrm{E}-05$ & stat evaluation pump tests & $\begin{array}{c}\text { silicified limestone } \\
\text { phosphatic }\end{array}$ & Margane et al. (2002) \\
\hline Wadi Um Ghudran Fm. & Aquifer & & $2.0 \mathrm{E}-05$ & stat evaluation pump tests & marl, limestone & Margane et al. (2002) \\
\hline \multicolumn{7}{|l|}{ Ajlun Group } \\
\hline \multirow[t]{2}{*}{ Wadi as Sir Fm. } & Aquifer & & $2.0 \mathrm{E}-05$ & stat evaluation pump tests & \multirow[t]{2}{*}{ karstified limestone } & Margane et al. (2002) \\
\hline & & & $\mathrm{b}$ & $1.0 \mathrm{E}-02-1.0 \mathrm{E}-01$ & & Parker (1969) \\
\hline Shueib Fm. & Aquitard & & $1.0 \mathrm{E}-09$ & estimated & marl, limestone & Margane et al. (2002) \\
\hline Hummar Fm. & Aquifer & & $2.0 \mathrm{E}-05$ & stat evaluation pump tests & limestone & Margane et al. (2002) \\
\hline Fuheis Fm. & Aquitard & & $1.0 \mathrm{E}-09$ & estimated & marl and limestone & Margane et al. (2002) \\
\hline Na'ur Fm. & $\begin{array}{l}\text { Aquitard/ } \\
\text { Aquifer }\end{array}$ & & 7.0 E-06/ 1.0 E-05 & estimated & marl, limestone & Margane et al. (2002) \\
\hline \multirow[t]{4}{*}{ Kurnub Group } & \multirow[t]{4}{*}{ Aquifer } & & $3.0 \mathrm{E}-05$ & stat evaluation pump tests & \multirow[t]{4}{*}{ sandstone } & Margane et al. (2002) \\
\hline & & & $1.2 \mathrm{E}-05$ & $2.0 \mathrm{E}-03$ & & JICA (1995) well No. 3 \\
\hline & & & $2.3 \mathrm{E}-05-5.8 \mathrm{E}-05$ & $1.0 \mathrm{E}-04$ & & Abu Ajamieh (1998) \\
\hline & & & $4.5 \mathrm{E}-05$ & & & Salameh and Udluft (1983) \\
\hline \multirow{2}{*}{ Zarqa Group } & \multirow{2}{*}{ Aquifer } & $91-143$ & $6.4 \mathrm{E}-06$ & $1.0 \mathrm{E}-02-4.0 \mathrm{E}-03$ & \multirow{2}{*}{$\begin{array}{l}\text { siltstone and } \\
\text { sandstone }\end{array}$} & JICA (1995) well No. 2 \\
\hline & & 100 & $9.3 \mathrm{E}-06$ & $1.0 \mathrm{E}-03$ & & JICA (1995) well No. 3/4 \\
\hline Azab Fm. & $\begin{array}{l}\text { upper part } \\
\text { aquiferous }\end{array}$ & & $1.0 \mathrm{E}-05$ & estimated & silt-, sandstone, limestone & Margane et al. (2002) \\
\hline Ramtha Fm. & Aquitard & & $1.0 \mathrm{E}-07$ & estimated & $\begin{array}{l}\text { silt-, sandstone, shale, } \\
\text { limestone, anhydrite, halite }\end{array}$ & Margane et al. (2002) \\
\hline Khreim Group & Aquitard & & $1.0 \mathrm{E}-07$ & estimated & $\begin{array}{c}\text { siltstone, mudstone,shale, } \\
\text { sandstone }\end{array}$ & Margane et al. (2002) \\
\hline \multirow[t]{4}{*}{ Ram Group } & \multirow[t]{4}{*}{ Aquifer } & & $1.0 \mathrm{E}-05$ & stat evaluation pump tests & \multirow[t]{4}{*}{ sandstone } & Margane et al. (2002) \\
\hline & & $205-262$ & $5.0 \mathrm{E}-05$ & $4.0 \mathrm{E}-03-6.0 \mathrm{E}-04$ & & JICA (1995) well No. 5 \\
\hline & & $120-369$ & $6.1 \mathrm{E}-05-1.9 \mathrm{E}-04$ & $1.0 \mathrm{E}-06$ & & JICA (1995) well No. 6 \\
\hline & & & $1.7 \mathrm{E}-05$ & $7.2 \mathrm{E}-04$ & & Abu Ajamieh (1998) \\
\hline
\end{tabular}




\section{HISTORICAL REVIEW OF LAND- AND WATER- USE IN LOWER JORDAN VALLEY}

The section is designed to understand the different conditions under which the unconsolidated system was. The natural, anthropogenically unaltered flow system is addressed, as well as the effects of major periods of water stress in the 60ies, the influence of the events of 1967 and their aftermath, the effects of extreme rainfall events, and the effects of periods of drought on the groundwater system. The transient groundwater flow model results will be compared with measured data indicating different types of stress.

\subsection{Pre-DeVelopment history of the LOWER Jordan VAlLey}

The lower Jordan Valley has a long history of human settlement and hence agriculture. Though throughout its history periods of minor usage or even abandonment occured. The city of Jericho, founded around the $9^{\text {th }}$ to $8^{\text {th }}$ century BC, is known to be the oldest continuously populated city in the world and is located just $8 \mathrm{~km}$ west of the study area. Excavations at Ghassul (around five kilometres north of Sweimeh) date back as far as to the Epipaleolithic Period (Ferembach 1959; Hennessy 1969, 1982; Habgood 1985; Lliott 1978; Moore 1973). From this time onwards the study area was continuously populated. During the Ayyubid- Mamluk era (1187 - 1516) the agricultural activity in the Jordan Valley reached its pre-modern peak. During that era sugar production existed on a large scale. Water driven sugar mills processed sugar cane. The sugar mills were used until the 1960s and were located mostly in the middle to northern part of the valley. The sequencing Ottoman rule, which lasted from the invasion of Jordan in 1516 till 1921 (the final settlement of the Ottoman empire was signed in the 'Treaty of Lausanne' in 1923), imposed taxes on land, agriculture, and commerce. This new tax system lead to a time of stagnation. From 1600 onward the valley was almost deserted (Khouri 1981).

However, the settlement and agricultural activities in former times were limited to the availability of water resources and good farming land. Within the area of interest the Jordan River flows in a 15 to $30 \mathrm{~m}$ deep gorge (Arabic Zor). Apart from the Jordan River flood plains, which can be considered as good farming land, the vicinity of the Jordan River consists of the previously described Lisan formation (chapter 2.2.2.3), which, is due to its high salt content, not suitable for farming. As a consequence only places near the outlets of major wadis, where an almost perennial flow of water from the eastern hills supplies enough water, were suitable for agricultural activities.

Upon the arrival of the first European and American explorers in the late $19^{\text {th }}$ century, most of the study area was described as a hot and uninhabited area, unsuitable for human settlement activities (Burckhardt 1822). In their survey of Western Palestine Conder and Kitchener (1883) described the area adjacent to the study area (from the River Jordan towards the Hills of the contemporary West Bank). Only one inhabited area 'Eriha' (Arabic for Jericho) with an estimated number of 300 inhabitants existed. Agriculture was restricted to the area near the wadis of the West Bank (Wadi el Qilt and Wadi Nueima), where different kinds of trees existed. During winter and spring times wheat and barley were grown. Vineyards were also reported to exist in the surroundings of Eriha. Water supply of Eriha was secured by a canal from 'Ain es Sultan' spring. To the east, the plain was reported to be more and more barren, and the salty soils were only covered with low bushes of the Alkali plant (Hubahib). In the Zor area, the flood plain of the Jordan river, a scatter growth of the tamarisk, the Zizyphus, and Rishrash (Agnus Castus) extends, and in parts near the river the brushwood becomes very thick, as already described by Burckhardt (1822). At that time the River Jordan, in the area of the of today's King Hussein bridge, had an extension of around $30 \mathrm{~m}$, and during the exceptionally wet year 1873/74 it even flooded the whole Zor area (Conder and Kitchener 1883).

Towards the end of the Ottoman rule local agriculture (wheat, olive trees, some fruits, and vegetables) and livestock breeding (camel, goats, and sheep) prevailed in the Jordan Valley. The land, which was called "mouchaa", was collectively owned (Jridi 2002). Springs and flowing water in wadis were the sources for irrigation. The water was either directly used or diverted by a hand made irrigation system, such as diversion weirs and earth ditches. Water was either stored in cisterns (some built in Roman 
times), or caught in some small earth dams, that dam up the flowing water of the different wadis, or groundwater from shallow hand dug wells. Irrigation until summer time became possible. In the late $19^{\text {th }}$ or the beginning of the $20^{\text {th }}$ century a cadastral survey ended in selling big plots of land to rich Bedouin families (i.e. Al Edwan tribe, which is until today the biggest land owner in the study area). The selling of the former collectively owned land changed the usage of land in the area. The time of stagnation came to an end. Bedouins with their slaves settled down in the Ghor area, while they still sent their livestock to the Highlands in summer (Philippe 2004).

After 1933 a second cadastre, drawn under British mandate (which lasted from 1921 until 1946, although Britain recognized Transjordan already in 1923 as a state), resulted in selling additional plots of land. Former slaves and sharecroppers were allowed to buy small plots of land (more than 50\% of the land was still property of the Royal Hashemite Family).

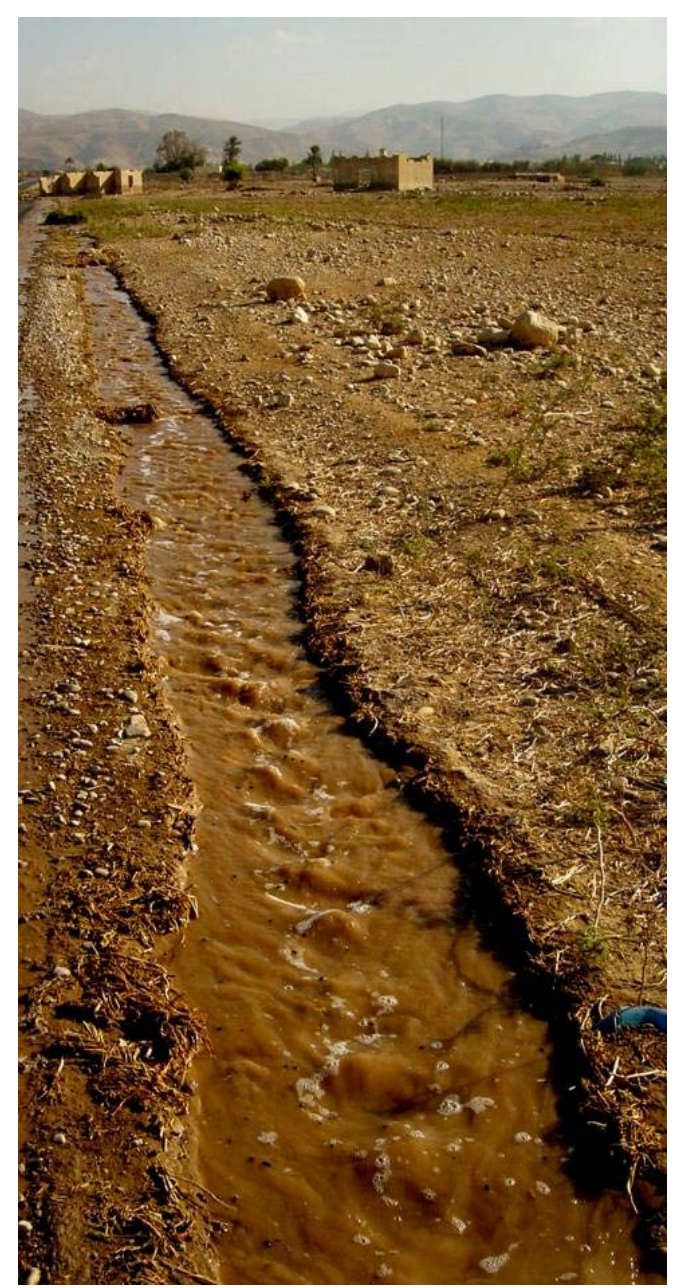

The first comprehensive report describing water use in the Jordan Valley was the 1939 published report "The water resources of Transjordan and their development" written by an Englishman called B.A. Ionides. According to the report only nine wells were drilled prior to 1938. Some tube wells existed under private ownership in the Ghor area. These wells were driven by paraffin oil engines, where the lift was not more than $50 \mathrm{~m}$ (Mc Donald 1951). In 1938 within this project a Haifa based drilling company drilled 18 modern wells. From 1938 to 1941 these wells served as observation wells. Regarding an alternative source of water the area around South Shuneh and Kafrein was considered the only favourable area for groundwater abstraction. Concerning agriculture he noted, that farming is only possible with the help of irrigation. Irrigation water came largely from perennial streams in the valley and only a few progressive irrigation systems existed. Bedouins irrigated their farmland via earth channels which divert the water from the outlets of major wadis (Fig. 3-1). Since most of the water infiltrated or evaporated on the way to the farmlands Ionides (1939) described these channels as highly inefficient. Some privately owned low lift irrigation systems which pumped water from the Jordan River to irrigated farmland cultivated in the Zor area existed. No lift to the Ghor area existed since the lift from Jordan River is more than $60 \mathrm{~m}$. Agriculture was based mostly on rain-grown crops, where wheat, barley, and corn were the dominant crops at that time.

Fig. 3-1: Contemporary earth ditch channel carrying water from the KAC.

It was already in 1946 that Ionides expressed the need for alternative water resources to enhance agriculture in the Jordan Valley. The water use prior to 1946 and different alternative water resources were discussed in detail in Ionides (1946). Ionides (1946) favoured the building of a canal that carries water from the Jordan and Yarmouk river in the north down to the area of Rama in the south. Along its course the canal should be supplemented with water from various major side wadis. An estimated length of about $100 \mathrm{~km}$ was given. A supply of 507 million cubic metres $\left(\mathrm{Mm}^{3}\right)$ was calculated.

\subsection{INTENSIVE DEVELOPMENT OF THE JORDAN VALLEY (1948 TO PRESENT)}

Up until 1948 only a few villages and two towns, Jericho and Beisan, existed in the Jordan Valley area. These towns were connected by dirt roads (Mc Donald 1951). A major transformation from an 
almost uninhabited area with only minor agriculture started after 1948. After the 1948 war Palestinian refugees along with increased engagement of major landowning Jordanian families resulted in the agricultural development of the Jordan Valley (Khouri 1981).

From 1947 to 1956 the government invested in a few simple projects to irrigate the lands around the side wadis. These investments included the implementation of basic diversion wires and small concrete channels (Fig. 3-2) in most of the side wadis in the Jordan Valley, including the outlets of Wadi Shueib and Wadi Kafrein (Philippe 2004). The construction was supervised by the 1947 founded new irrigation section of the department of lands and survey (Jridi 2002).

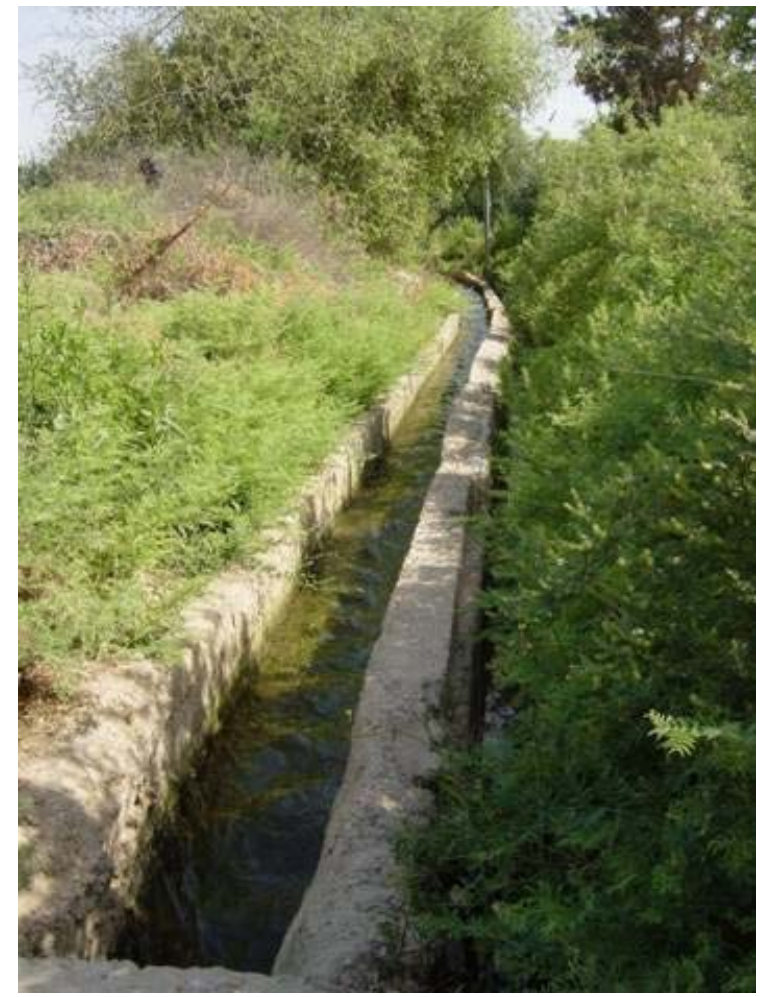

Fig. 3-2: Concrete channel near Wadi Shueib.

\section{East Ghor Canal}

In 1957 Jordanian and American engineers drew up first construction plans for the implementation of a trapeze-shaped canal to divert water from the northern end of the Jordan Valley down to the south. The canal is fed mainly by water from the Yarmouk River. Via a concrete tunnel between the Yarmouk River and the village of Addasiyyeh the water flows by gravity towards the south. Additional water from side wadis is added. Three weirs ensure the flow of water along its way to the south. The first section, paid by the U.S. government, was finished in 1961. Section two and three were completed in April 1964 and June 1966 respectively. Section three extended now from the Yarmouk River in the north southwards until $15 \mathrm{~km}$ to north of Karameh. Along the main channel, sections of pipes draw up and deliver water for irrigating farmlands along the Jordan Valley, thus becoming the most important sources for irrigation in the area of northern and middle Jordan Valley. In the northern to middle part of Jordan Valley the water of the canal is also used for domestic purposes.

After the initial East Ghor canal went into service a land reform took place. All irrigated area in the Jordan Valley became property of the Jordanian state. The land was divided into development areas (DA), which are further subdivided into Farming Units (FU), ranging from 30 to 50 dunums (Philippe 2004). A dunum or dönüm, was introduced in Jordan during the Ottoman Empire and vaguely defined as an area of land one man can till in one day. During the late Ottoman occupation one dunum was around $919.3 \mathrm{~m}^{2}$. At the times of the British Mandate in Palestine the metric dunum of 1,000 $\mathrm{m}^{2}$ was introduced (www.wikipedia.com). Every family could keep 20 to 40 dunums of irrigated land. Other farmers could buy licenses to farm FUs.

Since no irrigation water of the East Ghor Canal reached the study area until 1987 additional irrigation water resources to the already existing concrete channels at the outlets of the Wadi Shueib, Wadi Kafrein, and Wadi Hisban were necessary. A major increase in well drillings made extensive faming activities possible. According to Tleel (1963), the major phase of new well drilling started around the mid fifties and clear signs of overpumping could be seen by the beginning of the sixties. As a consequence, first drilling restrictions were issued in 1961. Between 1953 and 196362 new wells were drilled in the Karameh area, 122 in the area of South Shuneh, and 133 in the area of Sweimeh, Ghor el Rama and Ghor el Kafrein (Tab. 3-1). In the area of Sweimeh, Kafrein, and South Shuneh 10 structural holes, where 9 ranged between 82 to $277 \mathrm{~m}$ and one deep well (1,098 m, JV1; Philipps Petroleum), were drilled. The drilling of new wells and hence abstraction of larger quantities of groundwater reached its first peak in 1967. 
The events of 1967 brought almost all agricultural activities to a halt or even a major step back. In the battle of Karameh in 1968 buildings and homes throughout the study area were demolished and most inhabitants fled from the area. Individual farmers usually returned first to see if they still have a home. It was not before autumn 1971 that agricultural activities began to increase again (Khouri 1981). In 1971 there were fewer than 5,000 people living in the valley (compared to 60,000 before the 1967 war), by November 1979 the population increased to 85,000 inhabitants.

After the 1967 war a young Jordanian planning team took over and developed a three- year valley plan (for the period 1973-75). New machines and techniques (i.e. trucks and pickups; usage of hybrid varieties and chemical inputs; buying manure from goatkeepers) were introduced. Another factor that enhanced the redevelopment of the Jordan Valley was the availability of cheap labour. After Nassers rule, Egypt became more open and many Egyptians came into the area. From that time on only one Jordanian family member manages the farm, while the rest is done by cheap labour workers. In conclusion it can be stated that within a short period of about ten years the previous history of agricultural in the valley changed completely.

Tab. 3-1: Wells drilled between 1938 - 1963 (after Tleel 1963).

\begin{tabular}{|c|c|c|c|c|}
\hline year & Karameh & South Shuneh & Sweimeh & Total \\
\hline 1938 & 5 & 1 & 4 & 10 \\
\hline 1946 & & & 1 & 1 \\
\hline 1947 & & 5 & 2 & 2 \\
\hline 1948 & & & & 5 \\
\hline 1949 & & 1 & 1 & 1 \\
\hline 1950 & & 1 & 1 & 2 \\
\hline 1951 & & 1 & 1 & 2 \\
\hline 1952 & & 7 & & 2 \\
\hline 1953 & 1 & 4 & 8 & 8 \\
\hline 1954 & 1 & 8 & 7 & 13 \\
\hline 1955 & 2 & 9 & 2 & 14 \\
\hline 1956 & 3 & 7 & 9 & 22 \\
\hline 1957 & 6 & 13 & 12 & 34 \\
\hline 1958 & 9 & 7 & 21 & 45 \\
\hline 1959 & 17 & 20 & 25 & 66 \\
\hline 1960 & 21 & 21 & 25 & 46 \\
\hline 1961 & & 7 & 7 & 14 \\
\hline 1962 & & 2 & & 2 \\
\hline 1963 & & 17 & 18 & 37 \\
\hline no date & 2 & $\mathbf{1 3 1}$ & $\mathbf{1 4 5}$ & $\mathbf{3 4 3}$ \\
\hline total & $\mathbf{6 7}$ & & & \\
\hline
\end{tabular}

Two earth fill dams within the study area deliver excess water from their respective wadis for irrigation. These dams were the 1968 built Wadi Shueib dam (water is free of charge and every farmer owns a share of the water) with a capacity of around 2,3 $\mathrm{Mm}^{3}$ and Wadi Kafrein dam (managed by the Jordan Valley Authority (JVA)) with a capacity of 3,8 $\mathrm{Mm}^{3}$ (Salameh and Bannayan 1993). Wadi Kafrein dam was raised in 1997 which resulted in an increased capacity of $8.4 \mathrm{Mm}^{3}$ (Philippe 2004). Due to the ongoing deposition of sedimentary load, which is mainly transported as sediment load after heavy storm events, the capacity of both dams is diminishing. Both dams are leaky. As a consequence, they contribute largely to local recharge by seepage into the ground. This fact is apparent in the groundwater levels of the wells drilled downstream of the dams (Hizrallah 1973).

The extended East Ghor Canal entered service in June 1978. The canal was extended $18 \mathrm{~km}$ to the south and ended near the town of South Shuneh. Together with the extension of the canal a pressure pipe irrigation network covering 36,000 dunums of idle land went into service (Khouri 1981).

In 1986 the East Ghor Canal, renamed as King Abdullah Canal (KAC), experienced its third and, up to today, final extension (completed between 1984 and 1989) of 14,3 km to the south. Consequently the 
KAC is the third allochthonous source of irrigation water in the study area. However, its last extension is not effectively in use. Only excess water is pumped into the last section. The third section is not managed by the JVA and consequently, once the canal is supplied with excess water, anybody can place a pump into the canal and extract water (Fig. 3-3). During the eighties new farming techniques (i.e. drip irrigation, fertigation, and plastic mulch) were introduced.

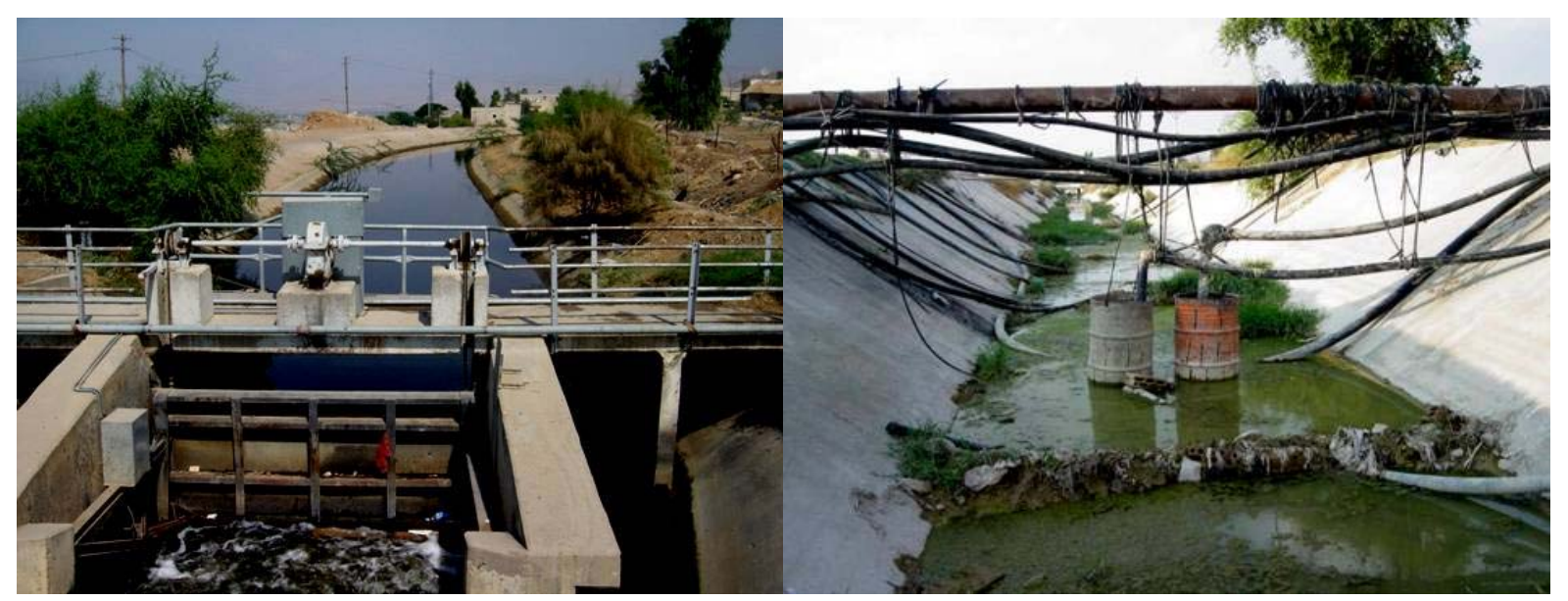

Fig. 3-3: KAC in middle Jordan Valley (left) and in its third extension in lower Jordan Valley (right).

Today, groundwater is still one of the major sources of irrigation water within the study area (Fig. 34). In Fig. 3-4 the different sources for irrigation water are illustrated. The figure is a result of a survey "Irrigation Water Sources and Water Use in the Southern Jordan Valley" undertaken by the GTZ within the framework of the Brackish Water Project. The area to the east of South Shuneh was not included in the map and was added by the author. In the study area the current water sources for irrigation are water from the canal, water stored in the dams of Wadi Shueib and Wadi Kafrein, water flowing along the course of Wadi Hisban, well water, and water from springs. However, irrigation water sources are often combined (Fig. 3-4). In the following the different irrigation water sources will be discussed:

The KAC maintained by the JVA (second extension) ends in the northern part of the study area. In its area of influence all farms are irrigated with water from the canal. Further to the south only surplus water from the second extension flows into the final extension of the KAC. Consequently only some minor farmlands around the canal are irrigated by water from the canal. Water from the canal is often mixed with water from different wells to irrigate farmlands. In the middle to southern part of the study area most of the water derives from wells. It should be noted, that the survey was undertaken in April to June 2002. As can be seen in chapter 6.2 land-use in the study area changed within the last decades. In the study area often more farmland was irrigated than it was surveyed by the GTZ during their field campaign in 2002. This additional farmland is only irrigated with water from wells. But drilling of new wells requires a permit issued by the Ministry of Water and Irrigation. On the other hand many illegal wells still exist, i.e. in fenced private farms which extract unknown quantities of groundwater. Drilling of illegal wells seized in the last years, since severe punishment could be enforced by the Ministry of Water and Irrigation, reaching as far as the confiscation of the drilling equipment. Some well owners sell their water and transport it with trucks from central loading stations (Fig. 3-6). In some cases brackish well water is mixed either with water from the canal, or water delivered from the surface reservoirs, or with flowing water in the wadi courses to get a better water quality. This method is highly questionable since the dilution of brackish water requires large amounts of freshwater. In order to irrigate salt sensitive crops like i.e. banana some farmers even invested in small desalinisation plants (Fig. 3-7). In the northeastern part of the study area farmland is irrigated by water from the Shueib dam and, since the dam capacity diminishes quickly after the rainy season, by well water in the following drier period of the year. The water stored in Wadi Kafrein Dam is managed by the JVA. Apart from this water irrigation water usage is left to the farmer. As a result the use of water is largely controlled by the financial means of the farm owner. Almost all farms have their own well or buy 
water from neighbouring well owners. Unlike the northern and middle Jordan Valley most of the farmers have their own off-farm irrigation network with private pipes. Often these private irrigation pipe systems are leaky and loose large amounts of water (Fig. 3-5). In the southern part of the of the study area some farmlands are irrigated with spring water.

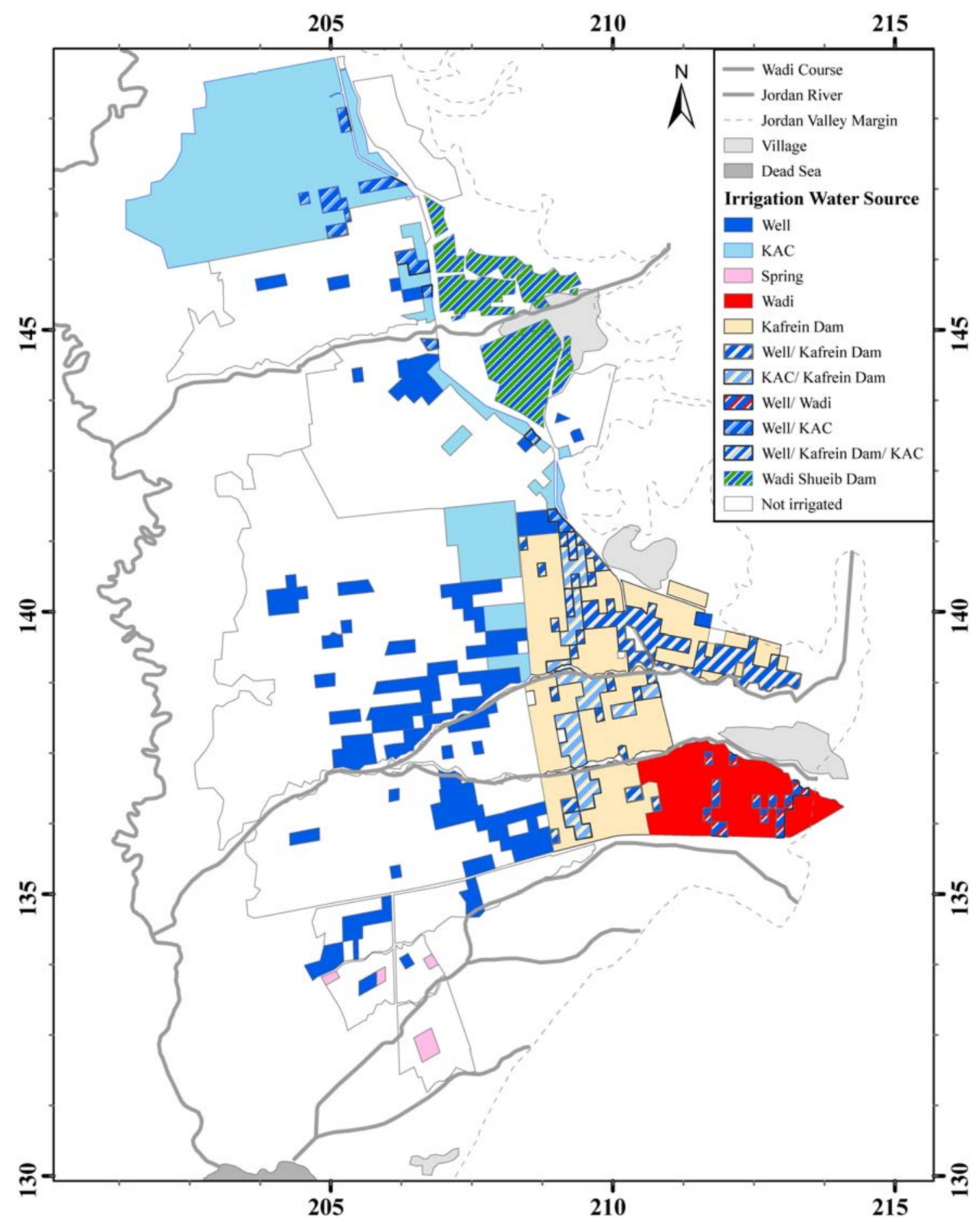

Fig. 3-4: Water sources for irrigation in the study area (slightly modified after GTZ 2002). 


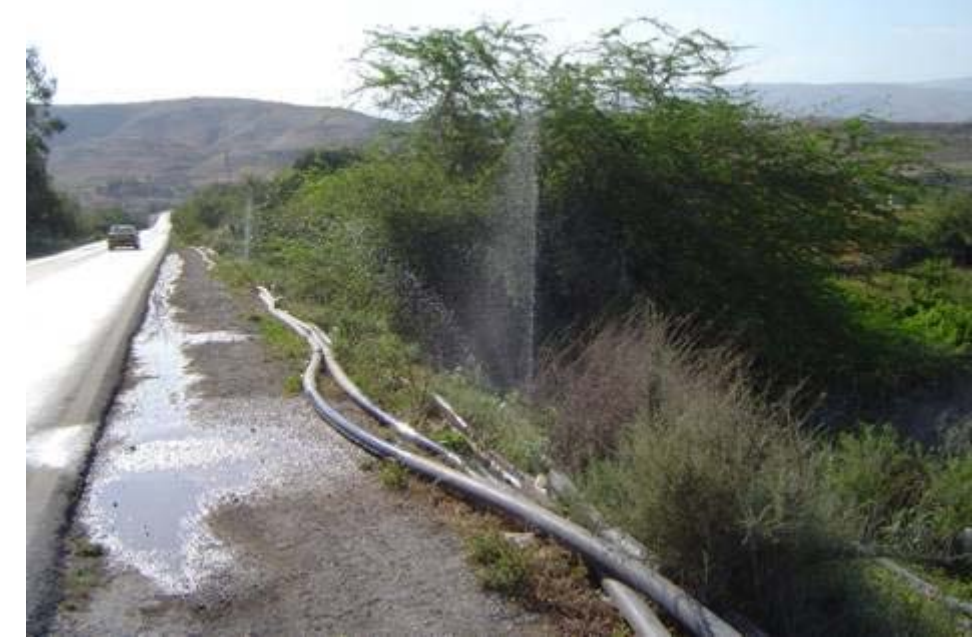

Fig. 3-5: Leaky private off-farm irrigation network near Kafrein.

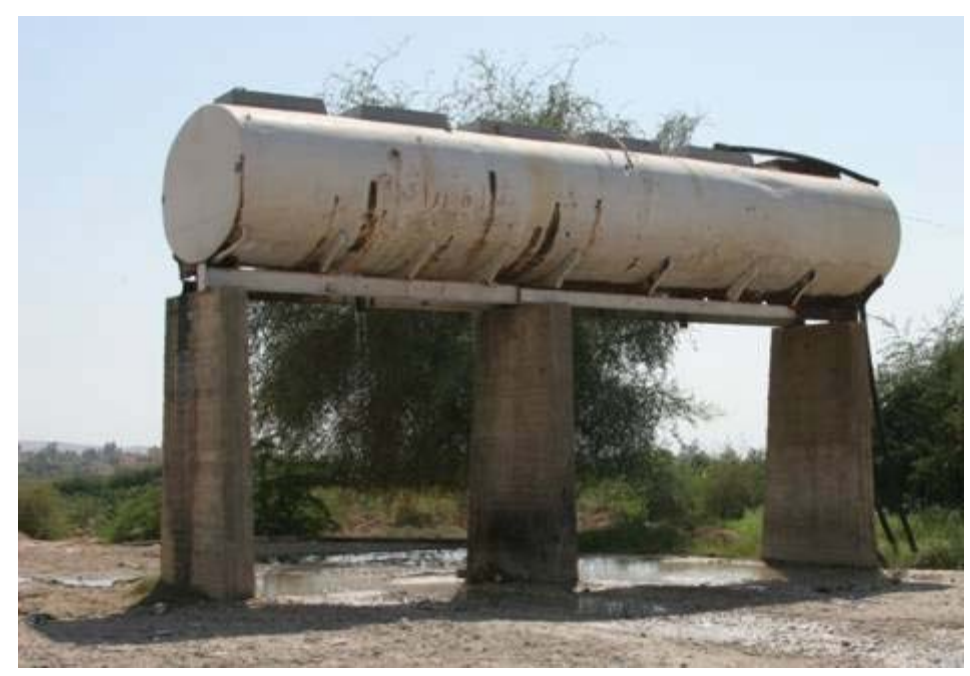

Fig. 3-6: Truck loading station near South Shuneh; selling of well water to farmers.

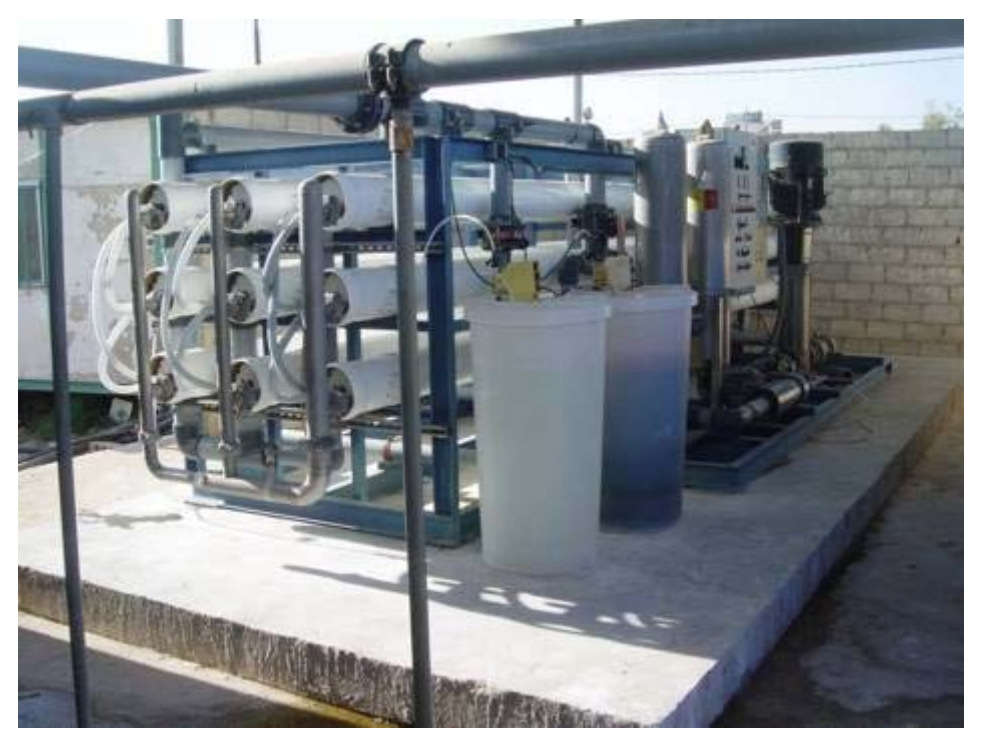

Fig. 3-7: Privately owned desalinisation plant in South Shuneh. Brackish well water is desalinated. Desalinated water is mainly used for irrigating banana farms. 


\subsection{IMPLICATIONS FOR THE GROUNDWATER BUDGET}

In this subchapter the impact of the previously described historical review of the development of the Jordan Valley on the groundwater budget will be discussed. For this discussion groundwater level information of all available wells in the study area was collected from various reports (Ionides 1939, Tleel 1963, Hizrallah 1973, BGR/WAJ 1996, MWI open files). In order to compare water table fluctuations from wells drilled in different locations (with different elevations about ground level and water level depths), the individual water levels were normalized. For every considered period the highest water level recorded in each well was set 0 . In this way a direct comparison of the different wells is possible.

\subsubsection{Prior to the development of the Jordan Valley}

In the Jordan Valley, apart from some hand dug and tube wells, no deep wells existed prior to the 1950s. The groundwater system in the alluvial aquifer was only anthropogenic influenced indirectly. The diversion of surface water at the outlets of the major wadis for small scale irrigation projects reduced infiltration into the alluvial aquifer. The observation wells drilled during the project "The water resources of Transjordan and their development" in 1938 were the first deep wells drilled within the study area (Fig. 3-8; Fig. 3-9).

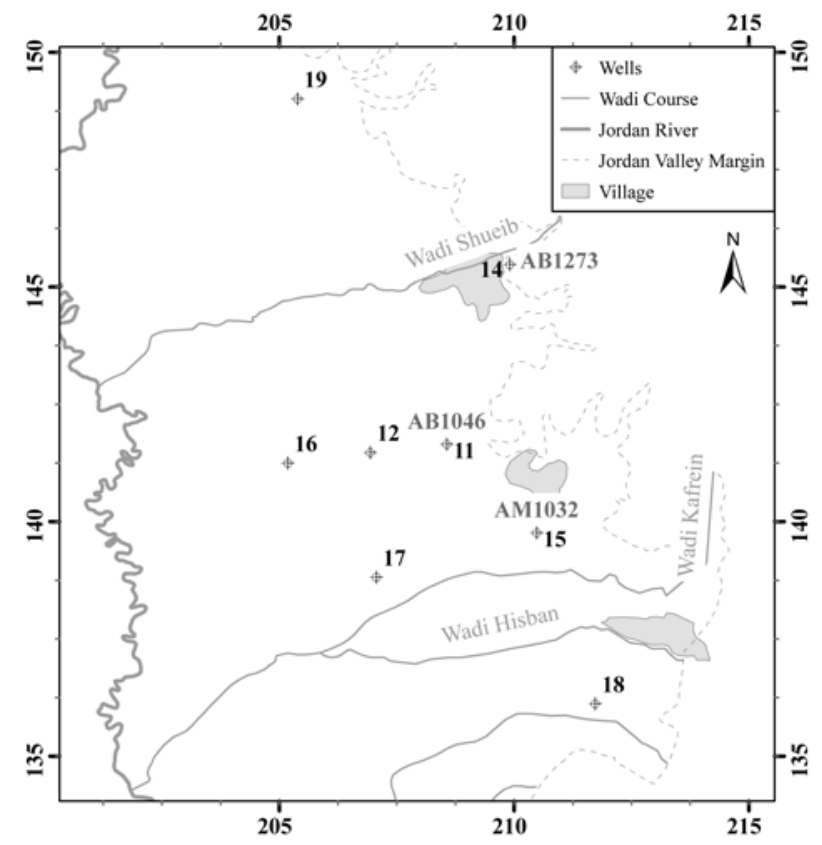

Fig. 3-8: Location of the wells drilled in 1938. The bold black numbers refer to the numbers given by the Ionides report. The gray ID code refers to the well ID code of the MWI.

The water tables in these wells were monitored on a monthly basis until 1941. Since no other wells were drilled during that time these measurements priovide valuable information about the uninfluenced groundwater system in the area. The water tables were not influenced by pumping neither within these wells nor by adjacent wells. In terms of water table fluctuation the wells AB 1273 (Ionides Well No. 14) and AM 1032 (Ionides Well No. 15) have similar trends. Both show an annual variation, reaching their highest water levels during summer and their lowest in the winter season. Whereby AB 1273 reacts more closely to precipitation events than AM 1032 (i.e. after the rainy season 1939/40). In general the water table in AB 1273 rises about one month earlier and reaches its highest levels also one month earlier than AM 1032. 
Well AB 1046 (Ionides Well No. 11) shows no annual variation, but rather a seasonal one. Its water level rise goes along with two seasons of intensive rainfall (1938/39 and 1939/40). A decline in the water table can be seen after the relatively dry rainy season of 1940/41, which undermines the hypothesis of a direct response to a seasonal trend. An explanation can be found in the location of this well. It is located relatively in the middle of the eastern border of the study area, between the major wadis draining surface water to the Jordan Valley. No influence of surface water percolation takes place. Groundwater inflow from the adjacent consolidated aquifers is also not expected. The well was drilled in the continuation of the Wadi Kafrein Syncline. Groundwater inflow into the alluvial aquifer is believed to happen more along the continuation of the Wadi Kafrein and Wadi Shueib flexures (chapter 2.2.3.3). The flow path to AB 1046 happened consequently via the fan apex of Wadi Kafrein in the alluvial aquifer to the north. High transmissivities together with a low gradient within the alluvial aquifer would lead to a weakening signal and to a more seasonal trend, rather than a monthly one. The major rise of the water table in the both consecutive wetter years (1938/39 and 1939/40) took place in March. In both years the rainy season started intensively in November. So the major rise took place with a delay of about four months and took place around two months later than in the other two wells described before.

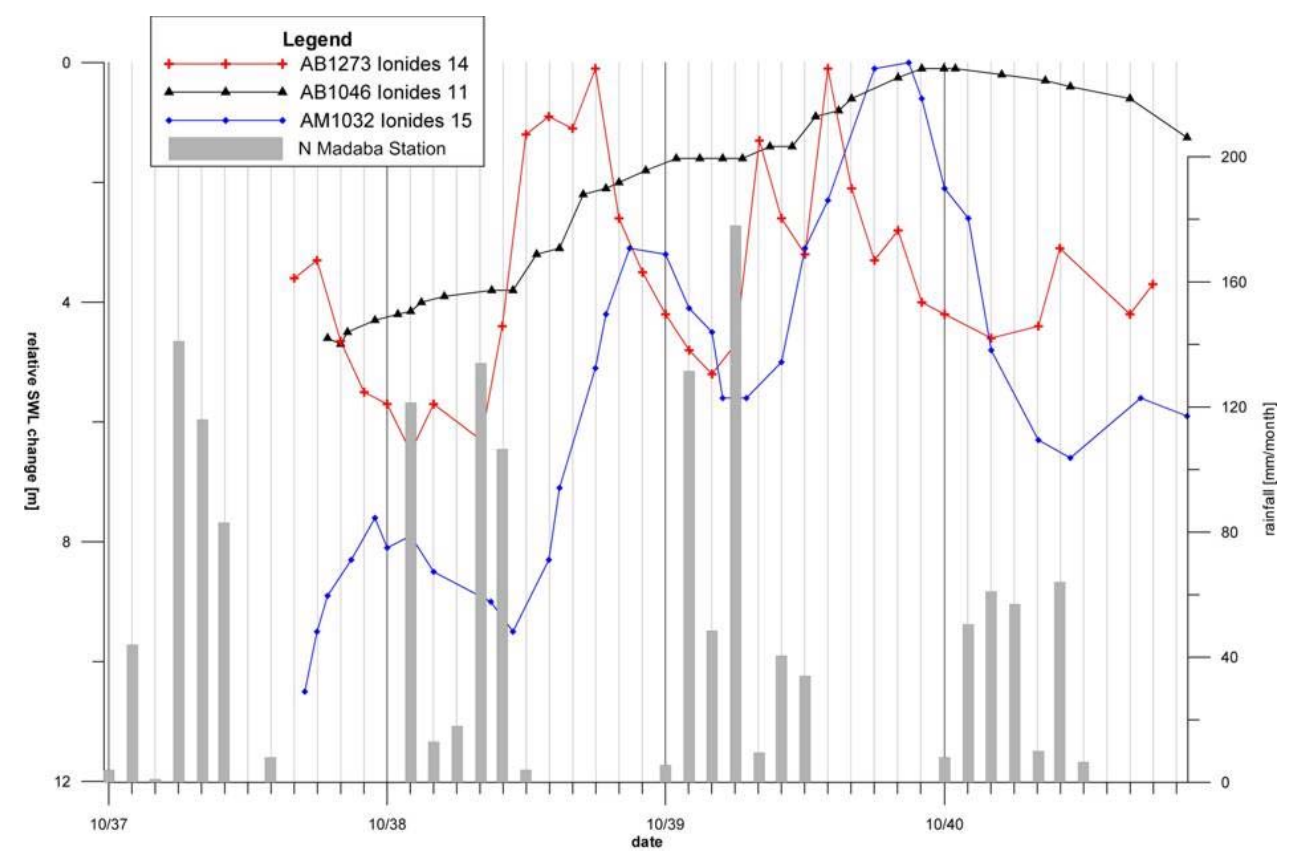

Fig. 3-9: Relative water table fluctuation in the observation wells and monthly precipitation recorded at the rainfall station in Madaba for the period 1938-41 (well data taken from Tleel 1963, precipitation data taken from MWI open files).

\subsubsection{Beginning of the early development phase in the Jordan Valley, the events of 1968 and their aftermath}

In the study area the major well drilling took place at the beginning of the mid fifties. This lead to an ever increasing groundwater abstraction. Fig. 3-10 shows the sharp drop in the water level between the pre-development period and the beginning of the 1960s, a time of heavy groundwater abstraction. During that period the groundwater level in the area of South Shuneh (AB 1273) dropped by more than twenty meters. Regardless of the intensity of rainfall (for the period from 1963 to 1967) the water level in well AB 1340 (located in the area of South Shuneh) decreased constantly. Intensive groundwater abstraction during this period can be assumed. Well AM 1032 (located in the area to the south of Kafrein) shows a different behaviour. The fluctuation of the groundwater table still follows a seasonal trend, which indicates either less groundwater abstraction or higher recharge to the unconsolidated aquifer in this area compared to the area of South Shuneh. 
The sharp rise of the groundwater table during the year of 1967 can be attributed to the intensive rain season of 1966/67 and not, as one might think, to the events of 1967 (Fig. 3-12). The smaller decline of all groundwater tables in Autumn could also be a result of the construction of dams at the outlets of Wadi Shueib and Wadi Kafrein. The consecutive rainy season (1967/68) was rather poor in terms of rainfall quantity. However, in 1968 the sharp depletion that usually occurs after the groundwater table reaches its peak in August to September is missing. The drop is rather small in the area of South Shuneh in particular. This can be explained by minor pumping activities and might be attributed to the effects of the battle of Karameh (March 21, 1968) and its aftermath. As described by Khouri (1981) during this period many farmers abandoned the Jordan Valley for the safer mountain regions and came back only on rare occasions, i.e. to do the necessary irrigation. None or only a few planting activities were reported. This is reflected clearly in the groundwater tables (Fig. 3-12). It should be noted, that for some intervals, where the water table is constant, the recording of AB 1338 must be questioned.

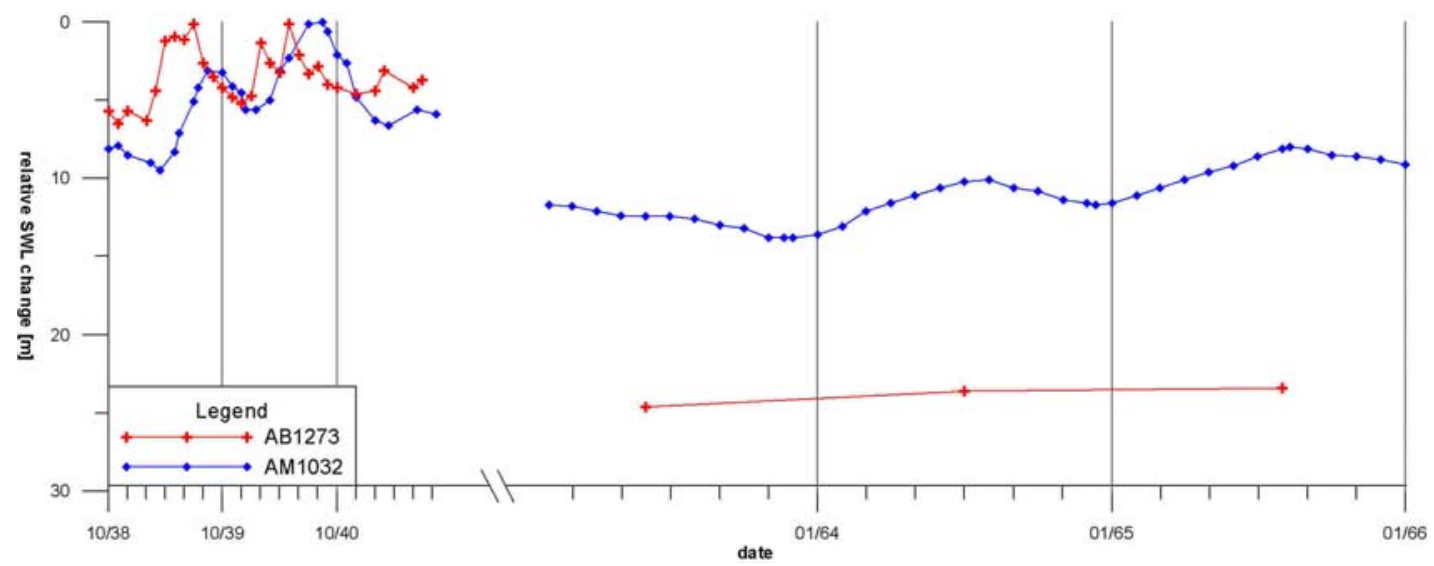

Fig. 3-10: Water level changes in study area between 1938 and 1966 (Tleel 1963 and MWI open files). Between 1941 and 63 no measurement records were available.

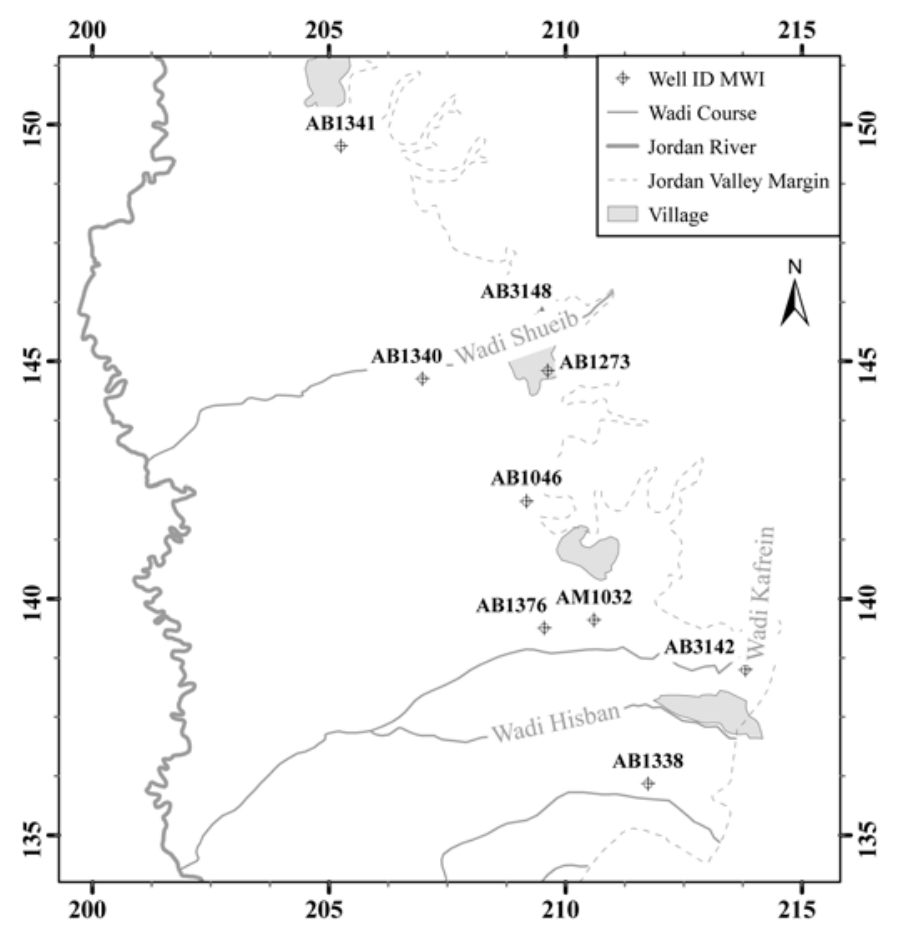

Fig. 3-11: Location of the wells monitored from 1962 to 1972 and 1980-2002 (MWI open files). 


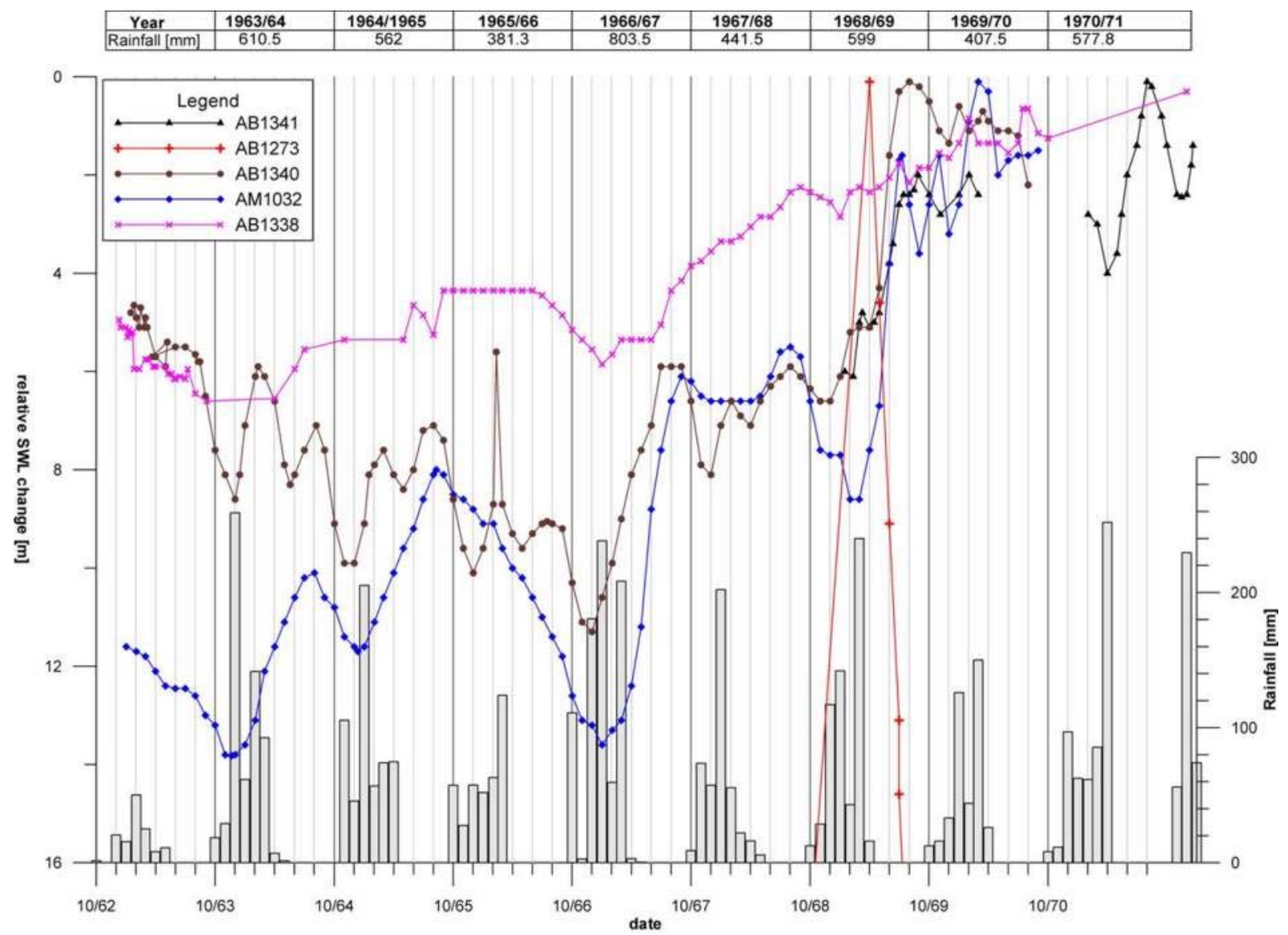

Fig. 3-12: Relative water table fluctuation in the observation wells and monthly and annual precipitation values recorded in Naur for the period 1962 till 1971 (MWI open files).

\subsubsection{Period 1980-1989}

The wet years of 1980/81 and 1982/83 lead to an increase in water level in all wells (Fig. 3-13). An exception is well AB 1342. It shows an almost constant head for its recorded period. Its location could be a possible explanation. The Sweimeh Observation well (AB 1342) is located near the village of Sweimeh, where recharge to the alluvial aquifer is different from the area of Kafrein and South Shuneh.

The effect of the final extension of the Extended East Ghor Canal on groundwater resources can be clearly seen in the constant rise of water levels in the area of South Shuneh (Fig. 3-13). Although the year 1987/88 can be considered as a year of above average rainfall. Therefore, a major rise in the groundwater table can be expected. The decline of the groundwater table during the winter season is very small. The consecutive rainy season can be regarded as nearly average. But even after this season the rise of the groundwater table is high. Recapitulatory it can be said, that after the final extension of the canal went into service, the stress on groundwater abstraction in its area of influence was reduced. In the area of Kafrein, an area which is not connected to the canal, a decrease in groundwater levels could be observed (Fig. 3-13). This is very obvioust when the groundwater tables of the wells in the Shuneh area (AB 1340 and AB 1341) are compared to the water levels in the Kafrein Observation well (AM 1032) for the rainy season 1988/89. 


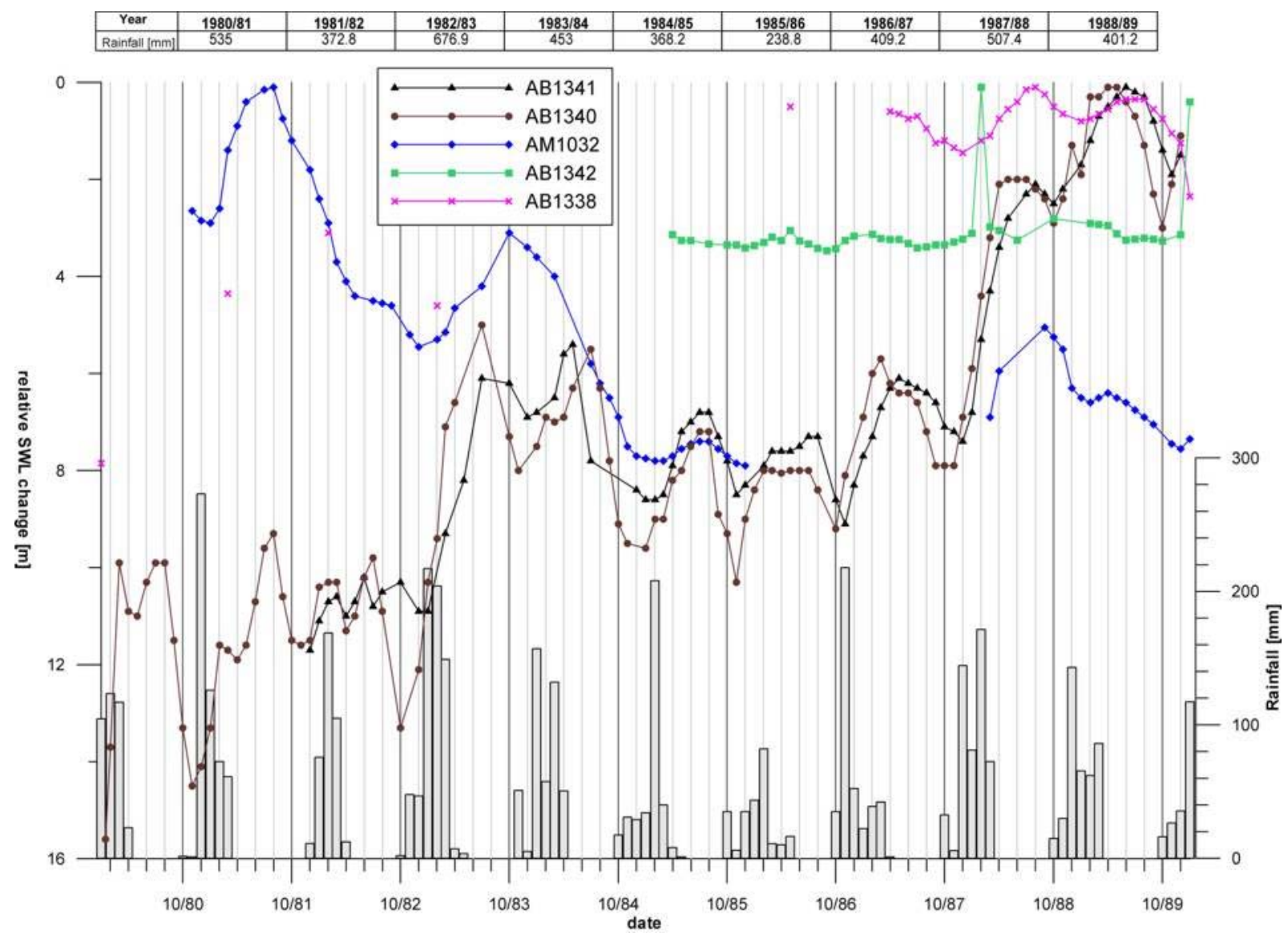

Fig. 3-13: Relative water table fluctuation in the observation wells and monthly and annual precipitation values recorded in Naur for the period 1980 - 89 (MWI open files).

\subsubsection{Period 1990- 2002}

The most eminent feature of this period is the intensive rain season of 1991/92 (Fig. 3-14). As a consequence a sharp rise in groundwater levels can be observed in all well records. The only exception is well AB 1342. Its hydrograph can be understood for reasons discussed above. This well is left out in the following considerations. The rise of the water level in terms of quantity is lowest in AB 1338. The sharp increase of its water table occurs later than in the other wells, indicating a different recharge mechanism and flow path. The increase of the groundwater level in this well happens after a two months delay and it takes place over a wider time span, but with a much smaller increase. While the water level in well AB 1338 increases for six to seven months, the water level in well AM 1032, which is located around three kilometres to the north of $\mathrm{AB} 1338$, increases sharply for a period not longer than 4 months. The rain intensive season of 1991/92 is followed by seasons of very poor rainfall. Consequently the water level show a fluctuating decrease until the wetter season 2001/02. Unlike in pervious periods well $A B 1341$ and $A B 1340$ show only one peak in a period ranging from February till April. The second peak, that usually occurred in August vanished. The seasonal low stays in the period before the rainy season (September to October). A possible explanation for increased pumping activity might be the adding of an additional planting season. 


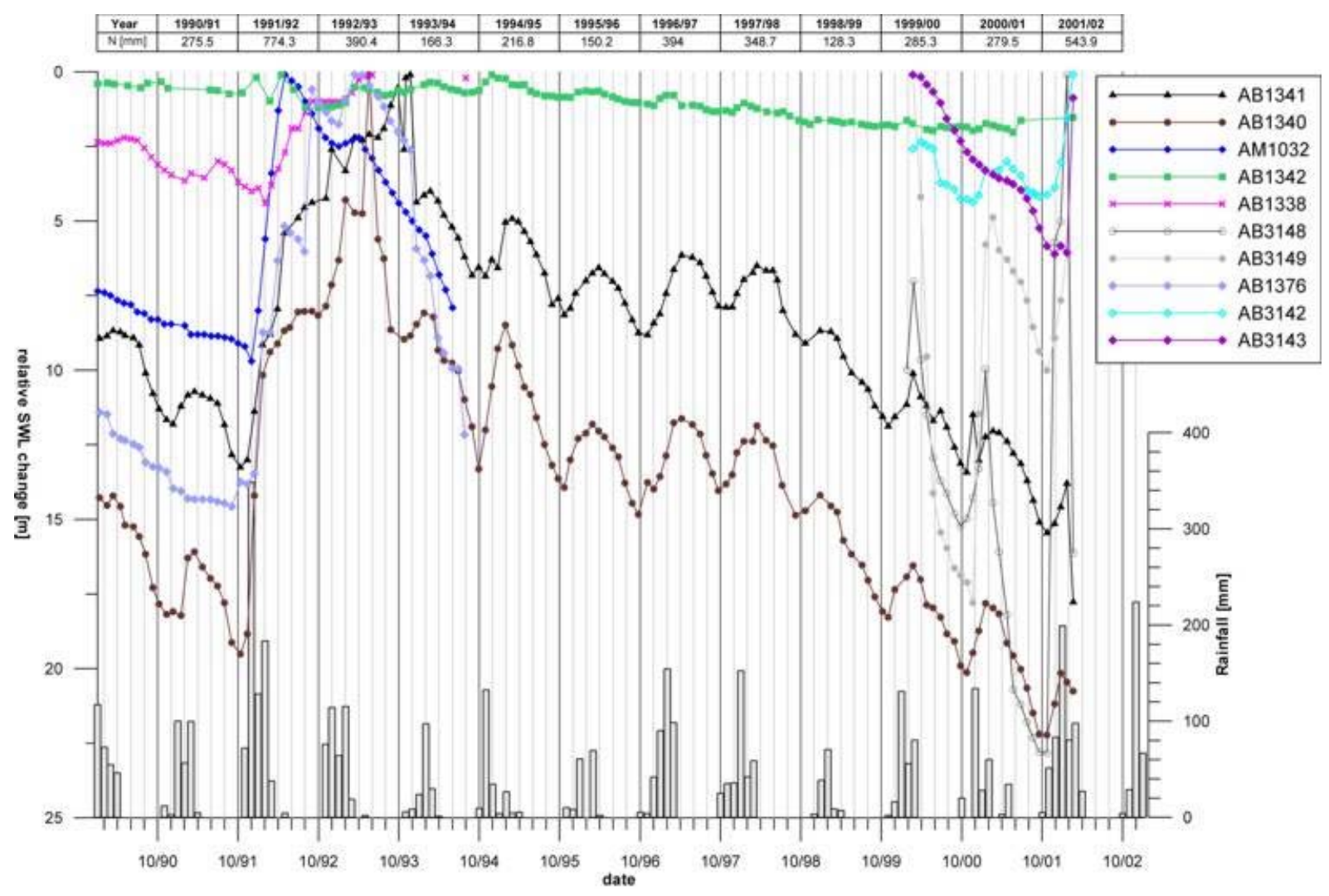

Fig. 3-14: Relative water table fluctuation in the observation wells and monthly and annual precipitation values recorded in Naur for the period 1990 - 2002 (MWI open files). 


\section{AQUIFER GEOMETRY AND PARAMETER CHARACTERISTICS}

\subsection{INTRODUCTION}

This chapter deals with the description of the geometry and composition of the unconsolidated aquifer and its hydraulic properties. Therefore this chapter is subdivided into two parts: a sedimentological description of outcrops in the study area and a second part, that deals with the sedimentological description of available well logs. The first part begins with a short description of the hinterland of the wider area of interest. This is followed by a short description of alluvial fan sedimentation and their characteristics in general and by a literature review of available publications on alluvial fan sedimentation in the surrounding areas. A description of the hydrogeologically important sedimentary facies is given along with the description of the available lithological well logs. The first part commences with an estimation of the total amount of eroded material of the wider area of interest. The second part begins with a description of the wells drilled in the study area. This is followed by a description of the hydraulic tests performed during the course of this study and by a review of aquifer tests available for the study area.

\subsection{DEPOSITS AND DEPOSITIONAL ENVIRONMENT OF THE UNCONSOLIDATED STRATA IN THE LOWER JORDAN VALLEY}

\subsubsection{Introduction}

Two different depositional environments prevail in Lower Jordan Valley: the deposition of allochthonous terrestrial coarse grained (conglomeratic) alluvial material from the surrounding wadis and autochthonous deposition of fine-grained lacustrine sediments of predecessors of the Dead Sea.

Sediments of three major alluvial fans in the Lower Jordan Valley come from three major drainage areas located to the east of the fans: Wadi Shueib, Wadi Kafrein, and Wadi Hisban (Fig. 4.2-1). All catchments drain westwards.

The Wadi Shueib catchment is about $20 \mathrm{~km}$ long, 6 to $10 \mathrm{~km}$ wide, $177 \mathrm{~km}^{2}$ in area, and the maximum catchment relief is $1,260 \mathrm{~m}$. The averages slope is $3.6^{\circ}$. The catchment area is underlain by carbonates (79.7 \%), marl-/ claystones (14.1\%), and Early Cretaceous soft sandstones (6.2 \%). The catchment of Wadi Kafrein is around $20 \mathrm{~km}$ long, $3 \mathrm{~km}$ wide in the lower part and $12 \mathrm{~km}$ in the upper, $195 \mathrm{~km}^{2}$ in area, and maximum catchment relief is $1,224 \mathrm{~m}$. The average slope is $3.5^{\circ}$. The catchment area is underlain by carbonates (72.2\%), marl-/ claystones (15.9\%), and Early Cretaceous soft sandstones (9.9\%). Wadi Hisban catchment is $15 \mathrm{~km}$ long, $6 \mathrm{~km}$ wide, has an area of $93 \mathrm{~km}^{2}$, and a maximum relief of $1,100 \mathrm{~m}$. The average slope is $4.2^{\circ}$. The catchment area is underlain by carbonates (65.6\%), marl-/ claystones (11.8\%), and Early Cretaceous soft sandstones (22.5 \%). To the south of these major wadis minor catchment areas drain northwest. Together they have a catchment area that is $15 \mathrm{~km}$ long, $8 \mathrm{~km}$ wide, with an area of $124 \mathrm{~km}^{2}$, and a maximum relief of $1,190 \mathrm{~m}$. The average slope is $4.6^{\circ}$. The catchment area is underlain by carbonates (65.2\%), marl-/ claystones (9.3\%), and Early Cretaceous soft sandstones (25.5\%).

Little is known about the nature, area, radial length, composition, and toe elevation of alluvial fans deposited within the study area. The apex elevation of Wadi Shueib, Wadi Kafrein, and Wadi Hisban is 160, 140, and $168 \mathrm{~m}$ below mean sea level (respectively). But even the recent apex locations and their elevation varied since late Pleistocene times. Recent interpretations of seismic data (Al-Zoubi et al. 2006) and a contour map of the base of the Jordan Valley Group allow speculation about a former deposition area around five to ten kilometres westwards of the present border consolidated/ unconsolidated strata. The slope of the consolidated strata buried under the unconsolidated strata is for the first five to 10 kilometres rather smooth compared to a bigger drop after it (Fig. 4.2-13). Mainly Holocene fan sediments cover the present day surface. These sediments are underlain by late Pleistocene lacustrine sediments that interfinger and overlay within isochronic deposited fan 
sediments. This can be seen in recent drainage channels and gullies developed in the Holocene sediments. The surface of the fan is covered by thin layers of Aeolian sediments. The proximal and mid-fan area is intensively used by agriculture.

Lithological logs of only eight wells constructed in 1938 were available. These wells were drilled within the project "The water resources of Transjordan and their development" implemented by Ionides in 1939 (chapter 3). The depth of the wells ranged from 106 to a mere $17 \mathrm{~m}$, depending on the purpose of the well drillings. None of these wells were drilled for production purposes. Two deep petroleum drillings "Jordan Valley-1" (JV-1) drilled by Phillips Petroleum with a total depth of $1,098 \mathrm{~m}$ and "Jordan Valley-2" (JV-2) drilled by the National Resource Authority of Jordan from 27.09.1991 to 21.04.1992 with a total depth of 1,417 m exist in the area. Only for JV-2 a lithological log was available. Both wells provide the depth of the Jordan Valley Group sediments but give no or very little information about the nature of its composition.

Other wells drilled in the area have either no drilling log or use the term alluvial for the description of the whole Jordan Valley Group. For none of the wells listed above are core or sediment samples available.

Only outcrops of the young Holocene to Late Pleistocene sediments exist. Regarding the age and accumulation of sediments in the deeper parts of the valley virtually nothing is known. Seismic information of the study area (Dr. Heinrichs, University of Göttingen, personal communication) reveals no information about the exact depth or the nature of the unconsolidated sediments. Drilling along with good sample description, geophysical logs, and cuttings would be highly desirable. In order to overcome the knowledge gap different methods were applied to get a better understanding of the nature of this unconsolidated strata. In this chapter an intensive literature review for similar sedimentary environments together with regional examples, field observation of the different lithofacies types, and well log information were combined. A combination of these methods leads to a better understanding regarding the distribution and amount of good quality groundwater which is stored in the alluvial sediments and the groundwater flow in this area in particular.

\subsubsection{Alluvial Fans}

Evolution, shape, deposition of and secondary processes on alluvial fans and their distinction from river delta and braided rivers are discussed in detail by Blair and McPherson (1994a) and Blair and McPherson (1994b). The following characteristics for developing a depositional model were taken into account (taken mostly from Blair and McPherson (1994a) and Blair and McPherson (1994b)):

\section{Primary processes on alluvial fans}

Sediment accumulation on alluvial fans, referred to as primary processes, take place as catastrophic events in high magnitudes, and, as much as sediment deposition is concerned, low frequency. Sediment deposition happens over the whole area either on active depositional lobes or, in case of small fans over the whole fan (not in channels like braided river systems). Two classes, fluid-gravity and sediment gravity flows are responsible for sediment accumulation on alluvial fans.

\section{Secondary processes on alluvial fans}

Processes reworking the primary deposition of fan sediments are called secondary processes. These processes follow the catastrophic discharge events and take place during a much larger time span (up to thousands of years) compared to the active deposition which happens during a very short time span. Such secondary processes are erosive overland flow, which results in the production of rills and gullies, and calcite sedimentation, which can be observed nowadays at the northeastern part of the Dead Sea. Very shallow groundwater tables downfan lead to evaporation, which results in the development of salt crusts or travertine. bioturbation, neotectonics, and weathering soil development complete the picture of secondary processes. 


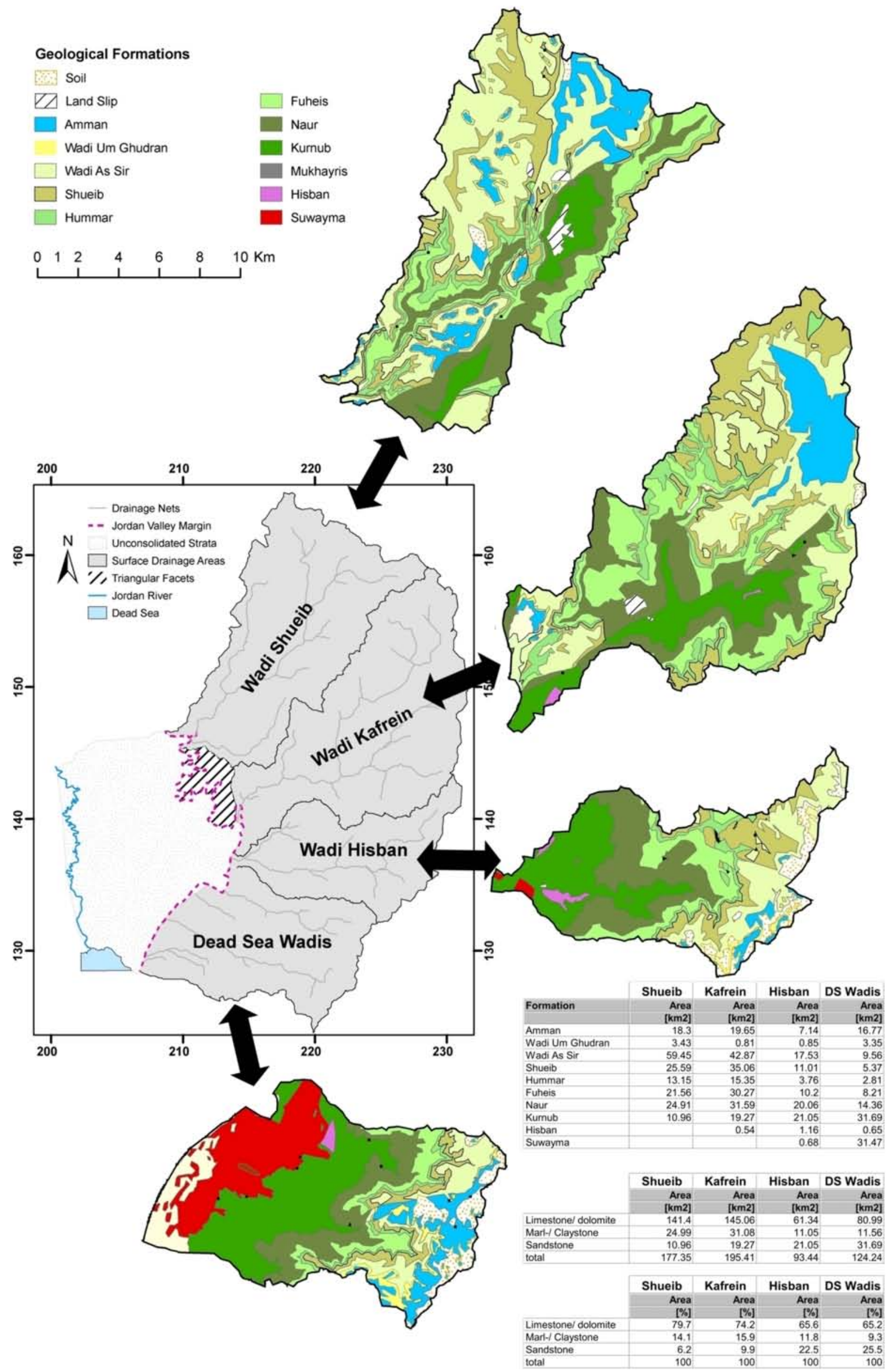


Fig. 4.2-1: Drainage net of the major catchment areas based on 1 : 50,000 scale topograhic maps provided by the Royal Geographic Center of Jordan (center map). Surface bedrock of the different catchments based on the 1 : 50,000 scale geological maps provided by the National Resources Authority of Jordan. Note, that the scale of the bedrock catchments differ from the drainage net map. Lower Right: Table of the surface bedrock area of each catchment for each geological Formation.

\section{Alluvial fan forms}

Alluvial fans are semi-circular, but with lateral constrictions, i.e. the influence of neighbouring fans, lead often to elongated fans perpendicular to the mountain front. On elongated fans incised channels may transport sediment masses away from the mountain front to the active depositional lobes of their respective fans. Their presence highly influences the form of the fan. Alluvial fans generally have a planconvex geometry and slopes range from 2 to $6^{\circ}$ in sheetflood dominated environments and up to 30 to $40^{\circ}$ in the zone of freefall accumulations (Blissenbach 1954). But slopes within the study area might be lower due to the deposition of the lacustrine facies which deposited to a higher extent in the mid basin and to smaller extend near the mountain fronts, thus reducing the general slope of the topography.

\section{Case studies from the western side of the Dead Sea combined with field observations}

According to Blair and McPherson (1994) mainly five key factors control the sedimentary processes and deposits on alluvial fans. These key factors are: lithology, shape and evolution of drainage basins, neighbouring environments, climate, and tectonism. All key factors are essentially the same on the western side of the Dead Sea. Therefore findings within these areas can be used to set up a principal sedimentary model for the study area. Several articles describe alluvial fan sedimentation on the western side of the Dead Sea directly or indirectly (i.e. Sneh 1979; Machlus et al. 2000; Bartov et al. 2002; Klinger et al. 2003). Due to the lowering of the Dead sea level (base-level), erosive overland flow cut channels (secondary process) deeply into the alluvial fan sediments. These channel outcrops reveal valuable information about the depositional nature of these fans.

Sneh (1979) reported coarse clastic sediments that interfinger with fine- grained lacustrine sediments. With increasing distance from the fan apex, the proportion of alluvial to lacustrine sediments decreases. The distal fan area is characterized by interlayered sand/mud facies. According to Frostick and Reid (1989) none of the alluvial fan sediments studied on western side of the Dead Sea can be regarded as debris flow deposits. Apart from boulders observed directly at the apex of the fan, as observed within the Holocene sediments of the study area, Frostick and Reid (1989) observed no downstream decline of grain-size: "neither is there any noticeable change in other sedimentary parameters, as bed thickness, distance of the apex or height in sedimentary sequence". An abrupt change from an alluvial to a lacustrine sequence was observed by Frostick and Reid (1989). Only seven incursions into the lacustrine Lisan Formation have been described, which gives a recurrence interval of these catastrophic events of around 1,000 years. Frostick and Reid (1989) explained the sharp change from fine laminated lacustrine sediments to alluvial sedimentation by the deposition of high magnitude discharge events that happen at low frequencies. On the base of the lake level curve of Lake Lisan Frostick and Reid (1989) attributed these high magnitude discharge events to climate change. Bowman (1971) studied the geomorphology of fans deposited on the western margin of the Dead Sea and describes the proximal part next to the Jordan Valley boundary escarpment as crudely stratified with a slightly cemented conglomeratic facies. According to Bowman (1971) the thickness of the studied fans reaches several tens of metres and has a sheet-like structure (indicator for fluid-gravity flow). The so-called rift escarpment is mantled by Pleistocene talus veneers. Klinger et al. (2003) studied three major alluvial fans near and at the Dead Sea. The Wadi Dahal fan, located to the southeast of the Dead Sea, shows Pleistocene fan segments covered by the lacustrine Lisan Formation, which is itself overlain by Holocene fan segments. Unlike the fans deposited within the study area, the present day morphology of the Wadi Dahal fan is around $-100 \mathrm{~m}$ above sea level (the maximum lake level of lake level was around $-160 \mathrm{~m}$ (chapter 2.2.2.3)). Therefore the Lisan Formation in the area of Wadi Dahal covers only the mid- and distal fan area. To verify the deposition of the whole Lisan section above the Pleistocene fan segments Klinger et al. (2003) dated lacustrine samples by using the 
$\mathrm{U} / \mathrm{Th}$ method and the alluvial deposits by using its rock varnish $\left({ }^{10} \mathrm{Be}\right.$ isotope method). Since no agriculture is practiced in the area, the different fan segments are easy to identify on satellite images and their extension and facies distribution of the fan can be mapped by remote sensing techniques. The other fan sites, the Hazeva area and Wadi Hever, are located to the southwest of the Dead Sea and to the west of the Dead Sea, respectively. The effect of slip rate on alluvial fan sedimentation for the areas southeast of the Dead Sea is discussed by Klinger et al. (2003). They studied alluvial fans whose feeder channels are continuously displaced by left-lateral strike-slip faults. Klinger et al. (2003) show, that the location of the major transform fault can strongly influence the shape and extent of alluvial fans. The effect of earthquakes on a coastal alluvial deposit is addressed in Enzel et al. (2000). They described the displacement of sediment accumulations caused by Holocene to recent earthquakes.

\subsubsection{Lithofacies types}

Different facies types were studied in 21 locations distributed along radial transects of fans in the study area (Fig. 4.2-2). Most of the stations were located in the present-day incised channel of Wadi Kafrein with exposure heights ranging from six meters down to several tens of centimetres. Additional locations were studied downfan of Wadi Hisban and in the incised channels and gullies of minor wadis along the northeastern area of the Dead Sea. In most of the outcrops only Holocene alluvial components overlying the lacustrine Lisan Formation were described. In some locations, alluvial horizons overlain by parts of the Lisan Formation could be found (Fig. 4.2-4). Nevertheless, only the upper part of the Lisan Formation is exposed in the study area. Except for the Pleistocene gravels, which can be found next to the East Bank escarpment, no outcrop older than the Lisan Formation was found. The different facies types were distinguished on the basis of grain size, texture, roundness, sorting, clast fabric, and stratification by using the classification scheme developed by Keller 1996 and Heinz et al. 2003 (Tab.4.2-1). However, the sedimentological investigations serve as a preparatory study for the hydrogeological conceptual flow model. Therefore only lithofacies types that are important for the regional groundwater flow are distinguished. The sedimentology of alluvial fans is very complex (Blair 1985, 1987). The sedimentological picture becomes even more complex, because the alluvial sediments interfinger and are underlain by lacustrine sediments of the predecessors of the Dead Sea. Only three different depositional environments were described and interpreted.
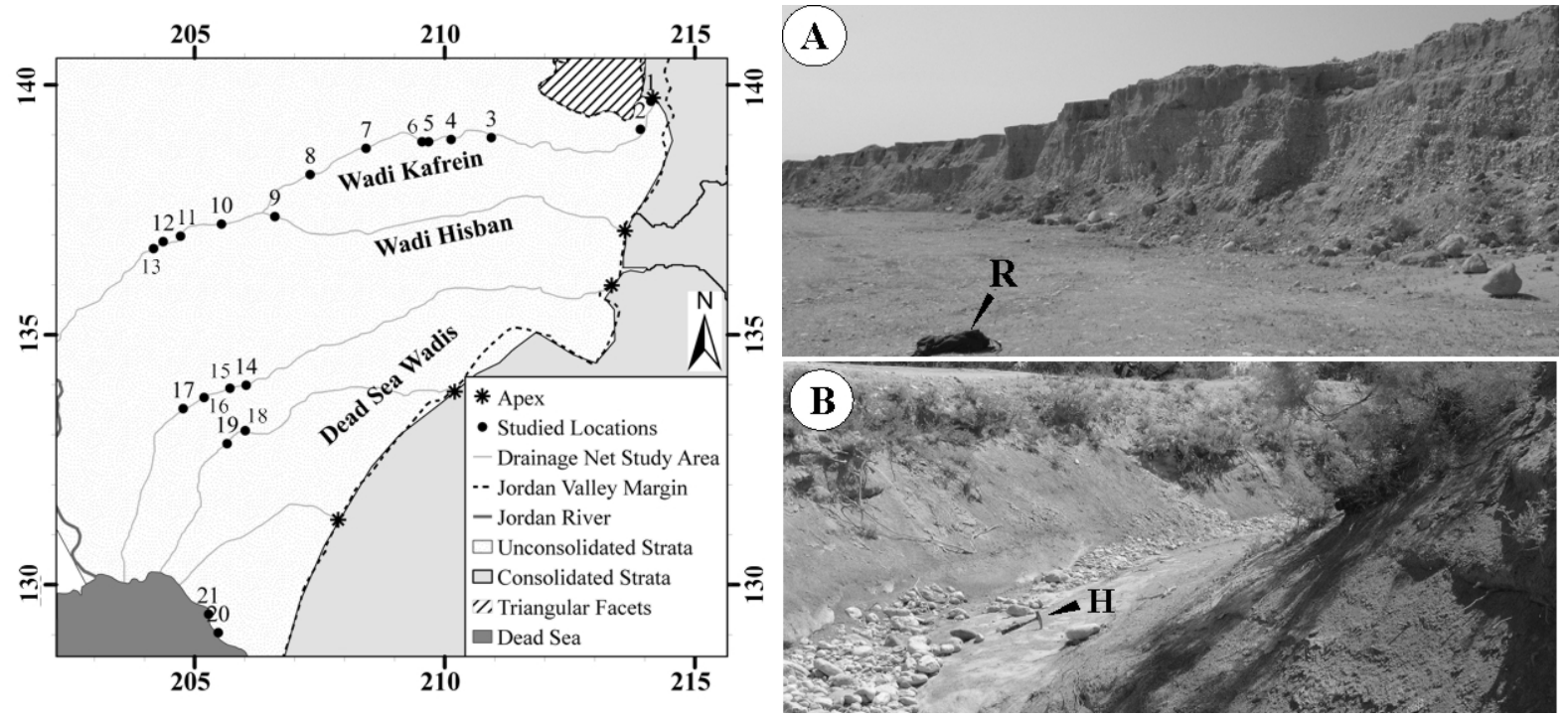

Fig. 4.2-2: Left: Map of the studied locations along the drainage nets together with fan apex locations of the major wadis. Right: (A) Photograph of the present mid-fan incised channel of Wadi Kafrein at station 10, a backpack (R) $65 \mathrm{~cm}$ long is provided for scale. In the background the $6 \mathrm{~m}$ high wall cut of the incised channel. (B) Photograph of a small gully at station 15, a hammer $(\mathrm{H}) 33 \mathrm{~cm}$ long is provided for scale. The bed consists of well rounded pebble gravel, while the wall cuts consists mostly of fine to middle sand. 


\section{Poorly sorted pebble gravel (Gcm--)}

\section{Description}

This facies is the most common in the study area and can be found in all outcrops. It consists of cobbly, coarse to very coarse pebbles in planar beds, 5 to $1.5 \mathrm{~m}$ thick, that are rhythmically interstratified with planar beds, 5 to $20 \mathrm{~cm}$ thick, of granular sand or sandy, granular fine to medium gravel. Bedding planes are always sharp and uneroded. This lithofacies can be further subdivided according to its distribution and minor components in a proximal and distal part. They are composed predominately of carbonate rocks derived from the erosion of the East Bank hinterland strata. A grain size analysis was conducted on the fraction finer than coarse pebbles at a distal area. For the fraction of $16 \mathrm{~mm}$ and bigger, a photo analysis was done by rectifying an outcrop photo in ArcGIS 9.0 and digitising the different fractions (Fig. 4.2-3).
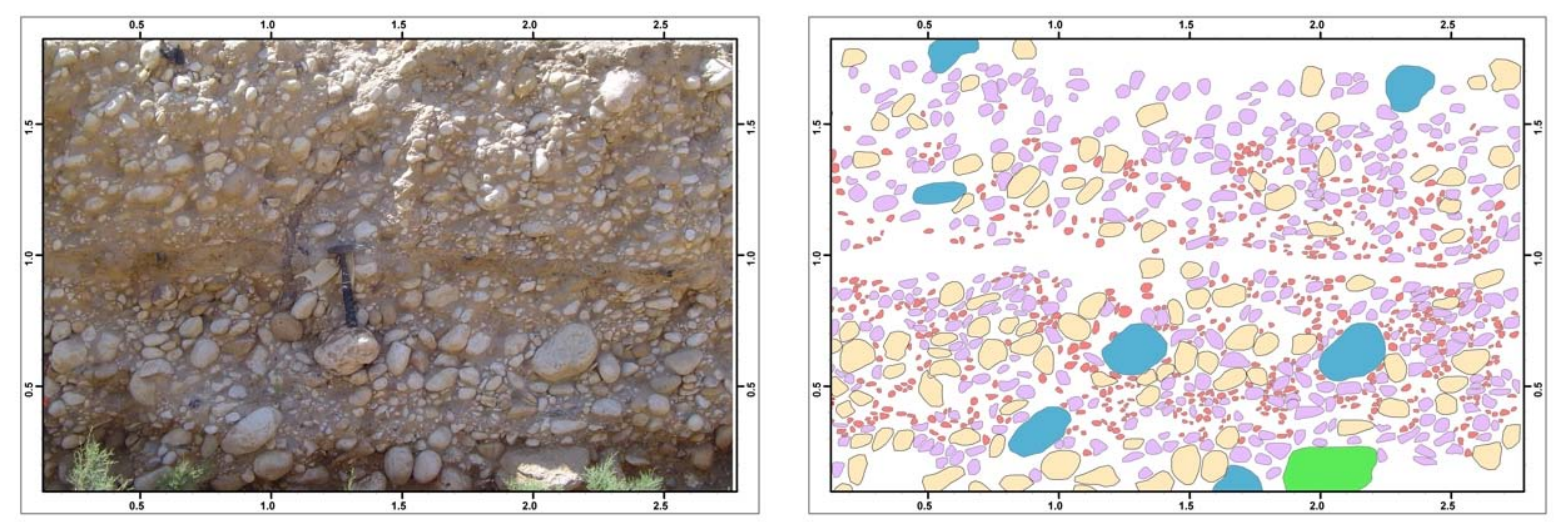

Fig. 4.2-3: Determination of grain size distribution of the components bigger than $1.6 \mathrm{~cm}$. Left: Outcrop photo; taken at distal fan location No. 16. A hammer $(33 \mathrm{~cm})$ is provided for scale (centre of the photo). Right: Five different digitized component classes: green: > $25.6 \mathrm{~cm}$; blue: 12.8 - $25.6 \mathrm{~cm}$; beige: 6.4 - $12.8 \mathrm{~cm}$; purple: 3.2 $6.4 \mathrm{~cm}$; red: $1.6-3.2 \mathrm{~cm}$.

Tab. 4.2-1 Lithofacies-code for description of gravel deposits in outcrops (modified and extended after Keller, 1996; Kleineidam, 1998).

\begin{tabular}{|c|c|c|}
\hline \multicolumn{2}{|c|}{ Indices/features } & $\begin{array}{l}\text { Abbreviation } \\
\text { b, boulder }\end{array}$ \\
\hline $\mathrm{i}_{1}$ & grain-size & $\begin{array}{l}\text { b, boulder } \\
\text { c, cobbles } \\
\text { s, sand } \\
\text { f, fines (silt/clay) }\end{array}$ \\
\hline $\mathrm{I}_{1}$ & grain-size & $\begin{array}{l}\text { G, gravel } \\
\text { S, sand } \\
\text { F, fines (silt/clay) }\end{array}$ \\
\hline $\mathrm{i}_{2}$ & texture & $\begin{array}{l}\text { c, clast-supported } \\
\text { m, matrix-supported }\end{array}$ \\
\hline $\mathrm{i}_{3}$ & stratification & $\begin{array}{l}\text { x, stratified } \\
\text { m, massive (no bedding) } \\
\text { g, graded (normal, inverse) }\end{array}$ \\
\hline $\mathrm{i}_{4}$ & additional information & $\begin{array}{l}\text { i, imbrication } \\
\text { a, alternation: e.g. o=open } \\
\text { framework, b=bimodal } \\
\text { h, horizontally stratified }\end{array}$ \\
\hline
\end{tabular}

\section{Gcm-X}

This lithofacies occurs only on the proximal part of the alluvial fans and is poorly to very poorly sorted, with a grains sizes that ranges from silt to cobbles. The facies is dominated by boulder- cobble and cobble-pebble components. The average clast size is 10 to $30 \mathrm{~cm}$ with a few medium boulders scattered around (Fig. 4.24A). The clasts are commonly rounded to well rounded. The a-axis of large clasts and boulders are usually orientated parallel to their flow direction. The gravels are clast supported, but there is a well-packed grey matrix, that consists mostly of clay to fine sand size. The lithofacies is massive and no bedding is visible. The contact to other lithofacies types is usually sharp. 
Gcm-

This facies occurs only in the mid-fan to distal areas. It comprises poorly to very poorly sorted pebbles and cobbles. The grain size ranges from silt to cobbles. The average clast size ranges from 4 to $12 \mathrm{~cm}$. The clasts are well-rounded. Only in the proximal part of the incised channels and gullies of Wadi Kafrein large boulders could be found. From this part further downfan a reduction in thickness of individual gravel layers can be seen, where the average clast size remains constant even in areas $10 \mathrm{~km}$ away from the Jordan Valley escarpment. Similar observations were made by Frostick and Reid (1989) in the incised channel of Nahal Ye'elim, Nahal Rahaf, and Nahal Ze'elim. Like in the Gcm-x facies described above the gravels are clast supported, but there is a well-packed light brown matrix, that consists mostly of clay to fine sand size. The lithofacies is massive and no bedding is visible and contact to other lithofacies types is usually sharp.

\section{Discussion and hydraulic implications}

This facies is very common in alluvial fan deposits (e.g. Blair 1987; Blair 1999a; Blair 1999b). Transport is fluid turbulent, where sediment and water remain in separate phases (Costa 1988). Deposition occurred rapidly as indicated by the poor to very poor sorting. The sharp boundaries to other lithofacies types, especially above and within the lacustrine facies, and the thickness of up to a few meters suggest deposition events of high magnitudes and low frequency (Hogg 1982) coming from the major wadis in the east as was observed in the alluvial sediments on the western side of the Dead sea (Frostick and Reid 1989; Reid and Frostick 1993). This facies is the most important regarding groundwater flow and storage.
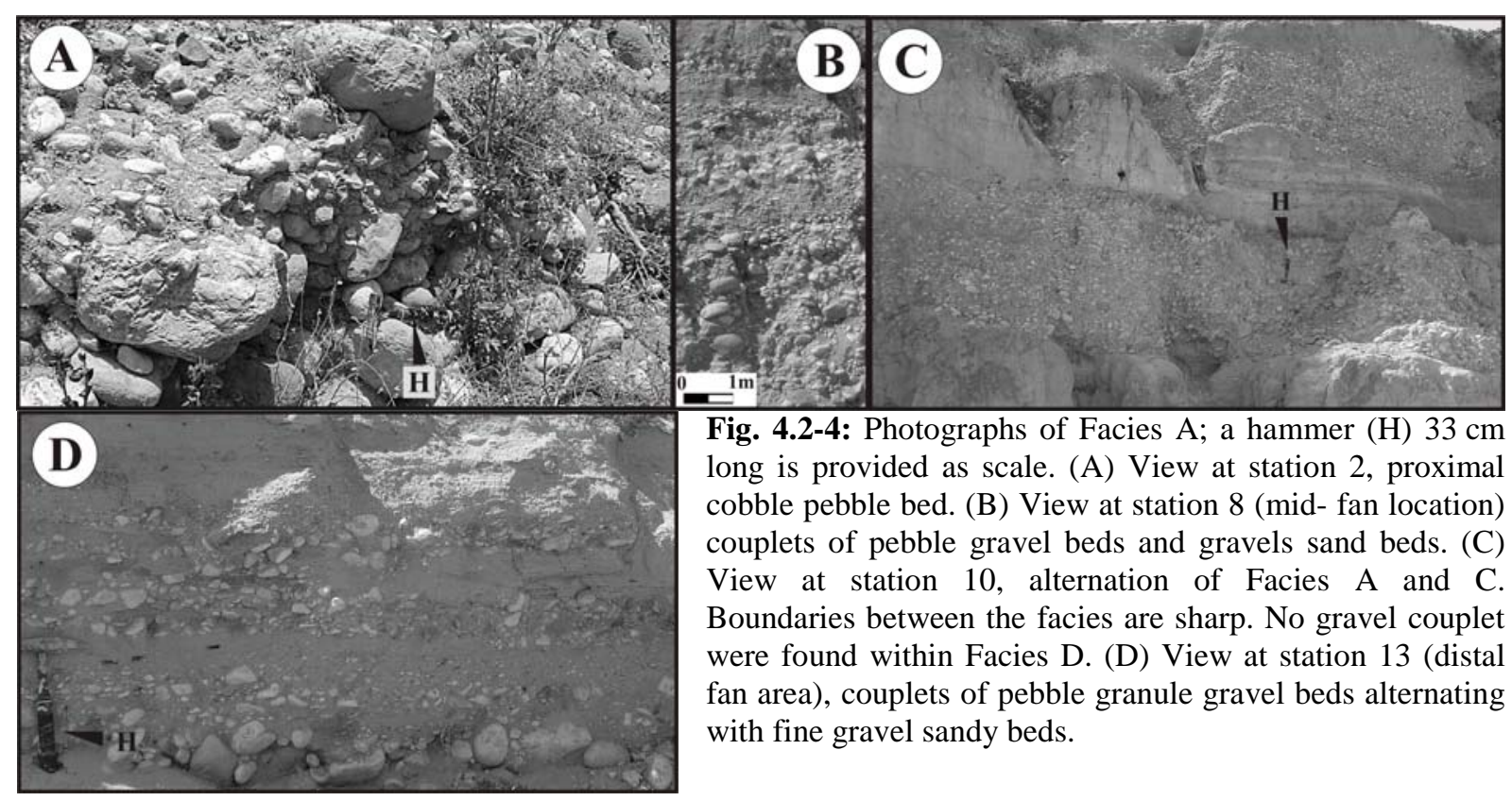

Fig. 4.2-4: Photographs of Facies A; a hammer $(\mathrm{H}) 33 \mathrm{~cm}$ long is provided as scale. (A) View at station 2, proximal cobble pebble bed. (B) View at station 8 (mid- fan location) couplets of pebble gravel beds and gravels sand beds. (C) View at station 10, alternation of Facies $\mathrm{A}$ and C. Boundaries between the facies are sharp. No gravel couplet were found within Facies D. (D) View at station 13 (distal fan area), couplets of pebble granule gravel beds alternating with fine gravel sandy beds.

\section{Facies B: Gulli deposits: Pebble-cobble lenses and irregular beds (Gcc)}

\section{Description}

This lithofacies type was only observed in some locations. It is made up of well rounded to very well rounded pebbly, cobbly coarse to fine boulder gravel. It is very to extremely poorly sorted and clast supported. Interclast spaces are either open or occupied by clay to silt, and are light brown in colour (Fig. 4.2-5).

Deposits exist in irregular to lenticular beds and are interstratified with the other facies types. Although widely spread, this facies is usually not very thick, ranging from a few pebbles up to 
laterally limited lenses of 10 to $150 \mathrm{~cm}$. Generally, the thicker intervals of this facies have a lenticular or convex cross- sectional geometry (Fig. 4.2-5). Facies B deposits, especially the more widespread beds, comprise bounding surfaces or bounding beds that separate the other facies.

No outcrop of incised channel deposits were found in the studied locations. However, these outcrops although important for groundwater flow and transport processes are expected to be small in number (Blair 1999a). The present day incised channel is five to twenty meters wide and one to six metres deep incised. No significant reduction of clast sizes can be seen along the channel course. Boulders of up to $98 \mathrm{~cm}$ length and $46 \mathrm{~cm}$ width can still be found around $4 \mathrm{~km}$ away from the fan apex. The cobbles and boulders are usually well rounded.

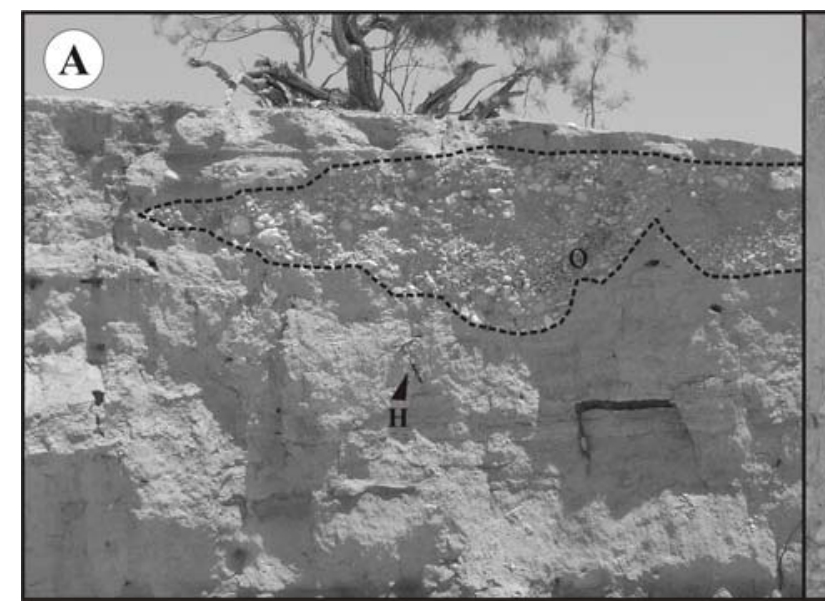

\section{B}

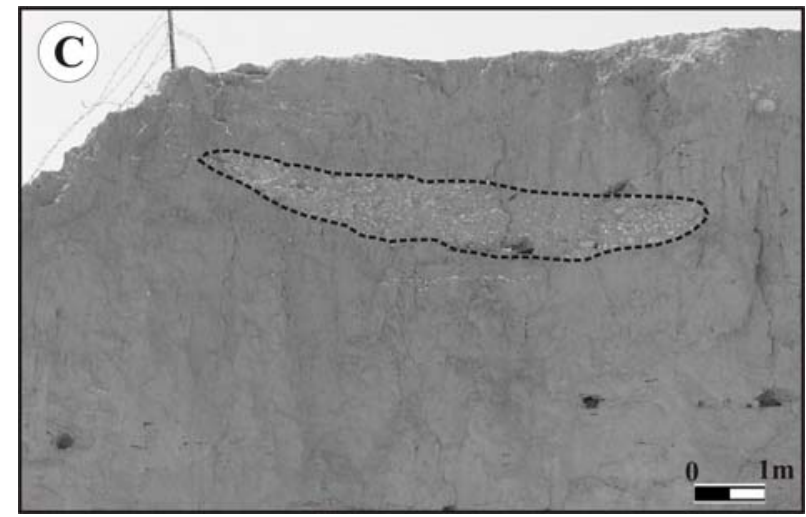

Fig. 4.2-5: Photographs of Facies B gully deposits (encircled areas); a hammer $(\mathrm{H}) 33 \mathrm{~cm}$ long is provided for scale (upper photographs). (A) View at station 14, pebbly cobble gravel lens $120 \mathrm{~cm}$ thick with basal trough surfaces on a sandy environment, open framework pebble gravel bed (o) within the gully deposits. (B) View from station 13, two lenses of well rounded gravel beds 7 to $20 \mathrm{~cm}$ thick deposited within a sandy matrix. (C) View from station 7, lenticular bed of bed of pebbly gravel of Facies B.

\section{Discussion and hydraulic implications}

This secondary gully facies is very common on alluvial fans and is described in detail by Blair (1999a). These deposits are formed after or at the recessional stage of the catastrophic discharge events which are responsible for the deposition of Facies A. These deposits form, when the catchment continues to drain water that does not carry significant amounts of sediment anymore. Consequently Facies A deposits are reworked. The lenticular geometry seen in the outcrops shows, that this facies forms mostly in rills and gullys, reworking its sediments. However, the erosional forces of water rework sediments smaller than medium coarse pebbles (Fig. 4.2-6), producing surface clast lag (Blair 1985, 1987). During falling stages of these overland flows smaller grain sizes might deposit on top of these deposits (Fig. 4.2-7B).

This facies is of local importance. Its hydraulic conductivity is similar to Facies A. However, in the case of an open framework, the hydraulic conductivity is expected to be much higher (Heinz et al. 2003). When Facies B developes in fine sands or within Facies $C$ it might act as drains on the groundwater pond by the low hydraulic conductivity of Facies C. 


\section{Facies C: Lacustrine Deposits (F-xh)}

\section{Description}

This lithofacies is present in almost all locations. It consists of soft interlayered thin laminae of white aragonite and laminae of dark detritus (Fig. 4.2-6). According to Reid and Frostick (1993) the grain size is clay to medium silt. The layer thicknesses are between 0,6 to $2 \mathrm{~mm}$ (Fig. 4.2-6 A). Thin layers of gypsum occur as well. Within this type small-scale slumps $(5-20 \mathrm{~cm})$ are common. Samples dissolved in distilled water reveal a very high amount of total dissolved solids (chapter 5.2). This facies is overlain or it interfingers the facies described above.

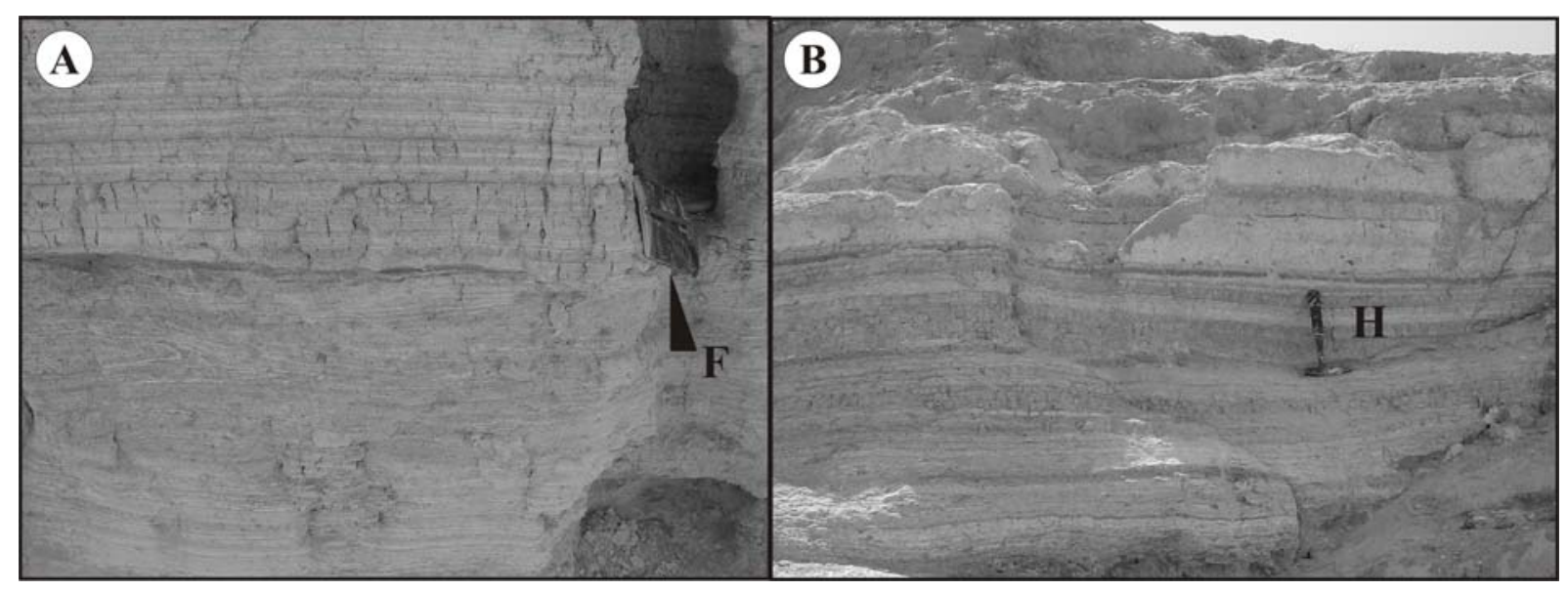

Fig. 4.2-6: Photographs of Facies C lacustrine Deposits; Field book (F) 15cm long and a hammer (H) $33 \mathrm{~cm}$ long provided for scale. (A) view at an outcrop close to the Baptism site of Jesus in Jordan, interlayered thin laminae of white aragonite and laminae of dark detrius. (B) view at station 3 (upper fan area) Lisan marls overlying Facies A.

\section{Discussion and hydraulic implications}

This facies is undoubtedly the so called Lisan Formation, which is described in detail by Bender (1965) and Begin et al. (1974) (chapter 2.2.2.3). Aragonite deposition takes place under relatively quiet lake conditions by evaporation (Katz and Kolodny 1977; Sneh 1979). The dark (grey to greygreen) detrius layers consist to a large degree of detritus derived from the carbonate rocks of the hinterland by high frequency floods of low intensities (Reid and Frostick 1993; Schramm 1997). Due to its small grain size hydraulic conductivities are low and groundwater within this facies or in its vicinity contains high amounts of total dissolved solids. Because of its softness, secondary processes, mostly erosion by overland flow, is strongly developed within this formation (Fig. 4.2-7). As a consequence gullies are quickly incised into these sediments. These gullies are often filled later by the Gcm facies described above.

\section{Additional Field Observations and their hydraulic implications}

Groundwater flow mimics the fan surface and flows from east to west. From the groundwater head map drawn on the basis of well heads in the area, an interconnectivity between the different alluvial sheets can be assumed. Whereas the depth to the water table decreases from around 40 to $50 \mathrm{~m}$ in the east down to $0.3 \mathrm{~m}$ or even emerges in incised channels or gullies in the west. The water level is not static during the year. At the end of the rainy season small springs were observed in gullies, that were found dry after the long hot summer. Local Bedouins report the same spring discharge behaviour for at least three other small springs. They usually appear around the middle of the rainy season and continue to flow until midsummer. The water usually infiltrates back after a few hundred meters flow into the alluvial sediments. The water is frequently ponded and used for local irrigation. The same pattern can be attributed to the spring of John the Baptist which dries out by the end of the summer season.

The fine-grained lacustrine sediments massively deposited in the distal fan area pond groundwater to the east. During the Geoprobe direct-push measurements confined conditions were often encountered 
in the distal fan area, where the water table rose after penetrating the Lisan Formation. Clearly visible, either by passing by or even in aerial photographs or high resolution satellite images, are wet soils in the western part of the study area. After penetrating these soils, the groundwater table was detected 0.3 to $0.6 \mathrm{~m}$ below ground level. The wet soil consequently derive from water moving upwards by capillary forces. In some areas steady-state evaporation of groundwater resulted in the development of salt crust on top of these soils. In the area northeast of the Dead Sea the alluvial sediments are cemented by precipitated carbonate materials (travertine).

Another secondary process can be observed in different gullies or in the downfan incised channel of Wadi Kafrein. The seasonal overland flow of drainage water from the East resulted in channels carved into the soft Lisan Formation. These channels were later filled by alluvial sediments (Fig. 4.2-7). In Fig. 4.2-7 B the deposition happened during various stages, first by the deposition of coarse to very coarse pebbles and cobbles and at later stages by the deposition of fine to very coarse dark brown sand. The boundary between the cobbles and sand components is sharp. Therefore the deposition of the sand facies succeeded deposition of the coarse cobble material. Within the sand facies a thin layer of pebbles can be seen, which hints at the fact, that the deposition of the sand facies took place during more than one event. The development of such secondary filled channels on the hydraulic regime is significant, since such highly conductive channels in low permeable environments reduce the impounding effect of the Lisan Formation and drain groundwater via these coarse grained channels towards the centre of the Jordan Valley.

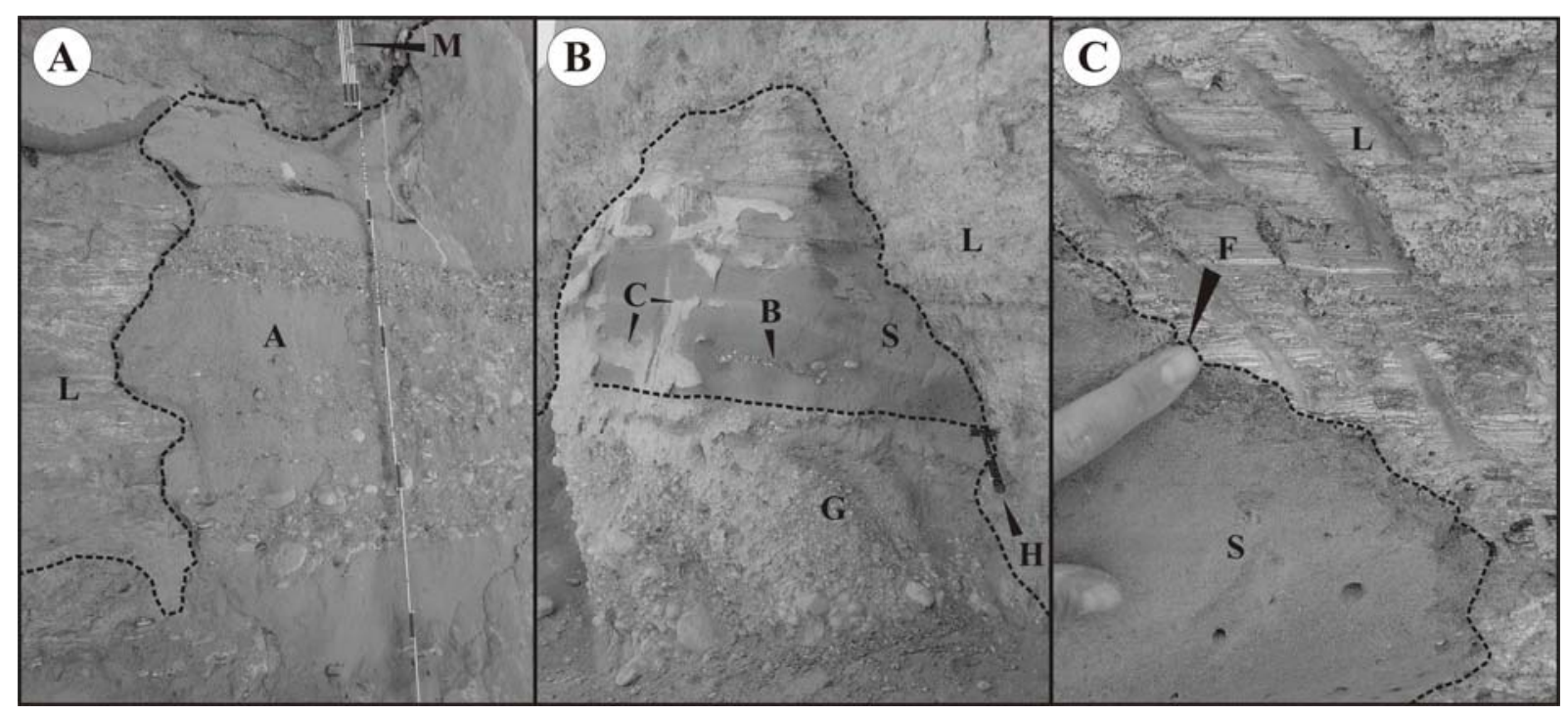

Fig. 4.2-7: Photographs of channels developed by secondary processes that are filled with alluvial material; a measuring rod (M) where each segment is $20 \mathrm{~cm}$ long, a hammer $(\mathrm{H}) 33 \mathrm{~cm}$ long, and a finger (F) are provided as scale. All photographs were taken in the vicinity of station 12 . The area is used as a quarry for sand and gravel. Therefore, contacts at these filled channels could be studied in detail. (A) Alluvial sheetflood deposits (A) deposited in a washed out channel in the Lisan Formation (L). Couplets of pebble gravel beds alternate with coarse sandy, granule pebble beds. (B) Lacustrine Lisan Formation (L) in the background. Cobbly, pebble gravel (G) separated by a sharp boundary from the overlying medium to coarse sand beds (S) The gravel bed is graded. A Couplet of granule gravel (B) is intercalated into the sand bed. Precipitated salt crusts (C) can be found on top of the gravel and sand beds. The source of these salt crusts could be the dissolution of salts within the Lisan Formation by drainage water. (C) Sand beds (S) deposited next to the white and grey laminated Lisan Formation (L). The boundary is very sharp. Sand beds deposited parallel to the deposition of the different laminae of the Lisan Formation indicating that its deposition took place in a channel developed after the deposition of the lacustrine sediments.

\subsubsection{Drilling Logs}

In the study area only outcrops in the incised channels and gullies, widened by secondary processes, are accessible. Outcrops are usually not higher than a few metres. Additional information regarding 
deeper sedimentary conditions can be obtained from neighbouring wadis with similar sedimentary conditions and lithology (wadis studied along the Dead Sea) and from boreholes. As described above only a few lithological logs of wells drilled in the area are available. Unfortunately their lithological descriptions are basic. Most of the available lithological descriptions distinguish only alluvial (whereby the term "alluvial" refers to unconsolidated material of all kinds including lacustrine components) and different hardrock lithologies. The wells drilled during the project in 1938 supervised by Ionides have a better lithological description (chapter 3). Here loam, marl, silt, sand, and gravel are distinguished. No further subdivision was made. Nevertheless, these descriptions reveal valuable information about the distribution of the lacustrine and the alluvial facies. Tab. 4.2-2 shows the percentage of alluvial facies versus lacustrine facies together with explanatory notes. The lacustrine facies is, apart from Well No. 19, drilled to the south of the village of Karameh, and Well No. 18, drilled close to the apex of Wadi Hisban, the major fraction of the drilling logs. The drilling logs of the different wells can be found in the Appendix. The fact, that most of the drilling logs consist of the Lisan Formation is not surprising. It can be addressed to the fact, that most of the alluvial components were deposited before the deposition of the lacustrine Lisan Formation. Near Karameh the thickness of the Lisan Formation is around $44 \mathrm{~m}$ (Gibbs 1992). Apart from drilling locations close to the present apex of the major wadis or next to the freefall area close to the boundary consolidated/ unconsolidated the Lisan Formation makes up most of the drilling log unconsolidated material. Unfortunately most of the wells drilled in the area are not deep enough. The deeper wells are Well 12, 15, and 18. The drilling logs of Well No. 12 and Well No. 15 show an increase in alluvial components starting from a penetration depth of 48 and $46 \mathrm{~m}$ respectively. Well No. 18 is an exception insofar that it was drilled close to the apex of Wadi Hisban. Its drilling log is therefore dominated by alluvial components. It should be noted, that although Well No. 14 is $106 \mathrm{~m}$ deep, only $46.55 \mathrm{~m}$ of alluvial material were encountered. The remaining 59.45 m were drilled into the Wadi As Sir Formation. From the few drilling logs described above it can be concluded, that most of the wells drilled in 1938 were not deep enough to penetrate the alluvial components older than the lacustrine Lisan Formation.

Different alluvial "incursion" as described before can also be depicted within most of the drilling logs. When a thickness of around 40 is assumed, four to six alluvial incursion, depending on the drilling location, can be depicted from the different drilling logs.

Tab. 4.2-2: Alluvial/ Lacustrine distribution along with remarks of the wells drilled in 1939 (Ionides 1939). PGE = Palestine Grid Easting; PGN = Palestine Grid Northing; All = fraction of Alluvial material; Lac $=$ fraction of Lacustrine material.

\begin{tabular}{|c|c|c|c|c|c|l|}
\hline Well & PGE & PGN & Depth & All & Lac & Explanatory notes \\
\hline [-] & {$[-]$} & {$[-]$} & {$[\mathbf{m}]$} & {$[\%]$} & {$[\%]$} & \\
\hline 11 & 209,170 & 142,060 & 40.20 & 36.4 & 63.6 & $\begin{array}{l}\text { Located between the major outlets of Wadi Shueib and } \\
\text { Wadi Kafrein, but close to the mountain front }\end{array}$ \\
\hline 12 & 206,900 & 141,500 & 84.80 & 25.5 & 74.6 & $\begin{array}{l}\text { Wadi Kafrein; distal of the mountain front; most of the } \\
\text { alluvial components are made up of sandy material }\end{array}$ \\
\hline 14 & 209,620 & 144,800 & 106.00 & 28.9 & 71.1 & $\begin{array}{l}\text { Sir) were drilled } \\
\text { Socated between the major outlets of Wadi Shueib and }\end{array}$ \\
\hline 15 & 210,600 & 139,550 & 71.30 & 21.3 & 78.7 & Located 3.4 km NW of Wadi Kafrein \\
\hline 16 & 205,200 & 141,250 & 11.70 & 3.0 & 97.0 & $\begin{array}{l}1.7 \text { km to the west of Well No.12; only 11.75 m were } \\
\text { penetrated }\end{array}$ \\
\hline 17 & 207,050 & 138,800 & 17.40 & 2.9 & 97.1 & 3.6 km west of Well No.15; only 17.4 m were drilled \\
\hline 18 & 211,740 & 136,090 & 61.20 & 63.6 & 36.4 & Located near the outlets of Wadi Kafrein and Hisban \\
\hline
\end{tabular}


\begin{tabular}{l|l|l|l|l|l|l|l|}
19 & 205,250 & 149,550 & 17.80 & 86.0 & 14.0 & $\begin{array}{l}0.8 \mathrm{~km} \text { S of Karameh; located close to the mountain front; } \\
\text { only } 17.8 \text { m were drilled }\end{array}$ \\
\hline
\end{tabular}

\subsubsection{Estimating the amount of eroded material}

\section{Introduction}

In order to estimate the amount of material that might be eroded from the hinterland (wider area of interest) and deposited in the lower Jordan Valley (study area), a simplified three dimensional reconstruction of the consolidated strata was prepared. The basis of this reconstruction is a structure contour maps of the Base of the Kurnub Group. From this strata onwards the younger layers were added on top of it. In order to estimate the volume of the eroded material, the present day morphology (DEM based on 1:50,000 topographic maps, Royal Geogrpahic Centre of Jordan) was subtracted from the uneroded top of the youngest layers. The volume was calculated by the difference multiplied by its respective surface area.

\section{Consolidated strata}

On the base of a structure contour map (base Kurnub Group) provided by Dr. Till Heinrichs (Göttingen University) in the western area and the base Kurnub Group contour map, prepared by the BGR/WAJ (1994), for the eastern area, a 3-D geological model for the area of the consolidated rocks was prepared. In order to fit the borders of the study area both maps were adjusted and extended to the north and south (Fig. 4.2-8). It should be noted, that the geological model is intended to represent the large catchment area of Wadi Shueib, Wadi Kafrein, Wadi Hisban and the Dead Seas Wadis (Fig. 4.28). Therefore only large structural features are included within this model. These features are discussed in detail in chapter 2.2.3.3. Small scale models, where e.g. small detachment faults or inclined faults etc. are included, require much more input data and a more detailed mapping program, which is beyond the focus of this study. The base of the Kunrub Group was chosen since it is the base of the lowermost aquifer modelled within this study. The elevation of younger formations on top of the Kurnub are based on the Kurnub base structure contour map.

The western part, provided by Dr. T. Heinrichs, is based on the geological map of Lenz (1999), mapped at a scale $1: 10,000$, the geological map of Karameh, published by the National Resource Authority of Jordan (NRA), mapped at a scale of $1: 50,000$ (Shawabkeh 2001), and lithology logs of some wells in the area, provided by the Ministry of Water and Irrigation of Jordan (MWI). Due to the detailed mapping of Lenz (1999) a relatively detailed picture of the structural features around the western end of Wadi Kafrein could be attained. Future detailed mapping of the relatively complicated area would be desirable in order to get a better picture of the structural features.

The eastern part of the of the consolidated strata is based on the maps provided by BGR/WAJ (1994). This part of the structure contour map is mostly based on well log data. Only very large scale features can be seen on this map, since the density of well logs is poor, especially in the area between the Mountain Highland and the Jordan Valley.

The structure contour map was digitised and transformed via triangulated irregular networks (TIN) into a raster data set by using the commercial ArcGIS 9.0 software package (ESRI Inc.). In order to represent the large and steep structural features of the study area a cell size of $50 \mathrm{~m}$ was chosen.

Since the thickness of the different formations cannot be added perpendicular to the dip of the formation, the exaggerated thickness has to be calculated for every cell of the grid. The exaggerated thickness can be easily calculated by using the formula:

$\mathrm{t}^{\prime}=\mathrm{t} / \cos \delta$

Where $\mathrm{t}^{\prime}=$ exaggerated thickness, $\mathrm{t}=$ true thickness, and $\delta=$ true dip of the unit. The true dip of every grid cell can be obtained by calculating the slope of the raster. When calculating the exaggerated thickness with the help of the raster calculator, the radian values of the different dip angles have to be used. A dip of up to $5^{\circ}$ can be neglected since the exaggerated thickness almost equals the true 
thickness. By using the Raster Calculator of the Spatial Analyst Tool the exaggerated thickness value for each grid cell can easily be calculated and be added on top of the respective raster cell. Too little is known about faults in the area. For most of the wider area of interest the shape, dip, and continuation through the different strata is either not known or insufficiently described, or drawings on the geological maps contradict each other. Only for some selected areas information exist. Therefore it was assumed, that faults mapped on the surface continue through every formation in a vertical direction. Furthermore it was assumed, that no thickness variation happens in areas of deformation. That is no thickness variation as a result of layer compressibility exists. The elevation added of each grid cell depends also on the thickness distribution of the different strata in the area. In the following paragraphs thickness distributions of the different geological formations for the wider area of interest are discussed respectively. The geological and hydrogeological properties and variations are addressed in chapter 2.2 and 2.3 .

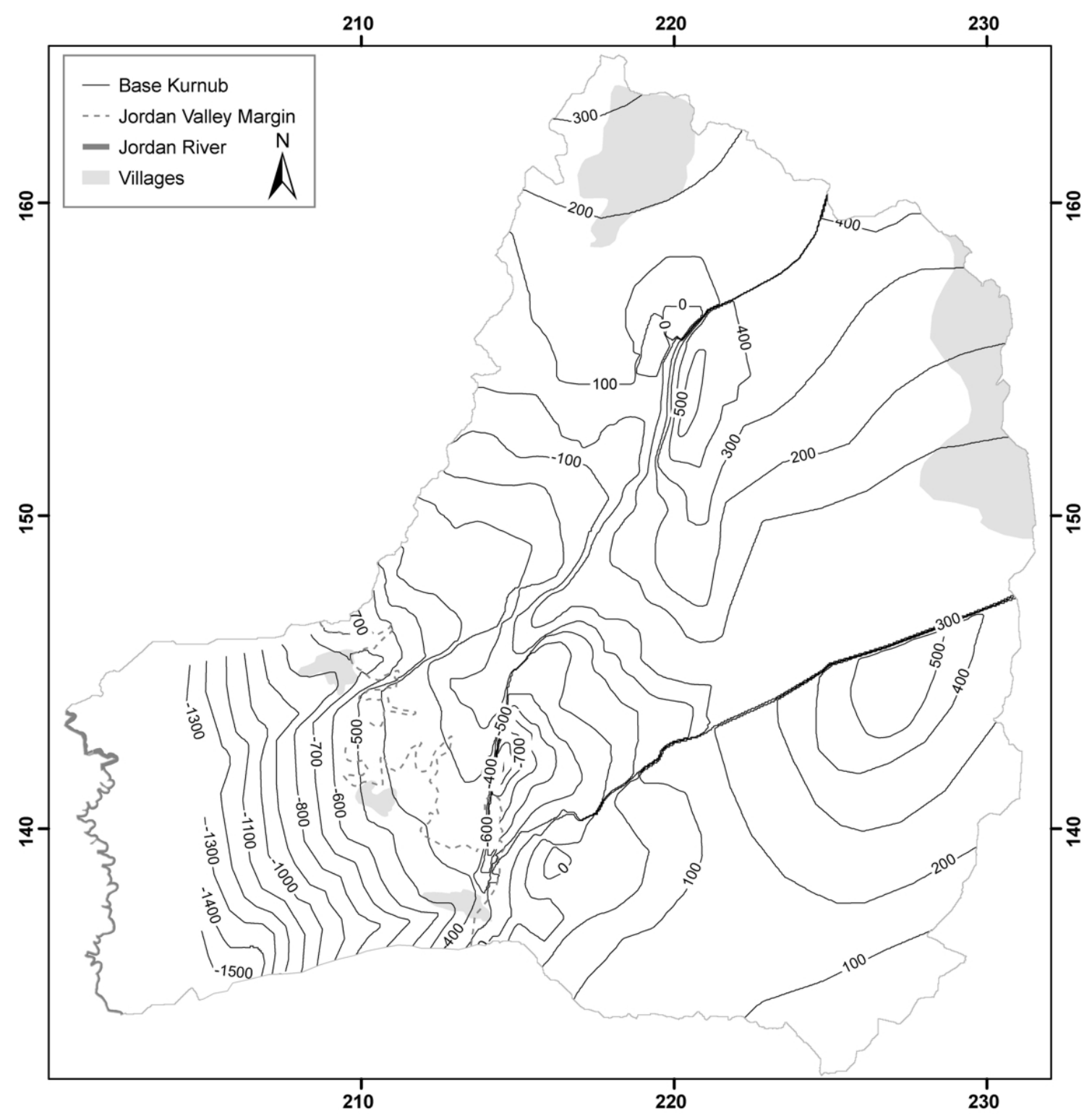

Fig. 4.2-8: Structure contour map of the base of the Kurnub Group. 
The terrigenous sandstones of the Kurnub Group consist of fluvial deposits, resulting from the erosion of the Arabian Craton located to the south and southeast of Jordan (Powell 1989). Consequently, the thickness varies from 244 to $270 \mathrm{~m}$ in the area of Zerqa Main down to $168 \mathrm{~m}$ in the area of Zerqa River (Powell 1989). Within the study area a whole section of the Kurnub Group is not present and no borehole information regarding the thickness of the Kunrub Group was available. Consequently the thickness was linearly interpolated from south to north, ranging from $250 \mathrm{~m}$ in the area close to Zerqa Main to 168 m near the Zerqa River.

\section{Top of Naur/ base of Fuheis Formation}

A more complete picture of the nodular and dolimitic limestones/ dolomites of the Naur Formation is available. Schulze et al. (2003) report a thickness of $140 \mathrm{~m}$ in Wadi Salihi, located around $30 \mathrm{~km}$ to the north and a thickness of 150 m near Wadi Abu Khusheiba, located around 5 to $10 \mathrm{~km}$ to the south of the study area. Kunz (2003) mapped a thickness of $110 \mathrm{~m}$ in the upper Wadi Shueib area and Becker (2000) a thickness of $110 \mathrm{~m}$ in the area of South Shuneh. The Naur Formation was penetrated by one well in the study area near Hisban. A thickness of $101 \mathrm{~m}$ was encountered, but the drilling log showed no clear information, if the Naur formation was fully penetrated, hence a minimum thickness of $101 \mathrm{~m}$ was assumed. The thickness determination from the geological map of Karameh (Shawabkeh 2001) using the three point problem revealed a dip of around $9^{\circ}$ and a true thickness of around $140 \mathrm{~m}$ near Al Hanni (218000/131500) and a dip of around $4^{\circ}$ and a true thickness of around $100-105 \mathrm{~m}$ near Mahis (222750/155500). A clear north- south trend can therefore be seen. Consequently a thickness of $110 \mathrm{~m}$ was assigned to the area of Wadi Shueib (from Salt to South Shuneh) and a thickness of $140 \mathrm{~m}$ to the southern part of the study area. Between these areas the thickness increases linearly (north to south).

\section{Top of Fuheis/ base of Hummar Formation}

The clay content of the Fuheis Formation, which consists predominately of marls and argillaceous and nodular limestones, increases towards the south. Schulze et al. (2003) give a thickness of $65 \mathrm{~m}$ in the northern sections of Wadi Salihi and $18 \mathrm{~m}$ in Wadi Abu Khusheiba. While Lenz (1999) estimated a thickness of $55 \mathrm{~m}$ in the area east of Kafrein, Becker (2000) mapped $70 \mathrm{~m}$ in the area of South Shuneh, Kunz (2004) $80 \mathrm{~m}$ in upper Wadi Shueib, Masri (1963) $80 \mathrm{~m}$ in the area of Sweileh, and Powell (1989) $57 \mathrm{~m}$ in the area of Wadi Ash Shita (in the area of Amman). A decrease from north to south in thickness can be seen, whereby an increase in clay content is noticeable. The above given thicknesses were arranged in polygons. Between the polygon the values were linearly interpolated. This can be justified by the clear north-south trend described by the authors above.

\section{Top of Hummar/ base of Wadi Shueib Formation}

The argillaceous dolostones and dolimitic limestones of the cliff-forming Hummar Formation has, according to Schulze et al. (2003), a thickness of $50 \mathrm{~m}$ in the area of Wadi Salihi. From there its thickness decreases towards the south to around $3 \mathrm{~m}$ in Wadi Abu Khusheiba. Within the framework of some master theses Becker (2000) estimated a thickness of $45 \mathrm{~m}$ in the area east of South Shuneh, Kunz (2003) mapped 45 to $50 \mathrm{~m}$ in the upper Wadi Shueib area, and Lenz (1999) measured a thickness of 40 to $45 \mathrm{~m}$ in the area east of Kafrein. Powell (1989) gives a thickness of $43 \mathrm{~m}$ in the area of Salt, $65 \mathrm{~m}$ in the area of Sweileh, and $60 \mathrm{~m}$ in the area of Wadi Ash Shita (Amman area). In a well drilled near Ash Shita, the Hummar Formation has a thickness of $55 \mathrm{~m}$. A combination of these different results does not give a clear trend. According to Schulze et al. (2003) the thickness decreases from 50 to $3 \mathrm{~m}$ in a north - south section. Taking the results given by the authors mentioned above a slight increase from north to south and an increase of thickness from west to east, at least for the area of interest, can be seen. However, the trend is not very clear. As a result a thickness of $45 \mathrm{~m}$ was assumed in the west of the study area with an increasing thickness towards the east, which reaches its highest value in the eastern to southeastern part of the study area $(60 \mathrm{~m})$. 


\section{Top of Wadi Shueib/ base of Wadi As Sir Formation}

The Wadi Shueib Formation consists of two lithological members: the marls and marly limestone in the lower and middle part and the massive nodular limestone in the upper middle to upper part. The formation has a thickness of 60 to $70 \mathrm{~m}$ in the area of Wadi Salihi (Schulze et al. 2003), $30 \mathrm{~m}$ in the area east of South Shuneh (Becker 2000), 35 to $50 \mathrm{~m}$ in the middle and upper area of Wadi Shueib (Parker 1970; Kunz 2003), $35 \mathrm{~m}$ in the area east of Kafrein (Lenz 1999), $47 \mathrm{~m}$ in a well near Wadi Ash Shita (MWI database) an $72 \mathrm{~m}$ in the area of Naur (Parker 1970).

Schulze et al. (2003) give a thickness of 60 to $70 \mathrm{~m}$ both for the northern (Wadi Salihi) and middle section of their study area (Wadi Mujib). However, combining the information available for the area of interest, an increase from west to east, at least for the area of Wadi Shueib, can be concluded (30 $\mathrm{m}$ in the area east of South Shuneh, 35 to $50 \mathrm{~m}$ in the middle to upper Wadi Shueib, and $60 \mathrm{~m}$ in the area of As Salt). The thickest part of the Wadi Shueib Formation was given by Parker (1970) in the eastern to southeastern part of the area.

\section{Top of Wadi As Sir/ base of Wadi Umm Ghudran}

The thickness of the dolomitic limestone of the Wadi as Sir Formation has a clear north - south trend. $130 \mathrm{~m}$ of thickness was mapped in the area east of South Shuneh (Becker 2000), 130 to $150 \mathrm{~m}$ in the upper Wadi Shueib (Kunz 2003), 90 in the area of Kafrein (Lenz 1999), 85 to $97 \mathrm{~m}$ in Amman area (Powell 1989), and $82 \mathrm{~m}$ in the area of Madaba (Powell 1989). A linear north - south interpolation between the northern end of the study area (130 m thickness) and the line Hisban - Amman (100 m) and a linear interpolation between the line Hisban - Amman (100 m thickness) and the southern end of the study area $(80 \mathrm{~m})$ was prepared.

\section{Top of Wadi Umm Ghudran/ base of Amman Formation}

The massive chalk and marlstone of the Wadi Umm Ghudran Formation, the lowermost member of the Belqa Group, succeeds the Wadi as Sir limestone. Within the wider area of interest no active deformation before Senonian times is known (chapter 2.2.3.3). In Late Coniacian the so called SyrianArc stress field (chapter 2.2.2.2) evolved. Most of the prominent folds and fault systems were built during this active tectonic phase, which received its final shape before the Eocene. The forming of this arc system affected the sedimentation and thickness distribution within the study area. High sediment accumulation took place in anticlinal structures or depressions, less sediment accumulation happened along the flanks of folds and flexures, and less or no sedimentation took place on top of synclinal or monoclinal structures. Using the thickness specifications given by the authors below, a structural induced thickness distribution of the Wadi Umm Ghudran Formation was done. The same would apply for the younger formations (Amman and Muwaqqar Formation). However, in some areas, like in the area around Salt, the Wadi Umm Ghudran Formation cannot be distinguished from the Amman Formation and is mapped therefore as one unit B1/2. Lenz (1999) reported a thickness of 20 to $30 \mathrm{~m}$ in the area east of Kafrein, Becker (2000) $40 \mathrm{~m}$ in the area east of South Shuneh, Powell (1989) a few metres in the area of As Salt and up to $60 \mathrm{~m}$ in the area of Amman. Between the synclinal and anticline structures, perpendicular to the strike the values were linearly interpolated since the thickness values in literature were not given as point data, rather as spatial information for a certain area. Consequently, a more detailed thickness variation along the structural features cannot be addressed.

\section{Top of Amman Formation}

The limestone of the Amman Formation is the youngest formation cropping out in the area. Powell (1989) gives a thickness of $60 \mathrm{~m}$ in Amman area. The deposition of the Amman Formation falls also into the evolving phase of the Syrian Arc System. Hence the same depositional condition as for the Wadi Umm Ghudran Formation applies. Unfortunately no other records of the study area as the one 
given above were available. Furthermore, the location of the thickness specification is wide. Therefore on average a thickness of $60 \mathrm{~m}$ was applied to the whole study area.

“Missing Formations" (already eroded rock volume)

The final regression in the area took place at the end of the Upper Eocene. Before, most of the structures built during the Syrian Arc deformation phase were part of a marine depositional system. However, some areas, like the cores of synclines and monoclines, have emerged from the sea. This leads to large thickness variations. From this time onward no new sediments were deposited.

In order to determine the rock volume that has eroded since the last sedimentation phase during Upper Eocenian times, the complete rock column, including the already eroded material, must be subject to investigation. Since no sediments younger than the Campanian Amman Formation crop out in the study area, the question remains, as to how much material has been deposited on top of the Amman Formation before it got eroded to its present shape. This volume has to be added on top of the Amman Formation.

It should be noted, that Wiesemann and Rösch (1969) reported a Phosphorite occurrence near Sweileh which belongs, according to the lithostratigraphic division of the German Geologic Mission (Bender 1974) to the Phosphorite Unit. The Phosphorite Unit is the equivalent of the Muwaqqar Formation. A thickness of around $35 \mathrm{~m}$ of the Phosphorite Unit in the area of Sweileh was reported. In some outcrops in central Jordan a thickness for the overlying Chalk- Marl Unit (Muwaqqar Formation, Jordanian Terminology; Ghareb and Taqiye Formation, Israeli Terminology) is given by Heimbach and Nuseibeh (1964), Heimbach (1965), and Ruef and Jeresat (1965) with $40 \mathrm{~m}$. No information regarding younger formations than the Muwaqqar Formation for the wider area of interest exists. Therefore it is not clear, if the thickness values reported above is the maximum or minimum thickness. To escape this knowledge gap, a look on the other side of the Dead Sea Transform (DST) was taken. The horizontal displacement of the DST started not before Middle Miocene times (chapter 2.2.2.3), so after the deposition of the late Eocene chalks. As a result, the total displacement of the DST must be rotated backwards for about $107 \mathrm{~km}$ (e.g. Dubertret 1932). The thickness determination in the central and upper Negev should be done carefully, since the area is also part of the so called Syrian Arc system. A thickness estimation was done on behalf of literature studies. Tab. 4.2-3 shows the stratigraphic chart for the period of interest in the Jordanian and Israeli terminology.

The average thickness of the Ghareb and Taqiye Formation in the considered area is around $40 \mathrm{~m}$ (Rosenfeld and Hirsch 2005). This is in good accordance with the Chalk- Marl Unit given above. The remaining thickness of the Eocene Formations was taken from the Avedat Group members: Mor, Nizzana, Horsha, and Matred Formation. The thickness of these formations is given by Benjamini (1979) for the Avedat Plaetau at Nahal Hava (located around 145/013) with around 110 to $160 \mathrm{~m}$. All sediments of the middle to upper Belqa Group consists mostly of chalk and chalky limestone, which can be regarded as soft to very soft.

This adds up to an additional thickness of around $200 \mathrm{~m}$, which has to be added on top of the Amman Formation. Since a whole section is eroded and it is unclear to what extend the study area is covered by these sediments a thickness of $200 \mathrm{~m}$ on top of the Amman Formation was added for the whole study area.

\section{Eroded and dissolved rock volume}

No detailed study regarding the uplift of the East Bank shoulder exists. Consequently no information regarding tectonic uplift rates and evolving slope gradients exist. Therefore only a simple calculation about eroded and dissolved rock volume can be made. Calculations are made with the help of the ArcGIS 9.1 (ESRI Inc.) software package. With the help of the raster calculator (available in the Spatial Analyst extension package of ArcGIS 9.1) the amount of eroded and dissolved rock volume can be estimated by using the following approach: the raster data set of the reconstructed top of the sedimentary rock cover (Top Belqa Formation or Top Amman Formation) is subtracted with the present day morphology raster data set (DEM) (Fig. 4.2-11). The result gives the elevation of eroded and dissolved rock column per grid cell (Fig. 4.2-9). In order to estimate the volume, each grid cell 
$\left(2,500 \mathrm{~m}^{2}\right)$ is multiplied with their respective eroded rock column (grid cell value). Tab. 4.2-4 shows the results of the eroded and dissolved rock volume for two scenarios: the top of the Belqa Group (including the "Missing Formations") and the top of the Amman Formation. Fig. 4.2-10 shows the thickness of the rock volume that has already been removed, either by physical or chemical weathering. For the estimation of reallocated physical weathered material as alluvial fan material, the estimated volume of $226.79 \mathrm{~km}^{3}$ for the Top of the Belqa Group can be discarded. Most of the sedimentary rocks that are younger than the Amman Formation are very soft in nature and were not encountered neither in drilling logs nor were they observed in the field. Consequently most, if not all, of these chalk or chalky sediments are not part of the alluvial fan components in the study area. To further undermine this assumption a closer look at alluvial fan in the northern part of the Jordan Valley should be taken. Here the hinterland consists mostly of Tertiary chalk and limestones. It is assumed that the volume calculated for the Top of the Amman Formation is mostly responsible for the alluvial components in the study area and further calculations are based on this assumption.

Tab. 4.2-3: Stratigraphic Table of the Jordanian and Israeli terminology for the considered areas (Jordanian Nomenclature after Masri 1963; Israeli Nomenclature after Fleischer 2002).

\begin{tabular}{|c|c|c|c|c|c|}
\hline & & Jordanic & n Nomenclature & Israe & penclature \\
\hline System & Epoch & Group & Formation & Group & Formation \\
\hline \multirow{2}{*}{ Quaternary } & Holocene & \multirow{5}{*}{ Jordan Valley } & Alluvium & \multirow{5}{*}{ Dead Sea } & \multirow{5}{*}{ Lisan } \\
\hline & Pleistocene & & Lisan & & \\
\hline \multirow{8}{*}{ Tertiary } & Pliocene & & Samra & & \\
\hline & Miocene & & & & \\
\hline & Oligocene & & Neogene & & \\
\hline & \multirow{4}{*}{ Eocene } & \multirow{9}{*}{ Belqa } & \multirow{4}{*}{ Umm Rijam } & \multirow{4}{*}{ Avedat } & Matred \\
\hline & & & & & Horsha \\
\hline & & & & & Nizzana \\
\hline & & & & & Mor \\
\hline & Paleocene & & Muwaqqar & \multirow{5}{*}{ Mt. Scopus } & Taqiye \\
\hline \multirow{4}{*}{$\begin{array}{c}\text { Upper } \\
\text { Cretaceous }\end{array}$} & Maastrichtian & & Al Hisa & & Ghareb \\
\hline & Campanian & & \multirow[t]{2}{*}{ Amman } & & Mishash \\
\hline & Santonian & & & & \multirow{2}{*}{ Menuha } \\
\hline & Coniacian & & Wadi Umm Ghudran & & \\
\hline
\end{tabular}




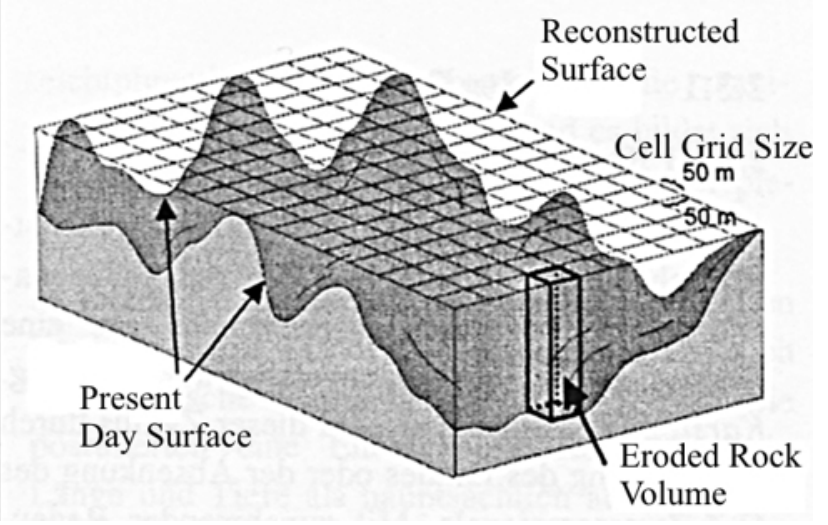

Fig. 4.2-9: Principle of determination of the eroded rock volume between two surfaces (Abel 2003).

Tab. 4.2-4: Calculated eroded rock volume. Left: Values calculated for the Top of the Belqa Group (including "missing Formations”. Right: Calculated eroded rock volume for the Top of the Amman Formation.

\begin{tabular}{|l|c|c|}
\cline { 2 - 3 } \multicolumn{1}{c|}{} & Top Belqa Group & Top Amman Formation \\
\hline Wadi Shueib eroded volume: & $68.8090 \mathrm{~km}^{3}$ & $33.9277 \mathrm{~km}^{3}$ \\
\hline Wadi Kafrein eroded volume: & $77.7296 \mathrm{~km}^{3}$ & $42.6032 \mathrm{~km}^{3}$ \\
\hline Wadi Hisban eroded volume: & $46.2637 \mathrm{~km}^{3}$ & $27.9081 \mathrm{~km}^{3}$ \\
\hline Wadi Ajun Musa eroded volume: & $25.2639 \mathrm{~km}^{3}$ & $17.0475 \mathrm{~km}^{3}$ \\
\hline Remaining small Wadis volume: & $8.0232 \mathrm{~km}^{3}$ & $5.4401 \mathrm{~km}^{3}$ \\
\hline
\end{tabular}

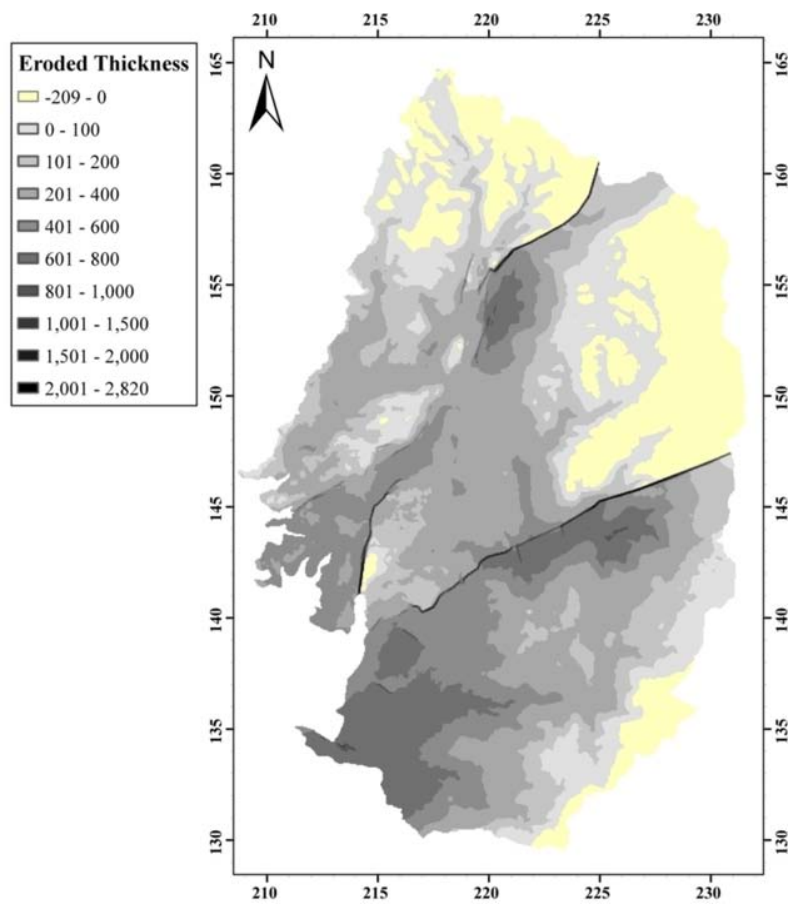

Fig. 4.2-10: Eroded thickness for the top of the Amman Formation.

During Plio- Pleistocene times the uplift of the East Bank shoulder accelerated. Consequently the whole wider area of interest was exposed and

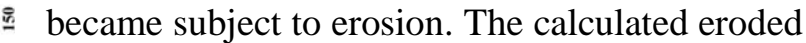
rock volume is a combination of physical and chemical weathering. Physical weathering processes include the displacement of rock components and accumulation in down gradient places, mostly as alluvial fans. Rainfall, an open carbon dioxide system and time resulted in the dissolution of a large portion of carbonate rocks (open system dissolution of calcite; chemical weathering). The denudation rate by dissolution \% of carbonate rocks can be estimated by different approaches. The most common approaches for estimating carbonate dissolution are hydrochemical budgeting and a thermodynamic equilibrium approach. Hydrochemical budgeting estimates the carbonate content in spring water and calculates the dissolution rate for the catchment area of the spring. The thermodynamic equilibrium approach is a semi-empirical approach, where carbonate dissolution rates are calculated with the help of kinetic parameters that affect carbonate dissolution (i.e. effective rainfall, temperature, $\mathrm{CO}_{2}$ partial pressure 
etc.). For this study the thermodynamic equilibrium approach was chosen. The difference between the calculated and dissolved rock volume should be the volume of allochthonous deposited alluvial material.

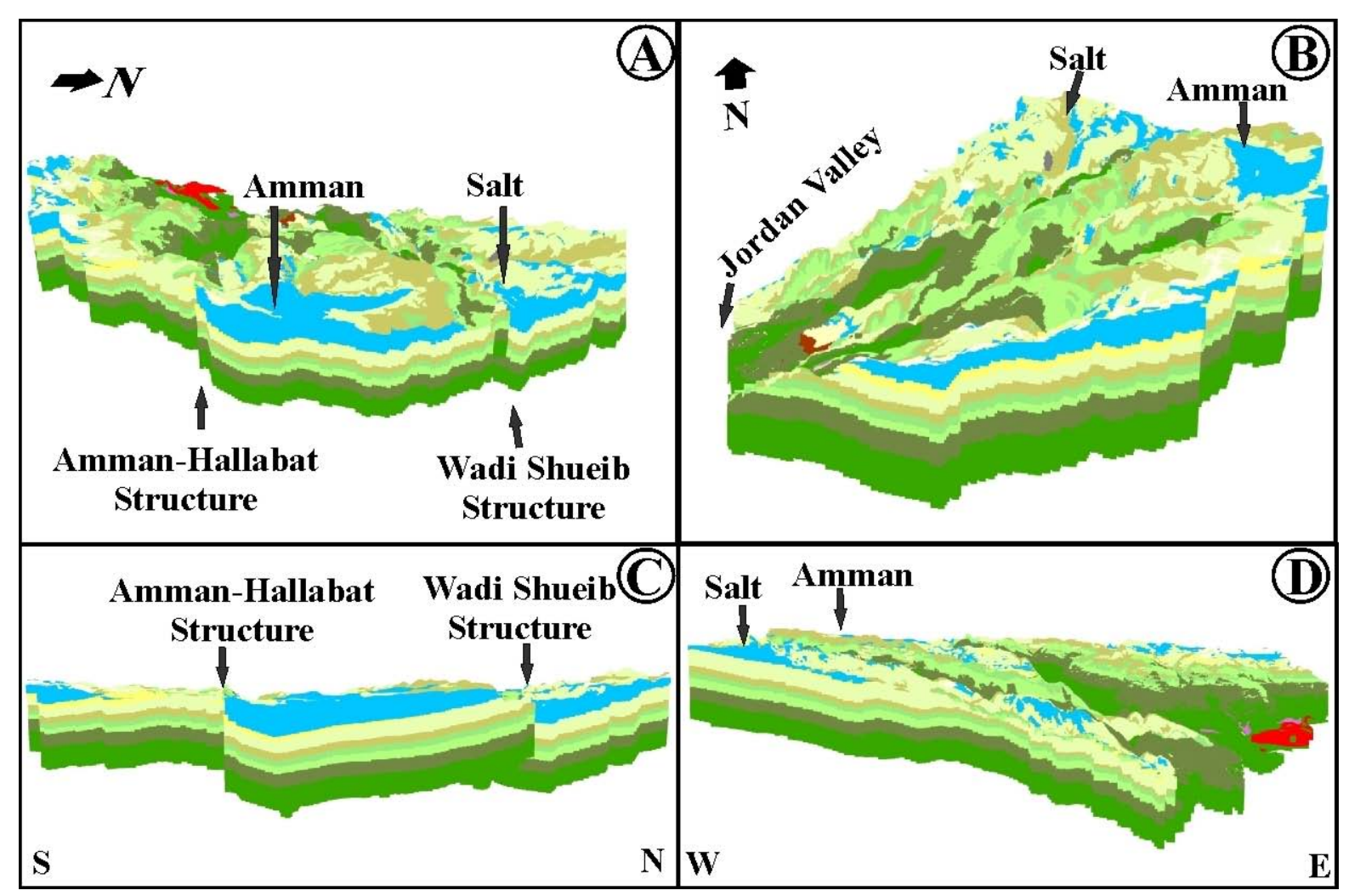

Fig. 4.2-11: 3-dimensional view of the reconstructed wider area of interest.

Dissolved carbonate rock volume (thermodynamic equilibrium approach)

The dissolution of calcium carbonate in distilled water is very little:

$$
\mathrm{CaCO}_{3} \Leftrightarrow \mathrm{Ca}^{2+}+\mathrm{CO}_{3}{ }^{2-} \quad \mathrm{K}_{\mathrm{cc}}=10^{-8.3}
$$

$\left[\mathrm{Ca}^{2+}\right]=10^{-4.15}=0.06 \mathrm{mmol} / \mathrm{l}$

But field data shows that $\mathrm{Ca}^{2+}$ concentrations in environmental systems are much higher. Therefore the dissolution of calcium carbonate depends on a series of other factors: $\mathrm{pH}$, temperature, availability of water, and above all the available $\mathrm{CO}_{2}$ partial pressure. The $\mathrm{pH}$ of rain water and in the uppermost soil can be assumed around the neutral point $\left(\mathrm{HCO}_{3}{ }^{-}\right.$dominant fraction).

The governing equilibrium conditions for $\mathrm{CaCO}_{3}$ dissolution are:

$$
\begin{aligned}
& \mathrm{CaCO}_{3} \Leftrightarrow \mathrm{Ca}^{2+}+\mathrm{CO}_{3}{ }^{2-} \\
& \mathrm{CO}_{3}{ }^{2-}+\mathrm{H}_{3} \mathrm{O}^{+} \Leftrightarrow \mathrm{HCO}_{3}{ }^{-}+\mathrm{H}_{2} \mathrm{O} \\
& \mathrm{CO}_{2(\mathrm{~g})}+\mathrm{H}_{2} \mathrm{O} \Leftrightarrow \mathrm{H}_{2} \mathrm{CO}_{3} \\
& \mathrm{H}_{2} \mathrm{CO}_{3}+\mathrm{H}_{2} \mathrm{O} \Leftrightarrow \mathrm{H}_{3} \mathrm{O}^{+}+\mathrm{HCO}^{-} \\
& + \\
& \overline{\mathrm{CO}_{2(\mathrm{~g})}+\mathrm{H}_{2} \mathrm{O}+\mathrm{CaCO}_{3} \Leftrightarrow \mathrm{Ca}^{2+}+2} \mathrm{HCO}_{3}{ }^{-} \\
& \begin{array}{l}
\mathrm{K}_{\mathrm{cc}}=10^{-8.3} \\
\mathrm{~K}_{2}^{-1}=10^{10.3} \\
\mathrm{~K}_{\mathrm{H}}=10^{-1.5} \\
\mathrm{~K}_{1}=10^{-6.3} \\
\hline \mathrm{K}=10^{-5.8}
\end{array}
\end{aligned}
$$

The corresponding law of mass action is:

$\left[\mathrm{Ca}^{2+}\right]\left[\mathrm{HCO}_{3}{ }^{-}\right]^{2} / \mathrm{pCO}_{2}=10^{-5.8}$

rearranging the equation above results in the following equation (assuming that activity is molality): 
$\mathrm{mCa}^{2+}=\left(10^{-5.8} * \mathrm{pCO}_{2} / 4\right)^{-1 / 3}$

Now the concentration of $\mathrm{Ca}^{2+}$ can be calculated as function of $\mathrm{CO}_{2}$ partial pressure (an open system, that means a continuous supply of $\mathrm{CO}_{2(\mathrm{~g})}$ can be assumed).

In order to estimate the dissolved limestone volume, different scenarios were calculated: two $\mathrm{CO}_{2}$ partial pressures $\left(10^{-1.5} \mathrm{~atm}\right.$, which is the highest $\mathrm{CO}_{2}$ partial pressure one can expect in soils, and $10^{-3.5}$ atm, which is the contemporary atmospheric pressure) for different effective precipitation amounts (200, 300, $400 \mathrm{~mm} / \mathrm{a})$. By assuming the density of limestone to be around $2.0 \mathrm{~g} / \mathrm{cm}^{3}$ the amount of denudation for the considered area can be calculated. Tab. 4.2-5 shows the calculated values for the different scenarios. It can be seen that the calculated values vary about one order of magnitude, depending on the amount of effective precipitation and the $\mathrm{pCO}_{2}$ applied. Therefore a more detailed picture regarding climatic parameters is desirable. For the estimation of limestone denudation rates (by dissolution) a value of 0.01 [atm] was used (Tab. 4.2-6).

Tab. 4.2-5: Calculated carbonate denudation rate for two different time steps and two different $\mathrm{pCO}_{2} \mathrm{pressures;}$ atm $=$ atmospheric pressure $\left(3.16 * 10^{-3}\right)$ and $\max =3.16 * 10^{-2}$, which is the highest $\mathrm{pCO}_{2}$ one can expect in soils.

\begin{tabular}{|c|c|c|c|c|}
\hline & $\mathrm{pCO}_{2}=\mathrm{atm}$ & $\mathrm{PCO}_{2}=\max$ & $\mathrm{pCO}_{2}=\mathrm{atm}$ & $\mathrm{pCO}_{2}=\max$ \\
\hline & Begin Pliocene & Begin Pliocene & End Pliocene & End Pliocene \\
\hline Effective N & Dissolved Volume & Dissolved Volume & Dissolved Volume & Dissolved Volume \\
\hline$[\mathrm{mm}]$ & {$\left[\mathrm{km}^{3}\right]$} & {$\left[\mathrm{km}^{3}\right]$} & {$\left[\mathrm{km}^{3}\right]$} & {$\left[\mathrm{km}^{3}\right]$} \\
\hline 200 & 12.98 & 60.20 & 4.67 & 21.80 \\
\hline 300 & 19.72 & 90.31 & 7.27 & 32.7 \\
\hline 400 & 25.95 & 120.41 & 9.34 & 43.60 \\
\hline
\end{tabular}

Tab. 4.2-6: Calculated carbonate denudation rate for different effective rainfall scenarios for a $\mathrm{CO}_{2}$ partial pressure of 0.01 [atm]. Since nothing is known about the lift of the East bank shoulders, values for the Begin and the End of the Pliocene are calculated.

\begin{tabular}{|c|c|c|}
\hline & $\begin{array}{c}\text { Begin Pliocene } \\
\text { Effective } \mathbf{N}\end{array}$ & $\begin{array}{c}\text { End Pliocene } \\
\text { Dissolved Volume }\end{array}$ \\
\hline Dissolved Volume \\
\hline $\mathbf{m m}]$ & {$\left[\mathbf{k m}^{3}\right]$} & {$\left[\mathbf{k m}^{3}\right]$} \\
\hline 200 & 41.00 & 14.53 \\
\hline 300 & 61.76 & 22.32 \\
\hline 400 & 82.00 & 29.58 \\
\hline
\end{tabular}

From the results of Tab. 4.2-6 it can be seen, that more information regarding climate, exposition to surface processes etc. is needed in order to estimated the volume of rocks dissolved by surface processes. However the calculations give a range in which dissolution processes might play a role. The range is from $14.53 \mathrm{~km}^{3}$ up to $82 \mathrm{~km}^{3}$, where an average value for the whole period of not more than $40 \mathrm{~km}^{3}$ is assumed as an upper limit. This would leave a rock volume of at least $86.93 \mathrm{~km}^{3}$ as possible alluvial rock components.

\section{Error discussion}

One problem of the geological reconstruction described above is the quality of the structure contour map of the Kurnub Group. This can be clearly seen in Fig. 4.2-12. On the left side of Fig. 4.2-12 the top view of the reconstructed geological map and on the right side the geological map published by the National Resources Authority of Jordan can be seen. It should be noted, that the white areas within the wider area of interest (Fig. 4.2-12 left) represent outcrop areas of formations older than the Lower 
Cretaceous Kurnub Group. Discrepancies can be seen mostly in the eastern part of the geological reconstruction. The eastern part of the reconstruction is based on the structure contour map compiled by the BGR WAJ (1994). This contour map is based on information of well data only and was used for a regional model of the geology of northern Jordan. Therefore its suitability is limited for a geological reconstruction of small areas. Taking existing geological maps and undertaking further field mapping will significantly increase the accuracy of the geological model. As a consequence, although the Amman Formation is the youngest hardrock formation, its reconstructed top is in some areas lower than the actual topography (Fig. 4.2-10).

Another uncertainty is the depositional environment during and after the Syrian Arc phase (chapter 2.2). Large thickness variations over short distances can be observed. This uncertainty can be reduced by future geological field mapping. Another result of the folding and faulting during the Syrian Arc deformation was intensified physical weathering. Consequently large amounts of rocks must have been mobilized. However, the Jordan Valley area as a morphological valley did not develop until the upper Lower Miocene (Horowitz 2001). Therefore these large amounts of rock material mobilized from the Syrian Arc phase onward up to the upper Lower Miocene might have been deposited outside the study area.

As can be seen by the different calculations made above, the carbonate dissolution calculations are another uncertainty. Apart from the uncertainties mentioned above, the semi-empirical thermodynamic approach requires certain assumptions: water and limestone are in equilibrium, i.e. karst water is saturated concerning calcite and carbonate dissolution happens under open system conditions $\left(\mathrm{CO}_{2}\right.$ is constantly available). These premises are not always fulfilled, e.g. runoff water during storm events is usually undersaturated with regard to calcite. On the other hand limestone surfaces are often covered by soil, thus reducing carbonate dissolution significantly.

Furthermore some areas were and are covered by the early Cretaceous Kurnub Group, which consists of silicate sands which are only to a very low degree subject to dissolution. However, the present day catchment areas of the wadis draining to Jordan Valley were used for this study.
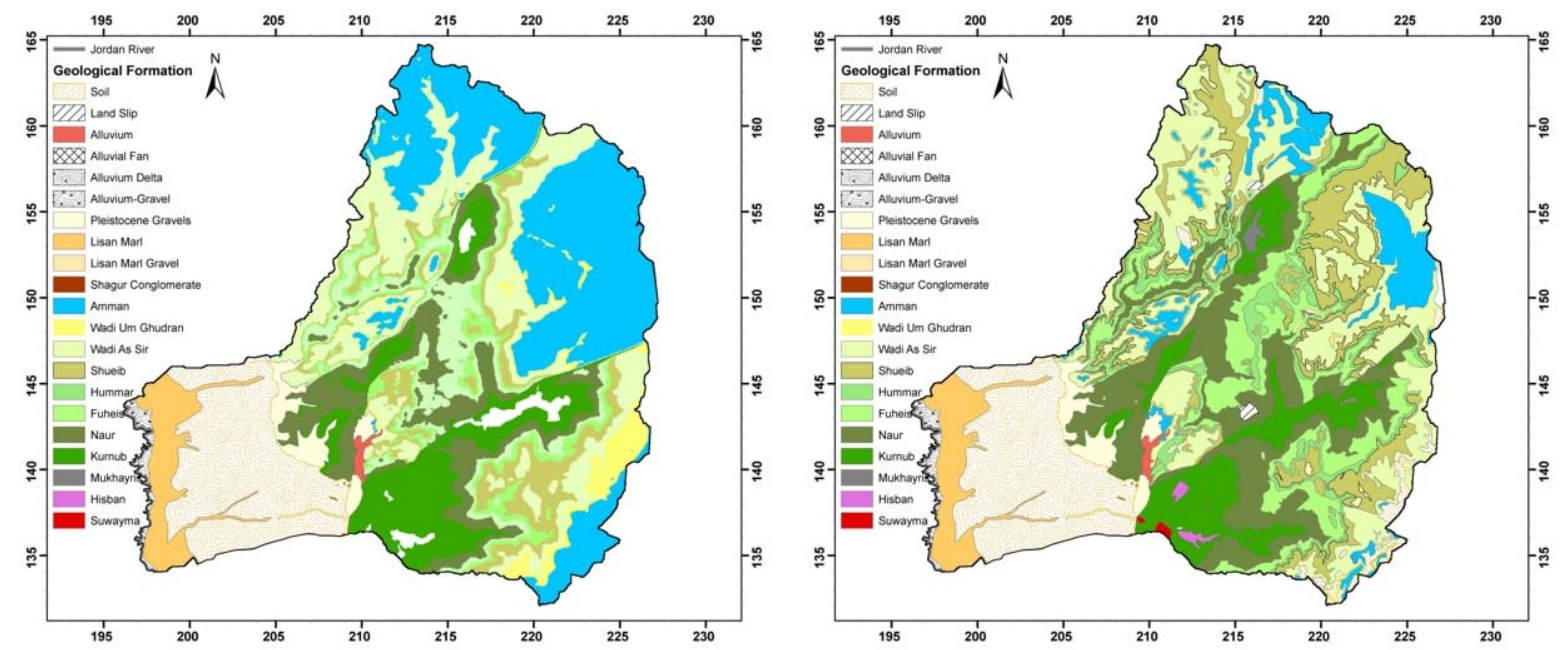

Fig. 4.2-12: Left: Results of the structural 3-D Model of some major wadis in the wider area of interest (based on the structure contour map of Fig. 4.2-8). The empty areas are the outcrop areas of the Triassic Zerqa Main Group. Right: Geological Map of the modelled area (NRA open files).

\section{Unconsolidated strata (Jordan Valley)}

On the basis of lithological drill records and indirect information, derived from the interpretation of seismic reflection data, a structure contour map for the base of the Jordan Valley Group has been prepared. Lithological information was collected from the MWI data base, the project report "The water resources of Transjordan and their development", the drilling information about the oil exploratory well Jordan Valley 1 (no drilling log was available; the lithological information was taken 
from Bender (1968)), and the drilling log of the oil exploratory well Jordan Valley 2 (NRA open files). Information from the interpretation of seismic data was insofar indirect, as the base of the Jordan Valley Group cannot be seen in the stacked pattern of the seismic lines. However, the structural setting of the different hardrock boundaries can be seen and transferred to the structural setting of the base of the Jordan Valley Group, i.e. the continuation of the Wadi Shueib and the Wadi Kafrein synclines. The structural base map of the Base of the Jordan Valley Group for most of the study area can be seen in Fig. 4.2-13. The map extends from the border unconsolidated/ consolidated strata in the east until the well drilling of Jordan Valley 2 in the west. The construction was not extended further to the west, since no information, neither well drilling nor seismic information was available.

Using the GIS- approach described above the volume of the unconsolidated Jordan Valley fill can be calculated. The wadi fill for the examined area is:

Volume of the JVG Group for the studied area: $41.63 \mathrm{~km}^{3}$

From the calculated volume of $41.63 \mathrm{~km}^{3}$ it can be seen, that the present day unconsolidated rock volume is around half the amount of the available rock volume calculated above. This rather small volume diminishes even more, since large portions of the deposited unconsolidated Jordan Valley Group were made up of autochthonous deposited lacustrine sediments. Consequently the "missing" remaining available rock volume must either be deposited further westward to the reconstructed area, where the basin becomes deeper, or as described above, the pre upper Lower Miocene depositional area does not coincide with the present day one, or a combination of the two possible explanations, where the second one is believed to take more reallocated material than the first one. Due to the left lateral motion of the DSTF and its displacement of around $107 \mathrm{~km}$ large parts of alluvial material could have also deposited south and southwest of the study area or within the Dead Sea pull apart basin.

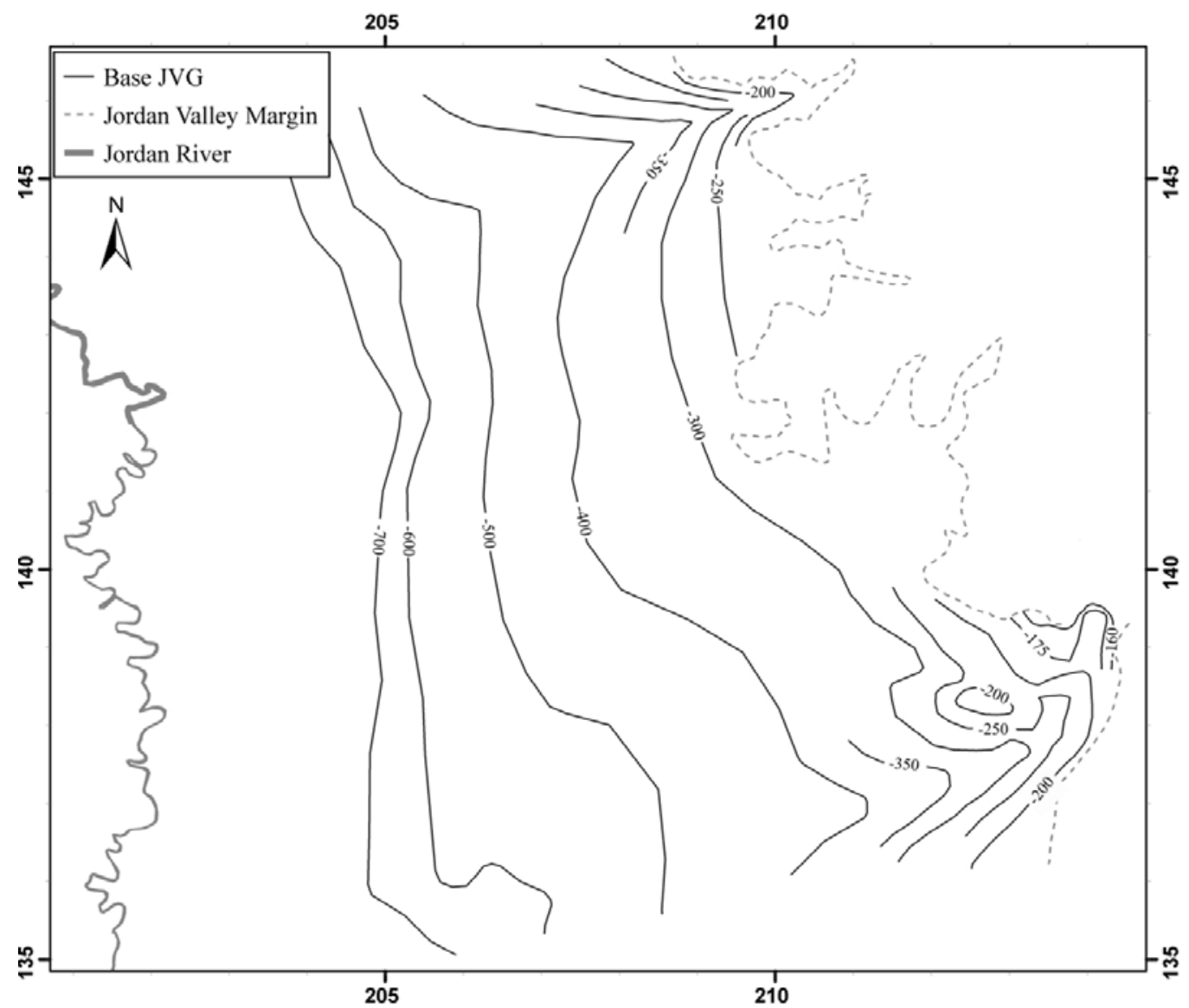

Fig. 4.2-13: Base of Jordan Valley Group. This map was prepared with the help of drilling logs of water wells (MWI open files), the two oil wells Jordan Valley 1 \& 2 (NRA open files), the 1 : 50,000 geological maps of Karameh (Shawabkeh 2001) and the interpretation of seismic lines (Al-Zoubi et al. 2006). 


\subsection{WELLS AND WELL HYDRAULICS}

\subsubsection{Introduction}

In this chapter the results of a well survey, undertaken in late 2004 will be presented. The chapter begins with a description of wells, their locations, constructions, and usage. This will be followed by a chapter on well hydraulics and aquifer characteristics. The chapter commences with a spatial overview of all available hydraulic information of the unconsolidated aquifer within the study area.

\subsubsection{Wells}

During a field campaign in late 2004 nearly all wells in the area of Rama and downstream of Rama, and some wells in the area of South Shuneh were subject to a survey (Fig. 4.3-1). 39 wells located on different farm sites were acquired in a questionnaire and stored in the geodatabase and are listed at the end of this thesis (Appendix). Unfortunately, because of outside influences, the time was too short for a complete well survey of the whole study area. The questionnaire consists of the investigation date, well location, well depth, static or pumped water level, electrical conductivity of well water, temperature, $\mathrm{pH}$, area irrigated by the well, age of the well, plants irrigated by the well water, main and minor irrigation season, and their respective pumping activity during these seasons, as well as comments on the respective wells. Basically the results regarding planting practices, planting seasons, and irrigation practises coincide with the description made in chapter 6.2. Best water quality can be found in the wells located in the east of the study area, there well water and water given by the JVA is mainly used to irrigated banana fields, where annual irrigation with good quality water is needed. Since crop rotation is practised, other vegetables are planted between the banana fields. Further to the west irrigation water quality becomes more salty and the most profitable crop, that is banana, cannot be planted. Here vegetable farming prevails. The western wells in the west and southwest are mostly wells drilled in private farms. There water is used to for recreation purposes (e.g. swimming pools and flowers) and some fruit trees.

Most wells in the study area were drilled by the order of farmers. Therefore wells were not built from a hydrogeologist's point of view. No or little information about well finishing, lithology, well screen positions and openings can be attained. Furthermore, well locations were chosen on the basis of land owning and not on a hydrogeological point of view.

The usual well design of irrigation wells in the study area can be described as follows: the surface screen and the in-casing consists of metal, no special designed well screens are used and usually the lowermost part of the in-casing is torch-cut (Fig. 4.3-2 left) which results in a limited ratio of open to closed area (because an adequate casing strength has to be maintained). Other disadvantages are: openings cannot be closely spaced and the sizes of the slot openings vary from slot to slot. Furthermore, openings are too big and cannot prohibit inflow of fine or medium to coarse sand. Therefore sand-filters, that filter the well water before it is pumped into either a storage tank or an irrigation pool, can often be seen (Fig. 4.3-2 right). Between the surface and inner casing no filter packs and pebble or cement grout is used. The space between the surface and inner casing is left open which makes special sampling and well log tests possible. Only very few wells have a well seal. Most of the wells have direct access to the well hole (Fig. 4.3-3 left). The in-casing is held in its position by a metal cross bar that prevents the falling of the in-casing into the well hole (Fig. 4.3-3 left). The pump is usually driven by diesel generators (Fig. 4.3-3 right). The fuel driven generators are mostly former truck engines, which are either located directly next to the well or at small distances to it (Fig. 4.3-3 right). Wells are located either directly next to the farm site or in a small concrete well house (Fig. 4.34). Since almost none of the wells in the study are sealed and fuel driven generators are often located next to the well hole, the danger of the contamination of groundwater is high (Fig. 4.3-3 right). 


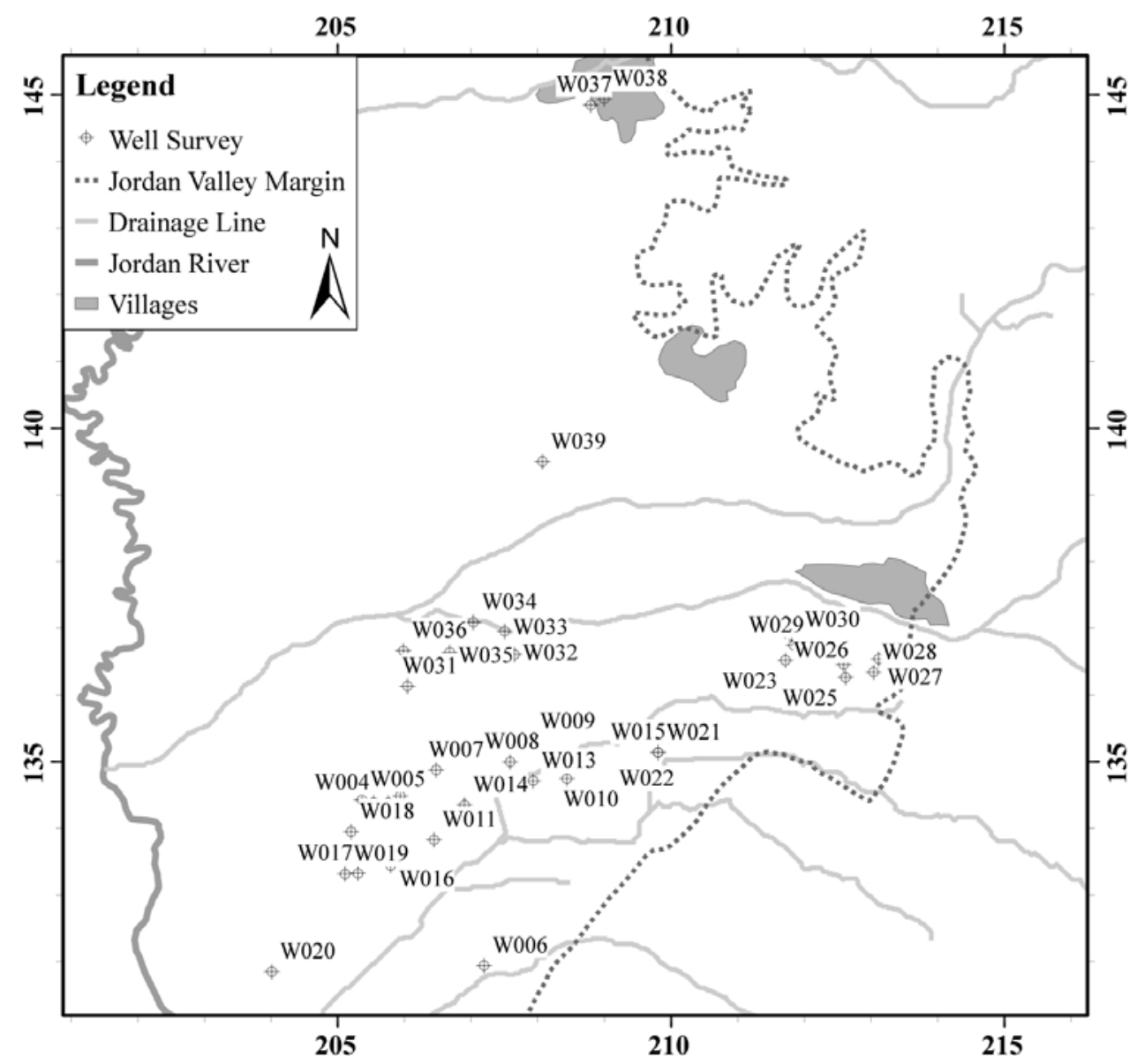

Fig. 4.3-1: Wells that were subject of the well survey.

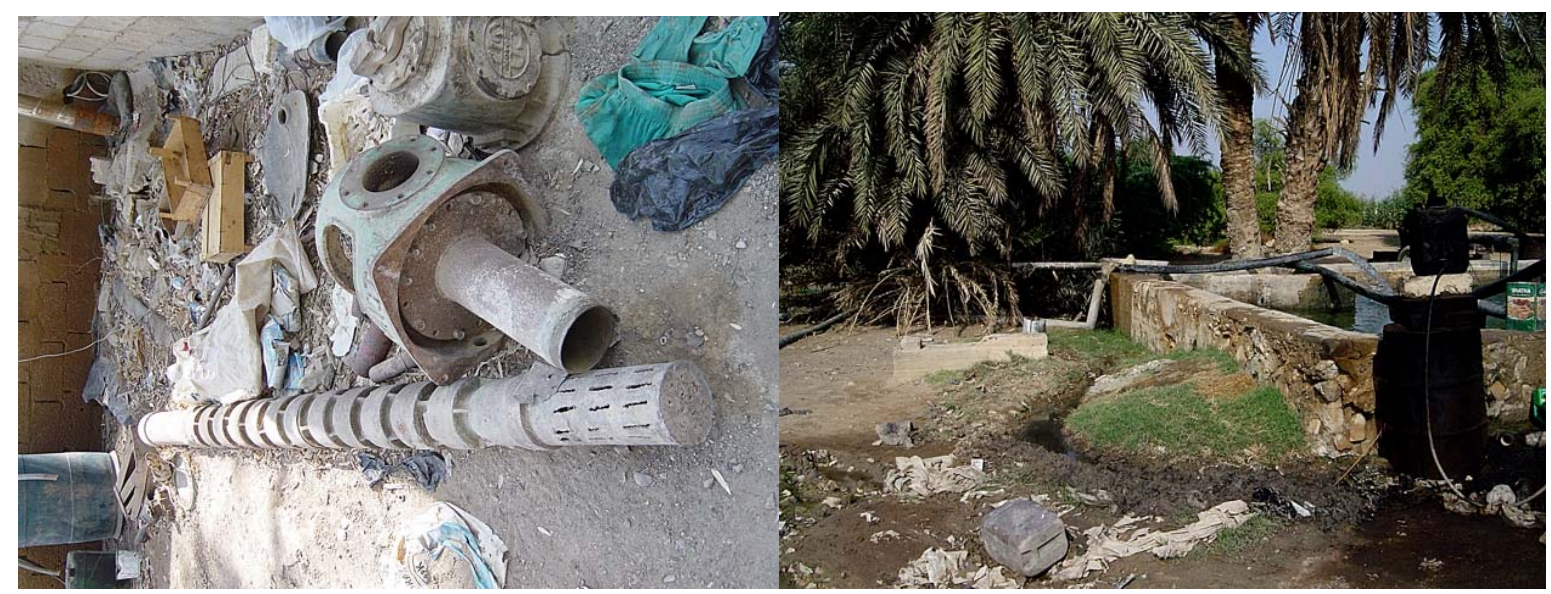

Fig. 4.3-2: Left: torch-cut inflow to the well pump. Right: Irrigation water storage pool. 


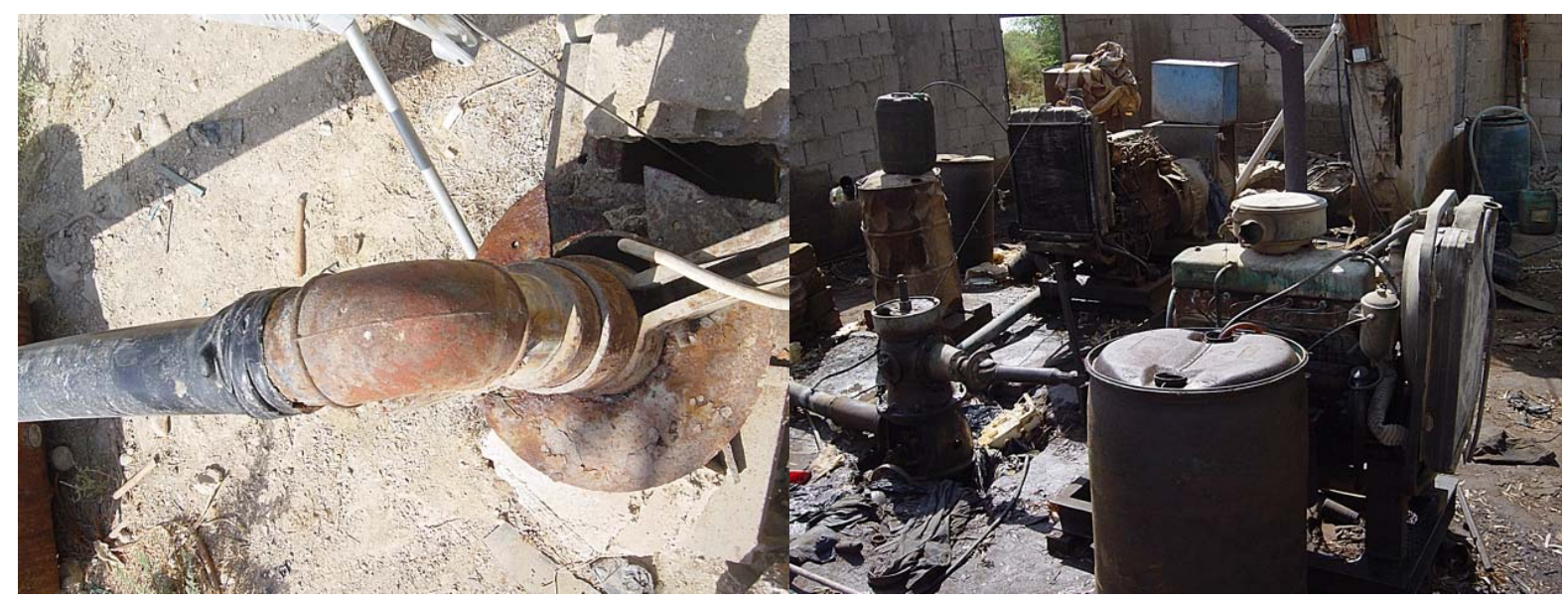

Fig. 4.3-3: Left: Access to the well hole; well pump is held by iron cross bars. Right: Pollution source, deriving from the diesel generators located direct in the vicinity of the open well hole (lower left corner).

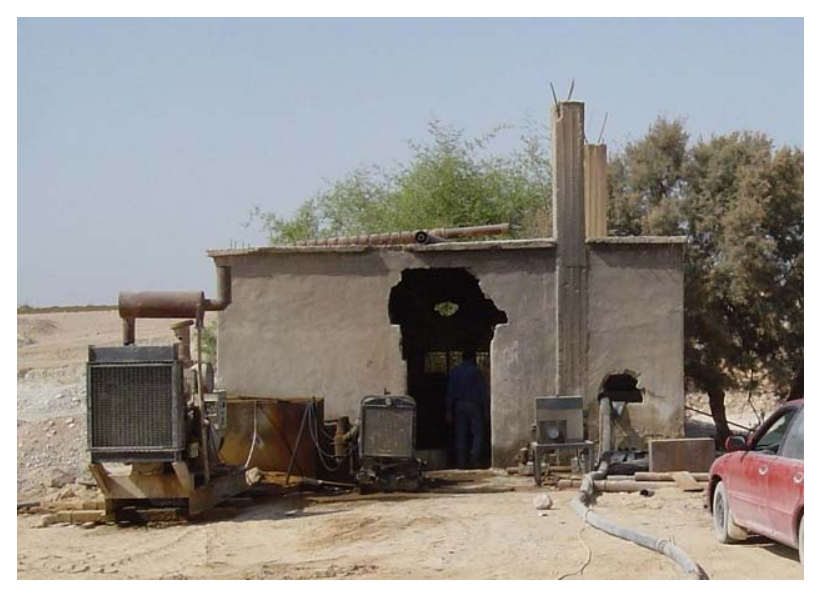

Fig. 4.3-4: Concrete well house. Outside: a former truck engine that is used as a diesel driven generator powering the well pump.

\subsubsection{Short-term single well pumping tests}

In order to get some insight into the hydraulic properties of the unconsolidated aquifer some aquifer tests were performed. No piezometer exist within the study area and the distances between the different wells are too large to allow a proper pumping test. Therefore only single- well test are applicable. However, the drawdown in a pumped well is influenced by well losses and well-bore storage. For most aquifer testing procedures an infinitesimal well radius is assumed and well-bore storage can be neglected. In reality wells do have a certain radius and thus a well-bore storage, which is very large compared to the storage capacity of a similar volume of the aquifer (Krusemann and de Ridder 1994). Therefore well-bore storage must be considered when analysing the drawdown data. Several single-well recovery- and some pump tests were performed and analysed by using the CooperJacob's straight- line method. This method can be applied in the wells of the study area when a certain condition is met. This condition will be discussed later. In addition this method does not require any corrections for non-linear well losses and can be used for confined and leaky aquifers.

\section{Method}

\section{Discharge determination}

Discharge measurements that are a prerequisite for aquifer tests proved to be a difficult task. The installation of water meters is not possible without major adjustments. As described in chapter 5.2.6 plastic pipes are smelted on the outlet of the in-casing. These plastic pipes carry water to an irrigation pool. The irrigation pool functions as a distributing reservoir for the drip irrigation system. Installing water meters on these black plastic pipes was not possible. Since no water meters could be installed, 
well discharge had to be determined by alternative methods. Two different methods were used. The first method is a direct method. The discharge of a well was determined by collecting a specific volume of discharged groundwater in either a barrel, or in an aluminium box, or in a brick pool (Fig. 4.3-5 left) while recording the time it took to fill it. The discharge rate was then obtained by dividing the volume of collected groundwater by the time it took to collect it.

The second method uses the results of projectile motion in order to calculate the average speed of the fluid particles that cross the end of the plastic pipe near the well with the speed $V_{0}$ (free jet of water). The discharge of the well can be determined by measuring the diameter of the plastic pipe and the calculation of the flow velocity. Assuming that the groundwater discharging the pipe follows parabolic trajectories, the distance between the groundwater leaving the pipe and falling into the storage pool $\left(\mathrm{X}_{\mathrm{pool}}\right)$ and the elevation of the plastic pipe above the pool ( $\left.\mathrm{Y}_{\mathrm{pool}}\right)$ was measured (Fig. 4.3-5 right). By assuming that the water particles, that are part of the free jet of groundwater, is a projectile in motion in the $x-y$ plane that is not subject to drag forces the flow velocity $V_{0}$ can be calculated. The water particle leaves the plastic pipe with the velocity $\mathrm{V}_{0}$ and orientation $\varphi$ with respect to the horizontal. The centre of the plastic pipe is at the coordinates $\left(0, \mathrm{Y}_{\text {pool }}\right)$. Then the equation of the trajectory of a fluid particle that exists from this point is given by:

$y(x)=-\left(\frac{g}{2 V_{0}^{2} \cos ^{2} \varphi}\right) x^{2}+(\tan \varphi) x+y 0$

By assuming that the water jet leaves the plastic pipe horizontally ( $\tan \varphi=0$ ) equation (1) becomes:

$\mathrm{y}(\mathrm{x})=-\left(\frac{\mathrm{g}}{2 \mathrm{~V}_{0}^{2}}\right) \mathrm{x}^{2}+\mathrm{y} 0$

The free jet of water hits the pool at the coordinates $\left(X_{\text {pool }}, 0\right)$. Therefore, at this point $y\left(X_{\text {pool }}\right)=0$. Setting the equation (2) to 0 and solving for the speed $V_{0}$ in terms of $g, X_{\text {pool }}$ and $Y_{0}$ gives:

$\mathrm{V}_{0}=\mathrm{X}_{\text {pool }} \sqrt{\frac{\mathrm{g}}{2 \mathrm{y}_{0}}}=\frac{\mathrm{X}_{\text {pool }}}{\sqrt{2 \mathrm{y}_{0} / \mathrm{g}}}=\frac{\mathrm{X}_{\text {pool }}}{\mathrm{t}_{\mathrm{f}}}$

where

$$
\mathrm{t}_{\mathrm{f}}=\sqrt{2 \mathrm{y}_{0} / \mathrm{g}}
$$

Thus, by knowing the local acceleration of gravity, g, and measuring both $\mathrm{X}_{\text {pool }}$ and $\mathrm{Y}_{\text {pool, }}$, it is possible to compute the speed $\mathrm{V}_{0}$. By multiplying $\mathrm{V}_{0}$ with the diameter of the plastic pipe the discharge of the well can be determined.
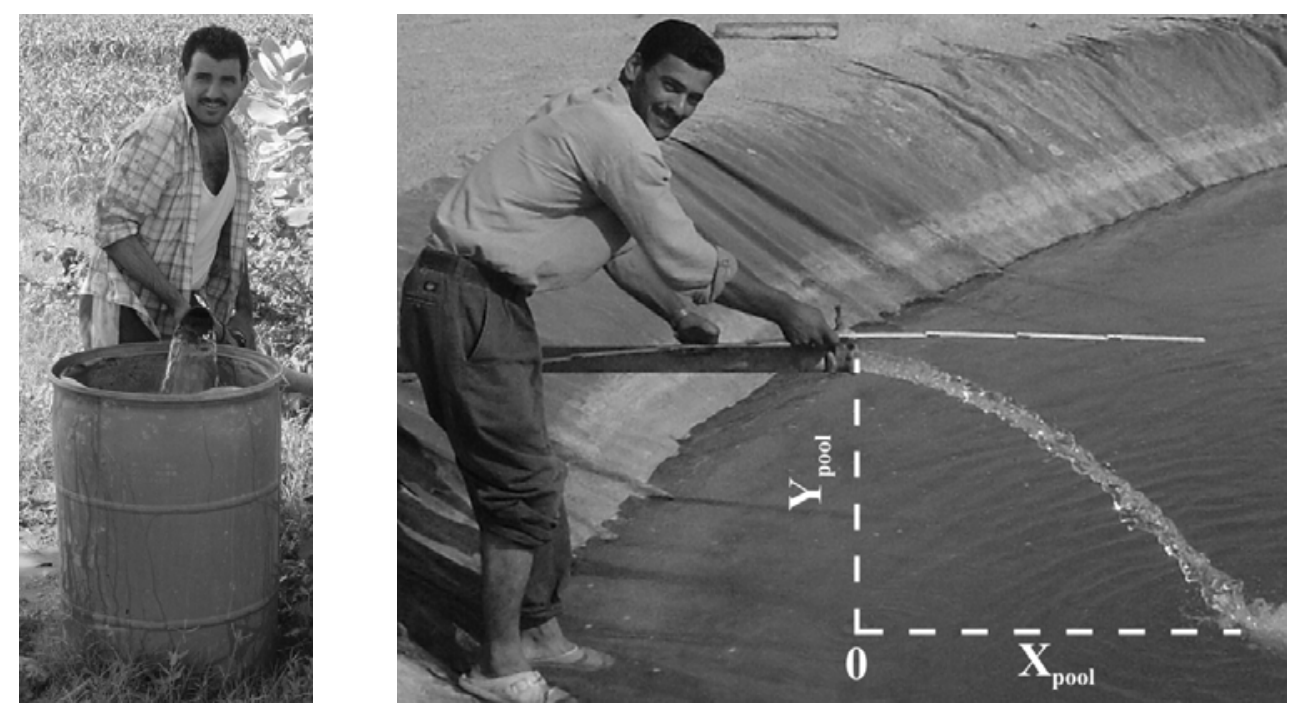

Fig. 4.3-5: Discharge measurements by using A) the direct method and B) the projectile in motion assumption for a free jet of water. 
Estimation of hydraulic parameters of the unconsolidated aquifer

Theis (1935) developed a well function for a confined aquifer that is pumped by a fully penetrating well:

$$
\mathrm{h}_{0}-\mathrm{h}=\mathrm{s}=\frac{\mathrm{Q}}{4 \pi \mathrm{T}} \mathrm{W}(\mathrm{u})
$$

where $\mathrm{h}_{0}=$ the static water level before pumping starts, $\mathrm{h}=$ water level during pumping; $\mathrm{s}=$ drawdown; $\mathrm{Q}$ = well discharge; $\mathrm{T}$ = transmissivity and

$W(u)=\int_{u}^{\infty} \frac{e^{-y}}{y} d y=-0.577216-\ln (u)+u-\frac{u^{2}}{2 ! 2}+\frac{u^{3}}{3 ! 3}-\frac{u^{4}}{4 ! 4}+\ldots$

where

$\mathrm{u}=\frac{\mathrm{r}^{2} \mathrm{~S}}{4 \mathrm{Tt}}$

Using the Theis solution is complicated. But when the values of $u$ are small (less than 0.01 ), the higher order terms of the infinite series are negligible and can be ignored (Jacob 1940; Cooper and Jacob 1946). With this Cooper-Jacob assumption the drawdown is calculated as:

$$
\mathrm{s}(\mathrm{t})=\frac{\mathrm{Q}}{4 \pi \mathrm{T}}(-0.577216-\ln (\mathrm{u}))=\frac{2.3 \mathrm{Q}}{4 \pi \mathrm{T}} \log \frac{2.25 \mathrm{Tt}}{\mathrm{r}^{2} \mathrm{~S}}
$$

This makes the Cooper and Jacob modification of the Theis equation easy to evaluate by using a simple graphical approach, where the drawdown is plotted versus the logarithm of time. Cooper and Jacob theory predicts that the data falls on a straight line. By using the following formula:

$\Delta \mathrm{s}=\mathrm{s}_{2}-\mathrm{s}_{1}=\frac{2.3 \mathrm{Q}}{4 \pi \mathrm{T}} \log \frac{\mathrm{t}_{2}}{\mathrm{t}_{1}}$

an evaluation of the aquifer test data becomes possible. When a drawdown $(\Delta s)$ difference of one logarithmic cycle is chosen, the transmissivity can be easily determined by:

$\mathrm{T}=\frac{2.3 \mathrm{Q}}{4 \pi \Delta \mathrm{s}}$

The same Cooper-Jacob assumption can be used for evaluating recovery test data (Fig. 4.3-7). The graphical plot is changed insofar that the residual drawdown is plotted against the logarithm of $t / t$ ', where $t=$ elapsed time since the start of the pumping test and 't' = time since pumping stopped (Fig. 4.3-6). For recovery tests the drawdown term in equation (7) is replaced by the residual drawdown:

$\Delta \mathrm{s}^{\prime}=\frac{2.3 \mathrm{Q}}{4 \pi \mathrm{T}} \log \frac{\mathrm{t}}{\mathrm{t}^{\prime}}$

by using the one log cycle approach described above, the transmissivity can be determined by:

$\mathrm{T}=\frac{2.3 \mathrm{Q}}{4 \pi \Delta \mathrm{s}}$

For single-well tests however, the $t>25 \mathrm{r}_{\mathrm{c}}^{2} / \mathrm{KD}$ condition has to be met. Furthermore, results of pumping test should always be evaluated critically. The calculated values only account for the area influenced by the pumping test. The results also depend on the condition of the well and its filtered screen. As mentioned above, well test analyses underlie certain assumption which do not fully apply in the study area. The calculated values are not exact and should be understood as an order of magnitude of transmissivity of the aquifer. One should also keep in mind that the transmissivity values derived from the well test can only be as good as the hydraulic connection of the well to the aquifer system. The method used in this study also accounts only for wells that fully penetrate the aquifer. However, the method can be applied to partially penetrated wells, when only an order of magnitude of transmissivity is desired. 


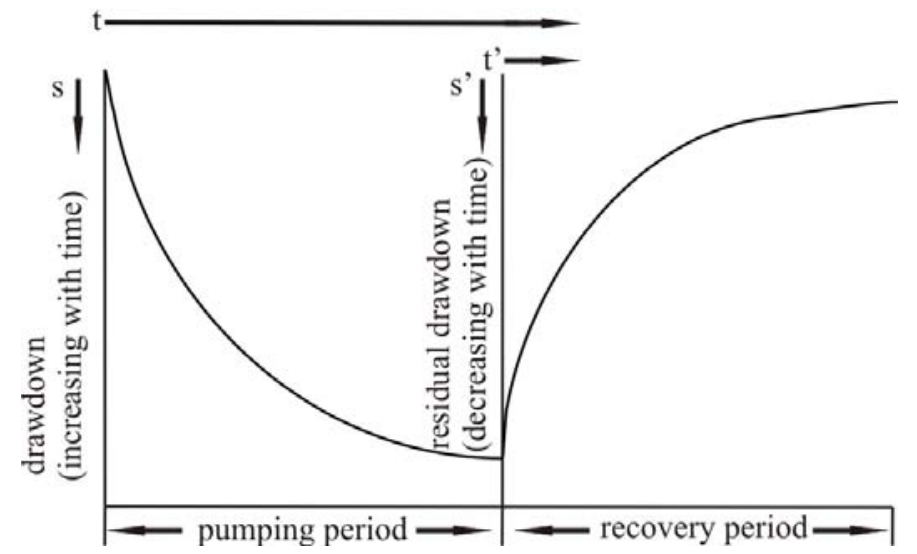

Fig. 4.3-6: Time drawdown and residual drawdown during pumping and recovery period.

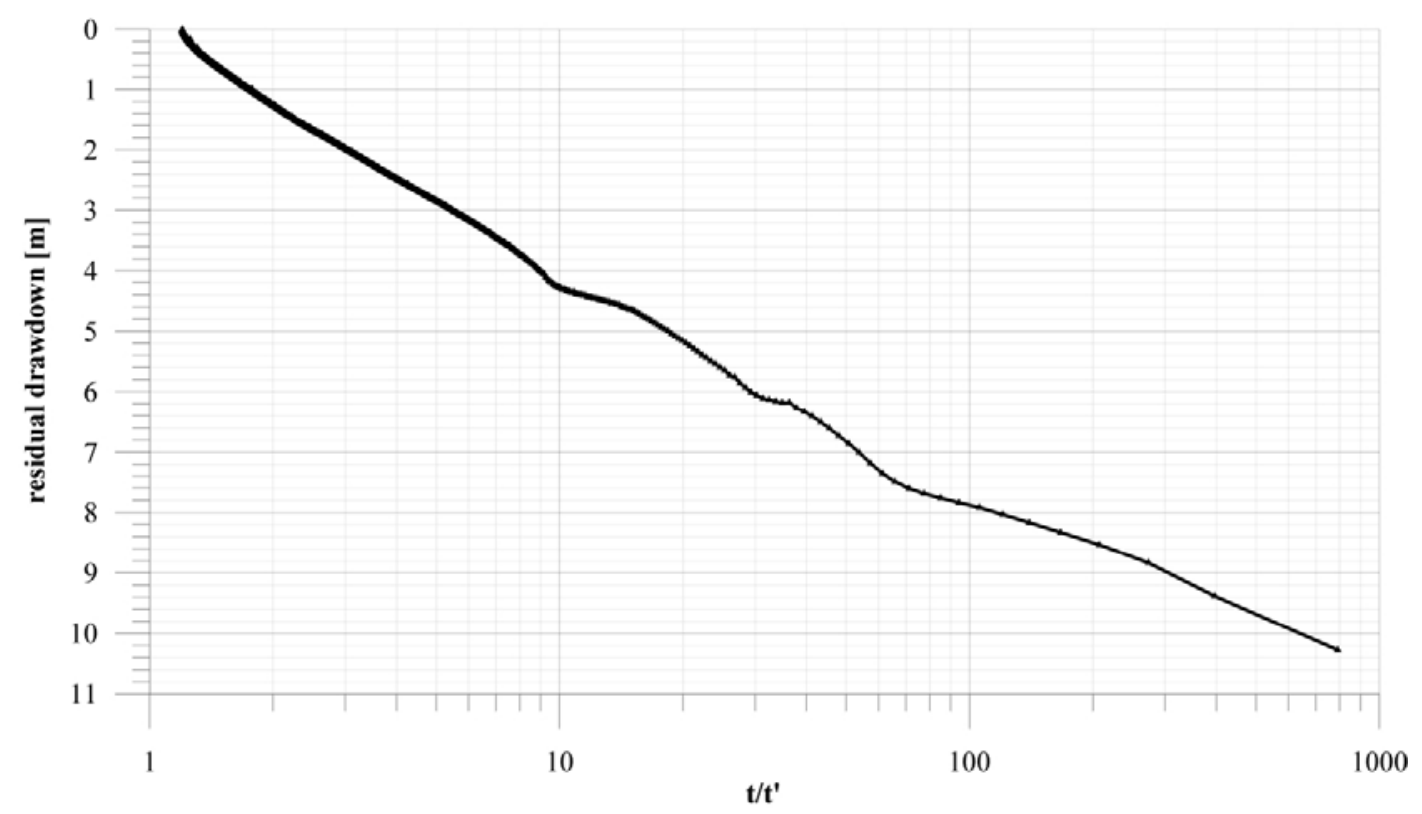

Fig. 4.3-7: Recovery test data of Well 040 plotted after the Cooper- Jacob Straight Line Method.

\section{$\underline{\text { Results }}$}

Fig. 4.3-8 shows the results and location of the collected well test data and well tests performed during the course of this study. In addition, complementary to pumping and recovery tests the well survey undertaken by Ionides (1939) and Hizrallah (1973) determined the specific- capacity of wells in the study area. These tests are easily performed by pumping a well at a constant discharge and dividing the pumping rate by the created drawdown. Specific- capacity tests give a rough estimation of transmissivity. However, the specific capacity of a well cannot be an exact criterion of the transmissivity, because the specific- capacity of wells is often affected by partially penetrated wells, well loss, and hydrogeologic boundaries.

The highest transmissivity as wells as specific capacity values can be found close to the Jordan Valley boundary, where the highest values were determined close to the apex of the major alluvial fans. Along the groundwater flow path to the west transmissivity and specific capacity values decrease which goes along with the lithological characteristics described in chapter 4.2. This general trend is superimposed by a high contrast in transmissivity. This can be explained the high variability of transmissivity of the JVG aquifer caused by the high variability of the sedimentary sequence which was described in chapter 4.2. 


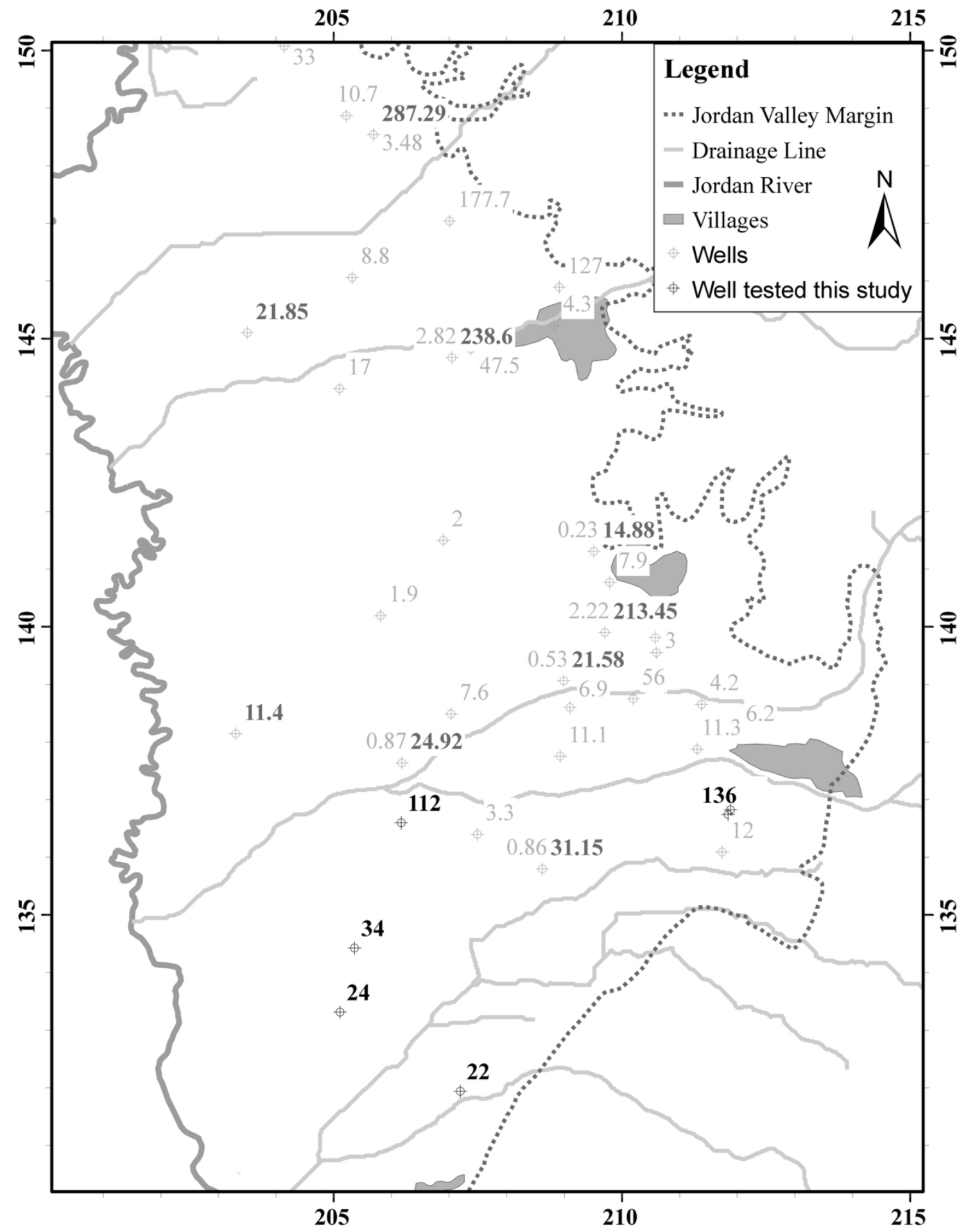

Fig. 4.3-8: Well tests in the study area. The light gray numbers represent the specific capacity values $\left[\mathrm{m}^{3} / \mathrm{hr} / \mathrm{m}\right]$ (data taken from Hizrallah 1973, Ionides 1939), the dark gray numbers transmissivity values [ $\left.\mathrm{m}^{2} / \mathrm{d}\right]$ as a results of pumping tests (Hizrallah 1973, MWI open files), and the black numbers transmissivity values [ $\left.\mathrm{m}^{2} / \mathrm{d}\right]$ as a results of pumping test performed in the course of this study in not previous investigated areas. 


\section{GROUNDWATER QUALITY AND SALINIZATION}

\subsection{INTRODUCTION}

In this section the water quality and fate of surface and groundwater entering the unconsolidated aquifer is described. Employing hydrochemical methods, information about flow direction and water quality alteration along the flow path is obtained. Groundwater quality of the unconsolidated aquifer in lower Jordan Valley displays a wide spectrum. Whereas the composition and concentration depends largely on the location of sampling points, the sampling date (because water quality varies both on a yearly and seasonal scale), and the pumping rate of the well. Sampling depth can also play an important role. Recharge to the unconsolidated aquifer comes from different sources: infiltration of surface water along the course of major wadis (mostly during the rainy season), inflow from different consolidated aquifers, irrigation return flow, and to a very small degree direct infiltration during rare single rainfall events. However, these singular events are believed to be negligible compared to other recharge sources, since the annual rainfall in South Shuneh is only $166 \mathrm{~mm} / \mathrm{y}$ and evaporation is very high (up to $2,000 \mathrm{~mm} / \mathrm{y}$ ). In general, freshwater resources can be found close to the apex of the major alluvial fans. Along the groundwater flow path from east towards the west the groundwater quality deteriorates.

Complementary to the geological and hydrochemical methods surface geophysical methods can be used to provide information about flow paths and about the salinization of groundwater in unconsolidated materials. Different geophysical methods, that are sensitive to electrical conductivity changes in the subsurface, were applied in order to distinguish freshwater from saltwater dominated areas. The methods include surface geophysics (vertical electric Schlumberger depth soundings, frequency domain electromagnetic soundings (MaxMin I-8), direct push measurements (Dipol and Wenner four point geoloectric probes), and soil sampling (distribution of soluble salt content with depth) in order to calibrate and verify the interpreted geophysical investigations.

\subsection{HYDROCHEMISTRY}

\subsubsection{Introduction}

A hydrochemical overview on groundwater resources on the Jordanian side of lower Jordan Valley and its surroundings has been published by Salameh (2001). The study area has been previously hydrochemical investigated by other researchers/ projects. Basic major ion analyses have been carried out by Tleel (1963), Hizrallah (1973), JICA (1995), Lenz (1999), and Becker (2000). Apart from major ions Kuisi (1998) analyzed samples from the area on common pesticides and fertilizers. Within the framework of "The Brackish water Project" the GTZ (2002) carried out a complete well survey in lower Jordan Valley, but unfortunately only the electrical conductivity of groundwater was measured.

This chapter focuses only on the hydrochemical quality of the wider area of interest and the study area (JVG aquifers) in particular. In order to investigate the mineralization of the unconsolidated aquifers in lower Jordan Valley, the possible end members of the groundwater of the Jordan Valley Group (JVG) aquifers will be discussed first. This will be followed by an in depth discussion of the spatial and temporal variation of groundwater quality within the study area. Afterwards possible salinization sources will be addressed. The chapter commences with some remarks on isotope hydrology. As a classification of fresh, brackish, saline, and brine waters the classification scheme developed by Davis and Dewiest (1967) will be used (Tab. 5.2-1). 
Tab. 5.2-1: Groundwater classification using Total dissolved solids (after Davis and Dewiest 1967).

\begin{tabular}{ll}
\hline Class & TDS $\left(\mathbf{m g ~ l}^{\mathbf{- 1}}\right)$ \\
\hline Fresh & $0-1,000$ \\
Brackish & $1,000-10,000$ \\
Saline & $10,000-100,000$ \\
Brine & $>100,000$ \\
\hline
\end{tabular}

\subsubsection{Possible end members}

In this section possible end members that affect the quality of the groundwater of the unconsolidated aquifer in the lower Jordan Valley will be addressed shortly. These end members include: groundwater of the recharge area, which will be followed by the groundwater composition of the different existing aquifers in the vicinity of study area, runoff water entering the Jordan Valley via major wadi outlets, and the soluble soil content of the Lisan Formation.

\subsubsection{Recharge area, upper flow course of the Mountain Aquifers}

Although this area does not contribute directly to the JVG aquifers, all recent recharge water falls on this area and either stays within this unit, or percolates to deeper units, or flows as interflow into the Jordan Valley. Most of the outcrops in the recharge area consists of Upper Cretaceous carbonates, only $11 \%$ consists of the lower Cretaceous varicolored soft sandstones of the Kurnub Group (chapter 4.2). Therefore only the carbonate Mountain Aquifers (mostly B2/A7, A4, A1/2) are discussed.

The salinity of groundwater (spring and well water) flowing within these aquifers is with $<600 \mu \mathrm{S} / \mathrm{cm}$ very low. The chemical major ion composition of the groundwater in the recharge area can be seen in Tab. 5.2-2. Well water samples were taken from the Ministry of Water and Irrigation database and spring samples from Werz (2006). The groundwater is of earth alkaline type with prevailing bicarbonates. All samples are of Calcium carbonate type and are characterized by $\mathrm{rHCO}_{3}^{-}>\mathrm{Cl}^{-}>$ $\mathrm{SO}_{4}{ }_{4}^{2-}$ anion sequence. In all samples the concentration of $\mathrm{Ca}^{2+}$ and $\mathrm{Mg}^{2+}$ exceed by far that of $\mathrm{Na}^{+}$and $\mathrm{K}^{+}\left(\mathrm{Ca}^{2+}>\mathrm{Mg}^{2+}>\left(\mathrm{Na}^{+}+\mathrm{K}^{+}\right)\right)$. The $\mathrm{Mg} / \mathrm{Ca}$ ratio is in the range of 0.5 to 0.77 . This can be explained by the lithology of the different formations, which consists of limestone and to a lower extent of dolomite. The $\mathrm{Na} / \mathrm{Cl}$ ratio is in the range of 0.66 to 0.76 .

All samples in this group are strongly undersaturated with respect to halite and gypsum and are around saturation with respect to calcite and dolomite.

The description of the upper flow and recharge areas is important insofar, as it resembles the "unaltered" chemical composition (end member) of groundwater before it dissolves different rock types or intermixes with different waters during their flow course down to the JVG aquifers.

\subsubsection{Groundwater in the vicinity of the unconsolidated aquifers}

Several wells were drilled in the vicinity of the Jordan Valley. These wells are located in Wadi Shueib, Wadi Kafrein, and Wadi Hisban close to the outcrop of the unconsolidated aquifers. In Wadi Hisban water is pumped mostly from the Naur Formation, or as a combination of the Kurnub Group and Naur Formation, and one well solely pumps from the Kurnub Group. In Wadi Shueib and its vicinity wells pump groundwater from the Hummar Formation. Two wells drilled in the vicinity of the study area (JICA 5 and 6) are believed to tap the Ram Group aquifer. These two wells complete the picture of consolidated aquifers, which might contribute to the unconsolidated aquifers.

Tab. 5.2-3 list the average chemical composition of samples taken from the different aquifers in meq/L. For well water samples ranging from the period of 1971 until today water samples from the Upper Cretaceous aquifers were divided into two different groups: "uninfluenced samples" and samples with an increased TDS content. 


\section{Upper Cretaceous Aquifers}

In years of increased pumping activities (1972 till 1976) the chemical composition of the well waters in the area of Wadi Hisban (Naur Formation) changed significantly and an increase in TDS is visible. Consequently only the "uninfluenced" samples were taken in order to detect a change in water quality from the recharge area towards the Jordan Valley.

\section{"Uninfluenced samples"}

All samples are of calcium carbonate type and are characterized by $\mathrm{rHCO}_{3}{ }^{-}>\mathrm{Cl}^{-}>\mathrm{SO}_{4}{ }^{2-}$ anion sequence. In all samples the concentration of $\mathrm{Ca}^{2+}$ and $\mathrm{Mg}^{2+}$ exceed by far that of $\mathrm{Na}^{+}$and $\mathrm{K}^{+}\left(\mathrm{Ca}^{2+}>\right.$ $\left.\mathrm{Mg}^{2+}>\left(\mathrm{Na}^{+}+\mathrm{K}^{+}\right)\right)$. The $\mathrm{Mg} / \mathrm{Ca}$ ratio is in the range of 0.76 to 0.81 , which can still be explained by the lithology of the aquifer rock composition. The $\mathrm{Na} / \mathrm{Cl}$ ratio is in the range of $0.75-0.81$.

The samples taken from the Hummar aquifer are higher mineralized than the samples taken from the recharge areas to the east. But this slight increase in TDS content can be explained by dissolution of aquifer material along the flow path to the west. The $\mathrm{Mg} / \mathrm{Ca}$ ratio stays within the same range. All water samples in this group are undersaturated with respect to halite and gypsum and are slightly oversaturated with respect to calcite and dolomite.

\section{Samples with increased TDS content}

The samples taken during this period are of Sodium Chloride type and are characterized by $\mathrm{rCl}^{-}>$ $\mathrm{HCO}_{3}{ }^{-}>\mathrm{SO}_{4}{ }^{2-}$ anion sequence. In these samples the concentration of Sodium exceeds by far the concentration of Magnesium and Calcium. The range of the $\mathrm{Mg} / \mathrm{Ca}$ ratio is between 0.97 to 1.10 , with an average of 1.03 . The $\mathrm{Na} / \mathrm{Cl}$ ratio is between 0.66 and 0.72 and has an average of 0.69 . This composition cannot be explained by the chemical composition of the Naur Formation and indicates a contribution form a different sources, either $\mathrm{NaCl}$ and $\mathrm{MgCl}_{2}$ rich brines or the dissolution of salt deposited within the Kurnub Group. Seeping water through faults from the highly pressurized Ram Group as a source of salinity can be ruled out, since this would result in a decrease of the $\mathrm{Mg} / \mathrm{Ca}$ ratio and an increase in the $\mathrm{Na} / \mathrm{Cl}$ ratio, as we will see later.

\section{Kurnub Group Aquifer}

Samples taken form the Kurnub Group aquifer show an increase in the TDS content and slightly increased values in the $\mathrm{Mg} / \mathrm{Ca}$ and $\mathrm{Na} / \mathrm{Cl}$ ratio. The Kurnub water is of earth alkaline type with increasing content of alkalies. Bicarbonates are still dominant whereby the portion of chloride and sulfate increases. Consequently the water is of $\mathrm{r} \mathrm{Ca}^{2+}>\mathrm{Mg}^{2+}>\mathrm{HCO}_{3}{ }^{-}$type. However, at least for the study area, a distinction of groundwater samples derived from carbonate aquifers cannot be made.

\section{$\underline{\text { Ram-Zerqa Group Aquifer }}$}

As reported in chapter 2.3 two deep wells were drilled in proximity of the study area: JICA 5 and 6 . Water samples taken from these wells are believed to be from the Ram Group Aquifer. Both water samples have, although they are located more than $10 \mathrm{~km}$ away from each other, little variation in their chemical composition. A TDS content of 5,476 and $5,475.73 \mathrm{mg} / \mathrm{L}$ was calculated. Therefore these water, unlike the waters discussed above, fall well within the range of brackish water. The water is of Sodium Chloride type. It shows an cation sequence of $\mathrm{Na}^{+}>>\mathrm{Ca}^{2+}>\mathrm{Mg}^{2+}>\mathrm{K}^{+}$and an anion sequence of $\mathrm{Cl}^{-}>>\mathrm{HCO}_{3}^{-}>\mathrm{SO}^{2-}$. The $\mathrm{Mg} / \mathrm{Ca}$ ratio is around 0.61 and the $\mathrm{Na} / \mathrm{Cl} 0.93$ thus indicating, that its high mineralization derives mostly from the dissolution of halite. The $\mathrm{Mg} / \mathrm{Ca}$ ratio is lower than in the other aquifers. 


\subsubsection{Chemical composition of runoff water at the outflow of major wadis}

Kuisi (1998) took samples in the course of Wadi Shueib near the village of South Shuneh and in the course of Wadi Kafrein, southeast of the village of Kafrein. Unlike the well waters, the mineral content of these samples show a strong seasonal trend (Tab. 5.2-4). Lowest TDS contents are found during and at the end of the rainy season and highest TDS contents can be found before the rainy season. The samples taken during summer show an intermediate mineral content. Since the mineral content of the surface water samples shows a wide range, no further conclusion can be drawn regarding the mineral content. However, since the chemical composition of well waters in the area show only little seasonal variation, it can be concluded that no major recharge during summer and autumn from surface water resources occurs.

Samples taken at the Kafrein dam site (Subah 1998; Lenz 1999) indicate the same as the samples taken by Kuisi (1998). The samples show a wide range in the mineral composition as well (Tab. 5.2$4)$.

\subsubsection{Chemical composition of soluble soil content of the Lisan Sediments}

During the field campaign in late 2004 soil sample of the lacustrine Lisan Formation were taken and analyzed for major ion components from soil eluates given by the DIN38414 Teil 4. The water extract was analyzed by using ion chromatography. Anions were analyzed on Dionex D320 KOH isocratic ASMHC and the cations on Dionex DX500 MSA isocratic CS16. Water that dissolves salts of the Lisan Formation can be classified as a of Sodium Chloride type. It shows an anion sequence of $\mathrm{Cl} \gg$ $\mathrm{HCO}_{3}>\mathrm{SO}_{4}$. The cation sequence has a sequence of $\mathrm{Na}>>\mathrm{Mg}>\mathrm{Ca}$. The $\mathrm{Mg} / \mathrm{Ca}$ ratio is around 1.16 and the $\mathrm{Na} / \mathrm{Cl}$ ratio around 0.57 .

Tab. 5.2-2: Water samples from the recharge area in the Mountain Highland (data taken from Werz 2006).

\begin{tabular}{|c|c|c|c|c|c|c|c|c|c|c|}
\hline location & No. & $\mathbf{E . C}$ & $\mathbf{C a}^{2+}$ & $\mathbf{M g}^{2+}$ & $\mathbf{N a}^{+}$ & $\mathbf{K}^{+}$ & $\mathbf{C l}^{-}$ & $\mathbf{H C O}_{3}{ }^{-}$ & $\mathbf{S O}_{4}{ }^{2-}$ & $\mathbf{N O}_{3}{ }^{-}$ \\
\hline & Samp & {$[\mu \mathbf{S} / \mathbf{c m}]$} & $\mathbf{m e q} / \mathbf{L}$ & $\mathbf{m e q} / \mathbf{L}$ & $\mathbf{m e q} / \mathbf{L}$ & $\mathbf{m e q} / \mathbf{L}$ & $\mathbf{m e q} / \mathbf{L}$ & $\mathbf{m e q} / \mathbf{L}$ & $\mathbf{m e q} / \mathbf{L}$ & $\mathbf{m e q} / \mathbf{L}$ \\
\hline Wells & $\mathrm{n}=11$ & 593.41 & 3.10 & 1.97 & 0.93 & 0.05 & 1.17 & 4.33 & 0.42 & 0.14 \\
\hline Springs & $\mathrm{n}=16$ & 550.31 & 3.54 & 1.32 & 0.75 & 0.03 & 1.13 & 3.63 & 0.43 & 0.47 \\
\hline
\end{tabular}

Tab. 5.2-3: Water samples taken from wells located close to study area (MWI open files) and from leaching of soil samples from the Lisan Formation.

\begin{tabular}{|c|c|c|c|c|c|c|c|c|c|c|}
\hline Aquifer & No. & $\mathbf{E . C}$ & $\mathbf{C a}^{2+}$ & $\mathbf{M g}^{2+}$ & $\mathbf{N a}^{+}$ & $\mathbf{K}^{+}$ & $\mathbf{C l}^{-}$ & $\mathbf{H C O}_{3}{ }^{-}$ & $\mathbf{S O}_{4}{ }^{2-}$ & $\mathbf{N O}_{3}{ }^{-}$ \\
\hline & Samp & {$[\mu \mathbf{S} / \mathbf{c m}]$} & $\mathbf{m e q} / \mathbf{L}$ & $\mathbf{m e q} / \mathbf{L}$ & $\mathbf{m e q} / \mathbf{L}$ & $\mathbf{m e q} / \mathbf{L}$ & $\mathbf{m e q} / \mathbf{L}$ & $\mathbf{m e q} / \mathbf{L}$ & $\mathbf{m e q} / \mathbf{L}$ & $\mathbf{m e q} / \mathbf{L}$ \\
\hline $\mathrm{A} 4$ & 153 & 778.83 & 3.49 & 2.49 & 1.75 & 0.10 & 2.35 & 4.25 & 1.05 & \\
\hline $\mathrm{A} 1 / 2$ "saline" & 34 & $2,079.60$ & 6.21 & 6.41 & 8.09 & 0.23 & 11.66 & 4.94 & 4.12 & \\
\hline $\mathrm{A} 1 / 2$ & 25 & 829.62 & 3.43 & 2.61 & 2.00 & 0.14 & 2.53 & 4.31 & 1.16 & \\
\hline $\mathrm{K}$ & 5 & $1,122.78$ & 4.45 & 3.60 & 3.10 & 0.27 & 3.97 & 5.47 & 2.05 & \\
\hline Ram & 2 & $7,891.18$ & 20.67 & 12.62 & 53.85 & 4.49 & 57.70 & 19.22 & 12.84 & 1.58 \\
\hline Lisan Leaching & 5 & & 32.24 & 36.30 & 116.25 & 11.17 & 203.50 & 29.49 & 19.40 & 1.42 \\
\hline
\end{tabular}


Tab. 5.2-4: Surface water samples taken at the outlets of major wadis (Wadi Shueib and Wadi Kafrein) (data taken from Kuisi 1998).

\begin{tabular}{|c|c|c|c|c|c|c|c|c|c|c|}
\hline Season & No. & $\mathbf{E C}$ & $\mathbf{C a}^{2+}$ & $\mathbf{M g}^{2+}$ & $\mathbf{N a}^{+}$ & $\mathbf{K}^{+}$ & $\mathbf{C l}^{-}$ & $\mathbf{H C O}_{3}{ }^{-}$ & $\mathbf{S O}_{\mathbf{4}}{ }^{2-}$ & $\mathbf{N O}_{3}{ }^{-}$ \\
\hline & Samp & {$[\mu \mathbf{S} / \mathbf{c m}]$} & $\mathbf{m e q} / \mathbf{L}$ & $\mathbf{m e q} / \mathbf{L}$ & $\mathbf{m e q} / \mathbf{L}$ & $\mathbf{m e q} / \mathbf{L}$ & $\mathbf{m e q} / \mathbf{L}$ & $\mathbf{m e q} / \mathbf{L}$ & $\mathbf{m e q} / \mathbf{L}$ & $\mathbf{m e q} / \mathbf{L}$ \\
\hline spring & 4 & 709 & 2.84 & 2.26 & 1.99 & 0.30 & 2.05 & 3.72 & 1.09 & 0.36 \\
\hline summer & 2 & 892 & 3.23 & 3.35 & 2.49 & 0.13 & 5.37 & 1.82 & 1.98 & 0.24 \\
\hline winter & 2 & 957 & 4.89 & 3.84 & 3.54 & 0.19 & 3.58 & 4.46 & 1.99 & 0.40 \\
\hline
\end{tabular}

Tab. 5.2-5: Water samples from the King Abdullah Canal (data taken from Kuisi 1998).

\begin{tabular}{|c|c|c|c|c|c|c|c|c|c|c|}
\hline Location & No & $\mathbf{E . C}$ & $\mathbf{C a}^{2+}$ & $\mathbf{M g}^{2+}$ & $\mathbf{N a}^{+}$ & $\mathbf{K}^{+}$ & $\mathbf{C l}^{-}$ & $\mathbf{H C O}_{3}{ }^{-}$ & $\mathbf{S O}_{4}{ }^{2-}$ & $\mathbf{N O}_{3}{ }^{-}$ \\
\hline & Samp & {$[\mu \mathbf{S} / \mathbf{c m}]$} & $\mathbf{m e q} / \mathbf{L}$ & $\mathbf{m e q} / \mathbf{L}$ & $\mathbf{m e q} / \mathbf{L}$ & $\mathbf{m e q} / \mathbf{L}$ & $\mathbf{m e q} / \mathbf{L}$ & $\mathbf{m e q} / \mathbf{L}$ & $\mathbf{m e q} / \mathbf{L}$ & $\mathbf{m e q} / \mathbf{L}$ \\
\hline Karameh & 4 & 2,300 & 5.20 & 4.27 & 11.23 & 0.88 & 11.15 & 7.02 & 3.71 & 0.90 \\
\hline Shuneh & 4 & 2,727 & 6.82 & 5.22 & 14.79 & 0.94 & 14.40 & 6.80 & 5.18 & 0.73 \\
\hline Rama & 1 & 2,360 & 6.87 & 5.23 & 11.20 & 0.65 & 13.71 & 4.69 & 4.91 & 0.49 \\
\hline
\end{tabular}

Tab. 5.2-6: Ionic ratios of the water samples from the recharge area.

\begin{tabular}{|c|c|c|c|c|c|c|c|c|c|c|}
\hline Location & $\mathbf{M g} / \mathrm{Ca}$ & $\mathrm{Na} / \mathrm{Cl}$ & $\mathbf{C a} / \mathbf{C l}$ & $\mathbf{M g} / \mathbf{C l}$ & $\mathbf{C a} / \mathbf{S O}_{4}$ & $\mathbf{N a} / \mathbf{C a}$ & $\mathbf{H C O}_{3} / \mathbf{C l}$ & $\mathbf{S O}_{4} / \mathbf{C l}$ & $\begin{array}{c}\mathrm{Ca} / \\
\left(\mathbf{S O}_{4}+\mathbf{H C O}_{3}\right)\end{array}$ & $\mathbf{K} / \mathbf{C l}$ \\
\hline & - & - & - & - & - & - & - & - & - & - \\
\hline Wells & 0.64 & 0.79 & 2.64 & 1.68 & 7.34 & 0.30 & 3.69 & 0.36 & 0.65 & 0.04 \\
\hline Springs & 0.37 & 0.66 & 3.14 & 1.17 & 8.22 & 0.21 & 3.22 & 0.38 & 0.87 & 0.03 \\
\hline
\end{tabular}

Tab. 5.2-7: Ionic ratios of surface water samples taken at the outlets of major wadis (Wadi Shueib and Wadi Kafrein).

\begin{tabular}{|c|c|c|c|c|c|c|c|c|c|c|}
\hline Season & $\mathrm{Mg} / \mathrm{Ca}$ & $\mathrm{Na} / \mathrm{Cl}$ & $\mathrm{Ca} / \mathrm{Cl}$ & $\mathrm{Mg} / \mathrm{Cl}$ & $\mathrm{Ca} / \mathrm{SO}_{4}$ & $\mathrm{Na} / \mathrm{Ca}$ & $\mathrm{HCO}_{3} / \mathbf{C l}$ & $\mathbf{S O}_{4} / \mathrm{Cl}$ & $\begin{array}{c}\mathrm{Ca} / \\
\left(\mathrm{SO}_{4}+\mathrm{HCO}_{3}\right)\end{array}$ & $\mathrm{K} / \mathrm{Cl}$ \\
\hline & - & - & - & - & - & - & - & - & - & - \\
\hline spring & 0.79 & 0.97 & 1.38 & 1.10 & 2.60 & 0.70 & 1.81 & 0.53 & 0.59 & 0.15 \\
\hline summer & 1.04 & 0.46 & 0.60 & 0.62 & 1.63 & 0.77 & 0.34 & 0.37 & 0.85 & 0.02 \\
\hline winter & 0.79 & 0.99 & 1.36 & 1.07 & 2.45 & 0.72 & 1.25 & 0.56 & 0.76 & 0.05 \\
\hline
\end{tabular}


Tab. 5.2-8: Ionic ratios of water samples taken from wells located close to study area and of leached soil samples from of the Lisan Formation.

\begin{tabular}{|c|c|c|c|c|c|c|c|c|c|c|}
\hline Aquifer & $\mathrm{Mg} / \mathrm{Ca}$ & $\mathrm{Na} / \mathrm{Cl}$ & $\mathrm{Ca} / \mathrm{Cl}$ & $\mathrm{Mg} / \mathrm{Cl}$ & $\mathrm{Ca} / \mathrm{SO}_{4}$ & $\mathrm{Na} / \mathrm{Ca}$ & $\mathrm{HCO}_{3} / \mathrm{Cl}$ & $\mathrm{SO}_{4} / \mathrm{Cl}$ & $\begin{array}{c}\mathrm{Ca} / \\
\left(\mathrm{SO}_{4}+\mathrm{HCO}_{3}\right)\end{array}$ & $\mathbf{K} / \mathrm{Cl}$ \\
\hline $\mathrm{A} 4$ & - & - & - & - & - & - & - & - & - & - \\
\hline $\mathrm{A} 1 / 2$ "sal" & 1.03 & 0.69 & 0.53 & 0.55 & 1.51 & 1.30 & 0.42 & 0.35 & 0.69 & 0.02 \\
\hline $\mathrm{A} 1 / 2$ & 0.76 & 0.79 & 1.36 & 1.03 & 2.96 & 0.58 & 1.71 & 0.46 & 0.63 & 0.06 \\
\hline $\mathrm{K}$ & 0.81 & 0.78 & 1.12 & 0.91 & 2.17 & 0.69 & 1.38 & 0.52 & 0.59 & 0.07 \\
\hline Ram & 0.61 & 0.93 & 0.36 & 0.22 & 1.61 & 2.61 & 0.33 & 0.22 & 0.64 & 0.08 \\
\hline $\begin{array}{c}\text { Lisan } \\
\text { Leaching }\end{array}$ & 1.16 & 0.57 & 0.16 & 0.18 & 1.14 & 3.85 & 0.15 & 0.09 & 0.66 & 0.05 \\
\hline
\end{tabular}

Tab. 5.2-9: Ionic ratios of water samples taken from the King Abdullah Canal.

\begin{tabular}{|c|c|c|c|c|c|c|c|c|c|}
\hline Location & $\mathbf{r M g} / \mathbf{C a}$ & $\mathbf{r N a} / \mathrm{Cl}$ & $\mathbf{C a} / \mathbf{C l}$ & $\mathbf{M g} / \mathbf{C l}$ & $\mathbf{C a} / \mathbf{S O} 4$ & $\mathbf{N a / C a}$ & $\mathbf{r H C O} / \mathbf{C l}$ & $\mathbf{r S O} 4 / C l$ & $\begin{array}{c}\text { rCa/ } \\
\text { (SO4+HCO3) }\end{array}$ \\
\hline & - & - & - & - & - & - & - & - & - \\
\hline Karameh & 0.82 & 1.01 & 0.47 & 0.38 & 1.40 & 2.16 & 0.63 & 0.33 & 0.48 \\
\hline Shuneh & 0.77 & 1.03 & 0.47 & 0.36 & 1.31 & 2.17 & 0.47 & 0.36 & 0.57 \\
\hline Rama & 0.76 & 0.82 & 0.50 & 0.38 & 1.40 & 1.63 & 0.34 & 0.36 & 0.72 \\
\hline
\end{tabular}

\subsubsection{Chemical composition of groundwater from the unconsolidated aquifer in the study area}

\subsubsection{Distribution Maps}

As stated in chapter 3 first attempts in characterizing the groundwater resources in lower Jordan Valley were undertaken by Ionides (1939). Before that period no deep wells existed in the area. Within the project "The water resources of Transjordan and their development" only eight new wells were drilled. First comprehensive spatial water quality plots can be made for the 60s, when Tleel (1963) undertook the first extensive well survey in the Jordan Valley. Groundwater quality distribution maps were computed with the data provided by Tleel (1963), since from the beginning of the sixties the study area was intensively used for agriculture. Therefore recent well analysis would not deliver the natural flow system, but rather a strongly anthropogenically influenced picture of the flow system. This altered system is addressed in section 5.2.4. In order to get an overview of the study area, the data was checked for accuracy (electro neutrality) and entered into a ArcGIS based geodatabase. Different distribution maps: electrical conductivity, different ions $\left(\mathrm{Cl}^{-}\right.$and $\left.\mathrm{SO}_{4}{ }^{2-}\right)$, and static water levels (SWL) were constructed.

Fig. 5.2-1 shows the relationship between groundwater contour lines (light gray colors) and isoelectrical conductivity lines (dark gray colors) for the year 1961. The groundwater contour lines are plotted in order to show the parallels between groundwater flow and water salinity. Since the focus of this chapter is on hydrochemistry, the groundwater contour lines are not labeled, but groundwater flows from east to west and groundwater level contour intervals are $5 \mathrm{~m}$.

As far as the spatial distribution of EC values is concerned, the lowest values were found in wells located next to the outlets of the major wadis. Downgradient the salinity increases. The highest conductivity values were measured close to the Jordan River (west of South Shuneh; around 143,000 
PGN) and in the south to southwest (Fig. 5.2-1). Some wells show regionally high salinities. The possible reason for these high values will be addressed in section 5.2.5. Between the alluvial fan sediments at the outlets of Wadi Shueib and the alluvial fan sediments of Wadi Kafrein and Wadi Hisban an increase in EC can be observed. This is in good accordance with the lithological logs of wells in the area (Appendix) and local groundwater flow. Lacustrine sediments, mostly the Lisan Formation, accumulated more between the alluvial fans than on the fans themselves. The highly soluble salt contents of the Lisan Formation could be the reason for the increased conductivity between the two major flow paths in the study area. These two major flow paths are the Wadi Shueib alluvial fan flow path and the combined flow path within the alluvial fans of Wadi Kafrein and Wadi Hisban. Groundwater flow is towards the west and almost no or no water flows between the two flow paths due to the low permeability of the Lisan Marls. However, Tleel (1963) already reported groundwater deterioration in wells with increased pumping activity. Therefore the "natural flow" and its quality was already influenced by pumping activities and the interpretation of the distribution maps should be done carefully.

In 1961 several cones of depression started to form in the study area and first signs of overpumping can be seen in the area northwest of South Shuneh (PGE 206,500/ PGN 144,750), just east of South Shuneh (PGE 208,000/ PGN 145,000), and $10 \mathrm{~km}$ west of the village of Rama (PGE 206,000/ PGN $139,000)$. Locally high salinities might be the result of inflowing water from the neighboring Lisan Formation as the cone of depression increases to the west and north, by upconing of salt water, or by return flow of higher saline irrigation water. In the southeast of the study area high salinities can be found. Since a large displacement fault is located directly in the vicinity of the sampled wells, these high salinities might be attributed to upconing water from the Zarqa or Ram Group. However, the ionic ratios of these well waters fit more to the composition of water that dissolved salts in the Lisan Formation. Well No. 11 (PGE 213,000/ PGN 134600) is only $45 \mathrm{~m}$ deep, completed within the possible thickness of the Lisan Formation (average thickness of the Lisan Formation in the study area: $40 \mathrm{~m}$ ). The water of Well No.11 has $\mathrm{Mg} / \mathrm{Ca}$ ratio of 1.88 , a Na/Cl ratio of 0.88 and $\mathrm{Ca} / \mathrm{SO}_{4}$ ratio of 0.86. These ratio are similar to the leached fraction samples of the Lisan Formation (Tab. 5.2-8) and not to the water samples taken from the Ram Group.

However, parameters like TDS and EC are only bulk parameters and are therefore not unambiguous. Nevertheless, an increase in salt concentration along the groundwater flow path towards the west and the detection of two different major flow paths (Wadi Shueib and Wadi Kafrein/ Hisban alluvial fan flow path) could clearly be seen. In Fig. 5.2-2 and Fig. 5.2-3 the Chloride and the Sulphate distributions is displayed.

Chloride was chosen, since chloride is usually the most conservative ion. Chloride is easily dissolved from the rock matrix, but rarely precipitated. Therefore concentration of chloride will increase or remain the same along the groundwater flow path. Only in case of dilution with fresher or more polluted water the chloride content of the groundwater will change its composition. Generally, chloride concentration distribution maps should follow groundwater head distribution maps, as long as there are no hydraulic sources or sinks. It should be noted, that this rule of thumb accounts only for fresh and brackish to saline waters and not for waters of brine concentration. However, no water of brine concentration was found neither in the studied literature, nor was measured in the field.

Fig. 5.2-2 shows a similar trend to the one shown in Fig. 5.2-1. The chloride distribution in the study area follow the groundwater head distribution. Areas, where hydraulic cones of depressions formed behave differently. An increased Chloride content is apparent in cones of depressions, i.e. the one developed northwest of South Shuneh and the one located $10 \mathrm{~km}$ west of Rama. This increase in concentration can be explained by reasons mentioned above.

Fig. 5.2-3 gives a partly different trend than Fig. 5.2-1 and Fig. 5.2-2. Especially in the southeast and south west of the study area. There the highest values regarding sulphate content are found. The water samples taken close to the fan apex of Wadi Kafrein/ Wadi Hisban show a higher Sulphate content than the groundwater samples taken close to the apex of Wadi Shueib. This might be addressed to the inflow of waters from different adjacent consolidated aquifers. Also, the area between South Shuneh an Wadi Kafrein, the deposition shadow of the major alluvial fans, show particularly high sulphate 
content. The increased groundwater salinity at the described cones of depression however cannot be seen in Fig. 5.2-3.

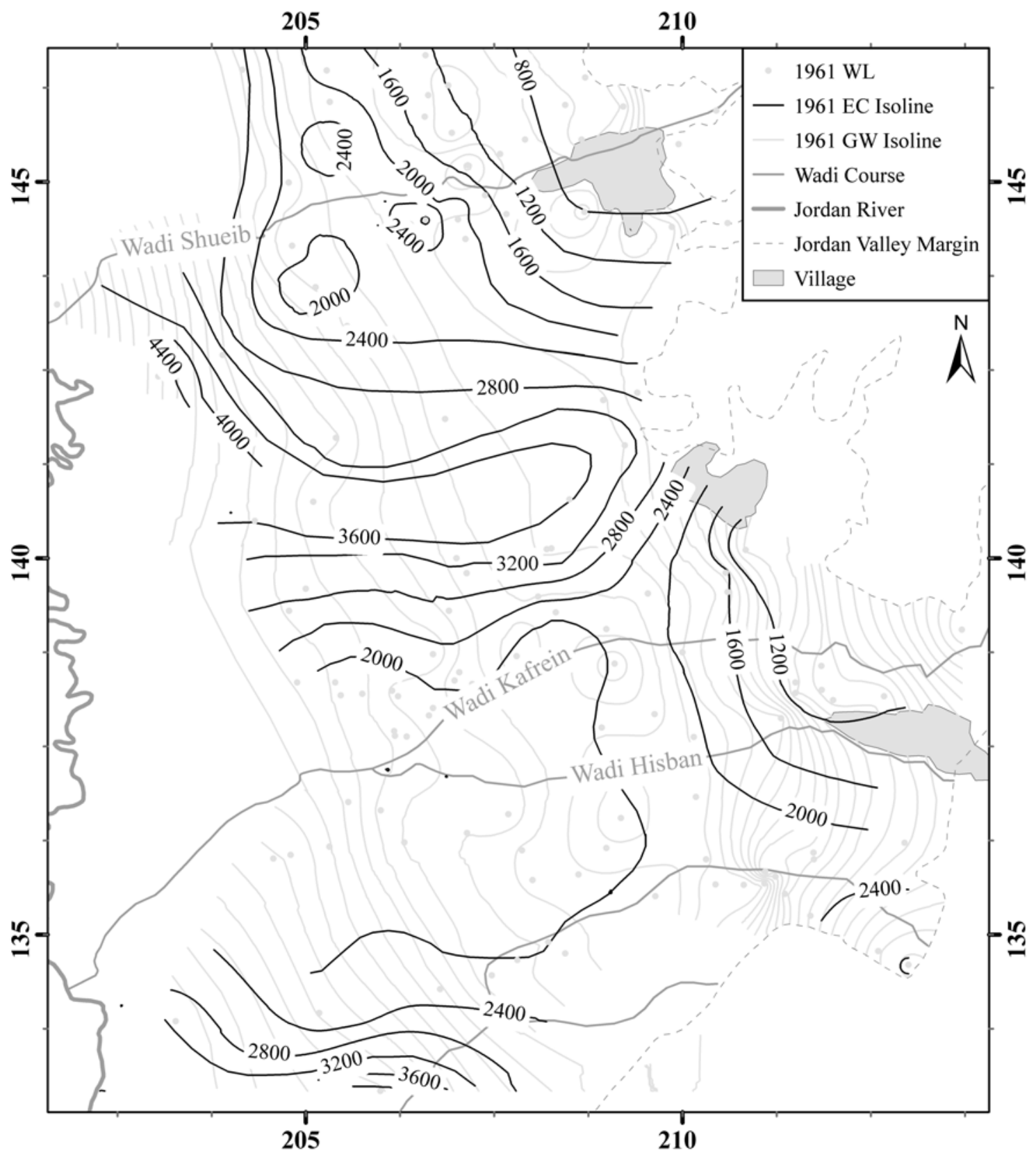

Fig. 5.2-1: Relationship between groundwater contour lines (middle gray color) and iso- electrical conductivity lines (in $\mu \mathrm{S} / \mathrm{cm}$; black color) of well water samples taken 1961. The gray dots represent gw level measurements locations at the different wells (based on the data given by Tleel 1963). The results of the analysis together with its location are the base of the interpolated lines. Groundwater contour lines are not labeled for better visibility of the iso- EC contour lines. Groundwater flow is from east to west; groundwater contour intervals are $5 \mathrm{~m}$.

Eight structural holes were drilled in the alluvial of the lower Jordan Valley. Seven ranging from 82 to $277 \mathrm{~m}$ and one deep well Jordan Valley 1 (JV1) reached its final depth at $1098 \mathrm{~m}$ b.g.l. It encountered groundwater containing up to $80,000 \mathrm{mg} / \mathrm{L}$ chlorides (NRA open files). Which indicates highly saline groundwater underlying the alluvial sediments. 


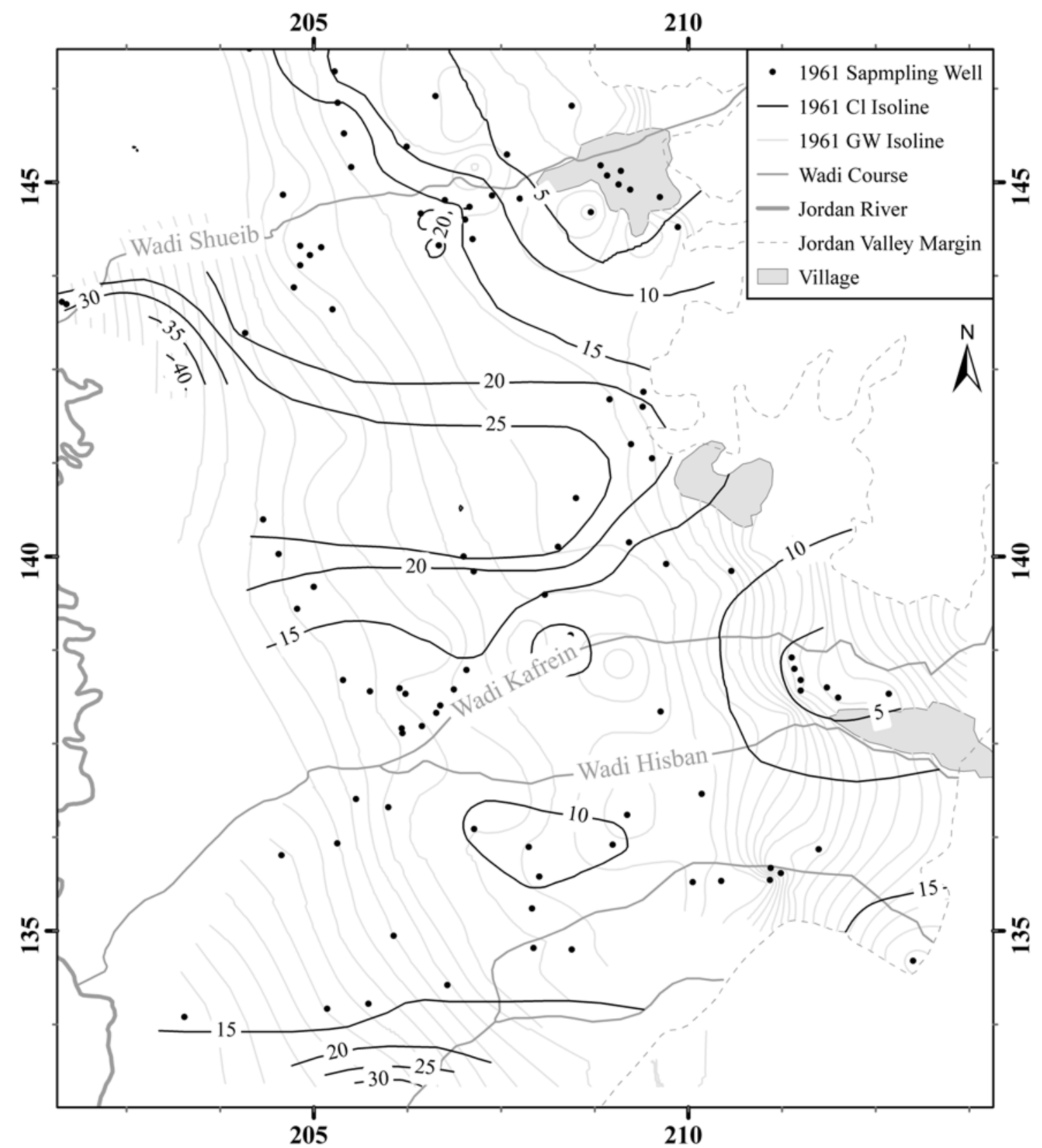

Fig. 5.2-2: Relationship between groundwater contour lines (middle gray colors) and Iso- Chloride concentration lines (meq/L; black color) of well water samples taken 1961. The black dots represent gw sampling locations. The results of the analysis together with its location are the base of the interpolated lines. Groundwater contour lines are not labeled for better visibility of the iso- EC contour lines. Groundwater flow is from east to west; groundwater contour intervals are $5 \mathrm{~m}$. 


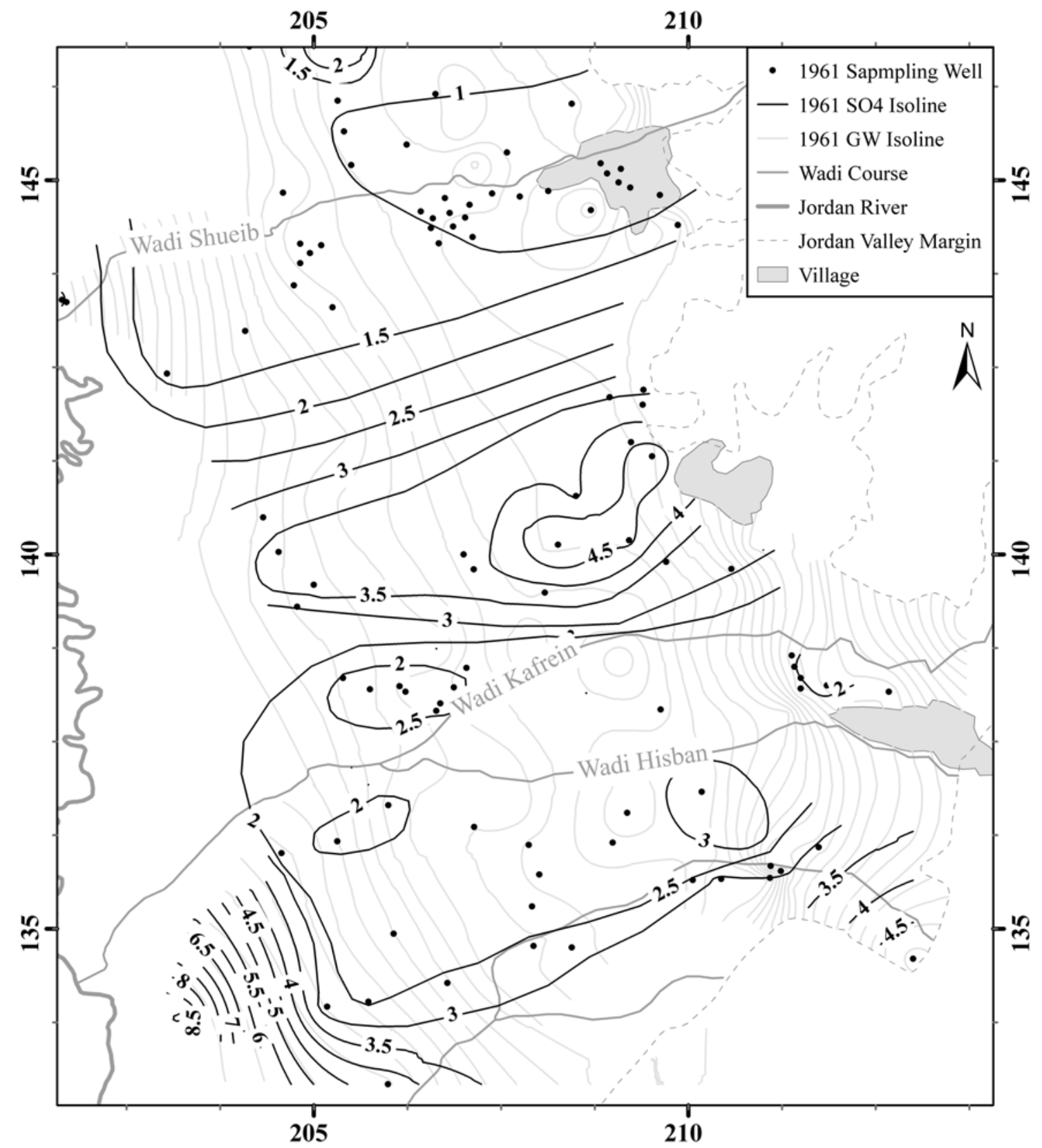

Fig. 5.2-3: Relationship between groundwater contour lines (middle gray color) and iso- sulphate concentration lines (meq/L; black color) of well water samples taken 1961 (data was taken from Tleel 1963). The black dots represent gw sampling locations. The results of the analysis together with its location are the base of the interpolated lines. Groundwater contour lines are not labeled for better visibility of the iso- EC contour lines. Groundwater flow is from east to west; groundwater contour intervals are $5 \mathrm{~m}$.

\subsubsection{Hydrochemical profiles}

In this sub chapter, variations of major ion concentrations along the two different flow paths within the alluvial sediments (Wadi Shueib and Wadi Kafrein/ Hisban) are closely examined. These profiles are examined using data of wells drilled close to the outlets of the major wadis in the east until the vicinity of the Jordan River in the west. As a base for the investigations the results of the water sampling campaign of Tleel (1963) were taken for reasons stated above. The major ions analysis of all available well samples which passed the accuracy test were taken and plotted with the help of the commercial software package AquaChem 5.0 (Waterloo Hydrogeologic Inc.). As described above, the freshwater 
resources of the study area are restricted to the apex area of the alluvial fans deposited at the outlet of Wadi Shueib and Wadi Kafrein/ Hisban (Fig. 5.2-4). The groundwater flows from east to west and southwest. Along its course the water salinity increases. No flow from north to south or south to north (only in cases of major pumping activity) takes place, as indicated by the zone of brackish groundwater between the two major flow paths (Fig. 5.2-1 through Fig. 5.2-3).

The wells used for the analyses of different flow paths are displayed in Fig. 5.2-4, which the well locations together with the well number used by Tleel (black numbers) and the electrical conductivity of groundwater samples from these wells (red numbers). An increase in salinity along the flow path can clearly be seen. The electric conductivity of the groundwater increases from around $900 \mu \mathrm{S} / \mathrm{cm}$ near South Shuneh to $5,400 \mu \mathrm{S} / \mathrm{cm} 1 \mathrm{~km}$ east of the Jordan River. The development of water quality along the flow path in the Wadi Shueib alluvial fan is also illustrated by a PIPER plot in Fig. 5.2-5. Here the number in the legend are the well numbers used by Tleel. The well location can be found in Fig. 5.2-4. The light gray area if Fig. 5.2-5 is the area of A4 water. This area is based on data from 25 groundwater samples taken from the A4 aquifer close to the Jordan Valley and east of Rama (MWI open files). The middle gray areas are the location of A1/2 waters. This area is based on data from 153 analysis taken from various wells close to the Jordan Valley and that is east of South Shuneh and Karameh. The dark gray area represents samples taken from the Kurnub aquifer. Since only one well is reported to pump solely from the Kurnub aquifer, the area represents only five samples from a single well, located close to the Jordan Valley, east of Rama. The hatched areas in the PIPER diagrams represents wells drilled in areas where the Lisan Formation dominates the sedimentological sequence. The smaller black spot represents the samples from JICA well No. 5 and 6 and therefore they represent water samples from the saline Ram Group.

The PIPER diagram along Wadi Shueib alluvial fan flow path shows a clear trend from the carbonate dominated aquifer of the mountain aquifer towards a more Chloride/ Sodium dominated water type. That is similar to the Lisan dominated water type. Taking this information together with the development of salinity along the flow path it can be said, that the water quality deteriorates along the flow path and that the salinity most probably derives from the leaching of salts precipitated within the Lisan sediments.

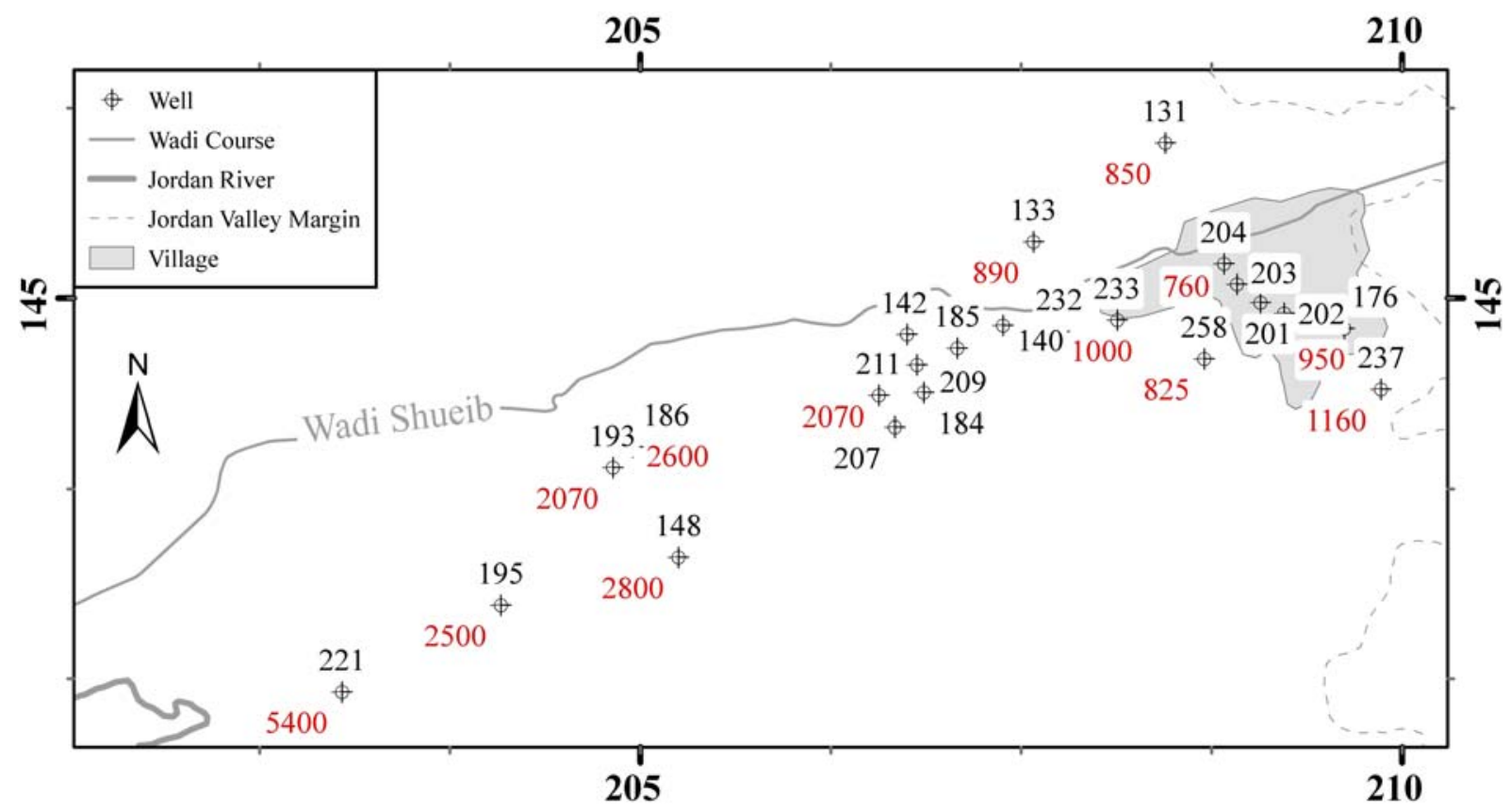

Fig. 5.2-4: Flow path from the village of South Shuneh in the east towards the southwest. The red values of the different wells represent the electrical conductivity of the well water, the black number the Well ID number used in the report of Tleel 1963 (data taken from Tleel 1963). 


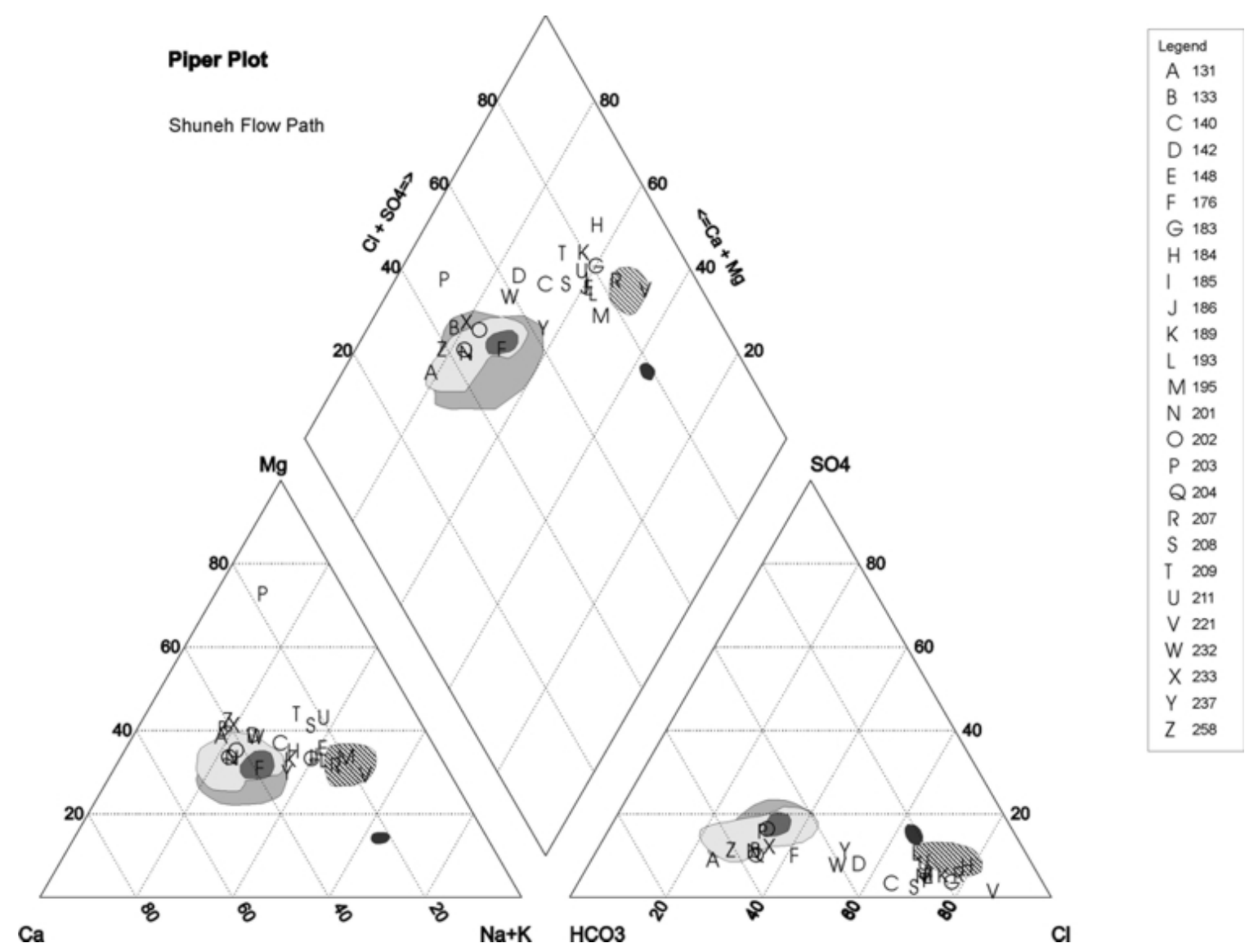

Fig. 5.2-5: PIPER diagram for the flow path of Fig. 5.2-4. A1/2 waters: middle gray; A4 waters: light gray; Kurnub waters: dark gray areas; Lisan Waters: hatched areas; Ram Group: small black area (data taken from Tleel 1963, colored areas are based on data from the MWI open files).

The same groundwater development can be seen along the alluvial fan flow path of Wadi Kafrein and Wadi Hisban. Fig. 5.2-6 shows the increase in salinity along the flow path from east to west whereby the well number used by Tleel are represented by black and the electrical conductivity of groundwater samples by red numbers. Here, the same observations as along Wadi Shueib alluvial fan flow path can be seen. The groundwater salinity increases significantly after the fresh mountain aquifer water enters the unconsolidated sediments of the Lower Jordan Valley. The electric conductivity of the groundwater increases from around $1,000 \mu \mathrm{S} / \mathrm{cm}$ near Rama to $3,180 \mu \mathrm{S} / \mathrm{cm} 1 \mathrm{~km}$ east of the Jordan River. The increase in salinity however is smaller and the salinity gradient along the flow path is much smaller than along the Wadi Shueib alluvial fan flow path. 


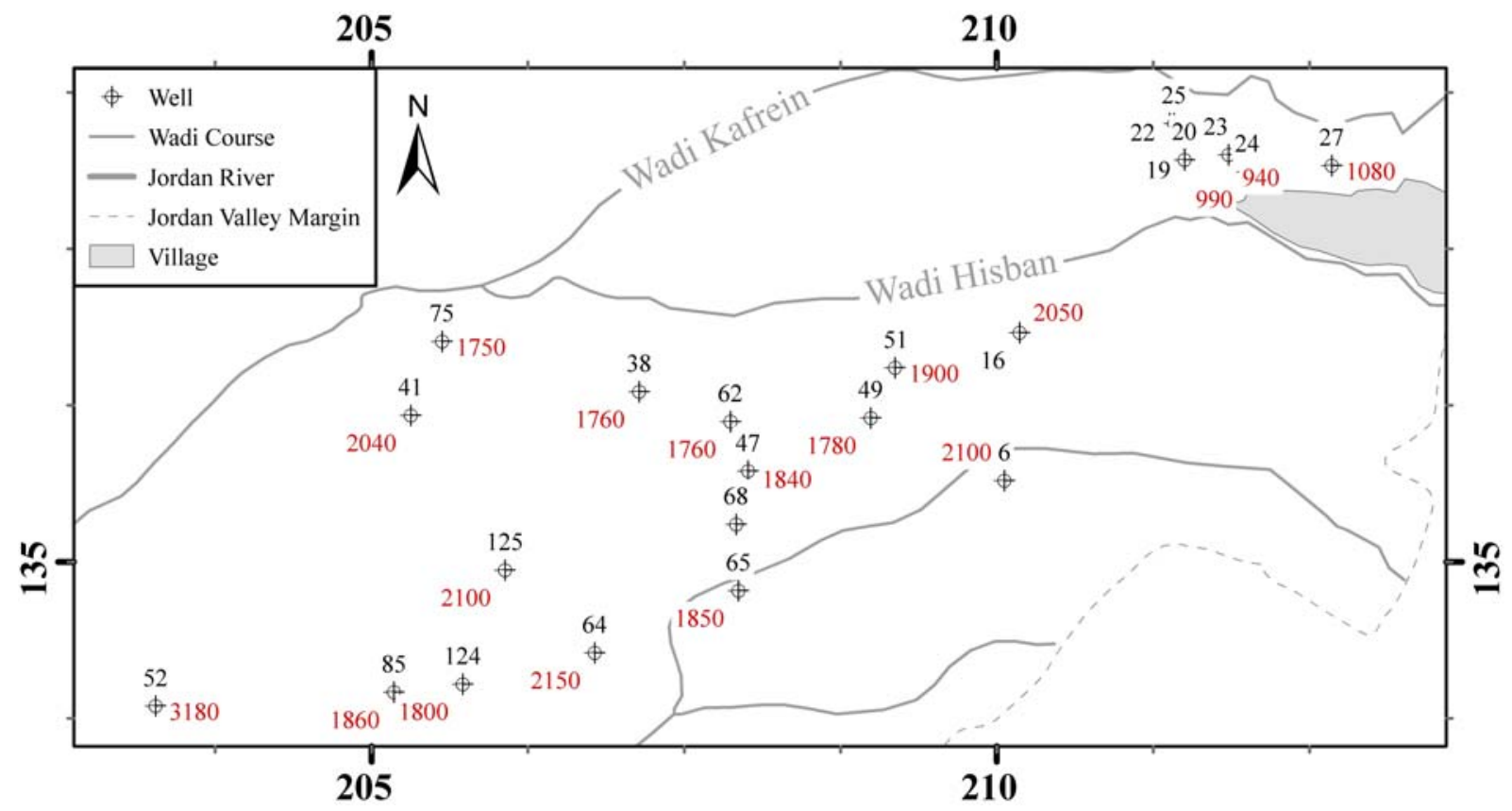

Fig. 5.2-6: Flow path from the village of Rama in the east towards the southwest. The red values of the different wells represent the electrical conductivity of the well waters, the black number the Well ID number used in the report of Tleel 1963 (data taken from Tleel 1963).

Fig. 5.2-7 shows a PIPER plot of the flow path from Rama in the east towards the southwest. The colored areas within the PIPER plot represent the same areas as described for Fig. 5.2-5. Here mixing with the Lisan end member is more apparent as indicated in Fig. 5.2-5.

Fig. 5.2-8 and Fig. 5.2-9 show the locations and a PIPER plot of the wells located between major flow paths of South Shuneh and Rama. The electrical conductivity (Fig. 5.2-8) and the chemical composition (Fig. 5.2-9) shows no major change from east to west. All well waters group around the area of the soluble soil content of the Lisan Formation. Therefore, flow between South Shuneh and Rama is probably negligible. 


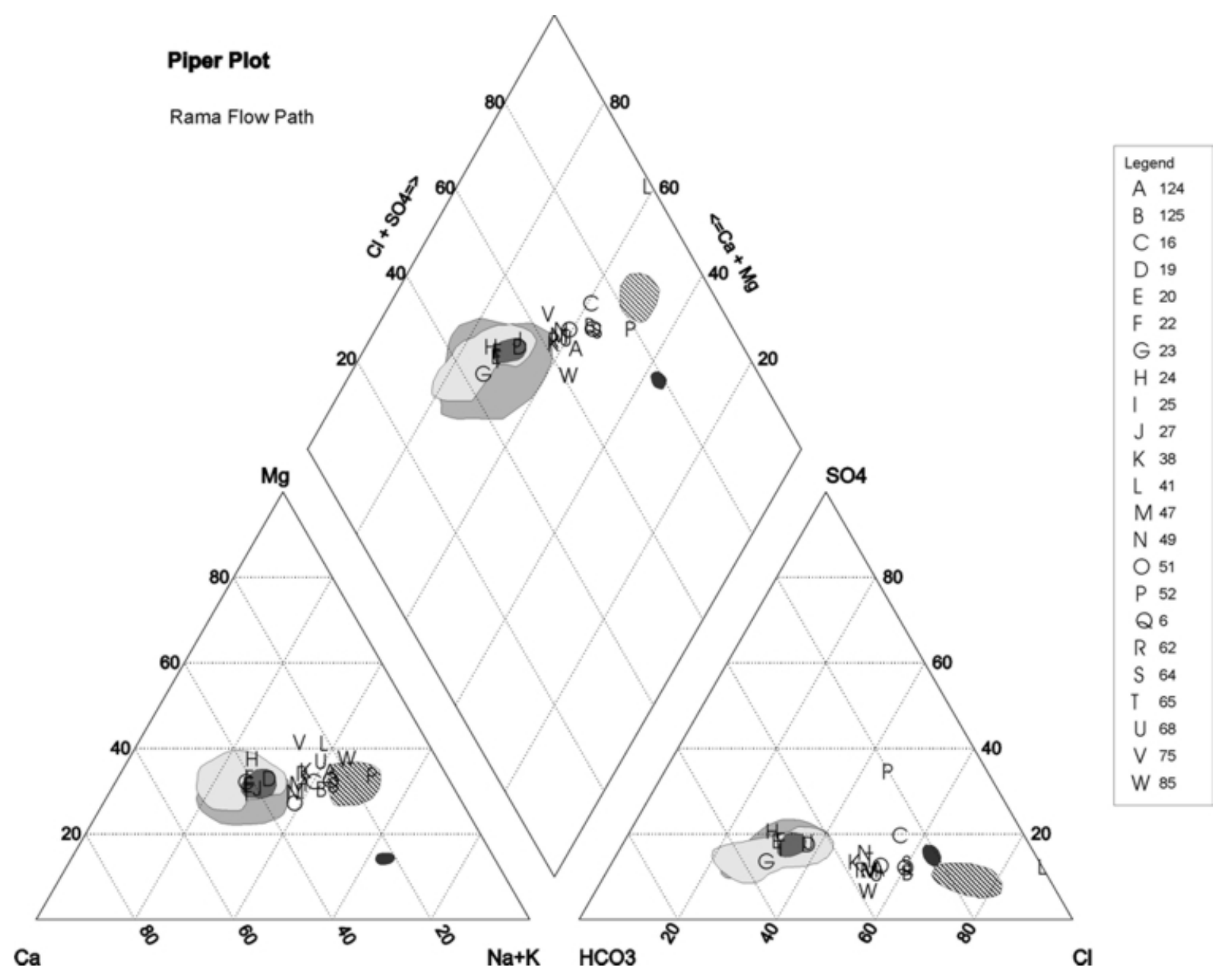

Fig. 5.2-7: PIPER diagram for the flow path of the Wadi Kafrein/ Wadi Hisban alluvial fan flow path. A1/2 waters: middle gray area; A4 waters: light gray area; Kurnub waters: dark gray area; Lisan waters: hatched areas; Ram Group: small black areas (data taken from Tleel 1963 and the colored areas are based on data from the MWI open files).

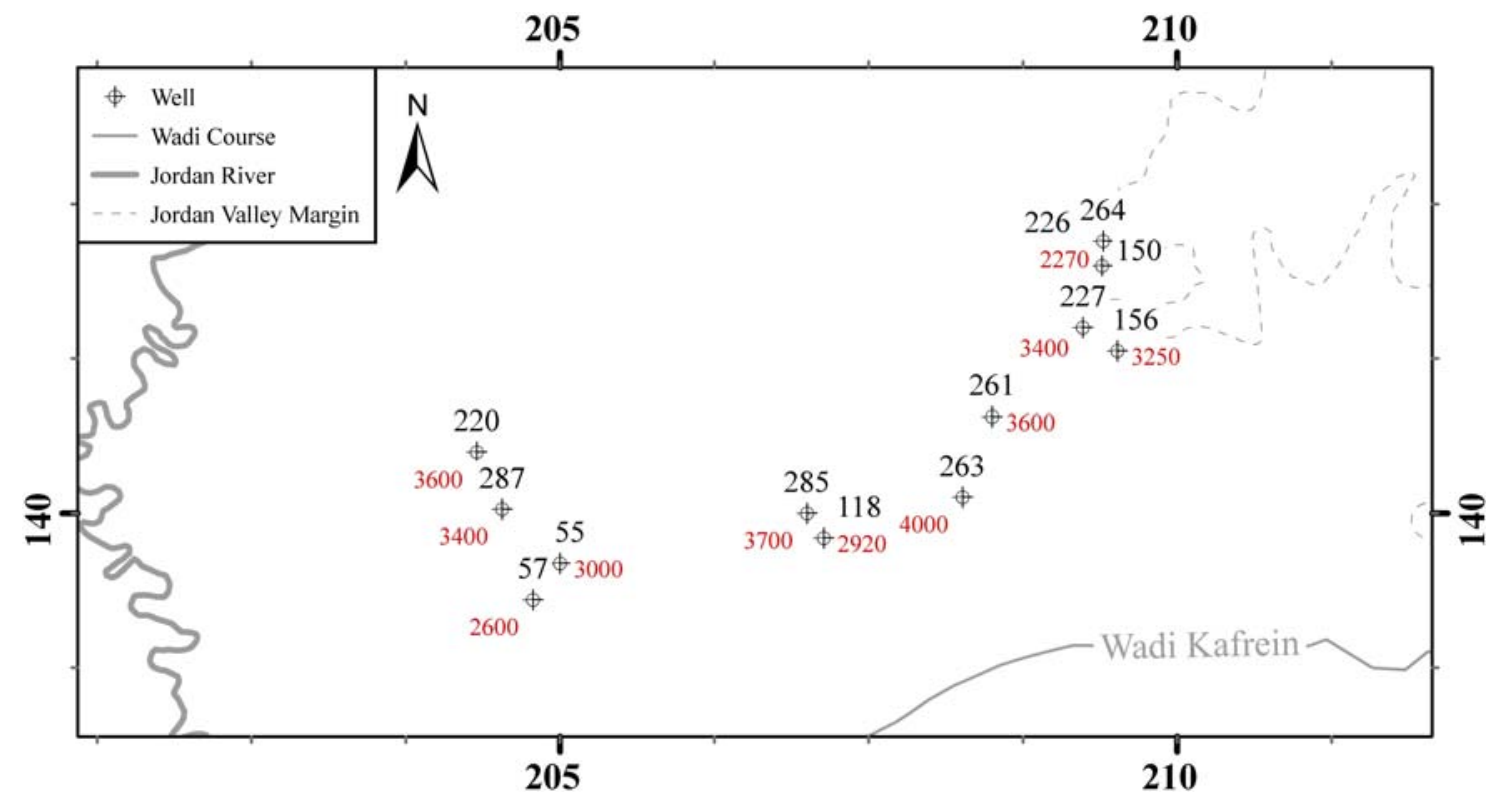

Fig. 5.2-8: Wells located between the major Flow Paths of South Shuneh and Rama. The red values of the different wells represent the electrical conductivity of the well waters, the black number the Well ID number used in the report of Tleel 1963 (data taken from Tleel 1963). 


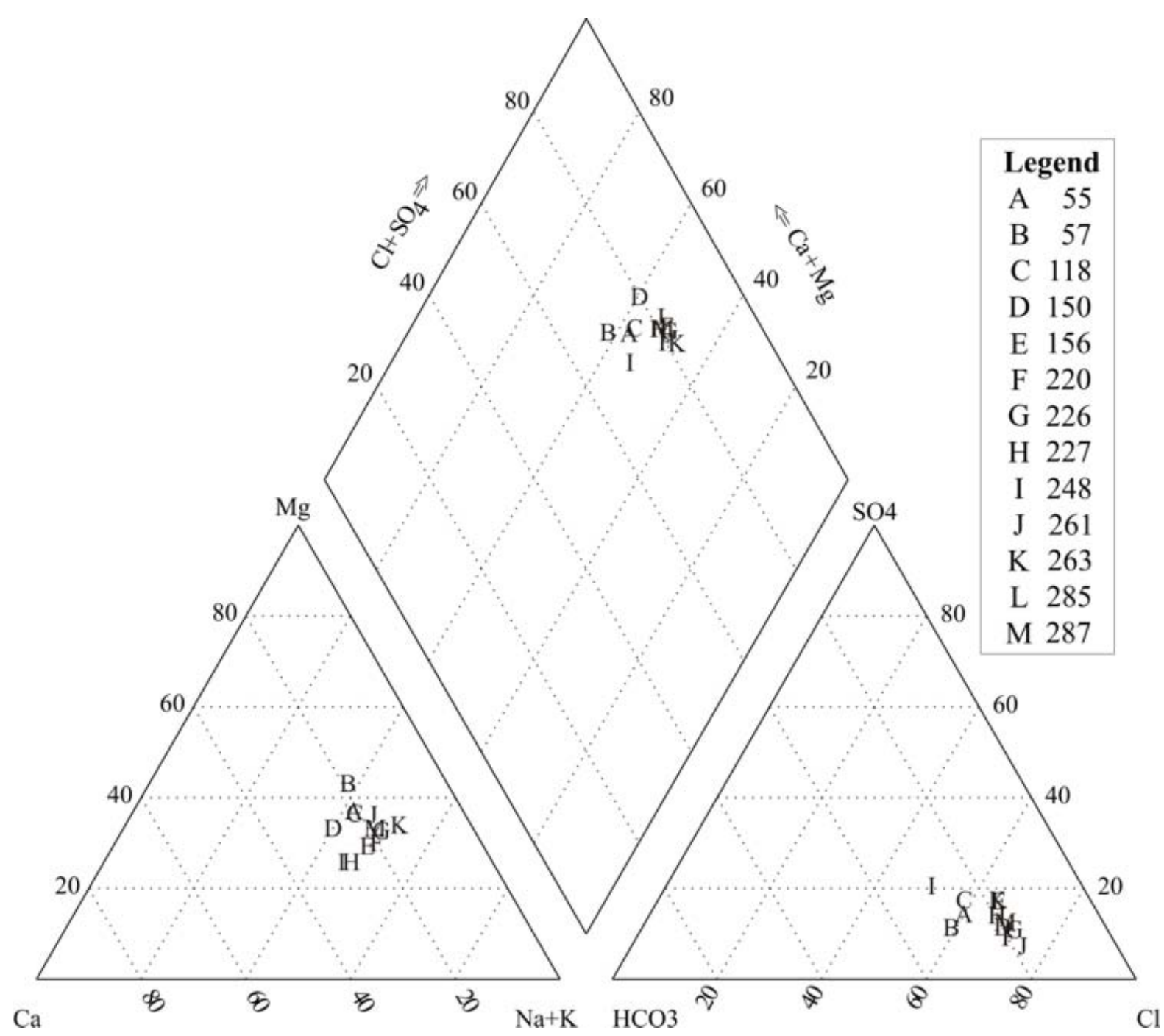

Fig. 5.2-9: PIPER diagram for the wells located between the flow paths of South Shuneh and Rama (Tleel 1963).

\subsubsection{Temporal evolution of groundwater quality}

\subsubsection{Introduction}

Distribution maps give only information about a narrow time window. Furthermore, the chemical composition of well waters in the area depend on a variety of factors which are not covered by scheduled sampling campaigns. Fig. 5.2-10 shows the dependence of electrical conductivity on sampling time during pumping, after pumping, and after the restart of the pumping activities. Even during steady-state pumping variations between 0.3 to $0.9 \mathrm{mS} / \mathrm{cm}$ can be observed. In times where the performance of the pump varies high fluctuation in electrical conductivity, but small variations in water depth can be seen. Consequently interpretation of chemical analysis of well waters should be done carefully. It should be mentioned, that strong variations of EC do not occur in all wells. Only in wells located in the east of the study area these strong fluctuations were observed. More information about hydraulic properties and salinity of well water during pumping tests were addressed in chapter 4.3. Furthermore, as discussed in chapter 3, the water level of the wells in the study area have a yearly trend, where highest water levels in an undisturbed groundwater flow environment are measured between July and August. Recharge to the groundwater system comes mostly from the adjacent mountain aquifers and from infiltrating runoff water. Therefore a drop in salinity can be expected. Apart form well locations well depth might also play a role. As described in chapter 4.2 the lacustrine 
Lisan Formation contains a high amounts of soluble salts. Consequently, wells pumping mostly from this formation carry also high amounts of dissolved salts.

In this sub chapter all available chemical analysis of the unconsolidated aquifer were collected, checked for plausibility and stored in a geodatabase. From this database some representative wells for the different areas were chosen. The areas include the area around South Shuneh, the area west of South Shuneh, the area west of Kafrein (between the major flow paths), the area around Rama, and the area downstream of Rama, and one well (AB1054) located close to the Western Slopes, around one to two kilometers south of Karameh (Fig. 5.2-11). However, this sub chapter begins with the earliest information about water quality, which were collected during 1938, after the drilling of the first deeper wells in the area.

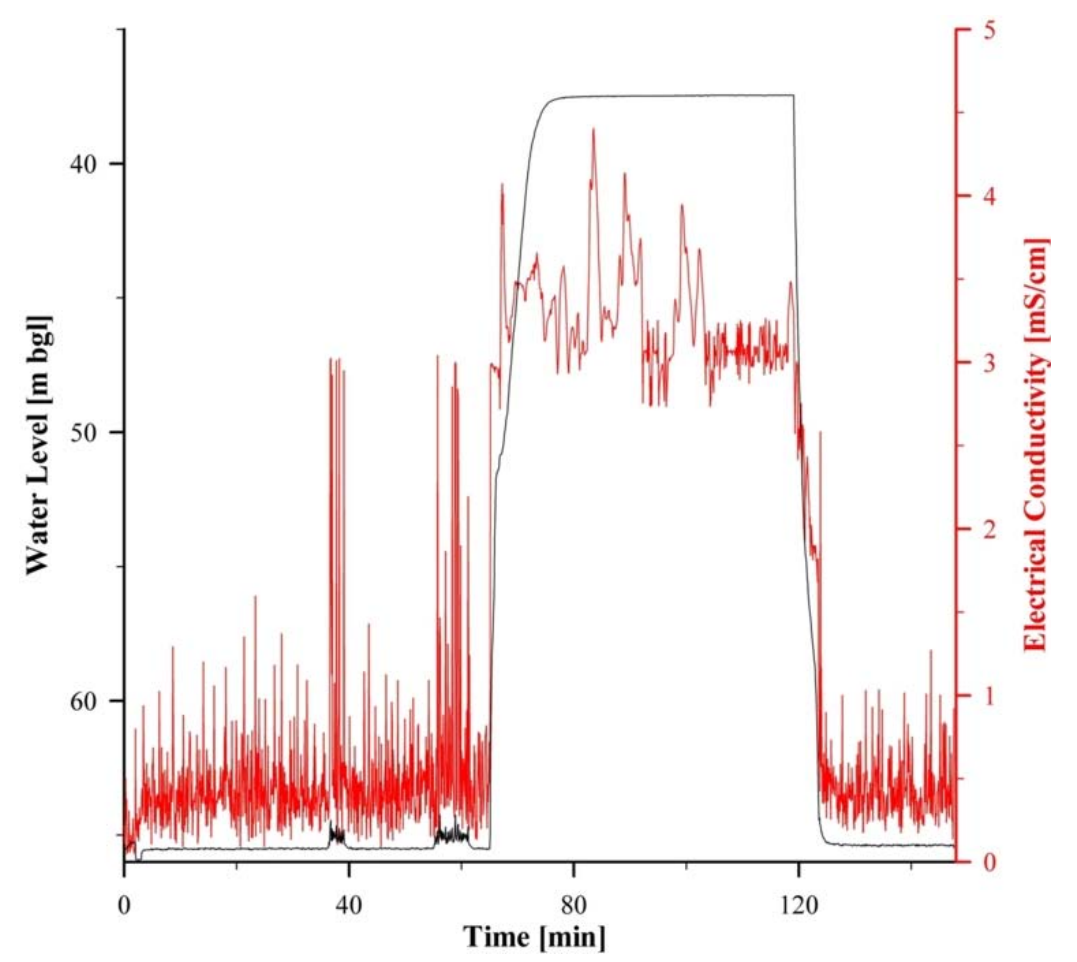

Fig. 5.2-10: Variation in electrical conductivity during pumping, after pumping, and after restarting the pumping activity of a well near Rama along with the recorded water level. Electrical conductivity depends strongly on the sampling time. 


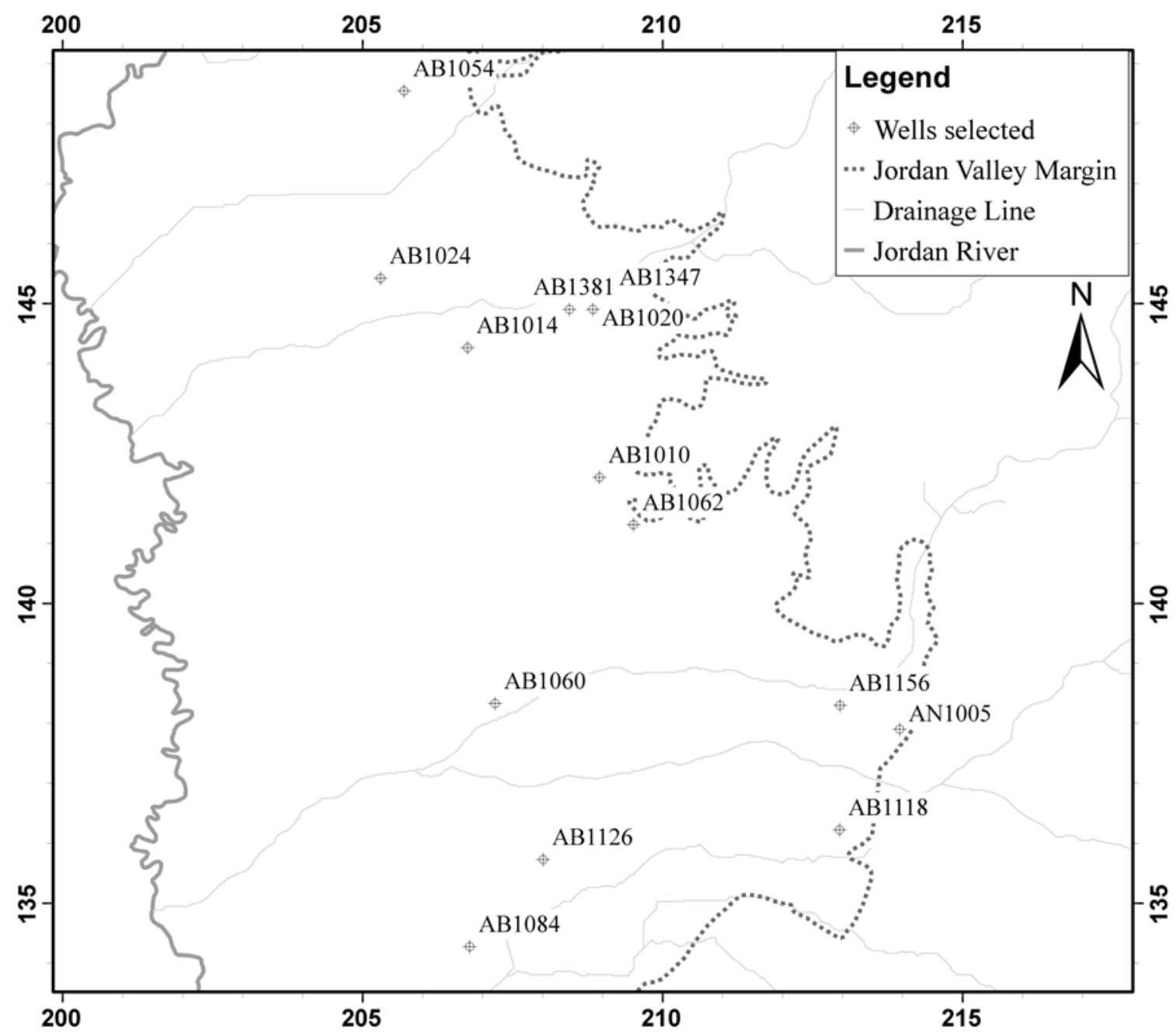

Fig. 5.2-11: Well selected for the temporal evolution of groundwater quality in the study area (locations taken from MWI open files).

\subsubsection{Pre-Development phase of the Jordan Valley}

As stated in chapter 6.1 large quantities of groundwater were already abstracted in the late fifties and at the beginning of the sixties. In the equipotential plots (Fig. 5.2-1 through Fig. 5.2-3) first signs of overpumping can be seen and the natural flow regime was already influenced. Therefore information about earlier periods are desirable. Only a few records about data from wells exist, too few to draw distribution maps. However, they deliver valuable information about the natural flow system before the intensive drilling period (Fig. 5.2-12).

Fig. 5.2-12 shows the location of these wells and the electrical conductivity values of the groundwater after the completion of these wells in 1938 along with major drainage lines. Unfortunately, only limited chemical information about the wells drilled during that time, such as chloride content, total dissolved solids (TDS), and hardness is available. No electrical conductivity values are reported, but, for better comparison with samples from other periods, they were calculated using the following formula (Hölting 2005):

$\mathrm{EC}[\mu \mathrm{S} / \mathrm{cm}]=\mathrm{TDS} / 0.64[\mathrm{mg} / \mathrm{L}]$

Freshwater can be found either near the outlets of major wadis or along the groundwater flow course from east towards west. In the sedimentologically low depositional energy areas (sedimentological "deposition shadow") Wadi Shueib in the north and Wadi Kafrein/ Hisban to the south no or little 
alluvial material were deposited and sediments consists mostly of lacustrine sediments (chapter 4.2) as indicated by drilling logs of these IONIDES wells (Appendix). These sediments, mainly the Lisan Formation, contain large amounts of soluble salts (Tab. 5.2-7) and show high electrical conductivities as apparent in the wells drilled in these areas $(3,600,3,300$, and 4,130 $\mu \mathrm{S} / \mathrm{cm})$. Due to the small grain size of the deposited material in that area (mainly clay to silt fraction), low permeabilities are expected and were reported by Ionides (chapter 4.3). The relatively high EC value of 2,460 $\mu \mathrm{S} / \mathrm{cm}$ close to the village of Kafrein might also be attributed to the presence of salt from the Lisan Formation or due to cross formation flow from saline formations below, whereas further to the west the lower value of $1,280 \mu \mathrm{S} / \mathrm{cm}$ can be attributed to the freshwater flowing west within the alluvial fan sediments near Rama.

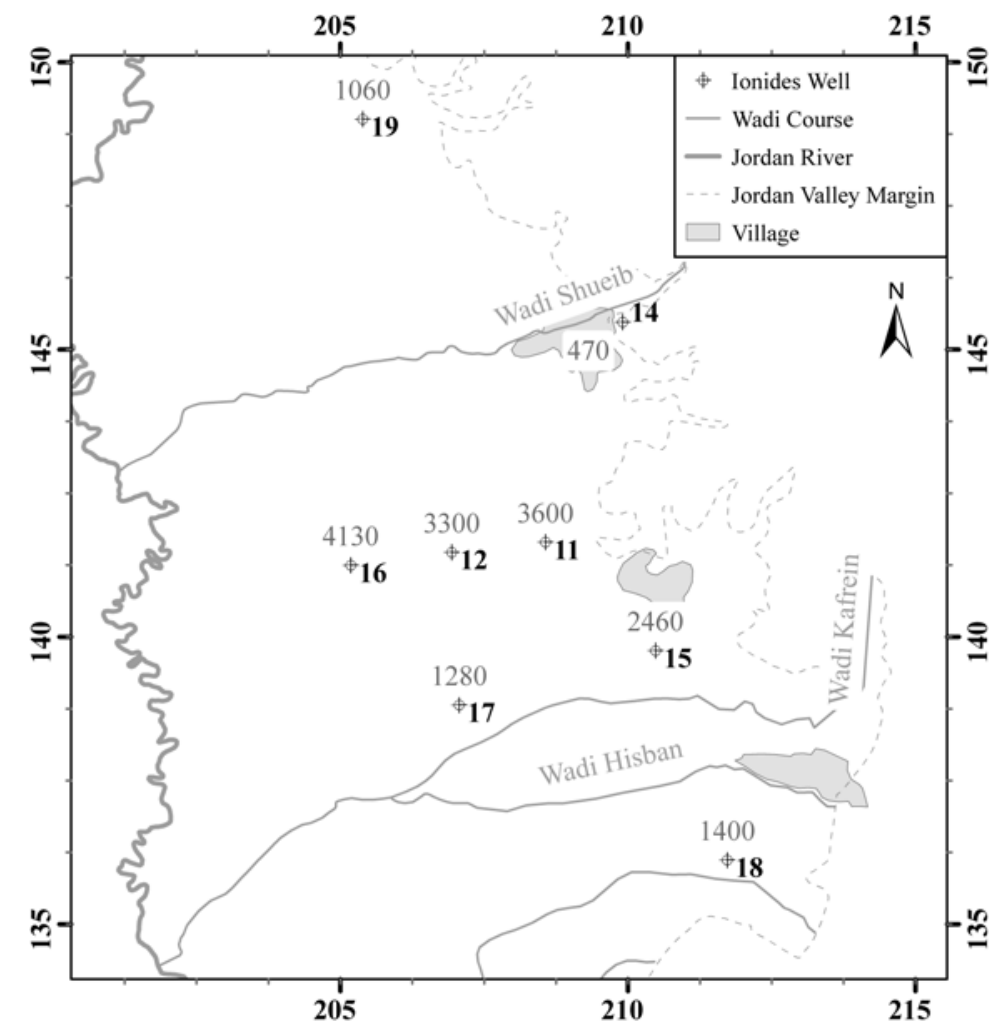

Fig. 5.2-12: Location and electrical conductivity values of some wells drilled in 1938. Electrical conductivity was calculated on the basis of TDS values (data is taken from Ionides 1939).

The over pumping of the water resources within the study area increased in the following years and reached its first peak in 1967. Large cones of depression already formed in the area of Rama and South Shuneh.

As stated in chapter 3, the major farming activities in the lower Jordan Valley increased during the late 50ies. 213 new wells were drilled in the district of Karameh, South Shuneh, and Sweimeh between 1957 and 1961. As a consequence, first drilling restrictions were issued in 1961. The influence of heavy groundwater abstraction on groundwater quality and the flow regime could already be seen in the first comprehensive groundwater evaluation undertaken between 1961 and 1963 (Fig. 5.2-1 through Fig. 5.2-7). The water salinity increased in all wells. Heavy groundwater extraction had the strongest influence on salinity downstream along the major flow paths. Here, the salinity increased from 1,280 to $1,900 \mu \mathrm{S} / \mathrm{cm}$. Close to the apex of the major alluvial fans, the groundwater quality deteriorated to a lesser degree, since freshwater inflow from the adjacent mountain aquifers takes place. The wells located between the major flow paths show almost no increase in salinity. Here only 
minor or no pumping activities take place since groundwater is already brackish and the hydraulic conductivity in these wells is low.

The events of 1967 had also a strong influence on the water quality. The water levels in the area recovered and along with it groundwater quality (Tab. 5.2-10).

Tab. 5.2-10: Groundwater samples before and after the events of $1967 / 68$. No samples before 1971 were available (MWI open files).

\begin{tabular}{|c|c|c|c|c|c|c|c|c|c|c|}
\hline Well ID & Date & $\mathbf{E . C}$ & $\mathbf{p H}$ & $\mathbf{C a}^{2+}$ & $\mathbf{M g}^{2+}$ & $\mathbf{N a}^{+}$ & $\mathbf{K}^{+}$ & $\mathbf{C l}^{-}$ & $\mathbf{H C O}_{3}{ }^{-}$ & $\mathbf{S O}_{4}{ }^{2-}$ \\
\hline & & [ $\mu \mathrm{S} / \mathbf{c m}]$ & & $\mathbf{m e q} / \mathbf{L}$ & $\mathbf{m e q} / \mathbf{L}$ & $\mathbf{m e q} / \mathbf{L}$ & $\mathbf{m e q} / \mathbf{L}$ & $\mathbf{m e q} / \mathbf{L}$ & $\mathbf{m e q} / \mathbf{L}$ & $\mathbf{m e q} / \mathbf{L}$ \\
\hline AB1014 & 25.10 .1967 & 2,300 & 7.31 & 5.58 & 7.07 & 9.39 & 0.66 & 14.15 & 5.80 & 1.58 \\
\hline AB1014 & 18.05 .1971 & 560 & 7.41 & 2.79 & 2.63 & 0.69 & 0.02 & 0.81 & 5.70 & 0.06 \\
\hline AB1020 & 26.10 .1967 & 3,650 & 7.01 & 8.73 & 10.95 & 16.08 & 1.12 & 27.99 & 5.39 & 2.79 \\
\hline AB1020 & 14.10 .1971 & 3,200 & 7.81 & 8.53 & 9.88 & 19.40 & 0.58 & 23.24 & 5.98 & 2.10 \\
\hline AB1058 & 22.10 .1967 & 2,100 & 7.21 & 6.83 & 5.84 & 7.38 & 0.51 & 12.71 & 4.81 & 2.95 \\
\hline AB1058 & 16.04 .1972 & 1,170 & 7.41 & 3.34 & 5.02 & 3.01 & 0.16 & 4.74 & 4.96 & 1.95 \\
\hline
\end{tabular}

\subsubsection{Water quality during the 70ies}

Fig. 5.2-13 and Fig. 5.2-14 show the development of water salinity during the 1970ies. Fig. 5.2-13 show wells with salinities of less than $2,300 \mu \mathrm{S} / \mathrm{cm}$. All these wells are located either at the apex of Wadi Kafrein and Hisban or downgradient of it, indicating either less pumping activities or higher recharge rates to the aquifer. But especially these areas are used for the water demanding banana fields (chapter 6.2) which makes the first assumption more likely. No groundwater quality deterioration within this period is noticeable in these wells. But the number of available samples is to poor to make further observations.

A different picture can be seen in Fig. 5.2-14. Here all wells with electric conductivities up to 4,500 $\mu \mathrm{S} / \mathrm{cm}$ are plotted. For these wells more analyses were available, which allows a closer look at water quality fluctuations. The wells located between the major flow paths AB1010 and AB1062 show very little variation with time and remain at almost constant values of 3,800 and 3,600 $\mu \mathrm{S} / \mathrm{cm}$ respectively. Well AB1060 shows the same behavior. The wells located in the area of South Shuneh show a different pattern. Here, high salinity fluctuations are noticeable. A large number of water samples were available for AB1020 allowing a more detailed analysis for seasonal variations. A strong dependence of water quality on rainfall and consequently recharge to the unconsolidated aquifer is apparent. During the poor rainy season of 1972/73 the salinity in the well increased considerably. The rain intensive season of 1973/4 lead to a strong decrease in groundwater salinity. The following rainy seasons had only low amounts of rainfall. Consequently an increase in electrical conductivity during the following years is visible. Although only a few samples were available, a similar trend can be assumed for well AB1024. Well AB1014 showed a strong increase in electrical conductivity. This might be attributed to increased farming activities after the events of 1967 and its aftermath. Most of the farming activities seized during 1967 and 1971. Highest conductivities were measured at the end of this period of observation, which coincide with measurements in other wells.

The course of increased groundwater salinity can be seen in Fig. 5.2-15. Here an aerial increase in groundwater salinity is visible. Electrical conductivity values of wells are plotted against the background of the Iso-Electrical- Conductivity contours of 1961 for different time steps (Autumn 1971, Autumn 1972, Spring 1977, Autumn 1995, and Spring 1996). For better visibility wells with increased salinity are marked by a yellow rectangle. Apart from wells located close to the apex of the major fans almost all wells show increasing salinity during the observed period. 


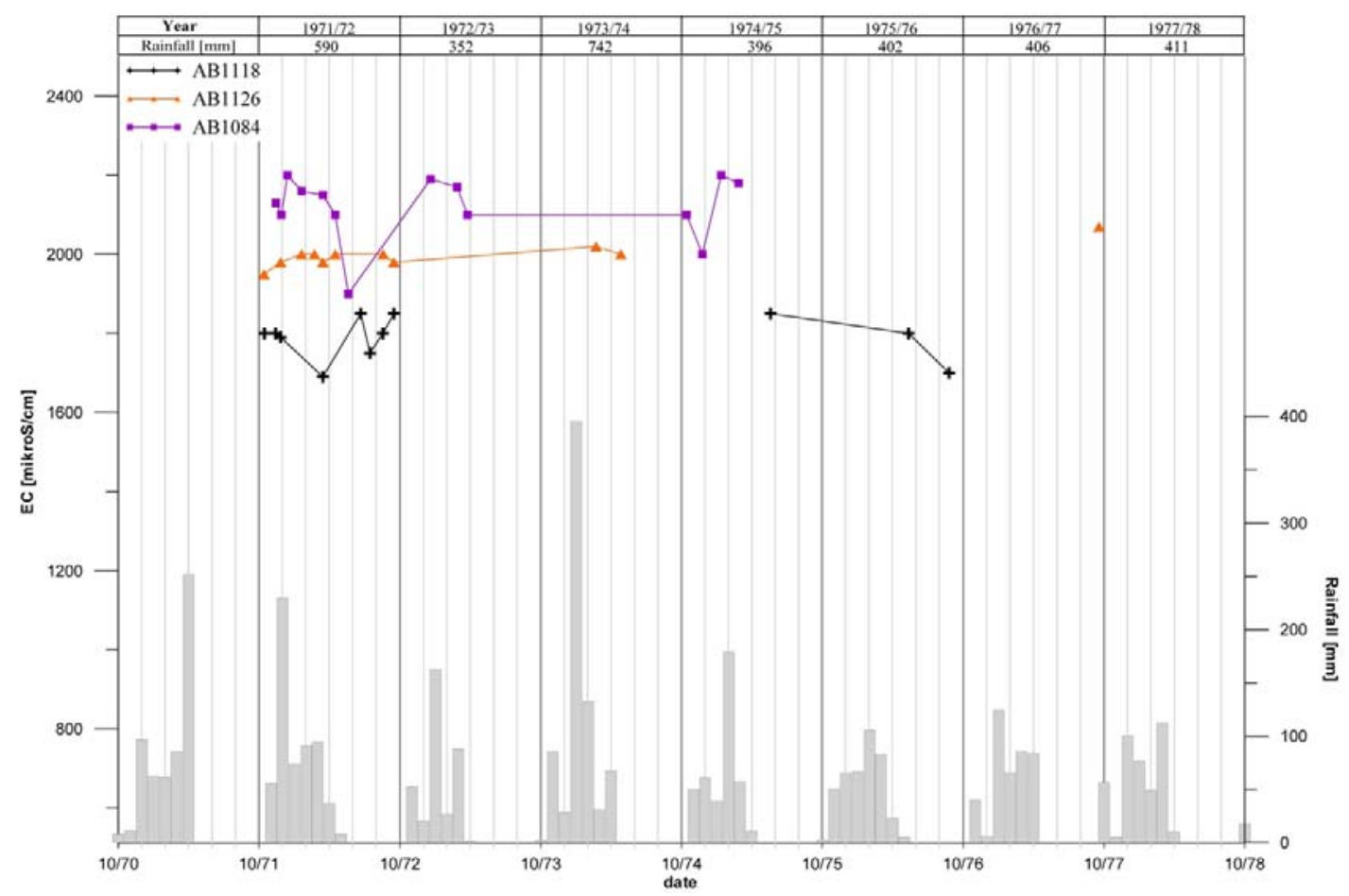

Fig. 5.2-13: Electric Conductivity measurements (in a range from 500 to $2400 \mu \mathrm{s} / \mathrm{cm}$ ) of water samples taken in the early to late 70ies of some selected wells in the study area versus monthly and yearly rainfall values at Naur station (MWI open files).

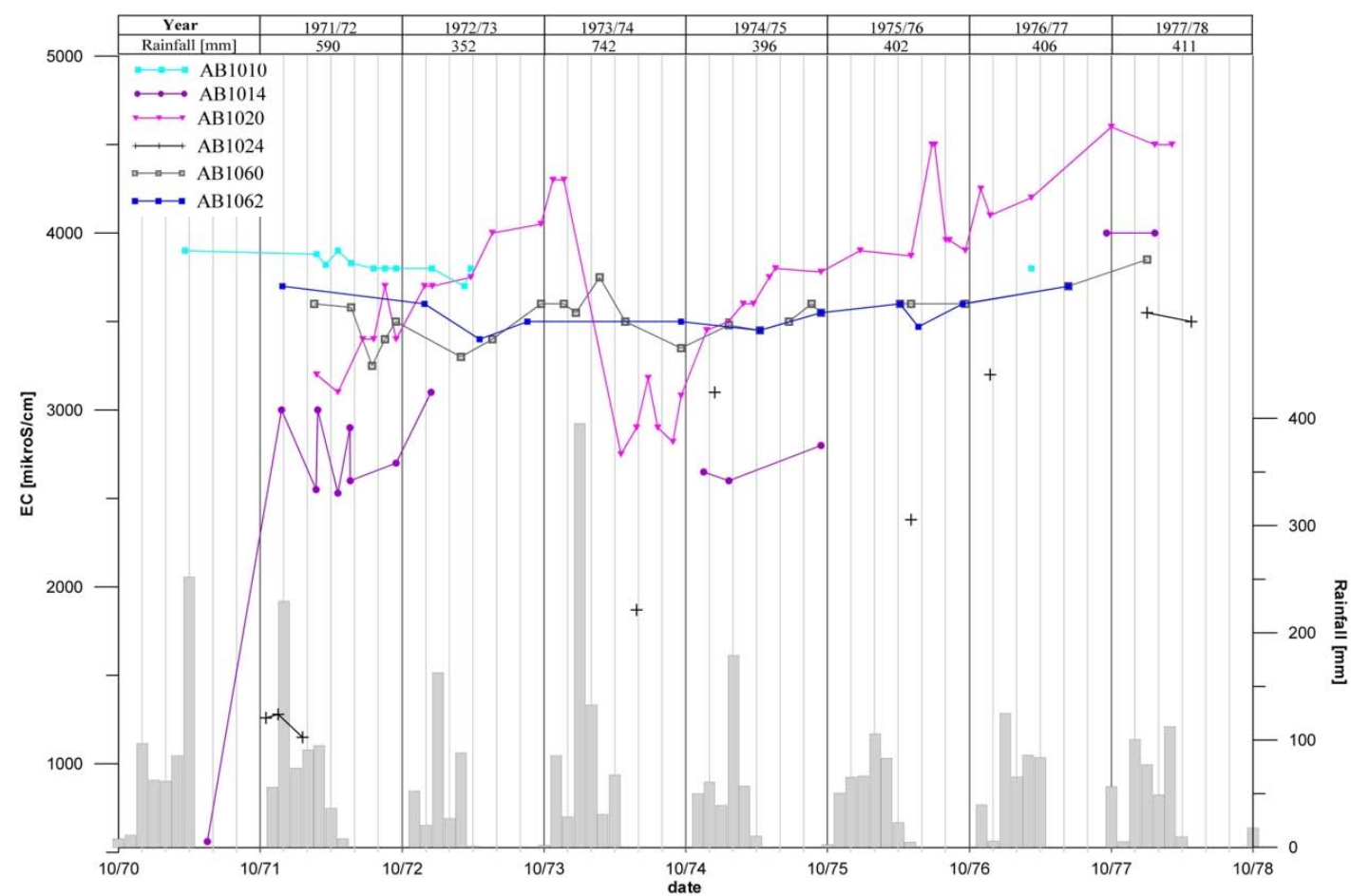

Fig. 5.2-14: Electric Conductivity measurements (in a range from 500 to $5,000 \mu \mathrm{s} / \mathrm{cm}$ ) of well water samples taken in the early to late 70ies of some selected wells in the study area versus monthly and yearly rainfall values at Naur station (MWI open files). 

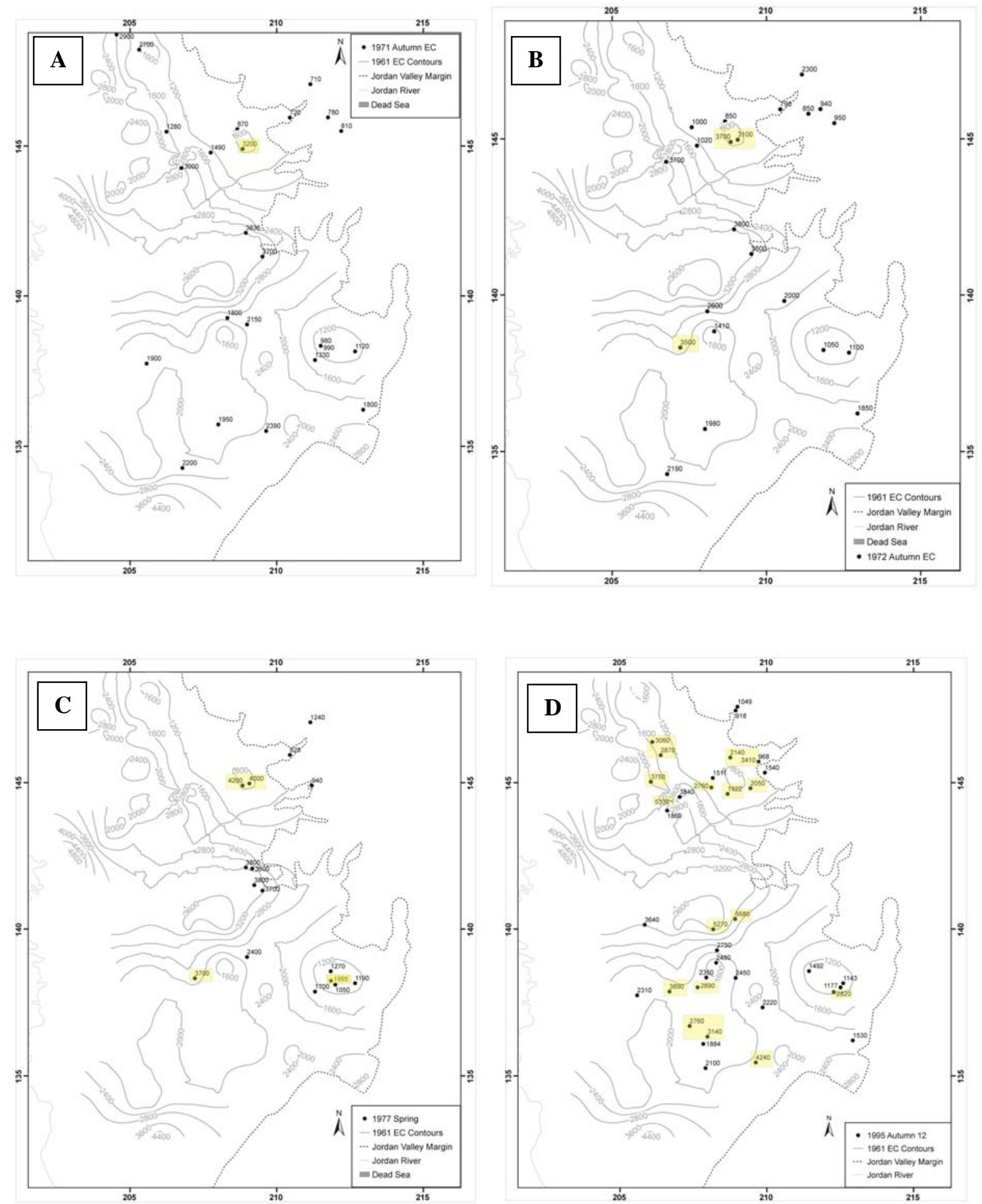


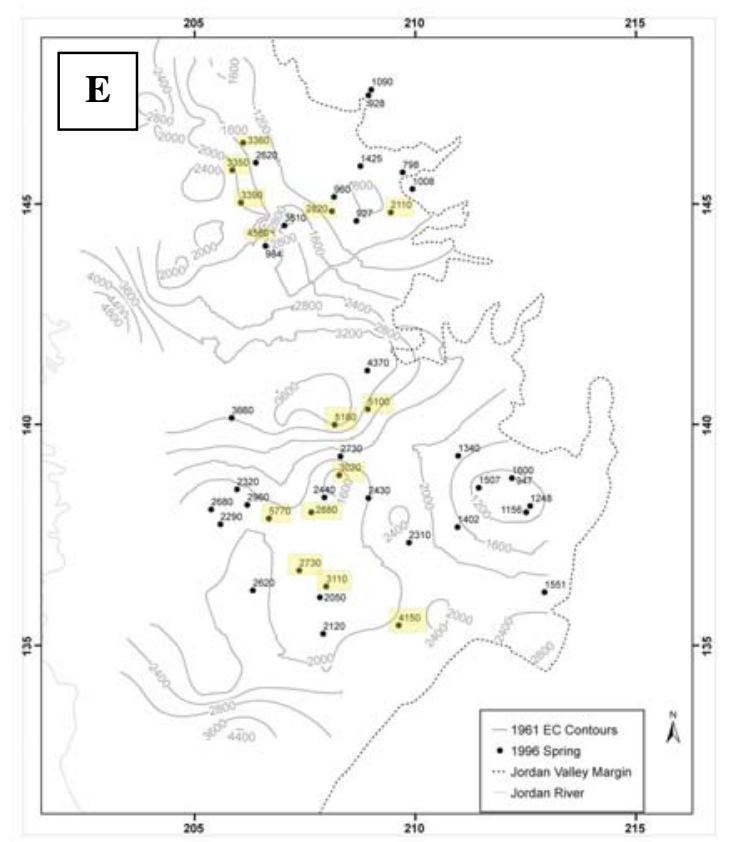

Fig. 5.2-15: Increasing salinities of wells in the study area. In all five figures (A through $\mathrm{E}$ ) the iso-electrical conductivity contour lines from 1961 (Fig. 5.2-1) are placed for orientation. Yellow squares mark groundwater of wells with increased electrical conductivity at different time steps. A: Autumn 1971 (MWI open files); B: Autumn 1972 (MWI open files); C: Spring 1977 (MWI open files); D: Autumn 1995 (Kuisi 1998); E: Spring 1996 (Kuisi 1998).

\subsubsection{Water quality during the 90ies}

Fig. 5.2-16 shows the development of groundwater EC for some selected wells during the period of 1991 to 2002. Well locations can be found in Fig. 5.2-11. The EC values show a strong seasonal variation. Highest EC values are measured at the end/ beginning of the rainy season. Lowest values are found between March to May, indicating a recharge system that reacts quickly to precipitation events in the mountain area. Wells located in the area of Rama (AN1005 and AB1156) show high variations indicating that caution should be taken in the interpretation of interpolated results of scheduled sampling campaigns.

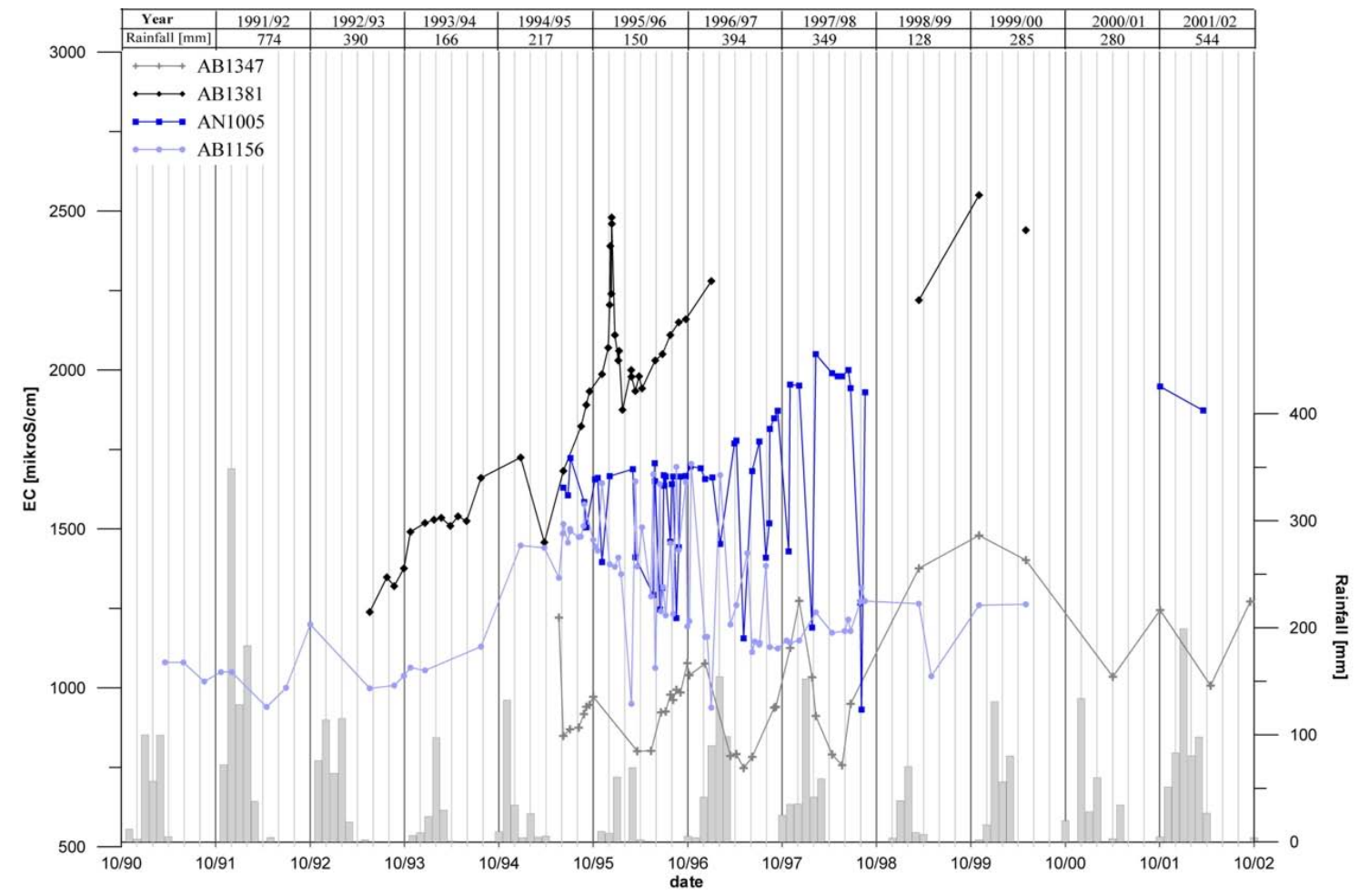

Fig. 5.2-16: Electric Conductivity measurements (in a range from 500 to $3,000 \mu \mathrm{s} / \mathrm{cm}$ ) of well water samples taken in the early 90 ies to the end of 2002 of some selected wells in the study area versus monthly and yearly rainfall values at Naur station (MWI open files). 


\subsubsection{Salinization sources}

In this sub chapter all available major ion analysis of the selected wells are used in order to derive possible salinization sources. An attempt to classify wells and their possible salinization sources in different groups is made with the help of ionic ratios. Ionic ratios have been used by many authors in order to classify different water types in the region (e.g. Rosenthal 1988, Rosenthal 1997, Salameh 2001).

\subsubsection{Wadi Kafrein/ Hisban alluvial fan flow path}

\section{$\underline{\mathrm{AB} 1156(13 \text { samples })}$}

A span from $999 \mu \mathrm{S} / \mathrm{cm}(19.05 .1993)$ to $1,578 \mu \mathrm{S} / \mathrm{cm}$ (27.08.1995) shows the 13 samples of well AB1156. The samples were collected in the period from 19.05.1993 to 27.08.1995. The $999 \mu \mathrm{S} / \mathrm{cm}$ sample can be classified as a $\mathrm{HCO}_{3}^{-}>\mathrm{Ca}^{2+}>\mathrm{Cl}^{-}>\mathrm{Mg}^{2+}$ type. The highest mineralized sample can be classified as a $\mathrm{Cl}^{-}>\mathrm{Na}^{+}>\mathrm{Ca}^{2+}>\mathrm{HCO}_{3}{ }^{-}>\mathrm{SO}_{4}{ }^{2-}>\mathrm{Mg}^{2+}$ type. The large drop in the $\mathrm{Ca} / \mathrm{Cl}$ and $\mathrm{Mg} / \mathrm{Cl}$ ratios and the large increase in the $\mathrm{Na} / \mathrm{Ca}$ ratio along with a slight increase in the $\mathrm{Na} / \mathrm{Cl}$ ratio indicate above all dissolution of $\mathrm{NaCl}$. This assumption is undermined by an almost constant $\mathrm{Cl}$ excess $(\mathrm{Cl}+\mathrm{NO} 3-\mathrm{Na}-\mathrm{K})$. It is noticeable that the highest calculated $\mathrm{Cl}$ excess was not the highest mineralized sample. The increased $\mathrm{SO}_{4}{ }^{2-}$ content is compensated mostly by $\mathrm{Ca}^{2+}$ since the $\mathrm{Mg}^{2+}$ concentration increases only slightly from the lowest to highest mineralized sample. Dissolution of $\mathrm{NaCl}$ is the major source of increased salinity in this well.

\section{AN1005 (28 samples)}

The samples of well AN1005 were collected between the 27.08.1995 and the 18.03.2002. The electrical conductivity of the 28 samples vary between $1,156(05.05 .1997)$ to $2,050 \mu \mathrm{S} / \mathrm{cm}$ (08.02.1998), where the $1,156 \mu \mathrm{S} / \mathrm{cm}$ sample can be classified as $\mathrm{Ca}^{2+}>\mathrm{HCO}_{3}{ }^{-}>\mathrm{Cl}^{-}>\mathrm{Na}^{+}>\mathrm{Mg}^{2+}$ and the 2,050 $\mu \mathrm{S} / \mathrm{cm}$ sample as $\mathrm{Cl}^{-}>\mathrm{Na}^{+}>\mathrm{Ca}^{2+}>\mathrm{HCO}_{3}{ }^{-}$. Like in well $\mathrm{AB} 1156$ the $\mathrm{Ca} / \mathrm{Cl}$ and $\mathrm{Mg} / \mathrm{Cl}$ ratio decreases significantly and the $\mathrm{Na} / \mathrm{Cl}$ increases even up to 0.98 . The calculated $\mathrm{Cl}$ excess does not increase with increasing salinity, in some samples the absolute $\mathrm{Cl}$-excess even decreases. Together with the large increase in the $\mathrm{Na} / \mathrm{Ca}$ ratio it can be concluded that mainly dissolution of $\mathrm{NaCl}$ is responsible for the increased salinity in these samples. The increased $\mathrm{SO}_{4}{ }^{2-}$ content derives mostly from the dissolution of $\mathrm{CaSO}_{4}$ and $\mathrm{MgSO}_{4}$, since the $\mathrm{rQ}$ stays in all sample around 0.6 to 0.7 and the $\mathrm{Ca} / \mathrm{SO}_{4}$ ratio decreases slightly.

\section{AB1060 (18 samples)}

The 18 samples, taken in the period between 01.03 .1973 and 22.01.1978, vary little in terms of electrical conductivity. The electrical conductivity varies between 3,300 (01.03.1973) and 3,850 $\mu \mathrm{S} / \mathrm{cm}$ (22.01.1978). The sample with the least mineral content can be classified as $\mathrm{Cl}^{-}>\mathrm{Na}^{+}>\mathrm{Mg}^{2+}>$ $\mathrm{Ca}^{2+}$ and the sample with the highest as $\mathrm{Cl}^{-}>\mathrm{Na}^{+}>\mathrm{Mg}^{2+}>\mathrm{SO}_{4}{ }^{2-}>\mathrm{Ca}^{2+}$ water.

With increasing salinity the $\mathrm{Ca} / \mathrm{Cl}$ and $\mathrm{Mg} / \mathrm{Cl}$ ratio decreases whereas the $\mathrm{Na} / \mathrm{Cl}$ ratio increases slightly and the $\mathrm{Na} / \mathrm{Ca}$ increases significantly. This indicates dissolution of $\mathrm{NaCl}$, which is undermined by a decreasing $\mathrm{Cl}$ and $\mathrm{Ca}-\mathrm{Mg}$ excess $\left(\mathrm{Ca}+\mathrm{Mg}-\mathrm{SO}_{4}-\mathrm{HCO}_{3}\right)$. The sulphate content shows the greatest variation in these samples. Compared to samples with high salinity and low sulphate content the high sulphate contents go along with a lower $\mathrm{Mg} / \mathrm{Ca}$ ratio and a higher $\mathrm{Ca} / \mathrm{Cl}$ ratio which is close to the $\mathrm{Mg} / \mathrm{Cl}$ ratio. An increase in sulphate can therefore be attributed to the dissolution of $\mathrm{CaSO}_{4}$ and an increased salinity with high chloride content that contains, apart from the dissolution of $\mathrm{NaCl}$, also the dissolution of $\mathrm{MgCl}_{2}$. It can be concluded that different salinization processes are responsible for the increased salinity in these samples. The most important factor for an increase in salinity is the dissolution of $\mathrm{NaCl}$. The second important factor is either the dissolution of $\mathrm{CaSO}_{4}$ in waters of high sulphate content or, as in the case of the highest mineralized samples, the dissolution of $\mathrm{MgCl}_{2}$. 


\section{AB1118 (13 samples)}

The 13 samples of well AB1118 were collected and analyzed between the end of 1967 and the summer of 1976. The electrical conductivity varied between $1,600(06.11 .1967)$ and $1,850 \mu \mathrm{S} / \mathrm{cm}$ (15.09.1972). Major Ions like Calcium, Magnesium, and Bicarbonate show little variations. The Sodium, Chloride, and Sulphate content shows the highest variations. $\mathrm{Cl}$ and $\mathrm{Mg}-\mathrm{Ca}$ excess varies between -0.5 and 0.75 . This together with a $\mathrm{Na} / \mathrm{Cl}$ ratio of around 0.9 to 1.0 show, that dissolution of $\mathrm{NaCl}$ is the major if not only source for the Chloride content of the samples. The rQ ratio which varies between 0.51 to 0.58 and a $\mathrm{Ca} / \mathrm{SO}_{4}$ ratio that varies mostly between 1.21 to 1.47 indicates that $\mathrm{SO}_{4}$ results from the dissolution of $\mathrm{CaSO}_{4}$.

\section{AB1126 (16 samples)}

With regard to the electrical conductivity as well as the major ion content the available chemical samples of well AB1126 show little variations. The electrical conductivity of the water samples vary between $1,980(26.11 .1971)$ to $2,070 \mu \mathrm{S} / \mathrm{cm}$ (18.09.1977). The samples were collected between 14.10.1971 and 18.09.1977. The water can be classified as $\mathrm{Cl}^{-}>\mathrm{Na}^{+}>\mathrm{HCO}_{3}^{-}>\mathrm{Mg}^{2+}>\mathrm{Ca}^{2+}$, whereby $\mathrm{NaCl}$ is the most prominent species. The $\mathrm{Cl}$ excess varies between 2.12 and 3.06, which is compensated by the $\mathrm{Ca}-\mathrm{Mg}$ excess.

\section{$\underline{\mathrm{AB} 1084 \text { (14 samples) }}$}

The samples of well AB1084 show small variations. The electrical conductivity varies between 1,900 (20.05.1972) to $2,200 \mu \mathrm{S} / \mathrm{cm}(14.12 .1971)$. The samples were taken between autumn 1971 and February 1975. The water can be classified as $\mathrm{Cl}^{-}>\mathrm{Na}^{+}>\mathrm{HCO}_{3}^{-}>\mathrm{Mg}^{2+}>\mathrm{Ca}^{2+}$. The high $\mathrm{Na} / \mathrm{Cl}$ ratio of 0.71 to 0.83 indicates that mostly the dissolution of $\mathrm{NaCl}$ is responsible for the mineralization of the samples. This can also be seen in the low $\mathrm{Cl}-$ and $\mathrm{Ca}-\mathrm{Mg}$ excess, that varies between 0.34 to 3.0 $\mathrm{meq} / \mathrm{L}$.

\subsubsection{Wells "Between the Major Flow Paths"}

\section{AB1010 (14 samples)}

The 14 samples of well AB1010 were taken between March 1971 and March 1982. The chemical composition of water samples from well AB1010 fluctuates very little, the least measured EC was $3,700 \mu \mathrm{S} / \mathrm{cm}(10.03 .1973)$ and the highest $3,900 \mu \mathrm{S} / \mathrm{cm}$ (18.04.1972). The water samples can be classified as $\mathrm{Cl}^{-}>\mathrm{Na}^{+}>>\mathrm{Mg}^{2+}>\mathrm{Ca}^{2+}$. The high Na/Cl ratio of 0.67 to 0.78 indicates, that dissolution of $\mathrm{NaCl}$ is the major source for salinization in this well. Minor sources are the dissolution of $\mathrm{MgCl}_{2}$ $\left(\mathrm{Mg} / \mathrm{Ca}\right.$ ratio is between 1.07 and 1.22) and to a lower degree $\mathrm{CaCl}_{2}$. The $\mathrm{Cl}$ - and $\mathrm{Mg}-\mathrm{Ca}$ excess show also, that the dissolution of $\mathrm{MgCl}_{2}$ and $\mathrm{CaCl}_{2}$ is around $50 \%$ of that of the $\mathrm{NaCl}$.

\section{AB1062 (14 samples)}

The 14 groundwater samples were taken between the end of 1971 and June 1977. the chemical composition of samples taken from well AB1062 varies, like of well AB1010, very little (Tab. 5.2-11). The lowest measured EC was 3,450 $\mu \mathrm{S} / \mathrm{cm}(18.04 .1973)$ and the highest 3,700 $\mu \mathrm{S} / \mathrm{cm}$ (27.11.1971). The water can be classified as $\mathrm{Cl}^{-}>\mathrm{Na}^{+}>>\mathrm{Mg}^{2+}>\mathrm{Ca}^{2+}$. The ionic ratios of the analyzed samples are within the same range as the water samples of well AB1010. Therefore, the same conclusions as derived above are valid.

\subsubsection{Wadi Shueib alluvial fan flow path}

\section{AB1014 (18 samples)}

The major ion concentrations in AB1014 varied considerably with time (Tab. 5.2-11). The lowest measured EC was $560 \mu \mathrm{S} / \mathrm{cm}(18.05 .1971)$ and the highest 4,000 $\mu \mathrm{S} / \mathrm{cm}(19.09 .1977)$. The lowest EC sample analyzed has the composition of typical limestone/dolomite water: $\mathrm{HCO}_{3}{ }^{-}>\mathrm{Ca}^{2+}>\mathrm{Mg}^{2+}$. Ionic 
ratios like $\mathrm{rMg} / \mathrm{Ca}, \mathrm{rCa} / \mathrm{Cl}, \mathrm{rMg} / \mathrm{Cl}, \mathrm{rNa} / \mathrm{Ca}, \mathrm{rHCO}_{3} / \mathrm{Cl}, \mathrm{rQ}$, and $\mathrm{r}(\mathrm{Ca}+\mathrm{Mg}) /(\mathrm{Na}+\mathrm{K})$ are with $0.94,3.44$, $3.24,0.25,7.03,0.48$, and 7.60 respectively typical for pure limestone derived groundwater. The sample with the highest mineralization shows a complete different picture. This sample can be characterized as a $\mathrm{Cl}^{-}>\mathrm{Na}^{+}>\mathrm{Mg}^{2+}>\mathrm{Ca}^{2+}$ type. A contribution of either salty groundwater or dissolution of precipitated salts must be assumed. As a result the ionic ratios $\mathrm{rMg} / \mathrm{Ca}, \mathrm{rCa} / \mathrm{Cl}, \mathrm{rMg} / \mathrm{Cl}$, $\mathrm{rNa} / \mathrm{Ca}, \mathrm{rQ}$, and $\mathrm{r}(\mathrm{Ca}+\mathrm{Mg}) /(\mathrm{Na}+\mathrm{K})$ changed to $1.23,0.31,0.38,1.97,0.19,1.04$, and 1.09 respectively. These ionic ratios are similar to those derived from the leached samples of the Lisan Formation and the saline water samples from the A1/2 aquifer. Dissolution of $\mathrm{NaCl}$ is the major source for increased salinity, followed by the dissolution of $\mathrm{MgCl}_{2}$ and $\mathrm{CaCl}_{2}$. This is indicated by the strong decrease in the $\mathrm{r}(\mathrm{Ca}+\mathrm{Mg}) /(\mathrm{Na}+\mathrm{K})$. The decrease in the $\mathrm{Na} / \mathrm{Cl}$ ratio along with the high $\mathrm{Cl}$ - and $\mathrm{Ca}-\mathrm{Mg}$ excess and the strong decreases of the $\mathrm{rSO}_{4} / \mathrm{Cl}$ show a large contribution of $\mathrm{MgCl}_{2}$ and $\mathrm{CaCl}_{2}$ in the high mineralized samples. Since the $\mathrm{Mg} / \mathrm{Ca}$ ratio increased from 0.94 to 1.23 the dissolution of $\mathrm{MgCl}_{2}$ is higher than the dissolution of $\mathrm{CaCl}_{2}$,

\section{AB1020 (40 samples)}

The electric conductivity in the well water samples of well AB1020 varies between 2,800 (22.04.1974) and 4,600 $\mu \mathrm{S} / \mathrm{cm}(01.10 .1977)$. The 40 available samples were collected between 23.02.1972 and 21.01.1978. The least groundwater samples in terms of salinity can be classified as: $\mathrm{Cl}^{-}>\mathrm{Na}^{+}>\mathrm{Mg}^{2+}>\mathrm{Ca}^{2+}$. The ionic ratios like $\mathrm{Mg} / \mathrm{Ca}, \mathrm{Na} / \mathrm{Cl}, \mathrm{Ca} / \mathrm{Cl}, \mathrm{Mg} / \mathrm{Cl}, \mathrm{Na} / \mathrm{Ca}, \mathrm{HCO}_{3} / \mathrm{Cl}, \mathrm{Q}$, and $(\mathrm{Ca}+\mathrm{Mg}) /(\mathrm{Na}+\mathrm{K})$ are $1.26,0.88,0.57,0.721 .53,0.47,0.93$, and 1.42. The groundwater samples of well AB1020 have a higher mineral content compared to the samples of well AB1014 and AB1024, although these wells are located further to the west than AB1020. Following the increase of dissolved salts along the flow course towards the west the samples of well AB1020 should have a lower mineral content. The samples with the highest mineralization can be classified as well as a $\mathrm{Cl}^{-}>\mathrm{Na}^{+}>\mathrm{Mg}^{2+}>$ $\mathrm{Ca}^{2+}$ type. However their mineral content is far higher. The $\mathrm{Ca} / \mathrm{Cl}$ and $\mathrm{Mg} / \mathrm{Cl}$ ratios decrease significantly, whereby the $\mathrm{Na} / \mathrm{Ca}$ ratio increases. Since the $(\mathrm{Ca}+\mathrm{Mg} /(\mathrm{Na}+\mathrm{K})$ ratio decreases from 1.42 down to 1.03 and the $\mathrm{Na} / \mathrm{Cl}$ ratio decreases only slightly it can be assumed, that mostly the dissolution of $\mathrm{NaCl}$ and to a smaller degree the dissolution of $\mathrm{MgCl}_{2}$ and $\mathrm{CaCl}_{2}$ (slight decrease in $\mathrm{rQ}$ ) are responsible for the increased salt content of the groundwater samples. A slight increase in the $\mathrm{Mg} / \mathrm{Ca}$ ratio indicates, that the dissolution of $\mathrm{MgCl}_{2}$ is higher than the dissolution of $\mathrm{CaCl}_{2}$.

\section{AB1024 (10 samples)}

Like the water samples of AB1014, the major ion composition of AB1024 fluctuates strongly during the sampled period (16.10.1971 to 04.05.1986). Where $1,050 \mu \mathrm{S} / \mathrm{cm}(04.05 .1986)$ was the lowest and $3,550 \mu \mathrm{S} / \mathrm{cm}(25.04 .1978)$ the highest measured electric conductivities. The least mineralized water is of $\mathrm{HCO}_{3}{ }^{-}>\mathrm{Cl}^{-}>\mathrm{Ca}^{2+}>\mathrm{Na}^{+}>\mathrm{Mg}^{2+}$ type. The ionic ratios of $\mathrm{Mg} / \mathrm{Ca}, \mathrm{Ca} / \mathrm{Cl}, \mathrm{Mg} / \mathrm{Cl}, \mathrm{Na} / \mathrm{Ca}, \mathrm{HCO}_{3} / \mathrm{Cl}$, $\mathrm{Q}$, and $(\mathrm{Ca}+\mathrm{Mg}) /(\mathrm{Na}+\mathrm{K})$ are with $0.90,0.84,0.75,0.95,1.03,0.62$, and 1.91 in a range of limestone/dolomite waters that are slightly enriched on halite. The highest mineralized sample is of $\mathrm{Cl}^{-}$ $>>\mathrm{Na}^{+}>\mathrm{Mg}^{2+}>\mathrm{Ca}^{2+}$ type. Like $\mathrm{AB} 1014$, either a contribution of salt enriched groundwater or the dissolution of precipitated salts within the surroundings sediments must be assumed. The ionic ratios $\mathrm{Mg} / \mathrm{Ca}, \mathrm{Ca} / \mathrm{Cl}, \mathrm{Mg} / \mathrm{Cl}, \mathrm{Na} / \mathrm{Ca}, \mathrm{HCO}_{3} / \mathrm{Cl}, \mathrm{Q}$, and $(\mathrm{Ca}+\mathrm{Mg}) /(\mathrm{Na}+\mathrm{K})$ changed to $1.12,0.34,0.38,1.70$, $0.22,1.07$, and 1.18. Tab. 5.2-14 shows that the $\mathrm{rNa} / \mathrm{Cl}, \mathrm{rCa} / \mathrm{Cl}, \mathrm{Mg} / \mathrm{Cl}, \mathrm{rHCO}_{3} / \mathrm{Cl}$ decreased significantly and $\mathrm{rSO}_{4} / \mathrm{Cl}$ slightly while the $\mathrm{rNa} / \mathrm{Ca}, \mathrm{rQ}$, and $\mathrm{rMg} / \mathrm{Ca}$ increased. The decrease in $\mathrm{Na} / \mathrm{Cl}$ ratio indicates that simple dissolution of halite cannot be responsible for the increased salinity. An increase in the $\mathrm{Mg} / \mathrm{Ca}$ ratio, together with an increased $\mathrm{rQ}$ indicates, that the dissolution of $\mathrm{MgCl}_{2}$ is higher than the dissolution of $\mathrm{CaCl}_{2}$. The high Cl- excess of $10.22 \mathrm{meq} / \mathrm{L}$ is compensated by Ca-Mg excess of 10.32. However, the dissolution of halite must be higher than the dissolution of $\mathrm{MgCl}_{2}$ and $\mathrm{CaCl}_{2}$, since the $\mathrm{Mg} / \mathrm{Cl}_{2}$ and $\mathrm{Ca} / \mathrm{Cl}_{2}$ ratios decrease significantly.

\section{AB1347 (8 samples)}

The eight available samples, collected between 12.05.1996 and 07.12.1996, show variations in electric conductivity between $802(12.05 .96)$ and $1,077 \mu \mathrm{S} / \mathrm{cm}(07.12 .96)$. The least mineralized sample can 
be classified as $\mathrm{HCO}_{3}{ }^{-}>\mathrm{Ca}^{2+}>\mathrm{Mg}^{2+}$. The ionic ratios of $\mathrm{rMg} / \mathrm{Ca}, \mathrm{rCa} / \mathrm{Cl}, \mathrm{rMg} / \mathrm{Cl}, \mathrm{rNa} / \mathrm{Ca}, \mathrm{rHCO}_{3} / \mathrm{Cl}$, $\mathrm{rQ}$, and $\mathrm{r}(\mathrm{Ca}+\mathrm{Mg}) /(\mathrm{Na}+\mathrm{K})$ are with $0.62,1.99,1.24,0.41,2.36,0.69$, and 3.68 in the same range as samples from the limestone/dolomite aquifer A1/2. The highest mineralized sample is of $\mathrm{HCO}_{3}^{-}>\mathrm{Cl}^{-}$ $>\mathrm{Ca}^{2+}>\mathrm{Mg}^{2+}$ type. The increased $\mathrm{Mg} / \mathrm{Ca}$ ratio along with the decreasing $\mathrm{Na} / \mathrm{Cl}$ ratio shows, that apart from the dissolution of $\mathrm{NaCl}$ a growing portion of $\mathrm{MgCl}_{2}$ is present in the higher mineralized samples. However, contributions of $\mathrm{NaCl}$ and $\mathrm{CaCl}_{2}$ are also noticeable from the decreasing $(\mathrm{Ca}+\mathrm{Mg}) / \mathrm{Cl}$ and $\mathrm{Mg} / \mathrm{Cl}$ ratio. The $\mathrm{Cl}$ - excess of 2.14 and the $\mathrm{Ca}-\mathrm{Mg}$ excess of 1.98 undermines the assumption that large portions of $\mathrm{MgCl}_{2}$ and $\mathrm{CaCl}_{2}$ are responsible for the increased salinity.

\section{AB1381 (22 samples)}

The groundwater samples of well AB1381 were taken between 19.05.1993 and 31.12.1996. Over this period the electrical conductivity shows, apart from a seasonal trend where lowest electrical conductivities were measured after the rainy season and highest at the beginning of the rainy season, a constant increase from 1,239 to $2,280 \mu \mathrm{S} / \mathrm{cm}$, whereby the first value represents the period after the rainy season and the latter the end of the dry period. Therefore the samples cannot be compared directly. The least mineralized sample can be classified as a $\mathrm{HCO}_{3}{ }^{-}>\mathrm{Ca}^{2+}>\mathrm{Cl}^{-}>\mathrm{Mg}^{2+}$ type. The higher mineralized sample can be classified as $\mathrm{Cl}^{-}>\mathrm{Mg}^{2+} \geq \mathrm{Na}^{+} \geq \mathrm{Ca}^{2+}$. A decrease in the $\mathrm{Ca} / \mathrm{Cl}$ and $\mathrm{Mg} / \mathrm{Cl}$ ratio together with in an increase in the $\mathrm{Na} / \mathrm{Ca}$ ratio could lead to the conclusion, that an increase in salinity derives mostly from the dissolution of $\mathrm{NaCl}$. But since the $\mathrm{HCO}_{3}{ }^{-}$content decreases slightly and the sulphate content increases only slightly an increase in $\mathrm{MgCl}_{2}$ and $\mathrm{CaCl}_{2}$ dissolution must also be assumed. Therefore the increased $\mathrm{Ca}$ and $\mathrm{Mg}$ contents in the younger samples derive from the dissolution of $\mathrm{MgCl}_{2}$ and $\mathrm{CaCl}_{2}$. The $\mathrm{Na} / \mathrm{Cl}$ ratio stays for the higher mineralized waters around the same range as for the lower mineralized sample and the $\mathrm{Cl}$ - excess increased significantly in the higher mineralized samples (from 2.29 to $7.07 \mathrm{meq} / \mathrm{L}$ ). This undermines the assumption, that the dissolution of $\mathrm{NaCl}$ in the higher mineralized samples goes along with the same order of magnitude as the dissolution of $\mathrm{MgCl}_{2}$ and $\mathrm{CaCl}_{2}$.

\subsubsection{South of Kafrein}

\section{AB1054 (42 samples)}

All 42 samples of well AB1054, although the well is located close to the mountain highlands, are highly mineralized and vary in terms of electrical conductivity between 3,300 to $5,250 \mu \mathrm{S} / \mathrm{cm}$. All water samples can be classified as $\mathrm{Cl}^{-}>\mathrm{Na}^{+}>\mathrm{Mg}^{2+}>\mathrm{Ca}^{2+}$. The Sulphate content that varies between 4 and $8.01 \mathrm{meq} / \mathrm{L}$, is high. The $\mathrm{Na} / \mathrm{Cl}$ ratio of around 0.5 indicates that only half of the dissolved Chloride derives from the dissolution of $\mathrm{NaCl}$. The other half derives mostly from $\mathrm{MgCl}_{2}$ and to a lesser extent from $\mathrm{CaCl}_{2}$. This can also be seen in the high $\mathrm{Cl}$ - excess which is compensated by the Ca$\mathrm{Mg}$ excess. The higher mineralized samples contain about the same major ion composition of the lower mineralized samples. No differentiation can be made, which indicates that the source of the higher salinization is the same as for the salinization of the lower mineralized samples.

\subsubsection{Conclusions}

In general it can be stated, that highest variations in terms of dissolved ion concentrations can be found in wells located close to the apex of the major alluvial fans. Within these wells it can also be seen, that the salinity increases until the beginning of the rainy season or shortly after it and decreases then from this period down to its yearly minimum during the summer period. Long term variations in these wells can be correlated to yearly precipitation amounts, where wet years (i.e. 1973/74) causes decreases in the groundwater salinities significantly and drier periods can lead to an increased of groundwater salinity. These observations might be correlated to the water demand in the area. The irrigation of water demanding crops (in terms of water quantity and quality), like banana, takes place in areas of high water quality fluctuations. This has a direct impact on the irrigation water consumption, where more water is needed in periods of drought and less water in wetter years. Strengthening the effect of high water consumption is the fact, that groundwater recharge is also smaller in drier periods, which lead to even higher water stress. The effects of the building of water dams and the King Abdallah 
Canal (chapter 3) on groundwater quality cannot be seen, since not enough water samples for these periods were available. However, the effect of the events of 1967 and their aftermath can clearly be seen. After the events water salinity reached their all time low in the available samples (apart from the scarce chemical information reported in Ionides 1939).

Samples of increased salt concentrations have mostly the same salinization trend. This trend can be described for each well separately. But a regional salinization trend can also be observed. Two different regional salinization trends can be depicted: one in wells located around the village of South Shuneh and the other in wells located around the village of Rama. Increased salinity in the samples of the wells in the Shuneh area usually have an $\mathrm{Mg} / \mathrm{Ca}$ ratio higher than 1.0, a Na/Cl ratio between 0.52 and 0.6, and high $\mathrm{Cl}-$ and $\mathrm{Mg}-\mathrm{Ca}$ excess concentrations. High salinity samples can therefore be characterized by increased dissolution of $\mathrm{NaCl}$ which goes along with high dissolution of $\mathrm{MgCl}_{2}$ and $\mathrm{CaCl}_{2}$. High salinity samples of wells located in the Rama area are characterized by a $\mathrm{Mg} / \mathrm{Ca}$ ratio which is usually below 1.0 , a high $\mathrm{Na} / \mathrm{Cl}$ ratio, usually between $0.77-0.98$, and consequently low $\mathrm{Cl}-$ and $\mathrm{Ca}-\mathrm{Mg}$ excesses. In addition, the sulphate content is higher in the Rama area and westwards of it than in the area of Shuneh.

Wells located either more to the west or between the major groundwater flow paths show higher salt concentrations in their water samples, but less variations. This accounts for wells in both areas: between the flow paths (AB1010 and AB1062) and south of Kafrein (AB1054). 
Tab. 5.2-11: The range of composition for the depicted wells in the study area. The lowest and highest content of each species for the available samples were chosen from MWI open files. (For well locations see Fig. 5.2-11.)

\begin{tabular}{|c|c|c|c|c|c|c|c|c|c|}
\hline Well ID & E.C & pH & $\mathrm{Ca}^{2+}$ & $\mathrm{Mg}^{2+}$ & $\mathrm{Na}^{+}$ & $\mathbf{K}^{+}$ & $\mathrm{CL}^{-}$ & $\mathrm{HCO}_{3}{ }^{-}$ & $\mathrm{SO}_{4}^{2-}$ \\
\hline & $\mu \mathrm{S} / \mathrm{cm}$ & & meq/L & meq/L & meq/L & meq/L & meq/L & meq/L & meq/L \\
\hline
\end{tabular}

\section{Rama Area}

\begin{tabular}{|l|c|c|c|c|c|c|c|c|c|c|}
\hline AN1005 & $\min$ & 1,156 & 6.86 & 4.31 & 3.07 & 3.39 & 0.26 & 4.13 & 4.01 & 1.55 \\
\hline & $\max$ & 2,050 & 7.42 & 7.79 & 4.37 & 9.12 & 0.56 & 9.44 & 5.68 & 4.99 \\
\hline
\end{tabular}

\begin{tabular}{|c|c|c|c|c|c|c|c|c|c|c|}
\hline $\mathrm{AB} 1156$ & $\min$ & 999 & 7.25 & 3.99 & 3.00 & 2.7 & 0.17 & 3.35 & 4.03 & 2.13 \\
\hline & $\max$ & 1,578 & 7.88 & 5.45 & 4.86 & 6.06 & 0.36 & 7.38 & 4.66 & 3.13 \\
\hline
\end{tabular}

\begin{tabular}{|c|c|c|c|c|c|c|c|c|c|c|}
\hline $\mathrm{AB} 1118$ & $\min$ & 1,600 & 7.11 & 5.08 & 4.19 & 6.03 & 0.51 & 6.94 & 5.6 & 2.25 \\
\hline & $\max$ & 1,850 & 7.81 & 6.03 & 4.77 & 7.99 & 0.86 & 8.67 & 6.42 & 4.64 \\
\hline
\end{tabular}

\begin{tabular}{|c|c|c|c|c|c|c|c|c|c|c|}
\hline $\mathrm{AB} 1060$ & $\min$ & 3,300 & 7.01 & 7.98 & 9.39 & 13.85 & 0.86 & 20.03 & 5.57 & 6.25 \\
\hline & $\max$ & 3,850 & 7.61 & 9.23 & 10.46 & 18.4 & 1.2 & 23.89 & 6.55 & 9.51 \\
\hline
\end{tabular}

\begin{tabular}{|c|c|c|c|c|c|c|c|c|c|c|}
\hline $\mathrm{AB} 1126$ & $\min$ & 1,980 & 7.01 & 5.03 & 5.67 & 7.25 & 0.3 & 9.99 & 4.14 & 2.25 \\
\hline & $\max$ & 2,070 & 7.61 & 6.28 & 7.65 & 8.35 & 0.56 & 11.41 & 6.77 & 3.6 \\
\hline
\end{tabular}

\begin{tabular}{|c|c|c|c|c|c|c|c|c|c|c|}
\hline $\mathrm{AB} 1084$ & $\min$ & 1,900 & 7.11 & 4.94 & 5.92 & 7.42 & 0.13 & 10.19 & 5.29 & 2.79 \\
\hline & $\max$ & 2,200 & 7.81 & 6.78 & 6.74 & 10.04 & 0.86 & 12.23 & 7.31 & 3.81 \\
\hline
\end{tabular}

Between the major groundwater flow paths

\begin{tabular}{|c|c|c|c|c|c|c|c|c|c|c|}
\hline $\mathrm{AB} 1010$ & $\min$ & 3,700 & 7.41 & 8.48 & 9.63 & 16.08 & 0.86 & 22.79 & 5.93 & 6.5 \\
\hline & $\max$ & 3,900 & 7.81 & 10.02 & 11.54 & 19.09 & 1.17 & 25.73 & 6.83 & 9.63 \\
\hline
\end{tabular}

\begin{tabular}{|c|c|c|c|c|c|c|c|c|c|c|}
\hline $\mathrm{AB} 1062$ & $\min$ & 3,450 & 7.11 & 8.03 & 9.14 & 15.08 & 0.79 & 20.03 & 5.9 & 6.35 \\
\hline & $\max$ & 3,700 & 7.81 & 9.18 & 10.95 & 17.87 & 1.25 & 21.97 & 7.14 & 9.59 \\
\hline
\end{tabular}

\section{South Shuneh Area}

\begin{tabular}{|c|c|c|c|c|c|c|c|c|c|c|}
\hline $\mathrm{AB} 1347$ & $\min$ & 802 & 7.28 & 3.96 & 2.47 & 1.63 & 0.12 & 1.99 & 4.16 & 0.38 \\
\hline & $\max$ & 1,077 & 7.45 & 4.19 & 3.31 & 2.68 & 0.17 & 4.21 & 4.71 & 0.73 \\
\hline
\end{tabular}

\begin{tabular}{|c|c|c|c|c|c|c|c|c|c|c|}
\hline $\mathrm{AB} 1020$ & $\min$ & 2,750 & 7.01 & 7.03 & 8.73 & 10.71 & 0.19 & 20.03 & 5.14 & 1.16 \\
\hline & $\max$ & 4,600 & 7.91 & 7.91 & 11.94 & 21.58 & 1.1 & 37 & 6.18 & 4.31 \\
\hline
\end{tabular}

\begin{tabular}{|c|c|c|c|c|c|c|c|c|c|c|}
\hline $\mathrm{AB} 1381$ & $\min$ & 1,239 & 7.1 & 4.82 & 4.4 & 4.4 & 0.17 & 4.52 & 5.64 & 0.85 \\
\hline & $\max$ & 2,280 & 8.23 & 6.79 & 7.43 & 7.62 & 0.38 & 13.05 & 6.19 & 1.18 \\
\hline
\end{tabular}




\begin{tabular}{|c|c|c|c|c|c|c|c|c|c|c|}
\hline $\mathrm{AB} 1014$ & $\min$ & 560 & 7.01 & 2.79 & 2.63 & 0.69 & 0.02 & 0.81 & 4.95 & 0.06 \\
\hline & $\max$ & 4,000 & 7.8 & 11.12 & 11.53 & 19.27 & 1.2 & 29.65 & 6.5 & 10.38 \\
\hline
\end{tabular}

\begin{tabular}{|c|c|c|c|c|c|c|c|c|c|c|}
\hline $\mathrm{AB} 1024$ & $\min$ & 1,050 & 7.01 & 3.7 & 3.32 & 2.75 & 0.16 & 4.43 & 4.47 & 1.48 \\
\hline & $\max$ & 3,500 & 9.01 & 8.68 & 9.72 & 14.76 & 0.81 & 25.23 & 5.56 & 3.43 \\
\hline
\end{tabular}

\section{South of Karameh}

\begin{tabular}{|c|c|c|c|c|c|c|c|c|c|c|}
\hline $\mathrm{AB} 1054$ & $\min$ & 3,300 & 7.00 & 8.28 & 9.39 & 12.06 & 0.2 & 22.54 & 4.00 & 3.2 \\
\hline & $\max$ & 5,250 & 8.01 & 16.16 & 17.78 & 21.1 & 1.63 & 40.39 & 8.01 & 8.05 \\
\hline
\end{tabular}

Tab. 5.2-12: The range of ionic ratios of the selected wells. The lowest and highest content for each species of all available samples were chosen from MWI open files and its resulting ratios calculated; rQ = $\mathrm{rCa} /\left(\mathrm{SO}_{4}+\mathrm{HCO}_{3}\right)$. (For well locations see Fig. 5.2-11.)

\begin{tabular}{|c|c|c|c|c|c|c|c|c|c|c|c|}
\hline STATION & Range & $\mathrm{Mg} / \mathrm{Ca}$ & $\mathrm{Na} / \mathrm{Cl}$ & $\mathrm{Ca} / \mathrm{Cl}$ & $\mathrm{Mg} / \mathrm{Cl}$ & $\mathrm{Ca} / \mathrm{SO}_{4}$ & $\mathrm{Na} / \mathrm{Ca}$ & $\mathrm{HCO}_{3} / \mathrm{Cl}$ & $\mathrm{SO}_{4} / \mathrm{Cl}$ & $\mathrm{rQ}$ & $\mathrm{K} / \mathrm{Cl}$ \\
\hline & {$[-]$} & {$[-]$} & {$[-]$} & {$[-]$} & {$[-]$} & {$[-]$} & {$[-]$} & {$[-]$} & {$[-]$} & {$[-]$} & {$[-]$} \\
\hline
\end{tabular}

\section{Rama Area}

\begin{tabular}{|c|c|c|c|c|c|c|c|c|c|c|c|}
\hline AN1005 & $\min$ & 0.57 & 0.81 & 0.64 & 0.41 & 0.73 & 0.72 & 0.54 & 0.23 & 0.4 & 0.04 \\
\hline & $\max$ & 0.87 & 0.98 & 1.18 & 0.86 & 2.96 & 1.28 & 1.18 & 0.67 & 0.73 & 0.07 \\
\hline
\end{tabular}

\begin{tabular}{|c|c|c|c|c|c|c|c|c|c|c|c|}
\hline $\mathrm{AB} 1156$ & $\min$ & 0.65 & 0.75 & 0.54 & 0.56 & 1.46 & 0.64 & 0.59 & 0.37 & 0.57 & 0.04 \\
\hline & $\max$ & 1.23 & 0.97 & 1.25 & 0.93 & 2.09 & 1.19 & 1.24 & 0.69 & 0.73 & 0.06 \\
\hline
\end{tabular}

\begin{tabular}{|c|c|c|c|c|c|c|c|c|c|c|c|}
\hline AB1118 & $\min$ & 0.72 & 0.82 & 0.6 & 0.48 & 1.21 & 1.17 & 0.62 & 0.26 & 0.51 & 0.06 \\
\hline & $\max$ & 0.93 & 0.96 & 0.74 & 0.69 & 1.97 & 1.58 & 0.93 & 0.59 & 0.69 & 0.1 \\
\hline
\end{tabular}

\begin{tabular}{|c|c|c|c|c|c|c|c|c|c|c|c|}
\hline $\mathrm{AB} 1060$ & $\min$ & 0.98 & 0.68 & 0.34 & 0.43 & 0.96 & 1.06 & 0.23 & 0.29 & 0.58 & 0.04 \\
\hline & $\max$ & 1.27 & 0.83 & 0.45 & 0.5 & 1.37 & 2.31 & 0.31 & 0.44 & 0.68 & 0.05 \\
\hline
\end{tabular}

\begin{tabular}{|c|c|c|c|c|c|c|c|c|c|c|c|}
\hline $\mathrm{AB} 1126$ & $\min$ & 0.9 & 0.69 & 0.48 & 0.53 & 1.42 & 1.22 & 0.54 & 0.24 & 0.52 & 0.03 \\
\hline & $\max$ & 1.26 & 0.77 & 0.57 & 0.67 & 2.61 & 1.54 & 0.68 & 0.39 & 0.64 & 0.05 \\
\hline
\end{tabular}

\begin{tabular}{|c|c|c|c|c|c|c|c|c|c|c|c|}
\hline $\mathrm{AB} 1084$ & $\min$ & 0.61 & 0.71 & 0.42 & 0.48 & 1.36 & 1.38 & 0.43 & 0.23 & 0.5 & 0.01 \\
\hline & $\max$ & 1.48 & 0.83 & 0.53 & 0.64 & 2.2 & 1.51 & 0.72 & 0.37 & 0.64 & 0.12 \\
\hline
\end{tabular}

Between the major groundwater flow paths

\begin{tabular}{|c|c|c|c|c|c|c|c|c|c|c|c|}
\hline $\mathrm{AB} 1010$ & $\min$ & 1.07 & 0.67 & 0.36 & 0.42 & 1.04 & 1.68 & 0.26 & 0.27 & 0.61 & 0.03 \\
\hline & $\max$ & 1.22 & 0.78 & 0.4 & 0.48 & 1.42 & 2.01 & 0.28 & 0.3 & 0.69 & 0.05 \\
\hline
\end{tabular}




\begin{tabular}{|l|c|c|c|c|c|c|c|c|c|c|c|}
\hline $\mathrm{AB} 1062$ & $\min$ & 1.12 & 0.67 & 0.35 & 0.45 & 0.96 & 1.53 & 0.27 & 0.26 & 0.56 & 0.04 \\
\hline & $\max$ & 1.26 & 0.8 & 0.43 & 0.49 & 1.38 & 2.07 & 0.31 & 0.44 & 0.67 & 0.05 \\
\hline
\end{tabular}

\section{South Shuneh Area}

\begin{tabular}{|c|c|c|c|c|c|c|c|c|c|c|c|}
\hline \multirow[t]{2}{*}{ AB1347 } & $\min$ & 0.62 & 0.62 & 1.09 & 0.78 & 2.9 & 0.41 & 1.1 & 0.21 & 0.66 & 0.02 \\
\hline & $\max$ & 0.93 & 0.82 & 1.99 & 1.24 & 5.68 & 0.75 & 2.36 & 0.52 & 0.8 & 0.04 \\
\hline \multirow[t]{2}{*}{ AB1020 } & $\min$ & 1.05 & 0.54 & 0.28 & 0.34 & 2.34 & 1.44 & 0.14 & 0.03 & 0.93 & 0.01 \\
\hline & $\max$ & 1.31 & 0.63 & 0.45 & 0.46 & 5.93 & 2.15 & 0.28 & 0.15 & 1.59 & 0.04 \\
\hline
\end{tabular}

\begin{tabular}{|l|c|c|c|c|c|c|c|c|c|c|c|}
\hline $\mathrm{AB} 1381$ & $\min$ & 0.88 & 0.52 & 0.52 & 0.58 & 3.22 & 0.6 & 0.41 & 0.16 & 0.69 & 0.02 \\
\hline & $\max$ & 1.12 & 0.66 & 1.07 & 0.97 & 4.2 & 1.01 & 1.05 & 0.27 & 0.91 & 0.04 \\
\hline
\end{tabular}

\begin{tabular}{|l|c|c|c|c|c|c|c|c|c|c|c|}
\hline $\mathrm{AB} 1014$ & $\min$ & 0.94 & 0.53 & 0.33 & 0.38 & 1.06 & 0.25 & 0.19 & 0.07 & 0.39 & 0.02 \\
\hline & $\max$ & 1.27 & 0.85 & 0.44 & 0.5 & 3.89 & 2.05 & 0.62 & 0.41 & 1.04 & 0.04 \\
\hline
\end{tabular}

\begin{tabular}{|c|c|c|c|c|c|c|c|c|c|c|c|}
\hline $\mathrm{AB} 1024$ & $\min$ & 0.9 & 0.51 & 0.34 & 0.38 & 2.04 & 0.65 & 0.22 & 0.08 & 0.62 & 0.02 \\
\hline & $\max$ & 1.21 & 0.79 & 0.84 & 0.86 & 5.89 & 1.7 & 1.01 & 0.33 & 2.74 & 0.04 \\
\hline
\end{tabular}

\section{South of Karameh}

\begin{tabular}{|l|c|c|c|c|c|c|c|c|c|c|c|}
\hline $\mathrm{AB} 1054$ & $\min$ & 0.89 & 0.37 & 0.29 & 0.36 & 1.28 & 1.18 & 0.11 & 0.1 & 0.67 & 0.01 \\
\hline & $\max$ & 1.64 & 0.75 & 0.52 & 0.56 & 3.49 & 2.02 & 0.26 & 0.25 & 1.2 & 0.06 \\
\hline
\end{tabular}

Tab. 5.2-13: Representative samples of the selected wells. Min $=$ representative sample of the lowest mineralized category; inter $=$ representative sample of the intermediate mineralized category; $\max =$ representative sample of the highest mineralized category (data taken from MWI open files). (For well locations see Fig. 5.2-11.)

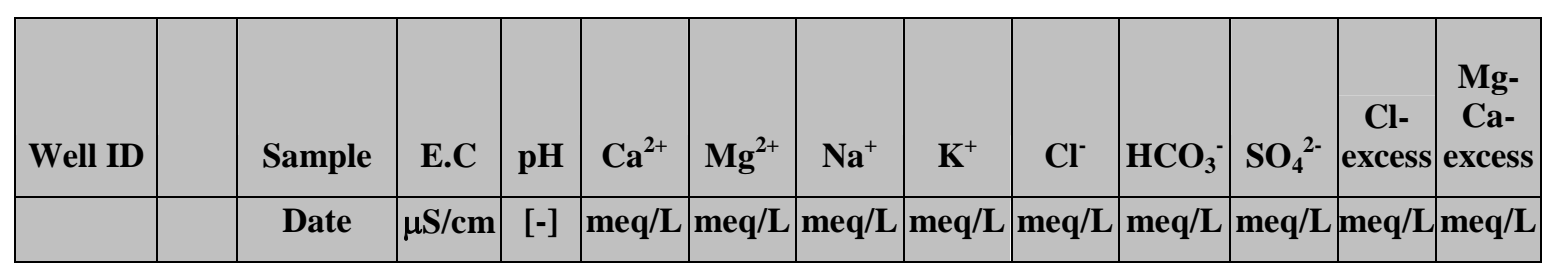

\section{Rama}

\begin{tabular}{|c|c|c|c|c|c|c|c|c|c|c|c|c|c|}
\hline AB1156 & $\min$ & 19.5 .1993 & 999 & 7.81 & 4.19 & 3.00 & 2.70 & 0.17 & 3.35 & 4.17 & 2.30 & 0.90 & 0.72 \\
\hline AB1156 & inter & 24.7 .1994 & 1,130 & 7.60 & 4.77 & 3.10 & 3.15 & 0.18 & 4.21 & 4.27 & 2.28 & 1.27 & 1.32 \\
\hline AB1156 & $\max$ & 27.8 .1995 & 1,578 & 7.30 & 5.14 & 3.53 & 5.50 & 0.36 & 6.57 & 4.15 & 3.58 & 1.10 & 0.94 \\
\hline AN1005 & $\min$ & 5.5 .1997 & 1,156 & 7.34 & 4.66 & 3.07 & 3.39 & 0.26 & 4.13 & 4.37 & 2.58 & 0.92 & 0.78 \\
\hline AN1005 & inter & 8.10 .1995 & 1,656 & 6.88 & 5.83 & 3.47 & 6.51 & 0.43 & 7.44 & 5.26 & 3.00 & 0.87 & 1.04 \\
\hline AN1005 & $\max$ & 8.2 .1998 & 2,050 & 6.88 & 6.51 & 4.35 & 8.79 & 0.53 & 9.44 & 5.68 & 4.70 & 0.60 & 0.49 \\
\hline AB1060 & $\min$ & 1.3 .1973 & 3,300 & 7.51 & 8.58 & 9.47 & 13.85 & 1.04 & 20.39 & 6.32 & 6.25 & 5.50 & 5.48 \\
\hline
\end{tabular}




\begin{tabular}{|c|c|c|c|c|c|c|c|c|c|c|c|c|c|}
$\mathrm{AB} 1060$ & inter & 21.8 .1975 & 3,600 & 7.21 & 9.08 & 10.21 & 15.17 & 0.99 & 21.49 & 6.14 & 8.32 & 5.33 & 4.82 \\
\hline $\mathrm{AB} 1060$ & $\max$ & 22.1 .1978 & 3,850 & 7.41 & 7.98 & 10.13 & 18.40 & 1.20 & 23.80 & 5.57 & 8.09 & 4.20 & 4.44 \\
\hline $\mathrm{AB} 1126$ & $\min$ & 26.11 .1971 & 1,980 & 7.21 & 5.93 & 6.83 & 7.25 & 0.46 & 10.47 & 6.77 & 3.16 & 2.76 & 2.84 \\
\hline $\mathrm{AB} 1126$ & $\max$ & 18.9 .1977 & 2,070 & 7.41 & 5.98 & 6.00 & 8.17 & 0.35 & 11.35 & 6.08 & 3.20 & 2.83 & 2.71 \\
\hline $\mathrm{AB} 1084$ & $\min$ & 20.5 .1972 & 1,900 & 7.41 & 4.34 & 6.41 & 7.42 & 1.10 & 8.89 & 7.09 & 3.25 & 0.37 & 0.42 \\
\hline $\mathrm{AB} 1084$ & $\max$ & 14.12 .1971 & 2,200 & 7.91 & 6.13 & 6.74 & 8.78 & 0.13 & 12.31 & 7.09 & 2.79 & 3.40 & 3.00 \\
\hline $\mathrm{AB} 1118$ & $\min$ & 6.11 .1967 & 1,600 & 7.41 & 5.13 & 4.77 & 6.03 & 0.63 & 6.94 & 6.42 & 2.60 & 0.28 & 0.88 \\
\hline $\mathrm{AB} 1118$ & $\max$ & 15.9 .1972 & 1,850 & 7.21 & 5.68 & 4.36 & 7.42 & 0.58 & 8.50 & 5.60 & 4.50 & 0.50 & -0.05 \\
\hline
\end{tabular}

Between the major groundwater flow paths

\begin{tabular}{|l|l|l|l|l|l|l|l|l|l|l|l|l|l|}
\hline $\mathrm{AB} 1010$ & $\min$ & 10.03 .1973 & 3,700 & 7.61 & 9.58 & 10.21 & 16.08 & 0.99 & 24.03 & 6.63 & 6.50 & 6.96 & 6.66 \\
\hline $\mathrm{AB} 1010$ & $\max$ & 18.04 .1972 & 3,900 & 7.71 & 9.33 & 10.54 & 18.79 & 0.86 & 24.57 & 6.36 & 8.38 & 4.92 & 5.12 \\
\hline $\mathrm{AB} 1062$ & $\min$ & 18.04 .1973 & 3,400 & 7.21 & 8.48 & 10.95 & 15.56 & 1.10 & 21.04 & 6.11 & 7.69 & 4.38 & 5.62 \\
\hline $\mathrm{AB} 1062$ & $\max$ & 27.11 .1971 & 3,700 & 7.11 & 8.73 & 11.03 & 16.51 & 1.15 & 24.62 & 7.14 & 6.35 & 6.96 & 6.27 \\
\hline
\end{tabular}

\section{Shuneh}

\begin{tabular}{|c|c|c|c|c|c|c|c|c|c|c|c|c|c|}
\hline $\mathrm{AB} 1014$ & $\min 18.05 .1971$ & 560 & 7.41 & 2.79 & 2.63 & 0.69 & 0.02 & 0.81 & 5.70 & 1.19 & 0.10 & -0.34 \\
\hline $\mathrm{AB} 1014$ & inter 25.10 .1967 & 2,300 & 7.31 & 5.58 & 7.07 & 9.39 & 0.66 & 14.15 & 5.80 & 1.58 & 4.10 & 5.28 \\
\hline $\mathrm{AB} 1014$ & $\max 19.09 .1977$ & 4,000 & 7.4 & 9.08 & 11.20 & 17.92 & 0.61 & 29.65 & 5.68 & 3.04 & 11.61 & 11.56 \\
\hline $\mathrm{AB} 1024$ & $\min$ & 04.05 .1986 & 1,050 & 7.76 & 3.70 & 3.32 & 3.52 & 0.16 & 4.43 & 4.47 & 1.48 & 0.96 & 1.07 \\
\hline $\mathrm{AB} 1024$ & inter 03.05 .1976 & 2,380 & 7.01 & 6.98 & 8.48 & 7.86 & 0.46 & 14.12 & 6.39 & 3.43 & 5.80 & 5.64 \\
\hline $\mathrm{AB} 1024$ & $\max 24.04 .1978$ & 3,550 & 9 & 8.68 & 9.72 & 14.76 & 0.79 & 25.23 & 5.46 & 2.62 & 9.81 & 10.30 \\
\hline $\mathrm{AB} 1020$ & $\min 22.04 .1974$ & 2,800 & 7.41 & 7.23 & 9.14 & 11.05 & 0.46 & 12.62 & 5.90 & 1.89 & 7.99 & 8.58 \\
\hline $\mathrm{AB} 1020$ & inter 14.09 .1975 & 3,780 & 7.41 & 8.78 & 11.61 & 16.47 & 0.43 & 28.24 & 5.88 & 2.70 & 11.34 & 11.81 \\
\hline $\mathrm{AB} 1020$ & $\max 01.10 .1977$ & 4,600 & 7.8 & 9.78 & 12.60 & 20.71 & 0.92 & 35.31 & 5.93 & 2.54 & 14.00 & 13.91 \\
\hline $\mathrm{AB} 1347$ & $\min$ & 12.5 .1996 & 802 & 7.33 & 3.96 & 2.47 & 1.63 & 0.12 & 1.99 & 4.71 & 1.02 & 0.63 & 0.70 \\
\hline $\mathrm{AB} 1347$ & inter & 7.7 .1996 & 926 & 7.45 & 4.18 & 2.97 & 2.12 & 0.16 & 3.06 & 4.52 & 1.60 & 1.44 & 1.03 \\
\hline $\mathrm{AB} 1347$ & $\max$ & 7.12 .1996 & 1,077 & 7.31 & 4.69 & 3.52 & 2.60 & 0.17 & 4.21 & 4.61 & 1.62 & 2.14 & 1.98 \\
\hline $\mathrm{AB} 1381$ & $\min$ & 19.5 .1993 & 1,239 & 7.10 & 4.82 & 4.40 & 2.90 & 0.17 & 4.52 & 5.82 & 1.21 & 2.29 & 2.19 \\
\hline $\mathrm{AB} 1381$ & inter 24.12 .1994 & 1,725 & 7.46 & 5.60 & 6.20 & 4.87 & 0.27 & 8.44 & 6.00 & 1.38 & 4.30 & 4.43 \\
\hline $\mathrm{AB} 1381$ & $\max 31.12 .1996$ & 2,280 & 8.23 & 6.79 & 7.62 & 6.84 & 0.32 & 13.05 & 5.36 & 2.15 & 7.07 & 6.91 \\
\hline
\end{tabular}

\section{Kafrein}

\begin{tabular}{|c|c|c|c|c|c|c|c|c|c|c|c|c|c|}
\hline AB1054 & $\min$ & 16.4 .1972 & 3,300 & 7.51 & 8.28 & 11.36 & 12.76 & 0.46 & 24.00 & 4.57 & 5.04 & 10.79 & 10.03 \\
\hline AB1054 & $\max$ & 24.7 .1975 & 5,250 & 7.61 & 12.52 & 17.78 & 21.10 & 0.97 & 40.39 & 5.01 & 7.04 & 18.32 & 18.26 \\
\hline
\end{tabular}

Tab. 5.2-14: Ionic ratios of the representative samples of the selected wells. Min = representative sample of the lowest mineralized category; inter = representative sample of the intermediate mineralized category; max = representative sample of the highest mineralized category (data taken from MWI open files). (For well locations see Fig. 5.2-11.) 


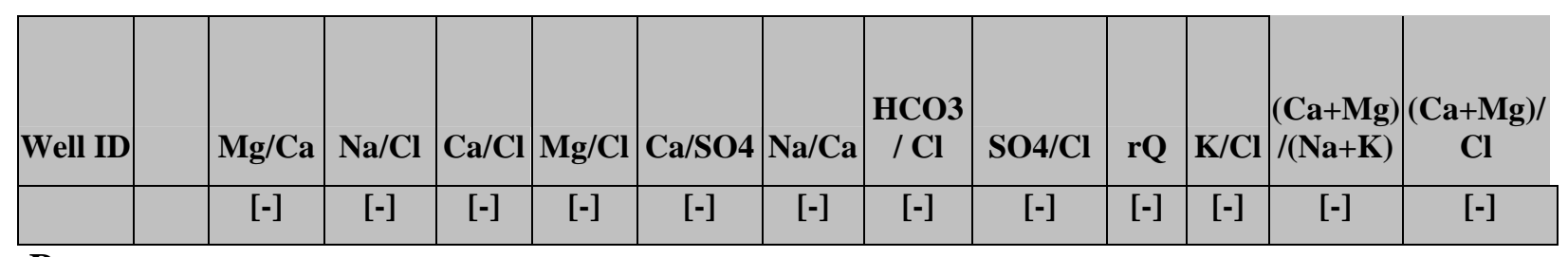

\section{Rama}

\begin{tabular}{|l|c|c|c|c|c|c|c|c|c|c|c|c|c|}
\hline AB1156 & $\min$ & 0.72 & 0.81 & 1.25 & 0.89 & 1.82 & 0.64 & 1.24 & 0.69 & 0.65 & 0.05 & 2.50 & 2.14 \\
\hline AB1156 inter & 0.65 & 0.75 & 1.13 & 0.74 & 2.09 & 0.66 & 1.02 & 0.54 & 0.73 & 0.04 & 2.36 & 1.87 \\
\hline AB1156 & $\max$ & 0.69 & 0.84 & 0.78 & 0.54 & 1.44 & 1.07 & 0.63 & 0.54 & 0.67 & 0.05 & 1.48 & 1.32 \\
\hline AN1005 & $\min$ & 0.66 & 0.82 & 1.13 & 0.74 & 1.81 & 0.73 & 1.06 & 0.62 & 0.67 & 0.06 & 2.12 & 1.87 \\
\hline AN1005 & inter & 0.60 & 0.87 & 0.78 & 0.47 & 1.94 & 1.12 & 0.71 & 0.40 & 0.71 & 0.06 & 1.34 & 1.25 \\
\hline AN1005 & $\max$ & 0.67 & 0.93 & 0.69 & 0.46 & 1.39 & 1.35 & 0.60 & 0.50 & 0.63 & 0.06 & 1.17 & 1.15 \\
\hline AB1060 & $\min$ & 1.10 & 0.68 & 0.42 & 0.46 & 1.37 & 1.61 & 0.31 & 0.31 & 0.68 & 0.05 & 1.21 & 0.89 \\
\hline AB1060 inter & 1.12 & 0.71 & 0.42 & 0.47 & 1.09 & 1.67 & 0.29 & 0.39 & 0.63 & 0.05 & 1.19 & 0.90 \\
\hline AB1060 & $\max$ & 1.27 & 0.77 & 0.34 & 0.43 & 0.99 & 2.31 & 0.23 & 0.34 & 0.58 & 0.05 & 0.92 & 0.76 \\
\hline AB1126 & $\min$ & 1.15 & 0.69 & 0.57 & 0.65 & 1.88 & 1.22 & 0.65 & 0.30 & 0.60 & 0.04 & 1.66 & 1.22 \\
\hline AB1126 & $\max$ & 1.00 & 0.72 & 0.53 & 0.53 & 1.87 & 1.37 & 0.54 & 0.28 & 0.64 & 0.03 & 1.41 & 1.06 \\
\hline AB1084 & $\min$ & 1.48 & 0.83 & 0.49 & 0.72 & 1.34 & 1.71 & 0.80 & 0.37 & 0.42 & 0.12 & 1.26 & 1.21 \\
\hline AB1084 & $\max$ & 1.10 & 0.71 & 0.50 & 0.55 & 2.20 & 1.43 & 0.58 & 0.23 & 0.62 & 0.01 & 1.45 & 1.05 \\
\hline AB1118 & $\min$ & 0.93 & 0.87 & 0.74 & 0.69 & 1.97 & 1.17 & 0.93 & 0.37 & 0.57 & 0.09 & 1.49 & 1.43 \\
\hline AB1118 & $\max$ & 0.77 & 0.87 & 0.67 & 0.51 & 1.26 & 1.31 & 0.66 & 0.53 & 0.56 & 0.07 & 1.26 & 1.18 \\
\hline
\end{tabular}

Between the major groundwater the flow paths

\begin{tabular}{|c|c|c|c|c|c|c|c|c|c|c|c|c|c|}
\hline $\mathrm{AB} 1010$ & $\min$ & 1.07 & 0.67 & 0.40 & 0.42 & 1.47 & 1.68 & 0.28 & 0.27 & 0.73 & 0.04 & 1.16 & 0.82 \\
\hline $\mathrm{AB} 1010$ & $\max$ & 1.13 & 0.76 & 0.38 & 0.43 & 1.11 & 2.01 & 0.26 & 0.34 & 0.63 & 0.03 & 1.01 & 0.81 \\
\hline $\mathrm{AB} 1062$ & $\min$ & 1.29 & 0.74 & 0.40 & 0.52 & 1.10 & 1.83 & 0.29 & 0.37 & 0.61 & 0.05 & 1.17 & 0.92 \\
\hline $\mathrm{AB} 1062$ & $\max$ & 1.26 & 0.67 & 0.35 & 0.45 & 1.38 & 1.89 & 0.29 & 0.26 & 0.65 & 0.05 & 1.12 & 0.80 \\
\hline
\end{tabular}

\section{Shuneh}

\begin{tabular}{|c|c|c|c|c|c|c|c|c|c|c|c|c|c|}
\hline AB1014 & $\min$ & 0.94 & 0.85 & 3.44 & 3.24 & 2.34 & 0.25 & 7.03 & 1.47 & 0.40 & 0.02 & 7.60 & 6.68 \\
\hline AB1014 & inter & 1.27 & 0.66 & 0.39 & 0.50 & 3.53 & 1.68 & 0.41 & 0.11 & 0.76 & 0.05 & 1.26 & 0.89 \\
\hline AB1014 & $\max$ & 1.23 & 0.60 & 0.31 & 0.38 & 2.99 & 1.97 & 0.19 & 0.10 & 1.04 & 0.02 & 1.09 & 0.68 \\
\hline \begin{tabular}{|l|}
$\mathrm{AB} 1024$ \\
\end{tabular} & $\min$ & 0.90 & 0.79 & 0.84 & 0.75 & 2.50 & 0.95 & 1.01 & 0.33 & \begin{tabular}{|l|}
0.62 \\
\end{tabular} & 0.04 & 1.91 & 1.59 \\
\hline AB1024 & inter & 1.21 & 0.56 & 0.49 & 0.60 & 2.04 & 1.13 & 0.45 & 0.24 & 0.71 & 0.03 & 1.86 & 1.09 \\
\hline AB1024 & $\max$ & 1.12 & 0.59 & 0.34 & 0.39 & 3.32 & 1.70 & 0.22 & 0.10 & \begin{tabular}{|l|}
1.07 \\
\end{tabular} & \begin{tabular}{|l|l|}
0.03 \\
\end{tabular} & 1.18 & 0.73 \\
\hline AB1020 & $\min$ & 1.26 & 0.88 & 0.57 & 0.72 & 3.83 & 1.53 & 0.47 & 0.15 & 0.93 & 0.04 & 1.42 & 1.30 \\
\hline AB1020 & inter & 1.32 & 0.58 & 0.31 & 0.41 & 3.25 & 1.88 & 0.21 & 0.10 & 1.02 & 0.02 & 1.21 & 0.72 \\
\hline AB1020 & $\max$ & 1.29 & 0.59 & 0.28 & 0.36 & 3.85 & 2.12 & 0.17 & 0.07 & 1.15 & 0.03 & 1.03 & 0.63 \\
\hline AB1347 & $\min$ & 0.62 & 0.82 & 1.99 & 1.24 & 3.89 & 0.41 & 2.36 & 0.51 & \begin{tabular}{|l|}
0.69 \\
\end{tabular} & 0.06 & 3.68 & 3.23 \\
\hline AB1347 & inter & 0.71 & 0.69 & 1.36 & 0.97 & 2.61 & 0.51 & 1.48 & 0.52 & 0.68 & 0.05 & 3.14 & 2.33 \\
\hline
\end{tabular}




\begin{tabular}{|l|l|l|l|l|l|l|l|l|l|l|l|l|l|}
$\mathrm{AB} 1347$ & $\max$ & 0.75 & 0.62 & 1.12 & 0.84 & 2.90 & 0.55 & 1.10 & 0.38 & 0.75 & 0.04 & 2.96 & 1.95 \\
\hline $\mathrm{AB} 1381$ & $\min$ & 0.91 & 0.64 & 1.07 & 0.97 & 3.99 & 0.60 & 1.29 & 0.27 & 0.69 & 0.04 & 3.00 & 2.04 \\
\hline $\mathrm{AB} 1381$ & inter & 1.11 & 0.58 & 0.66 & 0.73 & 4.06 & 0.87 & 0.71 & 0.16 & 0.76 & 0.03 & 2.30 & 1.40 \\
\hline $\mathrm{AB} 1381$ & $\max$ & 1.12 & 0.52 & 0.52 & 0.58 & 3.16 & 1.01 & 0.41 & 0.16 & 0.90 & 0.02 & 2.01 & 1.10 \\
\hline
\end{tabular}

\section{Kafrein}

\begin{tabular}{|c|c|c|c|c|c|c|c|c|c|c|c|c|}
\hline \begin{tabular}{|l|l}
$\mathrm{AB} 1054 \mathrm{~min}$ \\
\end{tabular} & 1.37 & 0.53 & 0.34 & 0.47 & 1.64 & 1.54 & 0.19 & 0.21 & 0.86 & 0.02 & 1.49 & 0.82 \\
\hline \begin{tabular}{|l|l}
$\mathrm{AB} 1054 \mathrm{n}$ \\
\end{tabular} & 1.42 & 0.52 & 0.31 & 0.44 & 1.78 & 1.69 & 0.12 & 0.17 & 1.04 & 0.02 & 1.37 & 0.75 \\
\hline
\end{tabular}

\subsubsection{Dating with the ${ }^{3} \mathrm{He}$-Tritium method}

\section{Introduction}

Little is know about the age of groundwater in the unconsolidated aquifer of the study area. The use of environmental or man made tracers for age and provenance of groundwater proved to be a powerful tool in hydrogeology (e.g. Cook and Herczeg 2000). Especially the helium-tritium method is an excellent tool for dating groundwater (Schlosser et al. 1988, 1989). Therefore, within the framework of a pilot study for the applicability of the ${ }^{3}$ Helium- Tritium method, samples from selected wells in the study area were taken. The samples were taken along the presumed Wadi Hisban alluvial fan flow path. In the following paragraphs the Helium-Tritium method is described, followed by the sampling and analyses procedure. Most of the information was taken from Sültenfuß and Massman 2004. The excursus commences with the description of the results and their implications for this study.

\section{Method}

Tritium method:

The use of Tritium for age determination is widely accepted. Apart from low analysis costs and easy sampling procedure, forty years of experience exists. Tritium is measured in tritium units (TU), which are defined as the ratio between tritium nuclei to ${ }^{1} \mathrm{H}$ hydrogen nuclei where $1 \mathrm{TU}=1 / 10^{18}{ }^{3} \mathrm{He} /{ }^{1} \mathrm{H}$ (or as activity per mass; $1 \mathrm{TU}=8.38 \mathrm{~Bq} / \mathrm{kg}$ ). As a results of surface nuclear bomb testing Tritium had its atmospheric peak concentration in the late 50ies and beginning of the 60ies. Surface atomic bomb testing stopped in the following period and the emission of large quantities of Tritium into the atmosphere seized. Tritium decays with a half-life of 12.32 years to ${ }^{3} \mathrm{He}$ (Lucas and Unterweger 2000). Therefore the contemporary concentration of Tritium in coastal areas is back at its pre- bomb natural concentration (usually around 2-5 TU in coastal areas). Tritium concentrations in continental areas are slightly higher. The total decay of one TU enlarges the ${ }^{3} \mathrm{He}$ concentration per kg water by 2.5 $* 10^{-12} \mathrm{Nml}$.

Age determination on the basis of Tritium concentrations

The comparison of the Tritium concentration in groundwater samples to Tritium concentrations in rainfall at the time of infiltration gives a time window. Fig. 5.2-17 shows the theoretical Tritium concentrations of samples taken throughout the period of 1962 to 1995 in Hof (Germany), if they would have been stored until the 01.01.2002 and analyzed at the same date (Sültenfuß and Massman 2004). Therefore the Tritium concentration of rainfall water in the infiltration area should be sufficiently known. In the case of a fast percolation to the saturated zone the Tritium concentration of rainfall water equals the one of groundwater. If infiltration happens over a larger time span, than a decay of the Tritium concentration of 5.5\%/year has to be assumed. Fig. 5.2-17 also illustrates, that groundwater that infiltrated between 1982 to 1995 and between 1967 to 1979, cannot be distinguished. 
In this study only a rough idea about the age of groundwater was desired; either very young or old water, or young water mixed with old water. Old water is understood in the sense of older than 80 years. High variations in Tritium concentrations between summer and winter, as reported by Sültenfuß and Massman (2004), are not expected in the study area, since precipitation falls only in the winter months. However, even during the winter months Tritium concentration may vary. But mixing of groundwater, that have different ages, results in the loss of significance of the sample when the Tritium method is applied alone.

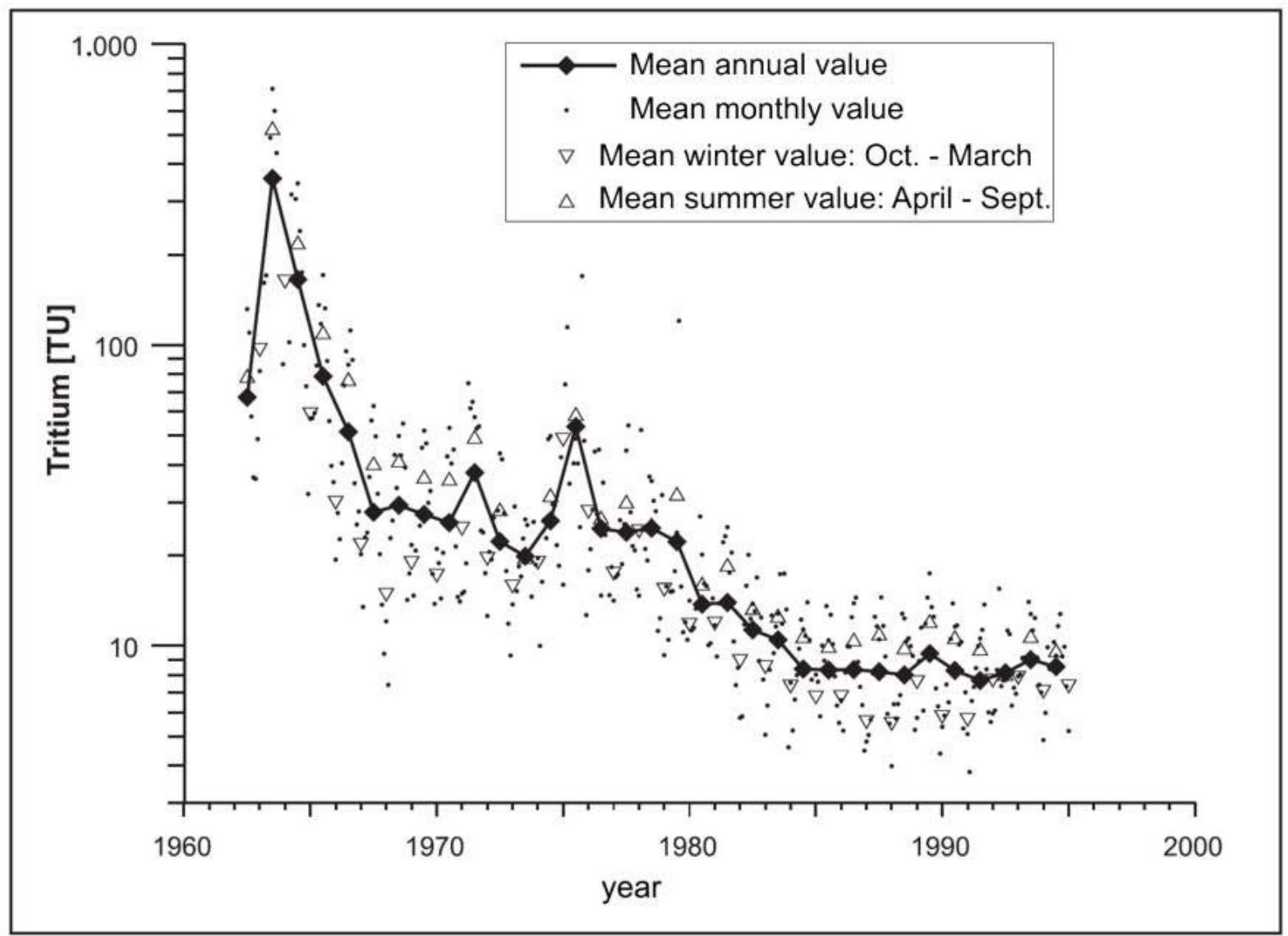

Fig. 5.2-17: Theoretical remaining Tritium concentration for rainwater samples taken and conserved between 1963 - 1995. The plot shows the theoretical results of an analysis of all samples on the 01.01.2002 (Sültenfuß and Massmann 2004).

\section{${ }^{3}$ Helium Tritium method}

The disadvantages of the above mentioned Tritium method can be avoided by using the ${ }^{3}$ HeliumTritium method. The combined method of measuring Tritium and ${ }^{3}$ Helium for the age determination of groundwater was already proposed in 1969 (Tolstinkhin and Kamenskij 1969). However the method was not used before the late 80ies (i.e. Schlosser et. al. 1988, 1989). Here, in addition to the measurement of the Tritium concentration its decay product ${ }^{3} \mathrm{He}$ is measured. ${ }^{3} \mathrm{He}$ is dissolved in groundwater as it flows in the saturated zone as long as it has no exchange with the atmosphere. ${ }^{3} \mathrm{He}$ is also chemically inert. From the relationship between the Tritium and ${ }^{3}$ Helium concentrations the groundwater age time window can be determined independent of seasonal or regional variations:

$\mathrm{T}=\lambda^{-1} * \ln \left(1+{ }^{3} \mathrm{He}^{*}{ }^{3} \mathrm{H}^{-1}\right)$

where

$\mathrm{t}=$ time parameter

$\lambda=$ decay constant $=0.05626 \mathrm{y}^{-1}$ 
Since the decay product ${ }^{3} \mathrm{He}$ is a gas, it results in the fact, that it fumigates when it gets in contact with the atmosphere. Therefore it can only accumulate once it is in and stays under a closed system condition. The ${ }^{3}$ Helium- Tritium method clock starts ticking once the infiltrated rainfall becomes under a closed system condition (no exchange with the atmosphere) and that is under saturated conditions. Once the infiltrated rainwater is under closed conditions, the decayed Tritium product ${ }^{3} \mathrm{He}$ accumulates until carefully sampled and analyzed. In addition, a determination of mixing with older Tritium free water is possible. ${ }^{3} \mathrm{H}$ and ${ }^{3} \mathrm{He}$ concentrations are summed up and are compared to the Tritium concentration of rainfall in the recharge area at the calculated time window.

However some prerequisite have to be fulfilled: first, all other helium sources must be quantified; second, once rainfall infiltrates into the saturated zone no exchange between groundwater and atmosphere must happen; and third, the dispersive transport must be $<<$ than the advective transport.

Regarding the first prerequisite, apart from ${ }^{3} \mathrm{He}$ generated by the decay of tritium, four other sources for helium exist: first, helium that was dissolved in the precipitation water according to the solution equilibrium ( $\mathrm{He}_{\text {equi }}$ ); second, surplus share accumulating from ${ }^{3} \mathrm{He}$ stored in the pores of the unsaturated material, that would dissolve into the infiltrating water on the way to the saturated zone $\left(\mathrm{He}_{\text {excess }}\right)$; third, Helium generated by the decay of Uranium and Thorium (which are generated in the subsurface), so called radiogene Helium ( $\mathrm{He}_{\mathrm{rad}}$ ); and forth, Helium exhalated from the earth deep zones through faults, the so called premodiale Helium ( $\left.\mathrm{He}_{\text {prim }}\right)$.

Therefore ${ }^{3} \mathrm{He}$ measured in the sample could have the following different ${ }^{3} \mathrm{He}$ components:

$$
{ }^{3} \mathrm{He}_{\text {sample }}={ }^{3} \mathrm{He}_{\text {trit }}+{ }^{3} \mathrm{He}_{\text {equi }}+{ }^{3} \mathrm{He}_{\text {excess }}+{ }^{3} \mathrm{He}_{\text {rad }}+{ }^{3} \mathrm{He}_{\text {prim }}
$$

Since ${ }^{3} \mathrm{He}_{\text {equi }}$ is a function of temperature, water salinity, and atmospheric pressure ${ }^{3} \mathrm{He}_{\text {equi }}$ can be calculated. ${ }^{3} \mathrm{He}_{\text {excess }}$ cannot be calculated directly, but estimated indirectly with the help of Ne Isotopes. The only source for Neon dissolved in water is of atmospheric nature.

$\mathrm{Ne}_{\text {sample }}=\mathrm{Ne}_{\text {equi }}$ (which can be calculated) $+\mathrm{Ne}_{\text {excess }}$

This makes the calculation of $\mathrm{He}_{\text {excess }}$ possible. A separation of the non-atmospheric generated ${ }^{3} \mathrm{He}_{\mathrm{rad}}$ and ${ }^{3} \mathrm{He}_{\text {prim }}$ is difficult. However, ${ }^{3} \mathrm{He}_{\text {prim }}$ only occurs in geological active fault zones. In waters where no anthropogenic generated Tritium is present an upper level for natural generated tritium can be estimated (usually around 5 TU for the continental Middle Europe; Roether 1967). That means, if the analyzed sample exceeds the estimated ${ }^{3} \mathrm{He}_{\text {trit }}$ plus the calculated ${ }^{3} \mathrm{He}_{\text {equi }}$ and ${ }^{3} \mathrm{He}_{\text {excess }}$ the presence of ${ }^{3} \mathrm{He}_{\text {prim }}$ must be assumed. ${ }^{3} \mathrm{He}_{\text {rad }}$ can be estimated with the help of ${ }^{4} \mathrm{He}_{\mathrm{rad}}\left({ }^{4} \mathrm{He}_{\mathrm{rad}}={ }^{4} \mathrm{He}_{\text {sample }}-{ }^{4} \mathrm{He}_{\text {equi }}-\right.$ $\left.{ }^{4} \mathrm{He}_{\text {excess}}\right)$.

\section{Sampling and Analyzing}

The noble gas samples were taken in a copper pipe (volume around 40ml) provided by the Institute of Environmental Physics of the University of Bremen (Fig. 5.2-18). Since exchange of the groundwater with the atmosphere would result in the outgassing of ${ }^{3} \mathrm{He}$, samples have to be taken carefully. Therefore a lucent plastic pipe was added between the outlet of the well water and the copper pipe on one side and a second one with a valve that will be partly closed during the sampling procedure. The flow of water in the pipe should be down to up. This enhances the pressure in the copper pipe and should prevent outgassing. Afterwards the pipe is closed, first at the outlet and than at the inlet. For each well two samples were taken (Fig. 5.2-19). The sampling procedure however proved to be a difficult task. Most, if not all wells in the study area were built in a basic way (chapter 4.3). No proper sampling valves at the well outlets are available. On the outlet of the well heads plastic pipes are plugged over the well head and smelted to the metal well head which makes sampling a difficult task. Moreover, the pumps in the irrigation well cannot be regulated. Either the pump is turned on or off. Since hydraulic conductivity in most wells is low compared to the pump capacity, strong variations in hydraulic head change are common (chapter 4.3.) and turbulent flow conditions within the well pipe might take place. This in turn leads to an exchange between the atmosphere and groundwater. High 
contamination with atmospheric air is the consequence. Unfortunately this happened in three out of the four selected wells. Only one sample was suitable for analyzing. The samples were transferred to Germany and analyzed in the Helium Isotope Laboratory at the Institute of Environmental Physics (University of Bremen). Detailed analytical procedures are described at Sültenfuß and Massman 2004.

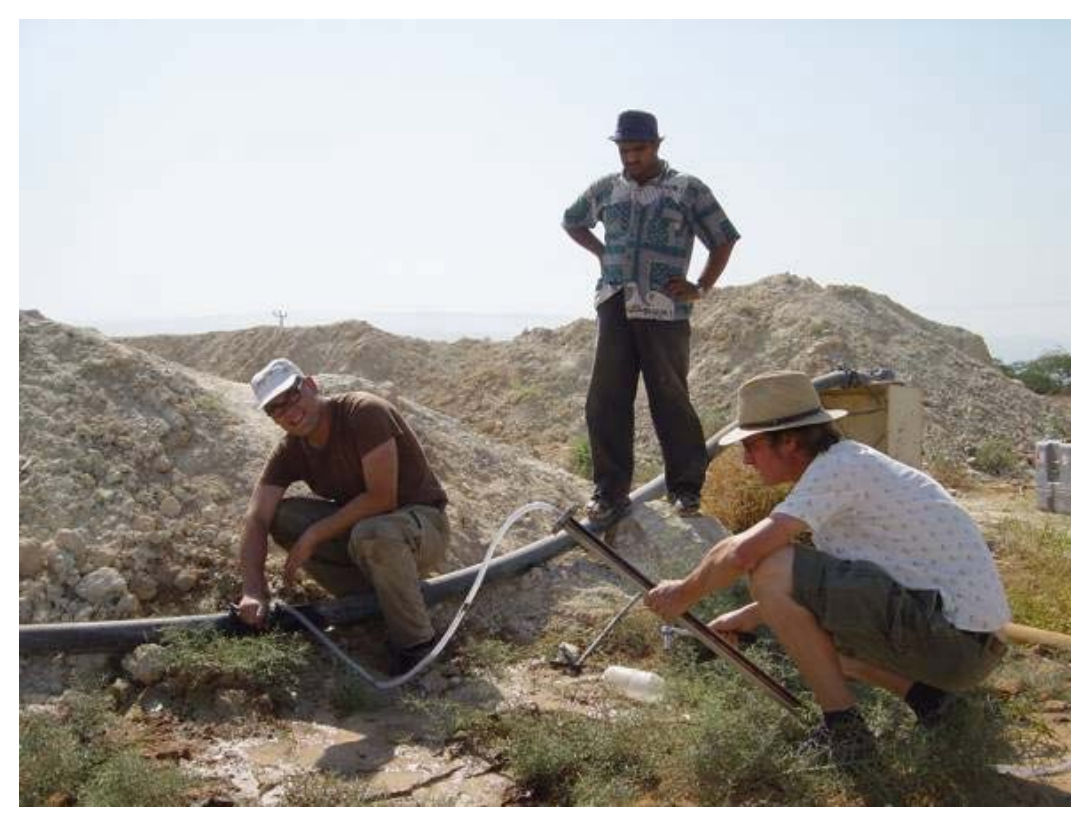

Fig. 5.2-18: Helium isotope sampling procedure.

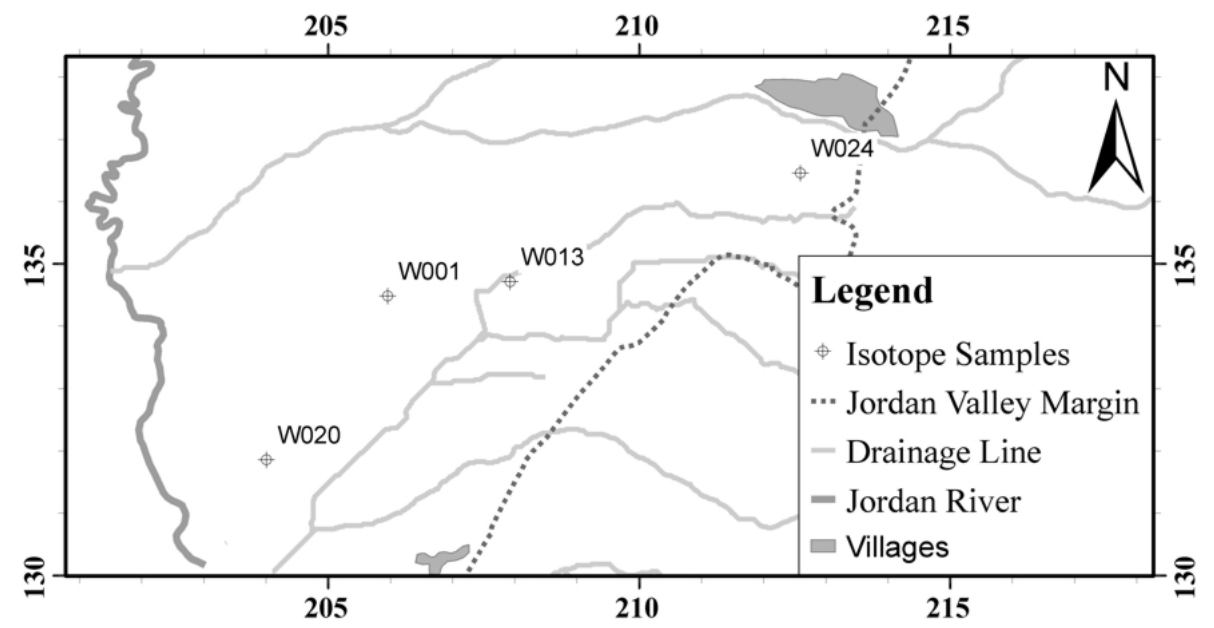

Fig. 5.2-19: Location of isotope sampling sites.

\section{Results}

For all sampling locations two Tritium and two He-Isotope analyses were taken. The Tritium concentrations are listed in Tab. 5.2-15 and represent average values. Only one He-Isotope Analysis, the sample from W024 was suitable for analyzing. In all other samples the atmospheric gas content was too high, which affirms that sampling from wells in the study area is difficult.

For the samples taken from wells W013 and W024 a clear contribution of water that infiltrated after 1950 can be stated. But the low Tritium concentrations can only be explained by a high fraction of water that is older than 1950 . Therefore a mixture of older with younger water can be concluded, whereby the highest fraction is older than 60 years. If the sample of well W001 is not a mixture between old and newer water an age of around 75 years can be assigned (when a natural concentration 
of $5 \mathrm{TU}$ is assumed). In the case of mixing, the sample can also consists of a small portion (1\%) containing Tritium (infiltrated after 1955) and a large portion (99\%) of old tritium free water. The sample of well W020 is free of Tritium. Therefore an age of $>100$ years can be assumed.

Tab. 5.2-15: Results of Tritium analysis. For each sample two analyses were conducted in the Helium Isotope Laboratory at the Institute of Environmental Physics (University of Bremen). The Tritium concentrations in the table are average values.

\begin{tabular}{|c|c|c|c|c|}
\hline Sample ID & $\begin{array}{c}\text { Tritium } \\
{[\mathrm{TU}]}\end{array}$ & $\begin{array}{c}\text { Tritium } \\
\text { error [TU] }\end{array}$ & $\begin{array}{c}\text { Fraction of young } \\
\text { components }\end{array}$ & Remarks \\
\hline W 001 & 0.08 & 0.02 & $<=1 \%$ & \\
\hline W 013 & 1.62 & 0.02 & $<10 \%$ & \\
\hline W 020 & -0.01 & 0.02 & $0 \%$ & Contains Mantle Helium \\
\hline W 024 & 1.08 & 0.02 & $<10 \%$ & \\
\hline
\end{tabular}

The Neon concentration of sample W024 was 2.5 times above the Neon equilibrium. This indicates a high content of atmospheric air in the sample. The ${ }^{4} \mathrm{He} / \mathrm{Ne}$ ratio shows, that apart from the high concentrations of atmospheric air, the sample contains another source of Helium (Fig. 5.2-20). Since the Tritium concentration is $1.08 \mathrm{TU}$, the contingent of tritiogene ${ }^{3} \mathrm{He}$ cannot exceed $16 \mathrm{TU}$ (antropoghenic generated Tritium with sufficient entry since 1955). Therefore the high ${ }^{3} \mathrm{He} /{ }^{4} \mathrm{He}-$ ratio cannot be explained by the accumulation of decayed Tritium but rather by the inflow of mantle components $\left({ }^{3} \mathrm{He}_{\text {prim }}\right)$. The composition of sample W024 is shown in Fig. 5.2-21.

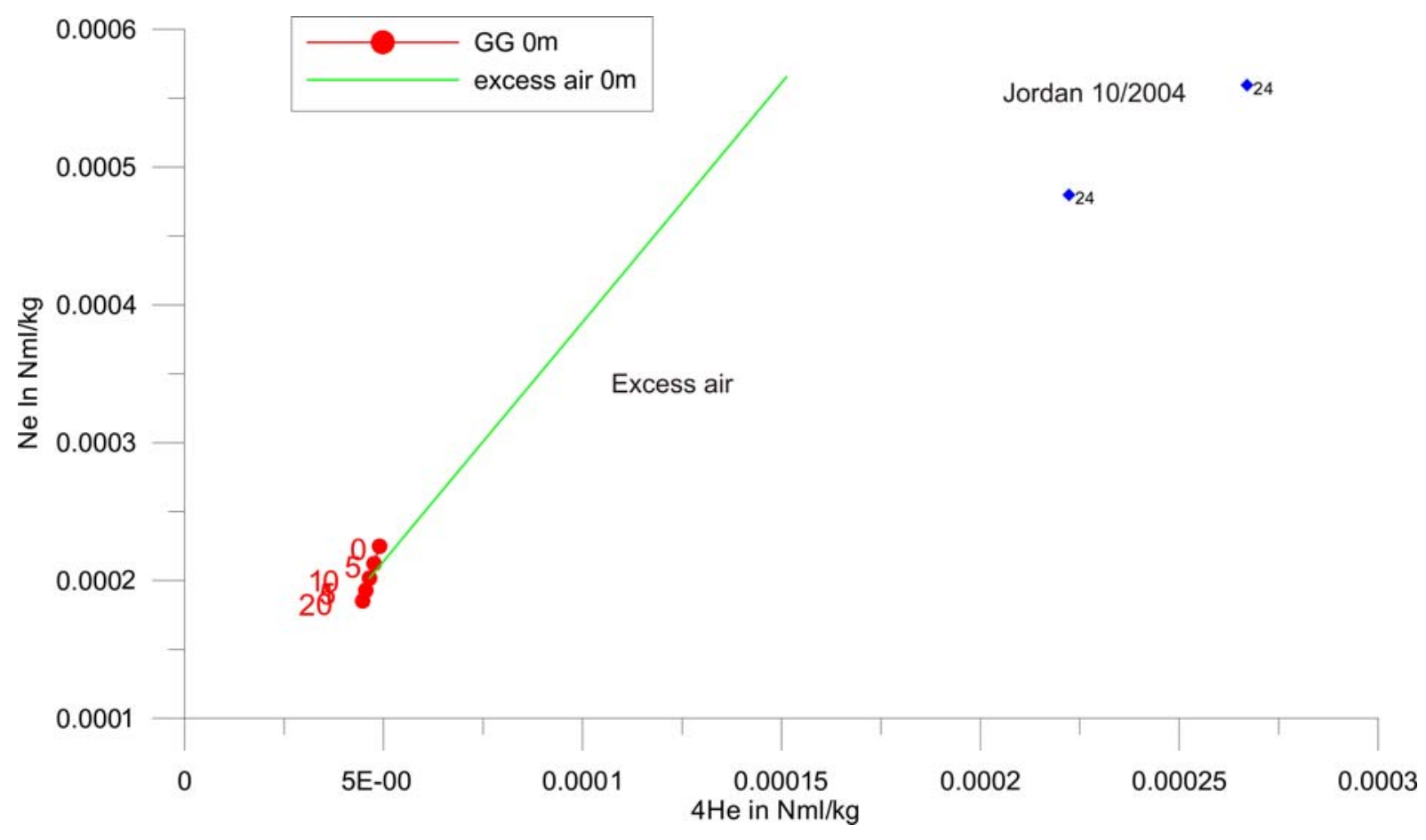

Fig. 5.2-20: ${ }^{4} \mathrm{He}-\mathrm{Ne}$ concentration of sample W024. 


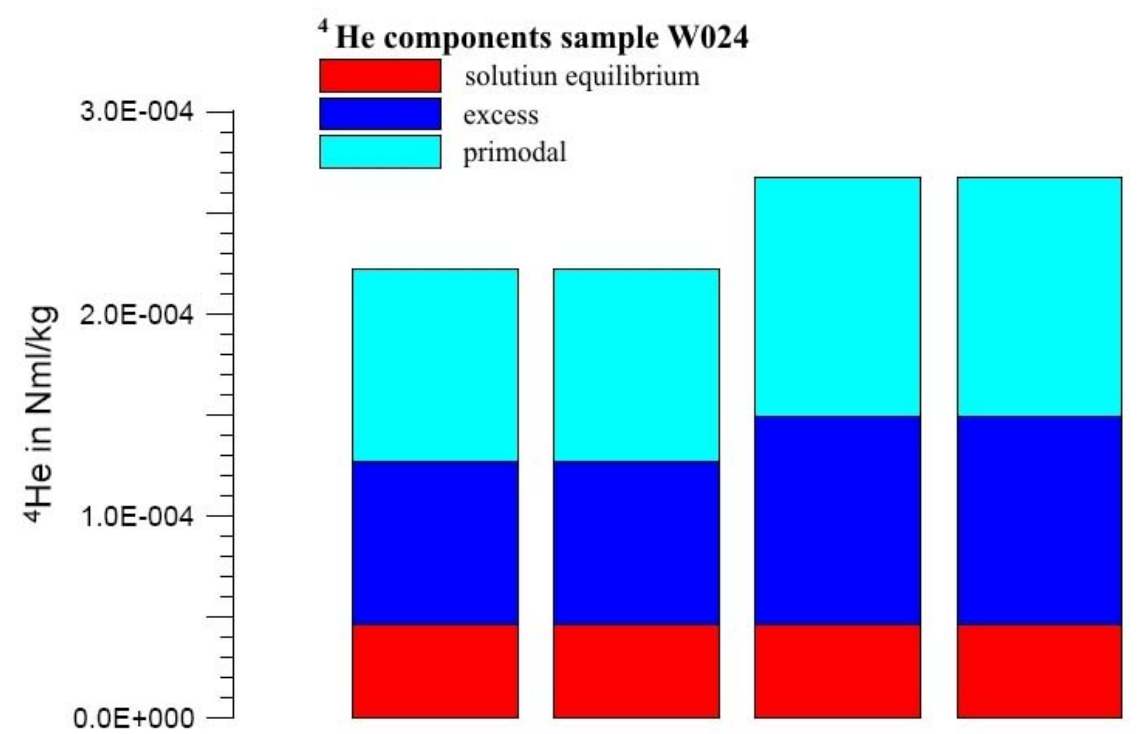

Fig. 5.2-21: ${ }^{4} \mathrm{He}$ - sample from well W024 split into its different components. 


\subsection{SPATIAL DISTRIBUTION OF SALINE GROUNDWATER FROM RESISTIVITY MEASUREMENTS}

\subsubsection{Introduction}

An arid climate prevails in the study area (chapter 2.1). As a result of tectonic activity a deep depression has formed (chapter 2.2). This depression was filled by eroded alluvial material from the hinterland and by lacustrine sediments of the predecessors of the Dead Sea. These lacustrine sediments carry high amounts of precipitated salts which lead to the deterioration of groundwater quality along its flow path towards the west (chapter 5.2). Different geophysical methods, that are sensitive to electrical conductivity changes in the subsurface, were applied in order to distinguish freshwater from saltwater dominated areas. The methods include surface geophysics (vertical electric Schlumberger depth soundings, frequency domain electromagnetic soundings (MaxMin I-8), direct push measurements (Dipol and Wenner four point geoloectric probes), and soil sampling (distribution of soluble salt content with depth) in order to calibrate and verify the interpreted geophysical investigations.

\subsubsection{Electromagnetic Measurements (MaxMin)}

\subsubsection{Introduction}

The main objective was to test the applicability of electromagnetic techniques in order to locate a fresh-/saltwater interface in the alluvial sediments of the lower Jordan Valley. However, during the course of this study it was discovered, that unlike in coastal areas, no fresh-/ saltwater interface exists in the study area. Due to the high salt content within the lacustrine sediments groundwater becomes more salty during its natural flow course from east to west by the dissolution of these soluble salts. Below, the principles of electromagnetic geophysical techniques are presented as well as the results of the field survey. This sub chapter commences with remarks on the applicability of this method in the study area.

\subsubsection{Electromagnetic techniques for subsurface exploration}

Electromagnetic (EM) methods can be subdivided into active and passive methods. Active EM methods use natural ground signals (Magnetotellurics) while passive EM methods employ an artificial transmitter to induce either a far- field (utilizing a high- powered military transmitter; VLF method) or a near- field (utilizing ground conductivity meters). The apparatus used in this study belongs to the latter group. The passive near- field methods can further be subdivided into a time- dependantelectromagnetic method (TDEM) or, as in the case of the MaxMin apparatus, into a frequencydependent- electromagnetic method (FDEM).

\section{MaxMin I-8 apparatus}

The MaxMin I-8 apparatus of the company APEX (Ontario, Canada), purchased within the context of the project, belongs to the so called two coil small loop systems. One coil serves as a transmitter and the other as a receiver (where the primary and secondary field is recorded, Fig. 5.3-1). During measurements the inter- coil separation is maintained at a fixed distance while moving along a survey transect in discrete measuring intervals. The two coils are interconnected by a reference cable delivering the primary field to the receiver (Fig. 5.3-2). 


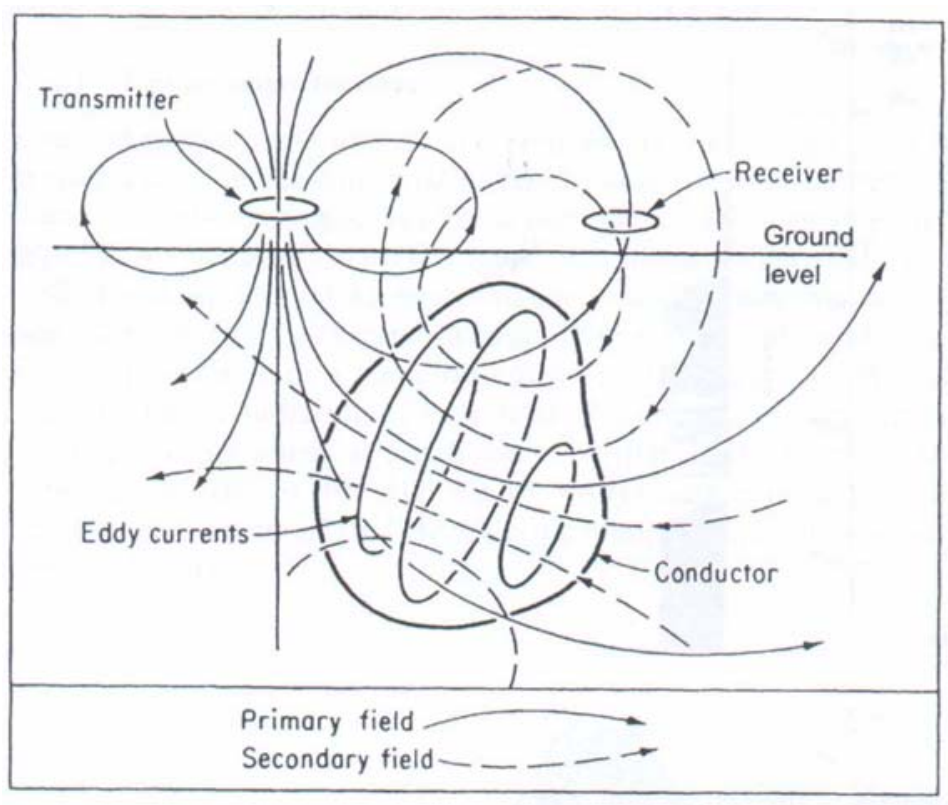

Fig. 5.3-1: Sketch of a EM survey (after Grand and West 1965).

The point of reference is the mid point of the transmitter- receiver distance. Different coil separations (i.e. 25, 50, 100, 200, $300 \mathrm{~m}$ ) and up to eight different frequencies (111, 222, 444, 888, 1,777, 3,555, 7,111 , and 14,080 Hz) can be measured and used. The depth penetration of the eight different frequencies deliver also information about certain depths. The depth penetration of the different frequencies is limited by the so called skin effect. The deepest penetration is reached by the lowest frequency. Best sensitivity of the system is found for the depth of $40 \%$ of the inter coil separation. Technically, the best resolution of resistivity contrasts can be found in these depths. Since the different frequencies, at a given separation, deliver information about different depth intervals, they can be used to perform depth soundings, similar to Schlumberger depth soundings (DC geoelectrics).
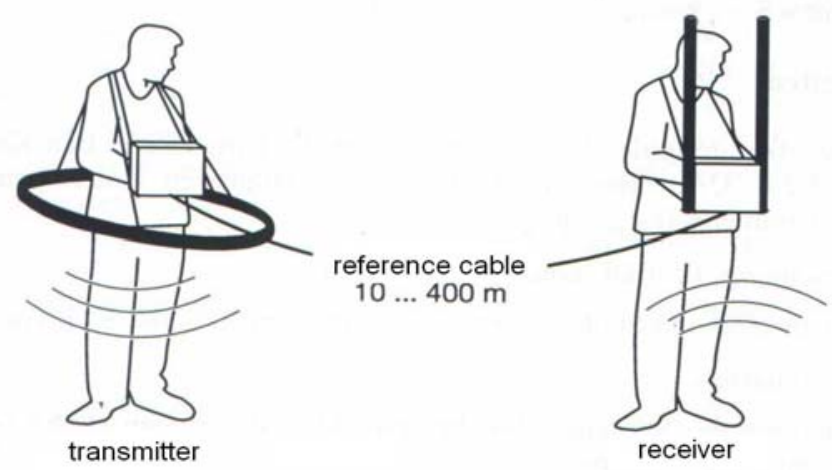

Fig. 5.3-2: Sketch of the MaxMin apparatus (Knoedel et al. 1997).

Layer models can be generated by using inverse or forward modeling programs. It should be noted, that the technical layer resolution of MaxMin measurements is somewhat lower than in Schlumberger soundings (commonly used for depth soundings), because it integrates over larger depths. But lateral variations of layer thickness should be easier and more precisely determined by using the MaxMin method. Another advantage is the small inter-coil separation compared to the large electrode separations necessary in Schlumberger depth soundings. The time consuming placing and coupling of the electrodes to dry alluvial sediments of the Jordan Valley can also be saved since the coupling to the ground happens by electromagnetic fields. 


\subsubsection{Interpretation of the results}

The measured profiles can be interpreted differently. To obtain a first idea of resistivity variations, the outphase and inphase can be plotted along the survey transect (Fig. 5.3-3). Another quick illustration of the measured data can be done by plotting the electric conductivity values calculated by the apparatus (Fig. 5.3-6 through Fig. 5.3-8). These calculated values underlie the assumption of a homogenous half-space. Because the penetration depth is frequency dependant first predictions about the resistivity distributions in the subsurface can be made by measuring different frequencies at the same inter-coil separation.

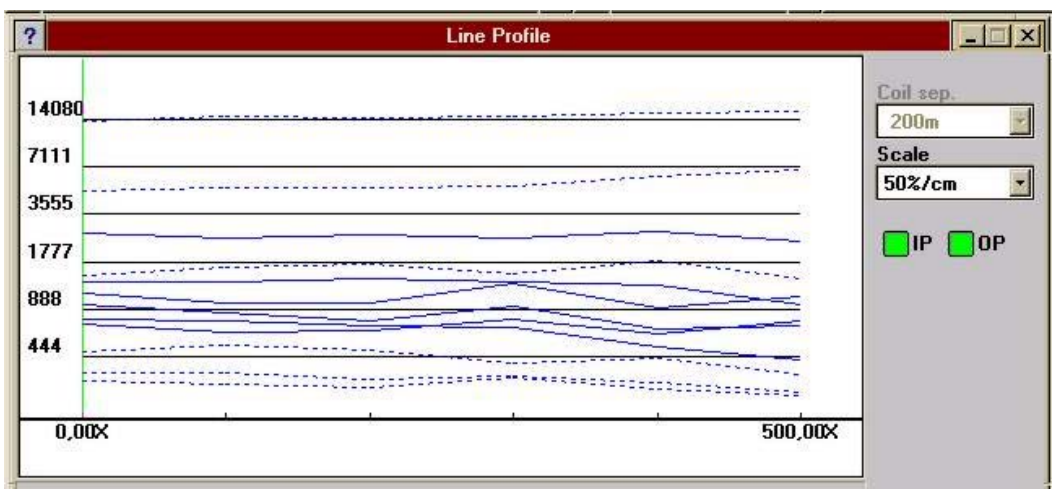

Fig. 5.3-3: In- and outphase plotted along a survey transect near the town of Kafrein in east- west direction.

A first approximate interpretation of the resistivity distribution and the quality of the data can be made by plotting the inphase against the quadrature, the so-called phasor plot (Fig. 5.3-4). Through the different points (one for each frequency) a curve can be drawn that can be compared to model curves.
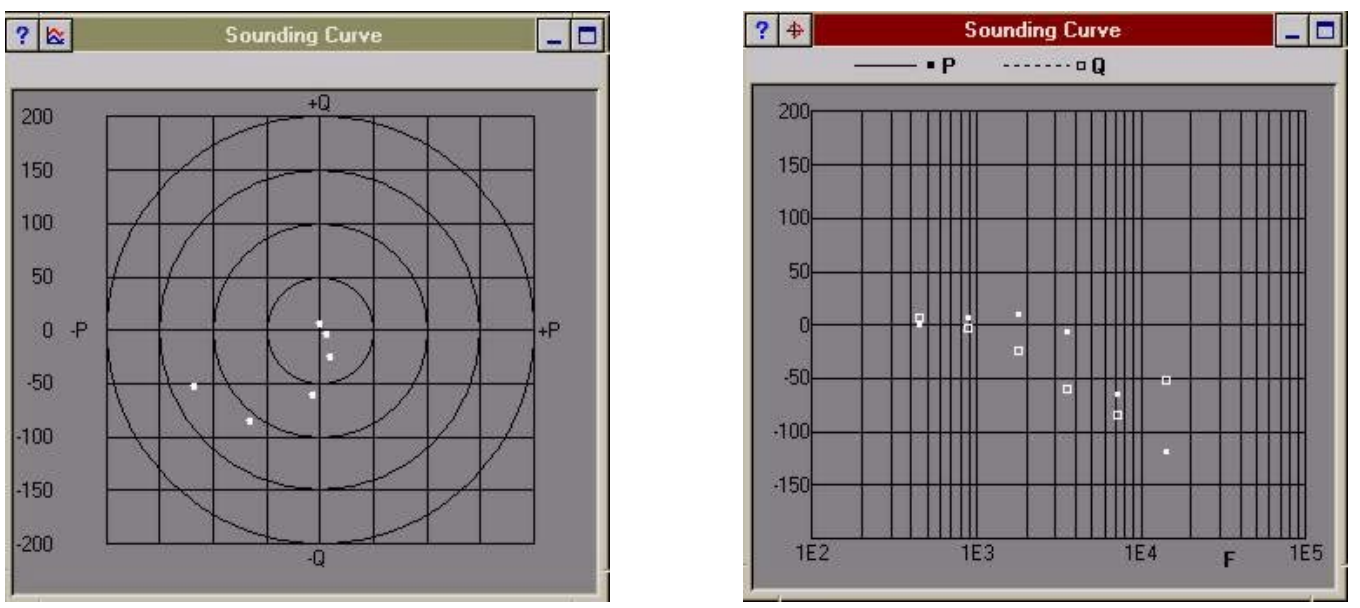

Fig. 5.3-4: left: Phasor plot of inphase and quadrature (after Reynolds, 1997); right: MaxMin sounding curve of the inphase and quadrature for the different recorded frequencies.

For more precise interpretation of the measured results inversion or forward modeling programs can be used. A layered subsurface model can be obtained either by depth soundings at single locations or as cross sections along a survey transect. 


\subsubsection{Results}

The first field campaign took place at the end of March until the end of June 2002 and was conducted in order to delineate a salt-/freshwater interface by using a frequency dependent electromagnetic method (FDEM) called MaxMin. For the measurements the APEX MaxMin I-8 apparatus was used. In addition to the measured profiles, intensive data and literature collection was done in order to calibrate and validate the calculated MaxMin interpretations.

\section{Field measurements:}

During the first measurement campaign, 61 profiles with various lengths and different inter coil separations were conducted. The length of the profiles varied from several hundred meters to three or four kilometres. Since different depths of a possible salt-/ freshwater interface were expected different inter coil separations were applied. The inter coil separation ranged from 50 over 100 to $200 \mathrm{~m}$. It should be noted that only six frequencies were measured at the latter two separations. Because of their unstable behaviour, the frequencies 111 and $222 \mathrm{~Hz}$ were omitted. Fig. 5.3-5 shows the location of the conducted profiles. Since the EM measurements are very sensitive to electrical power sources as well as to metal devices, measurement locations in the eastern part of the study area are limited.

For most of the measurement results forward or inverse modelling proved to be impossible. The problem of ambiguity couldn't be minimized. Therefore only qualitative results from the conducted profiles were used for interpretation purposes. Fig. 5.3-6 through Fig. 5.3-8 show interpolated plots for different apparent conductivities calculated by the MaxMin computer for different frequencies and the best fit conductivity. The different values were interpolated (universal kriging) (with the help of the ArcGIS 9.2 package (Spatial Analyst) developed by ESRI Inc. As described above, these results can only be seen as quantitative results, since the MaxMin computer calculates these values on the basis of a homogenous half space. However, because the penetration depth is frequency dependant, conclusion about the resistivity distribution with depth can be drawn by plotting the apparent conductivities for different frequencies.

The apparent conductivities calculated on the base of the $888 \mathrm{~Hz}$ frequency (Fig. 5.3-6) shows lowest conductivities around the outlets of the major wadis. Higher values are found in the western part of the study area and in the area between the major alluvial fans. The apparent conductivity values calculated on the base of $3555 \mathrm{~Hz}$ frequency shows a partial different picture. Here high conductivity values can also be found between the villages of Kafrein and Rama (Fig. 5.3-7). Since the frequency is higher than for the first plot, it can be assumed that higher salt content in surface soil might be the result of these higher values. Fig. 5.3-8 shows the best fit conductivity for the measured frequencies. The figure shows almost the same trend as Fig. 5.3-6. Lowest conductivities are found around the outlet of the major wadis and highest between the alluvial fans and in the west to southwest of the study area. These findings coincide with distribution maps of chapter 5.3.3.1. Therefore it can be assumed, that the salt content either of the deposited sediments or of the groundwater are responsible for high or low conductivities measured in the different profiles.

\subsubsection{Lessons learned}

Since the EM method is very sensitive to magnetic fields and since the study area is used intensively for agriculture, it was not always very easy to identify possible measurement sites. Such sources of disturbances are power lines, fuel driven generators, or metal pipes. In addition to these difficulties the salinization of the soil in lower Jordan Valley is far higher than expected which therefore reduces the penetration depth significantly. Especially in the west and southwest of the study area the upper soil salinization proved to be far too high, which prevents a deeper penetration. Therefore other methods that allow a deeper penetration in higher conductive environments were applied. However, the soundings give a soil conductivity distribution of the area, where lowest conductivities can be found near the outlets of the major wadis and highest in the west and between the outlets of the major wadis. 


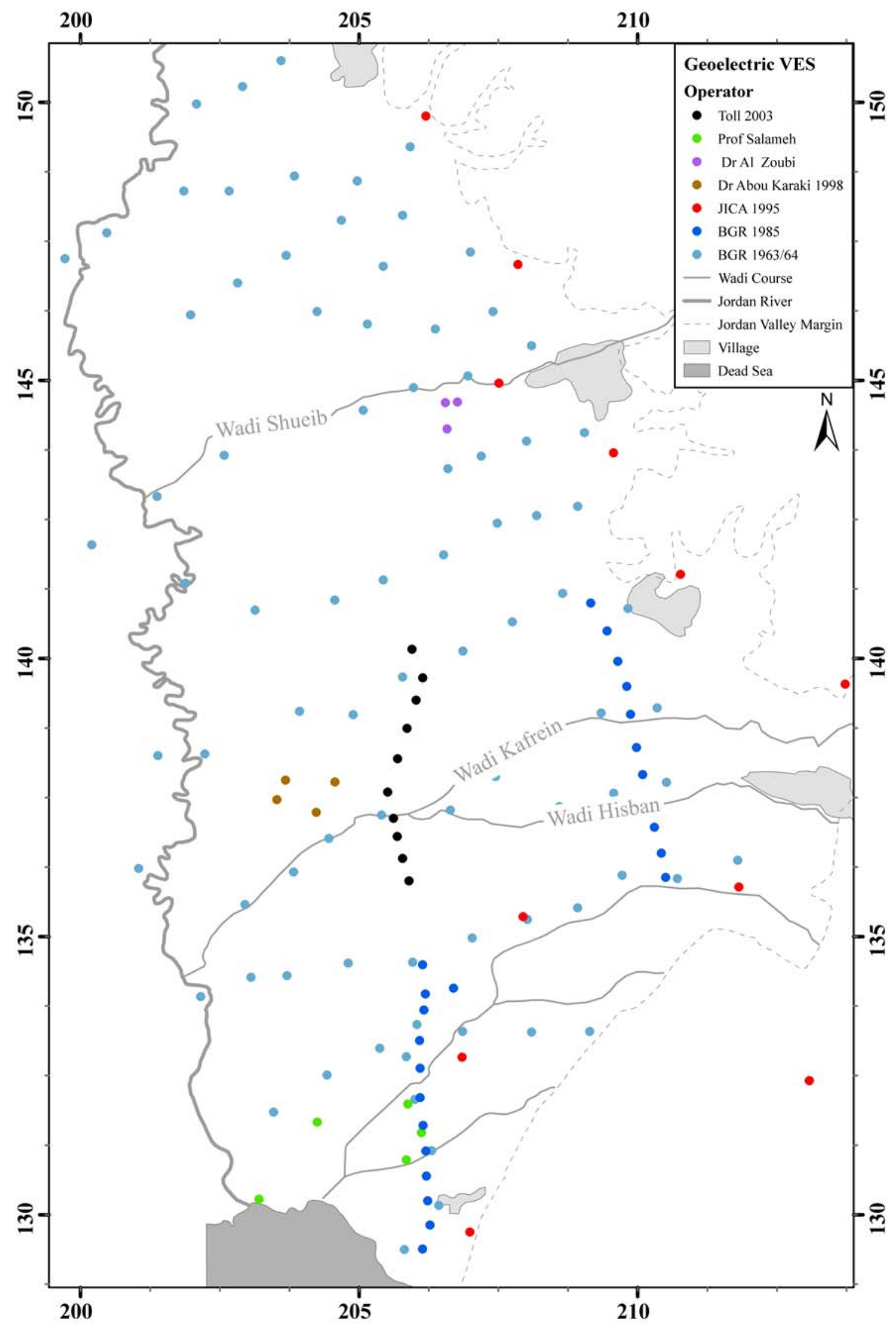

Fig. 5.3-5: Location of the conducted geophysical surface profiles. The MaxMin profiles are shown as solid red lines. The Schlumberger depth sounding locations are shown as points of different color, depending on the 
principal investigators (brown = BGR 1963/64; blue = BGR 1984/85; red = JICA 1995; dark green = Dr. Abou Karaki 1998; light green = Prof. Salameh; yellow = Dr. Al-Zoubi 1999; and black = Toll in 2003).

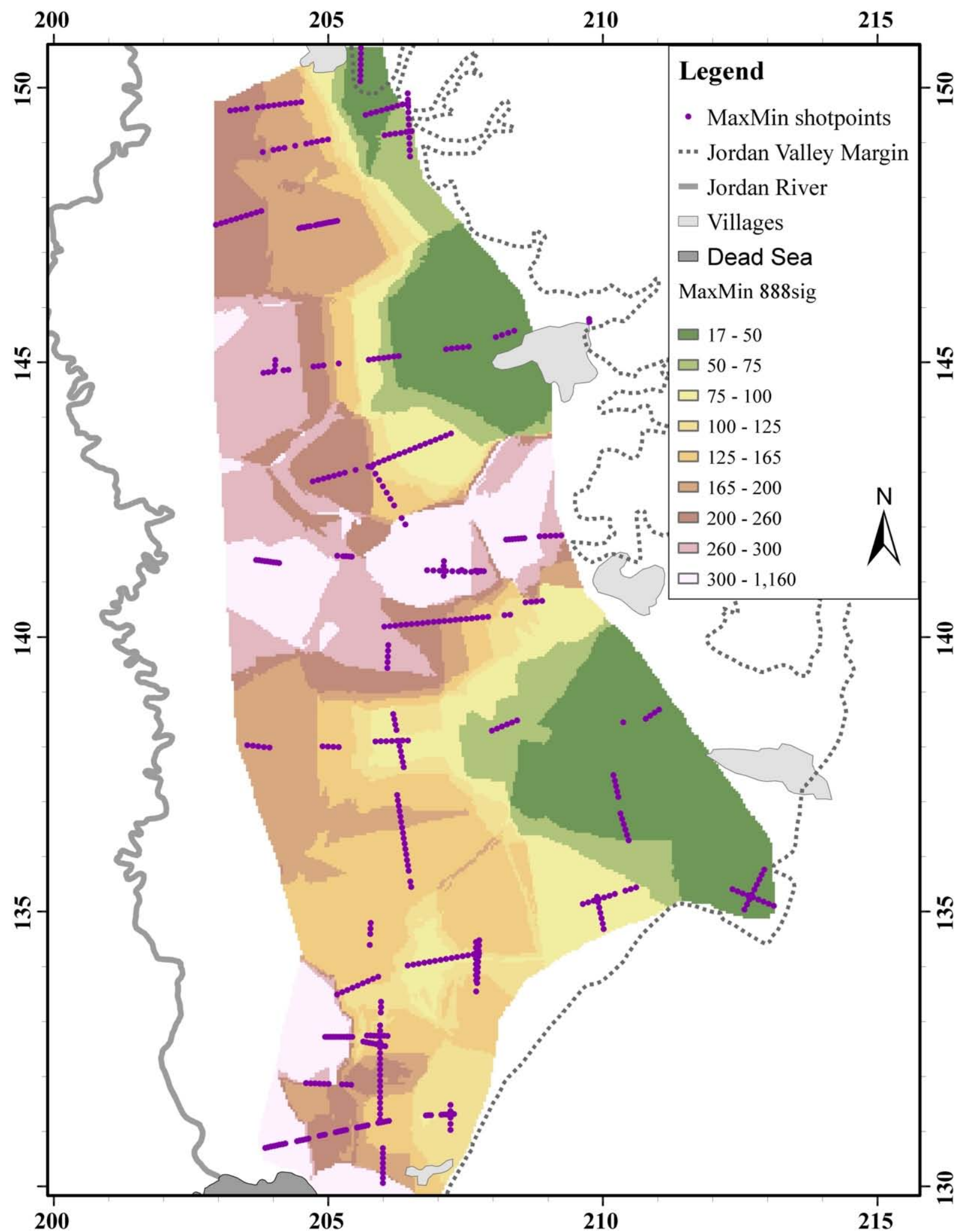

Fig. 5.3-6: Interpolated (universal kriging) plot of the apparent conductivity for one (888 $\mathrm{Hz}$ ) frequency calculated by the MaxMin apparatus. Violet points represent the conducted profiles. 


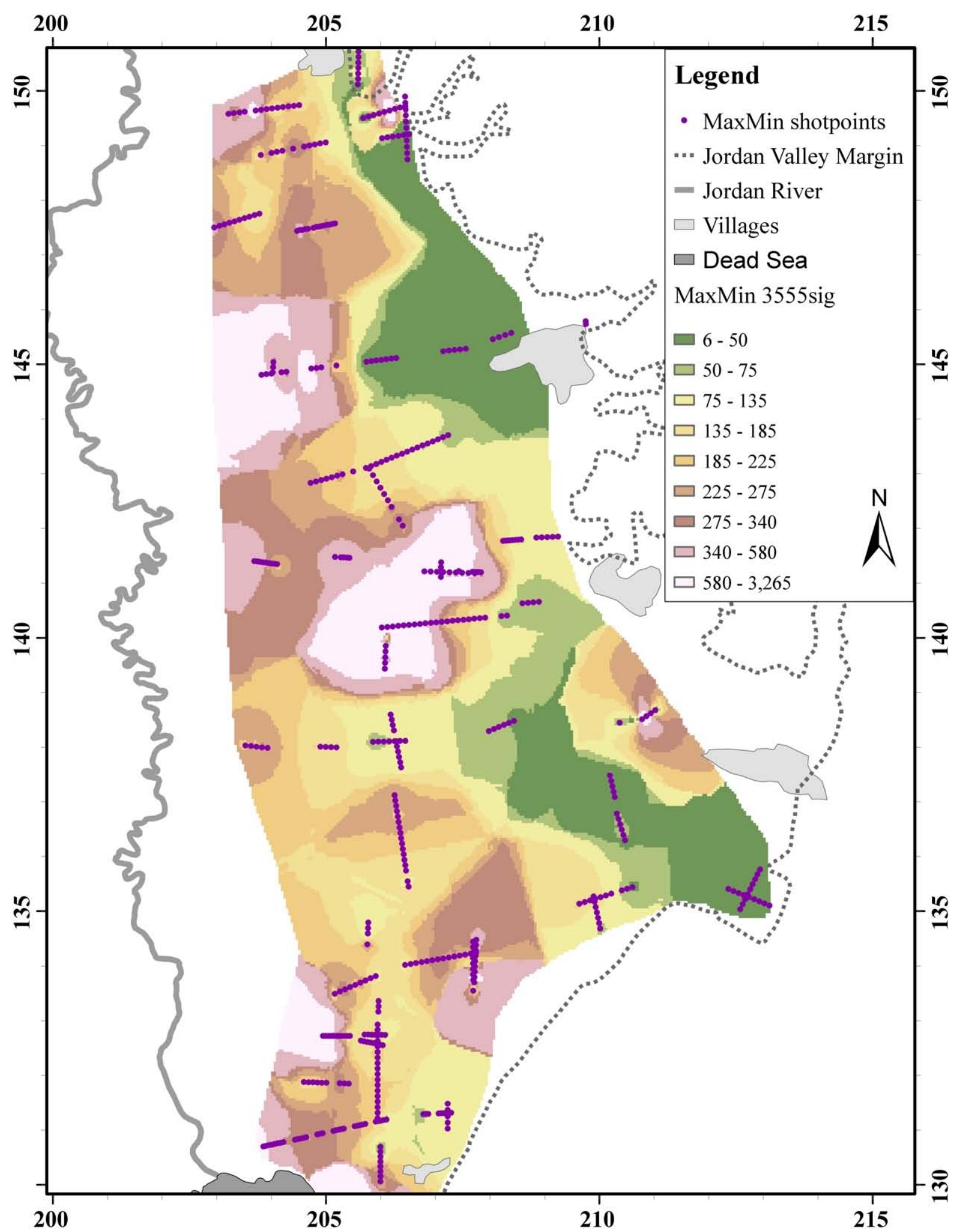

Fig. 5.3-7: Interpolated (universal kriging) plot of the apparent conductivity for one (3,555 Hz) frequency calculated by the MaxMin apparatus. Violet points represent the conducted profiles. 


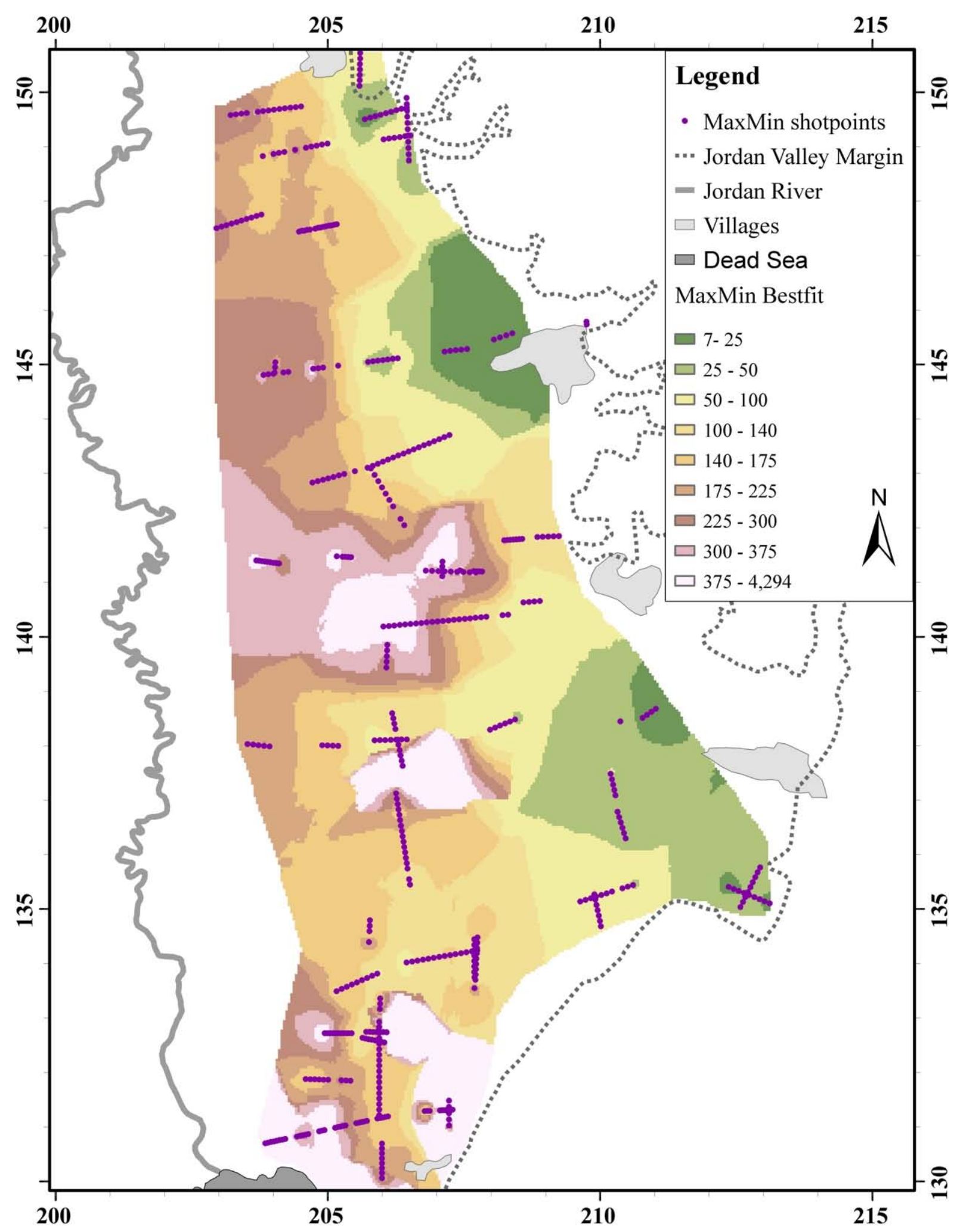

Fig. 5.3-8: Interpolated (universal kriging) plot of the apparent conductivity of the best fit calculated by the MaxMin apparatus. Violet points represent the conducted profiles.MaxMin best fit conductivity. 


\subsubsection{Vertical electric soundings (Schlumberger depth soundings)}

\subsubsection{Introduction}

Surface geoelectric resistivity soundings are a well established method in the investigation of freshsaltwater environments. Notable contributions to this subject are among others Flathe and Pfeiffer (1963), Flathe (1967, 1968), van Dam and Meulenkamp (1967), Zohdy (1969), Ginzburg and Levanon (1976), Urish and Frohlich (1990), and Frohlich et al. (1994). Apart from Flathe (1967) all other researches focused on phreatic coastal aquifers. Within the framework of different geoelectric resisitivity sounding campaigns, Flathe (1967) addressed the interpretation of geoelectrical measurements for solving hydrogeological problems. Examples from inland basins and coastal basins are given, whereby one case study deals with the resistivity distribution in the lower Jordan Valley. This subchapter deals with the applicability of geoelectric resistivity soundings for the characterisation of the unconsolidated aquifer in the study area. First, the principles and interpretation of the method will be discussed. Second, on the basis of sounding results undertaken during the course of this study, the information and limitations of this method will be addressed.

\subsubsection{DC Geoelectric Resistivity Method}

The basis of DC geoelectrics forms the induction of direct current into the subsurface. Fig. 5.3-9 shows the basic principle of a geoelectric resistivity measurement using a general four- electrode configuration. This configuration consists of a pair of current electrodes (A and B) that induce direct current I to the subsurface and a pair of potential electrodes ( $\mathrm{M}$ and $\mathrm{N})$ that measure the potential difference $\Delta \mathrm{U}$. The induction of direct current into the subsurface results in a stationary electrical field. This potential field, which depends on the distribution of the specific electrical resistivities in the subsurface, can be measured. Information regarding the electrical properties of a certain area of the subsurface can be attained from the potential difference between two points on the surface ( $\mathrm{M}$ and $\mathrm{N})$.

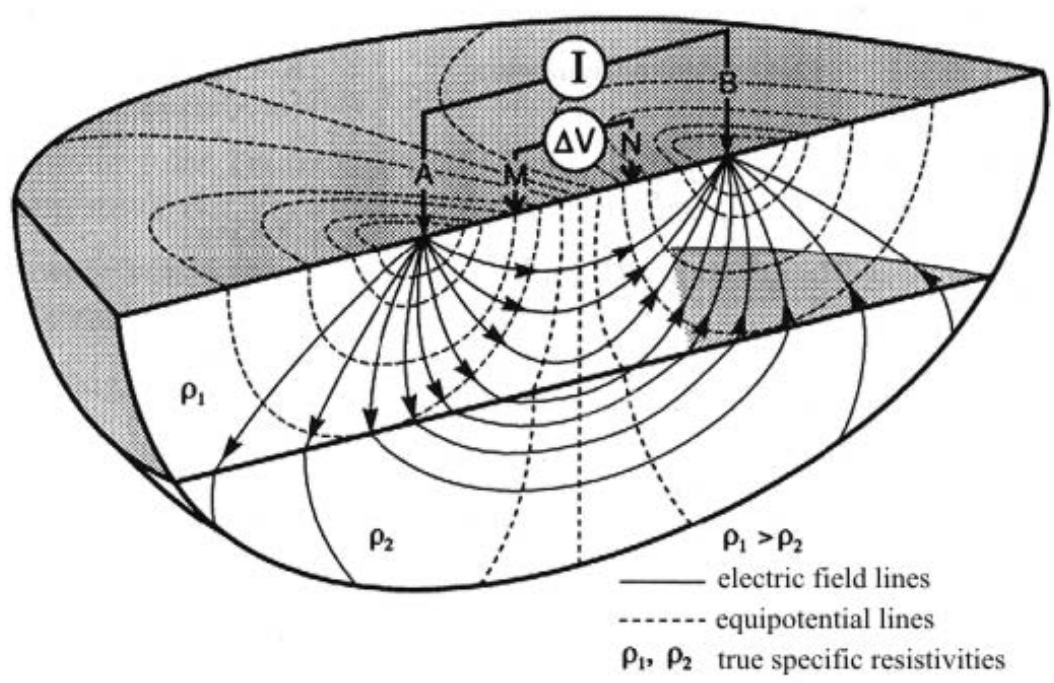

Fig. 5.3-9: The basic Principle of a geoelectric resistivity measurement using a general four- electrode configuration, that consists of a pair of current electrodes (A and B) and a pair of potential electrodes (M and N) (Flathe and Leibold 1976).

The electrodes (usually stainless steel pegs) are connected to the ground in different configurations to each other. By increasing the distance between the current electrodes A and B a deeper penetration of the subsurface by the electrical field can be reached. The penetration depth depends also on the geological set up, which are the electrical properties of the subsurface.

From the induced current $\mathrm{I}$ and the measured voltage $\mathrm{U}$ the resistance $\mathrm{R}$ can be calculated using Ohm's law: 
Taking the arrangement of the four electrodes towards each other into account results in a geometric factor $\mathrm{K}$, which is characteristic for a specific electrode arrangement. Using this factor $\mathrm{K}$, the aerial distribution of the electrical field around a point source either in a homogenous half- space (electrode on the ground) or full- space (electrode noticeable deep in the subsurface) is accounted for (Militzer 1985). The so-called Schlumberger configuration is predestined for vertical electric soundings (VES). The goal is to observe resistivity variations with depth. The mid-point of the Schlumberger array is kept fixed while the distance between the current electrodes is progressively increased. This results in an increasing depth penetration of the current lines, where the penetration depth depends on the resistivity of the subsurface. The geometric factor $\mathrm{K}$ for of the Schlumberger array along with its derivation is shown in Fig. 5.3-10.

\section{Schlumberger}

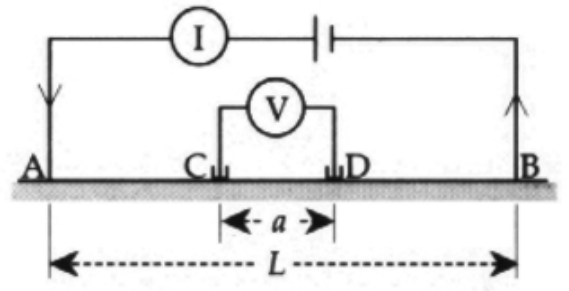

$$
\begin{array}{cc}
r_{\mathrm{AC}}=(L-a) / 2 & r_{\mathrm{AD}}=r_{\mathrm{CB}} \\
r_{\mathrm{CB}}=(L+a) / 2 & r_{\mathrm{DB}}=r_{\mathrm{AC}} \\
\rho_{\mathrm{a}}=\frac{\pi}{4} \frac{V}{I} \frac{\left(L^{2}-a^{2}\right)}{a}
\end{array}
$$

Fig. 5.3-10: Geometry of current and potential electrodes of the Schlumberger configuration (Lowrie 1997).

Under natural conditions the half- or full- space is not homogenous. A subsurface, that consists of layers with different electrical properties (different electrical resistivity) for example, influences the current field between electrode A and B (Fig. 5.3-9). Therefore, the resistivity measured is not the resistivity of a homogene halfspace, which was assumed above, but an apparent specific electric resistivity $\rho_{\mathrm{a}}$ of the subsurface, since the measured resistivity does not represent the true resistivity of any part of the ground (Militzer 1985):

$\rho_{\mathrm{a}}=\mathrm{K} * \mathrm{U}_{\mathrm{MN}} / \mathrm{I}[\Omega \mathrm{m}]$

By taking measurements with different electrode spacings (but maintaining the specific electrode configuration) predictions of electric resistivity for different depths of the subsurface are possible. It should be noted, that a simple direct current can cause charges to accumulate on the potential electrodes, which results in spurious signals. A common practise is to commutate the direct current so that its direction is reversed every few seconds. The little manual written by Flathe and Leibold (1976) proved to be very helpful for the field work. It should be mentioned, that, in order to achieve a electrode coupling to the ground, the electrodes should be watered in order to maintain the transition resistance between the electrodes and the ground low.

\subsubsection{Interpretation}

A first look at the quality of the data and the resistivity depth distribution can be made by plotting the effective electrode spacing (L/2 or $\mathrm{AB} / 2[\mathrm{~m}]$ ) against the measured apparent resisistivity $[\Omega \mathrm{m}]$. A smooth sounding graph should be the result of the measurement (Fig. 5.3-11 left). From the graph it is possible to pick first information about the number of layers and the range of their respective resistivity. A key assumption in depth sounding interpretations is, that material with different electric resistivities is horizontally layered. Should vertical boundaries between electric resistivities also be present, they would be recognized in abnormal and unexpected VES- curves. However, in the case of the study area no vertical boundaries are expected. The information about the number of layers and their respective resistivity range can be used to start one- dimensional inversion of the field data by using iterative procedures. This method assumes equations for theoretical responses of a multi- layered ground. Since only a one- dimensional approach (depth) is used each layer is characterized by its 
thickness and resistivity. Through iterative procedures the theoretical calculated curves are matched to the field data. The procedure is repeated as long as either the theoretical and the field data match to certain small mean error or until a stop criterion is reached. In this case the iterative procedure has to be repeated with different start values. This one dimensional inversion of the field data was undertaken by using the commercial software package RESIX by Interpex Ltd. at the Department of Geophysics at the University of Tübingen.

\subsubsection{Results}

In order to complete a geoelectric picture of the study area, the results of the VES, conducted within the framework of this study, should be seen as complementary soundings to soundings undertaken by previous investigators. The locations of all VES soundings are displayed in Fig. 5.3-5. The results of the VES, their significance, implications, and their limits will be illustrated by using two example VES. The remaining sounding graphs can be seen in Fig. 5.3-18.

Fig. 5.3-11 left shows the sounding graph of a VES at shot point No.2. On the right side possible interpretations of the shot point can be seen. The shortest spacings of $A B / 2$ show an already high conductivity of around $10 \Omega \mathrm{m}$. At bigger spacings the apparent resistivity decreases significantly (down to $4 \Omega \mathrm{m}$ ), before it reaches its maximum at the highest $A B / 2$ spacing. For the sounding graph it can be concluded, that a thin surface layer of a resistivity of around $10 \Omega \mathrm{M}$ is followed by a zone of a very low resistivity which is followed by a higher resistivity zone.
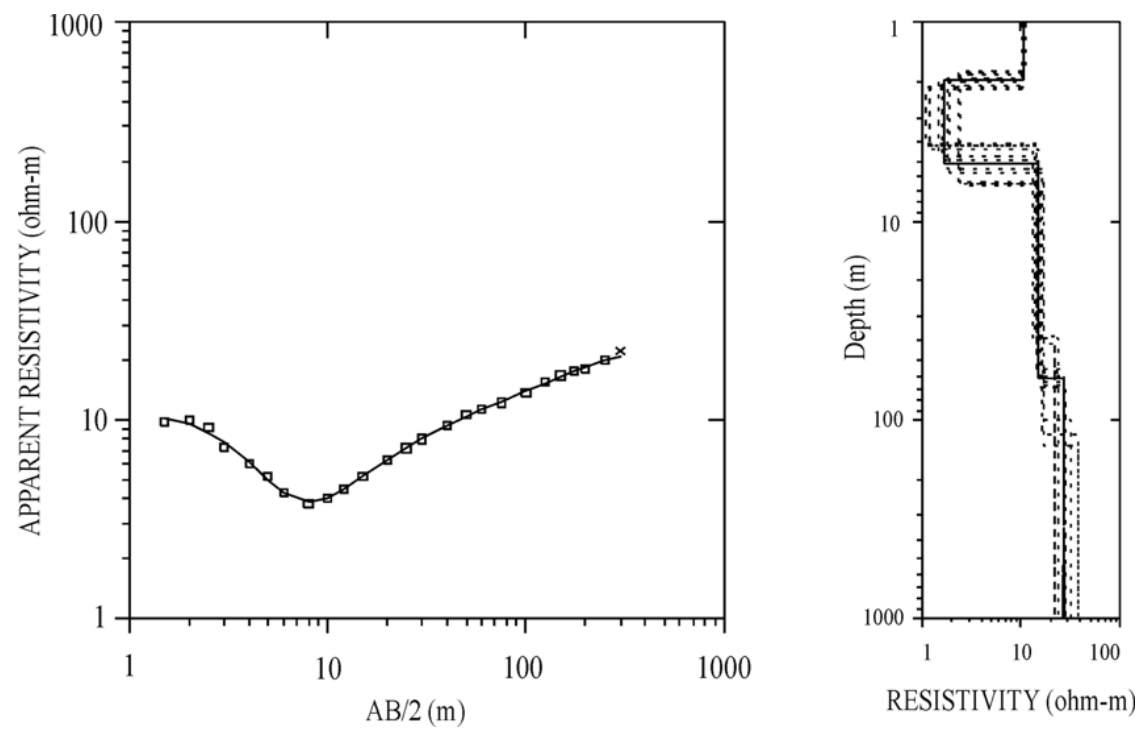

Fig. 5.3-11: Left: Smooth sounding graph of VES No. 2 undertaken within the course of this study (the location can be found in Fig. 5.3-5 (numbering of the VES goes from south to north). Right: Possible interpretations of a four layered model together with equivalence models (up to a mean error of $4 \%$ ).

On the right side of Fig. 5.3-11 an interpretation (solid line) of the shot point as a four- layered model together with a possible equivalent model (dashed lines) can be seen (up to an error of $4 \%$ ). This illustrates one of the problems one faces in interpreting surface geoelectric depth soundings and accounts for most of the surface geophysical methods: the problem of ambiguity. The interpretation difficulty multiplies when the number of layers is not known. This is shown in Fig. 5.3-12. For the sounding graph (E) interpretations as a 4-, 5-, 6-, and 7-layered model (solid line) along with their respective equivalent models (dashed lines, up to an error of $4 \%$ ) were undertaken. A purely physical interpretation of the geoelectric depth soundings cannot be made. However, this problem can be minimized or even eliminated by undertaking reasonable assumptions about the subsurface. These assumptions could be upper and lower resistivities ranges of the different layers and/or their respective thicknesses. These assumptions can be based on the knowledge of the geological underground, and/ or 
calibrations with other available data, like lithological logs of nearby wells or, like in the case of the study area, information about soil salinization and groundwater quality.
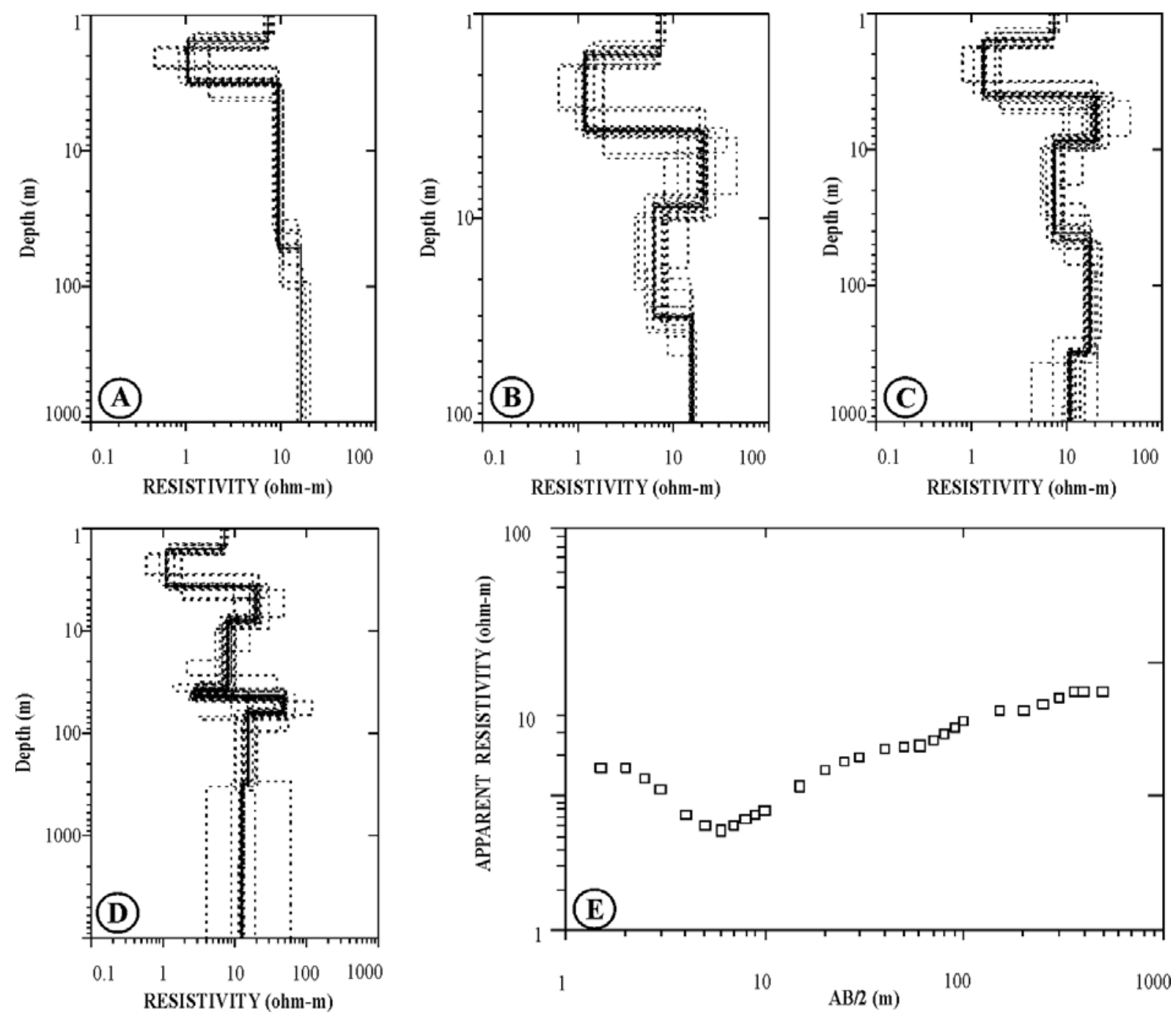

Fig. 5.3-12: Problem of ambiguity illustrated for one measured Schlumberger sounding curve. A: interpreted as a four layer case (including equivalent interpretations); B: interpreted as a five layer case (including equivalent interpretations); C: interpreted as a six layer case (including equivalent interpretations); D: interpreted as a seven layers case (including equivalent interpretations); E: sounding curve that formed the basis for the interpretations. All equivalence models for each layered model are in a range of up to $4 \%$ error tolerance.

The hydrogeological assumptions for the study area are difficult to estimate. The following factors play a role in the electrical conductivity of the subsurface (after Dietrich 1999):

- the geometric properties of the material (porosity, shape and size of the pores, number, shape, and size of the connected pore- necks, tortuosity)

- the degree of fluid saturation

- the concentration of dissolved salts

- temperature

- the amount, nature, and distribution of electric conductive bulk components

- electro-chemical interaction on the matrix surface

Tab. 5.3-1 shows the specific electric resistivity of some selected material, that is present in the study area. These values can be seen as an upper resistivity boundary for VES interpretations. Temperature and the presence of conductive bulk components is minimal. As stated in chapter 5.2, the highest 
variations are expected in the degree of fluid saturation and the concentration of dissolved salt within the different rock material. Therefore, major resistivity change in the subsurface does not depend on the nature of the rock material, but rather on the water saturation and on the concentration of the dissolved salt in the saturated and unsaturated zone. In subchapter 5.3.5.2 the relationship between the dissolved salt content of soil and subsurface conductivity is addressed and discussed on the base of soil analysis from the study area.

Tab. 5.3-1: Specific electric resistivity of some selected material (average values: (a) after Parchomenko 1965 and Dortman 1976, (b) after Nosske 1977; taken from Schön 1983).

\begin{tabular}{|c|c|c|c|}
\hline $\mathbf{( a )}$ & $\mathbf{R}[\mathbf{\Omega m}]$ & $\mathbf{( b )}$ & $\mathbf{R}[\mathbf{\Omega m}]$ \\
\hline Sandstone & $10-10^{4}$ & Quaternary gravel & $200-300$ \\
\hline Sand & $1-10^{4}$ & Quaternary sands & $100-300$ \\
\hline Clay & $1-20$ & Quaternary loam & $\sim 50$ \\
\hline Coal & $10-100$ & Quaternary clay & $\sim 20$ \\
\hline
\end{tabular}

\subsubsection{Comments/ Lesson learned}

Although VES has proved to be a tool for detecting a possible salt/ freshwater interface (Flathe 1967, Van Dam and Meulenkamp 1967, Ginzburg and Levanon 1976), it is difficult to detect exact depths due to large electrode separations, that are needed to penetrate the highly conductive underground of the study area. The processed data of these large separations can only be regarded as average values between these large electrode separations. Like all surface geophysical explorations they suffer from the problem of ambiguity. Therefore, the interpretations of VES proved to be a difficult task. Moreover the resistivity of the subsurface depends mostly on the dissolved salt concentration in the subsurface. Consequently lowering the problem of ambiguity by the means of hydrogeological assumptions is very limited since high variations in soil salinity exist in the study area (= high resistivity variations). It is believed that water flows in the coarse alluvial sediments which deposited during single events and are over- and underlain by clayey to marly lacustrine sediments (chapter 4.2). In order to investigate this geological complicated picture more selective information would be desirable. Hence direct measurements of resistivity with depth and/or of the chemical soil composition are strongly recommended. These pieces of information can be obtained by the employment of the Geoprobe direct push technique for larger depths, since they allow an almost undisturbed quick determination of different parameters, such as resistivity, adaptive determination of sampling points, gamma-ray, geotechnical parameters and are, compared to conventional drilling, very quick and reasonably priced. Since the different parameters are directly measured at the tip of the probe and different parameters can be determined at the same time, the problem of equivalence and or ambiguity can be minimized or even eliminated.

\subsubsection{Geoprobe direct-push geoelectric Measurements}

\subsubsection{Introduction}

As stated before, investigating the unconsolidated aquifers in the Jordan Valley is a challenging and ambitious task. Hence direct measurements of geological composition and geoelectrical resistivities are desirable. The employment of the Geoprobe direct push technique for larger depths has proved to be a suitable tool for reasons stated before. The Geoprobe 6610DT equipment was made available by the Centre for Applied Geoscience at the University of Tübingen and shipped to the study area.

\subsubsection{Method}

The method applied works according to the direct-push principle. Direct pushing (or hammering) of a measurement or coring probe into the ground forms the principle of the applied method (hence "directpush" technique). Since the different parameters are directly measured at the tip of the probe and 
different parameters can be determined at the same time, the problem of equivalence and/or ambiguity can be minimized or even eliminated.

A geoelectric four point "Pol-Pol" or "Wenner" arrangement located on top of a series of drill rods is pushed into the ground. Consequently the apparent resistivities of the material in the vicinity of the top of the rod is determinable and logging of apparent resitivities with depth is possible. The DC geoelectric method is described in chapter 5.3.3.2. The interpretation is straightforward. Since the electrode configuration (Wenner arrangement) is fixed the electric resistivity is calculated automatically by the recording device along with the depth of the probe and a continuous depth resistivity profile is stored in the measuring device (Fig. 5.3-13 left).

Using drilling rods of two different diameters (i.e. 2 1/8" and 1" inch rods), soil samples from any desired depth can be taken. Samples are not taken with the help of coring rods, but are taken with the help of disposable plastic tubes. Soil samples were taken from different depths and analysed for major ions.

The groundwater table was often encountered during the measurements. Since the degree of salinization of the subsurface soil and groundwater is of major interest, the depth of the water table and field parameters ( $\mathrm{pH}$, temperature, and electric conductivity) were determined, and water samples from various boreholes were taken.

\subsubsection{Results}

In the study area 21 direct-push geoelectric depth soundings were undertaken (Fig. 5.3-14). The lowest resistivities were found in the soundings E08, E01, E05, E10, and E20. The extremely low resistivity in the upper part of E08 can be attributed to two factors: the presence of the Lisan Formation and the high water content in the upper soil. In E05 the influence of a very shallow water table on resistivity variations can be seen very clearly. Here the groundwater table is as shallow as $18 \mathrm{~cm}$ below ground level. Capillary forces move the groundwater even up to the soil surface. Steady-state evaporation of groundwater in the area results in the formation of salt crusts on top of these soils as well as salt accumulation in the uppermost part of the soil. The soil in this areas consists of very fine sand to silty sand and is homogeneous in the studied section. In the profile of E05 high resistivity values are found in the top soil. These can be attributed to the low water content in this area. From the uppermost area down to the water table the resistivity decreases significantly down to $0.2 \Omega \mathrm{m}$ before it increases again to a value of about $1 \Omega \mathrm{m}$.

However, mostly no correlation between the encountered water table and strong resistivity variations exist. Higher resistivity variations occur in the upper two to four meters. Here, the resistivity can vary up to three orders of magnitude (E05, E15), but usually is not more than two order of magnitudes. These changes could most probably be attributed to changes in the water content of the upper soils and will be described in chapter 5.3.5 on the basis of the sounding E17.

Concerning the deeper part of the depth profiles, the highest resistivities can be found in the profiles taken west of Rama (E15 to E18), lowest west- northwest of Kafrein (E20 to E22). Resistivity variation in the deeper part of the profiles is usually smaller than one order of magnitude (between 1 to maximum 10).

\subsubsection{Comments/ Lessons learned}

The biggest advantage of direct-push geoelectrics is the direct measurement of resistivity with depth on the tip of the probe. No integration of different resistivity values of larger portions of the subsurface, as in the case of surface geoelectrics, is necessary. High resolution of the resistivity depth profiles are the result. Furthermore, more than one measurement can be performed in the borehole. It could be seen, that the water table has mostly no strong influence on the subsurface resistivity. As a result no sharp interface is developed around the water table, but rather a zone of lower resistivity. Usually a zone of lower resistivity can be seen above the water table. Soil sampling at the sampling points shows on the one hand a correlation between the soils and subsurface resistivity (E08) and on the other hand it shows a correlation between the water saturation of the sediments and the electrical resistivity (E05). This information can be used for calibrating surface VES. In order to properly calibrate VES (to see the true depth variation of resistivity) more than one depth sounding should be 
undertaken per one VES profile. One example of calibrating a VES with the help of direct-push can be seen in Fig. 5.3-13. Fig. 5.3-13 also illustrates the sensitivity to resistivity variations in the subsurface for both methods. The limitation of the direct-push geoelectric method is the small penetration depth of 20 to 30 meters compared to the penetration depth of surface VES. However, high electrode spacing and a powerful equipment for surface VES are necessary to penetrate bigger depths in a brackish environment. In boulder dominated area, like in the upper- and mid-fan areas no large penetration depths can be reached. Therefore the method is only applicable in the distal-fan area.
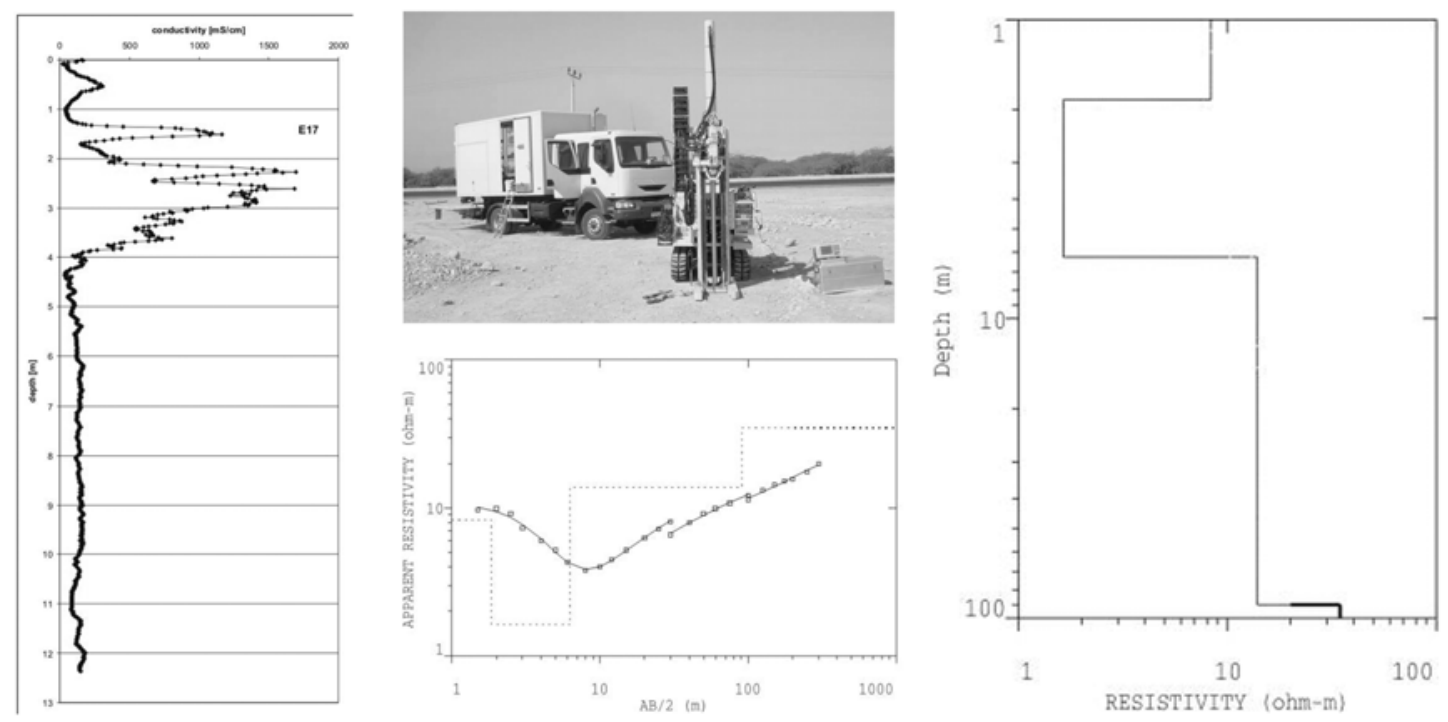

Fig. 5.3-13: A direct-push geoelectric depth profile versus a surface Schlumberger depth sounding. The soundings are made in the same location, about six km north of the Dead Sea.

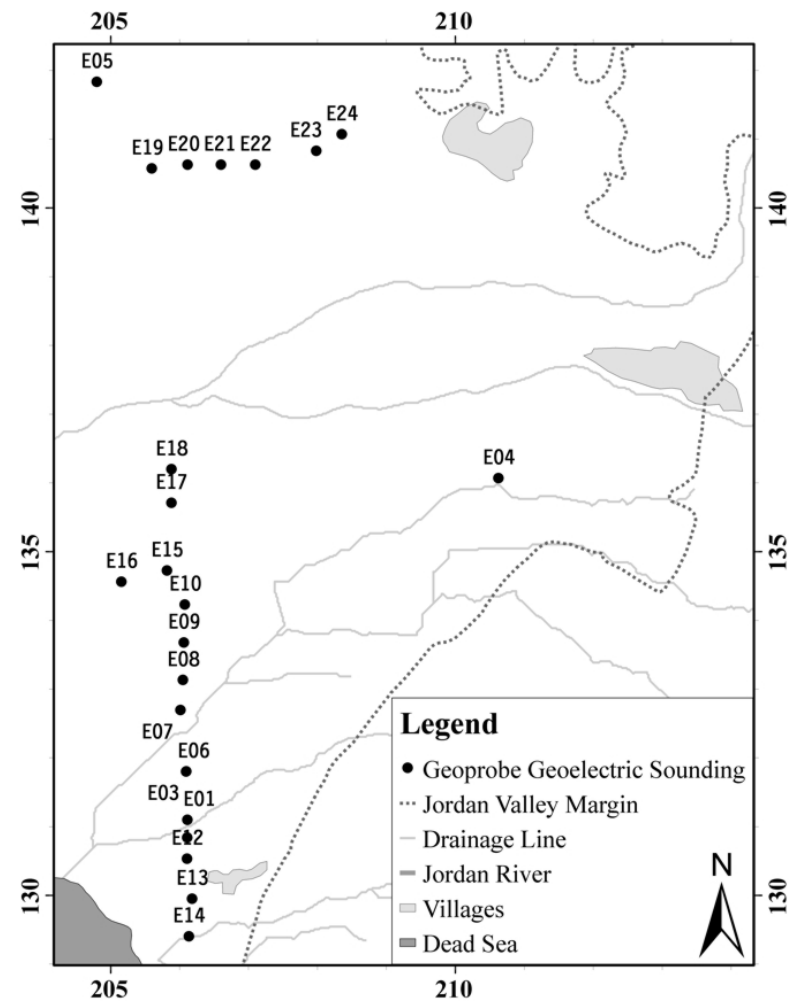

Fig. 5.3-14: Geoprobe geoelectric depth sounding points. 

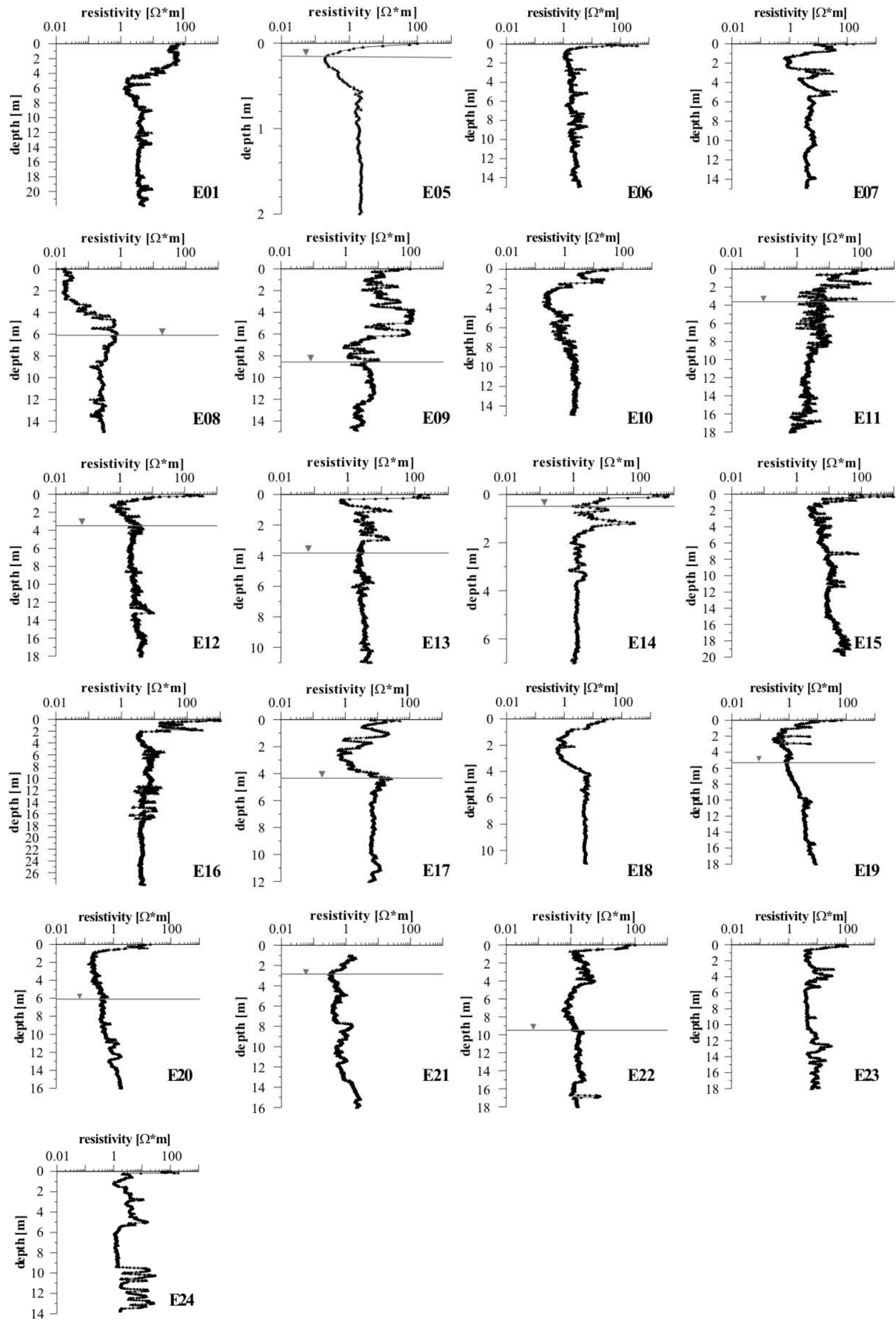

Fig. 5.3-15: Results of the Geoprobe geoelectric soundings. In places where the groundwater table was encountered the encountered depth below ground level is plotted as a straight line. 


\subsubsection{Chemical analysis of soil samples}

\subsubsection{Introduction and Method}

Investigations by the direct-push geoelectric method showed, that high resistivity variations in the upper part of the subsurface exist (chapter 5.3.4.3). These high variations cannot be explained by the change of the nature of the subsurface material. Variations in the pore fluid (water saturation, salts dissolved in the pore fluid, etc.) was assumed. In order to obtain more information of the degree and nature of the "upper" salinisation and to correlate the direct-push measurements, depth oriented soil samples were taken and analysed for major ion components from soil eluates given by the DIN38414 Teil 4. The water extract was analysed by using ion chromatography. Anions were analysed on Dionex D320 KOH isocratic ASMHC and the cations on Dionex DX500 MSA isocratic CS16.

\subsubsection{About soil salinity, water content and their relation to electrical resistivity}

In the following paragraph different approaches regarding the calculation of the specific electric resistivity of the pore fluid on the base of different parameters like water saturation, salts dissolved in the pore fluid, etc. will be discussed.

\section{$\underline{\text { Conductivity calculation of pore fluids }}$}

Low salt concentrations

For low salt concentration in solutions, ion interactions are negligible. For the conductivity of saline solutions $\sigma_{\mathrm{f}}$ the following relationship exists (after Schön 1996):

$$
\sigma_{f} \propto \sum_{i=1}^{N} \alpha_{i} C_{i} z_{i} v_{i} \quad \begin{array}{ll}
N_{i}: & \text { Number of Ions involved } \\
\alpha_{i}: \text { Degree of dissociation }, C_{i}: \text { Concentration }, z_{i}: \text { Valence } \\
v_{i}: \text { Motility of the ion i in solution, temperature dependent }
\end{array}
$$

After Keller and Frischknecht 1966 the electrical conductivity of fluids with low salt concentrations can approximately be calculated by using the following equation:

$$
\begin{gathered}
\sigma_{f}=F a \sum_{i=1}^{N_{i}} C^{a ̈ q}{ }_{i} v_{i} \quad \begin{array}{l}
F a: \text { Faraday constant } \quad F a=9,64845^{*} 10^{4} \mathrm{As} / \mathrm{mol} \\
C_{i}{ }^{a} q \text { : Equivalent concentration of available ions, } \\
=\text { concentration } \mathrm{C}_{\mathrm{i}} * \text { valence } \mathrm{z}
\end{array} \\
v_{i}: \text { Motility of the ion i in solution, temperature dependent }
\end{gathered}
$$

High salt concentrations

Unlike water solutions with low concentrations of dissolved salts, the mobility of ions in solution is limited. This reduces the electrical conductivity of the pore fluid. Therefore additional empiric parameters have to be included. A formula for resistivity calculations of $\mathrm{NaCl}$ solutions can be found at Worthington et al. 1990:

$$
\begin{aligned}
& \lg (\sigma \mathrm{f})=\mathrm{c1}+\mathrm{c} 2 * \lg \mathrm{C}_{\mathrm{mol}}+\mathrm{c} 3 *(\operatorname{lgC} \mathrm{mol})^{2}+\mathrm{c} 4 *\left(\operatorname{lgC} \mathrm{mol}^{3}+\mathrm{c} 5 *\left(\lg \mathrm{C}_{\mathrm{mol}}\right)^{4}\right. \\
& \\
& C_{m o l}[\text { mol/l]: Molar concentration of a NaCl solution } \\
& c 1-c 5: \text { concentration dependent empirical parameters }
\end{aligned}
$$

For ions other than $\mathrm{Na}^{+}$and $\mathrm{Cl}^{-}$dissolved in fluids a conversion to an equivalent $\mathrm{NaCl}$ concentration must be undertaken. Such a conversion is given by Desai and Moore (1969), where each ion has to be multiplied by factor, that can be derived from a chart (Fig. 5.3-16). The factor for each ion depends on the concentration of the total solids in solution. In Fig. 5.3-16 an example to determine the multiplier for $\mathrm{Ca}^{2+}$ and $\mathrm{Mg}^{2+}$ in a solution with $152 \mathrm{kppm}$ is shown. The multiplier for $\mathrm{Na}^{+}$and $\mathrm{Cl}^{-}$are both 1 . 
Since salt concentration within the soil of the study area are high, this approach is used for the following calculations.

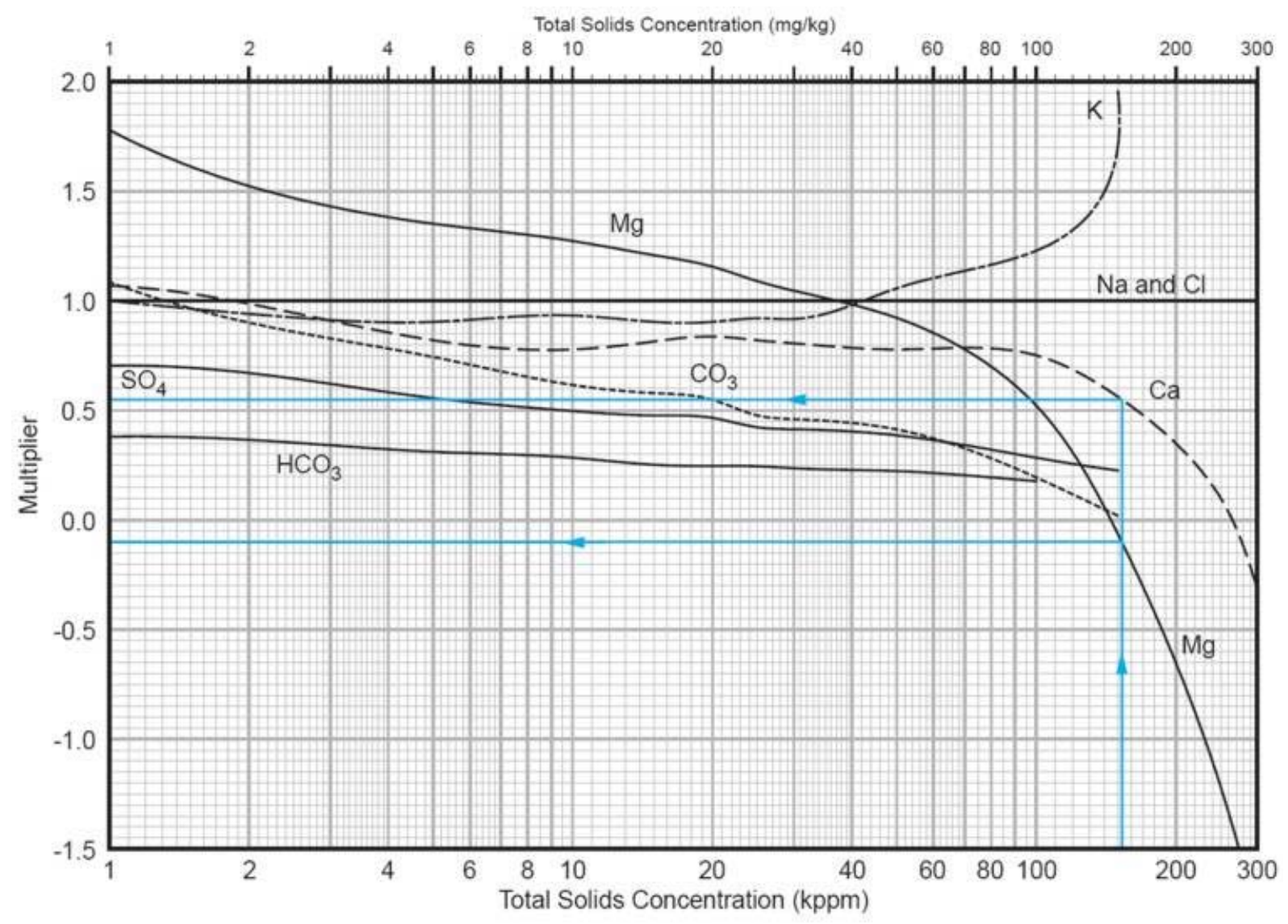

Fig. 5.3-16: Determination multipliers for salt solutions of different concentrations (after Desai and Moore 1969).

Saturated zone

If the subsurface material is saturated with conductive pore fluids, the bulk conductivity is negligible (Schön 1983). Therefore the total conductivity of the subsurface is determined by the contingent of the total volume of the pore fluid, which is in turn dependant on the porosity and the fluid saturation.

Assuming that the bulk conductivity $\sigma_{\mathrm{m}}$ in comparison with the conductivity of the pore fluid $\sigma_{\mathrm{f}}$ is negligible, the specific electrical resistivity of fully saturated material $\rho_{\mathrm{g}}$ can be described using the following relationship $\left(\sigma_{\mathrm{m}}<<\sigma_{\mathrm{f}}\right)$ :

$$
\sigma_{g}=\frac{\sigma_{f}}{F} \quad \text { or } \quad \rho_{g}=F * \rho_{f} \quad \text { where } \quad F=\frac{a}{P^{m}}
$$

The formation factor $F$ was empirical developed by Archie (1950) on the basis of drilling cores and characterizes the enlargement of the specific electric resistivity by the presence of a non-conductive rock matrix (formation). Therefore the formation factor depends on the inner structure of the pore volume and its moistening. Isolated water inclusion within the rock matrix have no effect on the conductivity of the subsurface (high resistivities). With increasing water saturation continuous current path lines develop. Therefore the formation factor is determined mostly by the geometric development of the conductive pore fluid in the bulk material. 
The empirical determined factor $a$ depends on the subsurface material. Dachnov (1962) estimated a = 1 for loose sands. Archie (1942) and Pirson (1963) also estimated the value of 1 for other unconsolidated material.

$P$ represents the effective porosity.

The cementation exponent $m$ depends on the consolidation of the subsurface material. For unconsolidated material $\mathrm{m}$ is influenced mostly grain shapes, which represents the of the pore channels. For rounded grains $\mathrm{m}$ is lower than for angular grains. Sand has a m value between 1.2 to 1.7 (unconsolidated sand around 1.3) and clay a range of m values between 1.8 and 3.0 (Dachnov 1962 and 1975, taken from Schön 1983).

Unsaturated zone

By building the ratio between the specific electric resistivity of saturated material to the water saturation the specific electrical resistivity for partial saturated rocks can be calculated:

$$
\begin{array}{ll}
\rho_{g t}=\frac{\rho_{g}}{S w^{n}} & \begin{array}{l}
\rho_{g t}: \text { Electrical resistivity of partial saturated rocks } \\
\rho_{g}: \text { Electrical resistivity of saturated rocks } \\
S w: \text { Water saturation } \\
n: \text { Saturation exponent }
\end{array}
\end{array}
$$

The saturation exponent $\mathrm{n}$ is also an empirical factor. Archie (1942) and Schlumberger (1989) give an average factor of 2. Following Worthington and Pallatt (1989) other values can be possible, where $n$ depends also on the saturation history, which is the sequence of previous saturation conditions and their respective capillary effects (Wothington et al. 1989 and 1990, Knight 1991).

For partial saturated rocks the following relation exists (following (6) and (7):

$$
\rho_{\mathrm{gt}}=\frac{\rho_{\mathrm{f}}}{\mathrm{Sw}^{\mathrm{n}} * \mathrm{P}^{\mathrm{m}}}
$$

Implementing (8) to the study area (lose sands: $m=1.3$ or marl: $m=2$ ) and assuming $n=2$ results in:

$$
\rho_{\mathrm{gt}}=\frac{\rho_{\mathrm{f}}}{\mathrm{Sw}^{2} * \mathrm{P}^{1.3}}
$$

Which shows the clear impact of water saturation on the specific electric resistivity.

\subsubsection{Method and Results}

The geoelectric direct-push locations E17 and E05 (location see Fig. 5.3-14) were chosen, because they represent two different situations encountered during the field campaigns. In the upper part of the soil E17 shows very low resistivities (Fig. 5.3-17), which is characteristic for the area and can be seen in most of the geoelectric direct-push soundings. The sounding E05 is a location where steady-state evaporation of a shallow groundwater table takes place. Consequently, salt accumulation in the uppermost part of the soil takes place. The degree of soil salinity for both locations was of major interest.

Next to the sounding locations (not more than half a meter away from the geoelectric direct-push sounding locations) soils samples were taken with the help of the direct-push drilling device Geoprobe 6610DT. The samples were taken using disposable plastic tubes, sealed, and stored until they were 
analysed at the laboratory of the University of Göttingen. However, it was not possible to store the plastic tubes under cool conditions. As a results the plastic tubes were exposed to heat for almost two months. Therefore the water content of the soil samples did not reflect the actual water content of the undisturbed soil. Another disadvantage is that the samples could not be stored in an upright position, but in a horizontal position. Furthermore the plastic tubes are small in diameter and the soil samples are compressed. As a result it is not possible to take undisturbed soil samples.

Tab. 5.3-2 shows the major ion component from soil eluates of the samples taken. As far as E17 is concerned high salt concentrations can be found in the upper $60 \mathrm{~cm}$ of the soil (E17-1 through -6), in the sample E17-15 and 16 (around 1.5 and $1.6 \mathrm{~m}$ below ground level), and a local higher salt concentration in E17-23 and 24 (around 2.3 to $2.4 \mathrm{~m}$ below ground level). However the depth designation to this location is not clear, since these samples were taken from the end of the disposable plastic tube and it is not clear, if the samples truly represent the drilled depth. Therefore these samples were excluded from further procession. The sample E05 shows the highest amount of salts in the first three samples $(\mathrm{E} 05-2,3,4)$ which are located 20, 30, and $40 \mathrm{~cm}$ below ground surface.

However, the salt concentration shown above is defined by mg of salt per $\mathrm{kg}$ of soil. In order to calculate the theoretical electrical resistivity of the soil samples the maximum possible salt concentration of pore water stored in the soil samples has to be determined. The following assumptions have been made: $1^{\text {st }}$, water can be stored in the soil up to its porosity value, a value of $45 \%$ was assumed for further calculations; $2^{\text {nd }}$ the bulk density of the soil is $1.5\left[\mathrm{~g} / \mathrm{cm}^{3}\right]$. Taking these two assumptions results in a maximum amount of $300 \mathrm{ml}$ water, that can be stored in one $\mathrm{kg}$ of soil. The next assumption is, that if pore water exists, the salt load of the salt is dissolved in the pore water. All values from Tab. 5.3-2 are converted into $\mathrm{mg}$ of salt per $\mathrm{L}$ of pore water. The calculated electrical resistivity from the soil eluates were calculated by the formulas given in chapter 5.3.5.2.

Tab. 5.3-3 shows the results of the carbonate and grain size analysis together with the calculated electrical resistivity of the soil analysis and the geophysical calculated electrical resistivity of the direct-push measurement for the samples E17 and E05. The results are also plotted in Fig. 5.3-17. It should be noted, that the water content of the samples was multiplied by four. The original water content of the undisturbed soil samples could not be preserved as mentioned above. Therefore this adaptation was made. After this adaptation the results of E17 fit into the geophysical measured range. The lower four samples were determined by the formula given for saturated conditions, since the samples were taken below the groundwater table. A large discrepancy between the calculated electrical resistivity and the measured resistivity at sample location E05 exist. 
Tab. 5.3-2: Depth oriented soil samples analysed for major ion components from soil eluates given by the DIN38414 Teil 4. The water extract was analysed by using ion chromatography. Anions were analysed on Dionex D320 KOH isocratic ASMHC and the cations on Dionex DX500 MSA isocratic CS16. The number, that fallows the location name is the depth below ground level in $\mathrm{dm}$.

\begin{tabular}{|c|c|c|c|c|c|c|c|c|c|c|}
\hline Sample & $\mathrm{Na}$ & K & Mg & $\mathrm{Ca}$ & $\mathrm{Cl}$ & $\mathrm{SO}_{4}$ & F & $\mathrm{Br}$ & $\mathrm{NO}_{3}$ & $\mathrm{HCO}_{3}$ \\
\hline & mg/kg & $\mathrm{mg} / \mathrm{kg}$ & $\mathrm{mg} / \mathrm{kg}$ & $\mathrm{mg} / \mathrm{kg}$ & $\mathrm{mg} / \mathrm{kg}$ & $\mathbf{m g} / \mathbf{k g}$ & $\mathrm{mg} / \mathrm{kg}$ & $\mathrm{mg} / \mathrm{kg}$ & $\mathrm{mg} / \mathrm{kg}$ & $\mathrm{mg} / \mathrm{kg}$ \\
\hline E17-1 & 4,438.9 & 456.3 & $1,140.3$ & 6,811.9 & $10,213.6$ & $16,782.7$ & 0.5 & 38.7 & 107.4 & 413.0 \\
\hline E17-2 & \begin{tabular}{|l|}
$3,698.3$ \\
\end{tabular} & 398.2 & 995.3 & $7,122.9$ & $8,456.9$ & $17,300.6$ & 0.6 & 35.5 & 89.1 & 473.5 \\
\hline E17-3 & $5,093.2$ & 454.9 & $1,155.4$ & $8,229.4$ & $10,655.0$ & $19,972.0$ & 1.3 & 44.9 & 96.3 & $1,244.3$ \\
\hline E17-4 & $6,612.5$ & 509.4 & $1,127.7$ & $5,872.7$ & $12,851.7$ & $14,068.2$ & 4.1 & 57.7 & 106.7 & $1,736.6$ \\
\hline E17-5 & $6,193.4$ & 480.2 & 959.6 & $5,116.6$ & 11404.0 & $12,567.4$ & 4.8 & 52.4 & 86.0 & $1,852.9$ \\
\hline E17-6 & 6,318.1 & 463.7 & 833.2 & 3,863.1 & 10964.0 & \begin{tabular}{|l|}
$9,797.0$ \\
\end{tabular} & 7.2 & 52.5 & 72.6 & $1,988.4$ \\
\hline E17-7 & $5,468.8$ & 391.3 & 585.0 & $1,998.4$ & 8974.9 & $5,215.3$ & 8.8 & 44.4 & 51.3 & $1,963.0$ \\
\hline E17-8 & $4,630.8$ & 350.3 & 482.8 & $1,576.4$ & 7386.6 & $4,285.8$ & 8.5 & 37.6 & 38.7 & $1,809.5$ \\
\hline E17-9 & \begin{tabular}{|l|}
$3,708.6$ \\
\end{tabular} & 279.3 & 287.1 & 627.6 & 5705.0 & $1,792.2$ & 8.3 & 29.3 & 26.7 & $1,460.2$ \\
\hline E17-10 & \begin{tabular}{|l|}
$3,242.7$ \\
\end{tabular} & 267.5 & 302.5 & 806.1 & 4707.4 & $2,608.4$ & 8.3 & 24.7 & 20.2 & $1,516.1$ \\
\hline E17-11 & $2,038.3$ & 174.4 & 144.5 & 322.5 & 2967.1 & $1,272.9$ & 6.5 & 15.0 & 11.4 & 622.4 \\
\hline E17-12 & $1,207.4$ & 129.6 & 130.3 & 558.9 & 1622.7 & $1,900.8$ & 6.5 & 8.0 & 5.5 & 522.8 \\
\hline E17-13 & $1,145.4$ & 142.2 & 166.7 & $1,456.6$ & \begin{tabular}{|l|}
1503.8 \\
\end{tabular} & $4,237.6$ & 6.5 & 7.1 & 4.1 & 532.2 \\
\hline E17-14 & 1,148.6 & 135.1 & 148.6 & 862.6 & 1418.8 & $2,774.5$ & 7.3 & 7.1 & 3.3 & 633.1 \\
\hline E17-15 & $1,412.8$ & 193.1 & 309.0 & $5,288.8$ & 1863.6 & $13,722.9$ & 7.8 & 6.9 & 1.7 & $1,033.9$ \\
\hline E17-16 & $2,428.3$ & 322.0 & 505.0 & $6,704.6$ & 3067.4 & $17,854.5$ & 11.6 & 11.9 & 2.1 & $1,888.8$ \\
\hline E17-17 & 972.0 & 120.8 & 106.9 & 318.4 & 1237.5 & $1,337.4$ & 5.7 & 6.5 & 1.9 & 420.6 \\
\hline E17-18 & 538.4 & 66.9 & 38.8 & 94.9 & 685.6 & 341.0 & 5.3 & 3. & .5 & 382.6 \\
\hline E17-19 & 306.8 & 49.2 & 43.1 & 193.8 & 399.9 & 571.6 & 2.4 & 2.2 & 0.9 & 272.8 \\
\hline E17-20 & 229.4 & 35.5 & 23.2 & 77.0 & 335.3 & 170.3 & 3.1 & 1.9 & 0.9 & 209.3 \\
\hline E17-21 & 245.4 & 38.9 & 29.4 & 86.8 & 372.8 & 236.2 & 3.6 & 2.1 & 1.2 & 168.0 \\
\hline E17-22 & 257.9 & 37.7 & 26.9 & 65.8 & 385.4 & 154.3 & 2.7 & 2.2 & 1.5 & 207.5 \\
\hline E17-23 & 785.0 & 95.5 & 84.4 & 170.0 & 1262.9 & 682.7 & 4.9 & 6.3 & 3.0 & 109.5 \\
\hline E17-24 & 514.9 & 76.5 & 60.5 & 127.8 & 819.6 & 482.1 & 5.8 & 3.6 & - & 134.7 \\
\hline E17-37 & 438.5 & 62.1 & 64.6 & 132.8 & 758.1 & 245.5 & 11.3 & 3.3 & 0.4 & 333.2 \\
\hline E17-38 & 549.1 & 75.7 & 71.8 & 131.5 & 889.0 & 295.3 & 12.3 & 4.0 & 0.3 & 388.2 \\
\hline E17-39 & 370.1 & 58.3 & 43.6 & 87.9 & 509.4 & 207.5 & 11.9 & 2.6 & 1.1 & 377.9 \\
\hline E17-61 & 183.6 & 107.0 & 44.8 & & & 163.8 & & 1. & .9 & 465.1 \\
\hline E17-63 & 204.4 & 114.1 & 51.1 & 108.2 & 327.1 & 200.6 & 10.9 & 2.7 & 1.1 & 455.8 \\
\hline E17-65 & 236.5 & 124.5 & 58.3 & 114.6 & 366.3 & 210.4 & 11.6 & 3.1 & 1.5 & 530.4 \\
\hline E17-108 & 146.2 & 30.0 & 53.4 & 131.4 & 404.3 & 179.2 & 2.7 & 2.8 & 0.4 & 171.7 \\
\hline E17-110 & 96.7 & 21.1 & 37.9 & 123.6 & 290.4 & 146.8 & 1.9 & 2.3 & 1.3 & 163.0 \\
\hline E17-112 & 55.9 & 19.6 & 27.3 & 100.0 & 145.4 & 115.2 & 1.7 & 1.2 & 0.4 & 216.8 \\
\hline E05-2 & $16,125.2$ & 640.9 & 3,709.9 & $21,245.7$ & $34,649.0$ & $50,902.7$ & - & 224.0 & $1,814.1$ & \begin{tabular}{|l|l}
862.6 \\
\end{tabular} \\
\hline E05-3 & $12,932.7$ & 685.2 & $2,996.4$ & $2,213.8$ & $30,344.4$ & 781.1 & - & 236.6 & $1,672.2$ & $2,135.3$ \\
\hline E05-4 & $13,552.2$ & 871.3 & $3,419.8$ & 2,628.9 & $32,722.8$ & 687.4 & - & 296.6 & $1,862.0$ & $3,252.9$ \\
\hline E05-6 & $10,793.2$ & 878.4 & $2,283.9$ & 2,488.1 & $25,657.3$ & 625.5 & - & 242.0 & $1,423.5$ & $2,521.3$ \\
\hline E05-7 & $8,284.5$ & 782.1 & $1,550.3$ & $1,772.9$ & $19,326.6$ & 463.3 & - & 199.8 & $1,058.7$ & $1,344.9$ \\
\hline E05-8 & 3,292.1 & 406.4 & 233.4 & 453.6 & $5,889.3$ & 504.8 & 10.7 & 74.8 & 326.4 & 735.1 \\
\hline E05-9 & $2,744.1$ & 349.9 & 159.2 & 364.8 & $4,552.3$ & 456.4 & 17.5 & 60.8 & 253.8 & 972.2 \\
\hline E05-10 & 2,018.6 & 264.2 & 106.7 & 293.3 & $3,144.8$ & 441.2 & 25.7 & 41.9 & 170.9 & 942.8 \\
\hline E05-11 & 1,569.1 & 215.4 & 93.6 & 259.4 & $2,521.5$ & 450.2 & 24.5 & 31.1 & 125.3 & 622.9 \\
\hline E05-12 & $1,231.4$ & 184.5 & 78.5 & 224.3 & $1,913.7$ & 443.9 & 26.0 & 23.5 & 92.7 & 582.9 \\
\hline E05-13 & $1,099.3$ & 173.0 & 84.7 & 201.9 & $1,600.1$ & 480.6 & 25.1 & 18.9 & 71.7 & 697.6 \\
\hline E05-14 & $1,006.5$ & 161.2 & 66.5 & 169.3 & $1,328.2$ & 477.3 & 27.7 & 14.8 & 53.3 & 727.1 \\
\hline E05-15 & 959.7 & 147.5 & 56.8 & 149.5 & $1,213.4$ & 443.1 & 26.5 & 12.9 & 44.9 & 727.3 \\
\hline
\end{tabular}




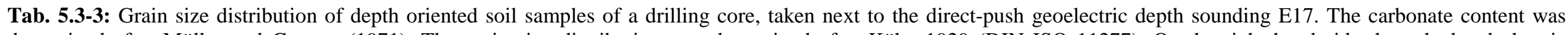
determined after Müller and Gastner (1971). The grain size distribution was determined after Köhn 1929 (DIN ISO 11277). On the right hand side the calculated electric

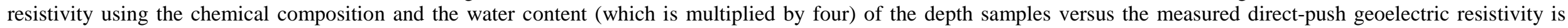
shown.

\begin{tabular}{|c|c|c|c|c|c|c|c|c|c|c|c|c|c|c|c|c|c|c|}
\hline \multirow[b]{2}{*}{ Sample } & \multicolumn{3}{|c|}{ Carbonate } & \multicolumn{6}{|c|}{ Silicate } & \multicolumn{6}{|c|}{ 100\% Silicate } & \multirow[b]{2}{*}{$\mathbf{W}$} & \multirow[b]{2}{*}{ calc elec. Res. } & \multirow[b]{2}{*}{ m. elec Res. } \\
\hline & $\mathrm{CaCO}_{3}$ & $\mathrm{MgCO}_{3}$ & tot $\mathrm{CO}_{3}$ & $\mathrm{SiO}_{2}$ & $>63$ & $20-63$ & 6,3-20 & $2-6,3$ & $<2$ & $\mathrm{SiO}_{2}$ & $>63$ & 20-63 & 6,3-20 & $2-6,3$ & $<2$ & & & \\
\hline & [\%] & [\%] & [\%] & [\%] & [\%] & [\%] & [\%] & [\%] & [\%] & [\%] & [\%] & [\%] & [\%] & [\%] & [\%] & {$[-]$} & {$[\Omega \mathrm{m}]$} & [Wm] \\
\hline E17-1 & 24.63 & 3.23 & 27.86 & 72.14 & 40.49 & 9.95 & 6.42 & 5.58 & 9.71 & 100 & 56.12 & 13.79 & 8.89 & \begin{tabular}{|l|}
7.73 \\
\end{tabular} & 13.46 & 0.20 & 10.77 & 18.03 \\
\hline E17-2 & 23.88 & 4.48 & 28.36 & 71.64 & 48.99 & 8.90 & 5.28 & 3.85 & 4.62 & 100 & 68.38 & 12.43 & 7.36 & 5.37 & 6.45 & 0.22 & 9.77 & 18.58 \\
\hline E17-3 & 30.35 & 4.97 & 35.32 & 64.68 & 35.36 & 9.81 & 7.29 & 5.12 & 7.11 & 100 & 54.67 & 15.17 & 11.27 & 7.92 & 10.99 & 0.29 & 4.91 & 11.61 \\
\hline E17-4 & 28.86 & 4.97 & 33.83 & 66.17 & 33.53 & 14.02 & 8.59 & 4.30 & 5.73 & 100 & 50.67 & 21.19 & 12.98 & 6.50 & 8.66 & 0.37 & 2.82 & 5.63 \\
\hline E17-5 & 31.09 & 3.73 & 34.83 & 65.17 & 32.94 & 10.38 & 8.98 & 4.65 & 8.22 & 100 & 50.55 & 15.93 & 13.78 & \begin{tabular}{|l|}
7.14 \\
\end{tabular} & 12.61 & 0.40 & 2.60 & 3.98 \\
\hline E17-6 & 32.78 & 4.97 & 37.75 & 62.25 & 29.14 & 13.22 & 9.23 & 5.01 & 5.65 & 100 & 46.81 & 21.24 & 14.83 & 8.05 & 9.07 & 0.40 & 2.67 & 3.63 \\
\hline E17-7 & 30.40 & 2.49 & 32.89 & 67.11 & 33.17 & 15.16 & 8.24 & 5.31 & 5.24 & 100 & 49.42 & 22.58 & 12.27 & 7.91 & 7.81 & 0.39 & 3.40 & 5.90 \\
\hline E17-8 & 29.80 & 3.48 & 33.28 & 66.72 & 35.03 & 11.17 & 7.62 & 3.91 & 8.99 & 100 & 52.50 & 16.74 & 11.43 & 5.86 & 13.48 & 0.36 & 4.82 & 8.11 \\
\hline E17-9 & 29.90 & 1.99 & 31.89 & 68.11 & 37.84 & 9.37 & 5.53 & 3.16 & 12.20 & 100 & 55.57 & 13.76 & 8.12 & 4.64 & 17.92 & 0.31 & 8.49 & 12.11 \\
\hline E17-10 & 26.82 & 3.48 & 30.30 & 69.70 & 42.73 & 7.99 & 3.49 & 2.40 & 13.09 & 100 & 61.30 & 11.46 & 5.01 & \begin{tabular}{|l|}
3.45 \\
\end{tabular} & 18.78 & 0.29 & 10.33 & 18.61 \\
\hline E17-11 & 24.42 & 1.99 & 26.41 & 73.59 & 54.56 & 6.18 & 2.01 & 1.36 & 9.48 & 100 & 74.14 & 8.39 & 2.73 & 1.85 & 12.88 & 0.20 & 34.78 & 20.78 \\
\hline E17-12 & 20.36 & 3.48 & 23.84 & 76.16 & 64.52 & 3.53 & 1.38 & 0.94 & 5.80 & 100 & 84.71 & 4.63 & 1.81 & 1.23 & \begin{tabular}{|l|}
7.62 \\
\end{tabular} & 0.13 & 103.79 & 16.95 \\
\hline E17-13 & 20.93 & 2.49 & 23.42 & 76.58 & 63.45 & 4.12 & 2.13 & 0.99 & 5.90 & 100 & 82.86 & 5.38 & 2.78 & \begin{tabular}{|l|}
1.29 \\
\end{tabular} & 7.70 & 0.16 & 60.43 & 9.87 \\
\hline E17-15 & 29.40 & 2.99 & 32.39 & 67.61 & 37.51 & 14.83 & 2.70 & 1.45 & 11.12 & 100 & 55.48 & 21.93 & 4.00 & 2.14 & 16.45 & 0.26 & 10.48 & 0.96 \\
\hline E17-16 & 34.77 & 3.97 & 38.74 & 61.26 & 17.79 & 9.25 & 4.95 & 6.68 & 22.59 & 100 & 29.04 & 15.10 & 8.07 & 10.91 & 36.88 & 0.52 & 2.15 & 1.40 \\
\hline
\end{tabular}




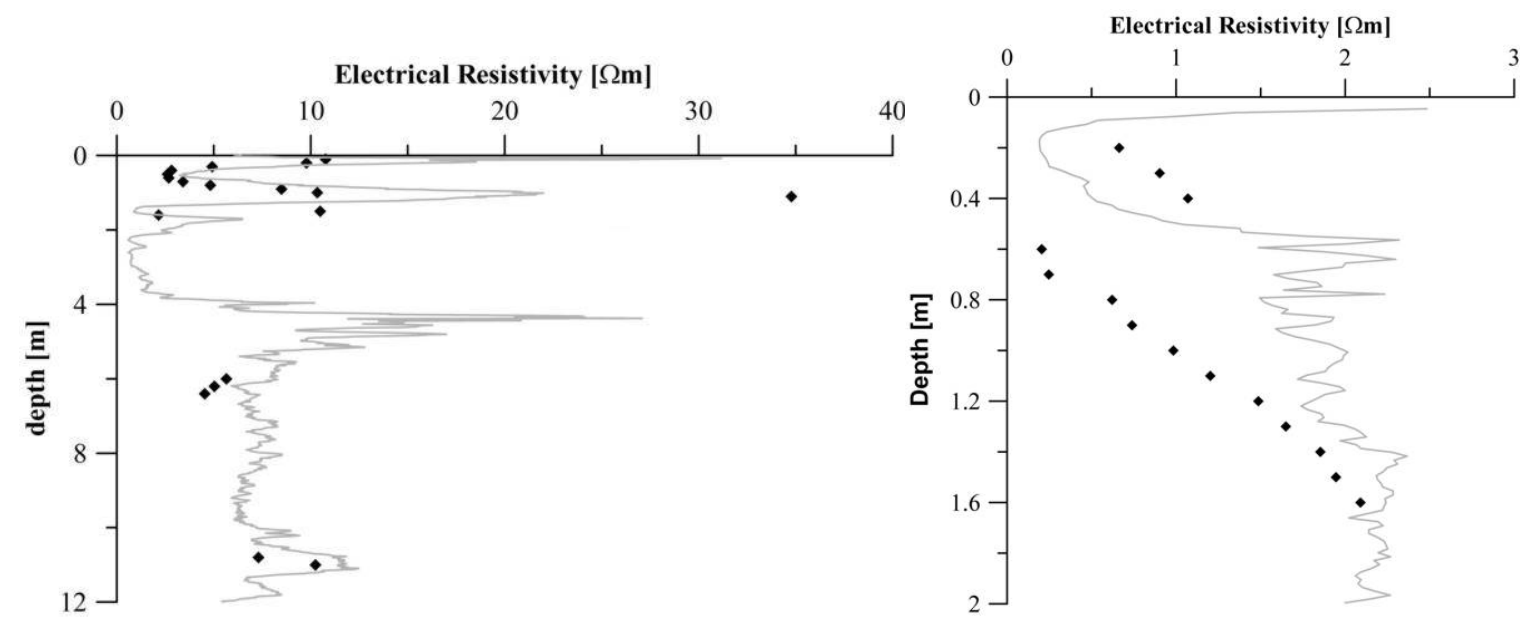

Fig. 5.3-17: Calculated electrical resistivity of the soil analysis (black dots) and the geophysical calculated electrical resistivity of the direct-push measurement (gray line) for the samples E17 (left) and E05 (right).

The groundwater table is located $0.5 \mathrm{~m}$ below ground level. Therefore the jump to lower resistivities derives from the application of the formula for saturated conditions. This illustrates the problem of the water saturation of the soil samples. The water saturation is a very sensitive parameter since he occurs $1 /$ square in the used equation.

\subsubsection{Conclusions/ Lesson learned}

Although the problem of taking undisturbed soil samples remains, it could be shown, that the ion content of pore fluid plays the major role for the low resistivities measured by geoelectric resistivity methods (both direct-push and surface geoelectrics). The direct-push geoelectric measurements undertaken in the study area show high resistivity variations in the profiles. Therefore it can be concluded that surface geophysical (electromagnetic as well as geoelectric) measurements can only be interpreted qualitatively and not quantitatively, since the problem of ambiguity cannot be resolved. Since high resistivity variations (around three orders of magnitude) prevail in the subsurface, that vary from point to point and do not directly depend on the groundwater table or are restricted to the lacustrine Lisan Formation, the problem of ambiguity cannot be overcome by hydrogeological assumptions. Only direct-push measurements can deliver picture about the depth - resistivity distribution. However, the depth penetration of these direct-push measurements strongly depends on the soil mechanical properties of the underground and is in the distal part between 20 to around $30 \mathrm{~m}$ and in the proximal part of the alluvial fans often only a few meters.

\subsubsection{Collected data of vertical electric soundings (Schlumberger depth soundings)}

\subsubsection{Introduction}

Together with the direct-push information all available vertical electrical measurements, starting from the measurements in the sixties up to the soundings undertaken in early 2003 were revised and if necessary reinterpreted. The measurements were made by different investigators, who emphasised different aspects in their respective work. Therefore all available VES were assembled and processed by an individual geoscientist. Afterwards these interpretations are combined in a consistent manner together with the chemical analysis of well waters, that show the spatial and temporal variations of the water quality in the lower Jordan Valley within the last 40 years.

A large number of vertical electric soundings have been undertaken in lower the Jordan Valley. The earliest and most extensive survey was conducted between November 1963 and February 1964 in the alluvial plains on both sides of the Jordan River (Fig. 5.3-5, only shot points within the study area are shown). A total number of 173 VES with electrode separations of up to $680 \mathrm{~m}$ were conducted by a 
geophysical team of the Federal Institute for Geosciences and Natural Resources (BGR) of the Federal Republic of Germany and the German Geological Mission in Jordan (Flathe et al. 1965). The soundings were arranged along the estimated groundwater flow direction in east-western profiles (Fig. 5.3-5, only shot points within the study area are shown), whereas the shot point separation was around 1,000 $\mathrm{m}$ (Flathe 1968). The electrode spacing was perpendicular to the profile. Unfortunately only a small number of sounding curves can be found in the appendix of the report.

The second major geoelectric sounding campaign was also operated by geophysicists of the BGR (Worzyk 1985). The soundings were undertaken during February until March 1985. The soundings concentrated on two north-south profiles (Fig. 5.3-5), one in the vicinity of the Dead Sea six kilometres northwards along the Dead Sea- Amman road and the second profile along the proposed extension of the East Ghor Canal (now King Abdullah Canal; chapter 3). This profile begins at the proposed end of the canal to around five kilometres north of it. In total 24 soundings were undertaken with a point separation of 400-600 m and electrode separation of up to 1,200 m. The electrode spacing was perpendicular to the profile directions.

The third major geophysical survey in the alluvial sediments of lower Jordan Valley was undertaken within the framework of "The study on brackish groundwater desalination in Jordan" project, financed by Japan International Agency (JICA) and operated by a geophysical team of the Mitsui Mineral Development Engineering Co. Ltd., Tokio , Japan. In 199530 VES were conducted at selective points (Fig. 5.3-5, only shot points within the study area are shown) with an electrode separation of up to $600 \mathrm{~m}$.

Some VES were shot at three selective sites. Five VES soundings were made available by Prof Salameh, of Jordan University. The soundings were undertaken in the area north of the Dead Sea. Four VES, shot at a Jordan Fishery farm, were conducted by geophysical team of Jordan University in June 1998 (Abou Karaki 1998).

Within the context of this study ten VES were conducted in February 2003 along a north- south profile, six kilometres north of the Dead Sea, along the road that leads to the baptism site at the Jordan River (Fig. 5.3-5). The sounding point separation was 400 to $600 \mathrm{~m}$, electrode separation up to $600 \mathrm{~m}$, and the electrode spacing was perpendicular to the profile directions.

\subsubsection{VES sounding undertaken within the course of this study}

As mentioned before, ten VES were undertaken within the course of this study. These soundings were placed at the distal fan area of Wadi Kafrein and Wadi Hisban (Fig. 5.3-5, black dots). The locations were chosen in order to get information about the temporal variability of groundwater quality within the alluvial fans of Wadi Kafrein and Hisban. Along the deposition area several E-W profiles were compiled by the BGR in 1964/65. These profiles give information about the development of groundwater bodies along their flow path towards the west. One N-S cross section in the proximal area was undertaken by the BGR in 1984/85. Although the research purpose was different, this survey gives valuable information about the subsurface in this proximal area. With the help of the ten soundings undertaken in early 2003 another N-S profile was conducted in the distal fan area. The purpose of this transect was to delineate the north-south extent of the fresher alluvial fan groundwater.

The sounding curves can be seen in Fig. 5.3-18 and their interpretation below. The RESIX program mentioned earlier was made available by the University of Tübingen and was used to interpret the results.

Except for sounding no. 4 all apparent resistivity values are between 1 and $40 \Omega \mathrm{m}$. Sounding no. 1, 3, 7,8 , and 9 have a high conductive surface layer, which might be attributed to shallow groundwater tables, which are followed by layers of higher resistivity. The southernmost soundings (1 to 4) show an increasing trend of apparent resistivity (around 10 to $20 \Omega \mathrm{m}$ ) at the largest electrode spacing, while the northernmost soundings (6 to 10) a decreasing trend of apparent resistivity at large electrode spacing (below $10 \Omega \mathrm{m}$ ). The border between the fresher water flowing in alluvial dominated environment and the lacustrine dominated environment could be placed between the shot points 4 and 6. 


\subsubsection{General situation/ Classification}

The first and most comprehensive survey, undertaken in 1963/64, gives the best spatial hydrogeological overview of the area. However, this survey can only be taken as a momentarily picture of the area valid for the winter 1963/64. Due to the large seasonal variations along with different pumping activities the system might undergo severe regional changes. By taking common shot points, that is sounding locations of different surveys at the same location, even temporal information regarding water levels or water quality development can be quantitatively obtained (chapter 5.3.6.5).

As stated above, the first intensive survey gives a comprehensive picture of the resistivity distribution within the shallow unconsolidated system in lower Jordan Valley. The range in resistivity values covers three orders of magnitude, ranging from 0.2 to $400 \Omega \mathrm{m}$.

In order to quantify areas of different electrical resistivity characteristics the VES interpretations were subdivided into different resistivity ranges. Van Dam and Meulenkamp (1967) determined the salinity of groundwater in the western Netherlands. They considered 40,12, and $3 \Omega \mathrm{m}$ as fresh, brackish, and saline water, respectively. Sabet (1975) estimated a range of $20 \Omega \mathrm{m}$ to several hundred $\Omega \mathrm{m}$ for the resistivity of clean sand and gravel saturated with freshwater in the southeastern region of Virginia. He also reported that the resistivity of the same sand containing silt, clay or brackish water is much lower. He concluded that freshwater is unlikely to be produced from horizons of resistivity less than $10 \Omega \mathrm{m}$. A classification scheme for different resisitivity ranges was developed by Zohdy et al. (1993) and modified by Nowroozi et al. (1999). Different resistivity values were correlated to different grain sizes and pore fluid salinity.

Based on these findings the available shot point data was classified. Six different groups were distinguished. The different groups can be seen in Tab. 5.3-5. All available VES were implemented in a geodatabase.

The different resistivity zones are characterized by the following characteristics:

$0.1-1 \Omega \mathrm{m}$ (dark red colour)

In this very low resistivity zone groundwater samples showed the following characteristics: $\mathrm{Mg}^{2+}: 197$; $\mathrm{Ca}^{2+}: 157 ; \mathrm{Na}^{+}: 725 ; \mathrm{K}^{+}: 138 ; \mathrm{Cl}^{-}: 1,645 ; \mathrm{Br}^{-}: 22,6 ; \mathrm{SO}_{4}{ }^{2-}: 154 ; \mathrm{HCO}_{3}{ }^{-}: 372 \mathrm{mg} / \mathrm{L}$. The sediments consist almost entirely of the saline Lisan Formation. The sediments are saturated with saline groundwater. Only a few soundings showed that low resistivity values.

1-10 $\Omega \mathrm{m}$ (red colour)

Sediments consists usually of marl (Lisan Formation) or in areas of steady-state evaporation in the top soil caused by very shallow groundwater tables of silt. Groundwater from this zone (apparent electrical resistivity: $4,4 \Omega \mathrm{m}$ ) has usually the following composition: $\mathrm{Mg}^{2+}: 130 ; \mathrm{Ca}^{2+}: 146 ; \mathrm{Na}^{+}: 371$; $\mathrm{K}^{+}: 41 ; \mathrm{Cl}^{-}: 822 ; \mathrm{SO}_{4}{ }^{2-}: 193 ; \mathrm{HCO}_{3}{ }^{-}: 405 \mathrm{mg} / \mathrm{L}$.

$10-25 \Omega \mathrm{m}$ (pink colour)

Groundwater from this zone (apparent electrical resistivity: $12 \Omega \mathrm{m}$ ) has usually the following composition: $\mathrm{Mg}^{2+}: 119 ; \mathrm{Ca}^{2+}: 78 ; \mathrm{Na}^{+}: 225 ; \mathrm{K}^{+}: 28 ; \mathrm{Cl}^{-}: 521 ; \mathrm{Br}^{-}: 0,1 ; \mathrm{SO}_{4}{ }^{2-}: 81 ; \mathrm{HCO}_{3}{ }^{-}: 421 \mathrm{mg} / \mathrm{L}$. Sediments are usually of low permeability, like chalks, marls, shales, argillaceous fine clastics. However, the higher hydraulic conductivity in this zone, resembles coarser material and water of better quality than in the zone described above. 

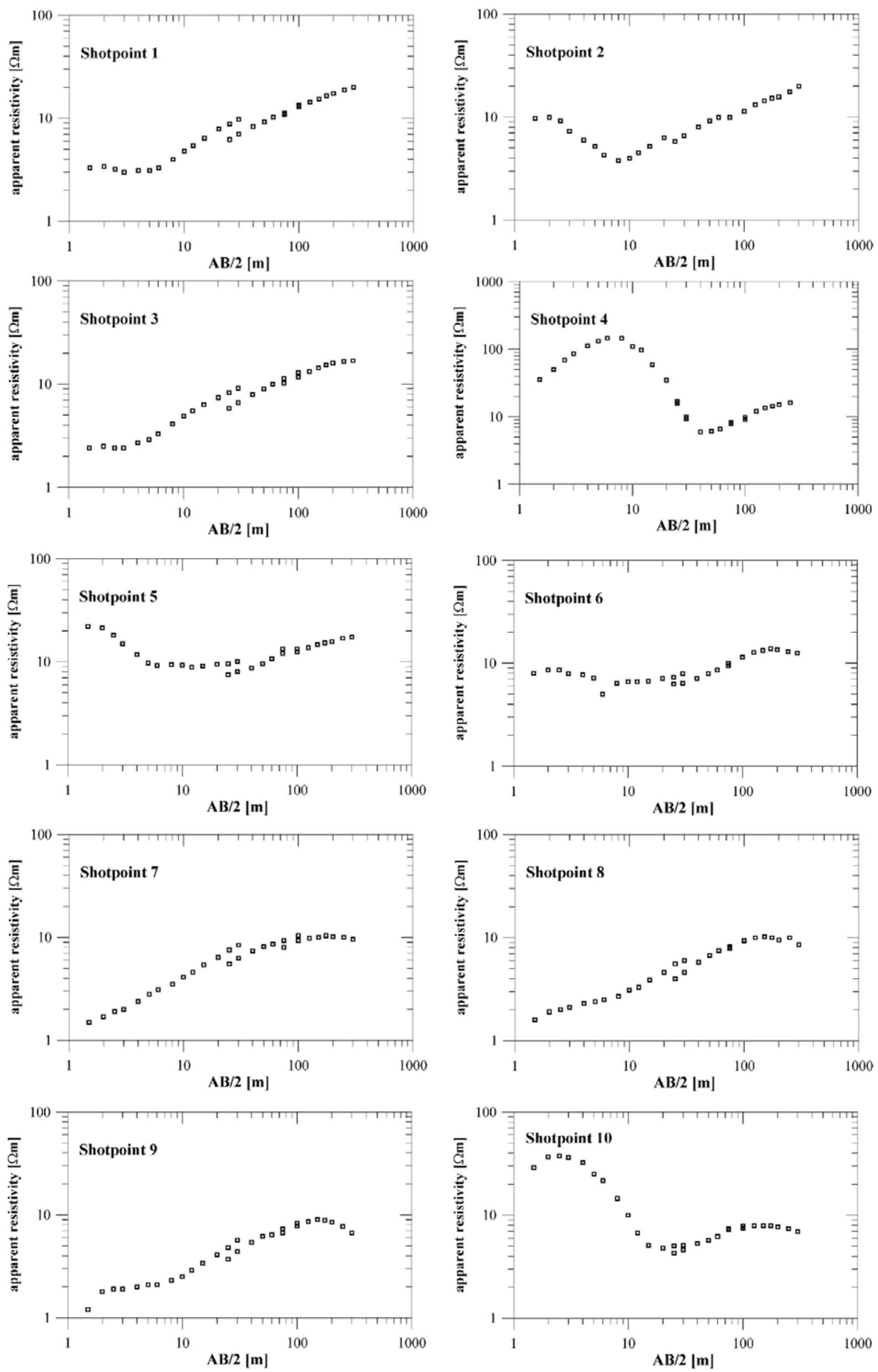
Fig. 5.3-18: VES soundings conducted in the course of this study. Location of sounding points can be found in Fig. 5.3-5, whereby the numbering of the sounding locations is from south to north (shot point 1 to shot point 10).

\section{Shotpoint 1}

\begin{tabular}{|c|c|c|c|}
\hline Layer & $\begin{array}{c}\text { Res } \\
{[\mathbf{\Omega} \mathbf{~ m}]}\end{array}$ & $\begin{array}{c}\text { Thick } \\
{[\mathbf{m}]}\end{array}$ & $\begin{array}{c}\text { Depth } \\
{[\mathbf{m}]}\end{array}$ \\
\hline 1 & 3.1 & 5.3 & 5.3 \\
\hline 2 & 17.2 & 8.5 & 13.7 \\
\hline 3 & 10.1 & 45.1 & 58.8 \\
\hline 4 & 30.2 & & \\
\hline
\end{tabular}

RMS error $=2.9$

\section{Shotpoint 4}

\begin{tabular}{|c|c|c|c|}
\hline Layer & $\begin{array}{c}\text { Res } \\
{[\Omega \mathbf{~ m}]}\end{array}$ & $\begin{array}{c}\text { Thick } \\
{[\mathbf{m}]}\end{array}$ & $\begin{array}{c}\text { Depth } \\
{[\mathbf{m}]}\end{array}$ \\
\hline 1 & 29.8 & 0.7 & 0.7 \\
\hline 2 & 353.6 & 2.3 & 3 \\
\hline 3 & 3.5 & 25 & 28 \\
\hline 4 & 25.5 & & \\
\hline
\end{tabular}

RMS error $=6.7$

\section{Shotpoint 7}

\begin{tabular}{|c|c|c|c|}
\hline Layer & $\begin{array}{c}\text { Res } \\
{[\Omega \mathbf{~ m}]}\end{array}$ & $\begin{array}{c}\text { Thick } \\
{[\mathbf{m}]}\end{array}$ & $\begin{array}{c}\text { Depth } \\
{[\mathbf{m}]}\end{array}$ \\
\hline 1 & 1.4 & 1.6 & 1.6 \\
\hline 2 & 5.6 & 5.8 & 7.3 \\
\hline 3 & 12.9 & 22.3 & 29.7 \\
\hline 4 & 10.6 & 139.5 & 169.1 \\
\hline 5 & 7 & & \\
\hline
\end{tabular}

RMS error $=2.3$

\section{Shotpoint 10}

\begin{tabular}{|c|c|c|c|}
\hline Layer & $\begin{array}{c}\text { Res } \\
{[\boldsymbol{\Omega} \mathbf{~ m}]}\end{array}$ & $\begin{array}{c}\text { Thick } \\
{[\mathbf{m}]}\end{array}$ & $\begin{array}{c}\text { Depth } \\
{[\mathbf{m}]}\end{array}$ \\
\hline 1 & 35.1 & 1.3 & 1.3 \\
\hline 2 & 47 & 1.4 & 2.7 \\
\hline 3 & 4.6 & 26.4 & 29.1 \\
\hline 4 & 9.9 & 108.5 & 137.6 \\
\hline 5 & 5.6 & & \\
\hline
\end{tabular}

RMS error $=3.4$

\section{Shotpoint 2}

\begin{tabular}{|c|c|c|c|}
\hline Layer & $\begin{array}{c}\text { Res } \\
{[\mathbf{~ m ]}]}\end{array}$ & $\begin{array}{c}\text { Thick } \\
{[\mathbf{m}]}\end{array}$ & $\begin{array}{c}\text { Depth } \\
{[\mathbf{m}]}\end{array}$ \\
\hline 1 & 9.9 & 2.1 & 2.1 \\
\hline 2 & 2.2 & 4.3 & 6.4 \\
\hline 3 & 12.6 & 38.9 & 45.3 \\
\hline 4 & 20.9 & & \\
\hline
\end{tabular}

RMS error $=2.5$

\section{Shotpoint 5}

\begin{tabular}{|c|c|c|c|}
\hline Layer & $\begin{array}{c}\text { Res } \\
{[\mathbf{\Omega} \mathbf{\text { m}}]}\end{array}$ & $\begin{array}{c}\text { Thick } \\
{[\mathbf{m}]}\end{array}$ & $\begin{array}{c}\text { Depth } \\
{[\mathbf{m}]}\end{array}$ \\
\hline 1 & 23.3 & 1.4 & 1.4 \\
\hline 2 & 0.1 & 14.5 & 16 \\
\hline 3 & 12.2 & 34.9 & 50.8 \\
\hline 4 & 18.6 & & \\
\hline
\end{tabular}

RMS error $=2.8$

\section{Shotpoint 8}

\begin{tabular}{|c|c|c|c|}
\hline Layer & $\begin{array}{c}\text { Res } \\
{[\mathbf{\Omega} \mathbf{~ m}]}\end{array}$ & $\begin{array}{c}\text { Thick } \\
{[\mathbf{m}]}\end{array}$ & $\begin{array}{c}\text { Depth } \\
{[\mathbf{m}]}\end{array}$ \\
\hline 1 & 1.6 & 1.5 & 1.5 \\
\hline 2 & 3 & 4.7 & 6.2 \\
\hline 3 & 7.5 & 31.9 & 38.1 \\
\hline 4 & 15.7 & 31.6 & 129.8 \\
\hline 5 & 6.4 & & \\
\hline
\end{tabular}

RMS error $=3.5$

\section{Shotpoint 3}

\begin{tabular}{|c|c|c|c|}
\hline Layer & $\begin{array}{c}\text { Res } \\
{[\mathbf{~} \mathbf{~ m}]}\end{array}$ & $\begin{array}{c}\text { Thick } \\
{[\mathbf{m}]}\end{array}$ & $\begin{array}{c}\text { Depth } \\
{[\mathbf{m}]}\end{array}$ \\
\hline 1 & 2.3 & 3.5 & 3.5 \\
\hline 2 & 12.7 & 11.4 & 14.9 \\
\hline 3 & 8.9 & 50 & 64.9 \\
\hline 4 & 29.3 & & \\
\hline
\end{tabular}

RMS error $=3.6$

\section{Shotpoint 6}

\begin{tabular}{|c|c|c|c|}
\hline Layer & $\begin{array}{c}\text { Res } \\
{[\mathbf{~ m ]}]}\end{array}$ & $\begin{array}{c}\text { Thick } \\
{[\mathbf{m}]}\end{array}$ & $\begin{array}{c}\text { Depth } \\
{[\mathbf{m}]}\end{array}$ \\
\hline 1 & 8 & 2.9 & 2.9 \\
\hline 2 & 5.3 & 7.9 & 10.8 \\
\hline 3 & 8.9 & 27.8 & 38.7 \\
\hline 4 & 16.1 & & \\
\hline
\end{tabular}

\section{Shotpoint 9}

\begin{tabular}{|c|c|c|c|}
\hline Layer & $\begin{array}{c}\text { Res } \\
{[\boldsymbol{\Omega} \mathbf{~ m}]}\end{array}$ & $\begin{array}{c}\text { Thick } \\
{[\mathbf{m}]}\end{array}$ & $\begin{array}{c}\text { Depth } \\
{[\mathbf{m}]}\end{array}$ \\
\hline 1 & 1.4 & 1.9 & 1.9 \\
\hline 2 & 2.9 & 6.2 & 8 \\
\hline 3 & 8.7 & 26.6 & 34.6 \\
\hline 4 & 10.7 & 94.3 & 129 \\
\hline 5 & 5.4 & & \\
\hline
\end{tabular}

RMS error $=3.7$

\begin{tabular}{|l|l|l|}
\hline Resistivity $[\Omega \mathrm{m}]$ & Sediments & Interpretation \\
\hline $0.1-1$ & Lisan Formation & Saline Water \\
\hline $1-10$ & Mainly Lisan Sediments & Salty brackish water; EC \\
\hline $10-25$ & Sandy clay, sandy gravel & Brackish water; EC $>3500 \mu \mathrm{S} / \mathrm{cm}$ \\
\hline $25-50$ & Sand, gravel, some clay & Poor quality fresh water; EC $1,500-3,000 \mu \mathrm{S} / \mathrm{cm}$ \\
\hline $50-100$ & Sand, gravel, no or minor clay & Good quality fresh water; EC $1,000-1,500 \mu \mathrm{S} / \mathrm{cm}$ \\
\hline$>100$ & Coarse sand, gravel, no clay & Very good quality fresh water; EC very small \\
\hline
\end{tabular}

Tab. 5.3-5: Resistivity of water and sediments (modified after Zohdy et al. 1993 and Nowroozi et al. 1999). 


\section{5-50 $\Omega \mathrm{m}$ (beige colour)}

Groundwater from this zone (apparent electrical resistivity: $30 \Omega \mathrm{m}$ ) has usually the following composition: $\mathrm{Mg}^{2+}: 74: \mathrm{Ca}^{2+}: 78 ; \mathrm{Na}^{+}: 146 ; \mathrm{K}^{+}: 28 ; \mathrm{Cl}^{-}: 425 ; \mathrm{Br}^{-}: 0,1 ; \mathrm{SO}_{4}^{2-}: 59, \mathrm{HCO}_{3}^{-}: 187 \mathrm{mg} / \mathrm{L}$. Sediments are usually less clayey and more sandy, typical for the mid-fan area.

\section{0-100 $\Omega \mathrm{m}$ (green colour)}

Groundwater from this zone (apparent electrical resistivity: $80 \Omega \mathrm{m}$ ) has usually the following composition: $\mathrm{Mg}^{2+}: 36: \mathrm{Ca}^{2+}: 78 ; \mathrm{Na}^{+}: 57 ; \mathrm{K}^{+}: 5 ; \mathrm{Cl}^{-}: 102 ; \mathrm{SO}_{4}{ }^{2-}: 57, \mathrm{HCO}_{3}{ }^{-}: 320 \mathrm{mg} / \mathrm{L}$. Freshwater prevails within these sediments. The sedimentary section is dominated by coarse alluvial material. These high resistivities usually occur only in the proximal fan area.

\section{$>100 \Omega$ m (blue colour)}

Sediments consist usually of dry alluvial components (sand and gravel). These high electrical resistivities are only found in non-saline environments close to the fan apex or close to the hinterland. This group is underlain by the 50-100 $\Omega \mathrm{m}$ group described above.

\subsubsection{Spatial information}

The results of the VES classification is shown in Fig. 5.3-19 through Fig. 5.3-21. Fig. 5.3-19 shows the classification results for each single VES sounding. Lowest resistivities are found in the west, close to Jordan River (dark red colour). The $1-10 \Omega \mathrm{m}$ group (red colour) is found either in the west, in Lisan dominated area as top soil layer, in areas subject to salt accumulation as a result of surface evaporation of a shallow groundwater table, or, as in the case of the area of Rama, underlies fresh groundwater.

The 10 - $25 \Omega \mathrm{m}$ group (pink colour) prevails also in Lisan dominated areas, but more to the east than the $1-10 \Omega \mathrm{m}$ group. This includes also the areas between the alluvial fan of Wadi Shueib and Wadi Kafrein/Hisban. Beige colours $(25-50 \Omega \mathrm{m})$ in the transition zone between the more brackish water in the Lisan dominated areas and the freshwater dominated area in the vicinity of the major wadis and northeastern area of the study area. Green colours $(50-100 \Omega \mathrm{m})$ can be seen in the freshwater dominated areas Rama and South Shuneh. Blue colours can usually only be found as top layer in the area of Rama, where they represent dry non-saline top soil. In the north of South Shuneh, the northeastern part of the study area, it can also represent low mineralized groundwater. However, their resistivity is only slightly higher than $100 \Omega \mathrm{m}$.

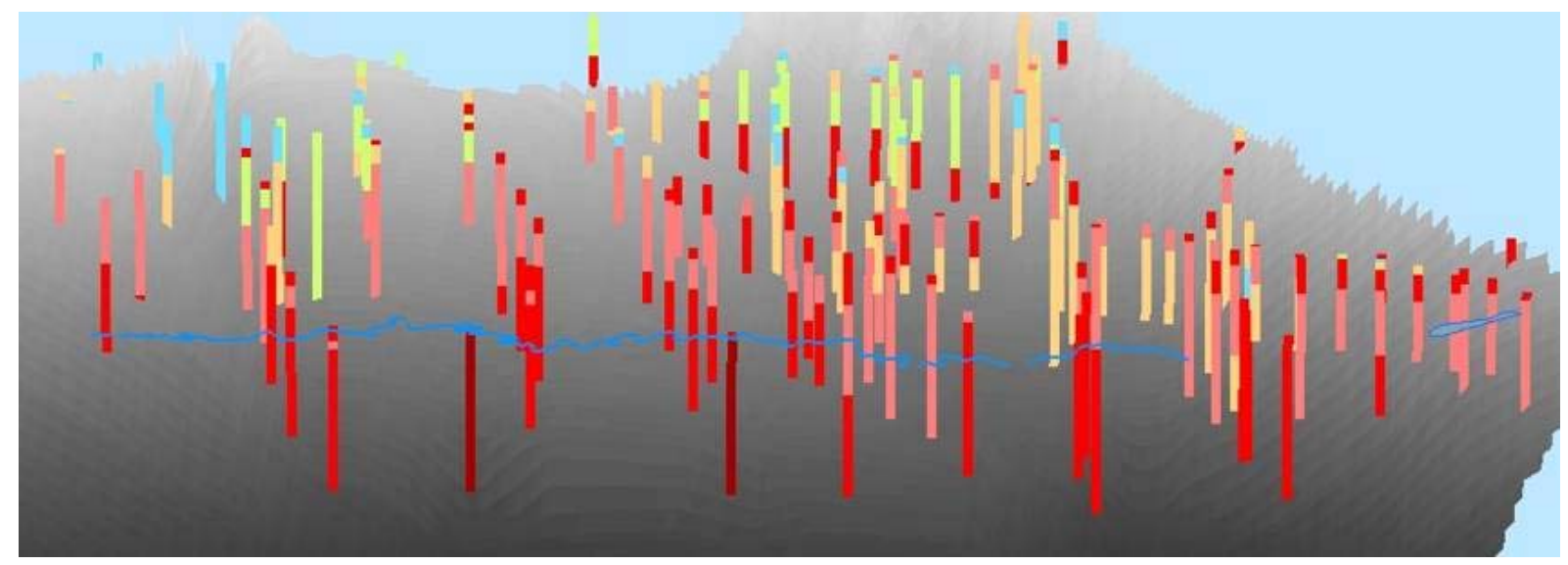

Fig. 5.3-19: 3-D view of all available VES soundings, classified into six different classes; dark red $=0.1-1$ $\Omega \mathrm{m}$, red $=1-10 \Omega \mathrm{m}$, pink $=10-25 \Omega \mathrm{m}$, beige $=25-50 \Omega \mathrm{m}$, green $=50-100 \Omega \mathrm{m}$, blue $=>100 \Omega \mathrm{m}$. The north-south flowing Jordan River (blue line), where north is on the left hand side and south on the right hand 
side, is shown for orientation. Sounding locations can also be found in Fig. 5.3-5. The gray raster in the background shows the base of the Jordan Valley Group.

North- south and east- west cross sections between the different VES soundings can be seen in Fig. 5.3-20 and Fig. 5.3-21. Here resistivity variations and the decrease in resistivity can be seen more clearly. The low resistivity zone between the area of South Shuneh and Rama (alluvial fan dominated areas) is clearly visible. As a result of the soundings undertaken in the course of this study the downfan influence of Wadi Kafrein/ Hisban alluvial fan as continuation of a higher resistivity area in an otherwise lower resistive environment is clearly apparent (the beige area in the westernmost northsouth profile in Fig. 5.3-21). The information gathered from the classification together with the results obtained in chapter 5.2 and chapter 4.3 will be used to set up a numerical flow model for the study area (chapter 7).

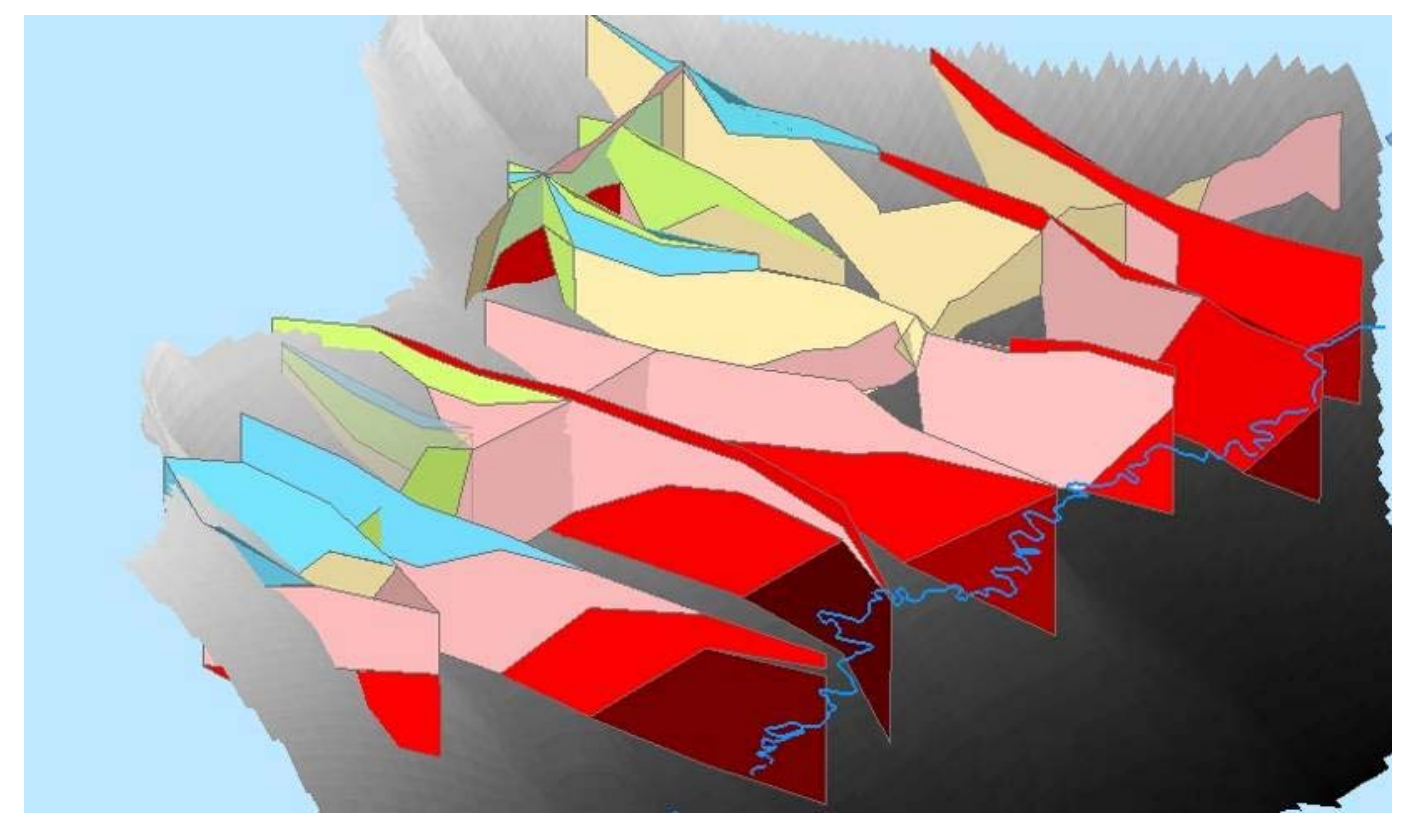

Fig. 5.3-20: 3-D cross sections of all available VES soundings, classified into six different classes; dark red = $0.1-1 \Omega \mathrm{m}$, red $=1-10 \Omega \mathrm{m}$, pink $=10-25 \Omega \mathrm{m}$, beige $=25-50 \Omega \mathrm{m}$, green $=50-100 \Omega \mathrm{m}$, blue $=>100 \Omega \mathrm{m}$. The north-south flowing Jordan River (blue line), where north is on mid-bottom side and south on the middleright side, is shown for orientation. The gray raster in the background shows the base of the Jordan Valley Group

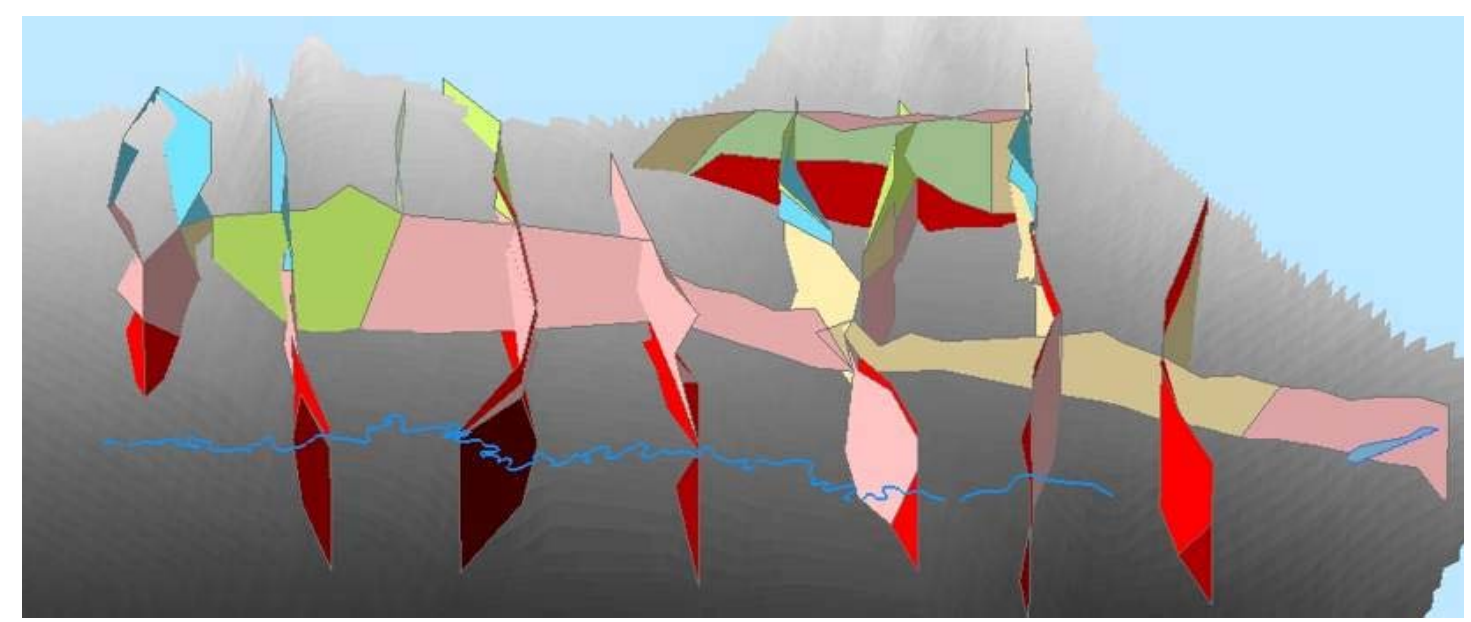

Fig. 5.3-21: 3-D cross sections of all available VES soundings, classified into six different classes; dark red = $0.1-1 \Omega \mathrm{m}$, red $=1-10 \Omega \mathrm{m}$, pink $=10-25 \Omega \mathrm{m}$, beige $=25-50 \Omega \mathrm{m}$, green $=50-100 \Omega \mathrm{m}$, blue $=>100 \Omega \mathrm{m}$. The north-south flowing Jordan River (blue line), where north is on the left hand side and south on the right hand side, is shown for orientation. 


\subsubsection{Temporal information:}

The temporal variation of groundwater quality within the unconsolidated aquifers of lower Jordan Valley can be seen in Fig. 5.3-22. Here VES shot points, that were shot at the same locations, but in different time steps can be seen. The resistivity of soils is dependant on different factors (chapter 5.3.5), such as the nature and or mixture of the soil material (e.g. gravel, sand, or clay), water content, and the concentration of dissolved salts. Since the nature of soils in the study area does not change and the water content does play only a minor important component, as compared to the concentration of the dissolved salts, variations in the salt concentrations of the pore fluid should be visible in depth sounding which are undertaken at the same location at different time steps. All younger sounding graphs show lower apparent resistivity values than their comparable sounding from the early 60ies. As described in chapter 3, the water table declined since the agricultural development of the Jordan Valley. Therefore increased apparent resistivity values should be expected in the sounding graphs of younger VES, since a larger portion of the upper soil is unsaturated with groundwater. However, in most of the sounding graphs (except $\mathrm{C}$ ) the biggest contrast in the sounding curves can be found at lower electrode spacing. This might be attributed to salt accumulation in the upper parts of the soil. Especially in the vicinity of the Dead Sea (A and B) the contrast is large. Here groundwater tables are very shallow which leads to evaporation of groundwater on the soil surface and salt accumulation in the upper part of the soil. At bigger electrode spacing the curves align and no increased salinisation trend can be seen. The sounding curves undertaken in the vicinity of Rawda and Kafrein (E and F) show a different trend. Here the younger sounding curve has a lower apparent resistivity for all electrode spacings (E) or has lower apparent resistivity values at larger electrode spacing (F). This might be attributed to the higher mineral content of groundwater in the area while the upper unsaturated area keeps its resistivity. As stated in chapter 5.2, the groundwater quality decreased since the beginning of the agricultural development, especially in the alluvial fan areas.

\subsubsection{Summary and Discussion}

The "deeper" salinization and its development since the early sixties can be seen by vertical electric soundings (VES) conducted by various agencies and are intermittently continued until today. Although VES has proved to be a tool for detecting a possible salt/ freshwater interface, its interpretation in lower Jordan Valley is difficult to perform for various reasons. In order penetrate desired depth of up to $100 \mathrm{~m}$ large electrode separations of up to one kilometre are needed to penetrate the highly conductive layers. Since it is believed that water flows along alternating channels or areas, more selective information would be desirable. Another problem is the problem of ambiguity. As stated in chapter 3 a large number of wells were drilled within the area of interest. Unfortunately almost no information regarding lithology was recorded. Since most surface geophysical investigations require a priori information for calibrating purposes, the interpretation of VES depends to a large extent on the experience and knowledge of the geoscientist. The third and most difficult problem regarding VES interpretation in lower Jordan Valley is the wide range of resistivities encountered in the subsurface. A range from 0.4 up to $800 \mathrm{Ohm} * \mathrm{~m}$ was encountered. The soil resistivity depends largely on the water and salt content within the subsurface itself. One the one hand salinity changes and water level depths can be monitored qualitatively by VES, but quantitative information can only be determined by either soil sampling or well monitoring or by direct- push measurements. 

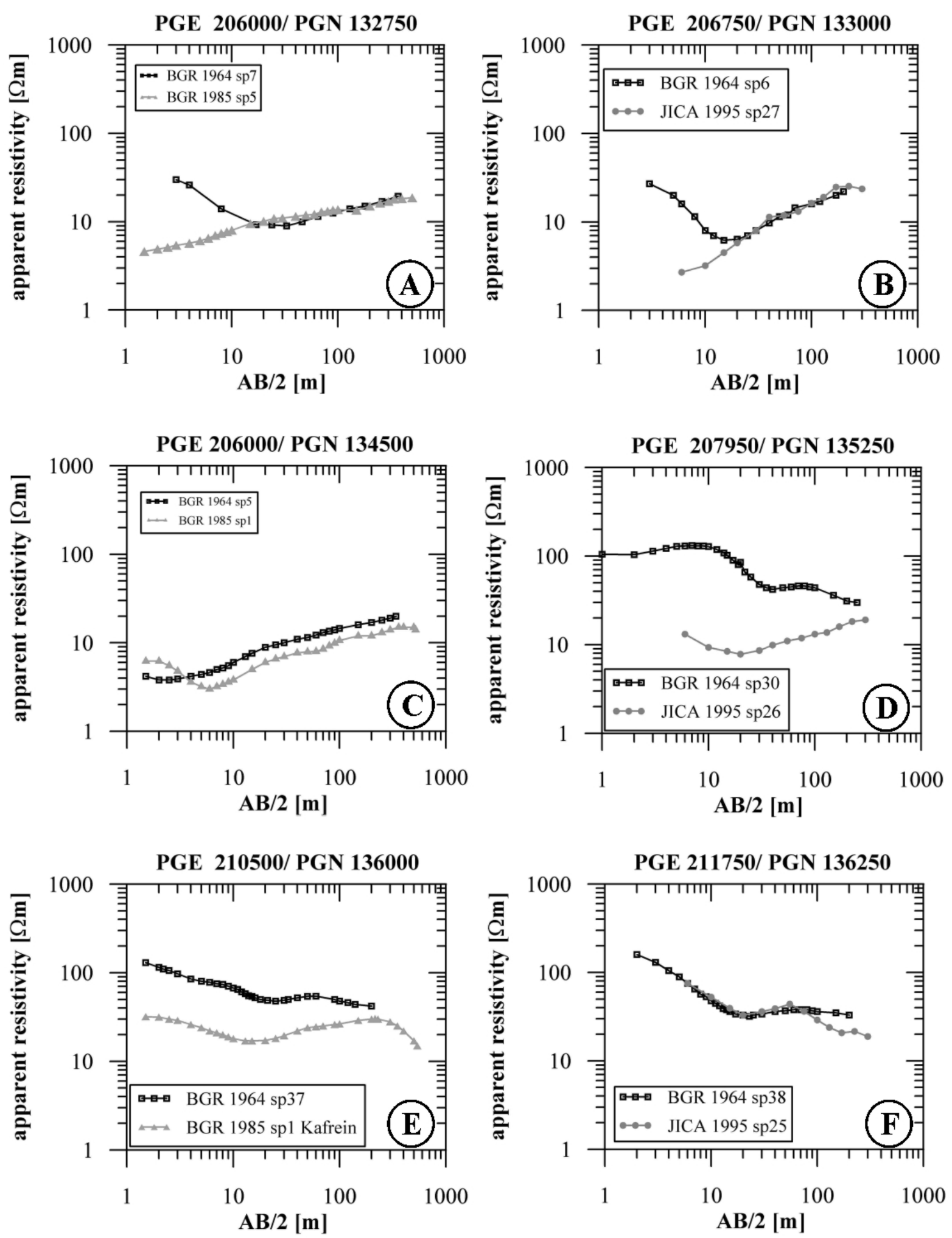

Fig. 5.3-22: VES sounding curves of soundings taken at the same location at different time steps. The location is given above each sounding curve pair (data taken from Flathe et al. 1965, Worzyk 1985, and JICA 1995). 


\subsubsection{Conclusion on the geophysical methods applied in the study area}

\section{Sources of salinization}

Different sources of salinization can be found in the soils of the lower Jordan Valley.

The primary source for high salt content in groundwater is the presence of the previously described Lisan Formation. Although the Lisan Formation is considered an aquitard, the presence of the Lisan Formation in the vicinity of the gravel aquifer is often responsible for the degradation of groundwater quality.

Due to the high evaporation rates, salt accumulates in the upper parts of the soils from the evaporation of rainfall during the rainy season or from irrigation during the dry season. Another reason for high contents of salt within the upper soil are local shallow groundwater tables. Since the grain size of most soils and sediments in the Jordan Valley is very small, salts, dissolved in pore water might move upwards due to capillary forces. During the dry season continuous evaporation of these wet soils leads to continuous transported of groundwater to the top soil by capillary forces. As a results salt accumulates in the top soil. During the late summer season the groundwater table falls and these previous wet areas dry out and leave salt crusts behind.

In the area close to the Dead Sea and in certain areas to the west of the study areas these wet soils have been identified. Since the neighbouring sediments area dry, these wet soils are easily detectable, simply by passing by. Due to the long absence of rainfall this phenomenon can be clearly seen in summer and autumn. Geoprobe direct-push soundings undertaken at the end of October 2004 showed within these wet soil areas a very shallow groundwater table often between 10 to $30 \mathrm{~cm}$ below surface. The Wenner four-point geoelectric direct-push log showed soil conductivities as high as $5300 \mathrm{mS} / \mathrm{m}$. The highest electrical conductivitites within the soils are found in the upper decimetres of the soils. This can be explained by accumulation of salt as a result of groundwater evaporation. Electric conductivity measurements of the groundwater resulted in conductivities as high as 16 to $20 \mathrm{mS} / \mathrm{cm}$. The local high contents of salt within the soils make the land unusable for agricultural purposes.

Since fresh water in the area is very scarce, water of high salinity is often used for irrigation and this further deteriorates the quality of the Jordan Valley soils. The overuse of fertilizer and the improper use of drip irrigation is another anthropogenic factor. 


\section{WATER BUDGET ESTIMATION}

\subsection{INTRODUCTION}

Within the area of interest, groundwater levels of some selected wells are monitored by the Ministry of Water and Irrigation. During a well survey, undertaken in late 2004, no water meters were encountered at the private irrigation wells. Although only a certain amount of irrigation water is free of charge farmers abstract water according to their respective needs. Therefore, this chapter attempts to estimate the minimum water demand to irrigate the cultivated areas. Estimations for certain periods of the last thirty years are prepared by undertaking the following steps:

First, the land-use; the kind of crops, cultivated in the study area, are evaluated.

Second, the irrigation techniques applied are presented.

Third, crop water requirements (the amount of water certain crops need during different growing stages), and the field water requirements (the amount of water needed to provide these plants with water without influencing the soil salinity) of the different crops planted in the study area are calculated.

Fourth, an aerial photograph together with Landsat data sets are used to identify the spatial extent of cultivated land during the last decades. Since these data sets were recorded at different periods of the year, they also give valuable information about seasonal planting practises. The area of cultivated land is calculated for different sectors in the study area. These different sectors are chosen according to their irrigation water sources.

Fifth, on the basis of the findings above, the minimum agricultural water consumption of the study area is calculated for the different periods. Although the real water consumption of the area might be much higher, this method gives an idea of how much water was at least needed to cultivate the land.

Sixth, a sample water budget for one year is set up by using the information gathered within this section. This water budget will be used to set up a steady state groundwater flow model (chapter 7).

\subsection{LAND-USE IN THE STUDY AREA}

On the markets in Jordan banana fetch high prices. Therefore it is the favourite plant of the farmers in the study area and is planted there since the 60ies. However, in terms of water demand, irrigation water quality, and soil quality banana plants are demanding plants. Every four to six years the soil needs to recover and the banana plot is switched to another part of the farmland (crop rotation). According to Philippe (2004) banana farms can be subdivided into three categories: large, smaller, and small family banana farms. Large banana farms consist of 200 to 400 dunums $\left(0.2-0.4 \mathrm{~km}^{2}\right)$. In the study area members of the Al Edwan clan own all large farms. Commonly one fourth of these farms are planted with banana plants. In March and September seedlings are planted. Around 110 plants/ dunum are planted and each year two to three shoots are kept. In order not to leave the remaining three quarters of the farming area idle, vegetables are grown. Smaller farms consist of 100 to 200 dunum $\left(0.1-0.2 \mathrm{~km}^{2}\right)$. Half of the farming land is planted with banana and the other half with vegetables. Every four to six years the plots are switched. The small family banana farms are made up of 30 to 50 dunum $\left(0.03-0.05 \mathrm{~km}^{2}\right)$. The land is divided into three plots. One plot is planted with banana seedlings and two with vegetables. The banana plot is switched every four to six years.

In places unsuitable for banana farming (high salt contents either within the irrigation water or the soil itself) vegetables like eggplant, zucchini, tomatoes, cucumbers, and peppers are grown. These places are located in the west and southwest of the study area. Some private farms also exist in the southwestern area. These farms were built for rich people from bigger cities like Amman or Salt and serve mostly recreation purposes. Most of these farms have a swimming pool fed by well water. Framing activities only exist to a minor degree. Fruit and palm trees are grown (i.e. Guava and Mango). Vegetables are cultivated to minor degree. Cheap labour workers, mostly Egyptians or Pakistanis, manage these farms as well as all other farms. Unlike the northern and middle part of the 
lower Jordan Valley, only few greenhouses exist. In these greenhouses vegetables, such as cucumber, tomatoes, and pepper are grown.

\subsection{IRRIGATION TECHNIQUES USED IN LOWER JORDAN VALLEY}

Two different irrigation techniques are applied nowadays in the lower Jordan Valley. Since its introduction in the eighties, drip irrigation (Fig. 6-1 left) is the most frequent method applied by the farmers. According to GTZ (2003) 70\% of all farms in the lower Jordan valley use this technique. In the study area drip irrigation is used almost entirely. However, drip irrigation systems require a pressurized pipe system. As stated above, different water sources for irrigation exist. But none of them delivers an on- demand pressurized system. In order to be independent, all farms possess irrigation pools (Fig. 6-1 right) where water can be pumped into the irrigation system on demand. Some pools are used to blend water from the Wadi course or the canal with more brackish well water. Although drip irrigation efficiency is often regarded to as $100 \%$ efficient, evaporation losses in the storage pools, pipe losses and improper use of the system reduces the efficiency down to 80\% (GTZ 2003). Drip irrigation is mostly used in combination with plastic mulch (Fig. 6-1 left) to improve weed control and decrease evaporation, which would result in salt accumulation in the topsoil. Fertigation, the injection of dissolved nutrients/ fertilizers into the irrigation water is the dominant fertilization practize. Since the drip irrigation system delivers the fertilizer directly to the planted crops fertigation is the most efficient fertilization method.

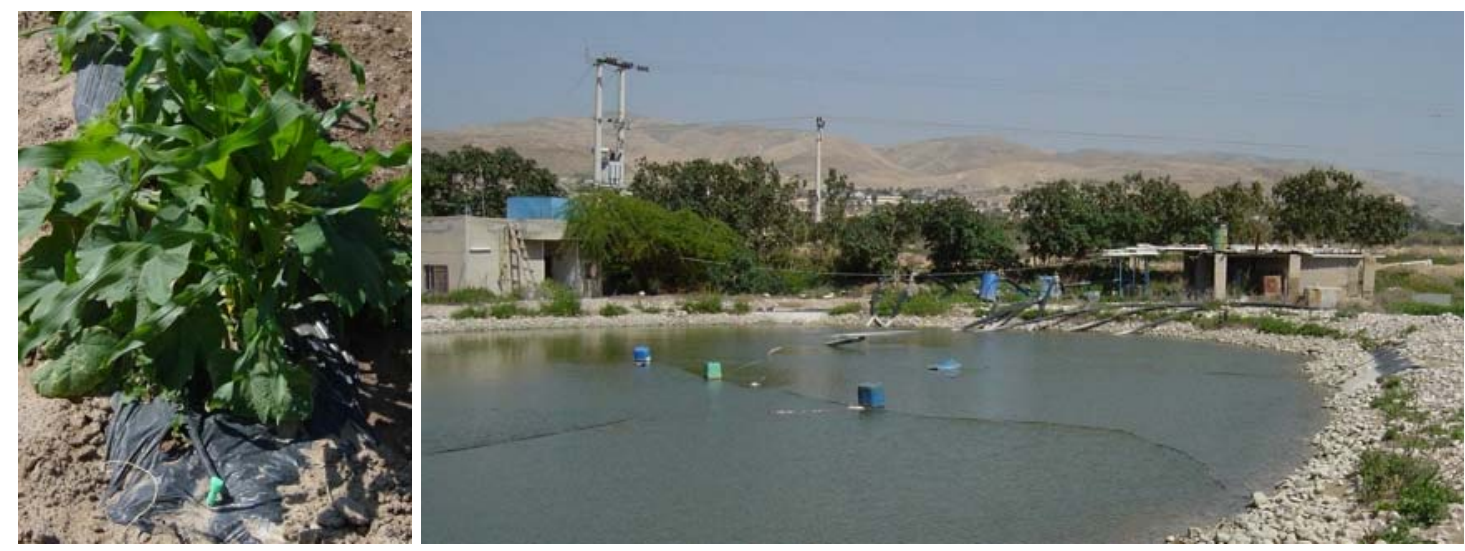

Fig. 6-1: Left: Drip irrigation in combination with plastic mulch. Right: Irrigation water pool. 3

In some places near the KAC furrow irrigation (Fig. 6-2) or border irrigation is used. The efficiency of furrow irrigation is around 60\% (GTZ 2003), depending on the properties of the underlying soil and the length of the furrow channel to the farm. But, only very few farms using this technique were observed during the field campaigns.

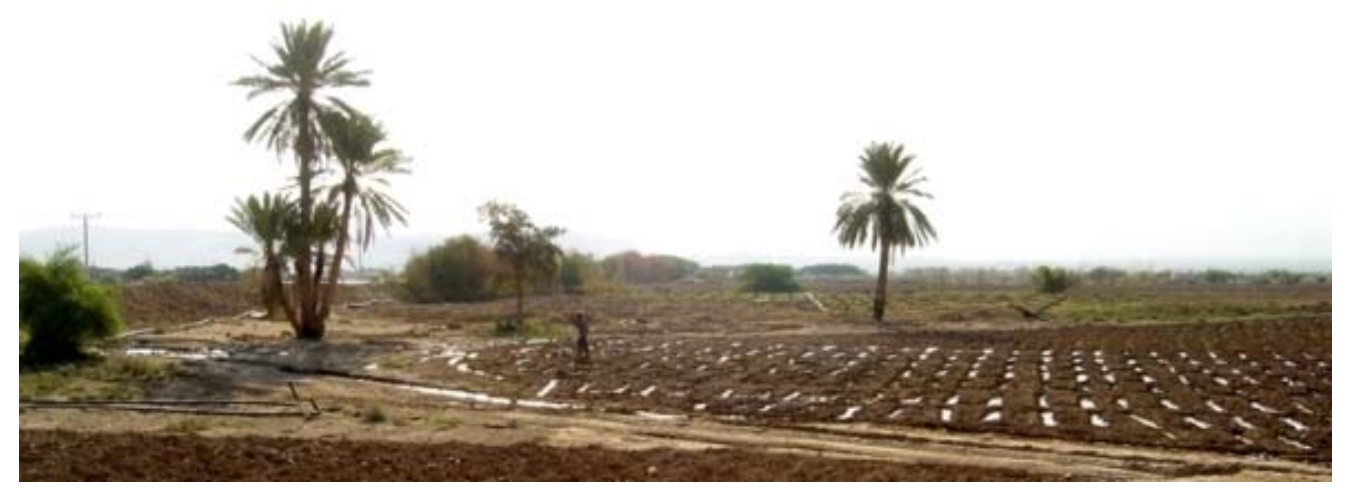

Fig. 6-2: Furrow irrigation with water from the King Abdallah Canal water. 


\subsection{CROP AND FIELD WATER REQUIREMENT}

The term crop water requirement is defined as the "amount of water required to compensate the evapotranspiration loss from the cropped field" (Allen et al. 1998). So crop water requirement refers to the amount of water that a specific crop needs to be supplied with at a specific growth stage. The crop water requirement highly depends on evapotranspiration. It can be formulated as:

$\mathrm{CWR}=\mathrm{k}_{\mathrm{c}} * \mathrm{ET}$

$\mathrm{CWR}=$ Crop Water Requirement

$\mathrm{k}_{\mathrm{c}}=$ crop coefficient (depends on the growth stage of the plant; Tab. 6-1)

ET = estimated Evapotranspiration (i.e. Penman-Monteith equation)

Tab. 6-1: Crop coefficients $\mathrm{k}_{\mathrm{c}}$ (FAO 1992, Euroconsult 1989).

\begin{tabular}{|c|c|c|c|c|}
\hline Crop & $\mathbf{K}_{\mathbf{c} 1}$ & $\mathbf{K}_{\mathrm{c} 2}$ & $\mathbf{K}_{\mathrm{c} 3}$ & $\mathbf{K}_{\mathrm{c} 4}$ \\
\hline Squash & $0.6(10 \mathrm{~d})$ & $0.8(20 \mathrm{~d})$ & $1.0(20 \mathrm{~d})$ & 0.8 \\
\hline Eggplant & $0.6(30 \mathrm{~d})$ & $0.85(40 \mathrm{~d})$ & $1.1(40 \mathrm{~d})$ & 0.9 \\
\hline Tomato & $0.6(30 \mathrm{~d})$ & $0.93(40 \mathrm{~d})$ & $1.25(40 \mathrm{~d})$ & 0.65 \\
\hline Potato & $0.6(30 \mathrm{~d})$ & $0.9(30 \mathrm{~d})$ & $1.2(30 \mathrm{~d})$ & 0.75 \\
\hline Sweet Corn & $0.6(20 \mathrm{~d})$ & $0.9(25 \mathrm{~d})$ & $1.2(30 \mathrm{~d})$ & 1.1 \\
\hline Wheat/Barley & $0.6(20 \mathrm{~d})$ & $0.86(25 \mathrm{~d})$ & $1.2(50 \mathrm{~d})$ & 0.2 \\
\hline Banana 1 st year & $0.5(120 \mathrm{~d})$ & $0.85(90 \mathrm{~d})$ & $1.1(120 \mathrm{~d})$ & $1(60 \mathrm{~d})$ \\
\hline Banana $>1$ 1st year & $1.0(120 \mathrm{~d})$ & $1.1(60 \mathrm{~d})$ & $1.2(180 \mathrm{~d})$ & $1.1(5 \mathrm{~d})$ \\
\hline
\end{tabular}

$\mathrm{K}_{\mathrm{c} 1}$ : initial stage: germination, seedling growth, hardly any ground cover $(<10 \%)$

$\mathrm{K}_{\mathrm{c} 2}$ : crop development stage: until effective full cover ( 70-80\%)

$\mathrm{K}_{\mathrm{c} 3}$ : mid season stage: full cover until start of maturing, discolouring, normally well past the flowering stage of annual crops

$\mathrm{K}_{\mathrm{c} 4}$ : late season: full maturity, discolouring, leaves dropping, harvest

The crop water requirement deals with the water requirements of the plant itself only. No irrigation water losses (even drip irrigation, normally regarded as $100 \%$ efficient was estimated by the GTZ (2003) to be in only $80 \%$ efficient in the Jordan Valley; furrow irrigation is labelled with $60 \%$ efficiency), or water required for soil leaching is integrated into the formula. Therefore the term field water requirement (FWR) was introduced. The term FWR accounts for these additional water demands:

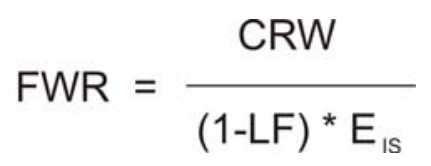

$\mathrm{LF}=$ leaching fraction

$\mathrm{E}_{\mathrm{IS}}=$ efficiency of the irrigation system in the farm reflecting all losses

Within the "Brackish Water Project", financed by the Deutsche Gesellschaft für Technische Zusammenarbeit (GTZ), guidelines for brackish water irrigation were developed for the Jordan Valley (GTZ 2003). The following calculations depend on the findings of these guidelines. 


\section{Squash:}

Recommended irrigation water salinity threshold: $<4.5 \mathrm{mS} / \mathrm{cm}$

$\mathrm{LF}_{\text {drip }}: 0.13$

$\mathrm{LF}_{\text {furrow: }} 0.16$

Growing season: The most favourable season for growing squash ranges from August till the end of March, where the average growing period for squash ranges from two (beginning of harvest season) to four (end of harvesting season) months.

Tab. 6-2: Weekly crop water requirement (CWR) for Squash in lower Jordan Valley in mm/week (Gtz 2003).

\begin{tabular}{|c|c|c|c|c|}
\hline Month & $\begin{array}{c}\mathrm{CWR}_{1} \\
\text { (10 days) }\end{array}$ & $\begin{array}{c}\mathrm{CWR}_{2} \\
\text { (20 days) }\end{array}$ & $\begin{array}{c}\mathrm{CWR}_{3} \\
\text { (20 days) }\end{array}$ & $\mathrm{CWR}_{4}$ \\
\hline August & 16.7 & 22.2 & 27.8 & 22.2 \\
\hline September & 14.0 & 18.6 & 23.3 & 18.6 \\
\hline October & 10.0 & 13.4 & 16.7 & 13.4 \\
\hline November & 7.3 & 9.8 & 12.2 & 9.8 \\
\hline December & 4.4 . & 5.9 & 7.4 & 5.9 \\
\hline January & 4.6 & 6.2 & 7.7 & 6.2 \\
\hline February & 6.4 & 8.5 & 10.6 & 8.5 \\
\hline March & 10.7 & 14.3 & 17.9 & 14.3 \\
\hline April & 13.0 & 17.4 & 21.7 & 17.4 \\
\hline
\end{tabular}

$\mathrm{CWR}_{1}$ : initial stage: germination, seedling growth, hardly any ground cover $(<10 \%)$

$\mathrm{CWR}_{2}$ : crop development stage: until effective full cover ( $\left.70-80 \%\right)$

$\mathrm{CWR}_{3}$ : mid season stage: full cover until start of maturing, discolouring, normally well past the flowering stage of annual crops

$\mathrm{CWR}_{4}$ : late season: full maturity, discolouring, leaves dropping, harvest

The above mentioned growing seasons together with the calculated CWR values above result in a minimum seasonal CWR of $128 \mathrm{~m}^{3} / \mathrm{du}$ for a cropping season ranging from November till the end of February and a maximum seasonal CWR of $285 \mathrm{~m}^{3} / \mathrm{du}$ for a cropping season ranging from August till the end of November. Consequently, the FWR ranges from $185 \mathrm{~m}^{3} / \mathrm{du}$ for drip irrigation systems ( $254 \mathrm{~m}^{3} / \mathrm{du}$ for furrow irrigation) to $409 \mathrm{~m}^{3} / \mathrm{du}$ for drip irrigation systems $\left(565 \mathrm{~m}^{3} / \mathrm{du}\right.$ for furrow irrigation systems).

\section{Eggplant:}

Recommended irrigation water salinity threshold: $<4.0-4.3 \mathrm{mS} / \mathrm{cm}$

$\mathrm{LF}_{\text {drip }}: 0.12$

$\mathrm{LF}_{\text {furrow: }} 0.38$

Growing season: The transplanting season of eggplant plants is around August to September. Harvesting time begins around November and might last for as long as the end of June ( around six to seven months). 
The above mentioned growing seasons together with the calculated CWR values below result in a minimum seasonal CWR of $564 \mathrm{~m}^{3} / \mathrm{du}$ for a cropping season ranging from September till June and a maximum seasonal CWR of $650 \mathrm{~m}^{3} / \mathrm{du}$ for a cropping season ranging from August till the end of May. Consequently the FWR ranges from $804 \mathrm{~m}^{3} / \mathrm{du}$ for drip irrigation systems $\left(1520 \mathrm{~m}^{3} / \mathrm{du}\right.$ for furrow irrigation) to $924 \mathrm{~m}^{3} / \mathrm{du}$ for drip irrigation systems ( $1748 \mathrm{~m}^{3} / \mathrm{du}$ for furrow irrigation systems).

Tab. 6-3: Weekly crop water requirement for eggplant in the lower Jordan Valley in mm/week (GTZ 2003).

\begin{tabular}{|c|c|c|c|c|}
\hline Month & $\begin{array}{c}\mathbf{C W R}_{\mathbf{1}} \\
\text { (30 days) }\end{array}$ & $\begin{array}{c}\mathbf{C W R}_{\mathbf{2}} \\
\mathbf{( 4 0} \text { days })\end{array}$ & $\begin{array}{c}\mathbf{C W R}_{\mathbf{3}} \\
\mathbf{( 4 0} \text { days })\end{array}$ & $\mathbf{C W R}_{\mathbf{4}}$ \\
\hline August & 16.7 & 23.6 & 30.5 & 25 \\
\hline September & 14 & 19.8 & 25.6 & 20.9 \\
\hline October & 10 & 14.2 & 18.4 & 15.1 \\
\hline November & 7.3 & 10.3 & 13.4 & 10.9 \\
\hline December & 4.5 & 6.3 & 8.2 & 6.7 \\
\hline January & 4.6 & 6.6 & 8.5 & 6.9 \\
\hline February & 6.4 & 9 & 11.7 & 9.6 \\
\hline March & 10.7 & 15.2 & 19.7 & 16.1 \\
\hline April & 13 & 18.4 & 23.9 & 19.5 \\
\hline May & 16.7 & 23.6 & 30.6 & 25 \\
\hline June & 19.3 & 27.4 & 35.5 & 29 \\
\hline
\end{tabular}

\section{Tomato:}

Recommended irrigation water salinity threshold: $<4.2 \mathrm{mS} / \mathrm{cm}$

$\mathrm{LF}_{\text {drip }}: 0.14$

Growing season: The favourable growing season for tomato is from mid December until the end of June. Harvesting time begins around the beginning of May and last for about one month.

Tab. 6-4: Weekly crop water requirement for tomato in lower Jordan Valley in mm/week (GTZ 2003).

\begin{tabular}{|c|c|c|c|c|}
\hline Month & $\begin{array}{c}\mathbf{C W R}_{\mathbf{1}} \\
\text { (30 days) }\end{array}$ & $\begin{array}{c}\mathbf{C W R}_{\mathbf{2}} \\
\mathbf{( 4 0} \text { days) }\end{array}$ & $\begin{array}{c}\mathbf{C W R}_{\mathbf{3}} \\
\mathbf{( 4 0} \text { days })\end{array}$ & $\mathbf{C W R}_{\mathbf{4}}$ \\
\hline December & 4.5 & 6.9 & 9.3 & 4.8 \\
\hline January & 4.6 & 7.2 & 9.6 & 5.0 \\
\hline February & 6.4 & 9.9 & 13.3 & 6.9 \\
\hline March & 10.7 & 16.6 & 22.4 & 11.6 \\
\hline April & 13.0 & 20.2 & 27.1 & 14.1 \\
\hline May & 16.7 & 25.9 & 34.8 & 18.1 \\
\hline June & 19.3 & 30.0 & 40.3 & 20.9 \\
\hline July & 19.0 & 29.5 & 39.6 & 20.6 \\
\hline
\end{tabular}

The above mentioned growing seasons together with the calculated CWR values above result in a minimum seasonal CWR of $273 \mathrm{~m}^{3} / \mathrm{du}$ for a cropping season ranging from December till the end of 
May and a maximum seasonal CWR of $439 \mathrm{~m}^{3} / \mathrm{du}$ for a cropping season ranging from March till the end of June. Consequently the FWR ranges from $398 \mathrm{~m}^{3} / \mathrm{du}$ for drip irrigation systems $\left(735 \mathrm{~m}^{3} / \mathrm{du}\right.$ for furrow irrigation) to $637 \mathrm{~m}^{3} / \mathrm{du}$ for drip irrigation systems $\left(1,179 \mathrm{~m}^{3} / \mathrm{du}\right.$ for furrow irrigation systems).

\section{Potato:}

Recommended irrigation water salinity threshold (GTZ): $<3.8 \mathrm{mS} / \mathrm{cm}$

$\mathrm{LF}_{\text {drip }}: 0.16$

$\mathrm{LF}_{\text {furrow: }}: 0.26$

Growing season: The growing season for potato in the lower Jordan Valley extents from the beginning of December until the end of April. Some farmers start planting potatoes as early as the beginning of October.

Tab. 6-5: Weekly crop water requirement for potato in the lower Jordan Valley in mm/week (Gtz 2003).

\begin{tabular}{|c|c|c|c|c|}
\hline Month & $\begin{array}{c}\mathbf{C W R}_{\mathbf{1}} \\
\mathbf{( 3 0}^{\mathbf{3 0}} \text { days) }\end{array}$ & $\begin{array}{c}\mathbf{C W R}_{\mathbf{2}} \\
\left.\mathbf{( 3 0}_{\mathbf{3}} \mathbf{\text { days }}\right)\end{array}$ & $\begin{array}{c}\mathbf{C W R}_{\mathbf{3}} \\
\left.\mathbf{( 3 0}_{\mathbf{3}} \text { days }\right)\end{array}$ & $\mathbf{C W R}_{\mathbf{4}}$ \\
\hline October & 10 & 15.1 & 20.1 & 12.5 \\
\hline November & 7.3 & 10.9 & 14.6 & 9.1 \\
\hline December & 4.5 & 6.7 & 8.9 & 5.6 \\
\hline January & 4.6 & 6.9 & 9.2 & 5.8 \\
\hline February & 6.4 & 9.6 & 12.8 & 8 \\
\hline March & 10.7 & 16.1 & 21.5 & 13.4 \\
\hline April & 13 & 19.5 & 26 & 16.3 \\
\hline
\end{tabular}

The above mentioned growing seasons together with the calculated CWR values above result in a minimum seasonal CWR of $161 \mathrm{~m}^{3} / \mathrm{du}$ for a cropping season ranging from October till the end of February and a maximum seasonal CWR of $220 \mathrm{~m}^{3} / \mathrm{du}$ for a cropping season ranging from January till April. Consequently the FWR ranges from $240 \mathrm{~m}^{3} / \mathrm{du}$ for drip irrigation systems $\left(363 \mathrm{~m}^{3} / \mathrm{du}\right.$ for furrow irrigation) to $326 \mathrm{~m}^{3} / \mathrm{du}$ for drip irrigation systems ( $495 \mathrm{~m}^{3} / \mathrm{du}$ for furrow irrigation systems).

\section{Sweet corn:}

Recommended irrigation water salinity threshold (GTZ 2003): $<3.8 \mathrm{mS} / \mathrm{cm}$

$\mathrm{LF}_{\text {drip }}: 0.16$

$\mathrm{LF}_{\text {furrow: }} 0.6$

Growing season: This crop is not very common since there is no processing for sweet corn in Jordan. However, it is grown to a certain extent in the study area (Fig. 6-1 left). The best season is the summer season. The best time for planting is end of February and the harvesting time is the end of May, beginning of June.

The above mentioned growing seasons together with the calculated CWR values above result in a minimum seasonal CWR of $266 \mathrm{~m}^{3} / \mathrm{du}$ for a cropping season ranging from September till the end of January and a maximum seasonal CWR of $284 \mathrm{~m}^{3} / \mathrm{du}$ for a cropping season ranging from the beginning of March till the end of May. Consequently, the FWR ranges from $395 \mathrm{~m}^{3} / \mathrm{du}$ for drip irrigation systems $\left(1,108 \mathrm{~m}^{3} / \mathrm{du}\right.$ for furrow irrigation) to $422 \mathrm{~m}^{3} / \mathrm{du}$ for drip irrigation systems $\left(1,184 \mathrm{~m}^{3} / \mathrm{du}\right.$ for furrow irrigation systems). 
Tab. 6-6: Weekly crop water requirement for sweet corn in the lower Jordan Valley in mm/week (Gtz 2003).

\begin{tabular}{|c|c|c|c|c|}
\hline Month & $\begin{array}{c}\mathbf{C W R}_{\mathbf{1}} \\
\text { (20 days) }\end{array}$ & $\begin{array}{c}\mathbf{C W R}_{\mathbf{2}} \\
\text { (30 days) }\end{array}$ & $\begin{array}{c}\mathbf{C W R}_{\mathbf{3}} \\
\text { (30 days) }\end{array}$ & $\mathbf{C W R}_{\mathbf{4}}$ \\
\hline February & 6.4 & 9.6 & 12.8 & 11.7 \\
\hline March & 10.7 & 16.1 & 21.5 & 19.7 \\
\hline April & 13 & 19.5 & 26 & 23.9 \\
\hline May & 16.7 & 25 & 33.4 & 30.6 \\
\hline June & 19.3 & 29 & 38.7 & 35.5 \\
\hline July & 19 & 28.5 & 38 & 34.9 \\
\hline August & 16.7 & 25 & 33.3 & 30.5 \\
\hline September & 14 & 20.9 & 27.9 & 25.6 \\
\hline October & 10 & 15.1 & 20.1 & 18.4 \\
\hline November & 7.3 & 10.9 & 14.6 & 13.4 \\
\hline December & 4.5 & 6.7 & 8.9 & 8.2 \\
\hline January & 4.6 & 6.9 & 9.2 & 8.5 \\
\hline
\end{tabular}

\section{Wheat/ Barley:}

Recommended irrigation water salinity threshold (GTZ 2003): $<5.4 \mathrm{mS} / \mathrm{cm}$ (Wheat) $/<7 \mathrm{mS} / \mathrm{cm}$ (Barley)

$\mathrm{LF}_{\text {drip }}: 0.10$

$\mathrm{LF}_{\text {furrow: }}: 0.16$

Growing season: Wheat/ Barley are grown in the winter (rainy) season and that is from November until June. The length of the growing period varies from 94 to 188 days. Yet there is no significant relationship between the length of the growing period and the productive yield.

Tab. 6-7: Weekly crop water requirement for wheat/ barley in lower Jordan Valley in mm/week (Gtz 2003).

\begin{tabular}{|c|c|c|c|c|}
\hline Month & $\begin{array}{c}\mathbf{C W R}_{\mathbf{1}} \\
\text { (20 days) }\end{array}$ & $\begin{array}{c}\mathbf{C W R}_{\mathbf{2}} \\
\mathbf{( 2 5} \text { days) }\end{array}$ & $\begin{array}{c}\mathbf{C W R}_{\mathbf{3}} \\
\mathbf{( 5 0} \text { days})\end{array}$ & $\mathbf{C W R}_{\mathbf{4}}$ \\
\hline November & 7.3 & 10.1 & 14.6 & 2.4 \\
\hline December & 4.5 & 6.2 & 8.9 & 1.5 \\
\hline January & 4.6 & 6.4 & 9.2 & 1.5 \\
\hline February & 6.4 & 8.8 & 12.8 & 2.1 \\
\hline March & 10.7 & 14.8 & 21.5 & 3.6 \\
\hline April & 13 & 18 & 26 & 4.3 \\
\hline May & 16.7 & 23.1 & 33.4 & 5.6 \\
\hline June & 19.3 & 26.8 & 38.7 & 6.4 \\
\hline July & 19 & 26.3 & 38 & 6.3 \\
\hline
\end{tabular}


The above mentioned growing seasons together with the calculated CWR values above result in a minimum seasonal CWR of $192 \mathrm{~m}^{3} / \mathrm{du}$ for a cropping season ranging from November till June and a maximum seasonal CWR of $250 \mathrm{~m}^{3} / \mathrm{du}$ for a cropping season ranging from January till the end of June. Consequently, the FWR ranges from $266 \mathrm{~m}^{3} / \mathrm{du}$ for drip irrigation systems ( $380 \mathrm{~m}^{3} / \mathrm{du}$ for furrow irrigation) to $347 \mathrm{~m}^{3} / \mathrm{du}$ for drip irrigation systems ( $496 \mathrm{~m}^{3} / \mathrm{du}$ for furrow irrigation systems).

\section{Banana:}

The most profitable, but also most questionable with regard to irrigation water quantity and quality is the banana crop. It is grown in large quantities in the study area. Despite the fact that a mean temperature of about $27^{\circ}$, which is given in the Jordan Valley, is optimal for its growth, bananas can be grown in a wide range of soils. The soil has to be fertile and above all well drained. Bananas are very sensitive to salinity, and soils with an EC of less than $1 \mathrm{mS} / \mathrm{cm}$ are required for good growth. Since bananas are a long duration crops, their total water requirements are high (annual irrigation). Furthermore, bananas require an ample and frequent supply of water. In the study area, drip irrigation is nowadays used. Since bananas are grown under conditions of high evaporation, low rainfall, and the irrigation water contains some amounts of salt, accumulation of salts at the boundary of wet and dry soil area will occur. Therefore intensive soil leaching is needed.

LF: 0.5

Growing season: The development of the plant can be divided into three periods: vegetative, flowering, and yield formation. The time from planting to shooting (vegetative) is about seven to nine months. The time from shooting to harvest (flowering and yield formation) is about three to six months. With mechanical cultivation the economic life is often four to six years long.

Tab. 6-8: Weekly crop water requirement for banana in the lower Jordan Valley in mm/week (GTZ 2003).

\begin{tabular}{|c|c|c|c|c|c|c|}
\hline \multirow[b]{2}{*}{ Month } & \multicolumn{3}{|l|}{ 1st year } & \multicolumn{3}{|l|}{$>1$ st year } \\
\hline & $\begin{array}{c}\text { CWR }_{1} \\
\text { (120 days) }\end{array}$ & $\begin{array}{c}\mathrm{CWR}_{2} \\
\text { (60-90 days) }\end{array}$ & $\begin{array}{c}\mathrm{CWR}_{3} \\
\text { (180 days) }\end{array}$ & $\begin{array}{c}\text { CWR }_{1} \\
\text { (120 days) }\end{array}$ & $\begin{array}{c}\mathrm{CWR}_{2} \\
\text { (60-90 days) }\end{array}$ & $\begin{array}{c}\mathrm{CWR}_{3} \\
\text { (180 days) }\end{array}$ \\
\hline January & 3.9 & 6.6 & 8.9 & 5.8 & 7.7 & 9.6 \\
\hline February & 5.3 & 9.0 & 12.2 & 8.0 & 10.6 & 13.3 \\
\hline March & 9.0 & 15.2 & 20.6 & 13.4 & 17.9 & 22.4 \\
\hline April & 10.9 & 18.5 & 25.0 & 16.3 & 21.7 & 27.1 \\
\hline May & 13.9 & 23.6 & 32.0 & 20.9 & 27.8 & 34.8 \\
\hline June & 16.1 & 27.4 & 37.0 & 24.2 & 32.2 & 40.3 \\
\hline July & 15.9 & 26.9 & 36.5 & 23.8 & 31.7 & 39.6 \\
\hline August & 13.9 & 23.6 & 32.0 & 20.9 & 27.8 & 34.8 \\
\hline September & 11.7 & 19.8 & 26.8 & 17.5 & 23.3 & 29.1 \\
\hline October & 8.4 & 14.2 & 19.2 & 12.5 & 16.7 & 20.9 \\
\hline November & 6.1 & 10.4 & 14.0 & 9.2 & 12.2 & 15.3 \\
\hline December & 3.7 & 6.3 & 8.5 & 5.6 & 7.4 & 9.3 \\
\hline
\end{tabular}

The above mentioned growing seasons together with the calculated CWR values above result in an annual CWR for up to one year old banana plants of $885 \mathrm{~m}^{3} / \mathrm{du}$ and an annual CWR for plants older than one year of $1,052 \mathrm{~m}^{3} / \mathrm{du}$ per year. The annual FWR (drip irrigation system) ranges from $2,209 \mathrm{~m}^{3} / \mathrm{du}$ to $2,631 \mathrm{~m}^{3} / \mathrm{du}$ for up to one year old plants and older than one year plants respectively. 
Tab. 6-9: Monthly Field Water Requirement of different crops in the lower Jordan Valley $\left[\mathrm{m}^{3} / \mathrm{du}\right]$. Two different irrigation systems are considered $(\mathrm{drip}=$ drip irrigation; furr $=$

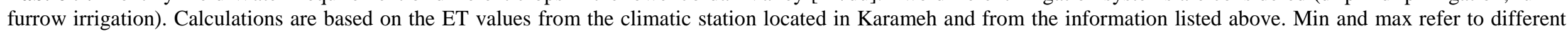

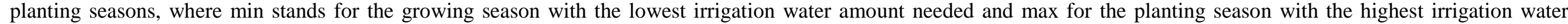
requirement.

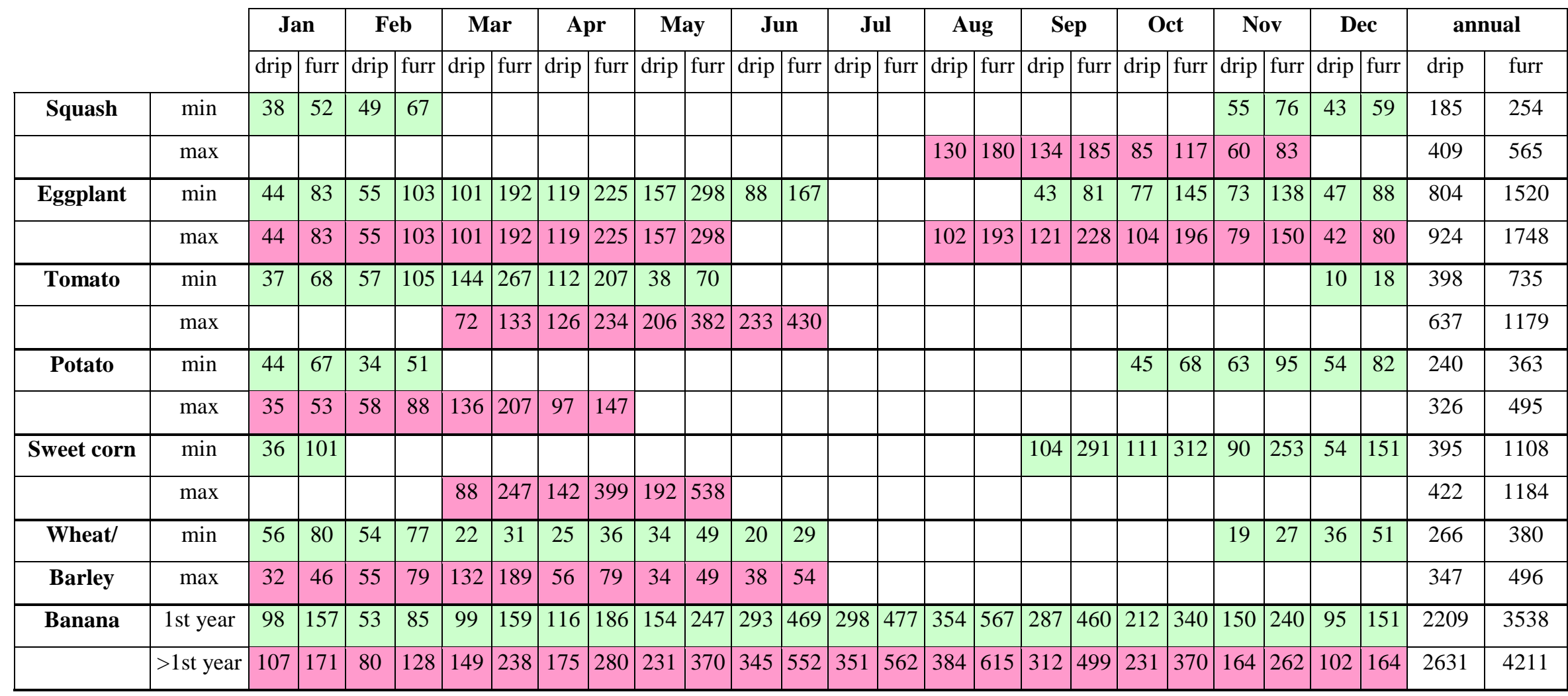

Monthly average values of vegetables and banana $\left[\mathrm{m}^{3} / \mathrm{du}\right]$ :

\begin{tabular}{|c|c|c|c|c|c|c|c|c|c|c|c|c|c|c|c|c|c|c|c|c|c|c|c|c|c|}
\hline Vegetable & average & 41 & 70 & 52 & 84 & 100 & 182 & 100 & 194 & 117 & 241 & & & & & & & 101 & 196 & 84 & 168 & 63 & 117 & 41 & 76 \\
\hline Banana & average & 103 & 164 & 67 & 107 & 124 & 199 & 146 & 233 & 193 & 309 & 319 & 511 & 325 & 520 & 369 & 591 & 300 & 480 & 222 & 355 & 157 & 251 & 99 & 158 \\
\hline
\end{tabular}




\subsection{Change in LAND-USE DETERmined by the USE of AN AERIAL PHotograph AND SATELLITE IMAGES}

Two different kinds of data sets were used to estimate the area of irrigated land during different periods of the last 40 years: an analogue aerial b/w photograph and Landsat data. The air photos were taken on the $22^{\text {nd }}$ of April 1961 (scale 1:100,000) and were collected from the Royal Geographic Centre in Amman/ Jordan. Five Landsat data sets ranging from 1973 until 2002 were attained from the website of the Global Landcover Facility (http://glcfapp.umiacs.umd.edu:8080/esdi/index.jsp). The GLCF is a centre for land cover science with a focus on research using remotely sensed satellite data and products to assess land cover change for local to global systems. It is also a member of the Research, Education, and Applications Solutions Network (REASoN) and as such is sponsored by the NASA Earth Science Enterprise. The GLCP offers a huge collection of Landsat data, which are downloadable free of charge. The obtained satellite scenes were already orthorectified. The following datasets were available:

- Landsat MSS image data acquired at the $01^{\text {st }}$ of January 1973 ,

- Landsat TM image data acquired at the $14^{\text {th }}$ of August 1987,

- Landsat ETM+ image data acquired at the $07^{\text {th }}$ of August 1999,

- Landsat ETM+ image data acquired at the $25^{\text {th }}$ of May 2000,

- Landsat ETM+ image data acquired at the $8^{\text {th }}$ of March 2002.

All scenes were processed with the commercial software package ENVI 4.3 (ITT Industries Inc.) and post-processed with commercial software package ArcGIS 9.1 (ESRI Inc.).

\subsubsection{Analogue aerial photographs}

The earliest insight on cultivated land available was an aerial photograph, taken on $22^{\text {nd }}$ of April 1961. This date falls towards the end of the crop period. Because of the small scale of 1:100,000 only parts of one aerial photograph was needed. The photograph was scanned at a resolution of 800 pots per inch (dpi) with a flat bed scanner. Almost no relief exists in the study area. The average slope towards the Jordan River is very smooth (around $2^{\circ}$ ). Therefore, no orthorectification of the aerial photograph was done and the photograph was directly imported into the ArcGIS program and georeferenced. The georeferencing of the photograph produced fairly good results, roadways on the aerial photograph for example coincide well with the roadways on the topographic map. The cultivated area was digitised as a vector shapefile and the expansion of the irrigated land was calculated by area field calculations and exported as database files (DBF). 


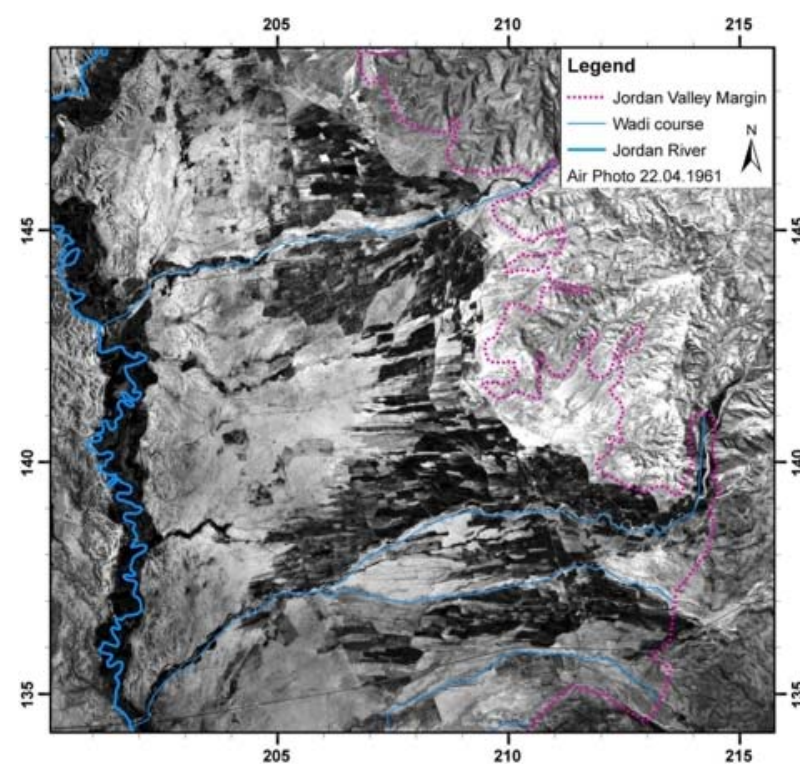

Fig. 6-3: Left: Aerial photograph, 22 ${ }^{\text {nd }}$ of April 1961. well location (well locations after Tleel 1963).

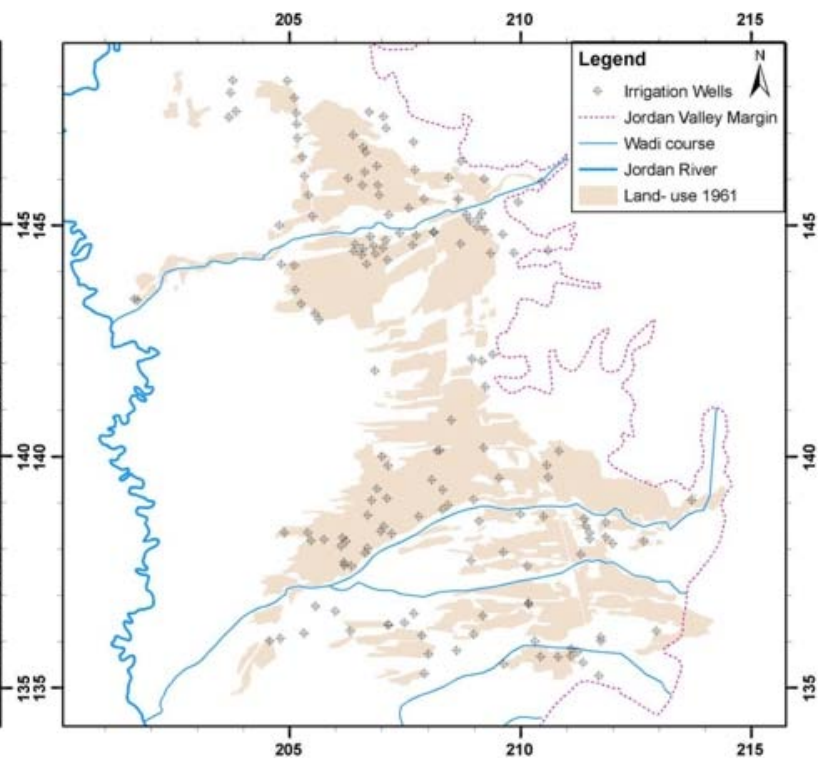

Right: Digitised area of land-use together with

Due to the poor quality and the large scale of the aerial photographs, not only different crops could not be distinguished, but it was not possible to identify irrigated areas from already harvested land as well. However, the spatial extent of cultivated area could be determined. Fig. 6-3 shows an extract of the aerial photograph on the left and the digitised farmland area on the right. The total area of farmland in 1961 was around $38 \mathrm{~km}^{2}$.

\subsubsection{Landsat data}

The aim of this subchapter is to use Landsat data to identify the area of irrigated land at different years and different periods during the year. According to Werz (2006) it is not possible to distinguish between different crops or between cultivated land and pastures with a Landsat data set. Therefore, the only goal of the classification was to identify planted areas. By post- processing of the classification results the natural vegetation was removed and the area of cultivated land was subdivided according to its irrigation water sources. The area of each subdivision was calculated.

\section{Pan-sharpening}

The Colour Normalized (Brovey) sharpening was applied to all ETM+ image data sets (Vrabel 1996). The Colour Normalized sharpening technique uses a mathematical combination of the colour image and high resolution data (15 meter resolution panchromatic band). Each band in the colour image is multiplied by a ratio of the high resolution data divided by the sum of the colour bands. The colour channel combination 541 was found to be most suitable to identify irrigated lands. The Colour Normalized function automatically resamples the three colour bands to the high-resolution pixel size using nearest neighbour convolution. The output RGB images have the pixel size of the input highresolution data $(15 \mathrm{~m})$.

\section{Supervised classification}

First, representative samples of two different groundcover types on the images were selected: vegetated areas and greenhouse areas. These groundcover types are also called classes of interest or regions of interest. The regions were chosen on the basis of field campaigns in Jordan. In order to obtain the results as accurate as possible, an adequate number of training areas for each class were graphically selected. Lillesand and Kiefer (2004) recommend a minimum amount of 10n to 100n pixel 
per training area, where $\mathrm{n}$ is the number of spectral bands used. The supervised classification method Parallelepiped was applied (Richards 1986). The Parallelepiped classification uses a simple decision rule to classify multispectral data. The decision boundaries form an n-dimensional parallelepiped classification in the image data space. The dimensions of the parallelepiped classification are defined based upon a standard deviation threshold from the mean of each selected class. If a pixel value lies above the low threshold and below the high threshold for all $\mathrm{n}$ bands being classified, it is assigned to that class. If the pixel value falls in multiple classes, the program ENVI assigns the pixel to the last class matched. Areas that do not fall within any of the parallelepiped classes are designated as unclassified. The results were exported as ESRI raster files.

\section{Post Processing}

The ESRI raster files were imported to ArcGIS 9.1 and converted to ESRI shapefiles. The shapefiles were edited. An arid to hyperarid climate prevails in the study area. So, apart from some small bushes and a few trees, no non-irrigated vegetation exists in most of the area. The only areas, where natural vegetation exists are areas with very shallow groundwater tables and within some Wadi courses and in the area close to the Dead Sea (Fig. 6-4 right). These areas were identified during field campaigns and erased from the supervised classification results. For the remaining cultivated land it was, as stated above, not possible to identify different crop types. As described above, the farmers in the test area use crop rotations. Therefore, it could not be assured that the existing crop types on the different images represent the vegetation during the acquisition of the training sites during the field campaign. However, in order to identify areas used for banana plantation, local farmers were questioned about crop plantation during field campaigns. Banana is the crop with the highest demand not only in terms of water quality but also quantity and it needs irrigation throughout the whole year. As Tab. 6-9 shows, only for some vegetables at certain growth stages, there is a bigger difference in water needs. The only exception are banana plants. A better estimation of minimum water needs for the area can be made, when areas planted with vegetable are distinguished from areas used for banana plantation. All later calculations depend on two categories: vegetables in general and banana. Since irrigation water has to be of good quality, only areas where irrigation water has good quality are considered feasible for banana plantation. The areas where only poor irrigation water is available were classified as areas unsuitable for banana plantation and labelled as vegetable areas. This is necessary, because bigger groundwater abstractions can be expected in areas used for banana plantation than in areas unsuitable for banana plantation.

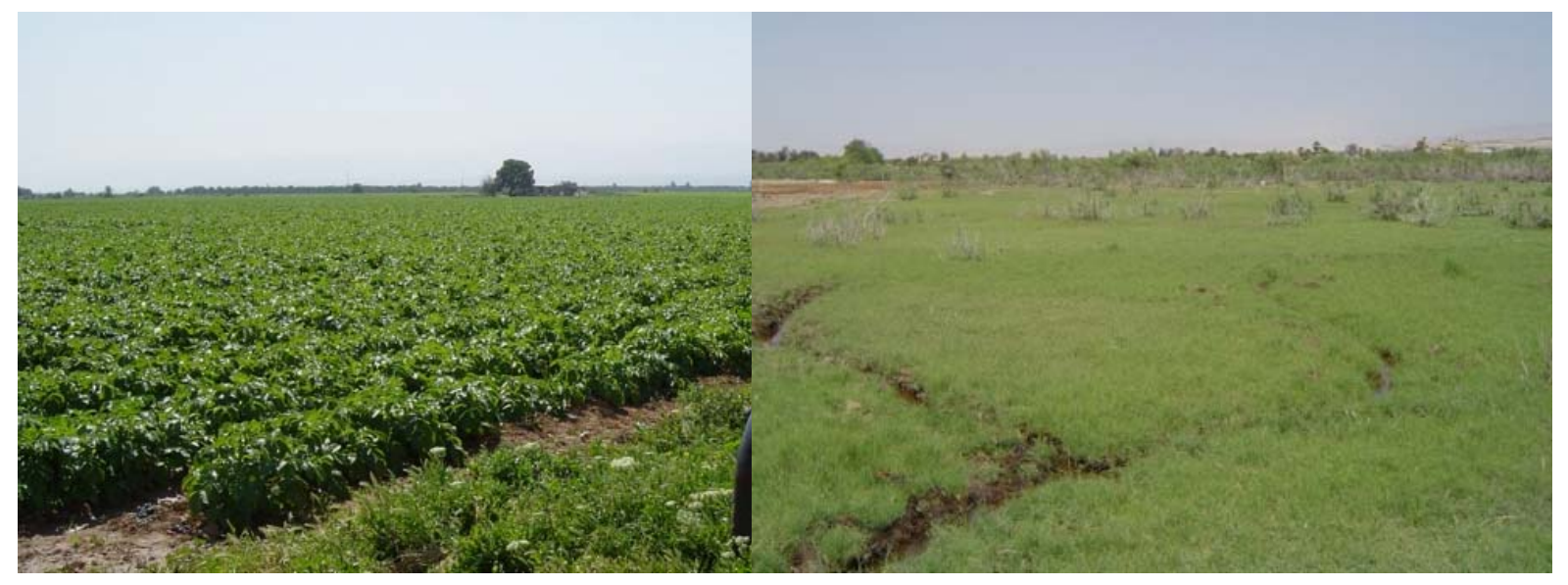

Fig. 6-4: Left: Irrigated farmland.

Right: Grassland near the shore of the Dead Sea. 


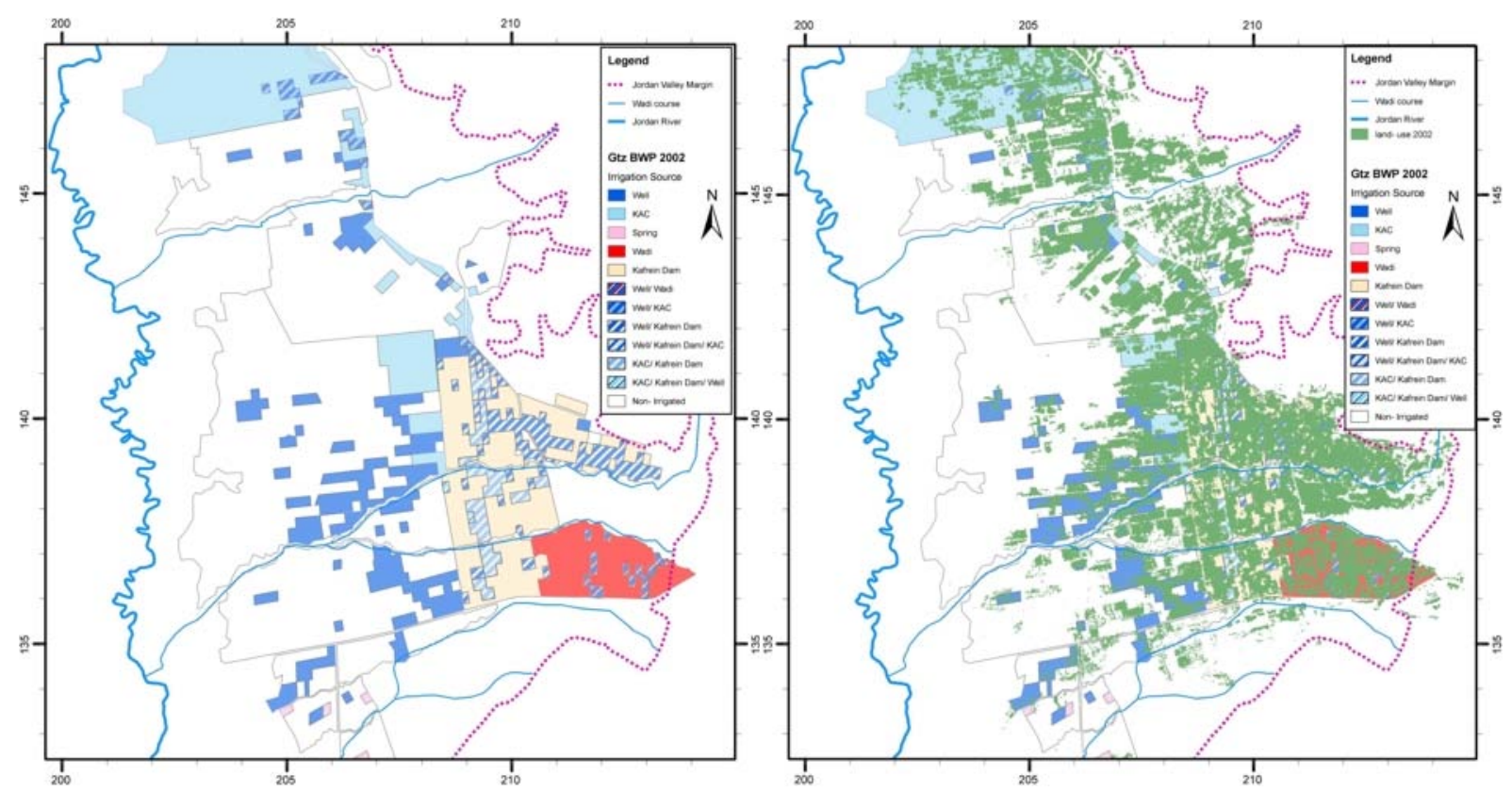

Fig. 6-5: Left: Irrigation water sources 2002 (GTZ 2003). Right: Overlay of irrigation water sources with the results of the supervised classification of the ETM+ image of March 2002.

The expansion of the irrigated land was calculated by area field calculations. On the basis of the findings of chapter 3 the irrigated areas were subdivided according to their irrigation water source. Fig. 6-5 shows on the left side the different irrigation water sources and their distribution as depicted by the GTZ (2003). On the right side of Fig. 6-5 an overlay of the supervised classification results of the ETM+ image, acquired at the $8^{\text {th }}$ of March 2002, is shown. The areas of irrigated land for each irrigation water source were determined and exported as database files (DBF).

\section{$\underline{\text { Results }}$}

MSS, $1^{\text {st }}$ of January 1973

The oldest data set available was recorded on the $1^{\text {st }}$ of January 1973. It was captured during the Landsat 1 mission with an Multispectral Scanner (MSS). The MSS was a cross-track (whiskbroom) scanner that acquired imagery in four channels (2 visible, 2 near-infrared) at a 79-meter resolution.

Fig. 6-6 shows the satellite image on the left and the supervised classification results of the MSS image on the right. Due to the low spatial resolution only limited results on irrigated areas can be obtained.

The data was acquired at the beginning of January. This falls within the winter cropping season. In 1973 planting and irrigation of crops was restricted to the winter season. Although the spatial resolution is low, it gives a good picture of the area used for agriculture. The total irrigated area was $24.48 \mathrm{~km}^{2}$. In 1973, the only irrigation water sources were water stored in dams at the outlets of Wadi Shueib and Wadi Kafrein, and water flowing in the course of Wadi Hisban as well as water from wells. Since the KAC was only completed in the upper Jordan Valley, no water from the canal was available. The biggest area was irrigated with well water $\left(13.69 \mathrm{~km}^{2}\right)$, followed by a combination of well water and reservoir water of Wadi Kafrein and Wadi Shueib $\left(6.01 \mathrm{~km}^{2}\right.$ and $2.75 \mathrm{~km}^{2}$ respectively) and the combination of well water with water flowing in the course of Wadi Hisban $\left(2.03 \mathrm{~km}^{2}\right)$. In the case of water coming from the Kafrein dam it should be noted that until 1997 the capacity of the Kafrein dam was only 3.8 MCM. Consequently most of the irrigation water in the area came from wells. 


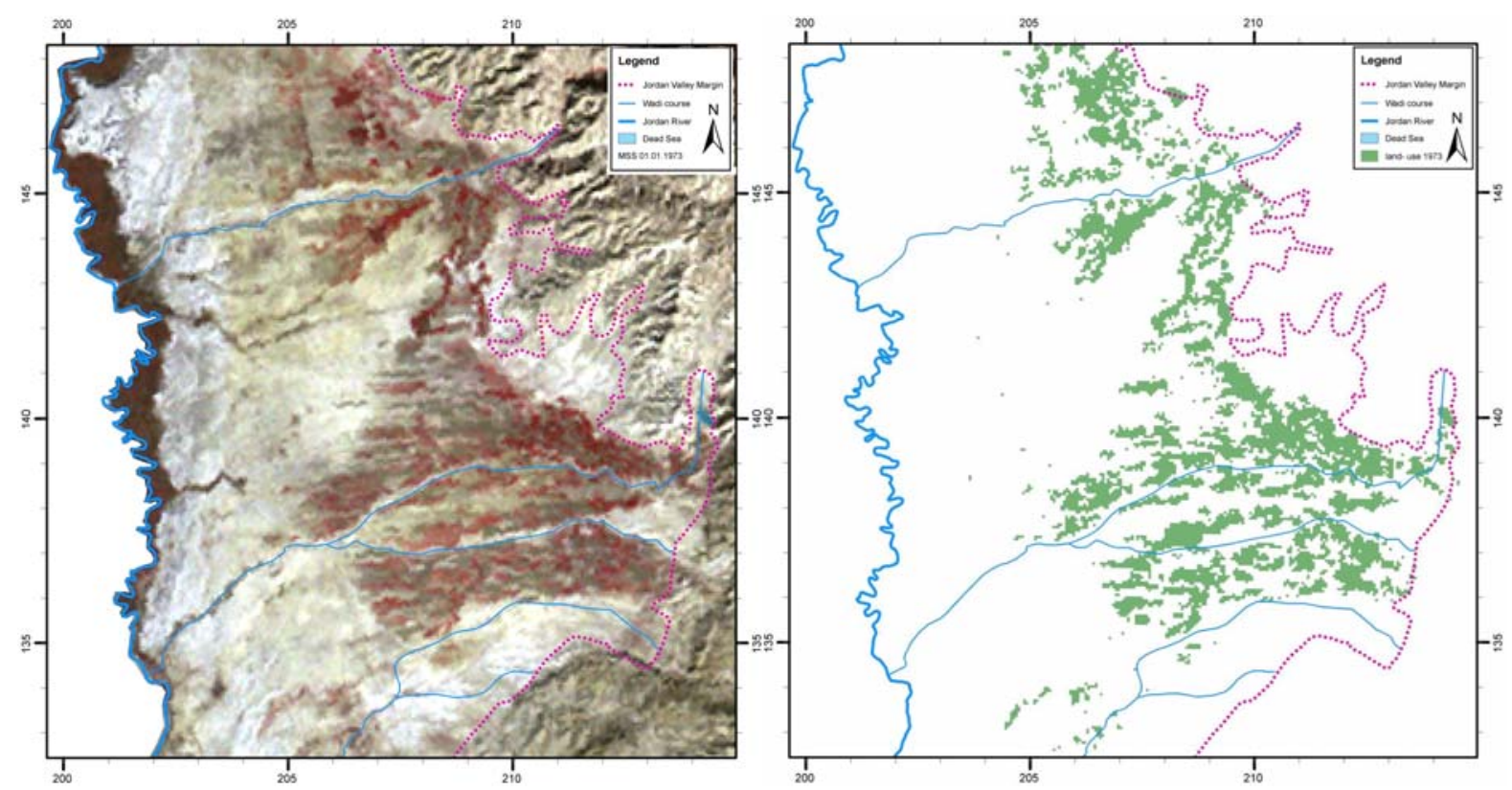

Fig. 6-6: Left: MSS satellite scene (channel combination 321). Right: Supervised classification results of the irrigated fields, $1^{\text {st }}$ of January 1973.

TM, $14^{\text {th }}$ of August 1987

The second data set was taken on the $14^{\text {th }}$ of August 1987. It was recorded by the Thematic Mapper (TM). The TM was used on Landsat- 4 and Landsat-5. The TM is a cross-track scanner providing seven multispectral channels (3 visible, 1 near-infrared, 2 mid-infrared, 1 thermal-infrared) at 30meter resolution (120 meter resolution for the thermal-infrared band).

Fig. 6-7 shows the satellite image on the left and the supervised classification results of the TM image on the right. The scene was shot in August. In August, apart from banana plants, which need annual irrigation, almost no crops are grown (Tab. 6-9). Consequently, the image gives valuable information about the extent of banana farming in the area.

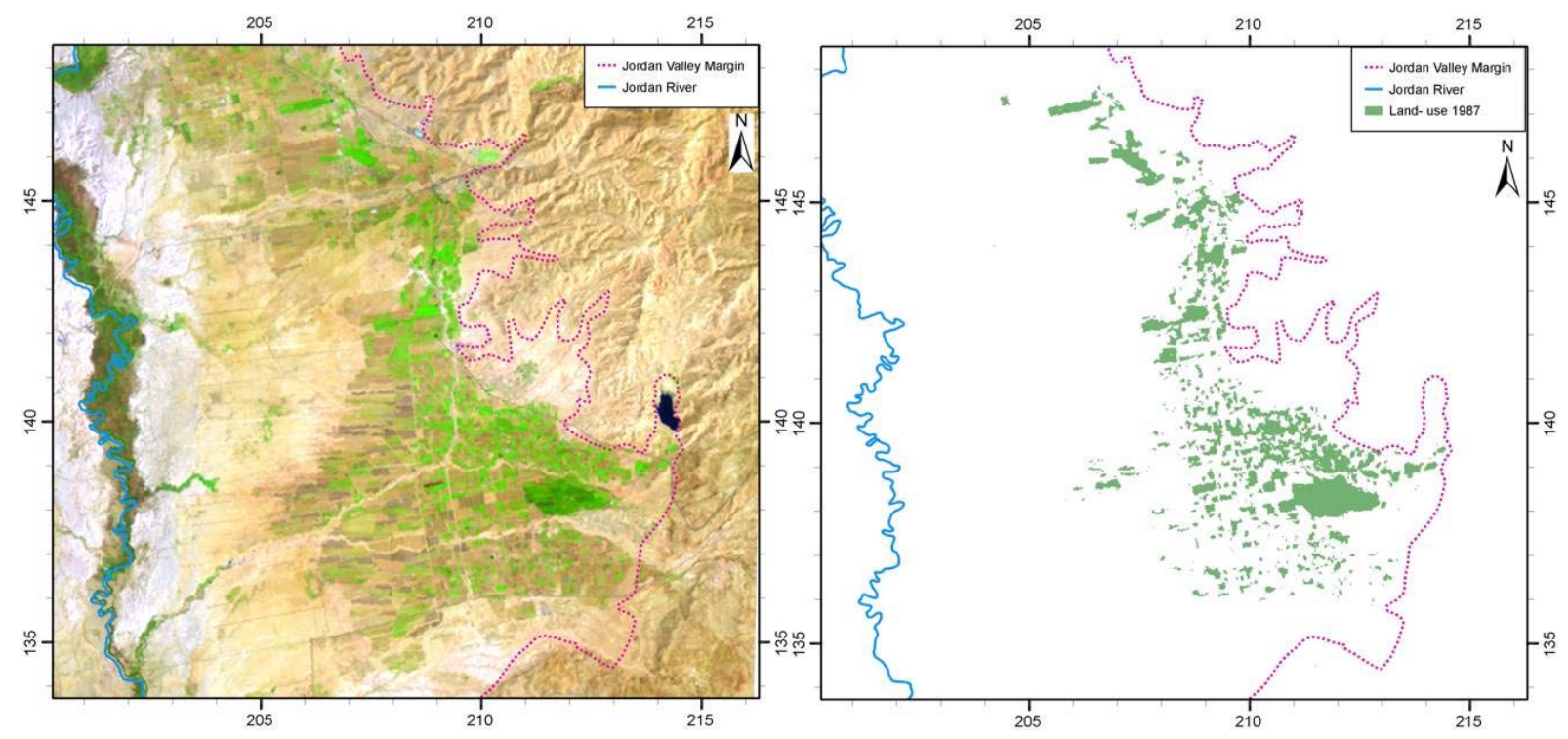

Fig. 6-7: Left: TM satellite image (channel combination 541). Right: Supervised classification results of the irrigated fields, $14^{\text {th }}$ of August 1987. 
The total irrigated area was around $14.74 \mathrm{~km}^{2}$. The KAC experienced its final extension in 1986 . Consequently, one irrigation water source was added to the study area. Most of the farming land was irrigated with a combination of well water and water from Kafrein dam $\left(8.34 \mathrm{~km}^{2}\right)$. Most of the irrigation water in the influence area of the Kafrein dam was still derived from wells. The area solemnly irrigated by wells was $2.21 \mathrm{~km}^{2}$. But contrary to the winter season the water was extracted in the eastern part of the study area near Rama where irrigation water suitable for the irrigation of bananas is available. The newly run KAC together with water from the surrounding wells irrigated an area of $1.41 \mathrm{~km}^{2}$. However, this area was mostly irrigated by well water, since the third extension of the canal carries only small amounts of water, especially in summer. The irrigated area around South Shuneh was solely irrigated with well water, since the reservoir of Shueib dam was already dry (Fig. 6-7). The irrigated area in the South Shuneh area was $1.38 \mathrm{~km}^{2}$. The combination of well water and water flowing in Wadi Hisban was used to irrigated a mere $1.4 \mathrm{~km}^{2}$.

ETM+, $07^{\text {th }}$ of August 1999

The third data set was acquired on the $7^{\text {th }}$ of August 1999. It was recorded with the Enhanced Thematic Mapper Plus (ETM+). The ETM+ instrument is similar to the earlier TM. An extra 15-meter resolution panchromatic band and an improved resolution for the thermal-infrared band (60-meters) was added.

Fig. 6-8 shows the satellite image on the left and the supervised classification results of the ETM+ image on the right. The image was also recorded during Summer. As stated above, the dominant crop in August are banana plantations. But the total irrigated area was with $17.65 \mathrm{~km}^{2}$ around twice as high as in 1999. The highest water demand existed in the area of Rama and Kafrein. The irrigated area had an extent of $8.29 \mathrm{~km}^{2}$. All irrigation water came from wells drilled in that area, since the Kafrein reservoir was already empty. The same applies for the irrigated area around South Shuneh. The total irrigated area around South Shuneh was $2.7 \mathrm{~km}^{2}$.The irrigated area south of Rama was $3.57 \mathrm{~km}^{2}$. In the area west of the influence area of the KAC $1.24 \mathrm{~km}^{2}$ were irrigated. In the influence area of the canal the irrigated area was $1.22 \mathrm{~km}^{2}$. As described above, most, if not all, irrigation water was derived from wells.

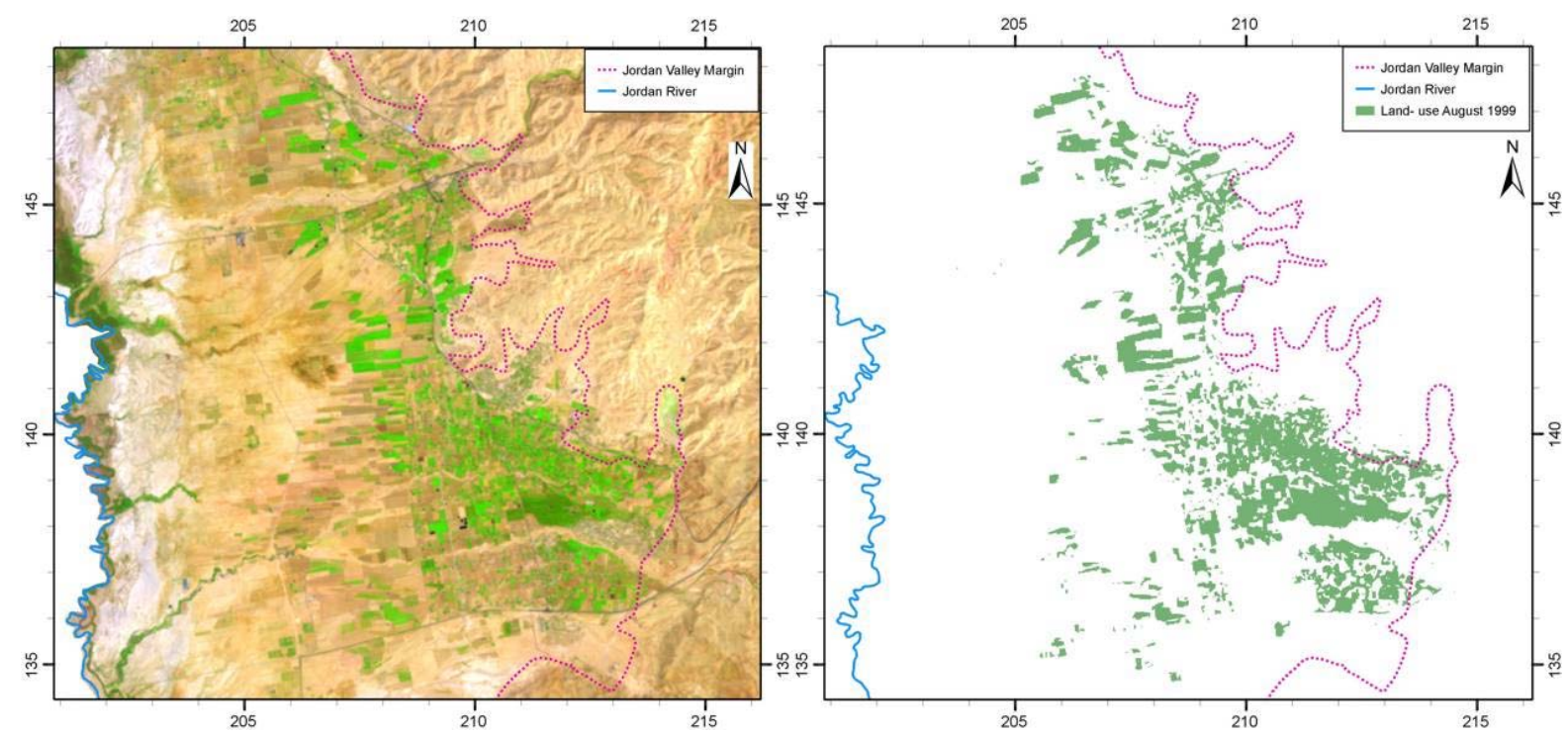

Fig. 6-8: Left: ETM+ satellite image (channel combination 541). Right: Supervised classification results of the irrigated fields, $7^{\text {th }}$ of August 1999.

ETM+, $25^{\text {th }}$ of May 2000

The fourth ETM+ data set was recorded on the $25^{\text {th }}$ of May 2000. Fig. 6-9 shows the satellite image on the left and the supervised classification results of the ETM+ image on the right. The image was taken 
towards the end of the main cropping season. Consequently a large irrigated area can be expected. The total irrigated area spread over $36.82 \mathrm{~km}^{2}$. Both reservoirs were filled. Almost half of the irrigated land was located in the influence area of the combination of the canal and well water $\left(17.49 \mathrm{~km}^{2}\right)$. Around $9.19 \mathrm{~km}^{2}$ of farmlands were irrigated in the influence area of the Kafrein reservoir and its surrounding wells. The irrigated farms in the west of the study area, which are mostly used for vegetable farming, had a dimension of around $7.49 \mathrm{~km}^{2} .2 .32 \mathrm{~km}^{2}$ of land were irrigated in the south of Rama and only $0.33 \mathrm{~km}^{2}$ in the area of South Shuneh (well and reservoir water).

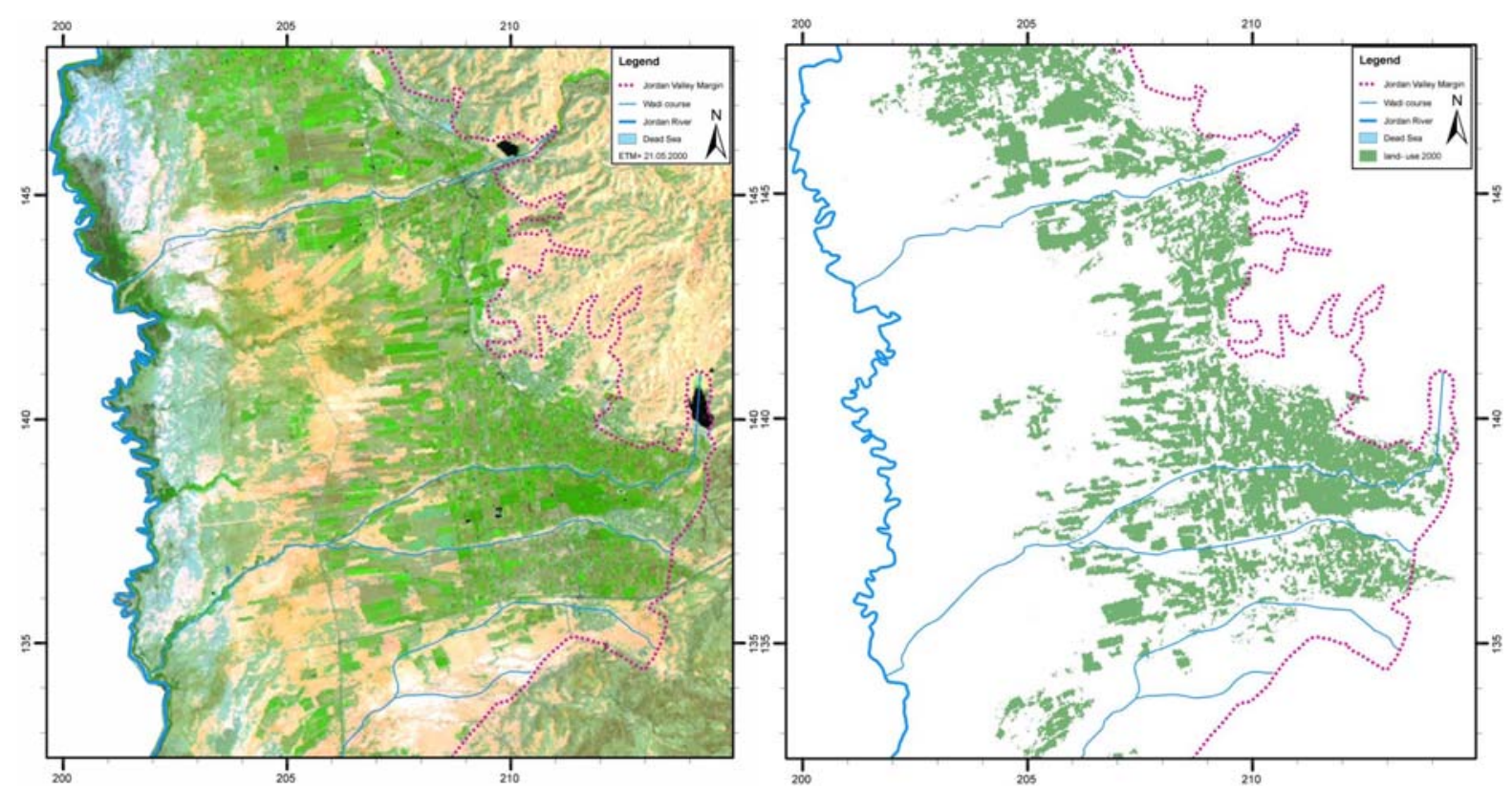

Fig. 6-9: Left: ETM+ satellite image (channel combination 541). Right: Supervised classification results of the irrigated fields, $25^{\text {th }}$ of May 2000.

ETM+, $8^{\text {th }}$ of March 2002

The last ETM+ data set was recorded on the $8^{\text {th }}$ of March 2002. Fig. 6-10 shows the satellite image on the left and the supervised classification results of the ETM+ image on the right. This image was taken one month before the picture acquired in 2000 .

A larger area of irrigated land can be expected, because it was recorded during the peak time of the cropping season. The total size of the irrigated area was $40.07 \mathrm{~km}^{2}$, which was the largest area of irrigated land identified on the available satellite data. Both reservoirs were still filled. Like in 2000, the largest area of irrigated land existed in the influence area of the canal $\left(17.77 \mathrm{~km}^{2}\right)$. It was followed by $11.82 \mathrm{~km}^{2}$ of mostly vegetable farmed irrigated land. $6.8 \mathrm{~km}^{2}$ of irrigated banana and vegetable fields were irrigated in the area between Kafrein and Rama and $3.46 \mathrm{~km}^{2}$ of farmland in the surroundings of Wadi Hisban. Again, only $0.21 \mathrm{~km}^{2}$ of land were irrigated in the influence area of the Shueib dam.

\subsection{CALCUlation of Minimum GroundWATER AbStraction Rates}

The findings of 6.2.2 to 6.2.5 were combined and used to calculate the minimum irrigation water amount that was necessary to irrigate the farmland depicted from the satellite images. For the calculations the following assumptions have been made:

- during the main cropping season, one third of the cultivated farmland is planted with banana plants (January, March, and May),

- in August no other plant except banana is grown, 
- in 1973 furrow irrigation prevailed in the study area. It was not before the eighties, that drip irrigation was introduced in the Jordan Valley,

- except for the Landsat image of 1973, drip irrigation is the only way of irrigating cultivated fields

The minimum water requirement for irrigating the cultivated land was calculated for each sector described in chapter 3 . These sectors are the well sector, the influence area of Wadi Hisban, the area between Rama and Kafrein, the influence area of Shueib dam, and the influence area of the KAC (Tab. 6-11). Two different categories for the field water requirement values were used: the vegetable and the banana category. For each month the average FWR of all vegetables and banana values were calculated. Fig. 10 shows the average monthly FWR values. The amount of banana cultivated land (30\% of the total area of each sector) and vegetable grown land (the remaining 70\%) was calculated and multiplied by the corresponding monthly field requirement values (Tab. 6-10). Tab. 6-11 shows the calculated minimum water requirement results for the study area.

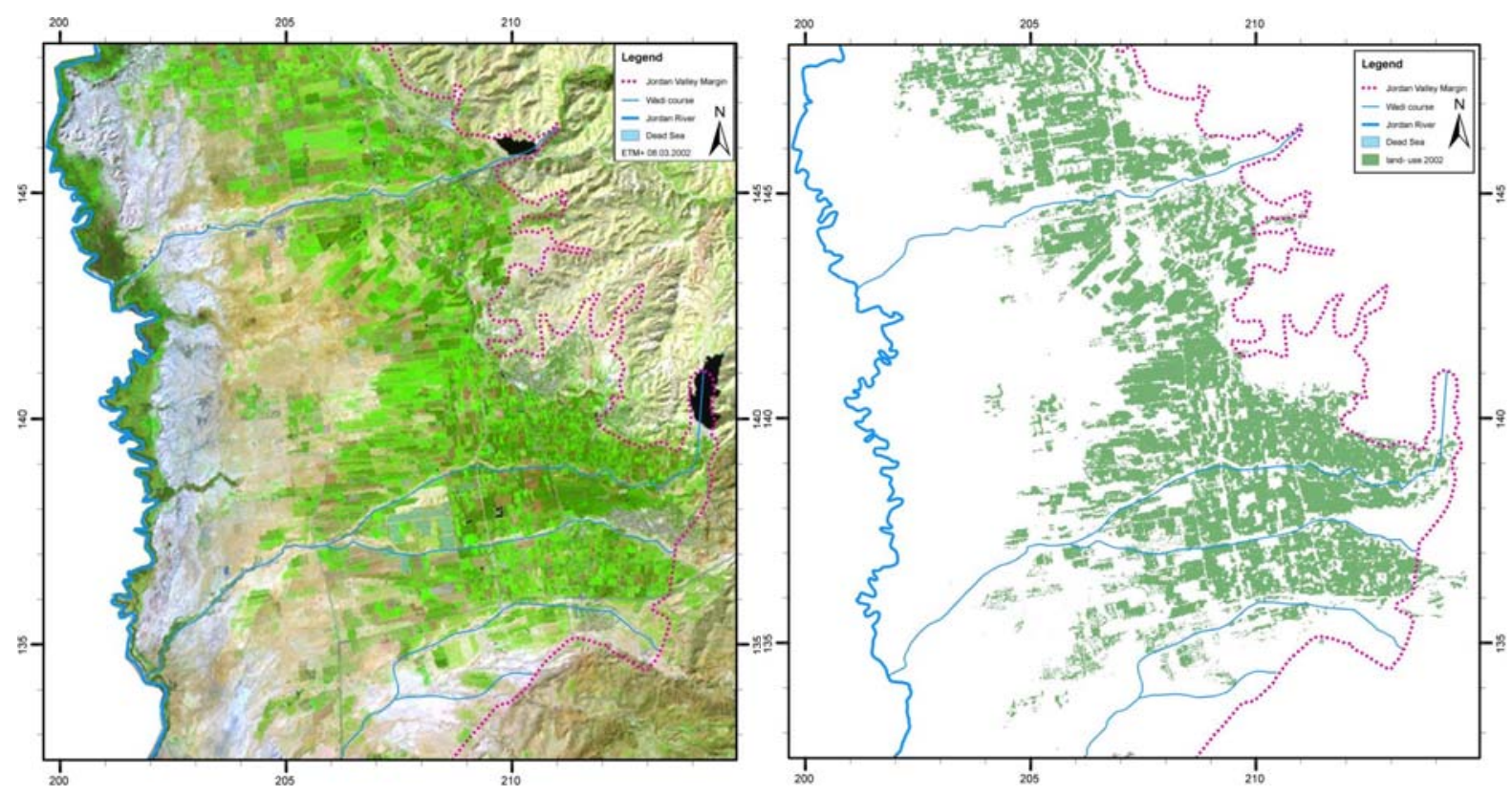

Fig. 6-10: Left: ETM+ satellite image (channel combination 541). Right: Supervised classification results of the irrigated lands, $8^{\text {th }}$ of March 2002.

Tab. 6-10: Average monthly Field Water Requirement values.

\begin{tabular}{|c|c|c|c|c|}
\cline { 2 - 5 } \multicolumn{1}{c|}{} & \multicolumn{2}{c|}{ drip } & \multicolumn{2}{c|}{ furrow } \\
\hline Month & vegetable & banana & vegetable & banana \\
\hline$[-]$ & {$\left[\mathbf{m}^{3} / \mathbf{k m}^{2}\right]$} & {$\left[\mathbf{m}^{3} / \mathbf{k m}^{2}\right]$} & {$\left[\mathbf{m}^{3} / \mathbf{k m}^{2}\right]$} & {$\left[\mathbf{m}^{3} / \mathbf{k m}^{2}\right]$} \\
\hline January & 40,667 & 102,500 & 70,333 & 164,000 \\
\hline March & 99,500 & 124,000 & 182,250 & 198,500 \\
\hline May & 116,857 & 192,500 & 240,571 & 308,500 \\
\hline August & 116,000 & 369,000 & 186,500 & 591,000 \\
\hline
\end{tabular}


Tab. 6-11: Summarized results of the area of irrigated land derived from the supervised classification of Landsat data sets $(1973-2002)$ together with Calculated minimum water demand $\left(\mathrm{Mm}^{3}=\right.$ million cubic metre) for the different periods.

\begin{tabular}{c|c|c|c|c|c|c|c|c|c|c|}
\cline { 2 - 13 } & \multicolumn{2}{c|}{ March 2002 } & \multicolumn{2}{c|}{ May 2000 } & \multicolumn{2}{c|}{ August 1999 } & \multicolumn{2}{c|}{ August 1987 } & \multicolumn{2}{c|}{ January 1973 } \\
\cline { 2 - 13 } & area & demand & area & $\mathbf{d e m a n d}$ & area & $\mathbf{d e m a n d}$ & area & demand & area & demand \\
\cline { 2 - 12 } & {$\left[\mathbf{k m}^{2}\right]$} & {$\left[\mathbf{M m}^{3}\right]$} & {$\left[\mathbf{k m}^{2}\right]$} & {$\left[\mathbf{M m}^{3}\right]$} & {$\left[\mathbf{k m}^{2}\right]$} & {$\left[\mathbf{M m}^{3}\right]$} & {$\left[\mathbf{k m}^{2}\right]$} & {$\left[\mathbf{M m}^{3}\right]$} & {$\left[\mathbf{k m}^{2}\right]$} & {$\left[\mathbf{M m}^{3}\right]$} \\
\hline West Vegetable & 11,82 & 1,26 & 7,49 & 1,05 & 3,57 & 0,41 & 2,21 & 0,26 & - & - \\
\hline Well/ KAC & 17,77 & 1,90 & 17,49 & 2,45 & 1,24 & 0,45 & 1,41 & 0,52 & 13,69 & 0,81 \\
\hline Hisban & 3,46 & 0,37 & 2,32 & 0,33 & 1,86 & 0,68 & 1,4 & 0,52 & 2,03 & 0,12 \\
\hline Shueib/Well & 0,21 & 0,02 & 0,33 & 0,05 & 2,70 & 0,98 & 1,38 & 0,51 & 2,75 & 0,16 \\
\hline KafreinWell & 6,80 & 0,73 & 9,19 & 1,29 & 8,29 & 3,01 & 8,34 & 3,08 & 6,01 & 0,36 \\
\hline \\
total
\end{tabular}

\section{Discussion of Results and possible errors}

The lowest minimum water demand was calculated for the MSS data set, acquired on the $1^{\text {st }}$ of January 1973. However, the low spatial resolution of this data set might lead to a large error. Especially in the bordering areas between the different farming units the $79 \mathrm{~m} \times 79 \mathrm{~m}$ ground cell of the spectral information of the Landsat MSS data often intermix with uncultivated areas, leading to a high amount of mixed pixels and uncertainty. Mixed pixels present a difficult problem for the image classification. Their characteristics are not representative for any single land cover type and therefore they cannot be clearly assigned to an informational class. This causes uncertainties in the applied classifications algorithms (Lillesand and Kiefer 2004). Within this study no spectral mixture analysis or fuzzy classification was applied to deal with the classification of the mixed pixels.

The water requirement shows a strong dependence on the season and although during summer only banana is grown (one third of the cultivated land during the major cropping season), the minimum water requirement is higher or almost as high as during main cropping season in spring time. In addition it should be noted that parts or even the full water requirement of vegetables is covered by natural rainfall during the winter season, which diminishes pumping activities. The calculations above show that when estimating water requirements a seasonal perspective is needed. Philippe (2004) or the Control Directorate of the JVA in Deir Allah calculates the crop water requirement with standard factors, which are constant for the entire year. As a result, the water demand for banana fields is around $15 \mathrm{~mm} /$ day/du (Philippe 2004) or $8 \mathrm{~mm} /$ day/du (JVA) and 2-3 mm/day/du for vegetable fields (Philippe 2004, JVA) regardless whether these crops are planted in winter or summer. Water requirement calculations made on the basis of Philippe (2004) or the Control Directorate of the JVA will lead to a high over- or underestimation (depending on the seasonal period) of irrigation water requirements. During the nineties, planting activities were intensified and more land was cultivated than in previous periods.

However, there are possible errors which might lead to the underestimation of irrigation water demand using remote sensing techniques. During early growth stages of the different plants, the cultivated area will not be classified as cultivated area, although actively irrigated, since its characteristic colour is still missing (Fig. 6-11 left). In certain areas in the study area vegetables are grown under a certain kind of fleece (Fig. 6-11 right). This fleece cannot be identified on the satellite images, since no comparison of ground truth data and the satellite spectral information could be made. Consequently, these areas were undocumented during the supervised classification. But during the field campaigns, these kinds of farming techniques were only observed in very few fields in the study area. Hence the resulting error can be assumed to be negligible. 


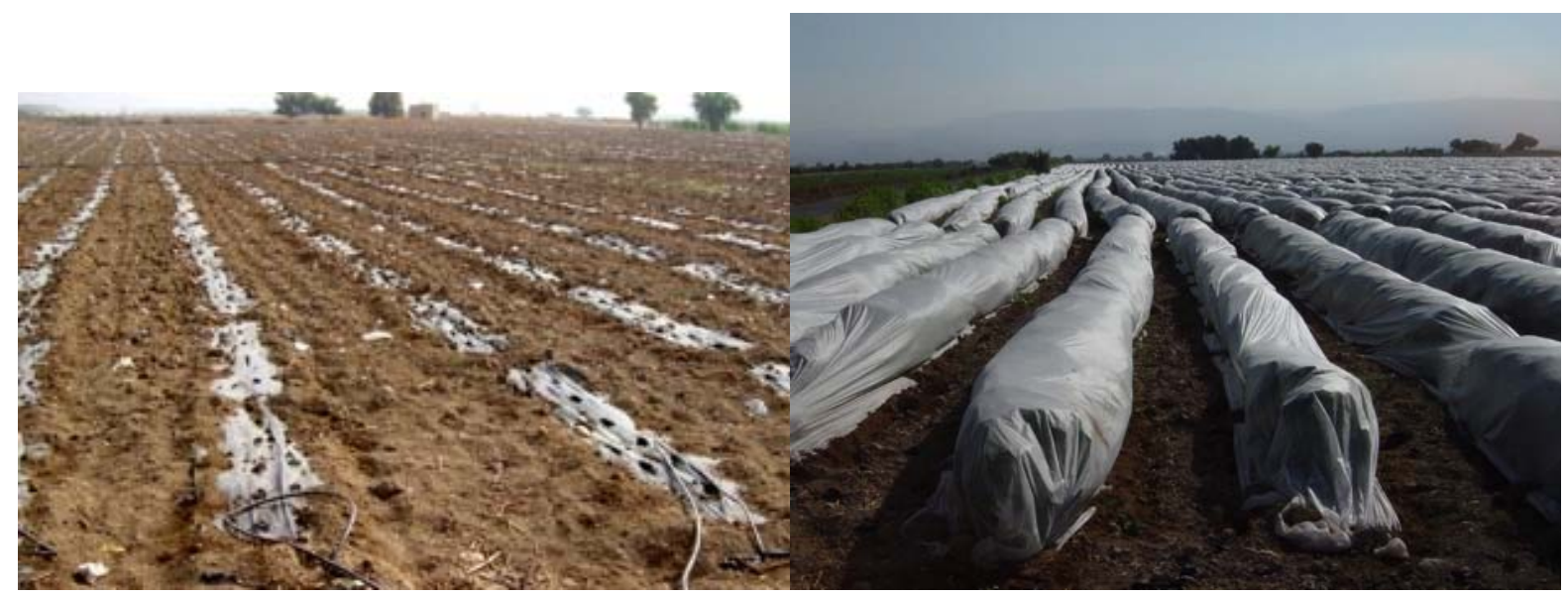

Fig. 6-11: Possible errors leading to underestimation of cultivated areas. Left: early growing stages of plants, which are already irrigated. Right: Vegetables grown under a fleece.

\subsection{A SAMPLE WATER BUdGet CALCULATION FOR THE STUdY AREA}

With the help of the information gathered above an average water budget for the period $1987-2002$ will be set up. This budget will be later used to set up a steady state flow model. However, due to incomplete data records, the surface flow of the study area has to be estimated from older records (1956-1968; taken from GTZ 1977). A trend line approach will be used to estimate the yearly surface flow from yearly rainfall records. A water budget for the study area can only be set up by making certain assumptions. These assumptions are: (a) the rainfall runoff relationship remains constant from 1956 until 2002, (b)since the completion of the surface dams at the outlets of Wadi Shueib and Wadi Kafrein the whole surface flow of these wadis is used to irrigate the field shown in Fig. 6-5, left, (c) the fields which are irrigated with water from the King Abdullah canal are excluded from the water budget and the classification of the satellite scenes, and (d) the field water requirement of the area represents the water need of the plants, which means, that irrigation return flow has not to be taken into account.

The water balance for the study area consists of the following components: input components into the study area are surface water stored in the Kafrein and Shueib dam, water flowing in Wadi Hisban and in some minor wadis in the southeast of the study area, and infiltrating groundwater from adjacent consolidated aquifers or the deep highly pressurized Ram Group aquifer; output components out of the study area are the water demand of the irrigated fields, which includes irrigation water from the storage dams and pumped groundwater, and outflow through the western border of the study area.

First, the amount of surface water available for irrigation in the study area is estimated. Since yearly rainfall for every period considered exists, the yearly rainfall (Naur Station) versus the available yearly surface flow (from the station in Wadi Shueib, Wadi Kafrein, and Wadi Hisban) were plotted in an $x-y$ diagram. The equation for each wadi derived from trend line through the available points (Fig. 6-12) was used to estimate surface flow for the considered period. An average flow (for the period 1987 2002) of $5.5 \mathrm{Mm}^{3}$ for Wadi Shueib, 5.3 for Wadi Kafrein, $3.93 \mathrm{Mm}^{3}$ for Wadi Hisban was calculated. For the remaining small wadis in the study area an average flow of $2 \mathrm{Mm}^{3}$ was assumed (according to their relative small catchment area). This amounts to a total of $16.8 \mathrm{Mm}^{3}$ for total available surface flow.

Taking the different planting and harvesting practices under consideration, the yearly field water requirement of the study area was calculated (Tab. 6-12). The calculation revealed that a total of around 31.5 million cubic meter of irrigation water is needed to irrigate the farmland in the model domain. Since no other information regarding planting activities exists for the study area this water demand is taken for the water budgeting. 


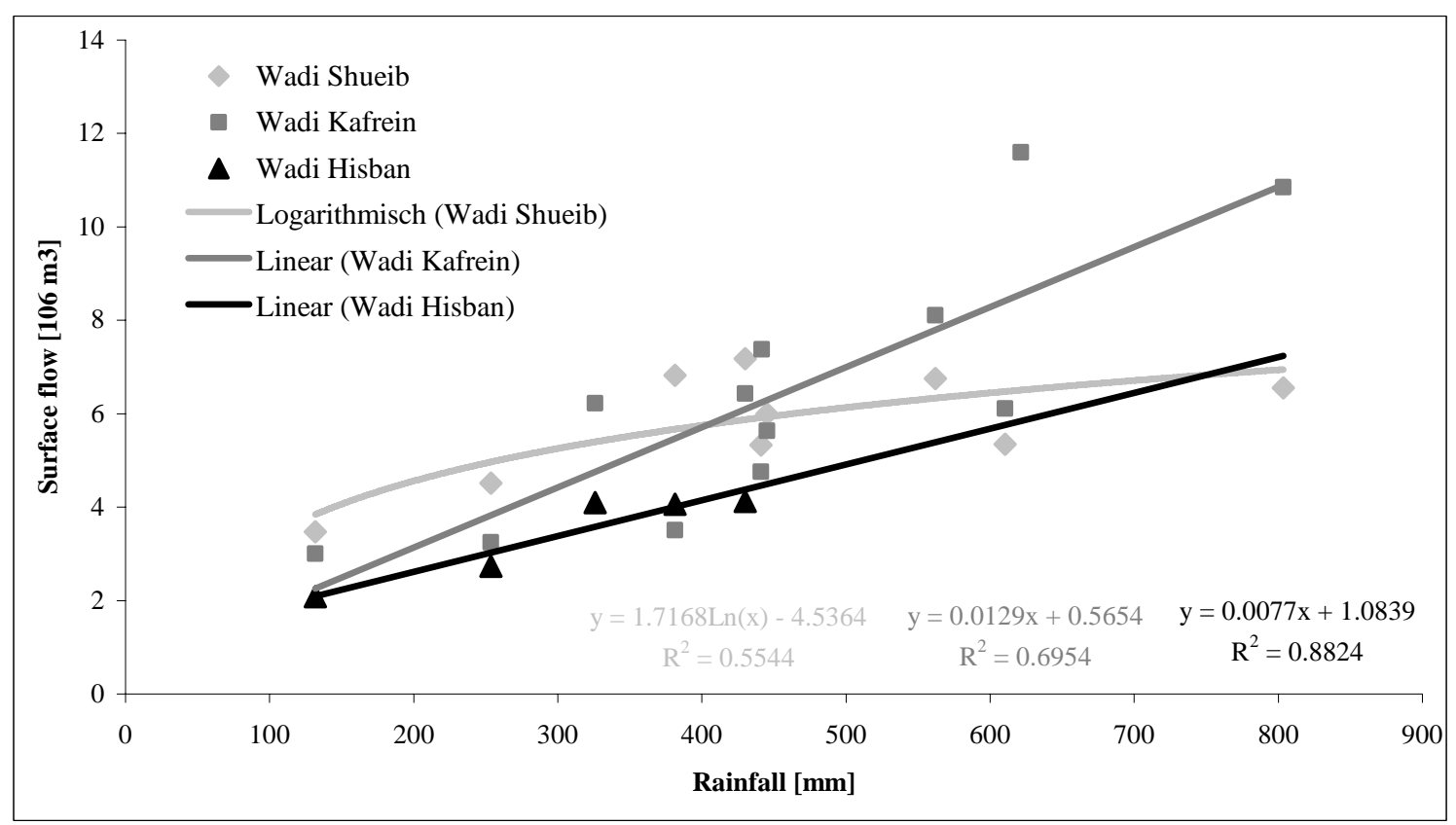

Fig. 6-12: Yearly rainfall values of Naur climatic station versus available surface flow values (Rainfall data taken from Ministry of Water and Irrigation open files, surface flow data taken from GTZ 1977).

The amount of pumped water in the study area can be calculated from the findings above. Since the water stored in the different dams together with the water flowing in Wadi Hisban are exclusively used to irrigated farmland within the study area, the deficit between the estimated field water requirement and the surface water flow represents the amount of groundwater that is necessary to irrigate the farmlands.

If a balanced budget for the study area is assumed, the groundwater inflow into the unconsolidated aquifer can be calculated as the water demand plus the outflow through the western boundary minus amount of available surface water. With the information gathered above a steady state flow model will be constructed.

\begin{tabular}{|c|c|c|c|c|c|c|c|c|c|c|c|c|}
\cline { 2 - 14 } \multicolumn{1}{c|}{} & Jan & Feb & Mar & Apr & May & Jun & Jul & Aug & Sep & Oct & Nov & Dec \\
\cline { 2 - 13 } \multicolumn{1}{c|}{} & [Mm3] & [Mm3] & [Mm3] & [Mm3] & [Mm3] & [Mm3] & [Mm3] & [Mm3] & [Mm3] & [Mm3] & [Mm3] & [Mm3] \\
\hline West Vegetable & 0,62 & 0,78 & 1,26 & 1,32 & 1,05 & 1,05 & 0,35 & 0,26 & 0,11 & 0,93 & 0,81 & 0,61 \\
\hline Well & 0,47 & 0,58 & 0,95 & 0,99 & 1,23 & 0,20 & 0,21 & 0,26 & 0,19 & 0,14 & 0,76 & 0,46 \\
\hline Hisban & 0,18 & 0,23 & 0,37 & 0,39 & 0,33 & 0,12 & 0,12 & 0,52 & 0,11 & 0,08 & 0,30 & 0,18 \\
\hline Shueib/Well & 0,01 & 0,01 & 0,02 & 0,02 & 0,05 & 0,40 & 0,40 & 0,51 & 0,38 & 0,28 & 0,02 & 0,01 \\
\hline KafreinWell & 0,36 & 0,45 & 0,73 & 0,76 & 1,29 & 1,16 & 1,16 & 3,08 & 1,09 & 0,80 & 0,58 & 0,35 \\
\hline
\end{tabular}

Tab. 6-12: Yearly water demand for the irrigated fields (excluding the portion irrigated areas from King Abdullah Canal). 


\section{FLOW MODELING}

\subsection{INTRODUCTION}

Groundwater systems in semi-arid areas frequently have not been sufficiently characterized hydrogeologically and long term data are generally not available. Long-term time series are necessary however to design future groundwater abstraction scenarios or to predict the influence of future climate change effects on groundwater resources. Fig. 7-1 illustrates how the findings of the different chapters were used to set up the different groundwater flow models and how the results interact with the developed geodatabase.

A conceptual model of flow is set up with the help of geological, hydrochemical, and geophysical methods. The water balance was set up with the help of historical data that were combined with remote sensing methods (chapter 6.7). Afterwards the model is setup and calibrated for steady state flow. The flow model is based on the FEFLOW finite element code (FEFLOW 5.2, WASY Ltd.). Input parameters were mostly pre-processed by the ArcGIS 9.2 software package (ESRI Ltd.) Afterwards a transient model is developed and applied to two time periods: 1955 - 1970 and 1975 2001. Each period has different stress situations placed upon the groundwater system. These stress periods include periods of maximum groundwater extraction, of abandonment of pumping activities, of extreme recharge events, and of drought.

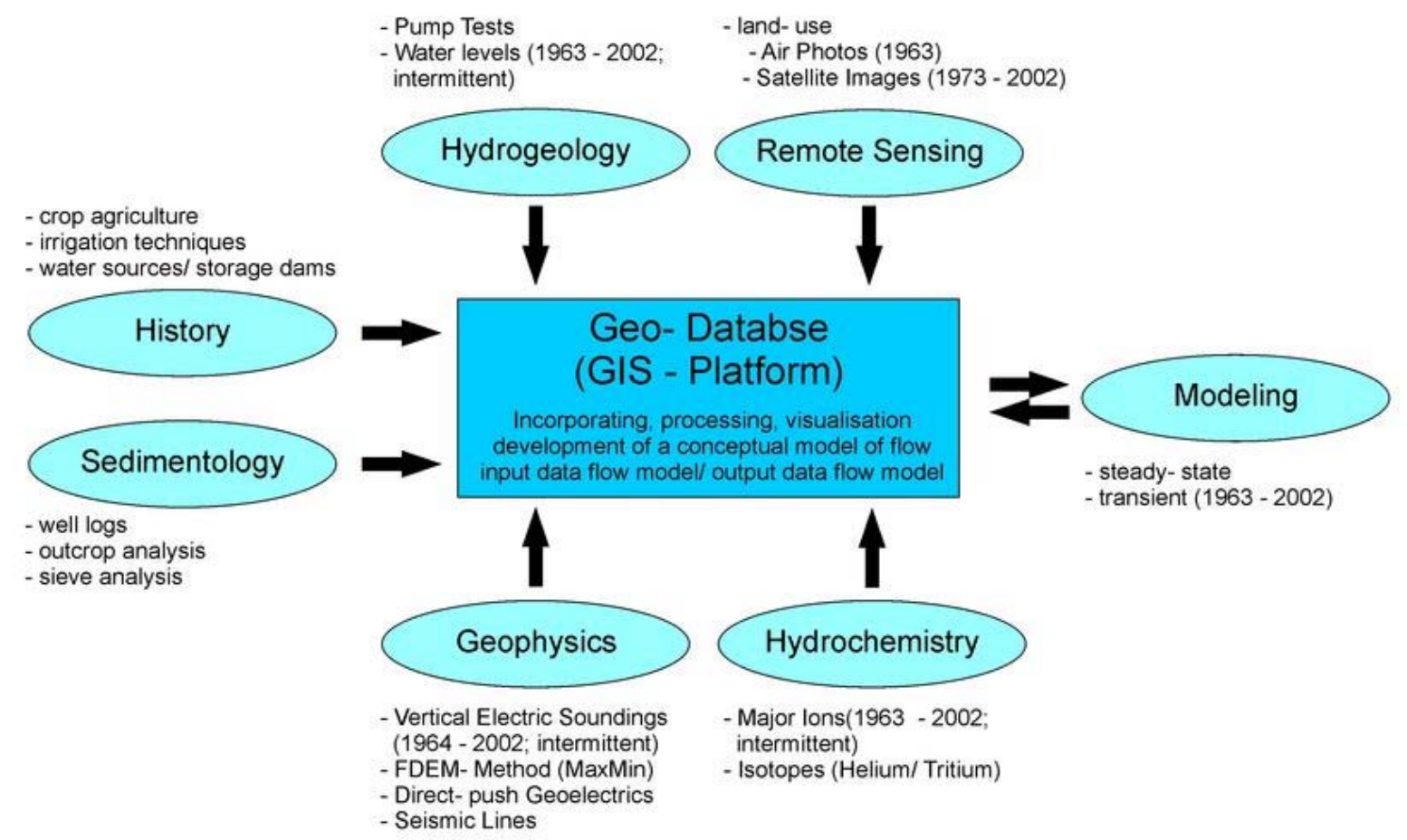

Fig. 7-1: Incorporation of the information of previous chapter into a geodatabase. With the help of the information gathered in the geodatabase a flow model is set up. The results of the flow modeling are stored afterwards in the same geodatabase.

\subsection{ConCEPTUAL Model Of Flow}

\subsubsection{Introduction, general situation}

Only the unconsolidated aquifer is subject to the modeling process (Fig. 7-2). From the geological perspective the study area is characterized by an alternation of alluvial and lacustrine material. The alluvial facies dominates the area close to the East Bank foothills, especially near the outlets of the 
major wadis. The lacustrine sediments dominate the western part of the study area and the area between the major alluvial fans (chapter 4.2). The general groundwater flow is from east to west, whereby the groundwater quality, in terms of total dissolved solids, deteriorates along its flow path (chapter 5.2). The groundwater system of the study area has undergone considerable change since its agricultural development (chapter 3). The present-day flow system is in a transient state and is responding to stresses imposed on it. This is manifested in groundwater heads as well as in groundwater quality. The groundwater flow gradient (high groundwater flow velocities) is small in the area dominated by alluvial material and becomes steeper to the west and southwest of the study area. The steepest gradients (low groundwater flow velocities) can be observed in the vicinity of the Jordan River and the Dead Sea. This behavior was also verified by the direct-push drilling along a north-south profile in the vicinity of the Dead Sea (chapter 5.3.4). This can be attributed to a) a reduction in grain size of the alluvial material in the more distal area and $b$ ) to an increase of the lacustrine fraction in the distal fan area.

\subsubsection{Aquifer Material}

Alluvial fans are semi-circular (assumed for the Wadi Shueib fan), but lateral constrictions, i.e. the influence of neighbouring fans (assumed in the case of Wadi Kafrein and Wadi Hisban fan), lead often to elongated fans perpendicular to the mountain front (Blair 1987). On elongated fans incised channels may transport sediment masses away from the mountain front to the active depositional lobes of their respective fans. Their presence highly influences the form of the fan. Alluvial fans generally have a planconvex geometry and slopes ranging from 2 to $6^{\circ}$ in sheetflood dominated environments and up to 30 to $40^{\circ}$ in the zone of freefall accumulations (Blissenbach 1954). But slopes within the study area might be lower due to the deposition of the lacustrine facies deposited to a higher extent in the mid basin and to smaller extents near the mountain fronts, thus reducing the general slope of the topography. Larger portion of alluvial material are deposited at the outlets of the major wadis. Along the depositional areas less alluvial and more lacustrine material accumulated. The area between the alluvial fans are dominated by lacustrine sediments. This assumption is undermined by lithological well logs (Appendix), the well water samples (chapter 5.2), and the classification results of the available VES (chapter 5.3). Taking these information together results in an onion shaped geometry around the outlet of the major wadis, where there coarsest material is found close to the apex and the finest distally from the alluvial fan. Consequently, as far as the distribution of hydraulic conductivities are concerned, highest conductivities are expected close to the fan apex of the major wadis. From there the hydraulic conductivity of the unconsolidated material diminishes further towards the west, either circular (Wadi Shueib alluvial fan) or elongated (Wadi Kafrein/Hisban alluvial fan). Lowest hydraulic conductivities are expected distal of the fan apex and in the sedimentary depositional shadow between the major alluvial fans. This proposed behavior is undermined by different well tests (chapter 4.3). Since the outlet of the major wadis are also geological synclines (chapter 2.2.3.1), the transmissivity in these areas are also higher due to the increased thickness of the unconsolidated material.

\subsubsection{System Boundaries}

Groundwater flow is from east to west, or east-north-east to west-south-west. The results of the hydrochemical and geophysical investigations indicated that no flow takes place from north to south or from south to north. Therefore the northern and southern boundaries can be regarded as no-flow boundaries. Groundwater inflow from the adjacent consolidated mountain aquifers into the studied unconsolidated aquifer takes place. Therefore a flux from east into the studied aquifer can be assumed. However, as it was described in the hydrogeological section, the flux is limited to the synclinal structures. The anticlinal structure between the synclines prevent the inflow of groundwater into the studied aquifer. Therefore a flux can only be assumed in the vicinity of the outlet of Wadi Shueib in the north and the outlet areas of Wadi Kafrein and Wadi Hisban and southeast of it. In the southwest and west of the study area (area of the Dead Sea and the Jordan River respectively) two different boundaries can be assumed: either a fixed head boundary or a flux boundary. MERC (2004) estimated a contribution of saline groundwater of around $10 \%$ to the Jordan River water. For the study area, this would amount to an average outflow of groundwater of around $3 \mathrm{Mm}^{3}$ per year in to the Jordan River. 
A constant head boundary condition was assigned to the vicinity of the Dead Sea and the Jordan River. However, the flux out of the model domain was monitored to fit the estimation made by MERC (2004).

\subsubsection{Flow Path}

The flow path was determined in chapter 6.4, where freshwater is entering the unconsolidated aquifer either from infiltration of surface water streams or from inflow of groundwater from the adjacent consolidated mountain aquifers. The inflow into the unconsolidated aquifer happens only in the area of the Wadi Shueib and the Wadi Kafrein syncline (chapter 2.2.3.1). This area coincide with the infiltration of the surface water streams of the major wadis. From this area groundwater flows towards the west or west-southwest. This could be seen in groundwater salinity maps, where the groundwater salinity increase along its flow path and becomes already brackish in the mid-fan area. Since the salinity of groundwater (in a north-south profile) is higher in the area between the major alluvial fans, the groundwater salinity maps show further, that no flow between the two major alluvial fan flow paths exists. The groundwater flow gradient (high groundwater flow velocities) is small in the area dominated by alluvial material and becomes more and more steep on the way towards the west ad southwest of the study area. The steepest gradients (low groundwater flow velocities) can be observed in the vicinity of the Jordan River and the Dead Sea. This behaviour was also verified by the directpush drilling along a north-south profile in the vicinity of the Dead Sea. This can be attributed to a) a reduction in grain size of the alluvial material in the more distal area and b) to an increase of the lacustrine fraction in the distal fan area.

\subsubsection{Recharge}

Recharge to the unconsolidated aquifer in the study area derives from three different sources: inflow of groundwater from the adjacent mountain aquifers, percolation of stream water from intermittent streams and during occasional intensive rainfall events. Since rainfall in the study area is very low (chapter 2.1.2) the amount of recharge from the third source can be neglected for the overall water budget. Different aquifers might contribute to the groundwater inflow into the studied aquifer. In the area of Shuneh the Wadi As Sir Formation (Upper Aquifer) underlies directly the unconsolidated aquifer. Further to the south, in the area of Rama and south of it, the unconsolidated aquifer is underlain by the Naur Formation (Fig. 7-4 left). For the same area even a contribution of the Ram Group aquifer (chapter 2.3) through an open fault system is possible. A large portion of groundwater recharge comes from infiltrating stream water that percolates along the flow course of the major wadis (Wadi Shueib, Wadi Kafrein, and Wadi Hisban). These intermittent streams flow seasonally during the winter rainy season and dry out towards the end of the summer season.

\subsubsection{Groundwater abstraction}

No water meters were encountered in the agricultural wells during the conducted field campaigns. Remote sensing data minimum groundwater abstraction rates were calculated for available remote sensing data. Together with information about plant growth, irrigation practises and irrigation water sources, an estimation of minimum groundwater abstraction for different time steps was performed. These estimations are addressed in the water budget section (chapter 6.7). A second major source of groundwater abstraction is evaporation. The reduction of groundwater transmissivities in the distal fan area leads not only to steeper groundwater flow gradients, but also to ponding of groundwater in the western area. Artesian conditions were reported in the area prior to the development of the area (chapter 3). In some areas the ponding of groundwater leads to steady state evaporation from bare soils of shallow groundwater tables. These wet soils can be observed either directly in the field, on aerial photographs, or in high resolution satellite images. Shallow groundwater under these wet soils were also encountered during direct-push soundings in the study area (chapter 5.3.4). The areas of groundwater evaporation are not steady, but vary with time. The largest area of groundwater evaporation from bare soils can be observed after the rainy season. From this time onwards the area of groundwater evaporation diminishes, but even at the beginning of the rainy season, large areas remain 
still under steady-state evaporation conditions. These areas were mapped from available remote sensing data and groundwater discharge of the aquifer system as a result of evaporation was estimated. However, evaporation losses might have been considerably larger in the past. Ionides (1939) reported many shallow hand dug wells, thus indicating very shallow groundwater conditions. With the beginning of the major development phase of the lower Jordan Valley groundwater levels declined and these hand dug wells fell dry. This can be taken also as an indicator that the area of the so- called "wet" areas diminished thus reducing the extraction of groundwater by steady-state evaporation. Another reason may be attributed the drop of the Dead Sea level during the last five decades by about $27 \mathrm{~m}$ with the corresponding lowering of the groundwater levels in the surroundings as a result of the readjustment of the salt/ freshwater interface and the lowering of the Jordan River bed along its flow path to the west of the study area.

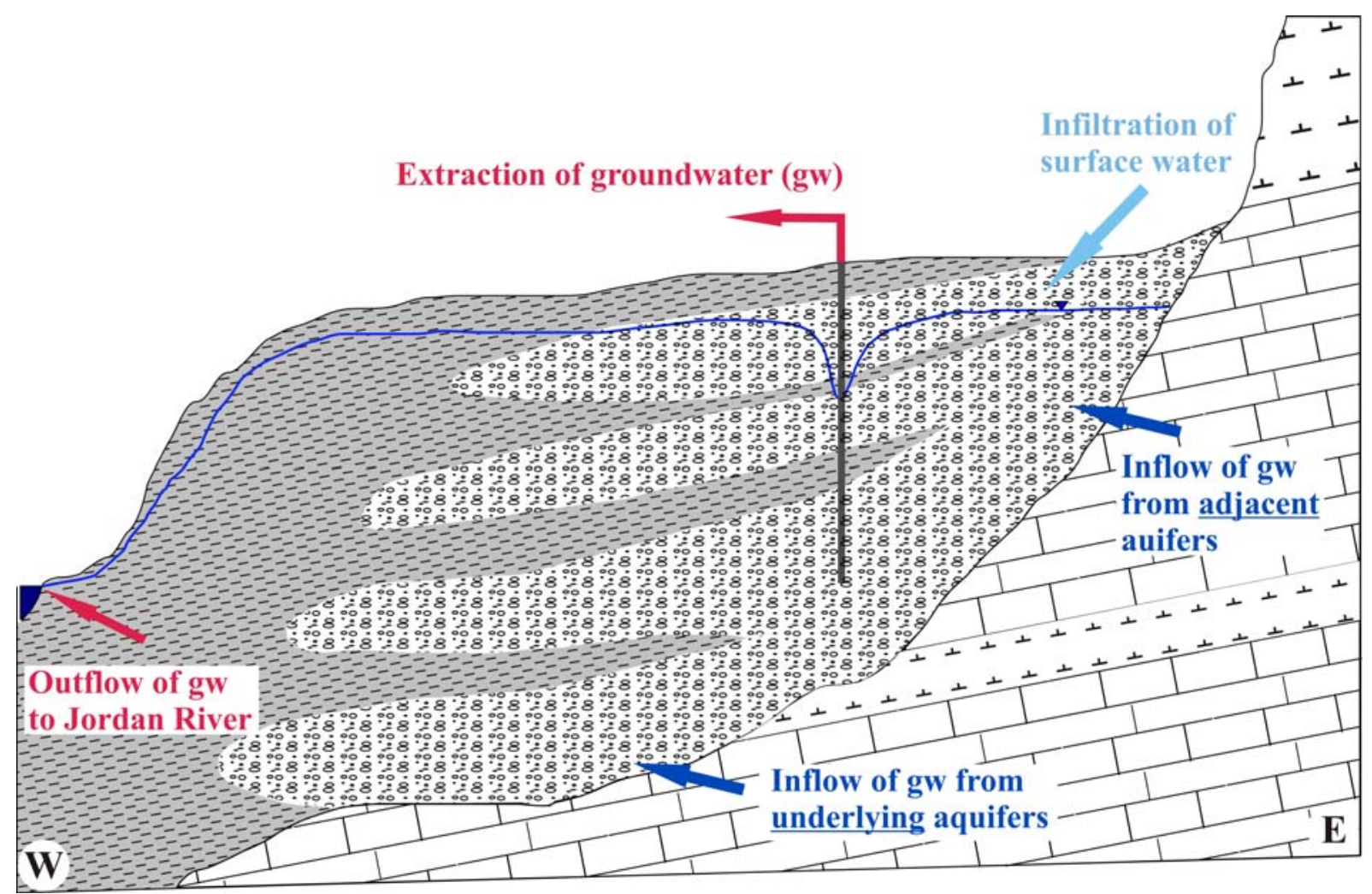

Fig. 7-2: Conceptual model of flow of the unconsolidated aquifer in the study area.

\subsection{FLOW MODELING}

\subsubsection{Model set-up and parameter estimation}

A considerable amount of input data is required to construct and verify a distributed flow model. The information gathered in the previous sections will be used to set-up this distributed flow model. The numerical flow model is based on the FEFLOW code (FEFLOW 5.2, WASY Ltd.). Input parameters were pre-processed by ArcGIS 9.2 (ESRI Ltd.).

Two different areas were distinguished for the creation of the supermesh elements: areas dominated by the alluvial fan facies and areas dominated by lacustrine facies. The area dominated by the alluvial fan facies was estimated based on the hydrochemical and geophysical sections (Fig. 7-3). Due to the active left lateral motion of the Dead Sea Transform Fault the elongated alluvial fans of Wadi Kafrein and Wadi Hisban experienced a north-south displacement. For the Wadi Shueib alluvial fan a semi circular shape was chosen, since most of the alluvial fan is located away from the main displacement fault. A triangular mesh of 29,438 elements with 14,960 nodes was generated on the base of the 
digitized results of the previous sections. In the influence areas of the surface wadis, the triangular nodes were generated and refined along the drainage line of the different surface wadis (Fig. 7-4 right). The mesh was refined in areas of high groundwater in- and output, e.g. along the flow course of the different wadis, and manually altered to avoid numerical problems with obtuse angles.

The following boundary conditions were set: No-flow at the northern, southern borders, and, for reasons stated above, in the middle of the eastern border. Fluxes were applied to the upper and lower part of the eastern boundary to simulate groundwater inflow from the adjacent consolidated mountain aquifers. Fixed-head boundaries were applied to the western boundary of the model domain. The recharge to the aquifer by infiltration of surface water was given by flux boundary conditions along the wadi flow path.

The calibration of a model is always crucial. The main problem is non-uniqueness. In order to reproduce observed values, e.g. groundwater elevation contours, unknown or not sufficiently known transmissivity etc. have to be adjusted. Accordingly, an over-parameterized model is unlikely to predict the impacts of a change in the system correctly, no matter how high the correlation between the calculations and the observations are. Just as crucial as the number of calibration parameters is their selection. Highly dependant parameters can produce identical results with different combinations.

The constraints for the hydrogeological model are subject to the following consideration: the groundwater tables should be reproduced correctly. This comparison between predicted and measured data is an important measure for the reliability of the final model. The verified model can afterwards be used to demonstrate impacts on future water abstraction scenarios and climate changes on the groundwater resources.

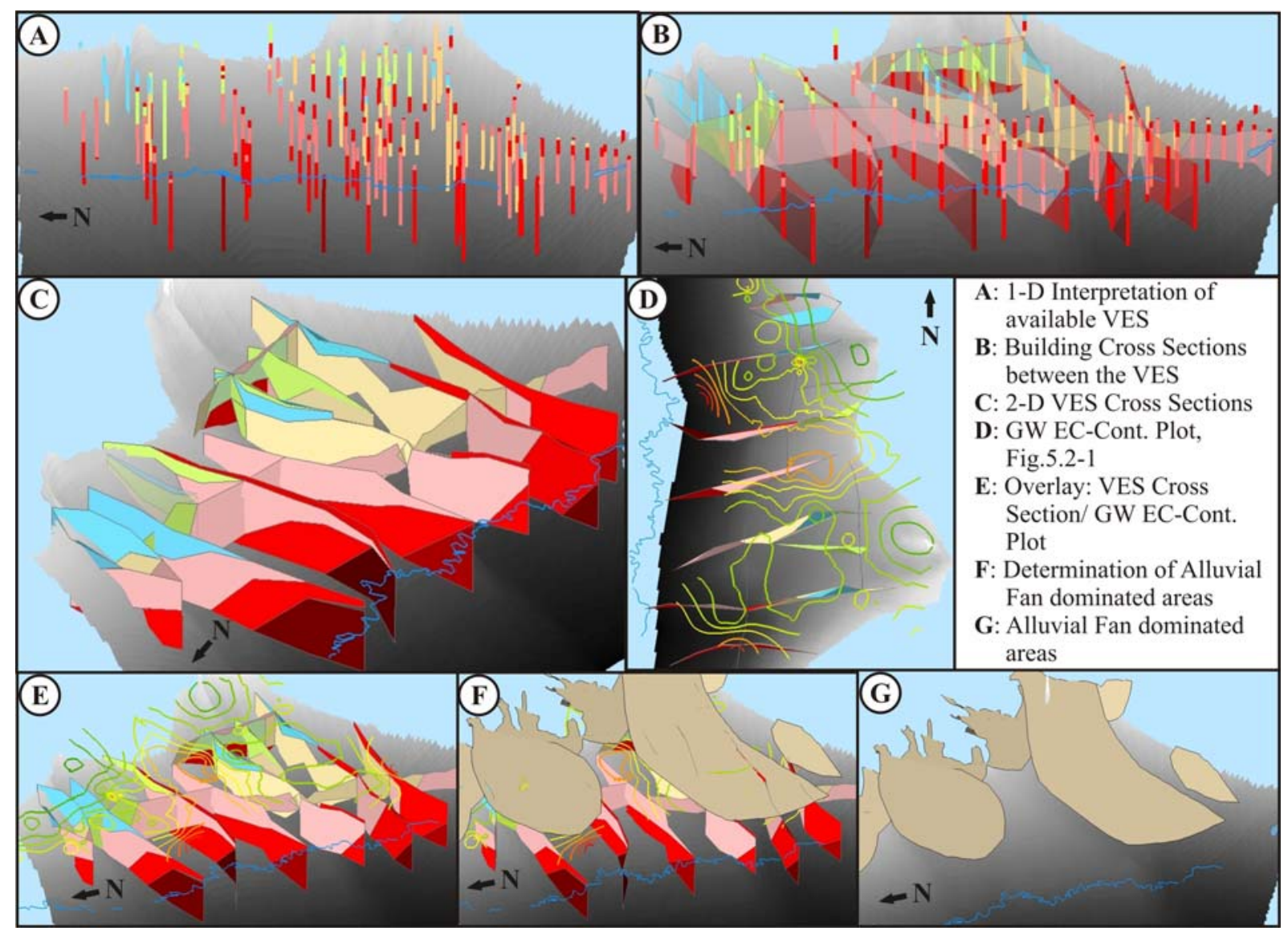

Fig. 7-3: Assumed influence area of alluvial fan sediments, depicted from the interpretation of VES and EC contour plots. 
The transmissivities have been measured at several locations. Pumping test data revealed changes in transmissivity between the upper fan area and the lacustrine dominated area (in an area that solely is made up of lacustrine formations in the distal fan area, no pumping tests were performed) are more than one order of magnitude. The information gathered for the setup of the conceptual flow model with regard to the flow materials was applied insofar, that the concentric zones of transmissivity (onion layers) were adjusted to the respective alluvial fan shapes (Fig. 7-5 left), where highest transmissivities were applied to the alluvial dominated areas in the upper fan area and lower transmissivity values in the lower to distal fan area. Lowest transmissivity values were applied to areas dominated by lacustrine sediments.

No recharge from rainfall was attributed to the model for reasons stated above. Recharge to the model domain were applied by flux boundary conditions either on the upper and lower eastern boundary or along the flow course of the different wadis (Wadi Hisban and the minor wadis southwest of it). The flux conditions on the eastern model boundary reflect the inflow of groundwater. The recharge to the unconsolidated aquifer from the infiltration of runoff and baseflow surface water is reflected by the flux conditions applied to the different wadi flow courses. An infiltration of $50 \%$ of the runoff water, that flows in the different wadis was assumed. However, infiltration into the unconsolidated aquifer will be, due to the coarser nature of the sediment material, higher in eastern part. Therefore it was assumed, that $60 \%$ of the infiltration water infiltrates in the first third, $30 \%$ in the second third, and $10 \%$ in the last third of the different wadi courses. The only exception is Wadi Shueib, here $60 \%$ infiltrates in the first one third and $40 \%$ in along the remaining two thirds of the wadi flow. Therefore 12 different fluxes, two for the groundwater influx in the area east of South Shuneh and the area east of Rama and ten for the different wadi sections, were assigned to the model (Fig. 7-5 right).
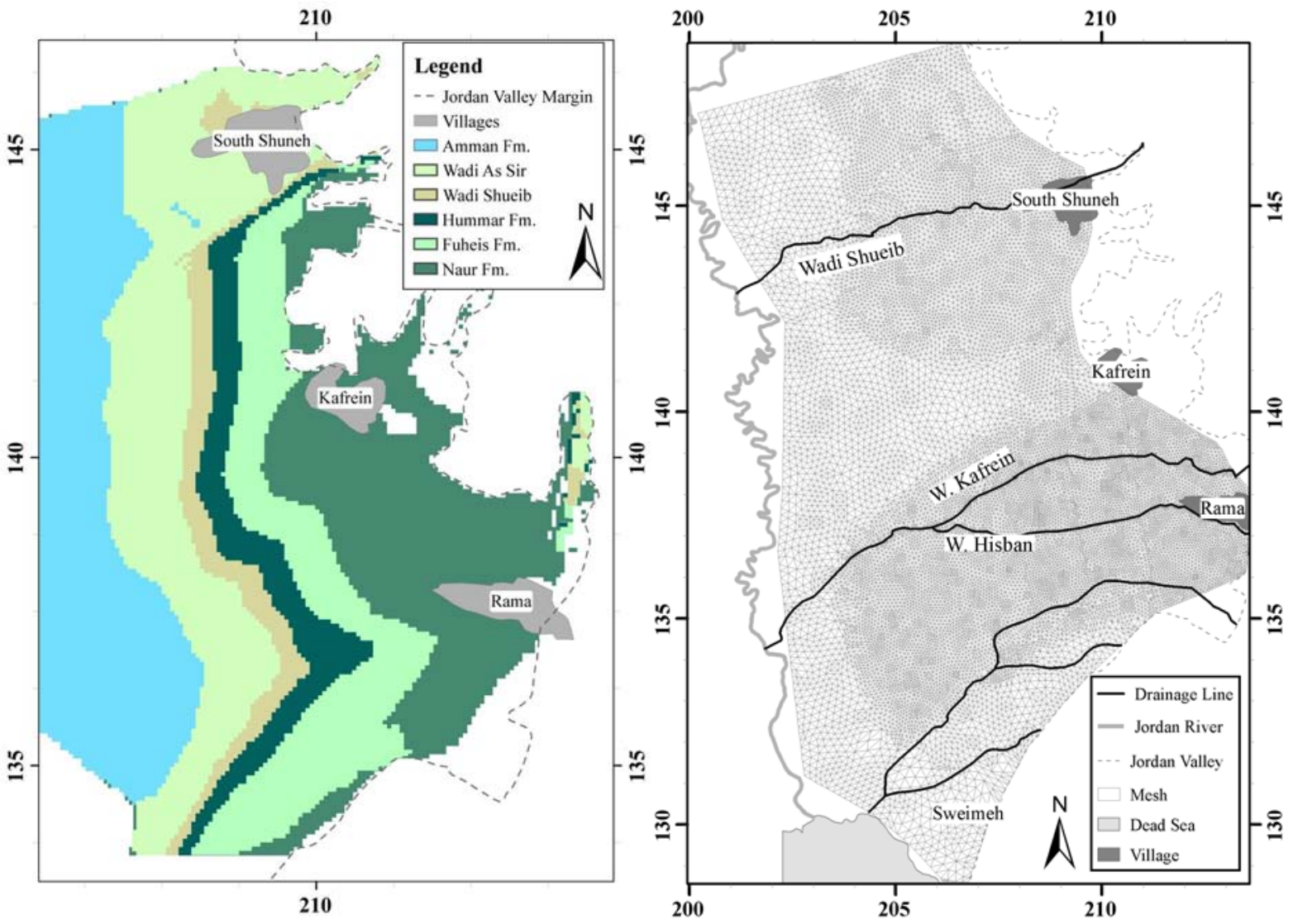

Fig. 7-4: Left: Consolidated strata underlying the unconsolidated valley fills. Right: Finite Element mesh of the study area. 

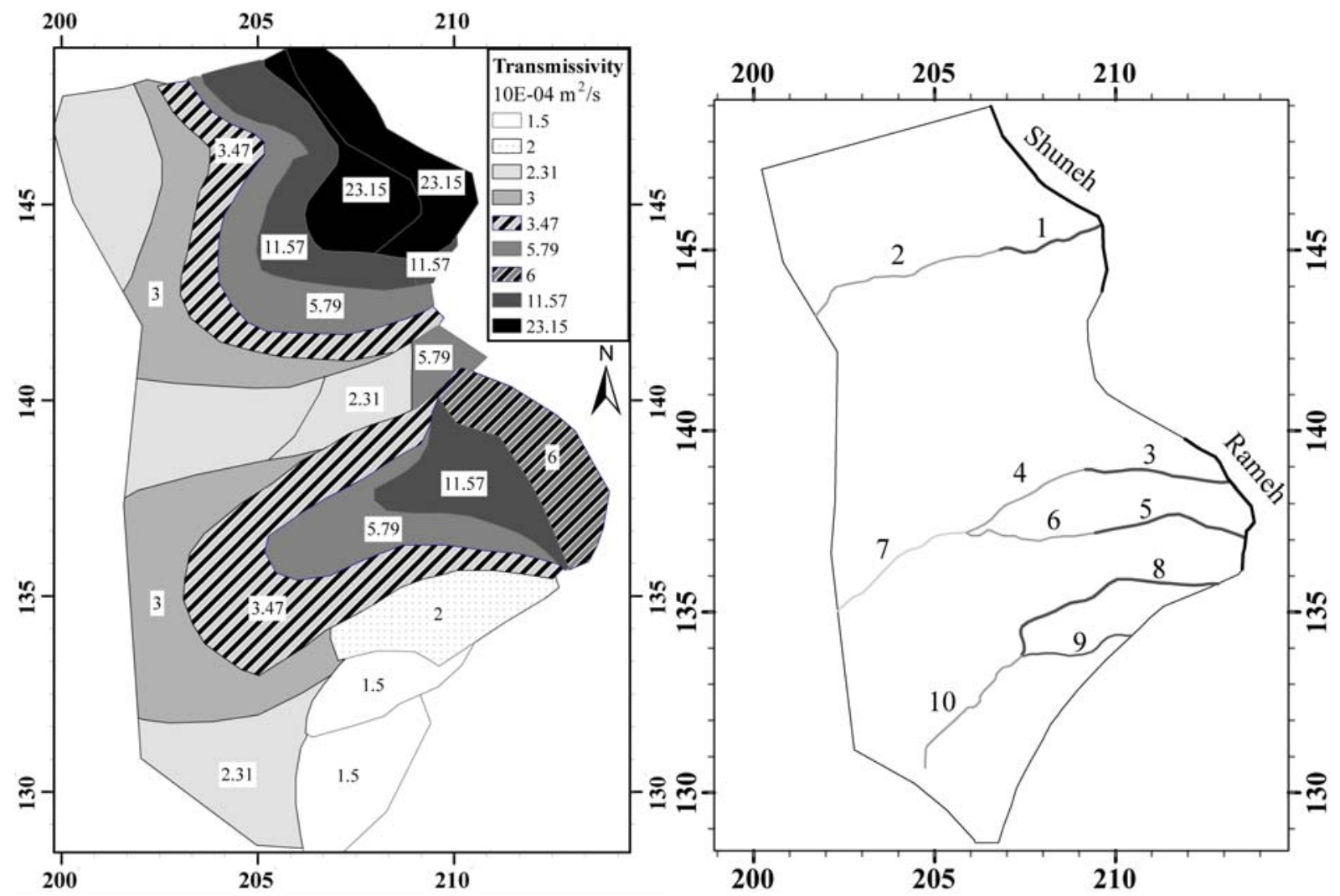

Fig. 7-5: Left: Transmissivity values for the different areas of the model domain $\left[10 \mathrm{E}-04 \mathrm{~m}^{2} / \mathrm{sec}\right]$. Right: Fluxlines assigned to the model domain. 1 through 10 represent inflow along the different wadis section and Rama and Shuneh represents the inflow of groundwater into the model domain.

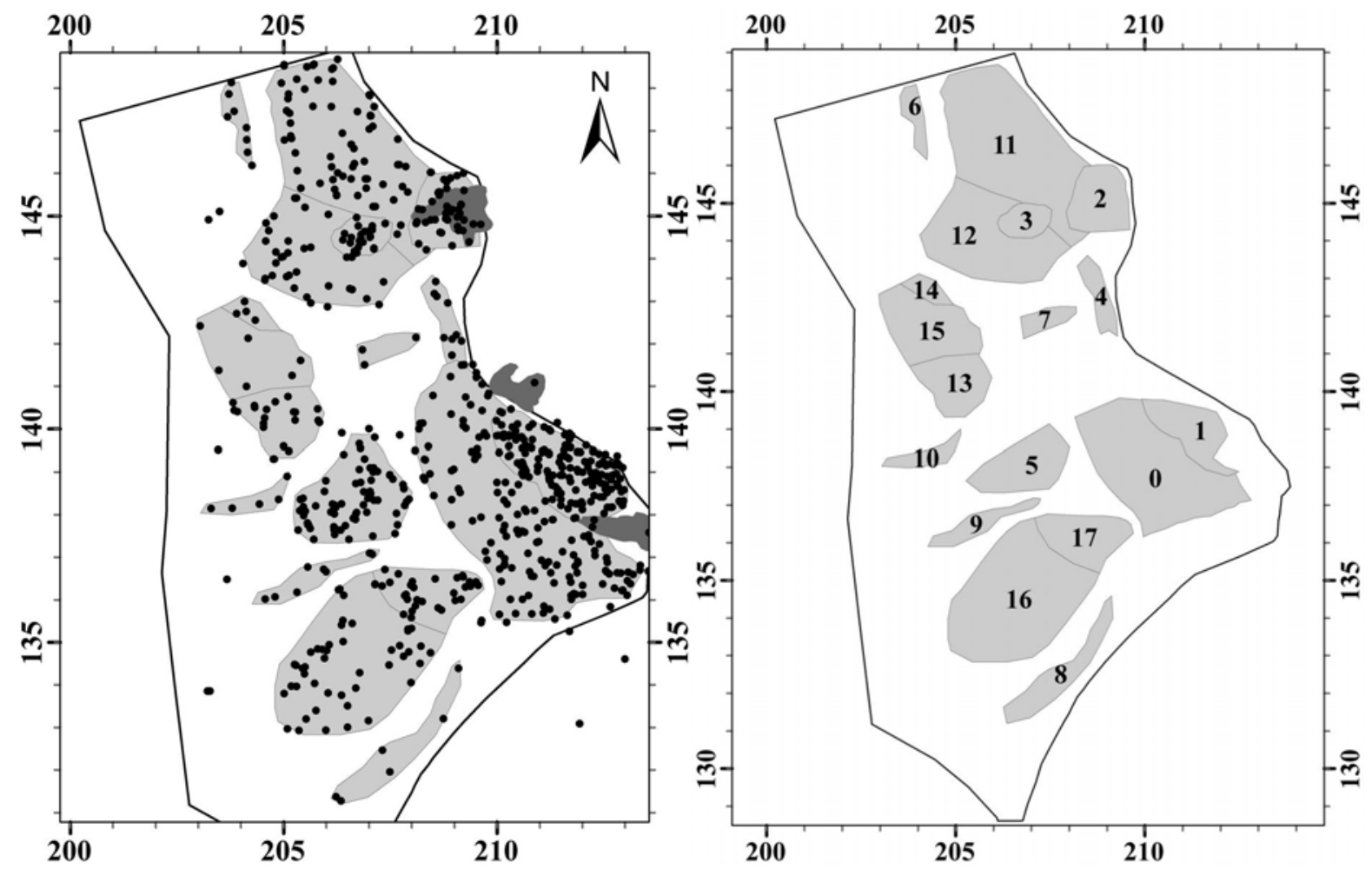

Fig. 7-6: Left: Well locations and groundwater extraction zones. Right: 17 different groundwater extraction zones depicted from the well location map. 
These extraction zones were created since no information regarding pumping amounts and duration of the wells in the study area exists. The basis of the these extraction zones are well locations (Fig. 7-6, left). Around the well locations polygons were drawn (Fig. 7-6, right) and its area calculated with the help of the ArcGIS 9.2 software (ESRI Inc.). These areas were later imported into FEFLOW and used as sinks and represent the pumping activity in the area (extraction of water per area of the polygon). However, variations in groundwater heads measured in single observation wells cannot always fit the calculated heads, because groundwater extraction in the model averages over a wider area (the whole area of a polygon) than the groundwater extraction that takes place through individual wells. But this method should be able to represent seasonal trends.

\subsubsection{Steady state calibration and results}

The goal of calibration is to obtain an optimal fit between the calculated and the measured data. In this approach, data consists of average groundwater heads (1987 - 2002) of available well data. The remaining parameters, like the transmissivity distribution, the inflow of groundwater from the adjacent mountain aquifers, the outflow through the western and southern boundaries, and the evaporation rate has been used for calibration. However, parameter ranges for each parameter have been defined and certain hydrogeological assumptions have been made.

A steady state calibration was carried out. This steady-state calibrated model can be applied to different development stages of the study area and to simulate impacts of future climate change scenarios on groundwater resources in this highly important agricultural area. The results of the steady state calibration can be seen in Fig. 7-7. A good fit between the calculated and observed data was achieved.

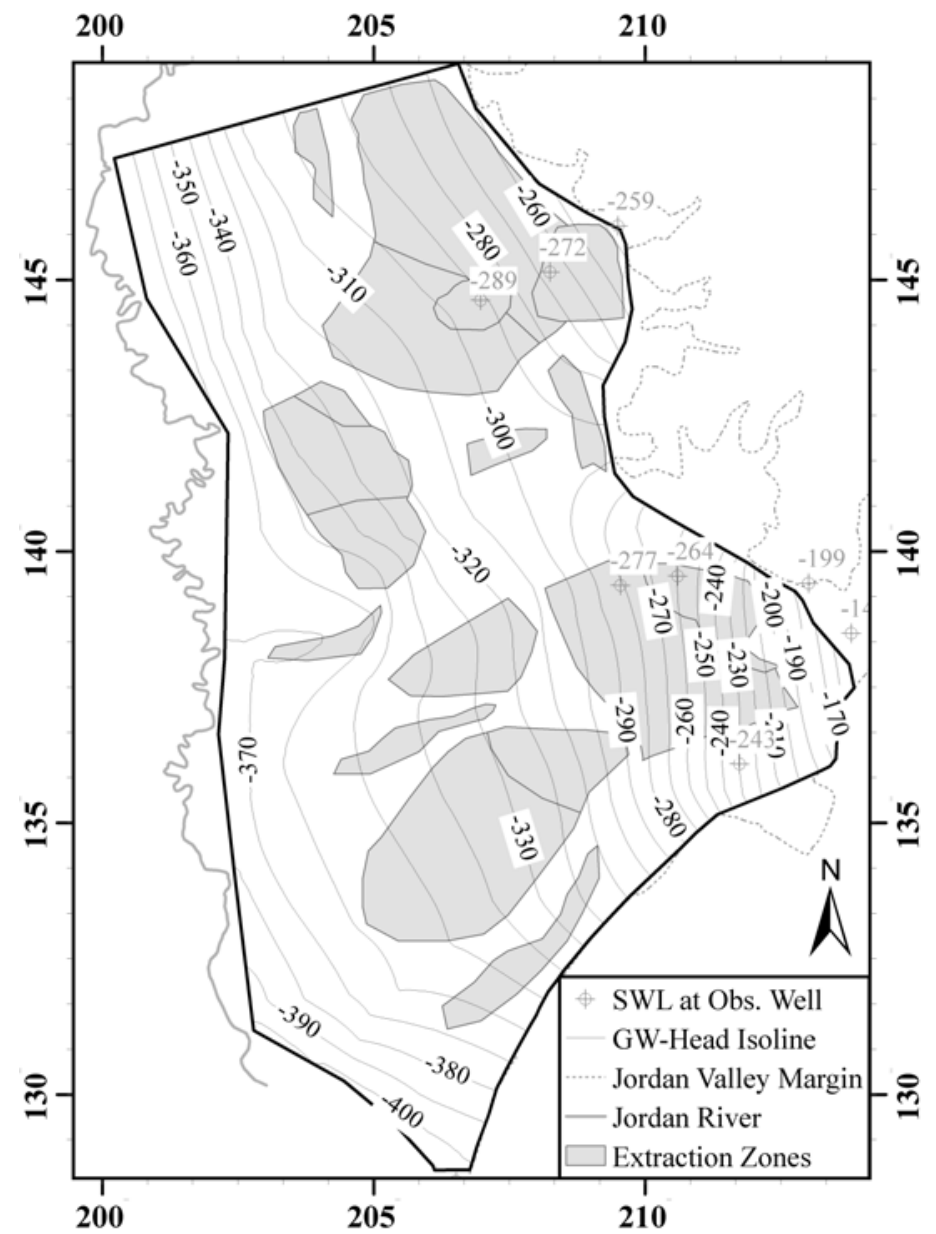

Fig. 7-7: Groundwater contour map of the steady state model versus available groundwater heads. 


\subsubsection{Transient model}

The steady state calibration was constructed to estimate the hydraulic parameters of the subsurface and the amount of groundwater inflow into the study area. In order to simulate the influence of pumping activities over time, a dynamic model was constructed. The basic geometric set-up and material parameters of the aquifer is analogous to the set-up used for the steady state simulations. The aquifer top elevations were taken from the 1: 25,000 topographic map (Royal Geographic Center) and aquifer bottom elevations were taken from chapter 6.3. The hydraulic conductivity values are shown in Fig. 78. The transient model was set up for unconfined flow. Additional input data required for transient simulations are (estimated values are given in brackets): the initial conditions and storativity (0.1). Moreover, the discretization of the variable time has to be defined (time steps were adapted automatically by FEFLOW). The dynamic model simulates the influence of irrigation on the groundwater household in the study area in two different steps. First, yearly variations of pumping activities and yearly variations of groundwater inflow into the model domain had to be estimated. Therefore a dynamic calibration was applied to the model domain. Second, the dynamically calibrated model is applied to two different time periods: 1955 - 1970 and 1975 - 2001. These periods were limited by data availability. No information (hard or soft) for the period 1970-1975 was available. No data was available for the period end 2001 onwards. The main difference between this steady state model and the model used for calibration starting from the 60ies onward is the modified discharge.

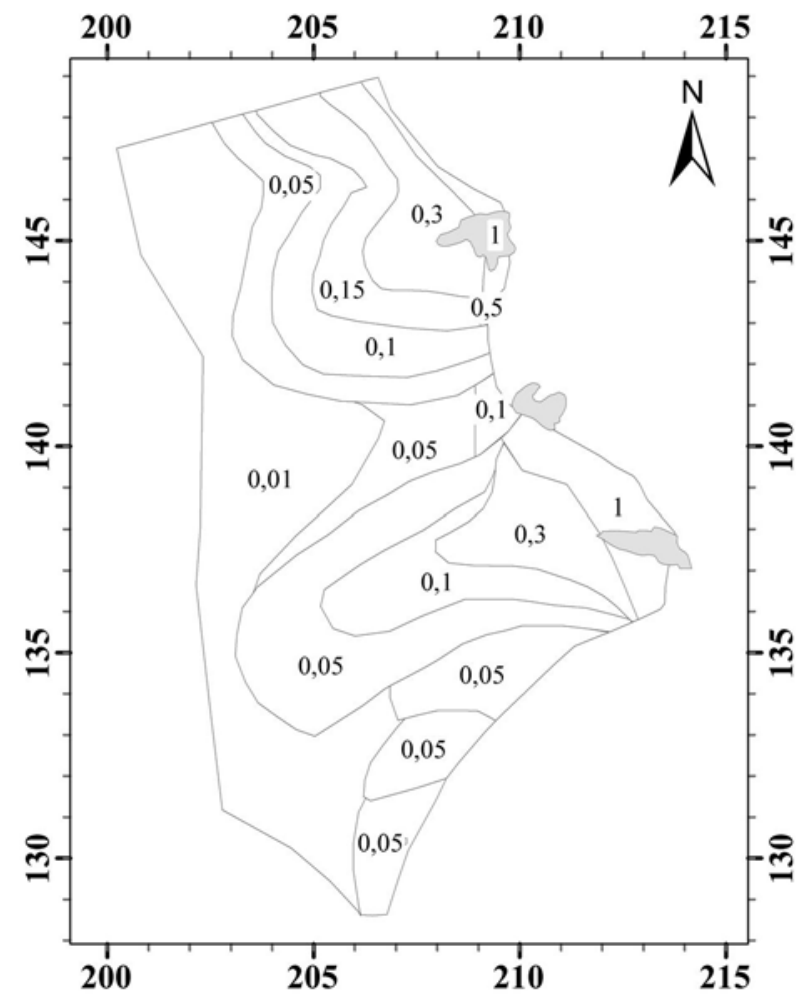

Fig. 7-8: Hydraulic conductivity values assigned to the different zones of the model domain [10E-04 m/s].

\subsubsection{Dynamic calibration and initial conditions}

In order to adjust the yearly variations of inflow and outflow into the model domain and to fine adjust the flow material parameters, a dynamic calibration for a period of 120 years have been undertaken. As far as the inflow and outflow of groundwater into the model domain is concerned, average values for the period of 1956 to 1968 were entered. Monthly stream flow data was taken from the Water Master Plan Vol. III prepared by the GTZ (1977). An infiltration of 50\% of the surface stream flow amount was assumed along its flow from the east towards the west. As in the case of the steady-state 
model a $60,30,10 \%$ estimation was made. The total recharge to the model domain was estimated by Tleel to be 3.7 in the area of Shunat Nimreen and 13.1 million cubic meters in the area of Kafrein and Rama. In order to reach a balance between inflow and outflow, the extraction zones, described above, were used. Two different pumping periods were assumed: a winter (first 200 days, no pumping activity) and a summer pumping period (the remaining 166 days). The difference between the recharge estimated by Tleel (1963) and the amount of the infiltrated surface stream water was assigned as groundwater inflow through the eastern flux boundary conditions near Shuneh and near Rama.

\subsubsection{Model run for the sixties}

The results of the dynamic calibration were used for the first modeling period. The modeling period began in October 1955 and lasted until September1970. In the mid fifties intensive well drilling began in the study area and subsequently groundwater abstraction increased until it reached its peak in the mid sixties (chapter 6.1). Unfortunately groundwater heads of different wells existed only from the period of 1962 to 1970.

Like in the case of the dynamic calibration, infiltration of half of the surface water coming from the eastern catchment area was assumed along the major wadis in the area. Along its flow towards the west the same assumption about infiltration rates were made. The monthly surface water flow was taken from the Water Master Plan GTZ (1977). Groundwater abstraction rates increased from the 1950ies and at the beginning of the sixties until the political conflict in 1968 and its aftermath the abstraction amount was kept constant. The same pumping seasons as used during the dynamic calibration were used. During the events of 1968 pumping activities seized for most of the study area and were reduced significantly up until the beginning of the 70ies due to the reasons stated in chapter 6.1. The inflow of groundwater into the study area is constant for the whole period.

The water budget of the transient model run can be seen in Fig. 7-9. It can be seen, that except for the events of 1968 and their aftermath the water balance is always negative. Even the rainfall intensive season 1966/67, which lead to an increase in the water table in the study area had a negative balance. Fig. 7-10 shows the measured versus calculated groundwater levels. A good match between the calculated and measured groundwater heads was achieved. The continuous decrease during the poor rainy season 1965/66 and the sharp increase of the groundwater levels during the rain intensive season 1966/67 could be represented correctly. The continuous increase of groundwater heads from 1967 until 1970 however, cannot be explained only by variations of drier or wetter years. Therefore, the assumption, that effects of the events of 1968 and their aftermath lead to no or only few pumping activities was validated, since this effect would only explain the behavior of the groundwater table in the study area. It should be noted, that the calculated groundwater heads in the area of Shunat Nimreen do not match as well as in the area around Rama. This can be attributed to usage of sinks instead of single well extractions for simulating groundwater abstraction. 


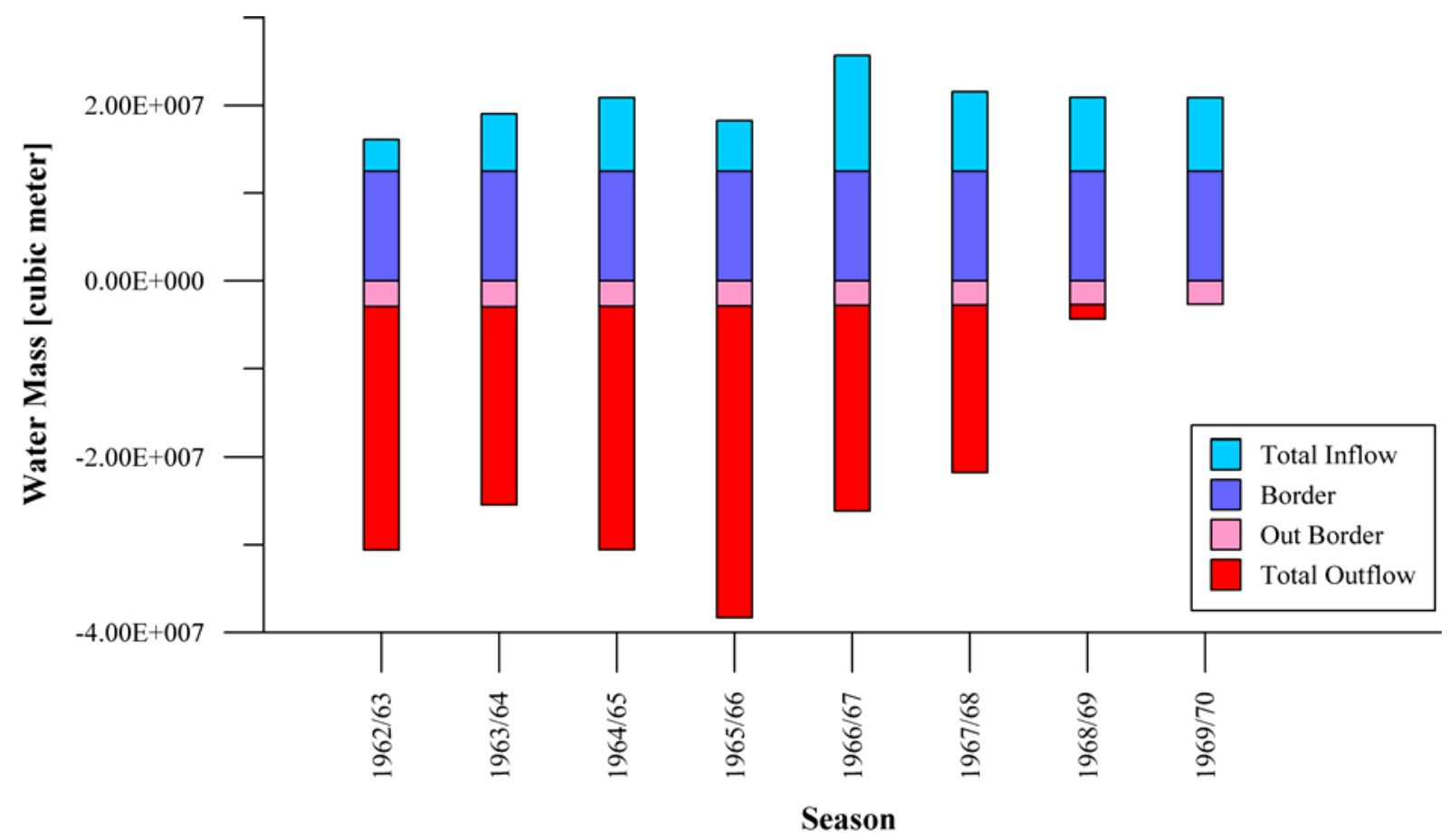

Fig. 7-9: Water budget for the period of 1962/63 to 1969/1970 of the transient model run; Total Inflow = Inflow of water along the different wadi sections (infiltration of surface water) together with flux through the eastern flux boundaries, Border = Inflow of groundwater through the flux boundaries (groundwater inflow), Out Border = Outflow of groundwater through the western flux boundaries (effluent groundwater to the Jordan River); Total Outflow = Out Border together with groundwater pumped from the different extraction zones.

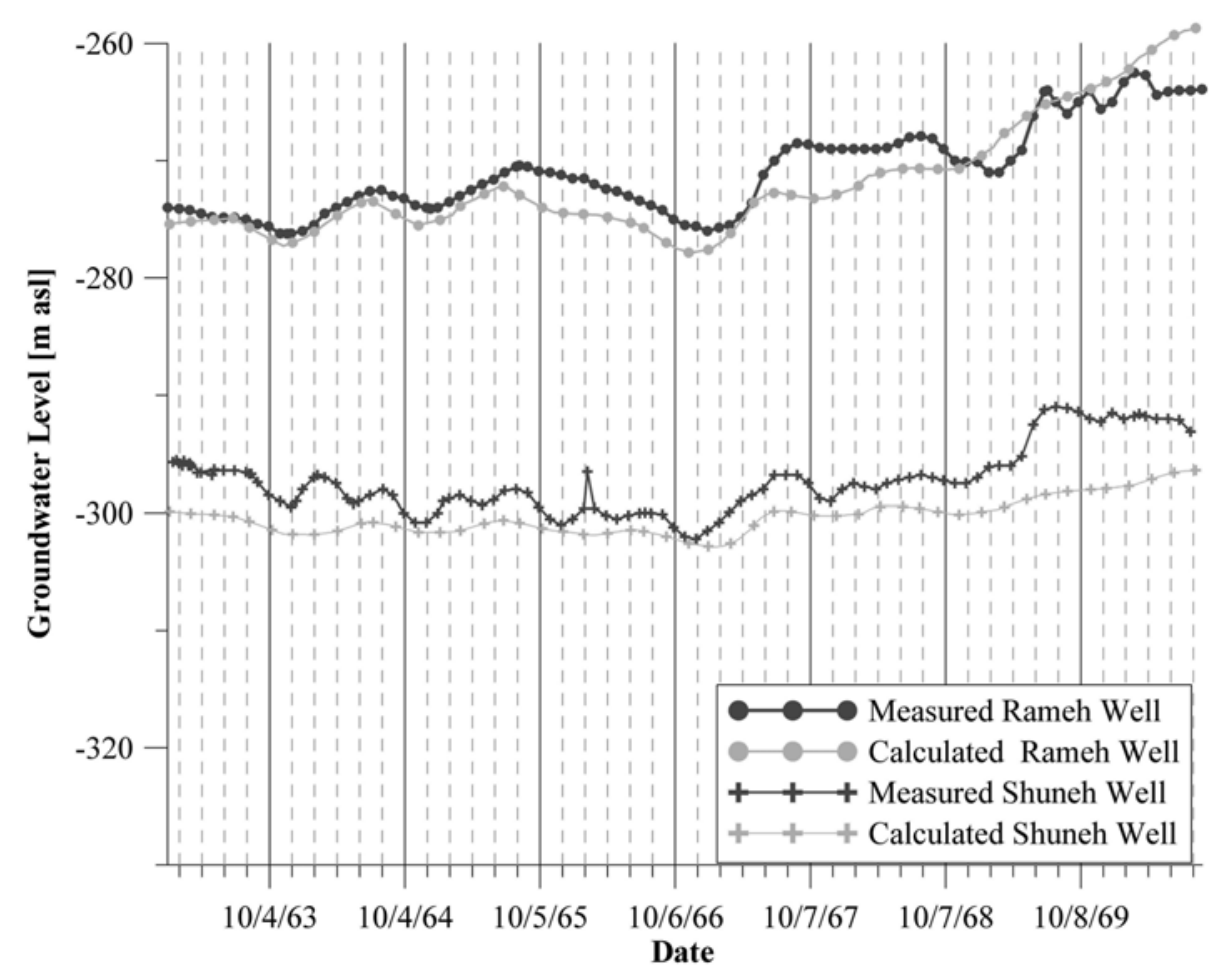

Fig. 7-10: Calculated versus measured groundwater heads for the period of 1963 to 1970. 


\subsubsection{Model run for the 80ies until 2001}

The second model period ranges from October 1975 until September 2001. Here groundwater extraction rates are based on the findings of chapter 6.2, where the minimum water requirements for the study area was estimated with the help of remote sensing data (Landsat data). Since the commissioning of two earth filled dams at the outlets of Wadi Shueib and Wadi Kafrein, both located close towards the east of the study area, infiltration of surface water seized along the course of these two wadis. No information regarding surface water flow in the hinterland of the major alluvial fans and the storage of water in the dams was available. Since the inauguration of the third extension of the KAK another irrigation water source is added to the area of Shunat Nimreen.

First, the field water requirement of the study area was determined with the help of the method described in chapter 6.2. Different Landsat scenes were used to determine the irrigated area in the study area. In order to estimate the yearly water requirement of the irrigated culture in the model domain, the Landsat scenes taken on $2^{\text {nd }}$ March 2002, on $21^{\text {st }}$ of May 2000, and on $14^{\text {th }}$ of August 1987 were used. These classified areas were allocated to the different extraction zones and their field water requirement (for drip irrigation) calculated according to the procedure described in chapter 6.2 (Tab. 7-1). Land use (vegetables or banana planting) for the different areas of the study area were considered as well as their respective growth stages. Taking the different planting and harvesting seasons under consideration, the yearly field water requirement, based on the classification results of the different Landsat scenes, was calculated (Tab. 7-2). The calculation revealed that a total of around 38 million cubic meter of irrigation water is needed to irrigated the farmland in the model domain. Since no other information regarding planting activities exist for the study area this water demand is kept constant for the whole modelling period.

For the second considered period, no data regarding surface flow in the different wadis was available. Therefore, the next parameter to be estimated is the amount of surface water available for irrigation in the study area. The best fit straight line method described in chapter 6.7 were used to estimate surface flow for the considered period. Tab.7- 3 shows the result of the surface flow estimations for the whole period 1975/76 - 1999/00.

Tab. 7-1: A: Irrigated area depicted for the different Landsat scene categorized into the extraction zones. B: Field water requirement (drip irrigation) for the different extraction zones.

\begin{tabular}{|c|c|c|c|c|}
\cline { 2 - 5 } \multicolumn{1}{c|}{ A } & $\mathbf{1 4 . ~ A u g}$ & $\mathbf{0 7 . ~ A u g}$ & $\mathbf{2 1 . ~ M a i}$ & $\mathbf{0 8 . ~ M r z ~}$ \\
\hline ID & $\mathbf{1 9 8 7}$ & $\mathbf{1 9 9 9}$ & $\mathbf{2 0 0 0}$ & $\mathbf{2 0 0 2}$ \\
\hline$[-]$ & {$\left[\mathbf{k m}^{2}\right]$} & {$\left[\mathbf{k m}^{2}\right]$} & {$\left[\mathbf{k m}^{2}\right]$} & {$\left[\mathbf{k m}^{2}\right]$} \\
\hline 0 & 5.47 & 3.56 & 6.88 & 9.98 \\
\hline 1 & 5.52 & 4.71 & 5.59 & 4.64 \\
\hline 2 & 2.68 & 1.13 & 1.99 & 1.71 \\
\hline 3 & 0.36 & 0.32 & 0.18 & 0.39 \\
\hline 4 & 4.02 & 0.82 & 1.35 & 1.35 \\
\hline 5 & 1.62 & 0.26 & 1.78 & 1.33 \\
\hline 6 & 1.04 & 0.12 & 2.16 & 1.37 \\
\hline 7 & 0.29 & 0.85 & 1.19 & 0.49 \\
\hline 8 & 0.00 & & 0.07 & 0.08 \\
\hline 9 & 0.29 & 0.09 & 0.18 & 0.48 \\
\hline 10 & 0.00 & & & 0.04 \\
\hline 11 & 3.78 & 1.23 & 3.58 & 5.04 \\
\hline 12 & 0.38 & 0.18 & 1.51 & 2.29 \\
\hline 13 & 0.00 & 0.02 & 0.40 & 0.43 \\
\hline 14 & 0.00 & & & 0.02 \\
\hline 15 & 0.00 & & & \\
\hline 16 & 0.47 & 0.37 & 1.62 & 1.01 \\
\hline 17 & 1.19 & 0.47 & 0.98 & 1.41 \\
\hline
\end{tabular}

\begin{tabular}{|c|c|c|c|c|}
\cline { 2 - 5 } \multicolumn{1}{c|}{ B } & 14. Aug & 07. Aug & 21. Mai & $\mathbf{0 8 . ~ M r z ~}$ \\
\hline ID & $\mathbf{1 9 8 7}$ & $\mathbf{1 9 9 9}$ & $\mathbf{2 0 0 0}$ & $\mathbf{2 0 0 2}$ \\
\hline$[-]$ & {$\left[\mathbf{m}^{3}\right]$} & {$\left[\mathbf{m}^{3}\right]$} & {$\left[\mathbf{m}^{3}\right]$} & {$\left[\mathbf{m}^{3}\right]$} \\
\hline 0 & $1.67 \mathrm{E}+06$ & $1.09 \mathrm{E}+06$ & $1.19 \mathrm{E}+06$ & $1.18 \mathrm{E}+06$ \\
\hline 1 & $1.69 \mathrm{E}+06$ & $1.44 \mathrm{E}+06$ & $9.70 \mathrm{E}+05$ & $5.47 \mathrm{E}+05$ \\
\hline 2 & $8.20 \mathrm{E}+05$ & $3.45 \mathrm{E}+05$ & $3.44 \mathrm{E}+05$ & $2.02 \mathrm{E}+05$ \\
\hline 3 & $1.09 \mathrm{E}+05$ & $9.73 \mathrm{E}+04$ & $3.20 \mathrm{E}+04$ & $4.65 \mathrm{E}+04$ \\
\hline 4 & $1.23 \mathrm{E}+06$ & $2.51 \mathrm{E}+05$ & $2.33 \mathrm{E}+05$ & $1.59 \mathrm{E}+05$ \\
\hline 5 & $1.88 \mathrm{E}+05$ & $3.05 \mathrm{E}+04$ & $2.07 \mathrm{E}+05$ & $1.32 \mathrm{E}+05$ \\
\hline 6 & $1.21 \mathrm{E}+05$ & $1.39 \mathrm{E}+04$ & $2.50 \mathrm{E}+05$ & $1.36 \mathrm{E}+05$ \\
\hline 7 & $3.38 \mathrm{E}+04$ & $9.85 \mathrm{E}+04$ & $1.38 \mathrm{E}+05$ & $4.85 \mathrm{E}+04$ \\
\hline 8 & & & $7.92 \mathrm{E}+03$ & $8.20 \mathrm{E}+03$ \\
\hline 9 & $3.36 \mathrm{E}+04$ & $1.09 \mathrm{E}+04$ & $2.13 \mathrm{E}+04$ & $4.77 \mathrm{E}+04$ \\
\hline 10 & & & & $4.38 \mathrm{E}+03$ \\
\hline 11 & $4.38 \mathrm{E}+05$ & $1.43 \mathrm{E}+05$ & $4.16 \mathrm{E}+05$ & $5.01 \mathrm{E}+05$ \\
\hline 12 & $1.40 \mathrm{E}+05$ & $6.80 \mathrm{E}+04$ & $2.90 \mathrm{E}+05$ & $2.84 \mathrm{E}+05$ \\
\hline 13 & & $1.80 \mathrm{E}+03$ & $4.70 \mathrm{E}+04$ & $4.24 \mathrm{E}+04$ \\
\hline 14 & & & & $2.24 \mathrm{E}+03$ \\
\hline 15 & & & & \\
\hline 16 & $5.41 \mathrm{E}+04$ & $4.29 \mathrm{E}+04$ & $1.89 \mathrm{E}+05$ & $1.01 \mathrm{E}+05$ \\
\hline 17 & $1.38 \mathrm{E}+05$ & $5.41 \mathrm{E}+04$ & $1.14 \mathrm{E}+05$ & $1.40 \mathrm{E}+05$ \\
\hline
\end{tabular}


Tab. 7-2: Field water requirement (drip irrigation) of different extraction zones. The values were calculated on the base of land-use (vegetable or banana) of the extraction zone and the area depicted from the different Landsat scenes.

\begin{tabular}{|c|c|c|c|c|c|c|c|c|c|c|c|c|}
\hline ID & Oct & Nov & Dec & Jan & Feb & Mar & Apr & May & Jun & Jul & Aug & Sep \\
\hline$[-]$ & {$\left[\mathrm{m}^{3}\right]$} & {$\left[\mathrm{m}^{3}\right]$} & {$\left[\mathrm{m}^{3}\right]$} & {$\left[\mathrm{m}^{3}\right]$} & {$\left[\mathrm{m}^{3}\right]$} & {$\left[\mathrm{m}^{3}\right]$} & {$\left[\mathrm{m}^{3}\right]$} & {$\left[\mathrm{m}^{3}\right]$} & {$\left[\mathrm{m}^{3}\right]$} & {$\left[\mathrm{m}^{3}\right]$} & {$\left[\mathrm{m}^{3}\right]$} & {$\left[\mathrm{m}^{3}\right]$} \\
\hline 0 & $1.90 \mathrm{E}+06$ & $1.36 \mathrm{E}+06$ & $8.55 \mathrm{E}+05$ & $8.85 E+05$ & $6.38 \mathrm{E}+05$ & $1.20 \mathrm{E}+06$ & $9.21 \mathrm{E}+05$ & $1.19 \mathrm{E}+06$ & $9.34 \mathrm{E}+05$ & $9.49 \mathrm{E}+05$ & $1.07 \mathrm{E}+06$ & $8.87 \mathrm{E}+05$ \\
\hline 1 & $8.69 \mathrm{E}+05$ & $6.19 \mathrm{E}+05$ & $3.90 \mathrm{E}+05$ & $4.04 \mathrm{E}+05$ & $2.92 \mathrm{E}+05$ & $5.47 \mathrm{E}+05$ & $6.22 \mathrm{E}+05$ & $8.05 E+05$ & $1.22 \mathrm{E}+06$ & $1.24 \mathrm{E}+06$ & $1.40 \mathrm{E}+06$ & $1.16 \mathrm{E}+06$ \\
\hline 2 & $3.21 \mathrm{E}+05$ & $2.28 \mathrm{E}+05$ & $1.44 \mathrm{E}+05$ & $1.49 \mathrm{E}+05$ & $1.08 \mathrm{E}+05$ & $2.02 \mathrm{E}+05$ & $2.29 \mathrm{E}+05$ & $2.97 \mathrm{E}+05$ & $2.97 \mathrm{E}+05$ & $3.01 \mathrm{E}+05$ & $3.41 \mathrm{E}+05$ & $2.82 \mathrm{E}+05$ \\
\hline 3 & 7.38E+04 & $5.26 \mathrm{E}+04$ & $3.32 \mathrm{E}+04$ & $3.43 \mathrm{E}+04$ & $2.48 \mathrm{E}+04$ & $4.65 \mathrm{E}+04$ & $2.47 \mathrm{E}+04$ & $3.19 \mathrm{E}+04$ & $4.84 \mathrm{E}+04$ & $4.91 \mathrm{E}+04$ & $5.56 \mathrm{E}+04$ & $4.60 \mathrm{E}+04$ \\
\hline 4 & $2.98 \mathrm{E}+05$ & $2.11 \mathrm{E}+05$ & $1.32 \mathrm{E}+05$ & $1.38 \mathrm{E}+05$ & $8.94 \mathrm{E}+04$ & $1.67 \mathrm{E}+05$ & $1.96 \mathrm{E}+05$ & $2.59 \mathrm{E}+05$ & $2.55 \mathrm{E}+05$ & $2.60 \mathrm{E}+05$ & $2.95 E+05$ & $2.40 \mathrm{E}+05$ \\
\hline 5 & $1.12 \mathrm{E}+05$ & $8.33 E+04$ & $5.43 \mathrm{E}+04$ & $5.40 \mathrm{E}+04$ & $6.92 \mathrm{E}+04$ & $1.32 \mathrm{E}+05$ & $1.32 \mathrm{E}+05$ & $1.55 \mathrm{E}+05$ & $2.43 \mathrm{E}+04$ & $2.43 \mathrm{E}+04$ & $2.61 \mathrm{E}+04$ & $2.57 \mathrm{E}+04$ \\
\hline 6 & $1.15 \mathrm{E}+05$ & $8.53 E+04$ & $5.56 \mathrm{E}+04$ & $5.53 E+04$ & 7.09E+04 & $1.35 \mathrm{E}+05$ & $1.35 \mathrm{E}+05$ & $1.59 \mathrm{E}+05$ & $1.06 \mathrm{E}+04$ & $1.06 \mathrm{E}+04$ & $1.14 \mathrm{E}+04$ & $1.13 \mathrm{E}+04$ \\
\hline 7 & $4.12 \mathrm{E}+04$ & $3.06 \mathrm{E}+04$ & $1.99 \mathrm{E}+04$ & $1.98 \mathrm{E}+04$ & $2.54 \mathrm{E}+04$ & $4.86 \mathrm{E}+04$ & $1.18 \mathrm{E}+05$ & $1.38 \mathrm{E}+05$ & $8.03 E+04$ & 8.03E+04 & $8.65 E+04$ & $8.52 E+04$ \\
\hline 8 & $6.75 \mathrm{E}+03$ & $5.02 \mathrm{E}+03$ & $3.27 \mathrm{E}+03$ & $3.25 E+03$ & 4.17E +03 & $7.96 \mathrm{E}+03$ & $6.37 \mathrm{E}+03$ & $7.48 \mathrm{E}+03$ & $0.00 \mathrm{E}+00$ & $0.00 \mathrm{E}+00$ & $0.00 \mathrm{E}+00$ & $0.00 \mathrm{E}+00$ \\
\hline 9 & $3.98 \mathrm{E}+04$ & $2.96 \mathrm{E}+04$ & $1.93 \mathrm{E}+04$ & $1.92 \mathrm{E}+04$ & $2.46 \mathrm{E}+04$ & $4.70 \mathrm{E}+04$ & $1.83 \mathrm{E}+04$ & $2.15 \mathrm{E}+04$ & $8.34 \mathrm{E}+03$ & $8.34 \mathrm{E}+03$ & $8.98 \mathrm{E}+03$ & $8.84 \mathrm{E}+03$ \\
\hline 10 & $3.38 \mathrm{E}+03$ & $2.51 \mathrm{E}+03$ & $1.63 \mathrm{E}+03$ & $1.63 \mathrm{E}+03$ & $2.09 \mathrm{E}+03$ & $3.98 \mathrm{E}+03$ & $0.00 \mathrm{E}+00$ & $0.00 \mathrm{E}+00$ & $0.00 \mathrm{E}+00$ & $0.00 \mathrm{E}+00$ & $0.00 \mathrm{E}+00$ & $0.00 \mathrm{E}+00$ \\
\hline 11 & $4.25 \mathrm{E}+05$ & $3.16 \mathrm{E}+05$ & $2.06 \mathrm{E}+05$ & $2.05 \mathrm{E}+05$ & $2.62 \mathrm{E}+05$ & $5.01 \mathrm{E}+05$ & $3.57 \mathrm{E}+05$ & 4.19E +05 & $1.16 \mathrm{E}+05$ & $1.16 \mathrm{E}+05$ & $1.25 \mathrm{E}+05$ & $1.23 \mathrm{E}+05$ \\
\hline 12 & $4.27 \mathrm{E}+05$ & $3.04 \mathrm{E}+05$ & $1.92 \mathrm{E}+05$ & $1.98 \mathrm{E}+05$ & $1.43 \mathrm{E}+05$ & $2.69 \mathrm{E}+05$ & $2.19 \mathrm{E}+05$ & $2.90 \mathrm{E}+05$ & $5.87 \mathrm{E}+04$ & $5.97 \mathrm{E}+04$ & $6.79 \mathrm{E}+04$ & $5.51 \mathrm{E}+04$ \\
\hline 13 & $3.58 \mathrm{E}+04$ & $2.66 \mathrm{E}+04$ & $1.73 \mathrm{E}+04$ & $1.72 \mathrm{E}+04$ & $2.21 \mathrm{E}+04$ & $4.22 \mathrm{E}+04$ & $3.98 \mathrm{E}+04$ & $4.67 \mathrm{E}+04$ & $1.52 \mathrm{E}+03$ & $1.52 \mathrm{E}+03$ & $1.63 \mathrm{E}+03$ & $1.61 \mathrm{E}+03$ \\
\hline 14 & $1.35 \mathrm{E}+03$ & $1.00 \mathrm{E}+03$ & $6.54 \mathrm{E}+02$ & $6.51 \mathrm{E}+02$ & $8.34 \mathrm{E}+02$ & $1.59 \mathrm{E}+03$ & $0.00 \mathrm{E}+00$ & $0.00 \mathrm{E}+00$ & $0.00 \mathrm{E}+00$ & $0.00 \mathrm{E}+00$ & $0.00 \mathrm{E}+00$ & $0.00 \mathrm{E}+00$ \\
\hline \multicolumn{13}{|l|}{15} \\
\hline 16 & $8.51 \mathrm{E}+04$ & $6.32 \mathrm{E}+04$ & $4.12 \mathrm{E}+04$ & $4.10 \mathrm{E}+04$ & $5.25 \mathrm{E}+04$ & $1.00 \mathrm{E}+05$ & $1.00 \mathrm{E}+05$ & $1.18 \mathrm{E}+05$ & $3.49 \mathrm{E}+04$ & $3.49 \mathrm{E}+04$ & $3.75 E+04$ & $3.70 \mathrm{E}+04$ \\
\hline 17 & $1.19 \mathrm{E}+05$ & $8.83 \mathrm{E}+04$ & $5.75 \mathrm{E}+04$ & $5.73 \mathrm{E}+04$ & $7.34 \mathrm{E}+04$ & $1.40 \mathrm{E}+05$ & $9.71 \mathrm{E}+04$ & $1.14 \mathrm{E}+05$ & $4.40 \mathrm{E}+04$ & $4.40 \mathrm{E}+04$ & $4.73 \mathrm{E}+04$ & $4.66 \mathrm{E}+04$ \\
\hline
\end{tabular}

The next step is to estimate the amount of pumped water for the model domain. Since the water stored in the different dams and the water flowing in Wadi Hisban is exclusively used to irrigated farmland within the study area, the deficit between the estimated field water requirement and the surface water flow represents the amount of groundwater that is necessary to irrigate the farmlands. The only exceptions are years with intensive precipitation. Usually direct precipitation on the irrigated farmlands can be neglected. However, rainfall intensive years (e.g. 1991/92) do contribute to the irrigation of the farmlands and also contribute recharge to the groundwater system. The last step in preparing the transient model was estimating different pumping periods for each year. Four different pumping periods were chosen to represent the extraction of groundwater for each season: $15^{\text {th }}$ of December until $15^{\text {th }}$ of March, $15^{\text {th }}$ of March until 31of May, $01^{\text {st }}$ of June until $31^{\text {st }}$ of July, and $01^{\text {st }}$ of August until $15^{\text {th }}$ of December. These periods were chosen according to the planting and harvesting season in the area (chapter 6.2). Since the rainy season is usually not very intensive until the mid of December and decreases usually by the end of March, very low to no pumping activities can be assumed for the first pumping season, low to very low pumping activities in the second pumping season, medium pumping activities in the third, and high to very high pumping activities in the last pumping season. These assumptions were applied to all extraction zones, which were labeled with shared irrigation sources (well plus surface water). For the different irrigation water sources see fig. 65 left. All extraction zones that have well water as their only irrigation water source, pumping activities throughout the whole planting season were applied. The last assumption to the transient model is related to the commission of the King Abdullah Canal in 1987. After its inauguration it serves a sole irrigation water source for most of the area north of South Shuneh. Therefore, starting with the commission of the canal pumping activities in its influence area seized. 
Tab.7- 3: Estimated surface flow in the different wadis. Rainfall was recorded at Naur rainfall station.

\begin{tabular}{|c|c|c|c|c|}
\hline season & $\mathbf{N}$ & W. Kafrein & W. Hisban & W. Shueib \\
\hline$[-]$ & {$\left[10 \mathrm{E}+06 * \mathrm{~m}^{3}\right]$} & {$\left[10 \mathrm{E}+06 * \mathrm{~m}^{3}\right]$} & {$\left[10 \mathrm{E}+06 * \mathrm{~m}^{3}\right]$} & {$\left[10 \mathrm{E}+06 * \mathrm{~m}^{3}\right]$} \\
\hline $1975 / 76$ & 401.8 & 5.75 & 4.18 & 5.59 \\
\hline $1976 / 77$ & 406.1 & 5.80 & 4.21 & 5.60 \\
\hline $1977 / 78$ & 411 & 5.87 & 4.25 & 5.62 \\
\hline $1978 / 79$ & 342.6 & 4.99 & 3.72 & 5.35 \\
\hline $1979 / 80$ & 805.9 & 10.96 & 7.29 & 7.16 \\
\hline $1980 / 81$ & 535 & 7.47 & 5.20 & 6.10 \\
\hline $1981 / 82$ & 372.8 & 5.38 & 3.96 & 5.47 \\
\hline 1982/83 & 676.9 & 9.30 & 6.30 & 6.66 \\
\hline $1983 / 84$ & 453 & 6.41 & 4.57 & 5.79 \\
\hline $1984 / 85$ & 368.2 & 5.32 & 3.92 & 5.45 \\
\hline $1985 / 86$ & 238.8 & 3.65 & 2.92 & 4.95 \\
\hline $1986 / 87$ & 409.2 & 5.84 & 4.24 & 5.61 \\
\hline $1987 / 88$ & 507.4 & 7.11 & 4.99 & 6.00 \\
\hline $1988 / 89$ & 401.2 & 5.74 & 4.17 & 5.58 \\
\hline \begin{tabular}{|l|}
$1989 / 90$ \\
\end{tabular} & 369.2 & 5.33 & 3.93 & 5.46 \\
\hline \begin{tabular}{|l|}
$1990 / 91$ \\
\end{tabular} & 275.5 & 4.12 & 3.21 & 5.09 \\
\hline \begin{tabular}{|l|}
$1991 / 92$ \\
\end{tabular} & 774.3 & 10.55 & 7.05 & 7.04 \\
\hline $1992 / 93$ & 390.4 & 5.60 & 4.09 & 5.54 \\
\hline $1993 / 94$ & 166.3 & 2.71 & 2.36 & 4.67 \\
\hline $1994 / 95$ & 216.8 & 3.36 & 2.75 & 4.86 \\
\hline $1995 / 96$ & 150.2 & 2.50 & 2.24 & 4.60 \\
\hline $1996 / 97$ & 394 & 5.65 & 4.12 & 5.56 \\
\hline $1997 / 98$ & 348.7 & 5.06 & 3.77 & 5.38 \\
\hline $1998 / 99$ & 128.3 & 2.22 & 2.07 & 4.52 \\
\hline $1999 / 00$ & 285.3 & 4.25 & 3.28 & 5.13 \\
\hline $2000 / 01$ & 279.5 & 4.17 & 3.24 & 5.11 \\
\hline
\end{tabular}

Fig. 7-11 shows the water budget for the period of 1980/81 until 2000/01. It can be seen that rain poor season lead to a negative water budget and rain intensive years to a positive one.

Fig. 7-12 shows the measured versus calculated groundwater heads. A good fit between calculated was achieved. However, the groundwater level fluctuations of the measured wells cannot be calculated exactly. This can be explained for the reason stated above (the usage of sinks instead of single well extractions for the simulation of groundwater extraction ). During the model run it became obvious, that groundwater inflow into the study area cannot be constant, as assumed during the model run for the sixties. In order to achieve a good results of calculated versus measured groundwater heads more groundwater inflow into the study area must take place during rain intensive seasons and less in rain poor seasons. 


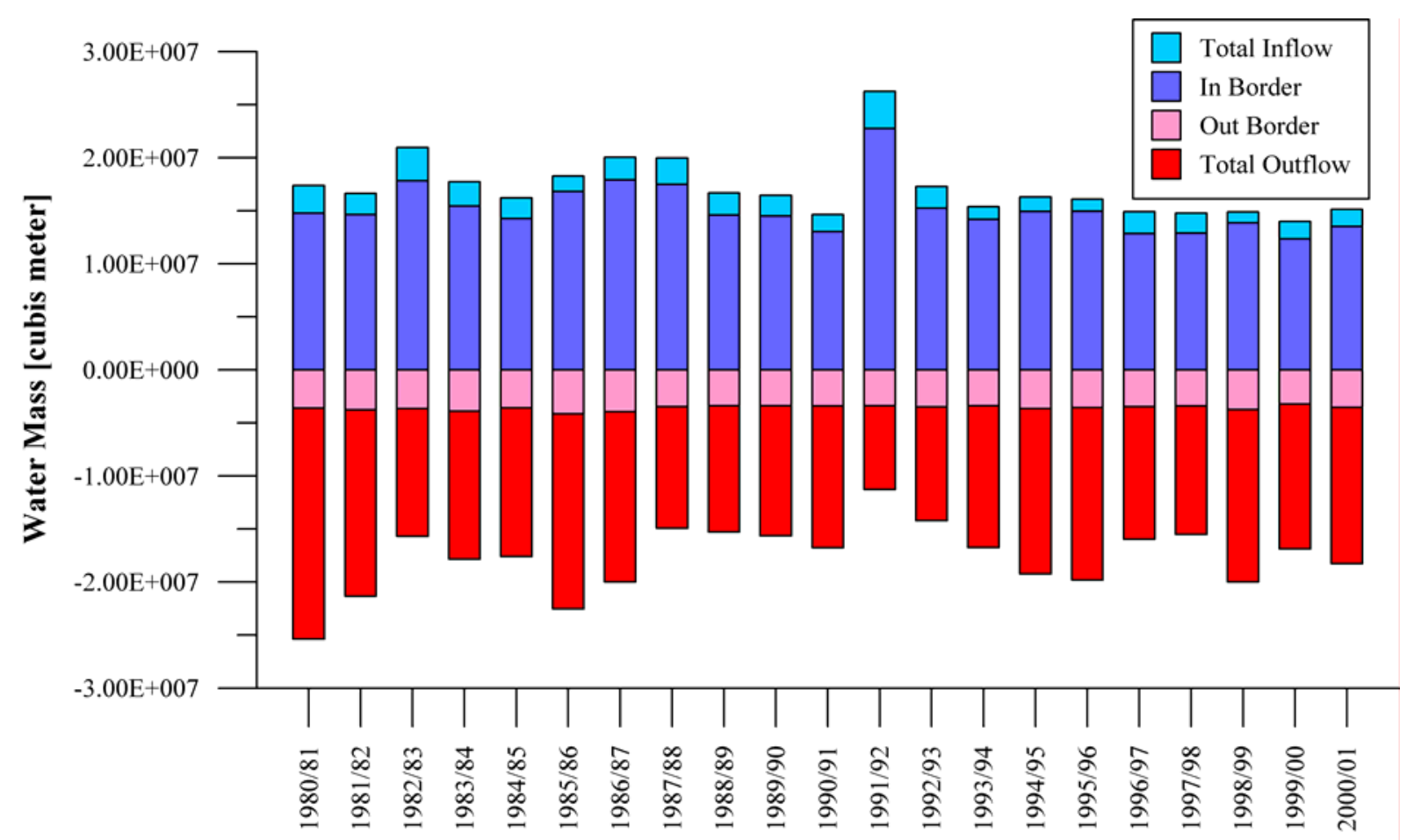

Season

Fig. 7-11: Water budget for the period of 1980/81 to 2000/01 of the transient model run; Total Inflow = Inflow of water along the different wadi sections (infiltration of surface water) together with flux through the eastern flux boundaries, Border = Inflow of groundwater through the flux boundaries (groundwater inflow), Out Border = Outflow of groundwater through the western flux boundaries (effluent groundwater to the Jordan River); Total Outflow $=$ Out Border together with groundwater pumped from the different extraction zones.

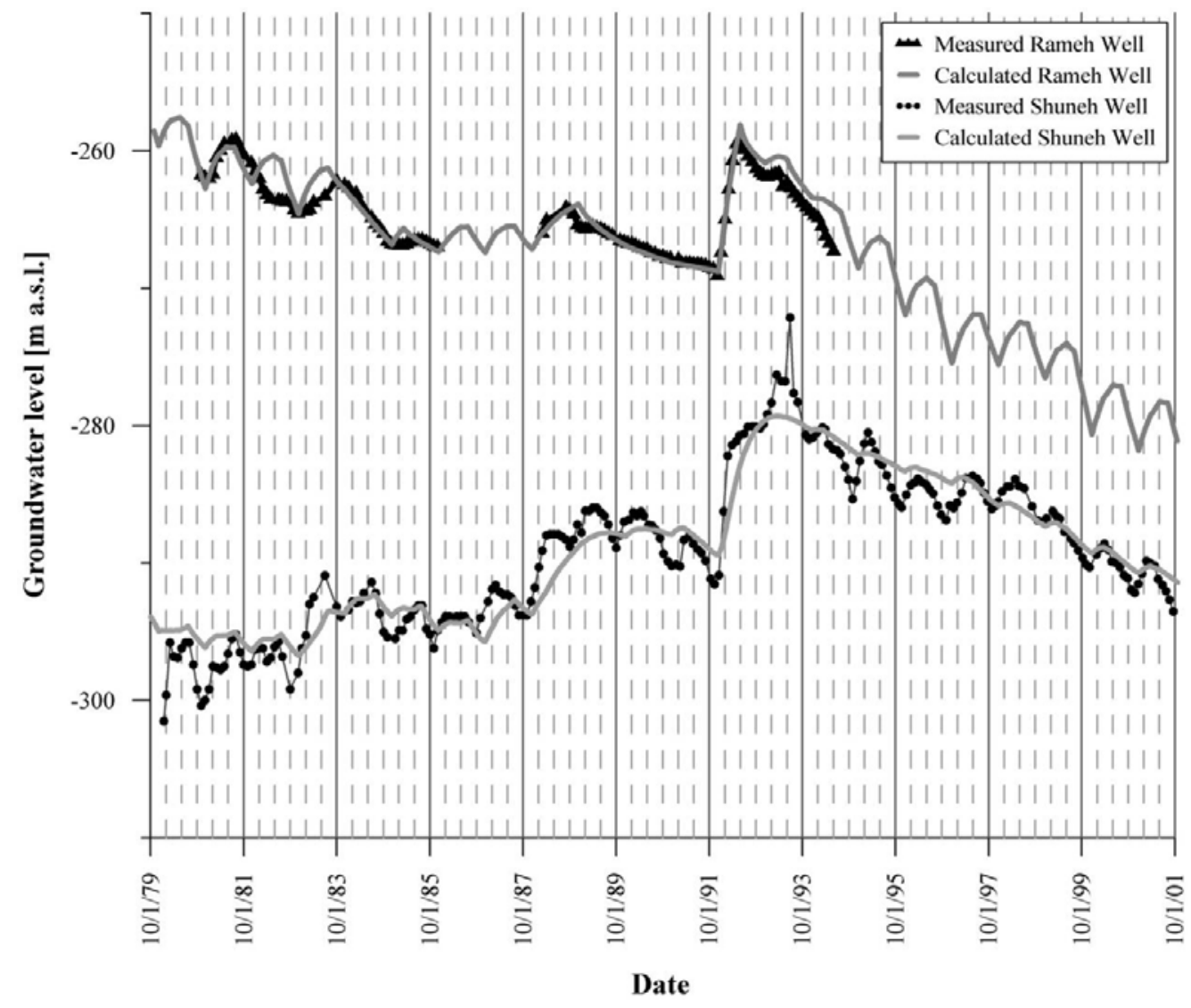

Fig. 7-12: Calculated versus measured groundwater heads for the period of 1980 until 2001. 


\section{SUMMARY AND IMPLICATIONS FOR GROUNDWATER MANAGEMENT/ RECOMMENDATIONS}

In this work an integrated approach is proposed that combines different types of available data and therefore overcomes data gaps common in many arid regions. This approach was demonstrated for the unconsolidated aquifer in the lowermost area of the Jordan Valley/ Jordan.

The conceptual model of flow was set up based on geological, hydrochemical, and geophysical methods. Geological methods were employed to determine the geometry of unconsolidated sediments, including the most important structural features of the study area. Furthermore, the nature of the sedimentary deposits and their subsurface contacts to the consolidated mountain aquifers were identified. By applying hydrochemical plots, the different flow paths of the groundwater in the unconsolidated aquifer and their change of composition along the flow path could be demonstrated. The plots were also used to distinguish areas dominated by hydraulically higher conductive material (alluvial deposits) from areas of lower conductive material (lacustrine deposits). It was shown, that no or almost no north-south flow takes place. A more precise picture of the subsurface and its salinity distribution is delivered by vertical electric soundings (VES). VES can be applied in any area were no information about the subsurface exists and a more precise distinction of the areas dominated by lower saline sediments from those with higher saline sediments was possible. The limitation of VES soundings and their applicability of other surface geophysical methods were shown with the help of direct-push geoelectric soundings and the analysis of sediment and pore water samples. Due to the high variation of salt content within the subsurface unambiguous interpretations of VES without multiple information about the subsurface is not possible. However, the VES soundings can be used qualitatively to distinguish areas of higher and lower electrical resistivity. 173 VES sounding data or interpretation data were collected. Six different resistivity classes were distinguished, where each class represents different information about the subsurface and its possible groundwater quality range.

An average water budget for the period of 1987 to 2002 was set up. Since no information about water extraction, i.e. active pumping wells and their respective pumping rates, available information regarding planted crops, planting seasons, different irrigation water sources were combined with remote sensing data (Landsat data) to overcome this data gap. Agriculture in the study area is only possible with artificial irrigation. The Minimum water demand of the area can therefore be calculated by using information about planted crops, planting and harvesting seasons, irrigation practices, and the agriculturally used area. The area was determined with the help of Landsat satellite images shot at different periods of the year. Knowing the different irrigation water sources a water budget that contains the different sources of irrigation water was set up. A total minimum water demand of 31.5 million cubic meter $\left(\mathrm{Mm}^{3}\right)$ was calculated. This demand is covered to $53 \%\left(16.8 \mathrm{Mm}^{3}\right)$ by surface flow and to $47 \%\left(14.7 \mathrm{Mm}^{3}\right)$ by pumped groundwater.

The general, the conditions and the stress periods under which the groundwater systems has been in the past were identified by doing a historical evaluation of reports available for the study area. In order to reliably predict the impacts of future climate change scenarios on the studied groundwater system a flow model must be tested against these constraints. A numerical 3-D flow model was set up by using the FEFLOW (Wasy Ltd.) software code. The geometrical and water budget information gathered with the integrated approach was incorporated into a steady- state model. This numerical flow model simulates the average flow conditions between 1987 and 2002 and was calibrated with available groundwater heads.

This numerical steady- state model was transformed into an unconfined 3-D transient model. After dynamic calibrating the model for 120 years, the model successfully simulated two different time periods: the first time period ranged from the first development phase until after the hostile event at the end of the sixties (1955-1970) and the second time periods ranged from the second development phase until the new millennium (1975-2001). The model was successfully able to simulate all extreme constraints that were put on the aquifer. These stress constraints included: periods of aquifer overexploitation during the sixties and the response of the aquifer to the stop of all pumping activities during the "six day war" and their aftermath, periods of drought, and one of the most intense rainfall season ever recorded in the study area (rainfall season 1991/92). Especially these extreme constraints deliver valuable information about the vulnerability of the studied aquifer system. The developed 
model should be able to successfully simulate future impacts on groundwater abstraction strategies or the impact of climate change scenario on the studied groundwater system. It should however be noted, that the model was developed for the whole study area. While it is evident that hydraulic properties are highly variable in space, the location and characteristics of the alluvial material is not known so that they cannot be adequately included into a groundwater model. Further field investigations are therefore necessary to develop a groundwater model, that would be applicable to small scale areas. Desirable investigations are especially:

- $\quad$ pumping tests with observation wells to assess the specific yield

- installing water meters in all wells to further validate the model

- a complete well survey to assess operating and non-operating wells, including measurements regarding well depth, depth of the pump, pump discharge, etc.

- gamma-ray depth profiles at all available well locations, in order to be able to subdivide the unconsolidated aquifer into further subunits

- permeability test of the lacustrine material

- a more precise investigation about the subsurface contact between the unconsolidated/ consolidated aquifers (shallow reflections seismic) to further enhance the knowledge about aquifer geometry

- investigating the "artificial recharge" of the surface dams at the outlet of the major wadis

- long-term pumping tests at wells close to the surface dams to investigate the interconnectivity between the dams and the unconsolidated aquifer

- groundwater hydrograph recording at high timely resolution

The groundwater resources of the unconsolidated aquifer should be used intensively, since high groundwater levels lead to steady- state evaporation of groundwater in the distal fan area. However, the extraction of groundwater should happen in a sustainable manner. Overexploitation, as practised during the 1960ies, leads to groundwater quality deterioration. Groundwater should be extracted in the upper to mid-fan area, since the salinity of the groundwater increases along the flow path to the west. In the mid-fan to more distal fan areas groundwater can be used to irrigated salt tolerant crops, like e.g. tomatoes or squash. Groundwater abstraction between the major alluvial fans should be avoided, since inflow to these areas can only occur from the major alluvial fans. In addition, these areas are dominated by the saline Lisan Formation. Furthermore, wells drilled in these areas will yield only small quantities of groundwater, since these areas are dominated by clays to silts. In general, groundwater should be abstracted rather from many wells pumped with medium pumping rates, than from few wells with high pumping rates. Increased pumping activities from single wells leads to a serious increase in groundwater salinity. Once the salinity increases, it is a rather long process to reduce the increased salinity. It should be noted, that in the upper to uppermost areas pumping activities can be high. Due to the high amount of groundwater entering from the neighbouring consolidated aquifers, and, more important, from leakage of the earth filled dams, increased salinity in these wells can be reversed quickly. In areas were the inflow from neighbouring consolidated aquifers is the only source of recharge, pumping rate should be medium, since increased pumping activities in the unconsolidated aquifer might lead to increase in salinity in the consolidated aquifers, which can only be reversed slowly.

In general the questions must be raised, if it is wise to plant crops with high water demand in an arid area. This is insofar important, that large areas in the upper fan areas are planted with banana plants, which demand large quantities of low saline irrigation water. Jordan faces today and even more in the future a severe water crisis, therefore all available resources should be used in the most efficient manner. 


\section{REFERENCES}

Abed, A. and El-Hiyari, M. (1986): Depositional environment and palaeogeography of the Cretaceous gypsum horizon in west-central Jordan. Sediment. Geol. 47: 109- 123

Abel, T. (2003): Untersuchungen zur Genese des Malmkarsts der Mittleren Schwäbischen Alb im Quartär und jüngeren Tertiär. Dissertation. University of Tübingen, Department of Applied Geology: 187p.

Abou Karaki, N. (1998): Geophysical resistivity survey in the Jordan Valley fisheries site. University of Jordan, Center for Consultation Technical Services and Studies, Amman, Jordan

Abu Ajamieh, M. (1998): Water Quality Improvement and Conversation Project-Assessment of Brackish Groundwater in Jordan. USAID in cooperation with the Ministry of Water and Irrigation; Amman, Jordan

Al- Rifaiy, I.A. and Cherif, O.H. (1987): Biostratigraphic aspects and regional correlation of some Cenomanian/ Turonian exposures in Jordan. Géol. Méditerr. XIV 3: 181 - 193

Al-Zoubi, A.S.; Heinrichs, T.; Sauter, M. and Qabbani, I. (2006): Geological structure of the eastern side of the lower Jordan Valley/ Dead Sea Rift: Reflection seismic evidence. Marine and Petroleum Geology, 23: 473484

Al-Kharabsheh-Atef, A. (1999): Influence of long-term overpumping on groundwater quality at Dhuleil Basin, Jordan. Forschungsergebnisse aus dem Bereich Hydrogeologie und Umwelt, 18: 2.1-2.10.

Allen, R.G.; Pereira, L.S.; Raes, D. and Smith, M. (1998): Crop evapotranspiration - Guidelines for computing crop water requirements - FAO Irrigation and drainage paper 56, FAO, Rome

Andrews, I.J. (1991): Paleozoic lithostratigraphy in the subsurface of Jordan. Subsurface Geology Bulletin No.2, NRA, Geology Directorate, Amman, Jordan, 67p.

Archie, G.E. (1942): The electrical resistivity $\log$ as an aid in determining some reservoir characteristics. Petroleum Technology, 5: 54-61

Archie, G.E. (1950): Introduction to the interpretation of resistivity measurements for complicated structural conditions. Geophysical Prospecting 7: 749 - 760

Bandel, K. (1981): New Stratigraphical and Structural Evidence for lateral Dislocation in the Jordan Rift Valley connected with a description of the Jurassic Rock Column in Jordan. N. Jb. Geol. Paläont. Abh, 161: 271308

Bandel, K. and Khoury, H. (1981): Lithostratigraphy of the Triassic in Jordan. Facies, 4: 1-26

Bartov, Y. (1974): A structural and palaeographical study of the central Sinai faults and domes. Unpublished PhD Thesis, Dept. Geol. Hebrew University, Jerusalem; 56p. [in Hebrew, English summary]

Bartov, Y. (1999): The geology of the Lisan Formation in Massada Plain and the Lisan Peninsula. Unpublished M.Sci. Thesis, Institute of Earth Sciences, The Hebrew University, Jerusalem, Israel, 61p.

Bartov, Y.; Stein, M.; Enzel, Y.; Agnon, A. and Reches, Z. (2002): Lake levels and sequence stratigraphy of Lake Lisan, the late Pleistocene precursor of the Dead Sea. Quaternary Research, 57: 9-21

Bar Yousef, O. (1987): Prehistory of the Jordan Rift. Israel J. Earth Sci 36: 107 - 119

Bayer, H.J. (1988): Wadi Araba und Jordantal, Ein tektonischer Graben und zugleich Blattverschiebung? Natur und Museum, 118: 33-45

Becker, K. (2000): Hydrological and Hydrogeological Investigations along Wadi Shueib - Jordan. Unpublished Diploma Thesis, University of Karlsruhe, Department of Applied Geology, Germany

Begin, B.; Ehrlich, A. and Nathan, Y. (1974): Lake Lisan: The Pleistocene precursor of the Dead Sea. Isr. Geol. Surv. Bull., 63: 30p.

Begin, Z.B. (1975): Palaeocurrents in the Plio-Pleistocene Samra Formation (Jericho Region, Israel) and their tectonic implication. Sediment. Geol., 14: 191-218

Begin, Z.B.; Broecker, W.; Buchbinder, B.; Druckman, Y.; Kaufman, A.; Magaritz, M.; and Nev, D. (1985): Dead Sea and Lake Lisan levels in the last 30,000 years. Geological Survey of Israel, Preliminary report 29/85: $1-18$

Begin, Z.B.; Ehrlich, A. and Nathan, Y. (1974): Lake Lisan: the Pleistocene precursor of the Dead Sea. Geol. Surv. Israel Report 63, Jerusalem, 30 p. 
Bein, A. (1976): Rudistid Fringing Reefs of Cretaceous Shallow Carbonate Platform of Israel. American Ass. of Petrol. Geol. Bull., 60, No.2: 258-272

Bein, A. und Weiler, Y. (1976): The Cretaceous Yafe Formation: A contour current shaped sedimentary prism of calcareous detrius at the continental margin of the Arabian Craton. Sedimentology, 23: 511 - 532

Ben-David, H. (1998): Modern and Holocene Debris Flows over the Western Escarpment of the Dead Sea. Unpublished M.Sc. Thesis; Hebrew University, Jerusalem, Israel

Bender, F. (1968): Geologie von Jordanien. Beiträge zur regionalen Geologie der Erde, Band 7, Gebrüder Bornträger; Stuttgart, p.230

Bender, F. (1974): Geology of Jordan. Gebrüder Bontraeger; Berlin

Bender, F.; Flathe, H. and Futian, A. (1965): Results from the hydrogeological and geoelectrical survey in the Jordan Valley. Jordan 1963 - 64. BGR. Hannover and Amman

Benjamini, C. (1979): Facies relationships in the Avedat Group Eocene in the northern Negev. Israel Journal of Earth Sciences, 28 (2-3): 47 - 69

Bentor, Y.K. and Vroman, A. (1960): The Geological Map of Israel, Scale 1: 100000, Mount Sdom, Sheet 16; Geological Survey of Israel, Jerusalem

Bentor, Y.K. and Vroman, A. (1954): A structural contour map of Israel with remarks on its dynamical interpretation. Bull. Res. Counc. Israel, Vol.4: 125- 185

Bentor, Y.K. and Vroman, A.J. (1951): Geological map of the Negev, Sheet 18: Avedat; Scale 1 : 100,000; Israeli Arm. Sci. Section; 98p.

Beydoun, Z.R. (1999): Evolution and development of the Levant (Dead Sea Rift) Transform structural controversy. IN: Mac Niocaill, C. and Ryan, P.D. (Eds.): Continental Tectonics, Geological Society of London, special publications, 164: 239-255

BGR (1996): Groundwater Resources of Northern Jordan. Rainfall, Spring Discharge and Baseflow. Spring Discharge in Northern Jordan. Central Water Authority Hashemite Kingdom of Jordan, Amman

Blair, T.C. (1985): Depositional chronology, sedimentary processes, and the resulting vertical stratification sequences in the Roaring River alluvial fan, Rocky Mountain National Park, Colorado. IN: Flores, R.M. and Harvey, M.D. (eds.): Field Guidebook to Modern and Ancient Fluvial System in the United States: Fort Collins, Colorado; Proceedings of the Third International Fluvial Conference: 96 - 101

Blair, T.C. (1987): Sedimentary processes, vertical stratification sequences, and geomorphology of the Roaring River alluvial fan, Rocky Mountain National Park, Colorado. Journal of Sedimentary Petrology, 57: 1-18

Blair, T.C. (1999a): Cause of dominance by sheetflood vs. debris - flow processes on two adjoining alluvial fans, Death Valley, California. Sedimentology, 46: 1015-1028

Blair, T.C. (1999b): Sedimentary processes and facies of the waterlaid Anvil Spring Canyon alluvial fan, Death Valley, California. Sedimentology, 46:. 913-940

Blair, T.C. and McPherson, J.G. (1994): Alluvial fans and their natural distinction from rivers based on morphology, hydraulic processes, sedimentary processes, and facies assemblages. Journal of Sedimentary Research, A64: 450-489

Blair, T.C.; McPherson, J.G. (1994a): Alluvial fan processes and forms. IN: Abrahams, A.D. and Parsons, A.J. (Hg.): Geomorpholohgy of Desert Environments. London: Chapman and Hall: 354-402

Blanckenhorn, M: (1914): Syrien, Arabien und Mesopotamien. Handbuch der Regionalen Geologie 5 (4), Heidelberg: 159p.

Blissenbach, E. (1954): Geology of alluvial fans in semi-arid regions. Geological Society of America 65: 175 190

Bowman, D. (1971): Geomorphology of the shore terraces of the late Pleistocene Lisan Lake (Israel). Palaeogeography, Palaeoclimatology, Palaeoecology, 9: 183-209

Bowman, D. (1997): Geomorphology of the Dead Sea western margins. IN: Niemi, T.M.; Ben-Avraham, Z. and Gat, J.R. (eds.): The Dead Sea - The Lake and Its Settings: 217 - 225; Oxford Monographs on Geology and Geophysics No. 36

Bowman, D. and Gross, T. (1992): The highest stand of Lake Lisan: 150 meters below MSL. Israeli Journal of earth Sciences, 41: 233 - 237 
Braun, M.; Levitte, D. and Arkin, Y.(1990): Field Trip No. 3: The Judea Group (Albian - Coniacian) in Israel: Lithostratigraphy and correlations. IN: International Geological Correlation Project (IGCP) 1990: Guidebook of the Cretaceous Field Conference, Israel; UNESCO, IUGS, GSI; (Project 245, Non-marine Cretaceous Correlation; Project 262 Tethyan Cretaceous Correlation), Jerusalem, Setember 5 - 15: 97p.

Braun, M:; Flexer, A.; Honigstein, A.; Rosenfeld, A. and Baida, U. (1987): Sedimentary setting of the Turonian, mainly Nezer Formation in the northern Negev (Israel) structures - A precursor of the Syrian Arc Folding phase. Newsl. Stratigr., 17 (2): 57 - 70

Buchbinder, B., Margaritz, M. and Buchbinder, L.G. (1983): Touronian to Neogene paleokarst in Israel. Palaeogeography, Paleoclimatology, Paleoecology, 43: 329-350

Burckhardt, J.L. (1822): Travels in Syria and the Holy Land. Association for Promoting the Discovery of the Interior Parts of Africa. London: 309p.

Chebaane, M., El-Naser, H., Fitch, J., Hijazi, A. and Jabbarin, A. (2004): Participatory groundwater management in Jordan: Development and analysis of options. Hydrogeological Journal, 12(1): 14-32

Condor, C.-R.; Kitchener, H.H. (1883): The Survey of Western Palestine. Memoires of the topography, orography, hydrography, and archaeology. Judea. London (Vol. III).

Cook, P.G. and Herczeg, A.L. (ed.) (2000): Environmental tracers in subsurface hydrology. Boston, Dordrecht, London; 529p.

Cooper, H.H. and Jacob, C.E. (1946): A generalized graphical method for evaluating formation constants and summarizing well field history. American Geophysical Union Trans., Vol. 27: 526 -534

Costa, J.E. (1988): Rheologic, geomorphic, and sedimentologic differentiation of water floods, hyperconcentrated flows, and debris fows. IN: Baker, V.R.; Kochel, R.C. and Patton, P.C. (eds.): Flood Geomorphology. Wiley, New York: 113 - 122

Dachnov, V. N. (1975): Geofiziceskie metody opredelenija kollektorskich svoistv is neftegasonasyscenija gornich porod. - Izdat. Nedra, Moskau.

Davis, S.N., DeWiest, R.J.M. (1967): Hydrogeology. Wiley, NewYork

Desai, K.P. and Moore, E.J.(1969): Equivalent NaCl Solutions From Ionic Concentrations; The Log Analyst 10; No. 3

Diabat, A. and Abdelghafoor, M. (2004): Geological map of Amman - 3153-I, 1:50.000, The Hashemite Kingdom of Jordan, Natural Resources Authority, Geology Directorate, Amman

Dietrich, P. (1999): Konzeption und Auswertung gleichstrom-geoelektrischer Tracerversuche unter Verwendung von Sensitivitätskoeffizienten. Dissertation, Geowiss. Fakultät Tübingen, TGA Nr. C50.

Dortman, A (1976): Fiziceskie svoistva gornich porod i polesnich iskapaemych. - Izdat. Nedra, Moskau.

Dottridge, J. and Abu-Nizar, J. (1999): Groundwater resources and quality in northeastern Jordan; safe yield and sustainability. Applied Geography, 19 (4): 313-323

Druckman, Y., Hirsch, F. and Weissbrod, T. (1982): The Triassic of the southern margin of the Tethys in the Levant and its correlation across the Jordan Rift Valley. Geol. Rundschau, 71: 919 - 936

Druckman, Y., Magaritz, M. and Sneh, A. (1987): The shrinkage of Lisan Lake as reflected by diagenesis of its marginal oolithic deposits. Israel J. Earth Sci. 36: 101 - 106

Dubertret, L. (1932): Les formes structurales de la Syrie et de la Palestine. Comptes Rendus l'Academie des Sciences, 195 : 66p.

Encyclopædia Britannica (2002); Encyclopaedia Britannica Inc, Chicago

Enzel, Y.; Kadan, G. and Eyal, Y. (2000): Holocene Earthquakes inferred from a fan-delta sequence in the Dead Sea Graben. Quaternary Research, 53: 34-48

Eshet, Y. (1983): A palynostratigraphic study of the Permo-Triassic succession in the Makhtesh Qatan-2 well, Negev, Israel. Geol. Surv. Israel Curr. Res., 1982: 15 - 20

Euroconsult (1989): Agricultural Compendium for Rural Development in the Tropics and Subtropics. Elsevier, Amsterdam: 740p.

Eyal, Y. (1996): Stress field fluctuations along he Dead Sea Rift since the Middle Miocene. Tectonics, 15 : 157 170 
Eyal, Y. and Reches, Z. (1983): Tectonic analysis of the Dead Sea Rift region since the late Cretaceous based on mesostructures. Tectonics, 2: 167 - 185

Eyal, Y.; Eyal, M and Kröner, A.(1991): Geochronology of the Elat terrain, metamorphic basement, and its implication for crustal evolution of the NE part of the Arabian-Nubian shield. Israel J. Earth Sci., 40: 5 - 16

FAO (1992): Crop Water Requirements. Irrigation and Drainage Paper No. 24. Rome

Ferembach, D. (1959). Le peuplement du Proche Orient au Chalcolithique et au Bronze Ancien. Israel Exploration Journal, 9: 221-228

Flathe, H. (1967): Interpretation of geoelectrical resistivity measurements for solving hydrogeological problems. Econ. Geol. Report, 26: 580-597

Flathe, H. (1968): Geoelektrische Untersuchung der Grundwasserversalzung im südlichen Jordantal. Geologisches Jahrbuch, 85: 767-782

Flathe, H. and Leibold, W. (1976): The smooth sounding graph. A Manual for Field Work in Direct Current Resistivity Sounding. BGR, Hannover: 48p.

Flathe, H. and Pfeiffer D.(1963): Outlines on the hydrology of the Isle of Madura (Indonesia): Subterranean Water. Proceedings of the General Assembly of Berkeley: 543-560

Flathe, H.; Bender, F. and Futian, A. (1965): Results from the hydrogeological and geoelectrical survey in the Jordan Valley. Jordan 1963 - 64. BGR, Hannover and Amman.

Fleischer, L. (2002): Stratigraphic Table of Israel. IN: Geological Framework of the Levant. Historical Productions Hall, Jerusalem; Plate VIII

Flexer, A (2001): The Pre-Neogene geology of the Near East. IN: Horowitz, A. (2001): The Jordan Rift Valley; A.A. Balkema Publishers; Lisse - Abingdon - Exton - Tokyo: 123 - 171

Flexer, A; Gilat, A. ; Hirsch,F. ; Honigstein, A.; Rosenfeld, A. and Rueffer, T. (1989): Late Cretaceous evolution of the Judean Mountains as indicated by ostracodes. Terra Res.: 349-358

Freund, R. (1961): Distribution of lower Turonian ammonites in Israel and the neighbouring countries. Bull. Res. Coun. Israel, 10G: 79 - 100

Freund, R.; Garfunkel, Z.; Zak, I.; Goldberg, M.; Weissbrod, T. and Derin, B. (1970): The shear along the Dead Sea Rift. Nature, 220: 253 - 255

Frohlich, R.K.; Urish, D.W.; Fuller, J. and O'Reilly, M. (1994): Use of geoelectrical methods in groundwater pollution surveys in a coastal environment. Journal of Applied Geophysics, 32: 139-154

Frostick, L.E. and Reid, I. (1989): Climatic versus tectonic controls of fan sequences: lessons from the Dead Sea, Israel. J. of the Geol. Soc., London, Vol. 146: 527-538

Gardosh, M. (1987): Water composition of late Quaternary lakes in the Dead Sea Rift. Israel Journal of EarthSciences, 36: 83-89

Garfunkel, Z. (1970): Tectonics of the western margins of the southern Arava. PhD dissertation. Dept. of Geol., Hebrew Uni. Jerusalem: 204pp.

Garfunkel, Z. (1981): Internal structures of the Dead Sea leaky Transform (Rift) in relation to plate kinematics. Tectonophysics, 80: 81-108

Garfunkel, Z. and Ben-Avraham, Z. (1996): The structure of the Dead Sea basin. Tectonophysics, 266: 155 - 176

Garfunkel, Z. and Horowitz, A. (1966): The Upper Tertiary and Quaternary morphology of the Negev. Isr. J. of Earth Sci., 15 (3): 101 - 117

Gerson, R.; Grossman, S. and Bowman, D. (1985): Stages in the creation of a large rift valley - geomorphic evolution along the southern Dead Sea Rift. IN: Hack, J.T. and Morisawa, M.: Tectonic Geomorphology. George, Allen \& Unwin: 53-73

Gibbs, A. (1986): Karameh Dam Project - Final Report - Volume 5 - Ground Investigations for the Karameh Dam. Jordan Valley Authority of the Hashemite Kingdom of Jordan, Amman

Ginzburg, A. and Levanon, A. (1976): Determination of a salt-water interface by electric resistivity depth soundings. Hydrological sciences bulletin - Bulletin des sciences hydrologiques, Nr. XXI: 561-568 
Goldberg, P. (1994): Interpreting late quaternary continental sequence in Israel. In: Bar Yousef, O. And Kra, R.S. (eds.): Late quaternary chronology and palaeoclimates of the Eastern Mediterranean.

Radiocarbon/Peabody Museum, Harvard University; 89 - 102

Grant, F.S. and West, G.F. (1965): Interpretation Theory in Applied Geophysics. McGraw-Hill, New York: 583 p.

Gregory, J.W. (1921): The rift valleys and geology of East Africa. Seeley Service and Co., London: 479p.

Gtz (1977): National Water Master Plan. Surface Water Resources. Natural water Resources Authority of the Hashemite Kingdom of Jordan, Amman. Vol. III.

GTZ (2002): Irrigation Water Sources and Water Use in the southern Jordan Valley. - data evaluation and maps. Prepared by Vallentin, A.; Srouji, F. and Abdel Jaber,S.. Issued by Ministry of Water and Irrigation Hashemite Kingdom of Jordan, Jordan Valley Authority and Brackish Water Project. Amman

Gtz (2003): Guidelines for Brackish Water irrigation in the Jordan Valley. Ministry of Water and Irrigation Jordan Valley Authority Brackish Water Project Hashemite Kingdom of Jordan, Amman

Habgood,P.J. (1985): Ghassulian Flake Stone Tools. Trasus, 3: 1-2: 47-60

Haq, B.V., Hardenbol, J. and Vail, P.R. (1987): Chronology of fluctuating sea levels since Triassic. Science, 235: 1156- 1167

Heinrichs, T.; AL-Zoubi, A.; Sauter, M.; Salameh, E. and Qabbani, I. (2004): Structure of the Shuna (Eastern Jericho) Basin, Lower Jordan Valley - interpretation of reflection seismic data, preliminary results. 5th Int Symp Eastern Mediterranean Geol, Thessaloniki, Proc 3: 1522-1525

Heinz, J.; Kleineidam, S.; Teutsch, G. and Aigner, T. (2003): Heterogeneity patterns of Quaternary glaciofluvial gravel bodies (SW- Germany): application to hydrogeology. Sedimentary Geology, 158: 1-23

Hempton, M. (1987): Constraints on Arabian plate motion and extensional history of the Red Sea. Tectonics, 6: 687-705

Hennessy, J. B. (1969): Preliminary report on the first season of excavations at Teleilat Ghassul. Levant I: 1-24

Hennessy, J. B. (1982): Teleilat Ghassul: Its place in the archaeology of Jordan. IN: Hadidi, A. (ed.): Studies in the History and Archaeology of Jordan. Department of Antiquities, Amman: 55-58

Hizrallah, B. (1973): Groundwater Resources of the Jordan Valley. Natural water Resources Authority of the Hashemite Kingdom of Jordan und Water Resources Division Groundwater Section. Amman

Hogg, S.E. (1982): Sheetfloods, sheetwashs, sheetflows, or? Earth-Science Review, 18: 59-76

Hölting, B. (2005): Einführung in die allgemeine und angewandte Hydrogeologie. Elsevier, Spektrum Akad. Verla., München: 326p.

Horowitz, A. (1979): The quaternary of Israel. Academic Press, New York, 394p.

Horowitz, A. (2001): The Jordan Rift Valley. A.A. Balkema Publishers; Lisse - Abingdon - Exton - Tokyo: 730p.

Hull, E. (1886); The survey of western Palestine: Memoir on the Geology and Geography of Arabia Petraea, Palestine and adjoining districts, with special reference to the mode of formation of the Jordan - Arabah Depression and the Dead Sea. Richard Bentley and Son, London: 154p.

Hunting Technical Services Ltd. (1993): The soils of Jordan - National Soil Map and Land Use Project, Level 1 Volume 2; Commission of the European Communities; Contract No. SEM/03/628/005; Ministry of Agriculture of the Hashemite Kingdom of Jordan, Amman

Husseini, M.I. (1992): Upper Palaeozoic tectono- sedimentary evolution of the Arabian and adjoining plates. Journal of the Geological Society, 149: 419-429

Husseini, M.I. and Husseini, S.I. (1990): Origin of the Infra-Cambrian salt basins of the Middle East. IN: Brooks, J. (ed.): Classic Petroleum Provinces. Geological Society Special Publication, 50: 279-292

Ionides, B.A. (1939): The Water Resources of Transjordan and thier development. Crown Agents, London: 372pp.

Ionides, B.A. (1946): Jordan Valley Irrigation in Transjordan. Engineering: 82-84

Jacob, C.E: (1940): On the flow of water in an elastic artesian aquifer. Trans. Amer. Geophys. Union, Vol. 21, Part 2: 574 - 586 
JICA (1995): The Study on brackish groundwater desalination in Jordan. Draft Final Report - Main report. Yachiyo Engineering Co. Ltd. and Mitsui Mineral Development Engineering Co. Ltd. Issued by the Ministry of Water and Irrigation Jordan Valley Authority. Brackish Water Project. Hashemite Kingdom of Jordan, Amman

Johnson, P.R. (1998): Tectonic map of Saudi Arabia and adjacent areas. Technical report USGS-TR-98-3, Ministry of Petroleum and Mineral Resources, Saudi Geological Survey, Saudi Arabia

Jridi, A. (2002): The Development of the Jordanian Jordan River Basin: the main historical steps. Issued by the Regional French Mission for Water and Agriculture (MREA). ENGREF. Amman.

Kadan, G. (1997): Evidence of Dead Sea fluctuations and neotectonic events in the Holocene Fan Delta of Nahal Darga. Unpublished M.Sc. Thesis, Ben Gurion University, Israel

Katz, A. and Kolodny, Y (1977): The geochemical evolution of the Pleistocene Lake Lisan-Dead Sea system. Geochimica et Cosmochimica Acta; Vol. 41: 1609-1626

Kaufman, A.; Yechieli, Y. and Gardosh, M. (1992): Reevaluation of the Lake-Sediment Chronology in the Dead Sea Basin, Israel, Based on New 230Th/U Dates. Quaternary Research, 38: 292-304

Kaufman, A: (1971): U- series dating of Dead Sea Basin carbonates; Geochim. Cosmochim. Acta, 35 (12): 1269 $-1281$

Keller, B. (1996): Lithofazies- Codes für die Klassifikation von Lockergesteinen. Mitt. Schweiz Ges. Boden Felsmech., 132: 1-8

Ken-Tor, Agnon, A.; Enzel, Y.; Stein, M.; Marco, S. and Negendank, J.F.W. (2001): High resolution geological record of historic earthquakes in the Dead Sea Basin. Journal of Geophysical Research, 106 (B2): 22212234

Khayat, S.; Hötzl, H.; Geyer, S. and Ali, W. (2006): Hydrochemical investigations of water from the Pleistocene wells and springs, Jericho area, Palestine. Hydrogeology Journal, 14: 192-202.

Khoury, R.G. (1981): The Jordan Valley. Life and society below Sea Level. Longman Group Limited, London: 238p.

Klein, C. (1982): Morphological evidence of lake level changes, western shore Dead Sea. Israel Journal of Earth Sciences, 31: 67- 94

Kleineidam, S. (1998): Einfluss von Sedimentologie und Sedimentpetrographie auf den Transport organischer Schadstoffe - Laborversuche. Dissertation, Department of Applied Geology, University of Tübingen, Germany

Klinger, Y.; Avouac, J.P.; Bourles, D. and Tisnerat, N. (2003): Alluvial deposition and lake - level fluctuations forced by late Quaternary climate change: the Dead Sea case example. Sedimentary Geology, 162: 119-139

Knight, R. (1991): Hysteresis in the electrical resistivity of partially saturated sandstones. Geophysics, 56 (12): 2139-2147

Knödel, K., Krummel, H. and Lange, G. (1997): Geophysik. Springer: Berlin- Heidelberg -New York: 1063p.

Köhn, M. (1929): Korngrößenbestimmung vermittels Pipettenanalyse. Tonindustrie-Zeitung, 55: 729-731

Köppen, W. (1931): Grundriss der Klimakunde. Walter de Gruyter, Berlin: 388p.

Krusemann, G.P. and de Ridder, N.A. (1994): Analysis and Evaluation of Pumping Test Data. International Institute for Land Reclamation and Improvement, Publication 47. Wageningen, The Netherlands: 377p.

Kuntz, D. (2003): Soils in the Wadi Shu'eib catchment area and thier proctective potential for groundwater. Unpublished Diploma Thesis. Universität Karlsruhe, Angewandte Geologie.

Landmann, G.; Abu Qudaira, G.M.; Shawabkeh, K.; Wrede, V. and Kempe, S. (2002): Geochemistry of the Lisan and Damya Formations in Jordan, and implications for palaeoclimate. Quaternary International, 89: 45-57

Lartet, L. (1869): Essai sur 1 géologie de la Palestine et des contrées avoisinantes telles aue l'Égypte et l'Arabie, comprenant les observations recueilles dans le cours de l'expedition du Duc de Luynes à la mer Morte. Ann. Sci. Geol. Paris, Vol. 1: 1 - 116 and 149 - 329

Lenz, S. (1999): Hydrogeological Investigations along Wadi al Kafrein and the Kafrein Reservoir. Unpublished Diploma Thesis, Universität Karlsruhe, Angewandte Geologie 
Lewy, Z. and Avni, Y. (1988): Omission surfaces in the Judea Group, Makhtesh Ramon region southern Israel, and their palaeogeographic significance. Israel Journal of Earth Science, 37: 105 - 113

Lillesand, T.M., and Kiefer, R.W. (2004): Remote Sensing and Image Interpretation. John Wiley and Sons, New York: 763 p.

Lliott, D.C.(1978): The Ghassulian Culture in Palestine : Origins, Influences and Abandonment. Levant, 10: 3754

Lowrie, W. (1997): Fundamentals of Geophysics. Cambridge Univ. Press, London: 354p.

Lucas, L.L. and Unterweger, M.P. (2000): Comprehensive review and critical evaluation of the half-life of Tritium. J. Res. Natl. Inst. Stand. Technol., 105: 541 - 545

Machlus, M.; Enzel, Y.; Goldstein, S.L.; Marco, S. and Stein, M. (2000): Reconstructing low levels of Lake Lisan by correlating fand-delta and lacustrine deposits. Quaternary International, 73/74: 137-144

Margane, A., Hobler,M. and Subah, A. (1999): Mapping of Groundwater Vulnerability and Hazards to Groundwater in the Irbid Area, N-Jordan. Zeitschrift für Angewandte Geologie, 45(4): 175- 187

Marie, A. and Vengosh, A. (2001): Sources of salinity in ground water from Jericho area, Jordan Valley. Ground Water, 39: 240-248

Masri, M. (1963): Report on the geology of the Amman, Zerqa area. Central Water Authority, Amman, 1-74.

MERC (2004): Water Quality along the Jordan River: A Geochemical Perspective on the Sources of Salts Final Report; Middle East Regional Cooperation Program (MERC); Project No.: M20-068: 170p.

McDonald and Partner (1951): Report on the proposed extension of Irrigation in the Jordan Valley. Issued by the Hashemite Kingdom of Jordan, Amman

McDonald, M. and Partners (1963): Salt - 1:25.000 C.W.A. Geologic Series - Sheet 215/150.- Jordan office for geological and engineering services, Amman

Mikbel, S.H. and Zacher, W. (1981): The Wadi Shueib structure in Jordan. N. Jb. Geol. Paläont.: 571-576

Mikbel, S.H. and Zacher, W. (1986): Fold structures in northern Jordan. N. Jb. Geol. Paläont.: 248-256

Militzer, H. \& Weber, F. (1985): Angewandte Geophysik. Band 2: Geoelektrik - Geothermik - Radiometrie Aerogeophysik. Springer, Berlin: 371

Moore, A. M. T. (1973). The Late Neolithic in Palestine. Levant, V: 36-78

Müller, G. and Gastner, M. (1971): The „Karbonat-Bombe, a simple device for the determination of the carbonate content in sediments, soils and other materials. N. Jb. Miner. Mh., 10: 466-469

Neev, D. (1960): A pre-Neogene erosion chanel in the southern coastal plain of Israel. Isr. Geol. Bull., 25: 20p.

Neev, D. and Emery, K.O. (1967): The Dead Sea, depositional processes and environments of evaporates. Isr. Geol. Surv. Bull., 41: 147p.

Niemi, T.M. (1997): Fluctuations of Late Pleistocene Lake Lisan in the Dead Sea Rift. IN: Niemi, T.M.; Ben Avraham, Z. and Gat, J.R. (editors.): The Dead Sea: the lake and its settings. Oxford University Press, New York: 226-236.

Niemi, T.M.; Ben-Avraham, Z. and Gat,J.R. (editors) (1997): The Dead Sea : the lake and its setting; Oxford University Press, New York: 286p.

Nosske, G. (1977): Elektrische Methoden in der Geophysik. IN: Lauterbach, R. (ed): Physik der Erdkruste. Akademie-Verlag, Berlin.

Nowroozi, A.A.; Horrocks, S.B. and Henderson, P. (1999): Saltwater intrusion into the freshwater aquifer in the eastern shore of Virginia: a reconnaissance electrical resistivity survey. Journal of Applied Geophysics, Nr. 42: $1-22$

Parchomenko, E. J. (1965): Elektriceskie svoista gornich porod. - Izdat. Nauka, Moskau

Parker, D.H. (1969): Investigations of the Sandstone Aquifers of East Jordan. The hydrogeology of the Mesozoic-Cenozoic Aquifers of the Western Highlands and Plateau of East Jordan. - UNDP/FAO 212 techn. Rep. 2 (AGL:SF/JOR 9), 4 Vols.; Rome

Parker, D.H. (1970): The hydrogeology of the Mesozoic- Cenozoic aquifers of the western highlands and plateau of East Jordan, 4 volumes; UNDP/ FAO 212, Rome; Technical report No. 2: 424p. 
Philip, J. et al. (12 co-authors) (2000) : Late Cenomanian ; IN : Dercourt, J.; Gaetani, M.; Vrielynck, B; Barrier, E.; Biju-Duval, B.; Brunet, M.F.; Cadet, J.P.; Crasquin, S. and Sandulescu, M. (eds.) : Atlas Peri-Tethys palaeogeographical maps, Map 14 ; CCGM/ CGMW, Paris

Philippe, J. (2004): Reclamation's history of the Jordan river Basin in Jordan, a focus on agriculture: past trends, actual farming systems and future prospective, Volume II. Open report, funded by the International Water Management Institute program “comprehensive assessment”: 185p.

Picard, L. (1943): Structure and evolution of Palestine. Bull. Geol. Dept. Hebrew Uni., Vol. IV, No. 2

Plakht, J. (2000): Quaternary units in Makhteshim, Negev Desert: similarities and peculiarities; Israel. J. of Earth Sciences, 49: 179 - 187

Powell, J.H. (1989a): Stratigraphy and Sedimentation of the Phanerozoic Rocks in Central and South Jordan Part A: Ram and Khreim Groups. Natural Resources Authority Bulletin, No. 11: 72p.

Powell, J.H. (1989b): Stratigraphy and Sedimentation of the Phanerozoic Rocks in Central and South Jordan Part B: Kurnub, Ajlun and Belqa Groups. Natural Resources Authority Bulletin, No. 11: 130p.

Quennell, A.M. (1956): The structural and geomorphic evolution of the Dead Sea Rift. The quarterly journal of the Geological Society of London, 114: 1-18

Reid, I and Frostick, L. (1993): Late Pleistocene Rhythmite Sedimentation at the Margin of the Dead Sea Trough: a Guide to Palaeoflood Frequency. IN: McManus, J. and Duck, R.W (editors): Geomorphology and Sedimentation of Lakes and Reservoirs: 259-273

Reynolds, J.M. (1997): An introduction to applied and environmental geophysics. Wiley, New York: 796p.

Richards, J. (1986): Remote sensing digital image analysis, an introduction. Springer, New York: 281 p.

Roether, W. (1967): Estimating the Tritium input to groundwater from wine samples: groundwater and direct run-off contribution to central European surface waters. Isotopes in Hydrology IAEA-SM-83/7: 73-91; IAEA Vienna

Rosenfeld, A. and Hirsch, F. (2005): The Paleocene - Eocene of Israel; IN: Hall, J.K.; Krasheninnikov, V.A.; Hirsch, F.; Benjamini, C. and Flexer, A. (eds.): Geological Framework of the Levant Vol. II: The Levantine Basin and Israel; Historical Productions Hall, Jerusalem: 826 p.

Rosenthal, E. (1988): Hydrochemistry of groundwater at unique outlets of the Bet Shean - Harod multipleaquifer system, Israel. Journal of Hydrology, 97: 75-87

Rosenthal, E. (1997): Thermomineral waters of Ca-chloride composition: review of diagnostics and brine evolution. Environmental Geology, 32: 245-250

Rotstein, Y.; Bartov, Y. and Hofstetter, A. (1991): Active compressional tectonics in the Jericho area, Dead Sea Rift. Tectonophysics, 198: 239-259

Sabet, M.A. (1975): Vertical electrical resistivity sounding locate groundwater resources: a feasibility study. Water Resources Bulletin, (73

Salameh E and Bannayan H (1993) Water Resources of Jordan. Present Status and Future Potentials. Friedrich Ebert Stiftung, Amman: 183p.

Salameh, E. (1980): The Suweilih Structure. N. Jb. Geol. Paläont.: 428-438

Salameh, E. (2001): Using Environmental Isotopes in the study of the recharge discharge mechanisms in the Yarmouk catchment area in Jordan. Amman.

Salameh, E. and Udluft, P. (1985): The hydrodynamic pattern of the central part of Jordan. Geologisches Jahrbuch, C38: 39-53

Salameh, E. and Haddadin, M.J. (2006): The Population-Water Resources Equation; IN: Haddadin, M.J. (ed.): Water Resources in Jordan; Resources for the Future, Washington: 7- 27

Salameh, E.; El-Naser, H. and Al-Zoubi, A (2004): Interim Report 2; Geohydraulics and Groundwater Flow Modelling for the Understanding of Groundwater Systems in the Jordan River Valley and the Adjacent Aquifers Project; funded by the German Ministry of Education and Research (BMBF) and the Israeli Ministry of Science and Technology (MOS); Amman

Salameh, E. and Al Farajat, M. (2007): The role of volcanic eruptions in blocking the drainage leading to the Dead Sea formation. Environ. Geol., 52: 519 - 527 
Schlosser, P.; Stute, M.; Dörr, C.; Sonntag, C.; and Münnich, K.O. (1988): Tritium/3He-dating of shallow groundwater. Earth Planet Sci Lett, 89: 353-362

Schlosser, P.; Stute, M.; Sonntag, C. and Münnich, K.O. (1989): Tritiogenic 3He in shallow groundwater. Earth Planet Sci Lett, 94: 245-256

Salzgitter Consult GmBH and Jordanian Consulting Engineer Co. (1992): Studies on Raising Kafrein Dam Final Report on Technical, Economic and Financial Feasibility and Preliminary Design; Part II - Main Report. Ministry of Water and Irrigation and Jordan Valley Authority; Amman, Jordan

Saman, J.J. and Al-Masri (1988): The Study Area between Hisban and Mukheiba - Final Report; Ministry of Water and Irrigation; Amman, Jordan

Sass, E. and Bein, A. (1982): The Cretaceous Carbonate Platform in Israel. Cretaceous Research: 135-144

Sass, E. and Oppenheim, M.J. (1966): The petrology of some Cenomanian sediments of the Judean Hills, Israel, and the palaeoenvironmental break of Motsa Marl. Isr. J. Earth Sci., 14: 91-107

Schlumberger (1989): Log Interpretation Principles/Applications: Houston (Schlumberger Educ. Services), SMP-7017

Schneider, W.; Abed, A.M. and Salameh, E. (1984): Mineral Content and Diagnetic Pattern - Useful Tools for Lithostratigraphic Subdivision and Correlation of the Nubian Series. Geol. Jb., B53: 55-75

Schön, J. (1983): Petrophysik - physikalische Eigenschaften von Gesteinen und Mineralen. - Enke, Stuttgart: 405p.

Schön, J. H. (1996): Physical Properties of rocks - Fundamentals and principles of petrophysics. Pergamon Press: 583p.

Schramm, A. (1997): Uranium series and 14C dating of Lake Lisan (Paleo-Dead Sea) sediments: implications for 14C time- scale calibration and relation to global paleoclimate. Dissertation at the Göttingen GeorgAugust- Universität, Faculty für Geowissenschaften und Geographie

Schramm, A.; Stein, M. and Goldstein, S.L. (2000): Calibration of the ${ }^{14} \mathrm{C}$ time scale to $>40$ ka by ${ }^{234} \mathrm{U}-{ }^{230} \mathrm{Th}$ dating of Lake Lisan sediments (last glacial Dead Sea). Earth and Planetary Science Letters, 175: 27 - 40

Schulze, F.; Lewy, Z.; Kuss, J. and Gharaibeh, A. (2003): Cenomanian-Turonian platform deposits in west central Jordan. Int. J. Earth Sci., 92: 641-660

Shaliv, G. (1989): Stages in the Tectonic and Volcanic History of Neogene Continental Basins in Northern Israel. PhD Thesis, Hebrew University, Jerusalem, Israel; 100pp.

Shawabkeh, K.F. (2001): Geological map of Al Karama - 3153-IV, 1:50.000, The Hashemite Kingdom of Jordan, Natural Resources Authority, Geology Directorate

SJ (1998): Statistical Yearbook of Jordan, Department of Statistics, Hashemite Kingdom of Jordan, Amman

Sneh, A. (1979): Late Pleistocene Fan-Deltas along the Dead Sea Rift. J. of Sed. Petrology, Vol. 49 No. 2: 541552

Steckler, M.S.; Berthelot, F.; Lybris, N. and Le Pichon, X. (1988): Subsidence in the Gulf of Suez: implications for rifting and plate kinematics. Tectonophysics, 153: 249 - 270

Subah, A. (1998): Environmental Isotope Study of the Artificial Recharge to the Groundwater in Jordan. Case of Jordan Valley. Unpubl. Report Water Resources Studies Dept., Ministry of Water and Irrigations MWI, Amman

Suess, E. (1909): Das Antlitz der Erde Vol. IV; Tempsky, Vienna: 789pp.

Sültenfuß, J. and Massmann, G. (2004). Datierung mit der ${ }^{3} \mathrm{He}-$ Tritium Methode am Beispiel der Uferfiltration im Oderbruch; Grundwasser, 9(4): 221-234

Theis, C.V. (1935): The relation between the lowering of the piezometric surface and the rate and duration of a well using groundwater storage. Trans. Am. Geophys. Union, 16: 519 - 524; Washington D.C.

Tleel, J.W. (1963): Inventory and groundwater evaluation Jordan Valley. Issued by the Central Water Authority of the Hashemite Kingdom of Jordan. Amman.

Toll, M.; Heinrichs, T.; Sauter, M. and Salameh E. (in preparation): An integrated approach for the hydrogeological investigation of the unconsolidated aquifers in lower Jordan Valley. IN: Hötzl, H. and Möller, P. (editors): Water Resources of the Jordan and Dead Sea Rift Valley. Springer; Berlin:17p. 
Tolstinkhin, I.N. and Kamenskij, I.L. (1969): Determination of groundwater ages by the T-3He method; Geochem Int., 6: 810-811

Ulbrich, U.; May, W.; Li, L.; Lionello, J.G.; Pinto, J.G. and Somot, S. (2006): The Mediterranean Climate Change under Global Warming; IN: Lionello, P.; Malanotte-Rizzoli, P. and Boscolo, R. (editors): Mediterranean Climate Variability; Elsevier, Amsterdam: 399 - 415

Urish, D.W. and Frohlich R.K. (1990): Surface elecrical resistivity in coastal groundwater exploration. Geoexploration, 26: 267-289

Van Dam, J.C. and Meulenkamp, J.J. (1967): Some results of the geo-electrical resistivity method in groundwater investigations in The Netherlands. Geoghys. Prosp., 15 (1): 92-115

Vrabel, J. (1996): Multispectral imagery band sharpening study. Photogrammetic Engineering and Remote Sensing, Vol. 62, No. 9: 1075-1083

Waldman, N.; Stein, M.; Starinsky, A. and Katz, A.(2000): Limnological changes in Lake Samra from geochemical and mineralogical evidence of the sedimentary section of Peratzim Valley; Israel. Israel Geological Society Annual Meeting Abstract, Ma’a lot: 126

Weiler, Y. (1966): Turonian sandstone in the vicinity of Jerusalem. Isr. J. Earth Sci., 15: 155-160

Weiler, Y. and Sass, E. (1972): Karstic sandstone bodies in the turonian limestone of Judea, Israel. Sediment. Geol., 7: 137-152

Weissbrod, T. (1969a): The Paleozoic of Israel and adjacent countries. Part I - The Paleozoic stratigraphy of southern Israel. Bull. Geol. Surv. Israel, 47: 1 - 35

Weissbrod, T. (1969b): The Paleozoic of Israel and adjacent countries. Part II - The Paleozoic outcrops in southwestern Sinai and their correlation with those of southern Israel. Bull. Geol. Surv. Israel, 48: 1 - 32

Weissbrod, T. (1981): The Paleozoic of Israel and adjacent countries (lithostratigraphic study). Geol. Surv. Israel Rep.; MP/600/81; 276pp.

Werz, H. (2006): The integrated use of GIS and remote sensing imagery for groundwater risk intensity mapping in the Wadi Shu'eib, Jordan. Dissertation. Universität Karlsruhe, Angewandte Geologie

Wiesemann, G.; Rösch, H. (1969): Das Apatit Vorkommen von Suweilih bei Amman (Nord- Jordanien). Beihefte Geologisches Jahrbuch, 81: 177-214

Worthington, A. E. and Pallatt, N. (1989): Effect of variable saturation exponent upon the evaluation of hydrocarbon saturation. - SPE paper 20538: 101-110

Worthington, A. E., Hedges, J. E. and Pallatt, N. (1990): SCA Guidelines for sample preparation and porosity measurement of electrical resistivity samples. - Part I. The Log Analyst: 20-28.

Worzyk, P.H. (1985): Geoelectrical Investigations in the Jordan Valley, Jordan. BGR. Hannover.

Zohdy, A.A.R. (1969): The use of Schlumberger and equatorial soundings on groundwater investigations near El Paso, Texas. Geophysics, 34: 713-728

Zohdy, A.A.R.; Martin, P. and Bisdorf, R.J. (1993): A study on seawater intrusion using direct-current soundings in the southeastern part of the Oxnard Plain, California. U.S. Geological Survey. (Open File Report 93 524): 139p. 


\section{APPENDIX}
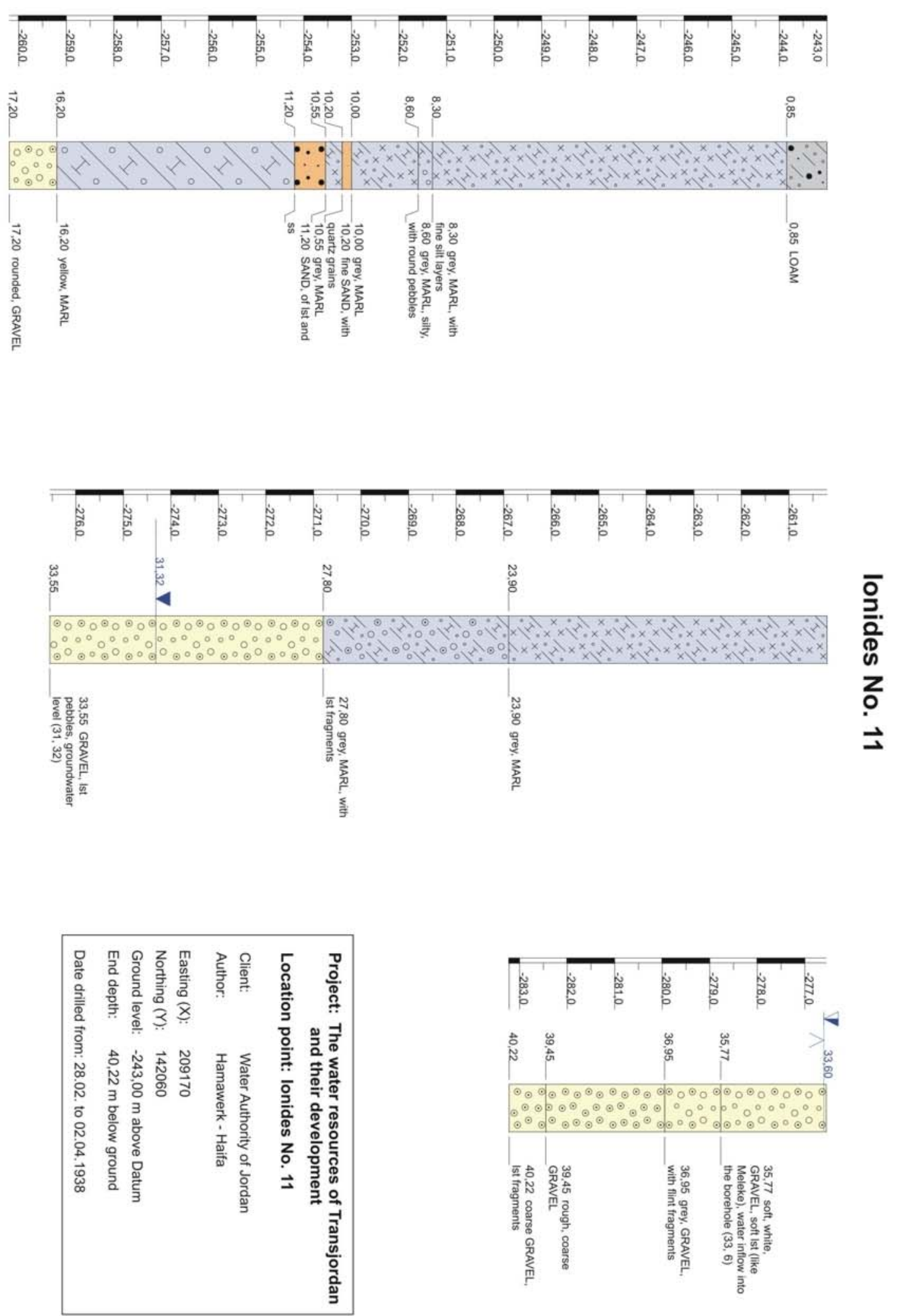


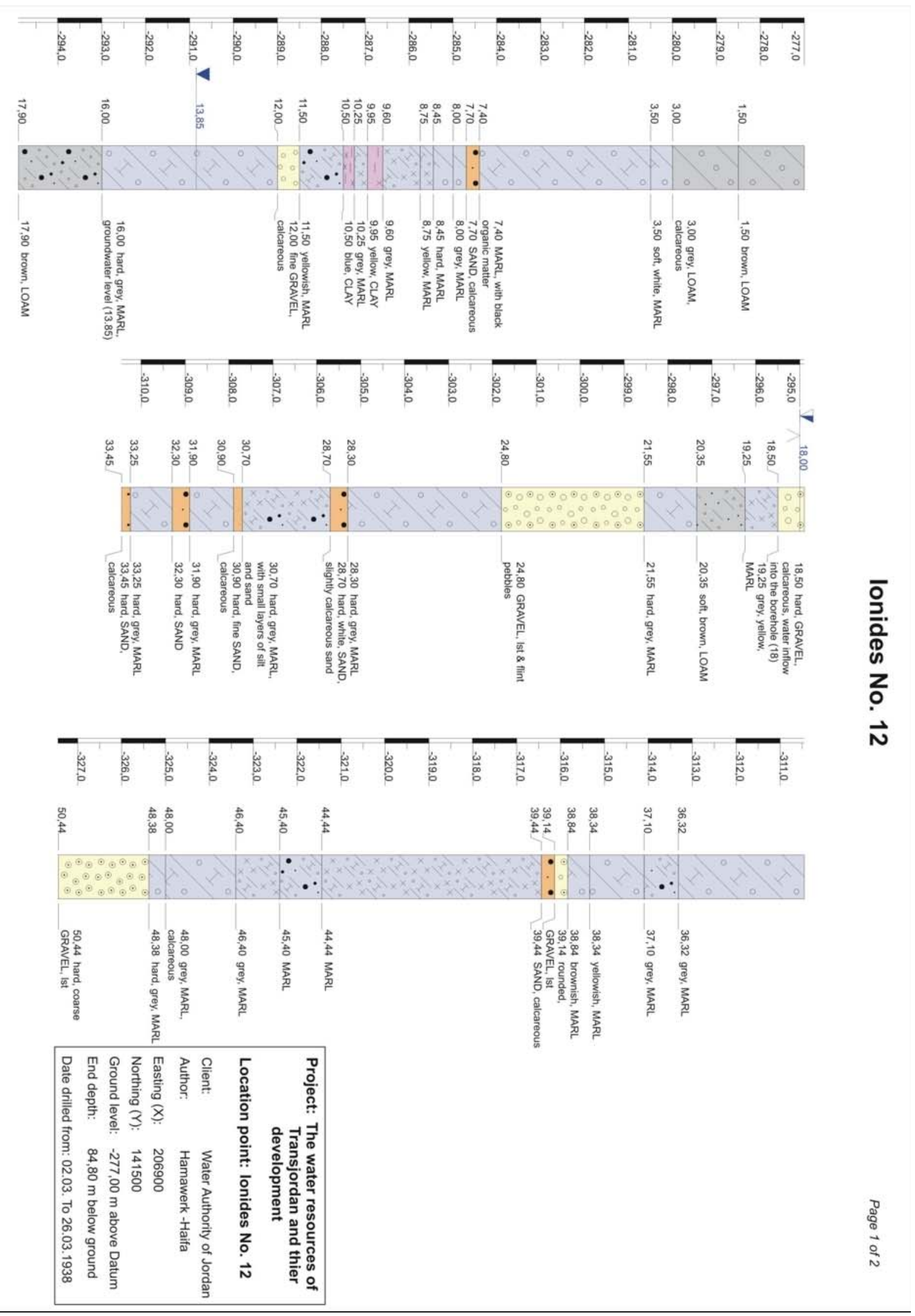



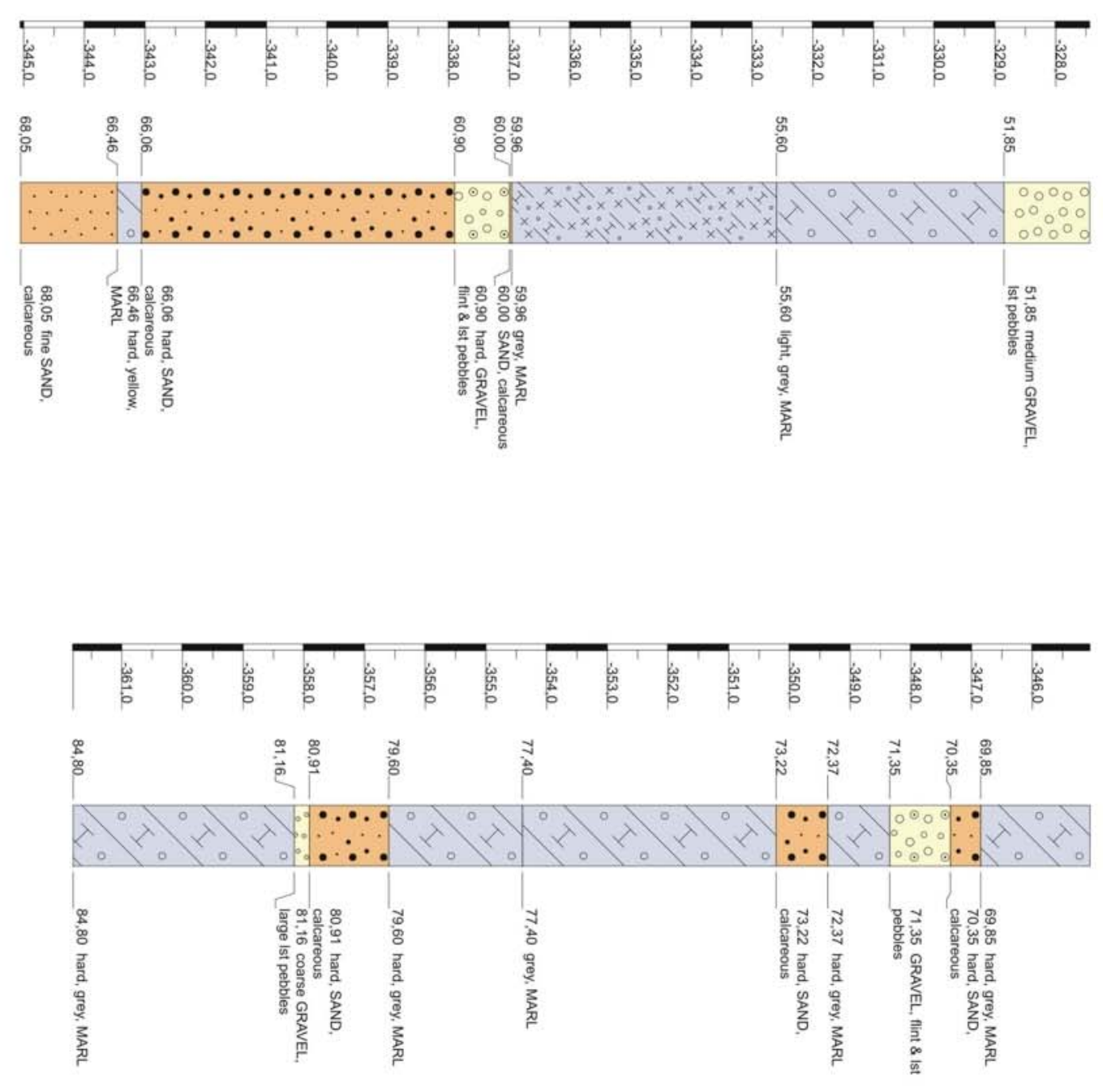

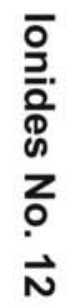

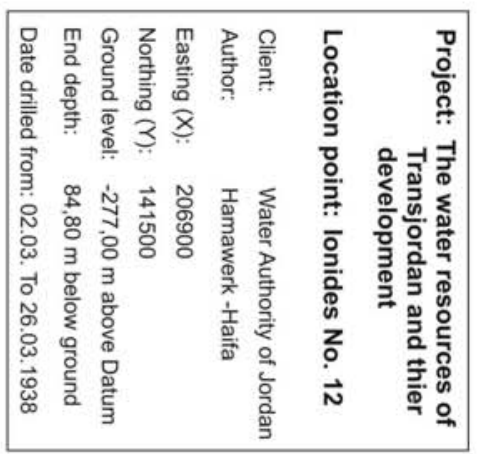




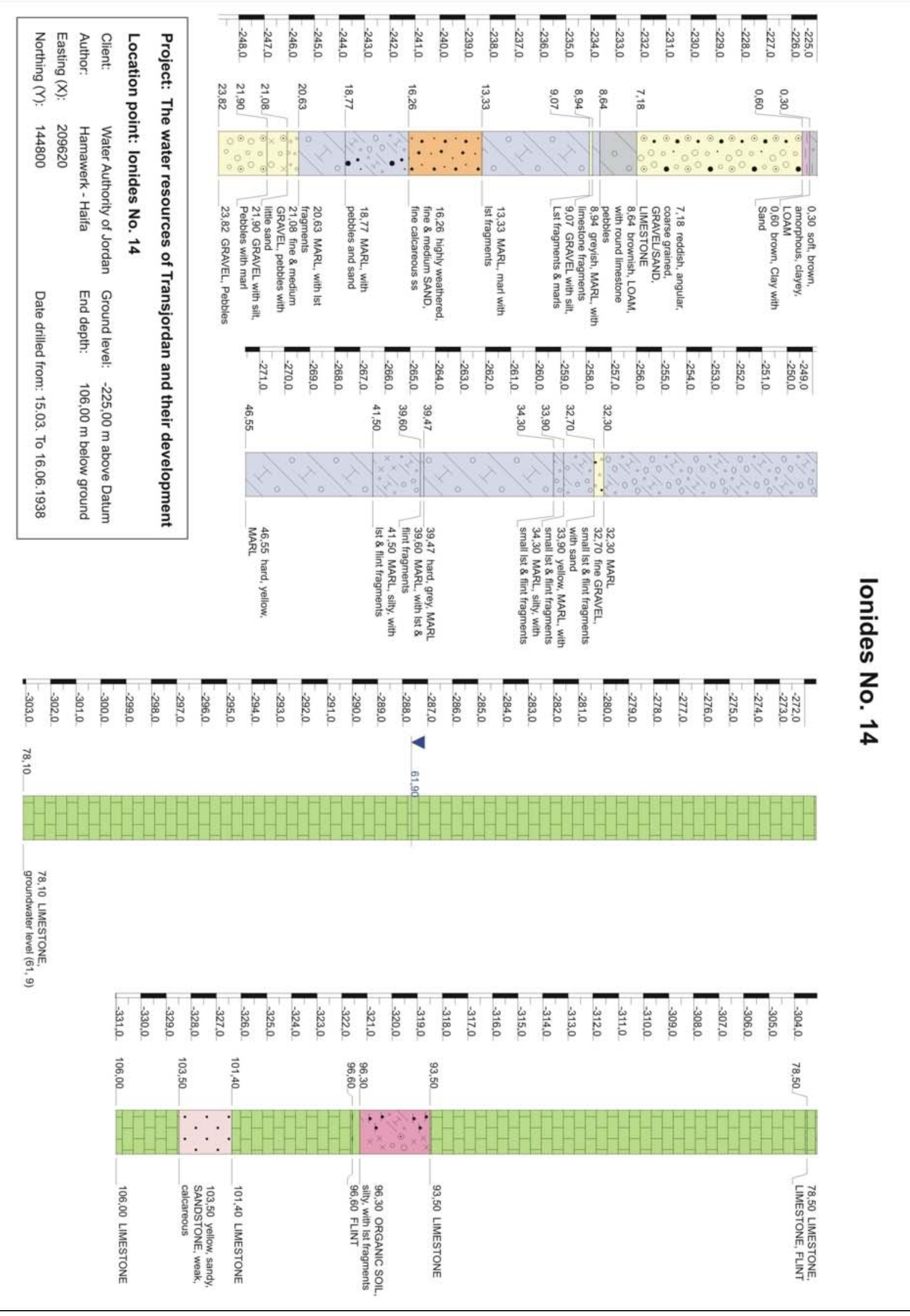




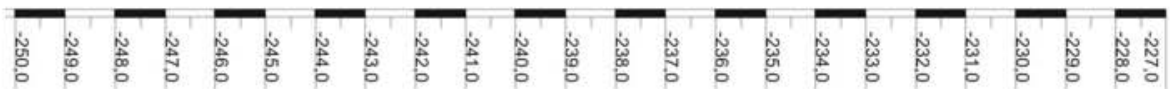

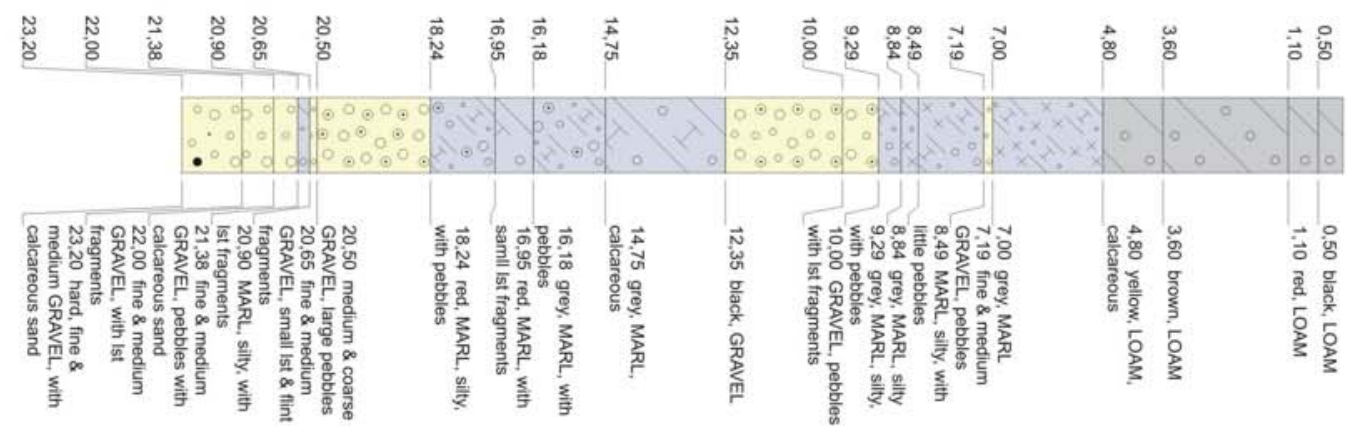

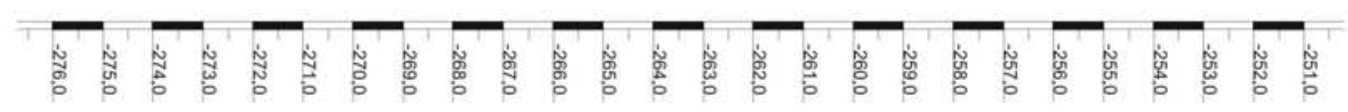

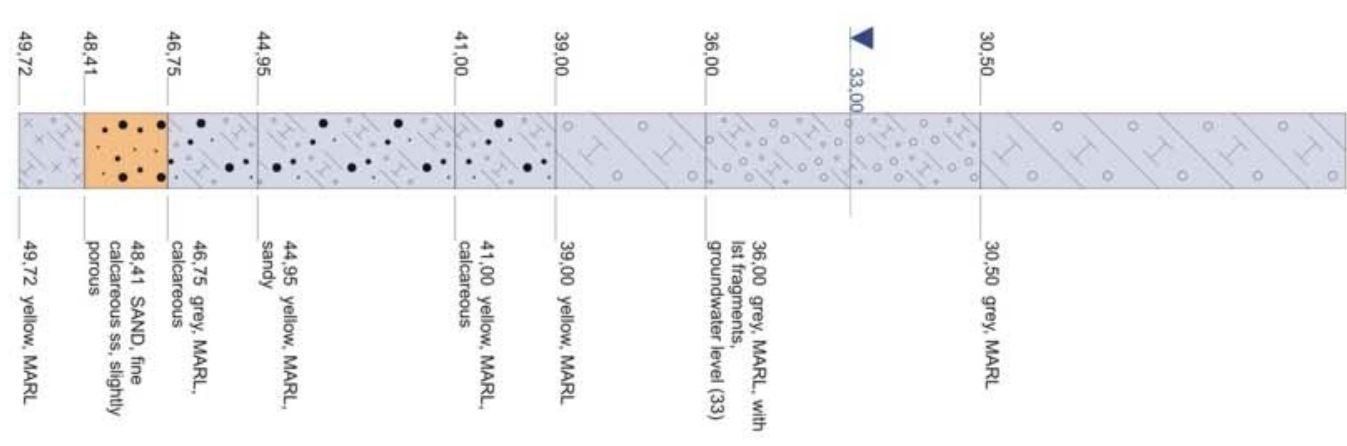

$\overline{0}$
$\overline{0}$
$\overline{0}$
z
zo
vे

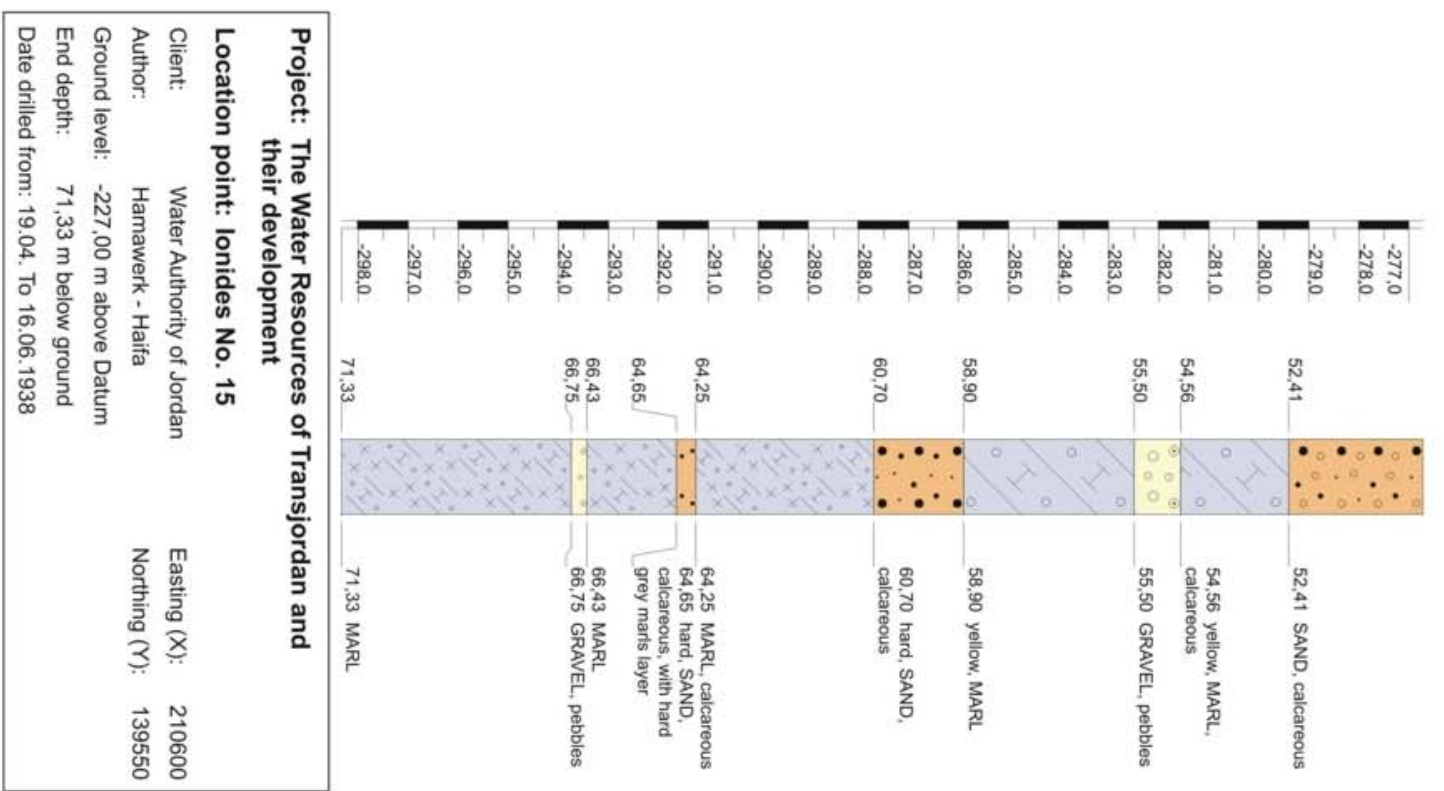


Ionides No. 16

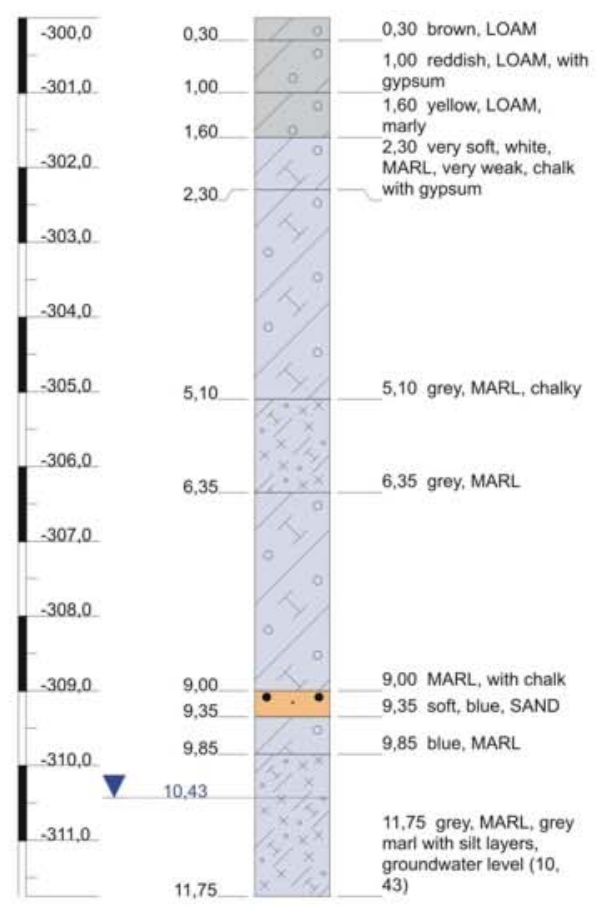

Project: The water resources of Transjordan and their development Location point: lonides No. 16

Client: Water Authority of Jordan $\quad$ Easting (X): 205200

Author: Hamawerk - Haifa Northing $(Y)$ : 141250

Ground level: $\quad-300,00 \mathrm{~m}$ above Datum

End depth: $\quad 11,75 \mathrm{~m}$ below ground

Date drilled from: 01.04 .1938 to 16.04 .1938 
Ionides No. 17

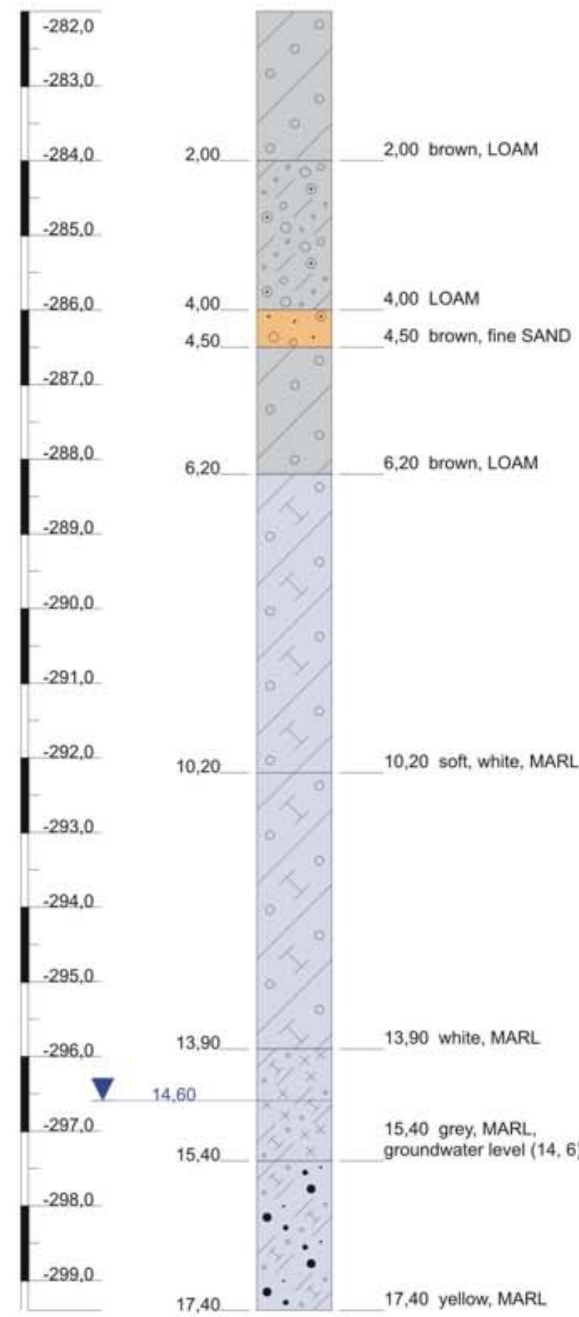

Project: The water resources of Transjordan and their development Location point: lonides No. 17

Client: Water Authority of Jordan $\quad$ Easting (X): 207050

Author: Hamawerk - Haifa Northing $(Y): 138800$

Ground level: $\quad-282,00 \mathrm{~m}$ above Datum

End depth: $\quad 17,40 \mathrm{~m}$ below ground

Date drilled from: 20.04 . to 30.04 .1938 


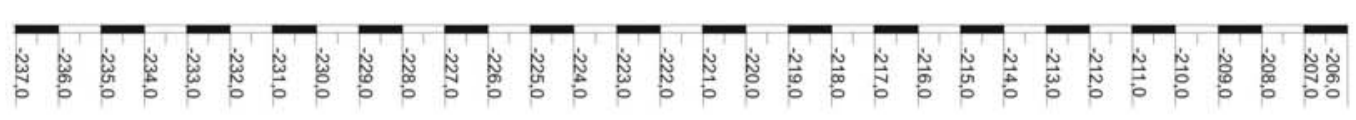

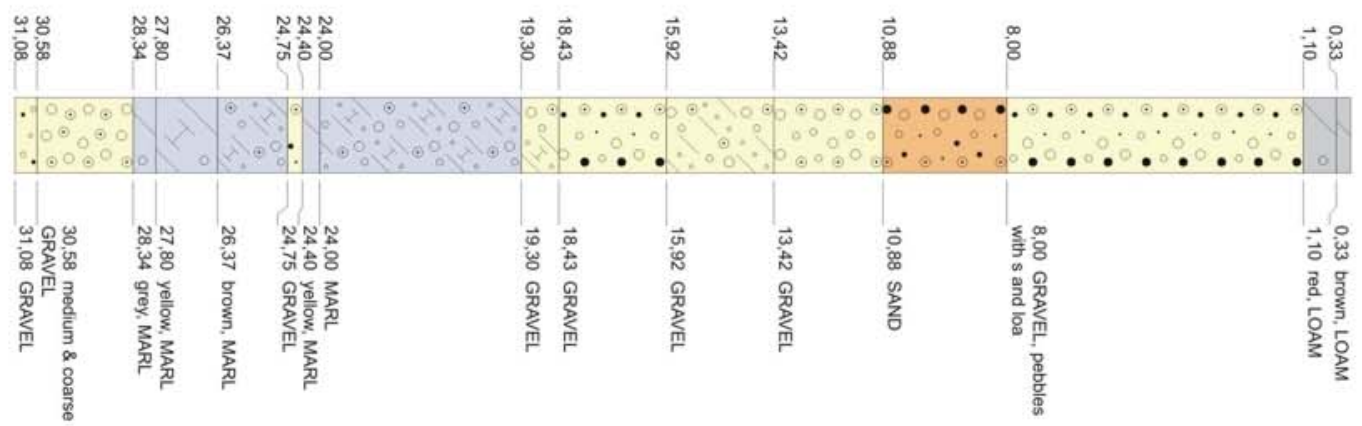

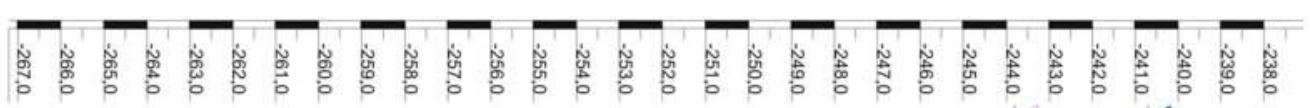

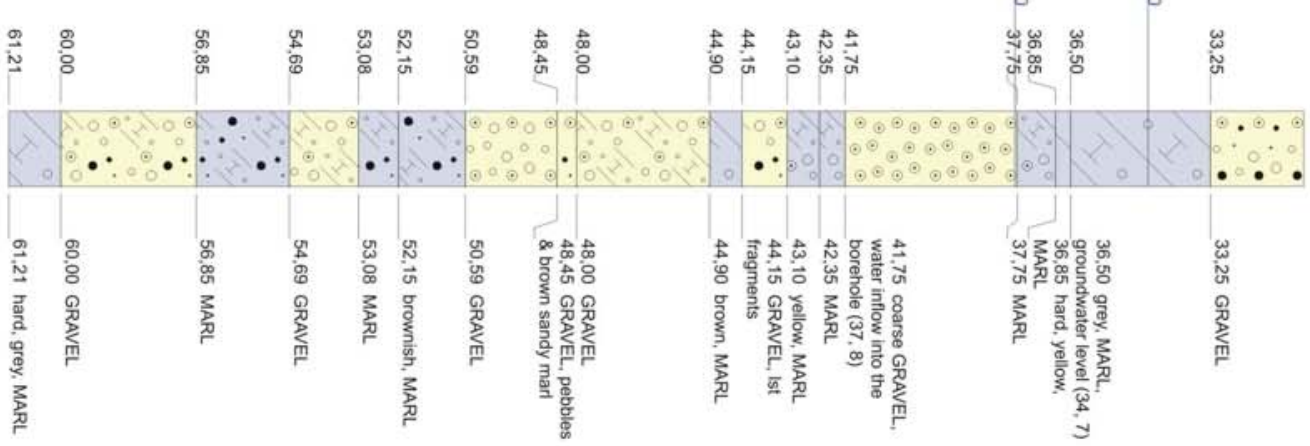

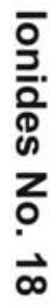

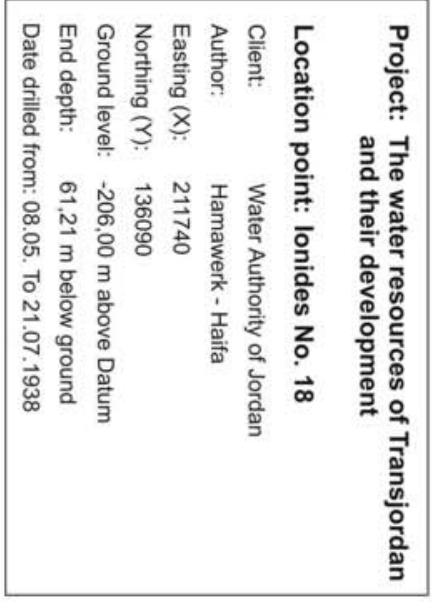




\section{Ionides No. 19}
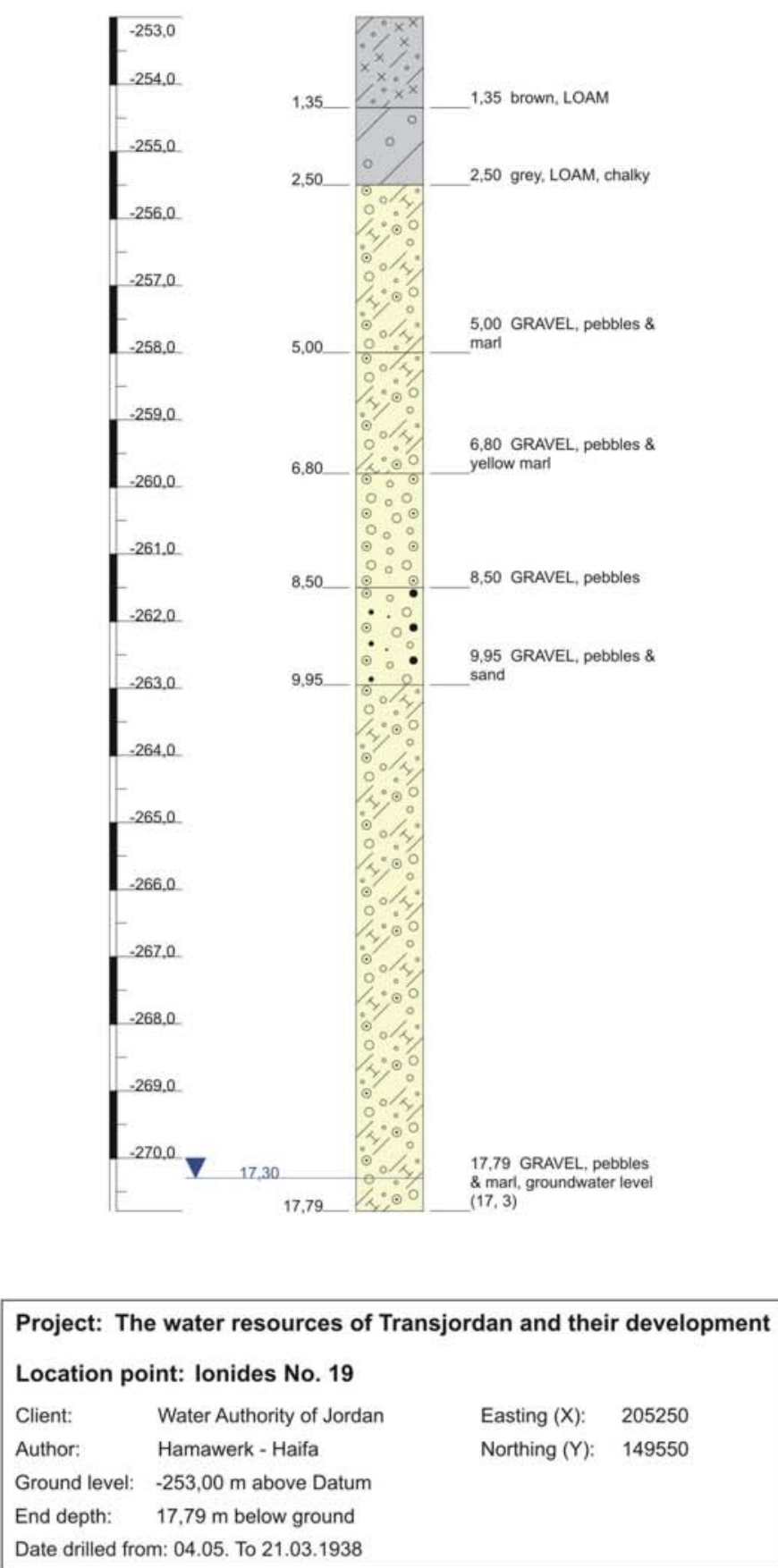
Results of the Farm Survey conducted within the course of this study.

\begin{tabular}{|c|c|c|c|c|c|c|c|c|c|c|c|}
\hline Farm & $\begin{array}{l}\text { farm } \\
\text { age } \\
\text { [a] }\end{array}$ & $\begin{array}{l}\text { water } \\
\text { source }\end{array}$ & $\begin{array}{l}\text { age } \\
\text { well } \\
\text { [a] }\end{array}$ & $\begin{array}{c}\text { depth } \\
\text { [m] }\end{array}$ & $\begin{array}{c}\text { SWL } \\
\text { [mbgl] }\end{array}$ & $\begin{array}{c}\mathrm{EC} \\
{[\mathrm{mS} / \mathrm{cm}]}\end{array}$ & $\mathbf{T}\left[{ }^{\circ} \mathbf{C}\right]$ & pH & $\begin{array}{l}\text { irr. } \\
\text { area } \\
\text { [du] }\end{array}$ & \begin{tabular}{|c|} 
pump. dur., \\
main \\
irrigation \\
season
\end{tabular} & $\begin{array}{l}\text { pump. dur., } \\
\text { minor } \\
\text { irrigation } \\
\text { season }\end{array}$ \\
\hline W001 & & well & & 45 & 11 & 2.51 & 27.7 & 7.11 & 70 & 12 h/d & $2-4 \mathrm{~h} / \mathrm{w}$ \\
\hline W002 & & well & & & 12.4 & 2.56 & 27.1 & 7.35 & & & \\
\hline W003 & & well & & & n.c. & & & & 75 & $5-12 \mathrm{~h}$ & \\
\hline W004 & & well & & & 13.3 & & & & 75 & & \\
\hline W005 & & well & & & 6.3 & 1.95 & 27 & 7.68 & 40 & $6 \mathrm{~h}$ & \\
\hline W006 & 3.5 & well & 4 & & 5.75 & & & & 35 & $10 \mathrm{~h} / \mathrm{w}$ & \\
\hline W007 & 3 & well & 3 & & 4.4 & 5.19 & 27.7 & 7.17 & 34 & $2 \mathrm{~h}, 4 / \mathrm{w}$ & $1 \mathrm{~h}, 2 / \mathrm{w}$ \\
\hline W008 & 10 & well & 8 & $\sim 30 \mathrm{~m}$ & 18 & & & & 120 & $5 \mathrm{~h}, 2 / \mathrm{w}$ & $5 \mathrm{~h}, 1 / \mathrm{w}$ \\
\hline W009 & 3 & well & 44 & 45 & $10 *$ & 3.13 & 26.7 & 7.21 & 180 & & \\
\hline W010 & 46 & well & 46 & 45 & 29.5 & & & & 200 & $8 \mathrm{~h}, 2 / \mathrm{w}$ & 2 h, $2 / w$ \\
\hline W011 & 3 & well & & 21 & n.c. & & & & 450 & ev.15 d & ev. $15 \mathrm{~d}$ \\
\hline W012 & 10 & well & 50 & 80 & $47,7 *$ & 3.41 & 34.8 & 7.18 & 200 & $18 \mathrm{~h}$ & $9 \mathrm{~h}$ \\
\hline W013 & 5 & & 20 & & & 4.39 & 26.1 & 7.38 & 125 & $2-9$ h/d & $5-6 \mathrm{~h} / \mathrm{w}$ \\
\hline W014 & & well & & & 9.17 & & & & & & \\
\hline W015 & & well & & & 39.9 & & & & & & \\
\hline W016 & 3 & well & & 45 & 8.8 & & & & 120 & $12 \mathrm{~h} / \mathrm{d}$ & $8 \mathrm{~h} / \mathrm{d}$ \\
\hline W017 & 1 & well & & & 5.65 & & & & 20 & 2 h, 3/d & \\
\hline W018 & & spring & & & & & & & 70 & $2 \mathrm{~h} / \mathrm{d}$ & $2 \mathrm{~h} / \mathrm{d}$ \\
\hline W019 & & well & 5 & & & & & & & & \\
\hline W020 & & well & & & & 2.57 & 27 & 7.54 & & & \\
\hline W021 & & & & & 38.63 & & & & & & \\
\hline W022 & & & & & 27.75 & & & & & & \\
\hline W023 & $\sim 40$ & well & 42 & & 67.6 & 2.64 & 25.7 & 7.3 & 25 & $24 \mathrm{~h} / \mathrm{d}$ & $7-8 \mathrm{~h} / \mathrm{d}$ \\
\hline W024 & $25-30$ & $\begin{array}{c}\text { well/ } \\
\text { spring }\end{array}$ & 6 & & 57.75 & 2.66 & 25.7 & 7.25 & 65 & $24 \mathrm{~h} / \mathrm{d}$ & $12 \mathrm{~h}$, ev. 2 \\
\hline W025 & 20 & well & 2 & & & 2.34 & 28 & 7.2 & & & \\
\hline W026 & 1 & $\begin{array}{c}\text { well/ } \\
\text { spring }\end{array}$ & & & n.c. & 2.66 & 26 & 7.15 & 12 & & \\
\hline W027 & 7 & $\begin{array}{c}\text { well/ } \\
\text { spring }\end{array}$ & & & 58.4 & 2.75 & 27.5 & & & $\begin{array}{c}\text { 6h, ev. 3-4 } \\
\text { days }\end{array}$ & 3h, ev. 3-4 d \\
\hline W028 & 9 & $\begin{array}{l}\text { well/ } \\
\text { MWI }\end{array}$ & 15 & 63 & n.c. & 2.67 & 27.7 & 7.48 & & $6 \mathrm{~h} / \mathrm{d}$ & $2 \mathrm{~h} / \mathrm{d}$ \\
\hline W029 & 1.5 & $\begin{array}{l}\text { well/ } \\
\text { MWI }\end{array}$ & 3 & & $62,73 *$ & 2.26 & 25.8 & 7.34 & 35 & $12 \mathrm{~h} / \mathrm{d}$ & $2-3 \mathrm{~h} / \mathrm{d}$ \\
\hline W030 & 10 & $\begin{array}{l}\text { well/ } \\
\text { MWI }\end{array}$ & 8 & & $61,53 *$ & 2.44 & 26.9 & 7.44 & 70 & $24 \mathrm{~h} / \mathrm{d}$ & \\
\hline W031 & 2 & well & old & $\sim 50$ & 3.48 & & & & 40 & $6 \mathrm{~h} / \mathrm{d}$ & $6 \mathrm{~h}, \mathrm{ev} .3-5 \mathrm{~d}$ \\
\hline W032 & & well & $>50$ & 80 & $30 *$ & 2.61 & 26.1 & 7.33 & & $24 \mathrm{~h} / \mathrm{d}$ & 10h, ev. $2 \mathrm{~d}$ \\
\hline W033 & & & & & 20.29 & & & & & & \\
\hline W034 & & well & 15 & 80 & & 4.01 & 27.1 & 7.32 & & $10 \mathrm{~h} / \mathrm{d}$ & $5-10 \mathrm{~h} / \mathrm{d}$ \\
\hline W035 & old & well & 5 & 55 & 12.39 & 5.34 & 26.4 & 7.25 & & $12 \mathrm{~h} / \mathrm{d}$ & $4 \mathrm{~h}$, ev. $2 \mathrm{~d}$ \\
\hline W036 & $>50$ & $\begin{array}{c}\text { well/ } \\
\text { spring }\end{array}$ & $>50$ & 42 & $12,23 *$ & 4.13 & 27.4 & 7.3 & 35 & $10 \mathrm{~h} / \mathrm{d}$ & $5 \mathrm{~h} / \mathrm{d}$ \\
\hline W037 & & well & & & 65.88 & & & & & $10-12 \mathrm{~h} / \mathrm{d}$ & 3-4 h, ev. 2-3 d \\
\hline W038 & & well & 5 & & 80.01 & & & & & $24 \mathrm{~h} / \mathrm{d}$ & 2-3 h, ev. $3 \mathrm{~d}$ \\
\hline W039 & & well & $>60$ & & $\sim 65$ & & & & & & \\
\hline
\end{tabular}

$*=$ Pump was running during

measurement

n.c. $=$ not detectable 


\begin{tabular}{|c|c|c|c|c|c|}
\hline Farm & Crop & $\begin{array}{c}\text { what grew } \\
\text { before }\end{array}$ & $\begin{array}{l}\text { irr. } \\
\text { (main) }\end{array}$ & $\begin{array}{c}\text { irr. } \\
\text { (minor) }\end{array}$ & comments \\
\hline W001 & eggplant, tomatoe,zuchini & & $\begin{array}{l}\text { june- } \\
\text { august }\end{array}$ & & \\
\hline \multicolumn{6}{|l|}{ W002 } \\
\hline W003 & Olives, Dates, Mango & & & & \\
\hline \multicolumn{6}{|l|}{ W004 } \\
\hline W005 & Guave, Palm & & & & \\
\hline W006 & Palm. Olive & & summer & winter & \\
\hline W007 & Guave, Palm & $\begin{array}{l}\text { tomato, } \\
\text { eggplant }\end{array}$ & $\begin{array}{l}\text { June- } \\
\text { October }\end{array}$ & $\begin{array}{l}\text { Oct - } \\
\text { Feb }\end{array}$ & \\
\hline W008 & Olives,Palm,Guave & \begin{tabular}{|c|} 
same, \\
vegetables
\end{tabular} & summer & winter & \\
\hline W009 & eggplant, zuchhini, tomatoe & $\begin{array}{l}\text { wheat, } \\
\text { barley }\end{array}$ & $\begin{array}{l}\text { March- } \\
\text { June }\end{array}$ & Nov-Jan & AB1086 \\
\hline W010 & Banana, Persim & vegetables & Jun-Sep & Oct-Mar & \\
\hline W011 & Persim & & & & 5 du planted, farm with stables (6 hourses) \\
\hline W012 & vegetables, water melon & & Feb-Dec & Jan-Feb & $\begin{array}{l}\text { another } 2 \text { wells exist, but they are not working } \\
\text { now }\end{array}$ \\
\hline W013 & Palm, Olive & vegetables & & & \\
\hline \multicolumn{6}{|l|}{ W014 } \\
\hline W015 & vegetables, melons & & & & no one there to ask \\
\hline W016 & Palm, Guava & vegetables & June-Sep & dec-mar & $\begin{array}{l}\text { the irrigation is daily, since ist the planting } \\
\text { season }\end{array}$ \\
\hline W017 & Palm & & June-Aug & Dec-Mai & \\
\hline W018 & $\begin{array}{l}\text { Melon, Tomato, eggplant, } \\
\text { Olive } \\
\end{array}$ & same & & & \\
\hline W019 & Olive & & & & $\begin{array}{c}\text { the well is not in use because of ist high salinity } \\
\text { but in case of weak spring discharge the well is } \\
\text { used }\end{array}$ \\
\hline W020 & & & & & it is an old well feeding two pools, artesian \\
\hline W021 & & & & & well is not in use \\
\hline W022 & & & & & this well is suppling the quarreys with water \\
\hline W023 & banana & \begin{tabular}{|c|} 
before ten \\
years \\
vegetables
\end{tabular} & Mai-Oct & Nov-Apr & the well was on during measuring swl \\
\hline W024 & banana, vegetables & & Mai-Oct & Nov-Apr & the well was on during measuring swl \\
\hline W025 & banana & vegetables & june-aug & nov-jan & constr. 2 years ago, but it silt up \\
\hline W026 & banana & lattece & jun-sep & oct-mai & in winter season only spring water is used \\
\hline W027 & vegetables & & Mai-Oct & nov-apr & field parameters were taken from the pool \\
\hline W028 & banana, lemon & $\begin{array}{c}\text { former } \\
\text { mine field }\end{array}$ & Mai-Oct & Nov-Apr & \\
\hline W029 & banana & $\begin{array}{c}\text { Zucchini, } \\
\text { eggplant }\end{array}$ & Jun-Aug & Jan-Feb & \\
\hline W030 & banana & vegetables & jun-Aig & feb-apr & \\
\hline W031 & persim/ palm & & jun-aug & dec-feb & pump was of since 28h; cow farm \\
\hline W032 & \begin{tabular}{|c|}
$\begin{array}{c}\text { corn, zucchini, vegetables in } \\
\text { general }\end{array}$ \\
\end{tabular} & & sep-oct & jan-feb & \\
\hline \multicolumn{6}{|c|}{\begin{tabular}{l|l} 
W033 & \\
\end{tabular}} \\
\hline W034 & same as W032 & & & & well is closed \\
\hline W035 & tomatoe, eggplant & vegetables & sep-nov & jan-feb & \\
\hline W036 & $\begin{array}{l}\text { tomatoe, cucumber, } \\
\text { eggplant }\end{array}$ & & aug-sep & dec-mar & \\
\hline W037 & banana & & jul-aug & dec-jan & pump was off since 10 days \\
\hline W038 & banana & & & & \\
\hline W039 & vegetables & & sep-oct & jan-feb & $\mathrm{AB} 1026$ \\
\hline
\end{tabular}


Lebenslauf

Name:

Mathias Toll

Geburtstag:

09. Juli 1974

Geburtsort:

Bensheim (Hessen)

Nationalität:

deutsch

Schulische Ausbildung:

09/85 bis 06/94 Gesamtschule, gymnasialer Zweig Geschwister-Scholl-Schule Bensheim

Hochschulreife

Studium:

WS 94/95 bis WS 97/98 Diplom-Geologie/ Paläontologie Technische Universität Darmstadt

Vordiplom: 31/03/1997

SS 98 bis SS01 Diplom-Geologie/ Paläontologie Eberhard-Karls-Universität Tübingen

Diplom: 31/08/2001

Promotion:

01/03 bis 12/07 Georg-August-Universität Göttingen

BMBF Projekt: "The German - Israeli - Jordanian - Palestinian Joint Research Program (GIJP)- Water Resources Evaluation for a Sustainable Development in the Jordan Rift Basin”

18. Dezember 2007 